Division of Geological \& Geophysical Surveys

PRELIMINARY INTERPRETIVE REPORT 2008-1

\title{
PRELIMINARY RESULTS OF RECENT GEOLOGIC FIELD INVESTIGATIONS IN THE BROOKS RANGE FOOTHILLS AND NORTH SLOPE, ALASKA
}

by

Marwan A. Wartes and Paul L. Decker, editors

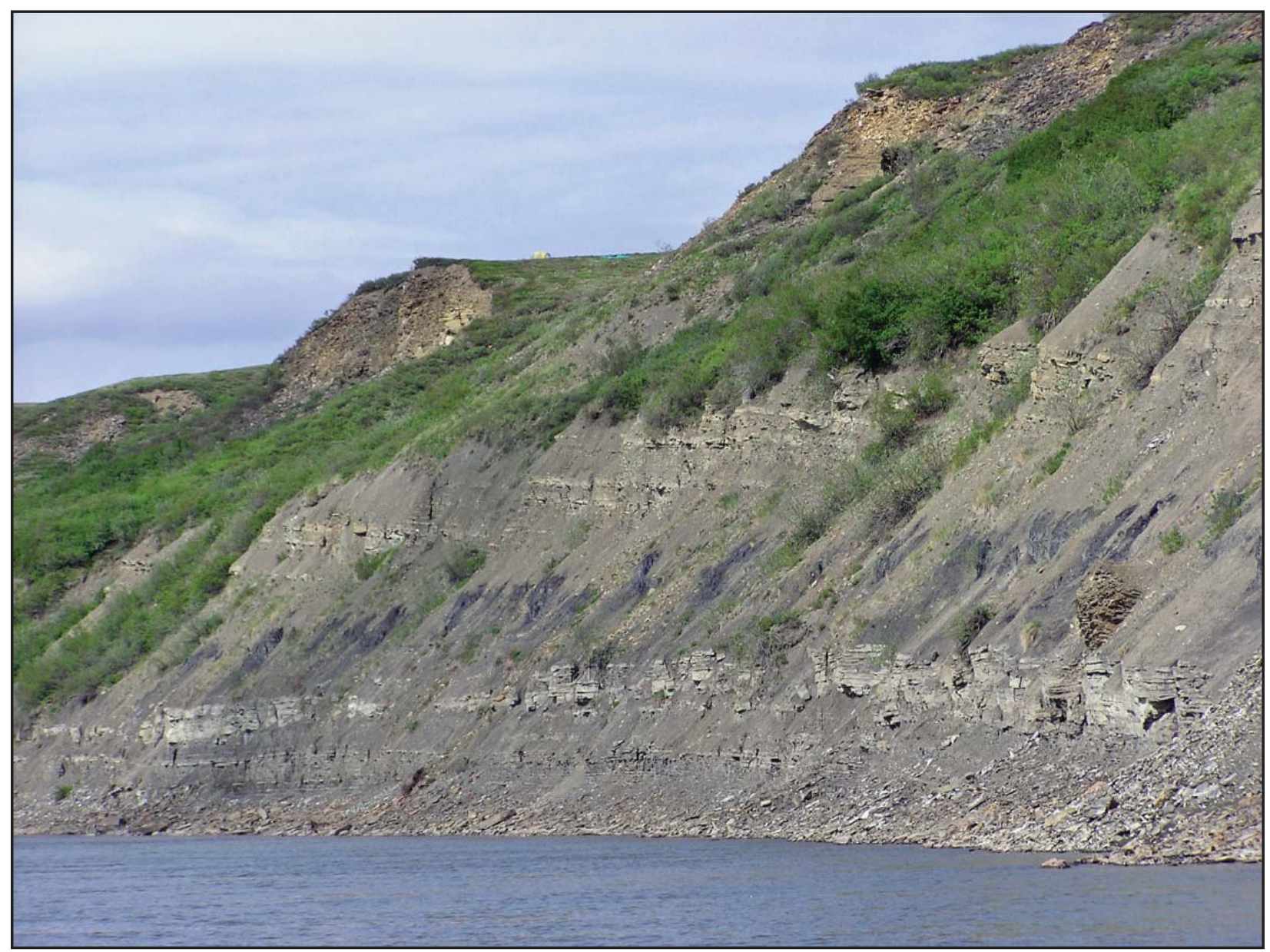

View of Albian deltaic facies in the Nanushuk Formation exposed along the Colville River, upstream of the confluence with the Awuna River (note the mountain tent along the skyline for scale). The prominent clinoforms downlapping the coal seam are interpreted as foresets of a prograding bayhead delta (see LePain and others, this volume, p. 41). Photo by Paul Decker.

March 2008

Released by

STATE OF ALASKA

DEPARTMENT OF NATURAL RESOURCES

Division of Geological \& Geophysical Surveys

3354 College Rd.

Fairbanks, Alaska 99709-3707 



\section{CONTENTS}

Page

A Overview of recent geologic field investigations, North Slope and Brooks Range foothills, Alaska......... 1 Marwan A. Wartes and Paul L. Decker (Includes Appendix A-1, p. 135; Sheet A-1, in envelope)

B Measured section and facies analysis of the Lower Cretaceous Fortress Mountain Formation, Atigun syncline, northern Alaska...

Marwan A. Wartes (Includes Sheet B-1, in envelope)

C Evaluation of stratigraphic continuity between the Fortress Mountain and Nanushuk Formations in the central Brooks Range foothills-Are they partly correlative?

Marwan A. Wartes

(Includes Appendix C-1, p. 179)

D Measured sections and preliminary interpretations of the Nanushuk Formation exposed along the Colville River near the confluences with the Awuna and Killik rivers

David L. LePain, Paul L. Decker, and Marwan A. Wartes

(Includes Appendix D-1, p. 195; Appendix D-2, p. 201; Sheets D-1-D-4, in envelope)

E Geochemistry of the Aupuk gas seep along the Colville River—Evidence for a thermogenic origin.........

Paul L. Decker and Marwan A. Wartes

F Stratigraphic and structural investigations in the Ivishak River and Gilead Creek areas:

Progress during 2007. 55

Paul L. Decker, Marwan A. Wartes, Wesley K. Wallace, David W. Houseknecht,

Christopher J. Schenk, Robert J. Gillis, and Jacob Mongrain (Includes Sheet F-1, in envelope)

G Turonian-Campanian strata east of the Trans-Alaska Pipeline corridor, North Slope foothills, Alaska: Progress during the 2001-02 and 2007 field seasons 85

David L. LePain, Russell Kirkham, Robert J. Gillis, and Jacob Mongrain
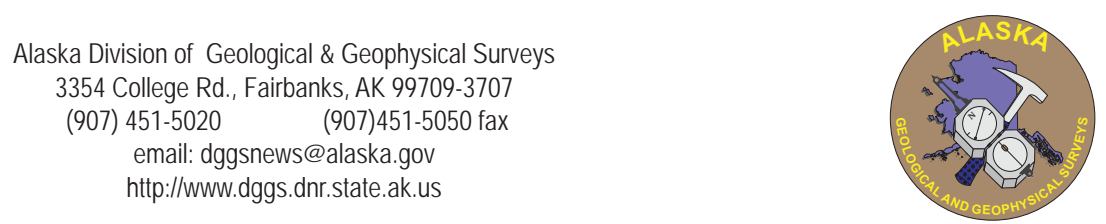



\title{
OVERVIEW OF RECENT GEOLOGIC FIELD INVESTIGATIONS, NORTH SLOPE AND BROOKS RANGE FOOTHILLS, ALASKA
}

\author{
by
}

\author{
Marwan A. Wartes ${ }^{1}$ and Paul L. Decker ${ }^{2}$
}

\section{INTRODUCTION}

In recent years, the Alaska Department of Natural Resources (DNR) has pursued a leadership role in advancing the understanding of North Slope geology and petroleum systems, primarily through stratigraphic studies and geologic mapping in the foothills of the northern Brooks Range (fig. 1). The North Slope Energy Program was developed in response to the need for high quality, publicly available geologic data to stimulate exploration for hydrocarbons in northern Alaska. Directed by the Division of Geological \& Geophysical Surveys (DGGS), this program is a multi-agency collaboration with geologists and geophysicists from the Division of Oil \& Gas (DOG), the United States Geological Survey (USGS), and the University of Alaska Fairbanks (UAF), among others.

In addition to original geological studies, we also led an annual two-day field trip aimed at highlighting key exposures that provide insight into the geologic evolution of the North Slope petroleum system. In 2007, this tour took place on June 29 and 30 and was attended by 21 geologists from seven oil and gas companies, in addition to geologists and directors from DGGS, DOG, and USGS. The summary presentation provided to attendees is included here as Appendix A-1.

This volume of collected papers is intended to offer timely summaries of recent data and interpretations (fig. 1 shows location of each study area). Some of the topics covered in papers in this volume include data acquired prior to the 2007 season. All of these reports are based in part on preliminary field evidence; final interpretations await additional analytical data, particularly biostratigraphic information.

\section{PROJECT STAFF}

In order to achieve our program objectives, we annually assemble a team with a cross-section of expertise sufficient to address topics relevant to understanding of the petroleum system in northern Alaska. During 2007, the following geologists participated in various aspects of field and/or analytical work, some of which are presented in various papers included in this volume:

Marwan Wartes (DGGS) —Clastic sedimentology, basin analysis, and tectonics Paul Decker (DOG) — Stratigraphy, structural geology, and petroleum geology

David LePain (DGGS) — Clastic sedimentology and sequence stratigraphy

Robert Gillis (DGGS) —Structural geology and thermochronology

Rocky Reifenstuhl (DGGS) - Reservoir quality and geologic mapping

Robert Swenson (DGGS) - Structural geology and petroleum geology

Wes Wallace (UAF)—Structural geology, tectonics, and geologic mapping

C. Gil Mull (Consultant)—Regional geology

Paige (Peapples) Delaney (DGGS) —Structural geology and geologic mapping

Andrea Loveland (DGGS) — Structural geology and geologic mapping

Ken Helmold (DOG) — Reservoir quality and basin modeling

Diane Shellenbaum (DOG) — Seismic stratigraphy and data processing

Peter Flaig (UAF, Ph.D student) — sedimentology and stratigraphy

Dolores van der Kolk (DGGS/UAF, MS student)—sedimentology and stratigraphy

Jacob Mongrain (DGGS/UAF, Ph.D student)—sedimentology and stratigraphy

In addition, we also benefitted from informal collaboration with several USGS geologists engaged in petroleum-related geological research in northern Alaska, including David Houseknecht, Tom Moore, Chris Schenk, and Chris Potter.

\footnotetext{
${ }^{1}$ Alaska Division of Geological \& Geophysical Surveys, 3354 College Rd., Fairbanks, Alaska 99709-3707

Email for Marwan A. Wartes: marwan.wartes@alaska.gov

${ }^{2}$ Alaska Division of Oil \& Gas, 550 W. 7th Ave., Suite 800, Anchorage, Alaska 99501-3560
} 

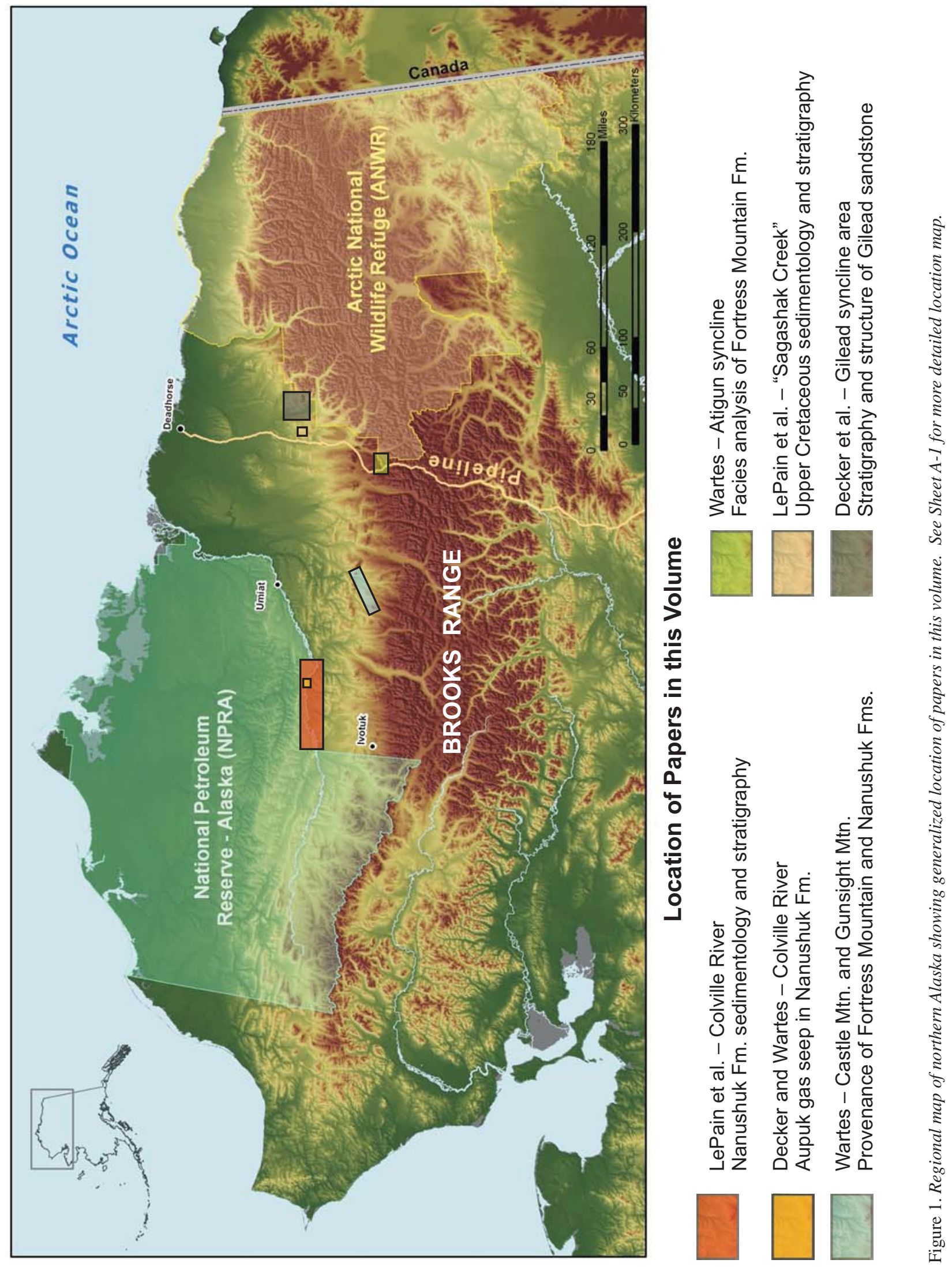


\section{SUMMARY OF 2007 FIELD PROGRAM}

In 2007, our team was based out of a temporary camp near Galbraith Lake from June 15 through July 10 (Sheet A-1). The majority of our work was helicopter supported and ranged from daily flights to multi-day spike camps that were deployed to remote locations. Sheet A-1 illustrates the coverage of our $\sim 700$ different field stations. In addition to sedimentologic and structural observations, an extensive selection of samples were collected, most of which require contracted analytical work. The results of these analyses were not yet available for inclusion in this volume, although subsequent publications will incorporate these data. Samples were collected for the following purposes:

- $\quad$ Lithology (representative)

- Thin sections

- $\quad$ Porosity and permeability

- RockEval and total organic carbon

- Vitrinite reflectance

- Hydrocarbon extract and biomarker typing

- Megafossil paleontology

- Microfossil paleontology (foraminifera and palynology)

- Whole-rock geochemistry

- Geochronology (tuff and bentonite)

- Apatite fission track thermochronology

- Detrital zircon geochronology

The following summary of our 2007 field work is intended to be a brief review; more detailed data and interpretations either appear within the papers in this volume, or will be expanded upon in future reports. The focus for our 2007 field studies can be geographically subdivided into a northern and southern belt (Sheet A-1) and are discussed below accordingly.

\section{Northern Belt (Cretaceous strata of the south-central Sagavanirktok Quadrangle)}

Previous reconnaissance work and stratigraphic studies by DGGS have documented a number of important exposures of Cretaceous strata between the Toolik and Echooka rivers (Sheet A-1). These outcrops expose several Brookian depositional sequences in a compact area and provide valuable insight into the time-transgressive northeastward progradation of genetically related shelf, slope, and deepwater facies. Through increased collaboration with DOG geologists, we have begun integrating detailed outcrop observations with available well and two-dimensional (2-D) seismic data, greatly increasing the robustness of our stratigraphic correlations and regional geologic models.

- $\quad$ Preliminary Sagavanirktok River Area Geologic Mapping —We have received state and federal funding to conduct a STATEMAP project in 2008 in the south-central Sagavanirktok Quadrangle (Sheet A-1). In preparation for this detailed (1:63,360-scale) mapping effort, we conducted reconnaissance work during the 2007 season. The area contains a number of large east-west-trending folds with uncertain gas prospectivity, but has never been mapped in detail (see Mull [1989] for 1:250,000-scale "strip maps” along the Dalton Highway). Our preliminary work helped identify geologically reasonable map borders and highlighted stratigraphic nomenclature issues. In particular, the stratigraphy of this map area is transitional between the Umiat area, where the formation designations largely focus on proximal units, and the Canning River area, which includes correlative distal units, but with differing stratigraphic nomenclature (Molenaar and others, 1986; Mull and others, 2003).

- Gilead sandstone (Torok Formation)_-Tertiary uplift of the northeastern Brooks Range has locally exposed the lower parts of the Brookian Sequence along the Phillip Smith mountain front (Pessel and others, 1990). These rocks include the Albian-Cenomanian Gilead sandstone (informal name), which provides unique insight into the early evolution of the basin that is largely concealed in the subsurface to the west (Reifenstuhl, 1991). To improve our understanding of the stratigraphy and structure of this area, a number of traverses were conducted during the 2007 field season along the Ivishak River, Gilead Creek, and across Gilead syncline (Sheet A-1). Our preliminary interpretations, summarized in Decker and others (2008), suggest that Albian to Turonian depositional environments near the southeastern 
margin of the Colville foreland basin may have been significantly different from the time-equivalent stratigraphic record farther west in the Umiat and Tarn/Meltwater areas.

- Terminal Nanushuk shelf edge-The terminal shelf edge of the easterly prograding Albian-Cenomanian Nanushuk-Torok depositional system is well defined by seismic and well log correlations in the area north of the Umiat baseline near the Itkillik River, some $80 \mathrm{~km}$ west of the Dalton Highway (for example, Houseknecht and Schenk, 2005). However, this depositional system also included a northerly prograding topset sequence derived from the Brooks Range that extended much farther east across the present-day foothills province (Molenaar, 1988; Huffman and others, 1988). The northern limit of the Nanushuk Formation within this transverse component of the system is very poorly known due to limited exposure, complex structure, and the lack of publicly available subsurface data. The Torok Formation is exposed along the Dalton Highway at a locality named "Ice Cut" (Mull, 1989; Sheet A-1). During the 2007 field season, we visited an enigmatic exposure of loosely consolidated pebble conglomerate and sandstone exposed east-northeast of Ice Cut. This isolated outcrop includes locally channelized facies that are not typical of the deepwater Torok Formation in this area, most notably with respect to grain size. On the basis of reconnaissance mapping, we suspect these gravels lie in the footwall of a thrust fault and may represent a preserved remnant of the most northerly Nanushuk topset facies. Whether part of the Nanushuk, Torok, or conceivably the Tuluvak Formation, this exposure has significant implications for paleogeographic, depositional environment, and thrust reconstructions, particularly with respect to the type and extent of prospective reservoirs in this area. More work is needed to evaluate multiple hypotheses that might explain this anomalous exposure.

- Seabee Formation - In outcrop, the Seabee Formation has been fairly well defined in the Umiat area (for example, Houseknecht and Schenk, 2005; Mull and others, 2004). However, despite significant hydrocarbon discoveries in more distal facies, such as the informally named Bermuda interval (Alaska Oil and Gas Conservation Commission, 1998; 2001), limited work has been published correlating the unit basinward to the east (Decker, 2007). During 2001, 2002, and 2007, D. LePain and colleagues conducted detailed sedimentologic work on Turonian-Campanian strata discontinuously exposed along an unnamed tributary between the Sagavanirktok and Ivishak rivers. We informally refer to this drainage as "Sagashak Creek" (Sheet A-1). Despite significant stretches of cover, we have been able to construct a composite stratigraphy along this traverse encompassing approximately 2,450 m of Upper Cretaceous section (LePain and others, 2008a). On the basis of biostratigraphic control, correlation with available subsurface data, and facies considerations, the lower portion of this section is designated as Seabee Formation and is interpreted as proximal basin-floor(?)-base-of-slope deposits (LePain and others, 2008a, this volume; 2008c).

We also revisited an exposure on the Sagavanirktok River, just downstream from the confluence with the Lupine River (Sheet A-1; see also LePain and others, 2002). This sandstone and shale section was originally mapped as Nanushuk Formation by Mull (1989). However, recent revisions to Cretaceous stratigraphic nomenclature (Mull and others, 2003) restrict the Nanushuk Formation to seismic topset facies. Based on the sedimentary facies at this location, such as the prevalence of sediment gravity flows, we presently interpret the section as dominantly deepwater deposits, of either the Cenomanian upper Torok Formation or Turonian Seabee Formation, or perhaps spanning the contact between these two units. This interpretation is supported by the locally abundant bentonite, tuff, and apparent tuffaceous sandstone, all of which are characteristic of Upper Cretaceous units. We are awaiting biostratigraphic analyses to assist formation designation and more precise ties to the nearby Lupine well (Sheet A-1).

- Hue Shale-At the type locality along Hue Creek in ANWR, the Hue Shale includes condensed basinal mudstone, bentonites, and tuff ranging from Aptian to Campanian in age (Molenaar and others, 1987). However, coeval Brookian strata in the central Sagavanirktok Quadrangle are much thicker and include more proximal slope facies of the Seabee and Canning Formations (fig. 2; LePain and others, 2008a). The transitional nature of these facies relationships is well illustrated at one locality along Sagashak Creek (Sheet A-1), where a conspicuous section of organic-rich mudstone and tuffaceous strata are intercalated with more sandstone-rich slope and base-of-slope(?) facies (LePain and others, 2008a). We interpret this as a direct outcrop example of the commonly depicted intertonguing of more proximal units with the condensed Hue shale (fig. 2). This interval was also noteworthy for 
Overview of recent geologic field investigations, North Slope and Brooks Range foothills, Alaska

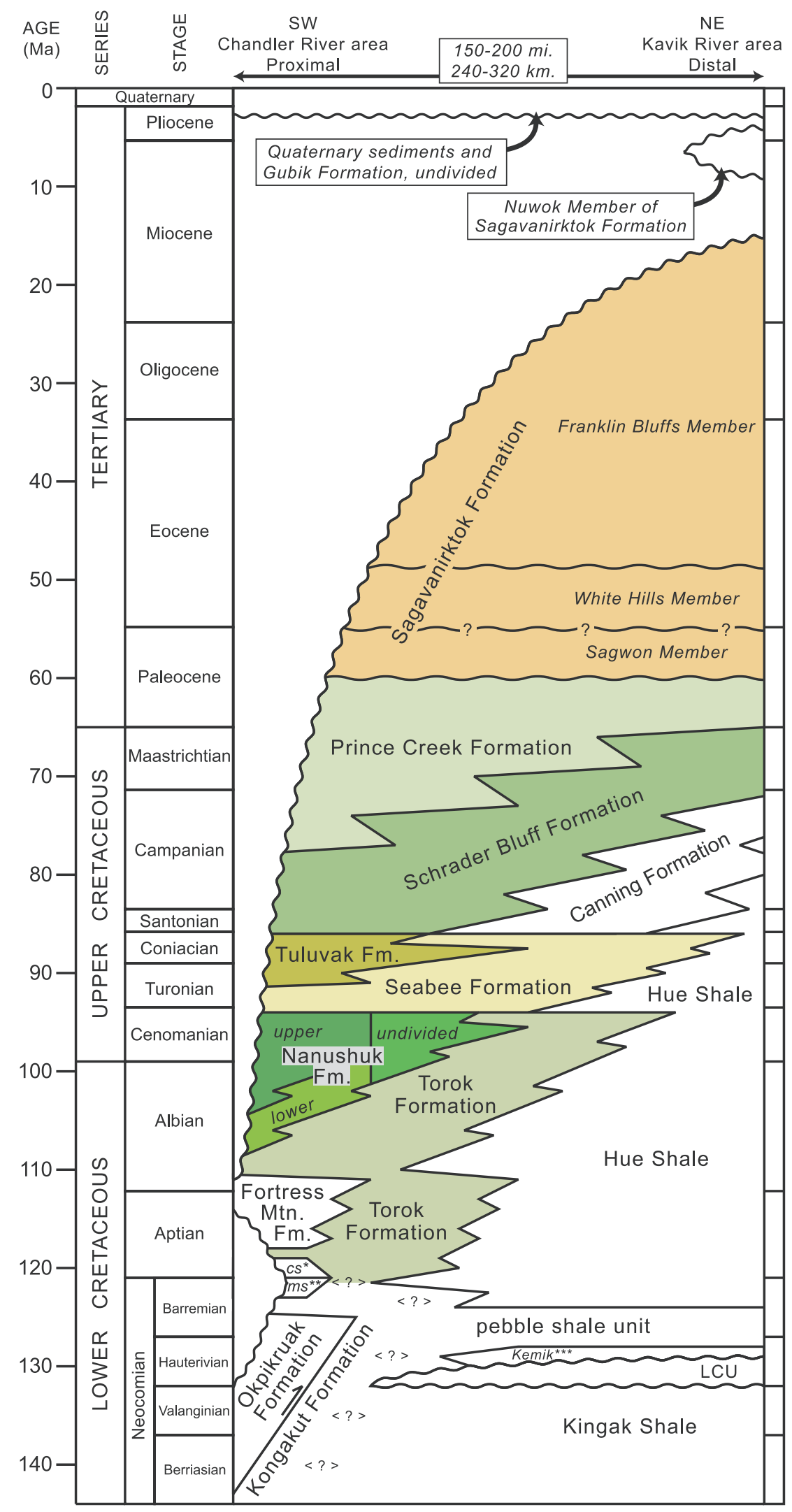

Figure 2. Chronostratigraphic column showing revised Cretaceous and Tertiary stratigraphic nomenclature of Mull and others (2003). cs* = cobblestone sandstone (informal unit) of Fortress Mountain Formation; ms** = manganiferous shale unit (informal). 
its strong hydrocarbon odor within shales and subjacent tuffaceous sandstone beds. The presence of this condensed zone is a potentially useful sequence stratigraphic marker and likely reflects sediment starvation, probably during transgressive and/or highstand conditions.

- Canning Formation - In outcrop, the term Canning Formation has historically been limited to the area east of about the Echooka River (Sheet A-1). Many Santonian-Campanian rocks in the central Sagavanirktok Quadrangle have been assigned instead to the Schrader Bluff Formation (Mull and others, 2003; C.G. Mull, unpublished mapping). However, recent well and seismic correlations indicate that shelfal strata of the lower and middle(?) Schrader Bluff Formation transition eastward into slope-clinoform deposits, and are thus more appropriately ascribed to the Canning Formation (for example, Houseknecht and Schenk, 2005; Decker, 2007). This is supported by biostratigraphic data and facies interpretations from Sagashak Creek area, where the Canning Formation is interpreted to overlie the Seabee Formation (LePain and others, 2008a, this volume; 2008c).

- Prince Creek and Schrader Bluff Formations - In 2007, we measured sections in the Schrader Bluff Formation at three localities. From west to east (proximal to distal) these sections were along the Toolik River, Sagashak Creek, and the Ivishak River (Sheet A-1). Detailed outcrop observations for the Sagashak section are reported in LePain and others (2008a), where the upward transition from upper slope Canning Formation into shelfal Schrader Bluff can be documented. An additional section measured along the Ivishak River expanded upon on earlier work by LePain in 1999, characterizing depositional environments ranging from distributary mouth bars and channels to stacked coarsening- and thickening-upward delta lobes. UAF graduate students Peter Flaig and Dolores van der Kolk collected detailed sedimentologic and stratigraphic data along the Toolik River where they documented intercalations of nonmarine coal-bearing facies of the Prince Creek Formation with shallow marine rocks of the Schrader Bluff Formation. Similar intertonguing relationships are interpreted in the subsurface (Decker, 2007). Subsequent work will seek to correlate these three exposures and consider their evolution in a sequence stratigraphic context.

\section{Southern Belt (proximal synorogenic foreland basin facies)}

Lower Cretaceous rocks in the Brooks Range foothills possess significant potential for large oil and gas accumulations, particularly shallow marine and turbidite facies of the Nanushuk-Torok system (for example, Houseknecht, 2003). Recent leasing activity, the potential opening of additional acreage in southern NPRA, and the move toward commercialization of North Slope gas all underscore the significance of this underexplored interval. During the 2007 field season, we continued a number of ongoing stratigraphic studies of Lower Cretaceous rocks in the foothills. The complex structural evolution of the foothills results in an increased exploration risk associated with maturation, migration, and trap formation. Therefore, the program also continued to evaluate the structural geology of the inner Brooks Range foothills (south of the Tuktu escarpment shown on Sheet A-1), documenting the geometry and style of deformation.

- Geologic Mapping in the Proximal Foreland Basin-In recent years, DGGS has conducted detailed (1:63,360-scale) geologic mapping across the central Brooks Range foothills, just north of the mountain front (for example, Peapples and others, 2007; Harris and others, 2002). Due to the complexity of the geology in this area, there remain significant unresolved questions that limit our ability arrive at a coherent structural/stratigraphic model for the evolution of the area. Our main focus in 2007 was along Peregrine Ridge, Section Creek, and Accomplishment Creek (Sheet A-1). This new detailed mapping data will be integrated with previous work to help develop a more regionally consistent framework.

- Burial History in the Proximal Foreland Basin-Recent geologic mapping, stratigraphic studies, thermal maturity data, and thermochronologic constraints have led us to conclude that a significant portion of the proximal foreland basin was deposited on top of the orogenic wedge-including the entire belt marked by the Early Cretaceous Fortress Mountain Formation. This observation suggests that an extensive Early Cretaceous wedge-top depozone (in the sense of DeCelles and Giles, 1996) existed in the southern Colville foreland basin. Syndepositional deformation within this zone may have promoted persistent structural highs that limited accommodation and thus burial (Wartes and Swenson, 2005). This model of foreland basin development partly explains anomalously low thermal maturity values observed by other studies along the Brooks Range foothills (for example, Cole and 
others, 1997; Mull and others, 2000). In order to test the wedge-top model, we collected a number of apatite fission track samples in 2007 from the Cobblestone Creek area. This region was selected in light of prior data that indicated abrupt northward increase in mid to Late Cretaceous stratigraphic burial (Mull and others, in review). Ultimately, future oil and gas exploration in the foothills will benefit from a basin model that can accurately predict burial history and maturation.

- Okpikruak Formation-Although the Berriasian-Valanginian Okpikruak Formation is unlikely to represent a viable reservoir interval, the unit does represent our only stratigraphic window into the early Neocomian record of foreland basin evolution. In 2007, we investigated several exposures in the Section Creek area (Sheet A-1). The northeastern Brooks Range has undergone significant Tertiary exhumation and, as a result, this is the only area where the Early Cretaceous orogenic wedge and overlying basal foreland basin strata are well exposed in long, coherent sections. Formation and age designations remain problematic in these rocks, although we discovered several new occurrences of the key Valanginian coquinoid limestone marker bed. We also anticipate having improved criteria following biostratigraphic analyses and further petrographic examinations.

- Phosphatic/Manganiferous Shale-This informal stratigraphic unit remains enigmatic, despite its unique lithofacies that includes a conspicuous reddish-brown, metallic-weathering sheen. The unit underlies the cobblestone sandstone member of the Fortress Mountain Formation and is best known from the Cobblestone Creek area (Sheet A-1; Mull and others, in review). The unusual shale may record the change in basin polarity (sediment dispersal direction) and the onset of Brookian deposition in this area, north of the advancing allochthons and Okpikruak flysch deposits. On the basis of stratigraphic position and limited biostratigraphic control, we speculate that the unit is correlative with the Kongakut Formation and Barremian Pebble Shale unit to the north (fig. 2). To allow better evaluation of these hypotheses, detailed sedimentologic data were collected in 2007 from the best-exposed section along Cobblestone Creek. The interpreted correlation with the Pebble Shale was supported by the first reported discovery of numerous outsized granules, pebbles, and cobbles floating within the shale. Further characterization of this interval awaits analytical data from newly collected petrographic, geochemical, and micropaleontology samples.

- Cobblestone Sandstone-The Aptian(?) Cobblestone Sandstone member of the Fortress Mountain Formation locally records the earliest sandstone deposition in the proximal foreland basin (Mull and others, in review). However, this distinctive lighter-weathering graywacke has not been recognized west of the Kanayut River (Harris and others, 2004). In 2007, we visited several key exposures of amalgamated sediment gravity flow deposits to collect additional sedimentologic and stratigraphic information. Most notably, an exposure along the Nanushuk River (Sheet A-1) included an unusual association of facies including poorly sorted conglomerate and breccia. The texturally immature facies, and clast composition were indistinguishable from a syntectonic unit we termed "Kfmv" in recent mapping farther west in the Siksikpuk River area (Peapples and others, 2007). This observation supports our earlier speculation that the two units are correlative and likely represent gradational facies equivalents of one another. If additional data further substantiate this interpretation, it will allow us to construct a more coherent model for basin evolution in this wedge-top environment (for example, Wartes and Swenson, 2005).

- Fortress Mountain Formation-DGGS has supported several years of stratigraphic research on the Fortress Mountain Formation, resulting in refined depositional environment interpretations and stratigraphic correlations (at the local to sub-regional scales). An example of this work from the Atigun syncline area is included in this volume (fig. 1; Sheet A-1; Wartes, 2008a, this volume). In collaboration with the USGS, another publication on the stratigraphy of the Fortress Mountain in the Siksikpuk River area should be published imminently (Houseknecht and others, 2007).

We conducted additional stratigraphic reconnaissance and sampling in 2007 near Toolik Lake (Sheet A-1). These are the northernmost exposures of the Fortress Mountain Formation in this area and have the potential to clarify the basinward evolution of this part of the clastic wedge. In particular, it remains unclear how this part of the upper(?) Fortress Mountain Formation relates to nearby exposures of the Nanushuk Formation. This important stratigraphic question is further addressed in another chapter in this volume through a comparison of detrital zircon ages within the two units (fig. 1; Wartes, 2008b, this volume). 
- Nanushuk Formation-DGGS has led a multi-year, outcrop-based investigation of the sequence stratigraphy and reservoir potential of the Nanushuk Formation. This work has resulted in numerous detailed measured sections throughout the central Brooks Range foothills and greatly improved our understanding of this depositional system. A major publication summarizing a substantial part of our Nanushuk investigations is now complete (LePain and others, 2008d) and will be released shortly after the publication of this volume. In addition to sequence stratigraphic analyses, this milestone synthesis includes a comprehensive summary of Nanushuk lithofacies, facies associations, ichnology, micropaleontology, and regional depositional environments. During 2007, we conducted limited follow-up work on the Nanushuk at Slope Mountain (Sheet A-1). Our main focus was revisiting a significant intraformational sequence boundary and better documenting the overlying facies association and erosional relief on the unconformity (LePain and others, 2008d).

We have also extended our Nanushuk studies westward in recent years, examining well exposed sections along the Colville River (fig. 1). Based on facies analysis, these exposures appear to reflect the development of river-dominated deltas, contrasting with the more pervasive wave influence observed to the east (for example, LePain and others, 2006; Huffman and others, 1988). These measured sections and preliminary correlations with publicly available seismic data are summarized in LePain and others (2008b) in this volume.

During our work along the Colville River, we sampled a gas seep in the Nanushuk Formation near the mouth of Aupuk Creek (fig. 1). Based on new geochemical data from this seep, we were able to demonstrate the gas is thermogenic in origin and likely represents condensate- or oil-associated gas generated at oil-window maturity. These results are included in Decker and Wartes (2008, this volume).

\section{SUMMARY}

The above discussion is intended only as a preliminary progress report that provides a brief introduction to recent field investigations, particularly during 2007. This volume is an effort to execute a rapid turn-around of many of our observations and preliminary interpretations, rather than delay distribution of data until all results are in. Additional work will be published as analytical data become available and as stratigraphic and structural interpretations continue to mature.

\section{ACKNOWLEDGMENTS}

This review incorporated the work of the entire geoscience team associated with the DNR North Slope Program (listed under project staff in the text). C.G. Mull deserves special mention-much of our work would not be possible without the geological framework he established during decades of field work in northern Alaska. D. LePain provided a helpful review of this manuscript. Finally, J. Robinson and P. Davis are thanked for their tireless editorial work in preparing this volume for publication.

Fieldwork was supported through a combination of state budget sources and substantial contributions from companies and individuals involved in the Alaska oil and gas industry. Recent sponsors included Anadarko Petroleum Corp., BG Alaska, Chevron, ConocoPhillips Alaska, Inc., ENI, Petro-Canada, Pioneer Natural Resources, Repsol YPF Exploration and Production Co., Shell International Exploration and Production Co., and Talisman Energy, Inc.

\section{REFERENCES}

Alaska Oil and Gas Conservation Commission, 1998, Conservation Order No. 430 (Tarn Pool Rules): Anchorage, AK, 7 p.

2001, Conservation Order No. 456 (Meltwater Pool Rules): Anchorage, AK, 9 p.

Cole, F.E., Bird, K.J., Toro, J., Roure, F., O’Sullivan, P.B., Pawlewicz, M.J., and Howell, D.G., 1997, An integrated model for the frontal Brooks Range and Colville Basin $250 \mathrm{~km}$ west of the Trans-Alaska Crustal Transect: Journal of Geophysical Research, v. 102, p. 20,685-20,708.

DeCelles, P.G., and Giles, K.A., 1996, Foreland basin systems: Basin Research, v. 8, p. 105-123. 
Decker, P.L., 2007, Brookian sequence stratigraphic correlations, Umiat Field to Milne Point Field, west-central North Slope, Alaska: Alaska Division of Geological \& Geophysical Surveys Preliminary Interpretive Report 2007-2, 19 p., 1 sheet.

Decker, P.L., and Wartes, M.A., 2008, Geochemistry of the Aupuk gas seep along the Colville River-Evidence for a thermogenic origin, in Wartes, M.A., and Decker, P.L., eds., Preliminary results of recent geologic field investigations in the Brooks Range foothills and North Slope, Alaska: Alaska Division of Geological \& Geophysical Surveys Preliminary Interpretive Report 2008-1, p. 47-53.

Decker, P.L., Wartes, M.A., Wallace, W.K., Houseknecht, David, Schenk, Christopher, Gillis, R.J., and Mongrain, Jacob, 2008, Stratigraphic and structural investigations in the Ivishak River and Gilead Creek areas: Progress during 2007, in Wartes, M.A., and Decker, P.L., eds, Preliminary results of recent geologic field investigations in the Brooks Range foothills and North Slope, Alaska: Alaska Division of Geological \& Geophysical Surveys Preliminary Interpretive Report 2008-1, p. 55-83, 1 sheet, measured section.

Harris, E.E., Mull, C.G., Montayne, S., and Reifenstuhl, R.R., 2002, Geologic map of the Dalton Highway (Atigun Gorge to Slope Mountain) area, southern Arctic Foothills, Alaska: Alaska Division of Geological \& Geophysical Surveys Preliminary Interpretive Report 2002-2, 1 sheet, scale 1:63,360.

Harris, E.E., Mull, C.G., Peapples, P.R., LePain, D.L., and Burns, P.A., 2004, New detailed (1:63,360-scale) mapping of the Brooks Range northern foothills and rangefront, Kanayut River area, Alaska: AAPG Abstracts with Programs, v. 13, p. 58-59.

Houseknecht, D.W., 2003, Brookian stratigraphic plays in the National Petroleum Reserve-Alaska (NPRA): U.S. Geological Survey Open-File Report 2003-039, 19 p.

Houseknecht, D.W, and Schenk, C.J., 2005, Sedimentology and sequence stratigraphy of the Cretaceous Nanushuk, Seabee, and Tuluvak Formations exposed on Umiat Mountain, north-central Alaska, in Haeussler, P., and Galloway, J.P., eds., Studies by the U.S. Geological Survey in Alaska, 2004, U.S. Geological Survey Professional Paper 1709B, 18 p., 1 plate.

Houseknecht, D.W., Schenk, C.J., and Wartes, M.A., 2007, Sedimentology and sequence stratigraphy of the Lower Cretaceous Fortress Mountain and Torok Formations exposed along the Siksikpuk River, north-central Alaska, in Haeussler, Peter J., and Galloway, John P., eds., Studies by the U.S. Geological Survey in Alaska, 2006: U.S. Geological Survey Professional Paper 1739-D, 27 p., 1 plate.

Huffman, A.C., Jr., Ahlbrandt, T.S., and Bartsch-Winkler, Susan, 1988, Sedimentology of the Nanushuk Group, North Slope, in Gryc, George, ed., Geology and exploration of the National Petroleum Reserve in Alaska, 1974 to 1982: U.S. Geological Survey Professional Paper 1399, p. 281-298.

LePain, D.L., Decker, P.L., and Wartes, M.A., 2008a, Turonian-Campanian strata east of the Trans-Alaska Pipeline corridor, North Slope foothills, Alaska: Progress during the 2001-02 and 2007 field seasons, in Wartes, M.A., and Decker, P.L., eds, Preliminary results of recent geologic field investigations in the Brooks Range foothills and North Slope, Alaska: Alaska Division of Geological \& Geophysical Surveys Preliminary Interpretive Report 2008-1, p. 85-134.

LePain, D.L., Decker, P.L., and Wartes, M.A., 2008b, Measured sections and preliminary interpretations of the Nanushuk Formation exposed along the Colville River near the confluences with the Awuna and Killik rivers, in Wartes, M.A., and Decker, P.L., eds, Preliminary results of recent geologic field investigations in the Brooks Range foothills and North Slope, Alaska: Alaska Division of Geological \& Geophysical Surveys Preliminary Interpretive Report 2008-1, p. 41-45, 4 sheets.

LePain, D.L., Decker, P.L., Wartes, M.A., Gillis, R.J., Mongrain, J.R., Kirkham, R., and Shellenbaum, D.P., 2008c, Sedimentology and Stratigraphy of Upper Cretaceous strata in the Sagavanirktok River area, east-central North Slope, Alaska: AAPG annual meeting abstracts, in press.

LePain, D.L., McCarthy, P.J., and Kirkham, R. 2006, Variations in facies stacking patterns in storm-influenced delta front and shoreface successions, Nanushuk Formation, central North Slope, Alaska [abs.]: Geological Society of America Abstracts with Program, v. 38, no. 5.

2008d, Sedimentology and sequence stratigraphy of the Nanushuk Formation in the central Brooks Range foothills, northern Alaska: Alaska Division of Geological \& Geophysical Surveys Report of Investigation, in press.

LePain, D.L., Kirkham, R., and McCarthy, P.J., 2002, Shoreline to basin transition (?) in Albian-Cenomanian strata east of the Sagavanirktok River, Brooks Range foothills, Alaska [abs.]: AAPG Pacific Section/SPE Regional Conference, Program and Abstracts, p. 87. 
Molenaar, C.M., Bird, K.J., and Collett, T.S., 1986, Regional correlation sections across the North Slope of Alaska: U.S. Geological Survey Miscellaneous Field Studies 1907, 1 sheet.

Molenaar, C.M., Bird, K.J., and Kirk, A.R., 1987, Cretaceous and Tertiary stratigraphy of northeastern Alaska, in Tailleur, I.L., and Weimer, P., eds., Alaskan North Slope Geology: Pacific Section, Society of Economic Paleontologists and Mineralogists and Alaska Geological Society, Book 50, v. 1, p. 513-528.

Molenaar, C.M., 1988, Depositional history and seismic stratigraphy of Lower Cretaceous rock in the National Petroleum Reserve in Alaska and adjacent areas, in Gryc, G., editor, Geology and exploration of the National Petroleum Reserve in Alaska, 1974-1982: U.S. Geological Survey Professional Paper 1399, p. 593-621.

Mull, C.G., 1989, Road log from Chandalar Shelf (Mile 237.1) to Prudhoe Bay (Mile 414), in Mull, C.G., and Adams, K.E., eds., Dalton Highway, Yukon River to Prudhoe Bay, Alaska: Alaska Division of Geological \& Geophysical Surveys Guidebook 7, v. 1, p. 101-131.

Mull, C.G., Harris, E.E., Reifenstuhl, R.R., and Moore, T.E., 2000, Geologic map of the Coke Basin-Kukpowruk River area, DeLong Mountains D-2 and D-3 quadrangles, northwestern Alaska: Alaska Division of Geological and Geophysical Surveys Report of Investigations 2000-2, 1 sheet, scale 1:63,360.

Mull, C.G, Houseknecht, D.W., and Bird, K.J., 2003, Revised Cretaceous and Tertiary Stratigraphic Nomenclature in the Colville Basin, Northern Alaska: U.S. Geological Survey Professional Paper 1673, 51 p.

Mull, C.G., Houseknecht, D.W., Pessel, G.H., and Garrity, C.P., 2004, Geologic map of the Umiat Quadrangle, Alaska: U.S. Geological Survey Scientific Investigations Map 2817-A, 1 sheet.

Mull, C.G., Harris, E.E., and Peapples, P.R., in review, Geologic map of the Cobblestone Creek-May Creek area, east-central Brooks Range foothills, Alaska: Alaska Division of Geological \& Geophysical Surveys Preliminary Interpretive Report, 1 sheet, scale 1:63,360, and booklet.

Peapples, P.R., Wallace, W.K., Wartes, M.A., Swenson, R.F., Mull, C.G., Dumoulin, J.A., Harris, E.E., Finzel, E.S., Reifenstuhl, R.R., and Loveland, A.M., 2007, Geologic map of the Siksikpuk River area, Chandler Lake Quadrangle, Alaska: Alaska Division of Geological \& Geophysical Surveys Preliminary Interpretive Report 2007-1, 1 sheet.

Pessel, G.H., Robinson, M.S., Clough, J.G., Imm, T.A., Reifenstuhl, R.R., Ryherd, T.J., Myers, M.D., and Mull, C.G., 1990, Preliminary geologic map of the Gilead Creek area, Sagavanirktok A-2 Quadrangle, Arctic Foothills, Alaska: Alaska Division of Geological \& Geophysical Surveys Public-Data File 90-18, 7 p., 1 sheet.

Reifenstuhl, R.R., 1991, Gilead sandstone, northeastern Brooks Range, Alaska; An Albian to Cenomanian marine clastic succession, in Reger, R.D., ed., Short Notes on Alaskan Geology 1991: Alaska Division of Geological \& Geophysical Surveys Professional Report 111, p. 69-76.

Wartes, M.A., 2008a, Measured section and facies analysis of the Lower Cretaceous Fortress Mountain Formation, Atigun Syncline, northern Alaska, in Wartes, M.A., and Decker, P.L., eds, Preliminary results of recent geologic field investigations in the Brooks Range foothills and North Slope, Alaska: Alaska Division of Geological \& Geophysical Surveys Preliminary Interpretive Report 2008-1, p. 11-24, 1 sheet.

Wartes, M.A., 2008b, Evaluation of stratigraphic continuity between the Fortress Mountain and Nanushuk Formations in the Central Brooks Range foothills-Are they partly correlative?, in Wartes, M.A., and Decker, P.L., eds, Preliminary results of recent geologic field investigations in the Brooks Range foothills and North Slope, Alaska: Alaska Division of Geological \& Geophysical Surveys Preliminary Interpretive Report 2008-1, p. 25-39.

Wartes, M.A., and Swenson, R.F., 2005, New constraints on the structural and stratigraphic development of the proximal Colville foreland basin; Implications for burial history and oil and gas exploration in the central Brooks Range foothills, northern Alaska, in GSA, Cordilleran Section, 101st annual meeting: AAPG, Pacific Section, 80th annual meeting, Abstracts with Programs, v. 37, no. 4, p. 92-93. 


\title{
MEASURED SECTION AND FACIES ANALYSIS OF THE LOWER CRETACEOUS FORTRESS MOUNTAIN FORMATION, ATIGUN SYNCLINE, NORTHERN ALASKA
}

\author{
by \\ Marwan A. Wartes ${ }^{1}$
}

\section{INTRODUCTION}

This study examines a thick $(>1,600 \mathrm{~m})$ section of the Lower Cretaceous Fortress Mountain Formation exposed at Atigun syncline in the foothills of the northern Brooks Range (figs. 1 and 2). To date, this interval has proven difficult to interpret (see introductory comments in Crowder, 1989); similar to other conglomerate-rich successions, limited faunal evidence and generally non-unique depositional processes hamper attempts at environmental reconstruction (e.g. Nemec and others, 1984). This ambiguity is reflected in widely varying earlier interpretations ranging from deep marine fan, to slope, to fan-delta, and even fluvial depositional settings (Crowder, 1987; 1989; Goff, 1990; Ryherd, 1990; Schenk and Bird, 1992). The purpose of this paper is to document the lithofacies and provide a composite, detailed measured section of the coarser, upper part of the formation exposed on the west face of Atigun syncline (Sheet B-1; fig. 2). This brief contribution will be followed by a more exhaustive manuscript that provides detailed lithofacies descriptions and interpretations, as well as discussion of provenance, reservoir quality, stratal stacking patterns, and fan delta classification (Wartes and Carroll, in prep.).

\section{GEOLOGIC SETTING}

The Early Cretaceous Fortress Mountain Formation (fig. 2) was deposited in the proximal reaches of the Colville foreland basin (Bird and Molenaar, 1992; Cole and others, 1997). The base is almost never exposed, but, on the basis of map relations, is usually inferred to be an angular unconformity (for example, Mull, 1985). The formation is poorly dated and plagued by limited, often long-ranging fauna. Most fossils suggest an early Albian

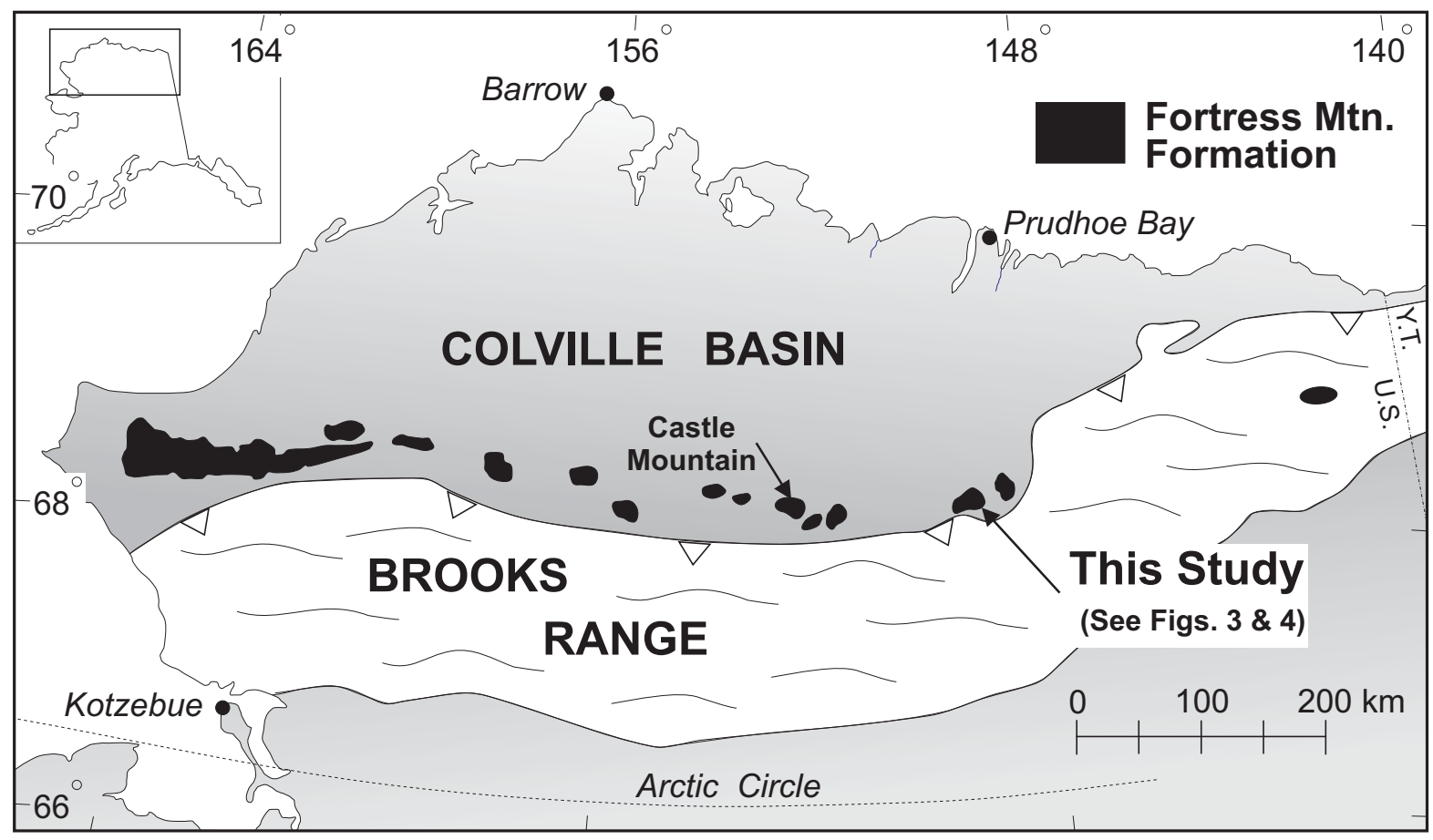

Figure 1. Distribution of principal Fortress Mountain Formation outcrops (modified from Crowder, 1987). 


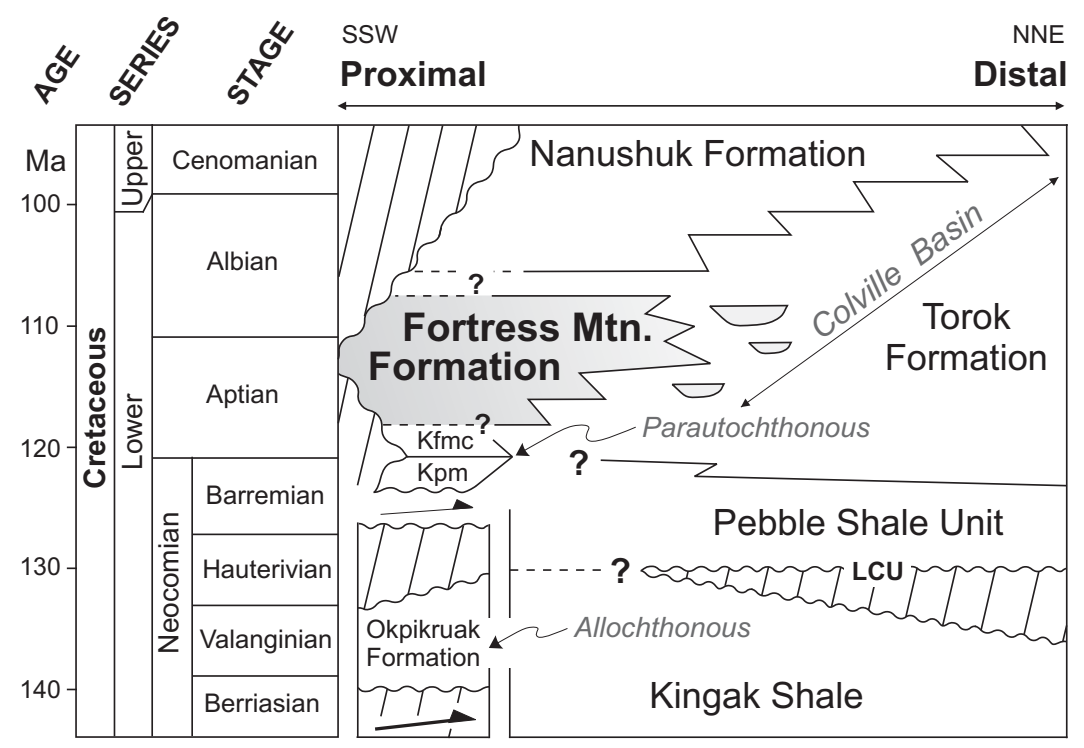

Figure 2. Chronostratigraphy of the Colville Basin, highlighting the stratigraphic and tectonic relationships between Lower Cretaceous units $(\mathrm{K} f \mathrm{mc}=$ cobblestone sandstone member of the Fortress Mountain Formation; Kpm=phosphatic-manganiferous unit; both adopted from Mull and others, 2003).

age (Molenaar and others, 1988). However, select micropaleontologic data indicate rocks as old as Hauterivian to Barremian may be present in the southern Colville Basin (fig. 2; Mickey and Haga, 1987; Mull, C.G., oral commun., 2004; Wartes, unpublished data). The type locality of the Fortress Mountain Formation has been defined at Castle Mountain (fig. 1) where an approximate thickness of 3,000 m was calculated for the type section (Patton and Tailleur, 1964).

The Fortress Mountain Formation often crops out in isolated, synclinal exposures defined by mesa-forming resistant conglomerate intervals (fig. 1). Finer-grained sandstone and siltstone facies are typically poorly exposed or covered by tundra. Rapid facies changes, especially the northward diminution of conglomerate beds, is characteristic of this formation (for example, Molenaar and others, 1988). Regionally, the Fortress Mountain Formation has been interpreted to reflect a wide array of depositional environments from basin plain to alluvial fan settings (Hunter and Fox, 1976; Crowder, 1987; Molenaar and others, 1988). The Fortress Mountain Formation grades northward into the Torok Formation, an interval characterized by poorly exposed finer-grained facies associations (Mull, 1985; fig. 2). The distinction between the Fortress Mountain and Torok Formations is somewhat arbitrary; most workers have restricted the Fortress Mountain Formation to surface exposures in the foothills of the Brooks Range (Molenaar and others, 1988).

This study focused on exposures of the Fortress Mountain Formation that crop out in Atigun syncline, a prominent open fold in the northernmost Brooks Range mountain front (figs. 3-5). Unlike most of the Brooks Range, these outcrops, lying just east of the Dalton Highway, are accessible by road (fig. 3; Mull and Harris, 1989). Previous investigations of this succession have established the general framework and basic lithofacies present (Crowder, 1987; 1989; Goff, 1990; Ryherd, 1990; Schenk and Bird, 1992; Wartes and Carroll, 2002). However, partial cover, complex facies relationships, and a lack of detailed sedimentologic analysis have resulted in considerable disagreement regarding interpreted depositional environments.

Cross sections typically depict Atigun syncline as asymmetric, with slightly steeper dips along the southern limb (for example, Mull and others, 1997). However, recent 1:63,360-scale mapping recognized more structural complexity, including local vertical dips along the north limb and compound folding in the eastern end of the syncline (Harris and others, 2002). Nevertheless, the syncline is only mildly deformed when compared with the underlying allochthonous rocks, composed in part of highly strained tectonic mélange mixed with sheared Okpikruak Formation (fig. 3; Mull and others, 1997). The basal contact of the Fortress Mountain Formation is a high-angle fault, and may have accommodated some south-vergent back-thrusting (fig. 3; Mull and others, 1997). Most authors agree that this fault is probably co-located on an angular unconformity that developed prior to deposition of the Fortress Mountain Formation (for example, Crowder, 1989).

The Fortress Mountain Formation at Atigun syncline has been informally subdivided into mappable scale lower and upper portions (figs. 3 and 6; Mull and others 1997; Harris and others, 2002). The lower Fortress Mountain Formation consists of a monotonous succession of concretionary siltstone and thin beds of very fine sandstone (figs. 6 and 7). This lower interval has also been mapped as Okpikruak Formation (Brosgé and others, 1979) and Torok Formation (Mull and Harris, 1989; Schenk and Bird, 1992). The interval exhibits locally variable deforma- 
tion, including tight folding, which may be syndepositional or reflect strain localization within this incompetent unit. The total thickness of this interval is not well constrained and complicated by an ambiguous basal contact, internal deformation, and inaccessible cliffs (fig. 7). However, this study ascribed a minimum of $450 \mathrm{~m}$ of section to the lower Fortress Mountain Formation, recognizing that a significantly thicker section is probable (fig. 6).

The upper Fortress Mountain Formation is informally defined here by the onset of thick conglomerate beds (figs. 6 and 7). This portion of the formation was studied in much greater detail in this study, a focus that is reflected by the emphasis on sandstone and conglomerate lithofacies in the subsequent facies analysis (Wartes and Carroll, 2002). During this study, approximately 1,135 m of upper Fortress Mountain Formation were measured on the west face of the syncline (figs. 5 and 6; Sheet B-1). The upper boundary of the formation is not preserved, obscuring the true depositional thickness of the unit. Previous reconnaissance studies have estimated a total formation thickness of 2,000 m (Crowder, 1987), 2,500 m (Mull and others, 1997), and 3,000 m (Crowder, 1989). This variability likely reflects different placements of the basal contact within Atigun Gorge. This study estimated approximately $1,650 \mathrm{~m}$ and is intended as a well-constrained minimum thickness for the Fortress Mountain Formation at Atigun syncline (fig. 6; Sheet B-1).

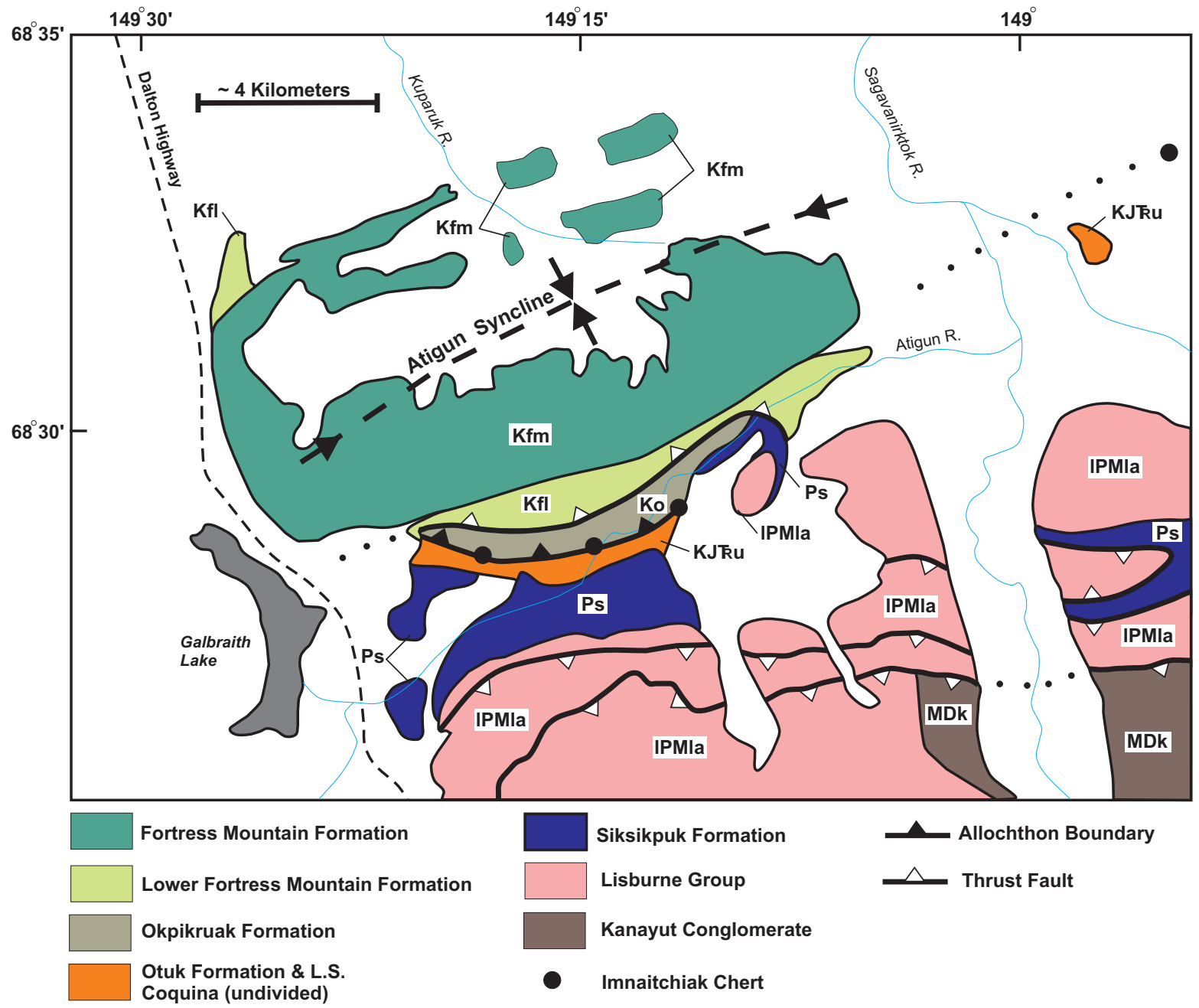

Figure 3. Simplified geologic map of the Atigun syncline area (modified from Mull and others, 1997). See Harris and others (2002) for more detailed 1:63,360-scale mapping. 


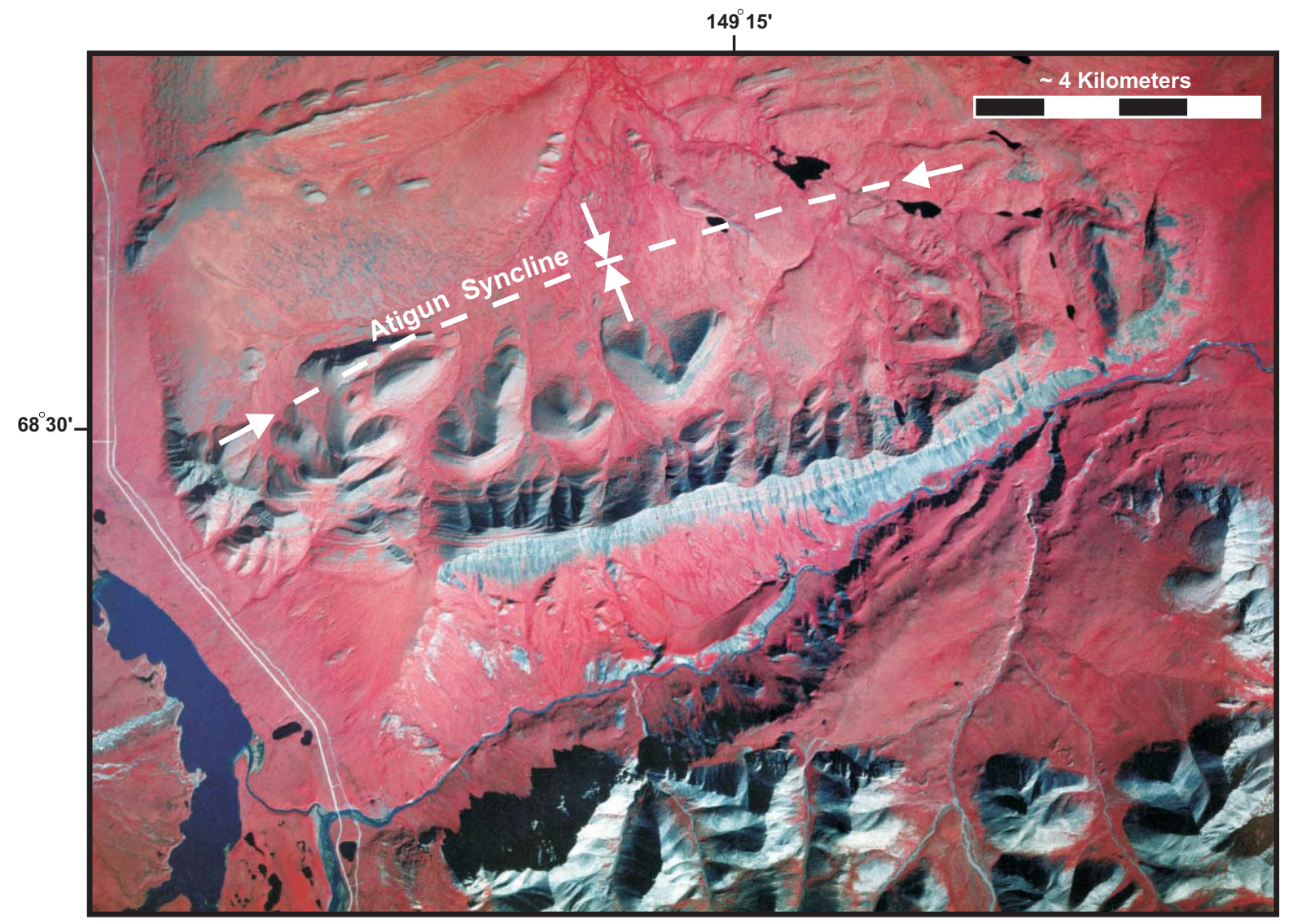

Figure 4. Air photo of the Atigun syncline area. Note the northward decrease in resistant outcrops, interpreted to reflect rapid basinward (northerly) fining of the Fortress Mountain Formation.

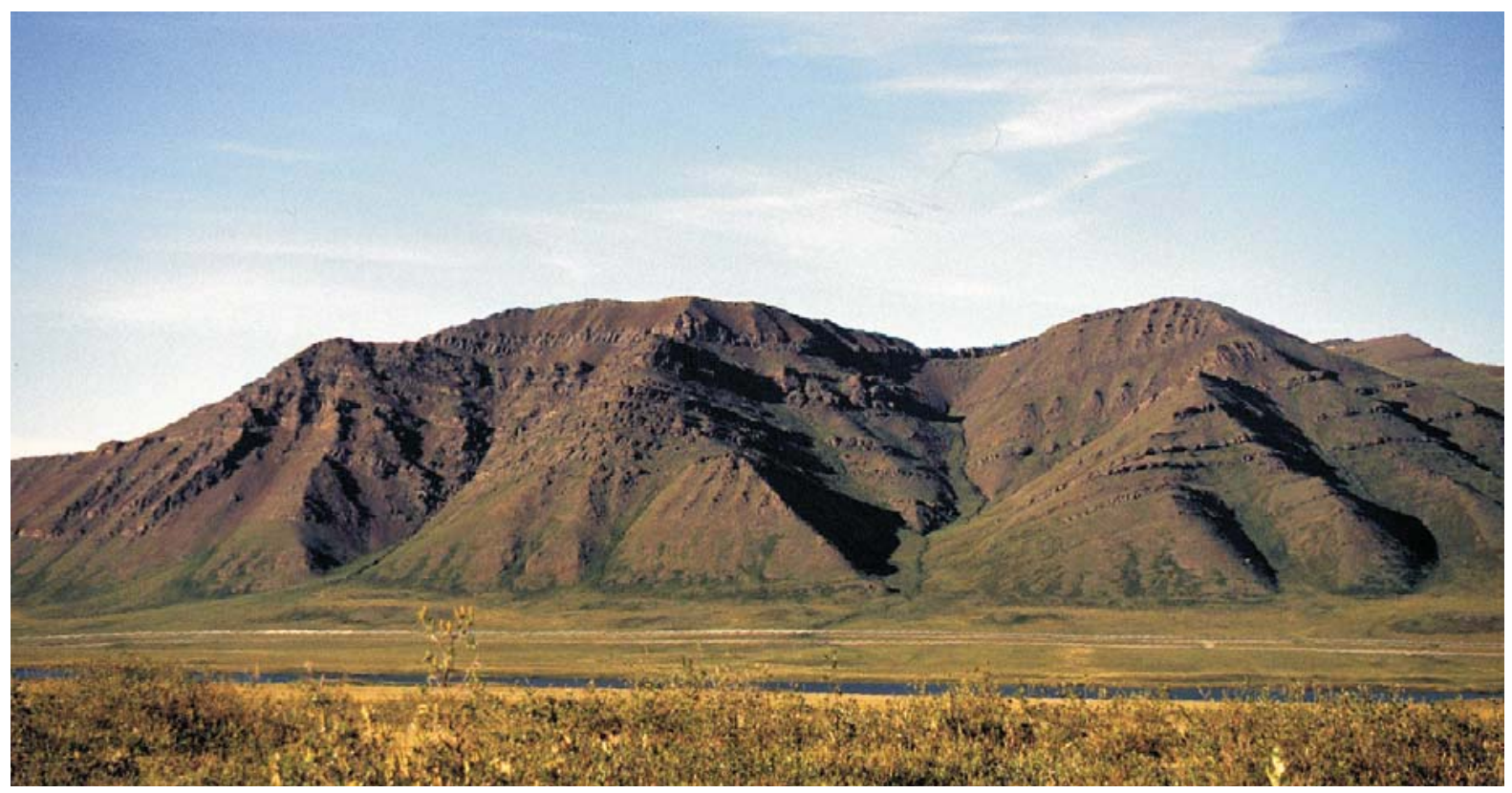

Figure 5. View of the west face of Atigun syncline where the composite section was measured (see Sheet B-1). 


\section{SEDIMENTOLOGY AND FACIES ANALYSIS}

Fan deltas form where alluvial fans prograde directly into a standing body of water (Nemec and Steel, 1988). The following section is organized around four depositional settings commonly recognized in modern and ancient fan deltas (for example, Rasmussen, 2000) and addressed below from proximal to distal: (1) alluvial, (2) delta front, (3) delta slope, and (4) prodelta. These settings interfinger laterally and often exhibit gradational contacts in vertical sections. Nevertheless, lithofacies (table 1 ) are grouped into nine unique, commonly occurring associations (table 2), which as a group suggest an environment and depositional process and provide insight into the evolution of the larger depositional system. In relating the lithofacies and facies associations in tables 1 and 2, care is taken to present observations and descriptions separate from interpretation.

Figure 6. Generalized stratigraphic column at Atigun syncline.

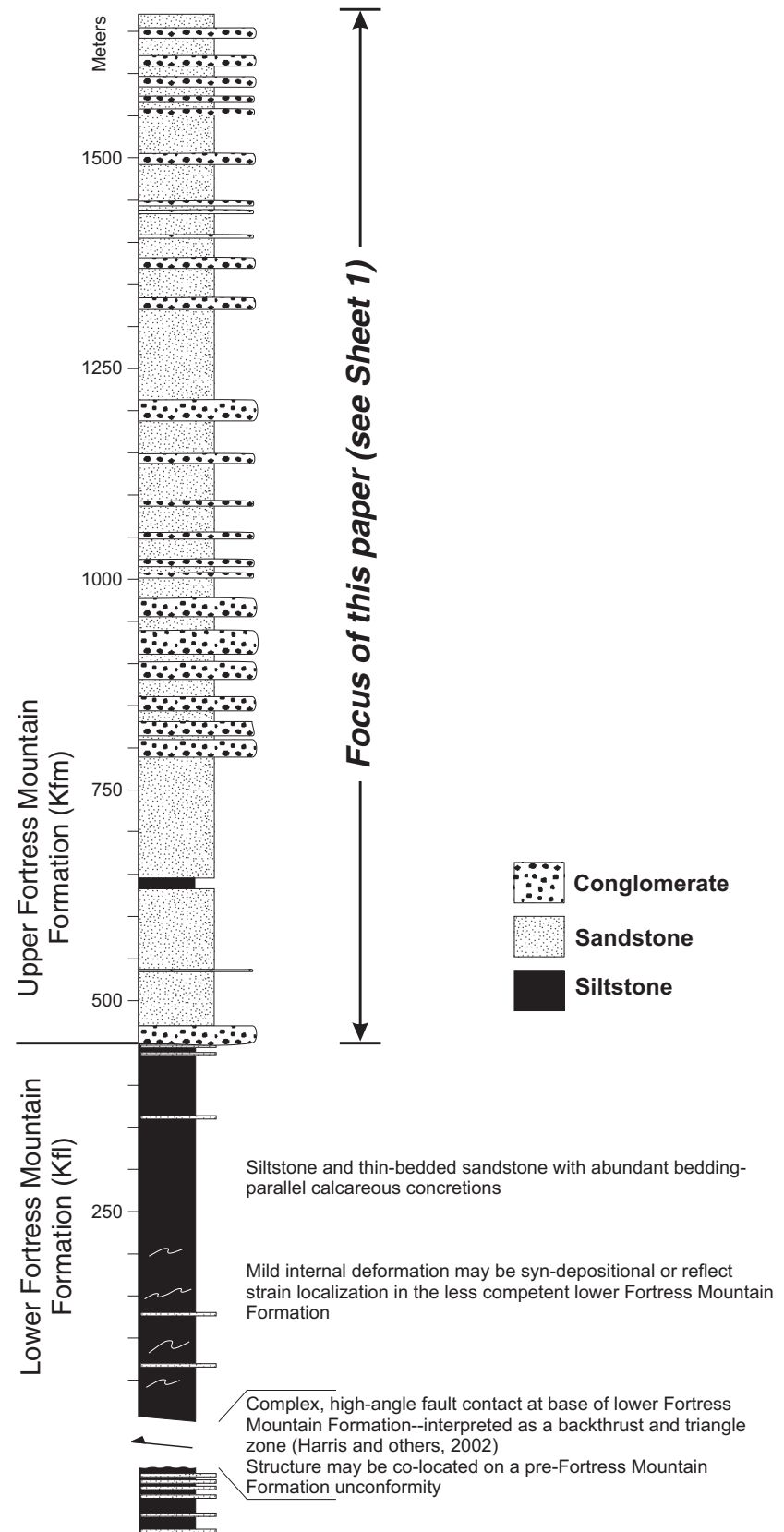

Sequence of thin-bedded turbidites--often intensely deformed into "broken formation" and structural melange (Mull and others, 1997) 


\section{Alluvial deposits}

Alluvial deposits include all recognized nonmarine environments and are collectively grouped under a single braided fluvial/alluvial fan facies association (table 2). The recognition of terminal alluvial deposits as distinct facies associations (different from genetically related subaqueous mouth bars) is an important, albeit often difficult, exercise when interpreting fan delta systems (Kleinspehn and others, 1984; Horton and Schmitt, 1996). The alluvial deposits at Atigun syncline include evidence for both confined and unconfined nonmarine depositional systems (table 1). Building on criteria established by other workers, channelized braided fluvial complexes are suggested by moderately sorted barforms and lenticular bedding (Clifton, 1973; Nemec and Steel, 1984; Hart and Plint, 2003). Paleocurrent evidence from imbricated clasts is consistent with northward progradation. Laterally persistent, unconfined alluvial fan facies are more difficult to definitively assign as nonmarine. In some cases, the designation is inferred from stratigraphic position at the top of thick upward-coarsening (and shoaling) conglomerate sequences.

Given the overall thickness of this conglomerate-rich succession, there is surprisingly sparse, unambiguous evidence for nonmarine sedimentation. An isolated coal bed was reported by Crowder (1989); however, the limited exposure does not allow one to reject a hypothesis that the bed represents a rafted allochthonous peat mat. The abundance of woody and carbonaceous debris indicates significant upstream vegetation was incorporated, probably from cannibalization of the delta plain. Although no paleosols or related diagnostic facies were observed in this study, it remains possible that delta plain deposits (such as overbank fine-grained facies) exist under

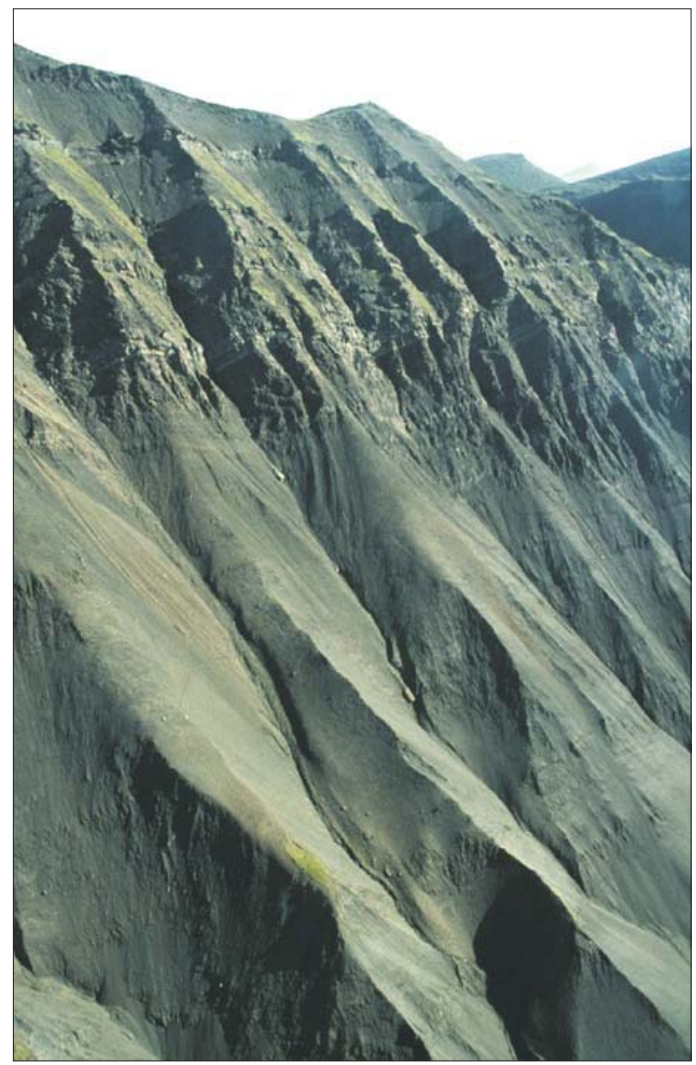

Figure 7. View of steep cliff exposures of the finegrained lower Fortress Mountain Formation in Atigun Gorge. some covered intervals.

Table 1. Description and interpretation of lithofacies (codes modified and extended from Miall [1978])

\begin{tabular}{|c|c|c|c|}
\hline Lithofacies & Code & Description & Interpretation \\
\hline & \multicolumn{3}{|c|}{ Conglomerate } \\
\hline $\begin{array}{l}\text { Massive clast- } \\
\text { supported } \\
\text { conglomerate }\end{array}$ & $\mathrm{Gm}$ & $\begin{array}{l}\text { Poorly sorted, massive to weakly stratified, } \\
\text { ungraded granule-pebble conglomerate; } \\
\text { often amalgamated; rare weak imbrication }\end{array}$ & $\begin{array}{l}\text { Cohesionless debris flow, } \\
\text { hyperconcentrated flow, and gravelly high- } \\
\text { density turbidity current }\end{array}$ \\
\hline $\begin{array}{l}\text { Graded clast- } \\
\text { supported } \\
\text { conglomerate }\end{array}$ & Gng & $\begin{array}{l}\text { Poorly sorted, granule-pebble conglomerate; } \\
\text { commonly grading into pebbly sandstone }\end{array}$ & $\begin{array}{l}\text { Rapid deposition of waning high- } \\
\text { concentration flow (floods) and gravelly } \\
\text { high-density turbidity current }\end{array}$ \\
\hline $\begin{array}{l}\text { Inversely graded } \\
\text { conglomerate }\end{array}$ & Gin & $\begin{array}{l}\text { Poorly sorted, granule-pebble conglomerate; } \\
\text { weak inverse grading in upper part of beds; } \\
\text { irregular bed tops with protruding clasts }\end{array}$ & Rapid freezing of cohesive debris flow \\
\hline $\begin{array}{l}\text { Matrix- } \\
\text { supported } \\
\text { conglomerate }\end{array}$ & Gmm & $\begin{array}{l}\text { Chaotic to massive, poorly sorted, matrix- } \\
\text { supported pebble to boulder conglomerate; } \\
\text { often subangular clasts }\end{array}$ & $\begin{array}{l}\text { Subaerial debris flow and } \\
\text { hyperconcentrated flow }\end{array}$ \\
\hline $\begin{array}{l}\text { Open-framework } \\
\text { conglomerate }\end{array}$ & Gof & $\begin{array}{l}\text { Well sorted, open-framework, granule-- } \\
\text { pebble conglomerate; bi-directional } \\
\text { imbrication of disk-shaped clasts }\end{array}$ & $\begin{array}{l}\text { Strong reworking and winnowing during } \\
\text { wave run-up; bedload deposition of } \\
\text { turbulent high-energy flow }\end{array}$ \\
\hline $\begin{array}{l}\text { Trough cross- } \\
\text { stratified } \\
\text { conglomerate }\end{array}$ & Gt & $\begin{array}{l}\text { Trough cross-stratified conglomerate; clast- } \\
\text { supported, moderate sorting }\end{array}$ & $\begin{array}{l}\text { Bedload traction current; migration of } \\
\text { sinuous crested gravel bedforms }\end{array}$ \\
\hline
\end{tabular}


Table 1. Description and interpretation of lithofacies (codes modified and extended from Miall [1978])continued

\begin{tabular}{|c|c|c|c|}
\hline Lithofacies & Code & Description & Interpretation \\
\hline & \multicolumn{3}{|c|}{ Conglomerate (continued) } \\
\hline $\begin{array}{l}\text { Mega-rippled } \\
\text { granule } \\
\text { conglomerate }\end{array}$ & GSr & $\begin{array}{l}\text { Mega-rippled granule conglomerate to very } \\
\text { coarse sandstone; poor to moderate sorting; } \\
\text { straight crested with } \sim 50 \mathrm{~cm} \text { wavelength and } \\
\sim 15 \mathrm{~cm} \text { amplitude }\end{array}$ & $\begin{array}{l}\text { Unidirectional and oscillatory bedload } \\
\text { traction current; migration of linear crested } \\
\text { bedforms }\end{array}$ \\
\hline $\begin{array}{l}\text { Conglomerate } \\
\text { lag }\end{array}$ & Glg & $\begin{array}{l}\text { Granule to very coarse sandstone stringers } \\
\text { and trains; } 1-5 \text { grains thick; horizontally } \\
\text { bedded or broadly lining low-angle bedforms }\end{array}$ & $\begin{array}{l}\text { Traction flow; size segregation due to } \\
\text { winnowing during barform migration or the } \\
\text { generation of low-relief scours }\end{array}$ \\
\hline Scour fill & Gsc & $\begin{array}{l}\text { Lens-shaped conglomerate beds with } \\
\text { irregular basal contact; rare weak imbrication }\end{array}$ & $\begin{array}{l}\text { Channel-form incision and infill of high- } \\
\text { concentration turbulent gravel flow }\end{array}$ \\
\hline
\end{tabular}

\begin{tabular}{|c|c|c|c|}
\hline \multirow[b]{2}{*}{$\begin{array}{l}\text { Planar-laminated } \\
\text { sandstone }\end{array}$} & \multicolumn{3}{|c|}{ Sandstone } \\
\hline & Sh & $\begin{array}{l}\text { Planar-laminated to thinly-bedded sandstone; } \\
\text { dominantly fine-grained }\end{array}$ & $\begin{array}{l}\text { Lower and upper flow regime planar flow; } \\
\text { tractive transport }\end{array}$ \\
\hline $\begin{array}{l}\text { Trough cross- } \\
\text { stratified } \\
\text { sandstone }\end{array}$ & St & $\begin{array}{l}\text { Cross-stratified sandstone; dominantly } \\
\text { trough, rare planar tabular geometry; thin to } \\
\text { thick bedded; occasional floating granules; } \\
\text { marine bivalves, occasionally in coquina } \\
\text { beds }\end{array}$ & $\begin{array}{l}\text { Traction current deposition from migration } \\
\text { of sinuous-crested (3-D) dune bedforms; } \\
\text { mid to upper part of lower flow regime }\end{array}$ \\
\hline Scour fill & Ssc & $\begin{array}{l}\text { Lenticular sandstone bed with irregular basal } \\
\text { contact }\end{array}$ & Erosive incision and subsequent infill \\
\hline $\begin{array}{l}\text { Steep sandstone } \\
\text { foresets }\end{array}$ & Scg & $\begin{array}{l}\text { Steeply inclined sandstone foresets }\left(15^{\circ}-\right. \\
\left.35^{\circ}\right) ; 40-50-\mathrm{cm} \text {-thick beds; occasional } \\
\text { internal grading }\end{array}$ & $\begin{array}{l}\text { Slipface deposition of large 2-D migrating } \\
\text { sand ridges or barforms }\end{array}$ \\
\hline $\begin{array}{l}\text { Rippled } \\
\text { sandstone }\end{array}$ & $\mathrm{Sr}_{1}$ & $\begin{array}{l}\text { Rippled sandstone; straight to sinuous } \\
\text { crested; rare interference pattern; } \\
\text { occasionally bioturbated }\end{array}$ & $\begin{array}{l}\text { Traction flow and migration of ripple } \\
\text { bedforms; low-flow regime }\end{array}$ \\
\hline $\begin{array}{l}\text { Mega-rippled } \\
\text { sandstone }\end{array}$ & $\mathrm{Sr}_{2}$ & $\begin{array}{l}\text { Mega-rippled coarse- to very-coarse-grained } \\
\text { sandstone; moderate sorting; straight crested } \\
\text { with } \sim 50 \mathrm{~cm} \text { wavelength and } \sim 15 \mathrm{~cm} \\
\text { amplitude }\end{array}$ & $\begin{array}{l}\text { Unidirectional and oscillatory bedload } \\
\text { traction current; migration of straight- } \\
\text { crested bedforms }\end{array}$ \\
\hline $\begin{array}{l}\text { Low-angle } \\
\text { cross-stratified } \\
\text { sandstone }\end{array}$ & Sl & $\begin{array}{l}\text { Thin-bedded, low-angle, cross-stratified } \\
\text { sandstone; occasionally laminated; rare } \\
\text { floating granules }\end{array}$ & $\begin{array}{l}\text { Bedload traction modified by long period } \\
\text { oscillatory(?) current }\end{array}$ \\
\hline $\begin{array}{l}\text { Massive poorly } \\
\text { sorted sandstone }\end{array}$ & $\mathrm{Sm}$ & $\begin{array}{l}\text { Massive, fine-grained sandstone with } \\
\text { abundant floating, very-coarse sandstone } \\
\text { grains and granules; occasional weak } \\
\text { grading; clasts oriented randomly or more } \\
\text { rarely in pockets; occasional unstable clast } \\
\text { orientations; scattered marine bivalves }\end{array}$ & $\begin{array}{l}\text { Sandy debris flows, hyperconcentrated } \\
\text { flows, and high-density turbidity currents; } \\
\text { rapid freezing of a traction carpet }\end{array}$ \\
\hline $\begin{array}{l}\text { Hummocky } \\
\text { cross-stratified } \\
\text { sandstone }\end{array}$ & Shc & $\begin{array}{l}\text { Hummocky cross-stratified sandstone; very } \\
\text { fine grained; bedform relief of } \sim 20 \mathrm{~cm}\end{array}$ & $\begin{array}{l}\text { Long period oscillatory-dominated } \\
\text { combined flow }\end{array}$ \\
\hline \multirow[t]{2}{*}{$\begin{array}{l}\text { Sandstone- } \\
\text { Mudstone } \\
\text { couplets }\end{array}$} & SM & $\begin{array}{l}\text { Thin-bedded couplets of graded medium- to } \\
\text { fine-grained sandstone and siltstone (various } \\
\text { Bouma sequences); mudstone rip-ups; } \\
\text { carbonaceous debris; ripples; bioturbation }\end{array}$ & $\begin{array}{l}\text { Low- to high-density turbidite currents and } \\
\text { hyperpycnal flows }\end{array}$ \\
\hline & \multicolumn{3}{|c|}{ Fine-grained deposits } \\
\hline $\begin{array}{l}\text { Massive } \\
\text { siltstone }\end{array}$ & Fml & Massive to weakly planar-laminated siltstone & Suspension deposits \\
\hline $\begin{array}{l}\text { Ripple- } \\
\text { laminated } \\
\text { siltstone }\end{array}$ & $\mathrm{Fr}$ & $\begin{array}{l}\text { Weakly graded very-fine-grained sandstone } \\
\text { to siltstone; commonly well rippled; } \\
\text { occasionally calcareous alteration of } \\
\text { sandstone }\end{array}$ & $\begin{array}{l}\text { Low-density, dilute turbidite currents and } \\
\text { hyperpycnal flows }\end{array}$ \\
\hline $\begin{array}{l}\text { Bioturbated } \\
\text { siltstone }\end{array}$ & $\mathrm{Fb}$ & $\begin{array}{l}\text { Massive siltstone with vertical burrows and } \\
\text { occasional horizontal feeding traces }\end{array}$ & Bioturbated deposits \\
\hline Coal & $\mathrm{C}$ & $\begin{array}{l}\text { Massive coal; } \sim 75 \mathrm{~cm} \text { thick; limited lateral } \\
\text { extent }\end{array}$ & $\begin{array}{l}\text { Concentration of organic matter in quiet } \\
\text { setting }\end{array}$ \\
\hline
\end{tabular}


Table 2. Summary of facies associations

\begin{tabular}{|c|c|c|c|c|}
\hline $\begin{array}{l}\text { Depositional } \\
\text { Setting }\end{array}$ & $\begin{array}{c}\text { Facies } \\
\text { Association }\end{array}$ & Lithofacies & Description and Occurrence & Interpretation \\
\hline \multirow[t]{2}{*}{ Alluvial } & Alluvial Fan & $\begin{array}{l}\text { (Gm, Gng, } \\
\text { Gin, Gmm, } \\
\text { Gsc, Ssc) }\end{array}$ & $\begin{array}{l}\text { Massive to weakly stratified } \\
\text { conglomerate; dominantly matrix- } \\
\text { supported fabrics; rare thin sandstone } \\
\text { beds; up to tens of meters thick; best } \\
\text { observed at Hoary Marmot Mountain }\end{array}$ & $\begin{array}{l}\text { Subareal debris flow and } \\
\text { sheet flood events in a } \\
\text { proximal alluvial fan }\end{array}$ \\
\hline & Delta Plain & $\begin{array}{l}\text { (Gm, Gng, } \\
\text { Gt, Glg, } \\
\text { Gsc, Sh, St, } \\
\left.\text { Ssc, } \mathrm{Sr}_{1}, \mathrm{C}\right)\end{array}$ & $\begin{array}{l}\text { Horizontally stratified conglomerate and } \\
\text { lesser sandstone; rare broad channel- } \\
\text { form geometry; occurs at the top of } \\
\text { coarsening-upward sequences; } \\
\text { intimately associated with the mouth bar } \\
\text { facies association }\end{array}$ & $\begin{array}{l}\text { Gravel-dominated, braided } \\
\text { fluvial system characterized } \\
\text { by flood stage processes; } \\
\text { limited preservation of } \\
\text { overbank facies }\end{array}$ \\
\hline \multirow[t]{4}{*}{$\begin{array}{l}\text { Fan Delta } \\
\text { Front }\end{array}$} & Mouth Bar & $\begin{array}{l}\text { (Gm, Gng, } \\
\text { Gin, Gt, } \\
\text { Gr, Glg, } \\
\text { Gsc, Sh, St, } \\
\mathrm{Ssc}, \mathrm{Sr}_{1}, \\
\mathrm{Sr}_{2}, \mathrm{Sm}, \\
\mathrm{Scg}(?))\end{array}$ & $\begin{array}{l}\text { Planar-bedded, sheet-like intervals of } \\
\text { coarsening-upward conglomerate with } \\
\text { minor sandstone intervals; often forms a } \\
\text { relatively sharp contact Mewith } \\
\text { underlying fine-grained sandstone of the } \\
\text { distal mouth bar and shoreface facies } \\
\text { associations }\end{array}$ & $\begin{array}{l}\text { Progradation of river- } \\
\text { dominated mouth bars into a } \\
\text { shallow marine setting; rapid } \\
\text { deposition (flood events) of } \\
\text { sediment-laden flows; } \\
\text { variable reworking by wave } \\
\text { processes }\end{array}$ \\
\hline & Beachface & $\begin{array}{l}\text { (Gof, Gr, } \\
\text { Sh, Sr1, } \\
\text { Sr2) }\end{array}$ & $\begin{array}{l}\text { Thin, distinct zones of well sorted } \\
\text { conglomerate and sandstone; beds are } \\
\text { laterally discontinuous and grade into } \\
\text { poorly sorted lithofacies; where present, } \\
\text { usually occur at the very top of } \\
\text { coarsening-upward trends }\end{array}$ & $\begin{array}{l}\text { Intense winnowing during } \\
\text { wave run-up; probable } \\
\text { reworking of previously } \\
\text { deposited mouth bar gravels }\end{array}$ \\
\hline & $\begin{array}{l}\text { Distal Mouth } \\
\text { Bar }\end{array}$ & $\begin{array}{l}\text { (Gm, Gng, } \\
\text { Gsc, St, } \\
\text { Ssc, Sm, } \\
\text { Fml) }\end{array}$ & $\begin{array}{l}\text { Massive, pebbly sandstone and lesser } \\
\text { conglomerate; laterally continuous } \\
\text { geometry; intercalated with the } \\
\text { shoreface facies association and } \\
\text { commonly grades upward into mouth } \\
\text { bar conglomerate }\end{array}$ & $\begin{array}{l}\text { Flood-influenced sandy } \\
\text { debris-flow deposition; } \\
\text { offshore of active sites of } \\
\text { mouth bar lobe progradation }\end{array}$ \\
\hline & Shoreface & $\begin{array}{l}\text { (Gt, Gr, } \\
\text { Glg, Sh, St, } \\
\mathrm{Sr}_{1}, \mathrm{Sr}_{2}, \mathrm{Sl} \\
\mathrm{Scg}(?) \\
\text { Fml, Fb) }\end{array}$ & $\begin{array}{l}\text { Thin-bedded or laminated sandstone; } \\
\text { usually cross-stratified; interbedded } \\
\text { with distal mouth bar deposits }\end{array}$ & $\begin{array}{l}\text { Discontinuous influence of } \\
\text { wave processes (storm?); } \\
\text { located off-axis of active } \\
\text { mouth bar settings }\end{array}$ \\
\hline \multirow[t]{3}{*}{$\begin{array}{l}\text { Fan Delta } \\
\text { Slope }\end{array}$} & Turbidite & $\begin{array}{l}\text { (Sh, } \mathrm{Sr}_{1}, \\
\mathrm{SM}, \mathrm{Fml})\end{array}$ & $\begin{array}{l}\text { Very-fine-grained sandstone separated } \\
\text { by siltstone drapes; tabular and laterally } \\
\text { continuous; coarsen and thicken upward } \\
\text { into distal mouth bar or shoreface facies } \\
\text { associations }\end{array}$ & $\begin{array}{l}\text { Pelagic silt deposition, } \\
\text { punctuated by sandy } \\
\text { turbidites and possible } \\
\text { hyperpycnal flows }\end{array}$ \\
\hline & Storm & (St, Sl Shc) & $\begin{array}{l}\text { Fine- to very-fine-grained sandstone; } \\
\text { usually laminated and characterized by } \\
\text { low-angle cross-stratification; } \\
\text { interstratified with the turbidite facies } \\
\text { association }\end{array}$ & $\begin{array}{l}\text { Combined oscillatory and } \\
\text { unidirectional flow set up by } \\
\text { large storm wave orbitals }\end{array}$ \\
\hline & Channel & $\begin{array}{l}\text { (Gm, Gng, } \\
\text { Sm, Ssc) }\end{array}$ & $\begin{array}{l}\text { Sharp-based channel-forms, } \\
\text { approximately } 10 \text { m deep, and filled } \\
\text { with flat-lying conglomerate fining- } \\
\text { upward to sandstone; conglomerate } \\
\text { includes rip-ups of underlying mudstone }\end{array}$ & $\begin{array}{l}\text { Incision of submarine } \\
\text { channel, possibly during } \\
\text { base level fall; subsequent } \\
\text { bypass and eventual infilling } \\
\text { of pre-existing sediment } \\
\text { conduit }\end{array}$ \\
\hline Prodelta & Prodelta & $\begin{array}{l}\text { (Fml, Fr, } \\
\text { Fb) }\end{array}$ & $\begin{array}{l}\text { Continuous sheet-like deposits, defined } \\
\text { by calcareous very-fine-grained } \\
\text { sandstone horizons; ripple trains } \\
\text { common, bioturbation present; } \\
\text { characterizes several hundred meters of } \\
\text { continuous section in the lower Fortress } \\
\text { Mountain Formation }\end{array}$ & $\begin{array}{l}\text { Pelagic deposition with } \\
\text { minor low-density silt- } \\
\text { dominated turbidites }\end{array}$ \\
\hline
\end{tabular}




\section{Fan delta front deposits}

The fan delta front marks the subaqueous nearshore setting characterized by the interplay of riverine (flood-dominated) and marine (wave-dominated) processes (Kleinspehn and others, 1984; Rasmussen, 2000). The four principal facies associations include: (1) proximal mouth bar, (2) beachface, (3) distal mouth bar, and (4) shoreface (table 2). The fan delta front is a natural trap for gravel as both stream- and mass flow-dominated alluvial systems decelerate upon entering a standing body of water (for example, Nemec and Steel, 1984). The best exposures at Atigun syncline occur in conglomeratic fan delta front deposits which dominate the southernmost coarse-grained exposures (fig. 5). The component facies associations reflect the interaction of flood-dominated and marineinfluenced processes (tables 1 and 2). However, it should be noted that many of these deposits are closely interbedded and certainly existed lateral to one another at any given time. The proximal mouth bar facies association is characterized by massive, poorly sorted mass-flow deposits that rapidly fine northward into distal mouth bar facies association (fig. 8). The subaqueous nature of these deposits is confirmed by occasional marine bivalves and probable wave-related megaripples (fig. 9; Sheet B-1).

The shoreface facies association is often poorly exposed and interpreted to underlie extensive tundra-covered intervals along the southern limb of the syncline. This association is dominated by cross-stratified sandstone (fig. 9) and records episodes of wave reworking of the fan delta front. This association is often closely interbedded with distal mouth bar deposits, suggesting a competition between sediment delivery during flood events and marine reworking by waves. However, the limited conglomerate may suggest that shoreface deposits are best developed (and preserved) in inactive sectors of the fan delta, possibly removed from sites of active sediment influx. The beachface facies association records a key zone where wave run-up produces thin accumulations of strongly winnowed, openframework gravel (fig. 9). Beachface deposits, where present, occur in the upper portion of conglomerate-dominated packages (Sheet B1 ), and record the precise shoreline position. Similar to the shoreface facies association, the preservation of wave-reworked beach deposits probably reflects sites on the fan delta front not actively receiving land-derived sediment (Lopez-Blanco, 1993).
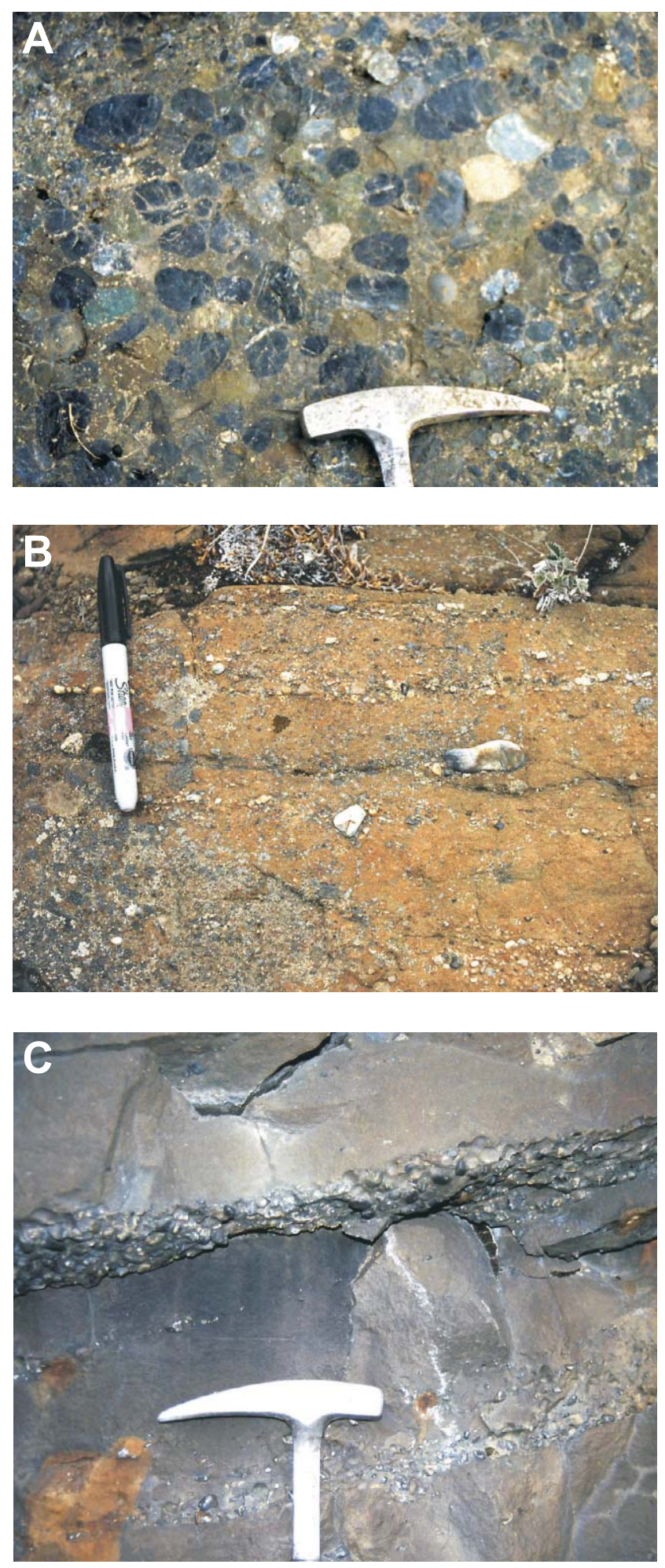

Figure 8. Photos of proximal and distal mouth bar facies associations. (A) Typical texture within matrix-rich, massive pebble conglomerate. (B) Poorly sorted fine-grained sandstone with floating granules and pebbles common to the distal mouth bar facies association. (C) Discontinuous coarse sandstone to granule lags in fine-grained sandstone. 

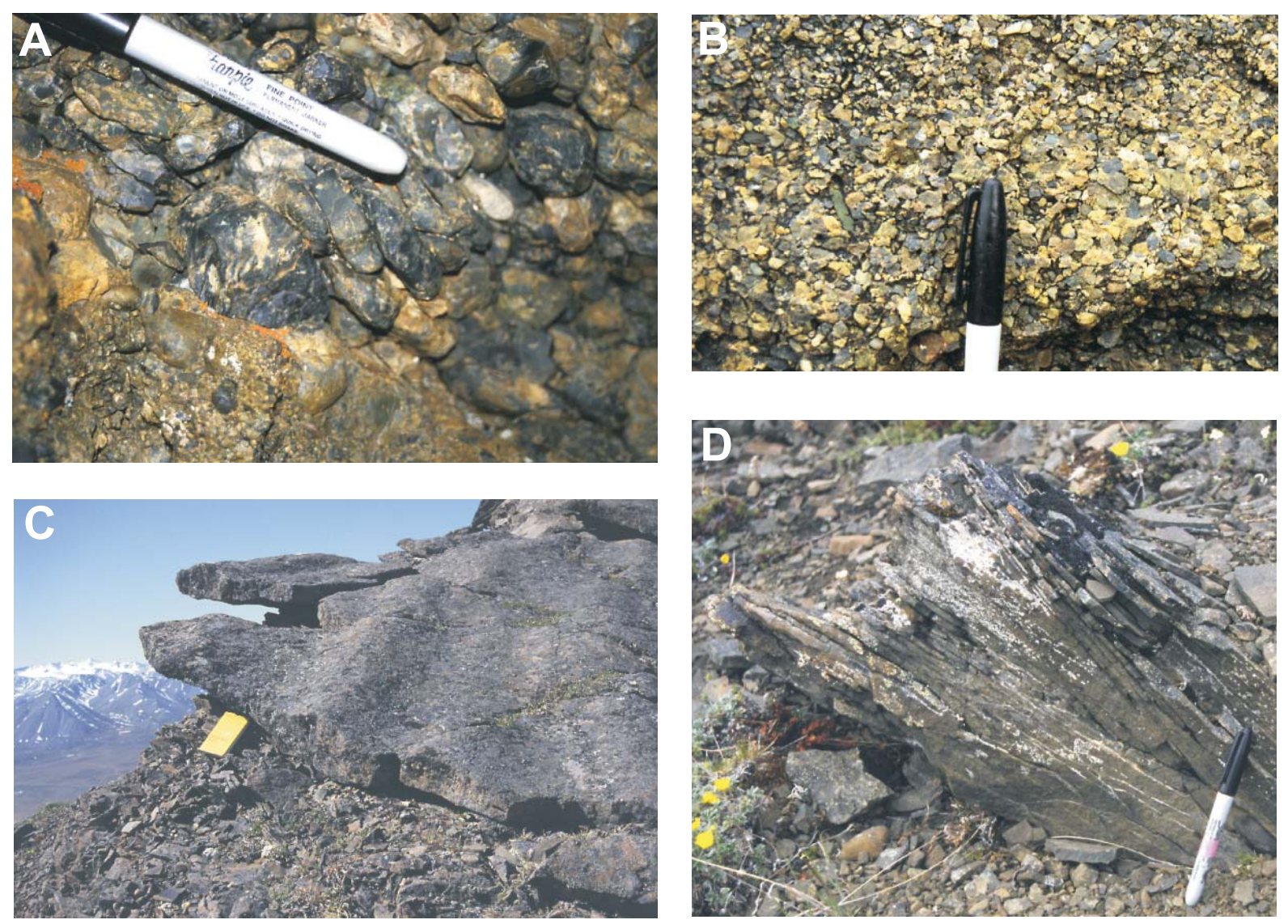

Figure 9. Photos of wave-influenced sedimentary structures within the fan delta front. (A) Example of well developed openframework textures in foreshore gravel. The majority of clasts are north dipping, suggesting imbrication during wave run-up. (B) Moderate to well sorted granule conglomerate interpreted as wave-winnowed foreshore facies. (C) Straight crested megaripples formed by wave reworking of mouth bar deposits; sense of transport is to the south. (D) Thin-bedded, cross-stratified sandstone typical of the shoreface facies association.

\section{Fan delta slope deposits}

The fan delta slope setting (in the sense of Postma, 1984) lies basinward of the fan delta front and below wave base (excepting large storms). The delta slope is here subdivided into three component facies associations: (1) turbidite, (2) storm, and (3) channel/chute (table 2). Fan delta slope deposits at Atigun syncline tend to be conglomerate-poor, leading to limited exposure. The three recognized facies associations reflect a spectrum of processes including: delta-fed turbidity currents (fig. 10), hyperpycnal flows, periodic storm reworking, and the incision and backfilling of small channels. Fan delta slope deposits are locally observed along the southwest corner of the fold where they mark the lower portions of large upward-coarsening packages that shoal upward into proximal fan delta front deposits. It remains possible that fan delta slope facies, particularly the turbidite association, exist beneath covered swales between resistant conglomerate beds (Sheet B-1). Nevertheless, this environment is best preserved in select stream cuts in the central and northern portions of the syncline and is suspected to underlie much of the tundra-covered regions (figs. 3 and 4). The increased abundance of fan delta slope facies to the north is consistent with the interpreted northward deepening of the basin.

\section{Prodelta deposits}

The prodelta environment lies basinward of the fan delta slope. Similar to normal deltas, the prodelta setting is typically dominated by fine-grained deposits and represents the most distal component of a deltaic prism. Prodelta deposits are largely confined to the fine-grained lower Fortress Mountain Formation, which was not examined in detail during this study (generalized in fig. 6). This monotonous sequence of siltstone and very fine sandstone records the most distal component of this depositional system. The lower Fortress Mountain Formation is best 

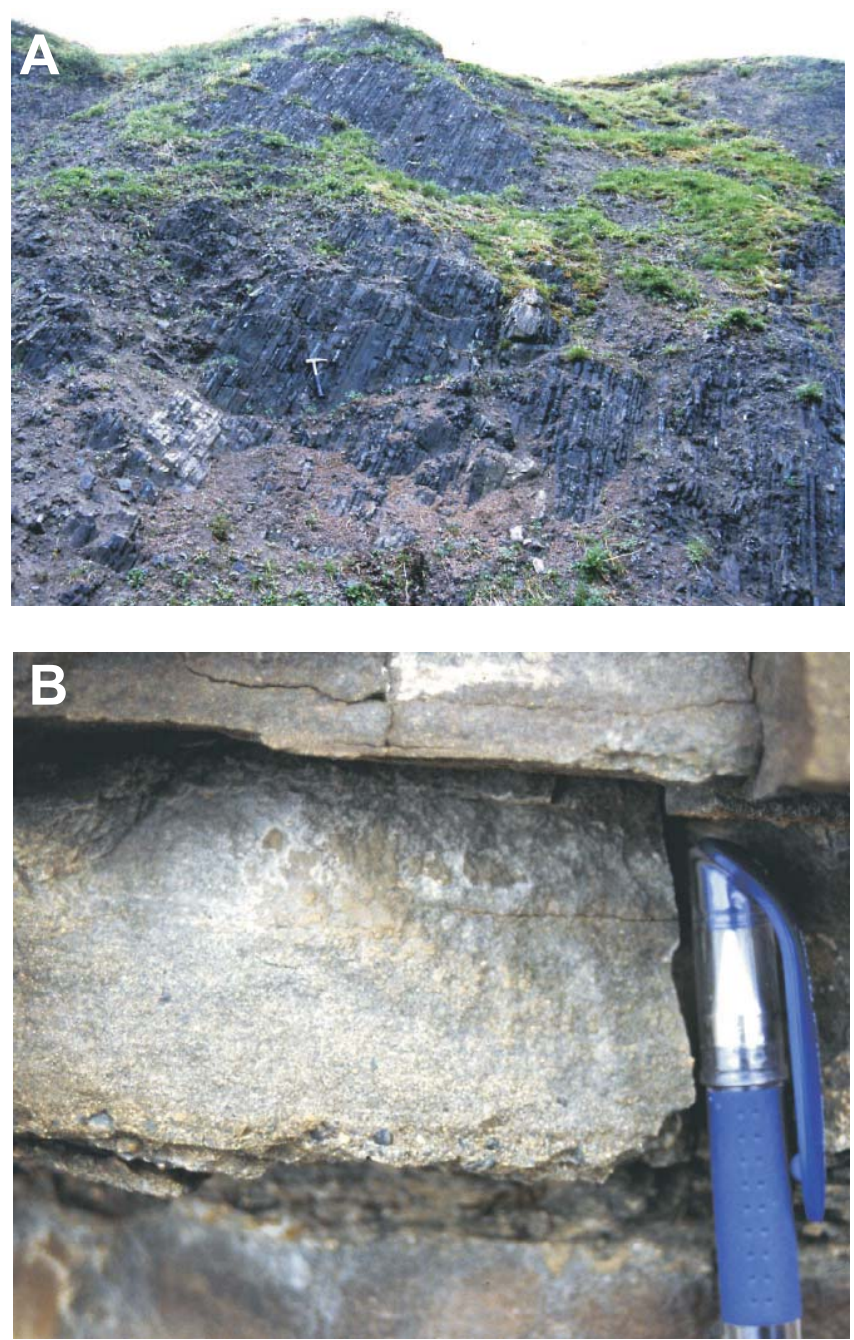

Figure 10. Photos of fan delta slope facies. (A) Rhythmic, very finegrained sandstone-dominated turbidites. (B) Example of well preserved Bouma A and B subdivisions. displayed in steep cliff exposures on the southern limb of the fold (fig. 7), although prodelta deposits are also observed in a small quarry in the northwest limb of the fold (figs. 3, 4, and 6).

\section{DISCUSSION AND CONCLUSIONS}

The body of evidence in the preceding analysis and outlined in tables 1 and 2 supports the interpretation that Atigun syncline was the site of a long-lived fan deltaic depocenter along the ancestral mountain front of the Brooks Range orogen. The distribution of the nine facies associations is schematically reconstructed in figure 11 . This fan delta model best reconciles the close association of wave, fluvial, and mass flow processes recognized in this study. The key observations constraining this interpretation stem from the new recognition of wave-related associations, especially the mega-rippled surfaces and imbricated foreshore gravels (fig. 9). These important environmental interpretations are bolstered by wave-generated, landward-directed paleocurrents that effectively limit the water depth to well within fair-weather wave base. As noted by many authors, knowledge of the shoreline position is a key stratigraphic marker in fan deltas (Wescott and Ethridge, 1980; Bourgeois and Leithold, 1984; Massari and Parea, 1988; Horton and Schmitt, 1996).

Paleocurrents, such as large proximal mouth bar foresets, indicate a dominantly northward direction of progradation (fig. 12). A northward deepening of the basin is further indicated by the abrupt loss of conglomerate beds to the north (fig. 4). This general pattern of deposition is consistent with prevailing paleogeographic models calling for a northward, transverse growth of the proximal Brookian clastic wedge (for example, Bird and Molenaar, 1992).

Atigun syncline is a surprisingly isolated accumulation of coarse clastic sediment (fig. 1). The lack of similar facies to the east, in the Phillip Smith Mountains, is clearly related to deeper levels of erosion associated with Tertiary uplift (O’Sullivan and others, 1997). However, based on recent DGGS mapping west of Atigun syncline, the Fortress Mountain Formation consists of conglomerate-poor facies. The next significant accumulation of conglomerate is nearly $100 \mathrm{~km}$ west of Atigun syncline (fig. 1). The isolated nature of thick conglomeratic facies cannot be wholly explained as an artifact of erosional or structural effects. Instead, it seems more likely that the limited map extent of this facies is a primary depositional feature (also suggested by Mull, 1985) reflecting the localized development of widely spaced fan deltas. Similar to alluvial fans, most fan deltas are isolated systems with limited influence on neighboring environments (Orton and Reading, 1993). It is tempting to interpret the thick accumulation at Atigun syncline as the depositional record of a major mid-Cretaceous trunk drainage. Vincent and Elliott (1997) demonstrated that major paleovalleys in the Spanish Pyrenees persisted through long periods of mountain belt evolution. Further analogies and insight can be drawn from the North American Cordillera, where Lawton and others (1994) interpreted localized accumulations of gravel as the record of long-lived, antecedent drainages controlled by transverse structural zones. 


\section{Fan Delta Depositional System}

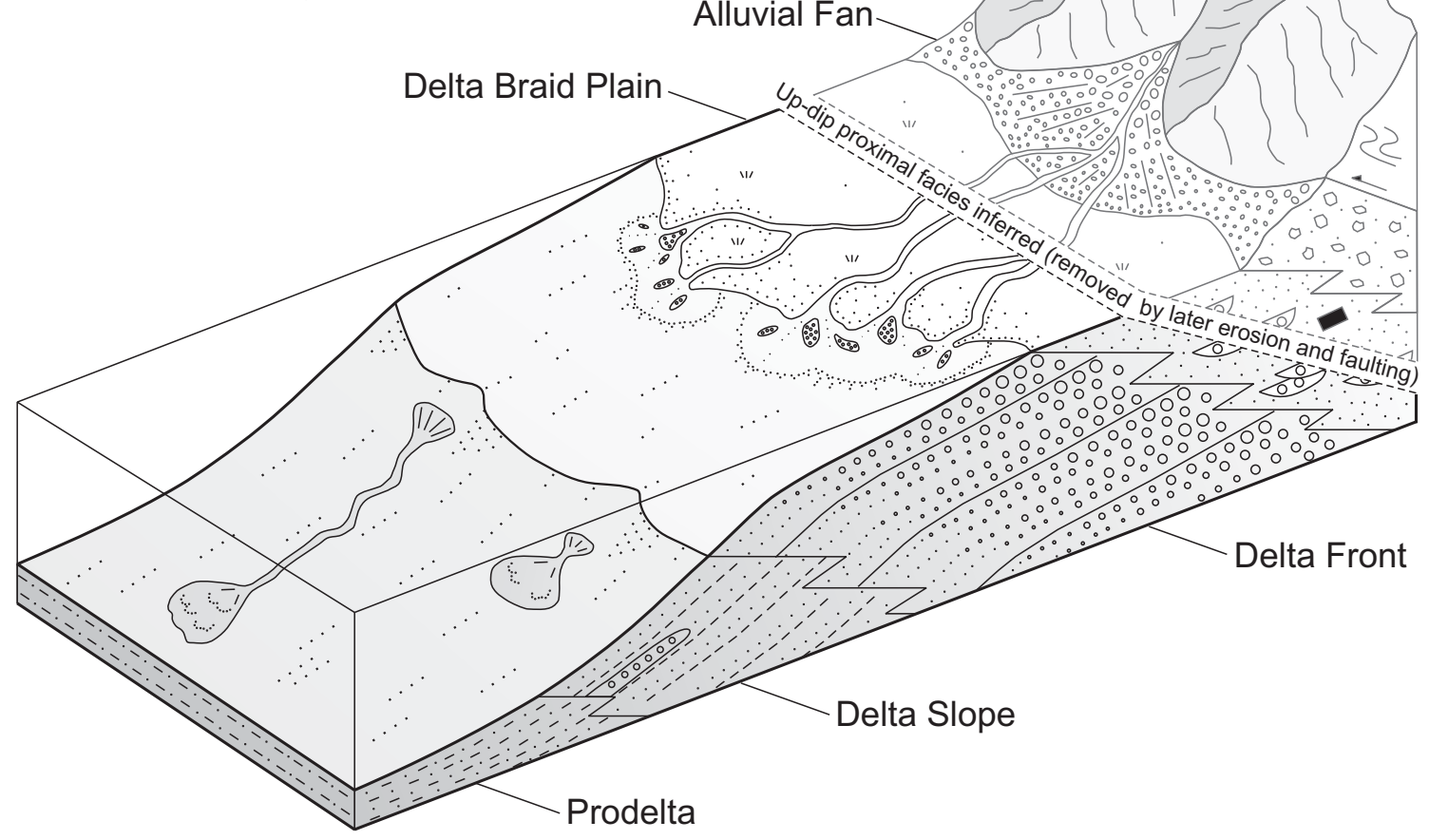

Figure 11. Summary block diagram illustrating the interpreted relationship of various facies components of the Atigun fan delta depositional system.

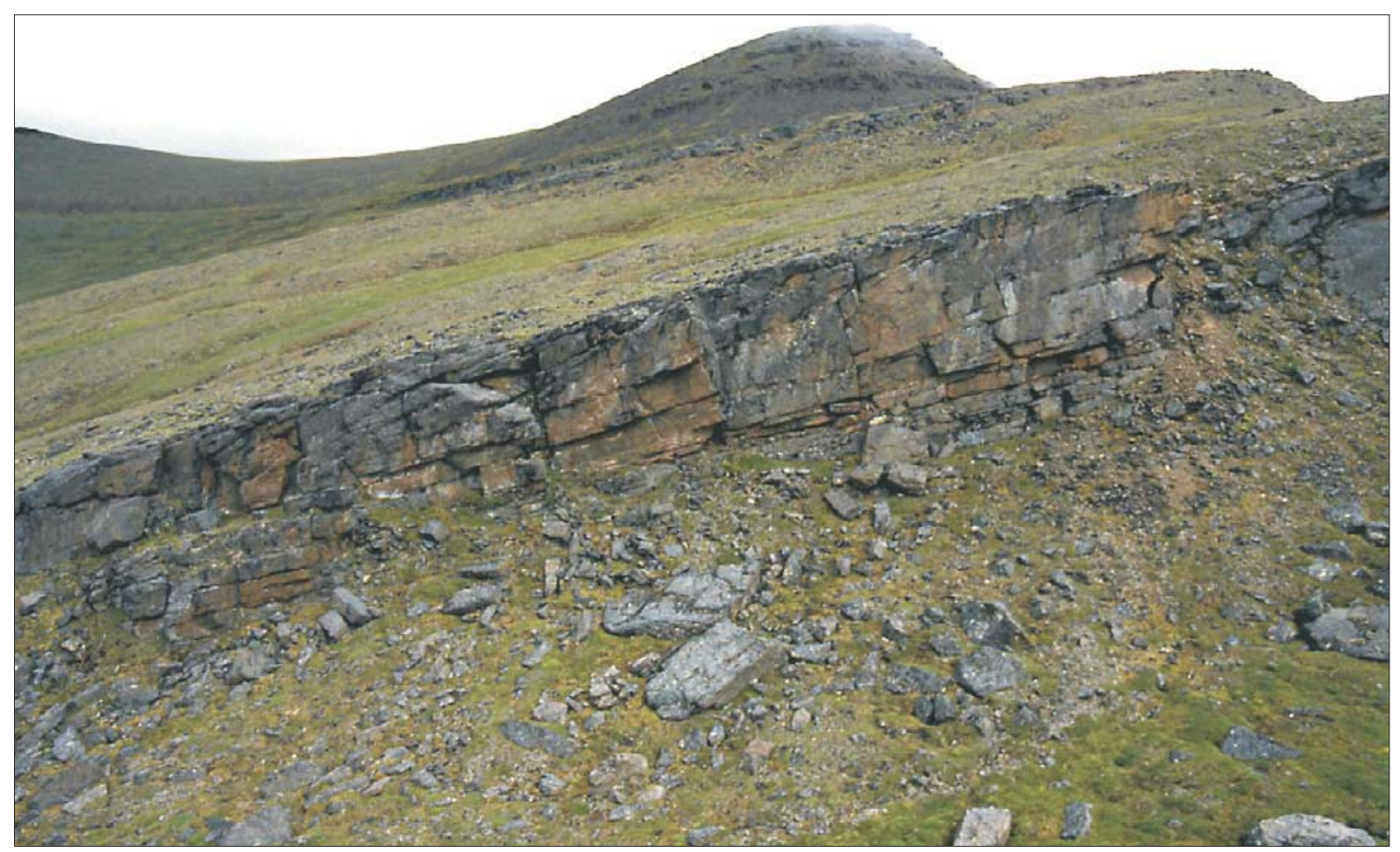

Figure 12. Prominent basinward-dipping shingled mouth bar foresets indicating northward (to the left) progradation of the fan delta system. Resistant cliff is approximately $15 \mathrm{~m}$ high. 


\section{AKNOWLEDGMENTS}

Support for fieldwork on the Fortress Mountain Formation was generously provided to the University of Wisconsin by Anadarko Petroleum Corporation. DGGS field studies on the North Slope are supported by industry contributions from Anadarko, FEX, BG Alaska, Chevron, Petro-Canada, Pioneer Natural Resources, ENI, Shell, and ConocoPhillips. Funding for DGGS geologic mapping in the Atigun area was provided by the state of Alaska and the U.S. Geological Survey STATEMAP program (award no. 01HQAG0054). A. Carroll, E. Parcher-Wartes, and S. Montayne are thanked for help in the field. This work benefited from numerous conversations with G. Mull, A. Carroll, D. LePain, J. Pietras, R. Reifenstuhl, E. Harris, D. Houseknecht, C. Schenk, and D. Hite. This paper benefitted from review comments by D. LePain.

\section{REFERENCES}

Bird, K.J., and Molenaar, C.M., 1992, The North Slope foreland basin, Alaska, in Macqueen, R.W., and Leckie, D.A., eds., Foreland basins and fold belts: AAPG Memoir no. 55, p. 363-393.

Bourgeois, J., and Leithold, E.L., 1984, Wave-worked conglomerates-depositional processes and criteria for recognition, in Koster, E.H., and Steel, R.J., eds., Sedimentology of gravels and conglomerates: Canadian Society of Petroleum Geologists, Memoir 10, p. 331-344.

Brosgé, W.P., Reiser, H.N., Dutro, J.T., Jr., and Detterman, R.L., 1979, Bedrock geologic map of the Phillip Smith Mountains quadrangle, Alaska: U.S. Geological Survey Miscellaneous Field Investigations Map MF 879-B, 2 sheets, scale 1:250,000.

Clifton, H.E., 1973, Pebble segregation and bed lenticularity in wave-worked versus alluvial gravel: Sedimentology, v. 20, p. 173-187.

Cole, F.E., Bird, K.J., Toro, J., Roure, F., O’Sullivan, P.B., Pawlewicz, M.J., and Howell, D.G., 1997, An integrated model for the frontal Brooks Range and Colville Basin 250 km west of the Trans-Alaska Crustal Transect: Journal of Geophysical Research, v. 102, p. 20,685-20,708.

Crowder, R.K., 1987, Cretaceous basin to shelf transition in northern Alaska; deposition of the Fortress Mountain Formation, in Tailleur, I.L., and Weimer, P., eds., Alaskan North Slope geology: Pacific Section, SEPM, Bakersfield, CA, v. 50, p. 449-458.

1989, Deposition of the Fortress Mountain Formation, in Mull, C.G., and Adams, K.E., eds., Dalton Highway, Yukon River to Prudhoe Bay, Alaska: Alaska Division of Geological \& Geophysical Surveys Guidebook 7, v. 2, p. 293-301.

Goff, R.A., 1990, Stratigraphy and sedimentology of the Fortress Mountain Formation at Atigun syncline, northern Alaska: Fairbanks, Alaska, University of Alaska Fairbanks, M.S. Thesis, 122 p.

Harris, E.E., Mull, C.G., Montayne, S., and Reifenstuhl, R.R., 2002, Geologic map of the Dalton Highway (Atigun Gorge to Slope Mountain) area, southeastern Arctic Foothills, Alaska: Alaska Division of Geological \& Geophysical Surveys Preliminary Interpretive Report 2002-2, 1 sheet, scale 1:63,360.

Hart, B.S., and Plint, A.G., 2003, Stratigraphy and sedimentology of shoreface and fluvial conglomerates; Insights from the Cardium Formation in Northwest Alberta and adjacent British Columbia: Bulletin of Canadian Petroleum Geology, v. 51, no. 4, p. 437-464.

Horton, B.K., and Schmitt, J.G., 1996, Sedimentology of the lacustrine fan-delta system, Miocene Horse Camp Formation, Nevada, USA: Sedimentology v. 43, p. 133-155.

Hunter, R.E., and Fox, J.E., 1976, Interpretation of depositional environments in the Fortress Mountain Formation, central Arctic Slope: United States Geological Survey Circular 733, p. 30-31.

Kleinspehn, K.L., Steel, R.J., Johannessen, E., and Netland, A., 1984, Conglomeratic fan-delta sequences, Late Carboniferous-Early Permian, western Spitsbergen, in Koster, E.H., and Steel, R.J. eds., Sedimentology of gravels and conglomerates: Canadian Society of Petroleum Geologists, Memoir 10, p. 279-294.

Lawton, T.F., Boyer, S.E., and Schmitt, J.G., 1994, Influence of inherited taper on structural variability and conglomerate distribution, Cordilleran fold and thrust belt, western United States: Geology, v. 22, p. 339-342.

Lopez-Blanco, M., 1993, Stratigraphy and sedimentary development of the Sant Llorec del Munt fan-delta complex (Eocene, southern Pyrenean foreland basin, northeast Spain), in Frostick, L., and Steel, R.J., (eds.), Tectonic controls and signatures in sedimentary successions: International Association of Sedimentology, Special Publication 20, p. 67-89.

Massari, F., and Parea, G.C., 1988, Progradational gravel beach sequences in a moderate- to high-energy, microtidal marine environment: Sedimentology, v. 35, p. 881-913. 
Miall, A.D., 1978, Lithofacies types and vertical profile models in braided river deposits: A summary, in Miall, A.D., ed., Fluvial sedimentology: Canadian Society of Petroleum Geology Memoir 5, 859 p.

Mickey, M.B., and Haga, H., 1987, Jurassic-Neocomian biostratigraphy, North Slope, Alaska, in Tailleur, I.L., and Weimer, P., eds., Alaskan North Slope geology: Pacific Section, SEPM, Bakersfield, CA, v. 50, p. 397-404.

Molenaar, C.M., Egbert, R.M., and Krystinik, L.F., 1988, Depositional facies, petrography, and reservoir potential of the Fortress Mountain Formation (Lower Cretaceous), central North Slope, Alaska, in Gryc, G., ed., Geology and exploration of the National Petroleum Reserve in Alaska, 1974-1982: U.S. Geological Survey Professional Paper 1399, p. 257-280.

Mull, C.G., 1985, Cretaceous tectonics, depositional cycles, and the Nanushuk Group, Brooks Range and Arctic Slope, Alaska, in Huffman, A.C., ed., Geology of the Nanushuk Group and related rocks, North Slope, Alaska: U.S. Geological Survey Bulletin 1614, p. 7-36.

Mull, C.G., and Harris, E.E., 1989, Road log from Chandalar Shelf (mile 237.1) to Prudhoe Bay (mile 414), in Mull, C.G., and Adams, K.E., eds., Dalton Highway, Yukon River to Prudhoe Bay, Alaska; Bedrock geology of the eastern Koyukuk Basin, central Brooks Range and eastcentral Arctic Slope: Alaska Division of Geological \& Geophysical Surveys Guidebook 7, vol. 1, p. 101-126.

Mull, C.G., Glenn, R.K., and Adams, K.E., 1997, Tectonic evolution of the central Brooks Range mountain front; Evidence from the Atigun Gorge region: Journal of Geophysical Research, v. 102, no. B9, p. 20,749-20,772.

Nemec, W., and Steel, R.J., 1984, Alluvial and coastal conglomerates; Their significant features and some comments on gravelly mass-flow deposits, in Koster, E.H., and Steel, R.J., eds., Sedimentology of gravels and conglomerates: Canadian Society of Petroleum Geologists Memoir 10, p. 1-31.

1988, What is a fan delta and how do we recognize it?, in Nemec, W., and Steel, R.J., eds., Fan deltas; Sedimentology and tectonic settings: London, Blackie and Son, p. 3-13.

Nemec, W., Steel, R.J., Porebski, S.J., and Spinnangr, A., 1984, Domba Conglomerate, Devonian, Norway; Process and lateral variability in a mass flow-dominated, lacustrine fan-delta, in Koster, E.H., and Steel, R.J., eds., Sedimentology of gravels and conglomerates: Canadian Society of Petroleum Geologists Memoir 10, p. 295-320.

Orton, G.J., and Reading, H.G., 1993, Variability of deltaic processes in terms of sediment supply, with particular emphasis on grain size: Sedimentology, v. 40, p. 475-512.

Patton, W.W., and Tailleur, I.L., 1964, Geology of the Killik-Itkillik region, Alaska: U.S. Geological Survey Professional Paper 303G, p. 409-500.

Postma, G., 1984, Slumps and their deposits on fan delta front and slope: Geology, v. 12, p. 27-30.

Rasmussen, H., 2000, Nearshore and alluvial facies in the Sant Llorenc del Munt depositional system; Recognition and development: Sedimentary Geology, v. 138, p. 71-98.

Ryherd, T.J., 1990, Fan-delta deposition in the Cretaceous (Albian) Fortress Mountain Formation, central North Slope, Alaska [abs.]: AAPG Bulletin, v. 74, p. 753.

Schenk, C.J., and Bird, K.J., 1992, Depositional sequences in Lower Cretaceous rocks, Atigun syncline and Slope Mountain areas, Alaska North Slope, in Dusel-Bacon, C., and Till, A.B., eds., Geologic Studies in Alaska by the U.S. Geological Survey, 1992: U.S. Geological Survey Bulletin 2068, p. 48-58.

Vincent, S.J., and Elliott, T., 1997, Long-lived transfer-zone paleovalleys in mountain belts; An example from the Tertiary of the Spanish Pyrenees: Journal of Sedimentary Research, v. 67, no. 2, p. 303310.

O'Sullivan, P.B., Murphy, J.M., and Blythe, A.E., 1997, Late Mesozoic and Cenozoic thermotectonic evolution of the central Brooks Range and adjacent North Slope foreland basin, Alaska-including fission track results from the Trans-Alaska Crustal Transect (TACT): Journal of Geophysical Research, v. 102, p. 20,821-20,845.

Wartes, M.A., and Carroll, A.R., 2002, Detailed facies analysis of the Lower Cretaceous Fortress Mountain Formation, Atigun syncline, northern Alaska [abs.]: American Association of Petroleum Geologists, Pacific Section Meeting Abstracts, AAPG Bulletin, v. 86, no. 6, p. 1,162.

Wescott, W.A., and Ethridge, F.G., 1980, Fan-delta sedimentology and tectonic setting-Yallahs fan-delta, southeast Jamaica: American Association of Petroleum Geologists Bulletin, v. 64, p. 374-399. 


\title{
EVALUATION OF STRATIGRAPHIC CONTINUITY BETWEEN THE FORTRESS MOUNTAIN AND NANUSHUK FORMATIONS IN THE CENTRAL BROOKS RANGE FOOTHILLS_ARE THEY PARTLY CORRELATIVE?
}

\author{
by
}

Marwan A. Wartes ${ }^{1}$

\section{INTRODUCTION}

The Colville Basin in northern Alaska is a large east-trending foreland basin that developed north of the Brooks Range fold and thrust belt in the Early Cretaceous (Mull, 1985; Bird and Molenaar, 1992; figs. 1-2). The southern margin of the basin is generally regarded as gas-prone, although it remains underexplored relative to the rest of the North Slope (Houseknecht and Bird, 2006). Seismic data are poor throughout this belt (Molenaar, 1988), leading to uncertainty regarding regional stratigraphic relationships.

The purpose of this paper is to examine the poorly understood stratigraphic relationship between the Fortress Mountain and Nanushuk ${ }^{2}$ Formations - two of the most prospective siliciclastic units exposed in the inner foothills. Many previous workers have interpreted the two units as discrete depositional cycles, often separated by a "tongue" of mudstone-dominated Torok Formation (Mull, 1985; Moore and others, 1994; fig. 3). However, in the field the relationship between the two formations is unclear and the two distinct belts of resistant exposures are never observed in close spatial association (fig. 2). To date, it has been difficult to prove the two units did not overlap in time, leading some workers to entertain the hypothesis that the uppermost Fortress Mountain Formation graded northward into the lower Nanushuk Formation (Kelley, 1990). In addition to ambiguous field relationships, available biostratigraphic constraints have largely proven insufficient to address this question. This study takes an alternate approach, testing the stratigraphic continuity of the two units on the basis of their provenance characteristics - specifically, the novel application of detrital zircon geochronology. Preliminary results strongly suggest the two units represent different depositional sequences.

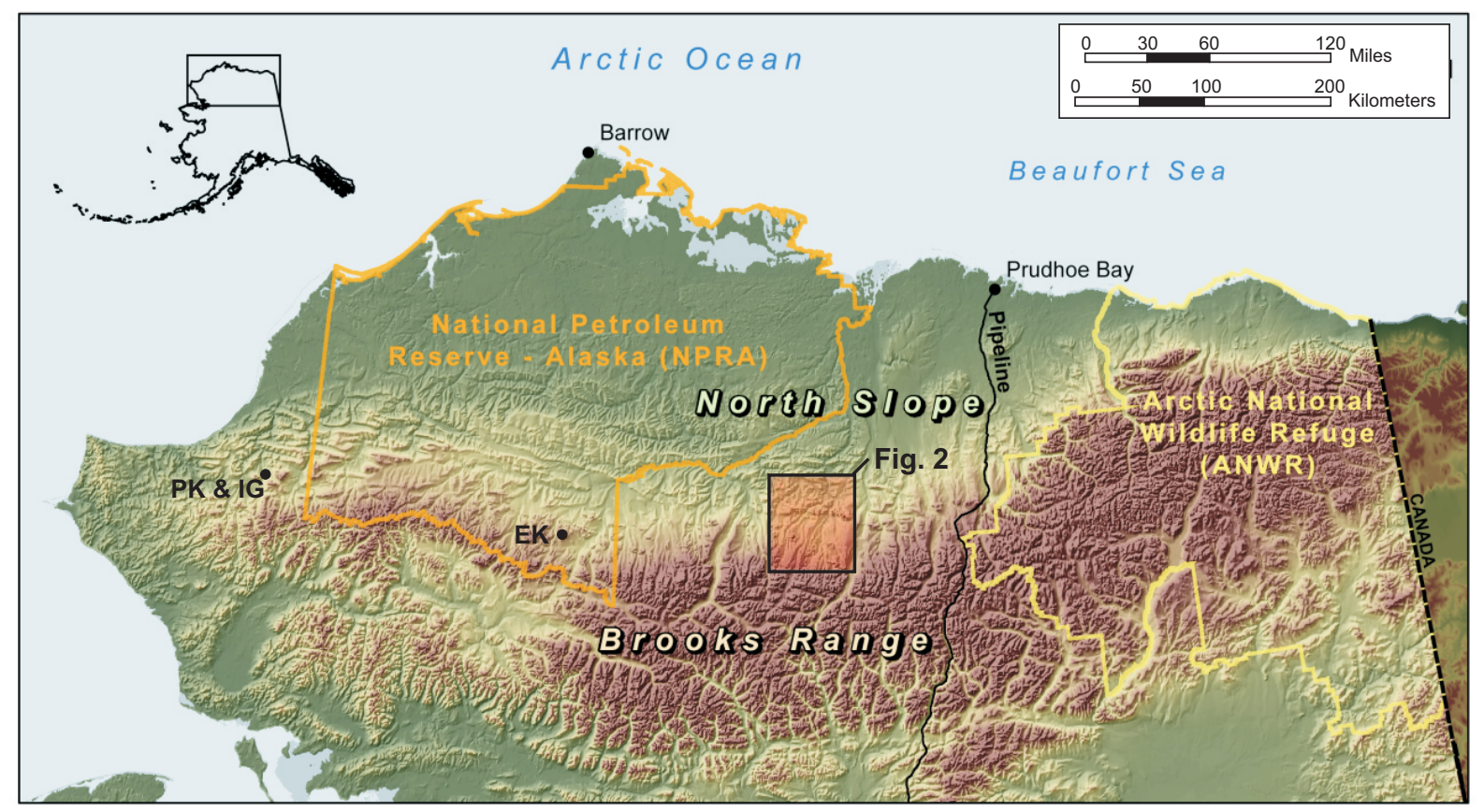

Figure 1. Regional location map of northern Alaska. Initials refer to localities outside of the study area that are mentioned in the text (PK \& IG = Poko Mountain and Igloo Mountain; EK = Ekakevik Mountain).

\footnotetext{
${ }^{1}$ Alaska Division of Geological \& Geophysical Surveys, 3354 College Rd., Fairbanks, Alaska 99709-3707 Email for Marwan A. Wartes: marwan.wartes@alaska.gov

${ }^{2}$ The Nanushuk has historically been ascribed Group status (Detterman, 1956). However, in a comprehensive revision and simplification of Brookian stratigraphic nomenclature, Mull and others (2003) suggested the Nanushuk be demoted to formation rank.
} 


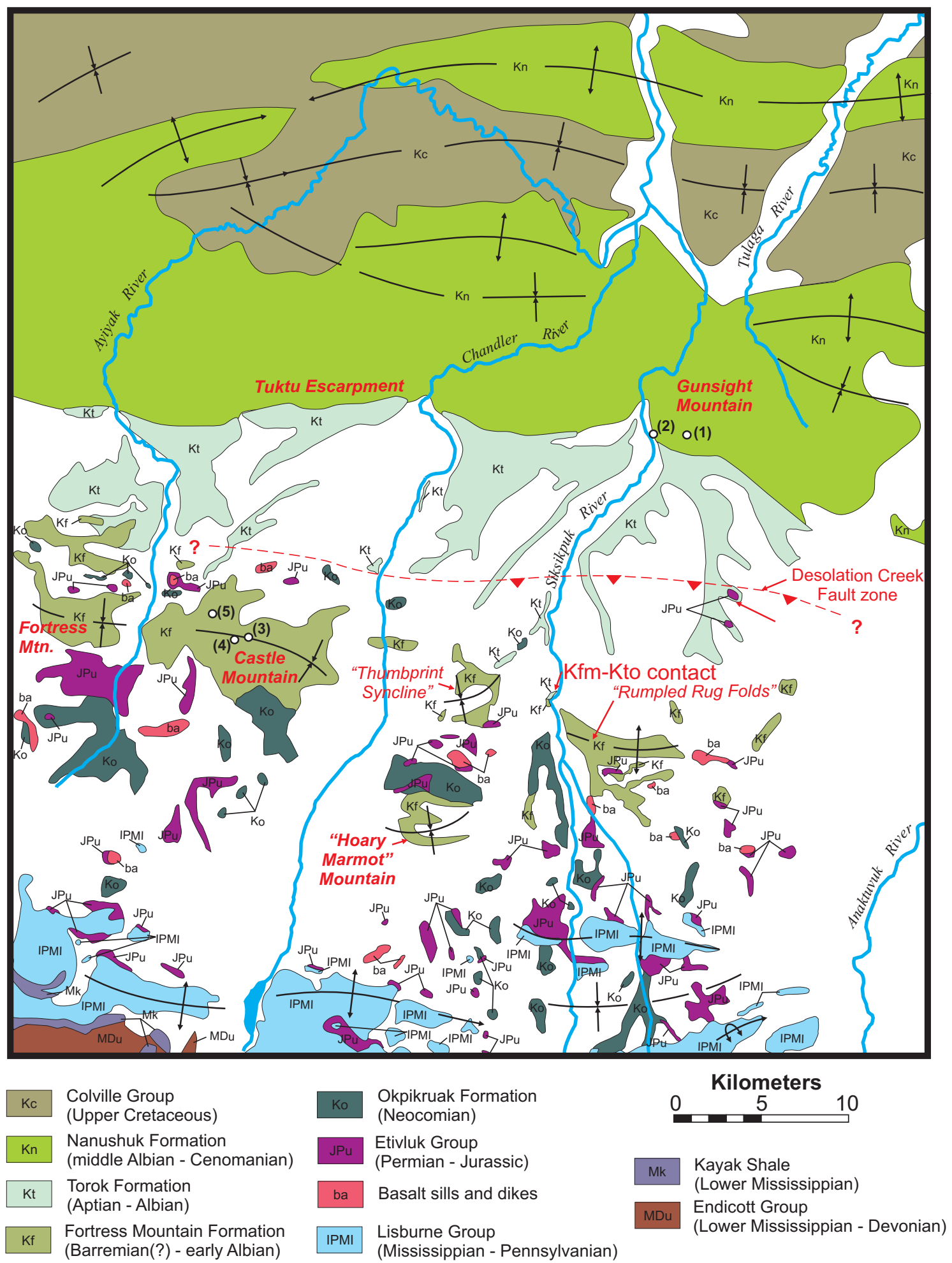

Figure 2. Generalized geologic map of the east-central foothills (modified slightly from C.G. Mull, unpublished mapping). Numbered locations refer to samples in this study (see table 1). 


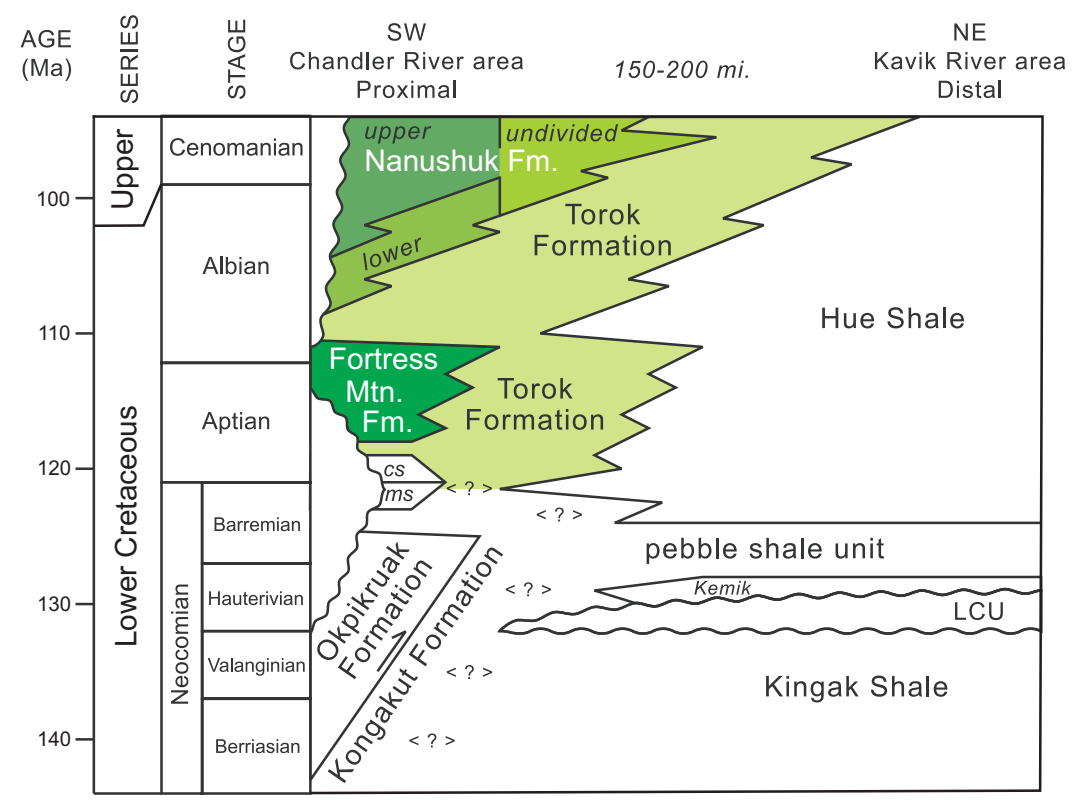

Figure 3. Chronostratigraphy of middle Cretaceous units in northern Alaska showing revised stratigraphic nomenclature (modified from Mull and others, 2003). $c s=c o b$ blestone sandstone (informal unit); ms = manganiferous shale unit (informal).

\section{EXISTING CONSTRAINTS}

\section{Map relationships}

Early reconnaissance mapping recognized that at a regional scale progressively younger Brookian units typically crop out from south to north (Patton and Tailleur, 1964). This general observation supports the interpretation that the southerly belt of Fortress Mountain Formation is older than the more northerly Nanushuk Formation trend. However, the top of the Fortress Mountain Formation is almost never exposed. Moreover, the two units are never observed together, but are instead separated by a poorly exposed, low-relief succession of finer-grained Torok Formation (figs. 2 and 4). The broad zone of Torok Formation exhibits locally complex deformation with variable fold vergence (Peapples and others, 2007). The northerly part of the Torok belt is generally interpreted as a structurally thickened triangle zone beneath a south-vergent roof thrust near the base of the Nanushuk Formation (Moore and others, 2004; Wallace and others, 2006). The uplift and subsequent erosion of post-Torok rocks has obscured the relationship between the Fortress Mountain Formation and proximal reaches of the Nanushuk Formation (fig. 4).

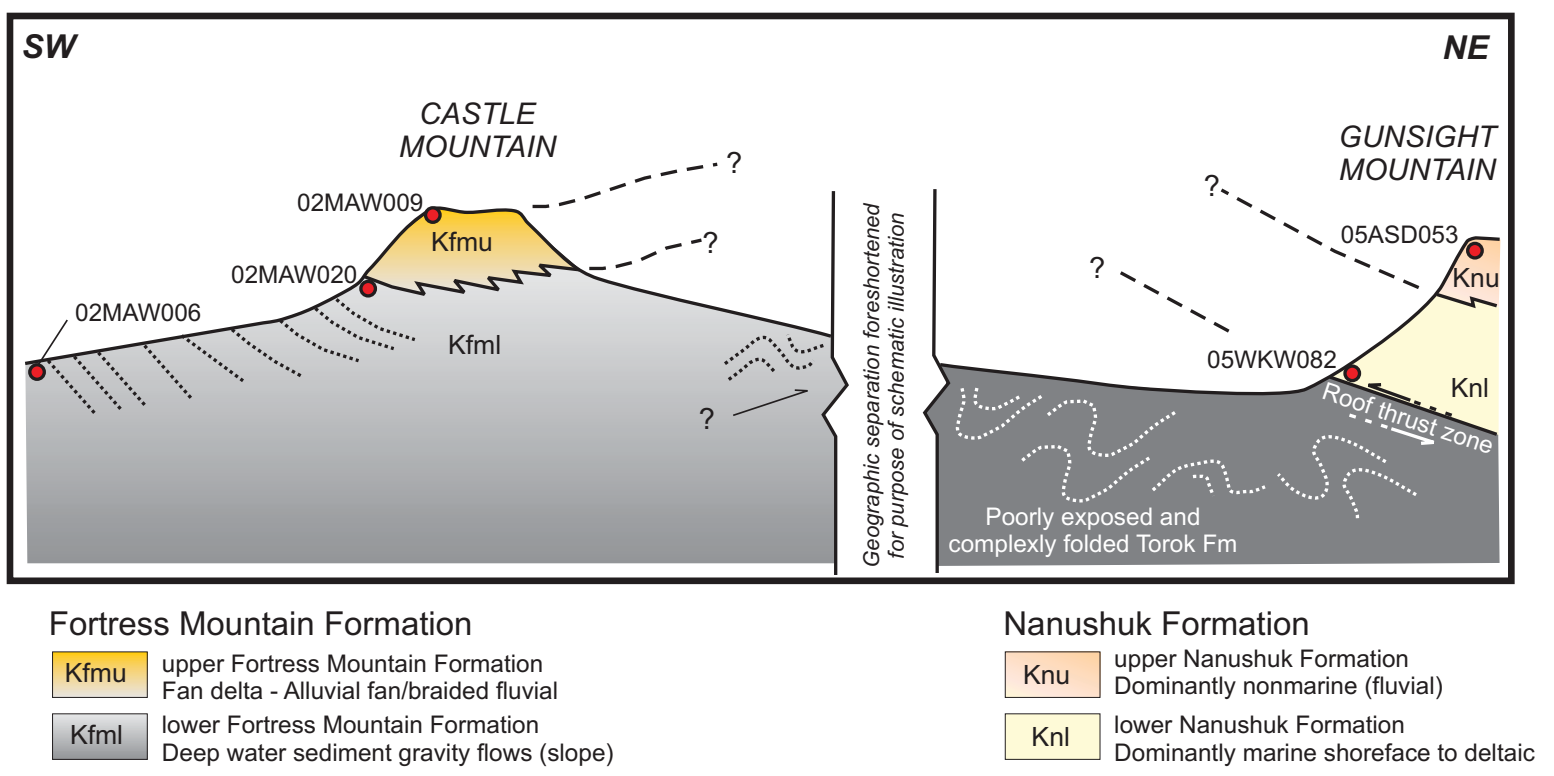

Figure 4. Schematic cross section illustrating the geography of the Fortress Mountain and Nanushuk trends and the stratigraphic uncertainty of their relationship. Note the relative location of samples in this study. 


\section{Stratigraphic Relationships}

The Fortress Mountain Formation includes a variety of facies ranging from deep marine basin floor up through alluvial fan environments (Wartes, 2008, this volume; Houseknecht and others, 2007; Crowder, 1989; Molenaar and others, 1988; Hunter and Fox, 1976). The type section of the Fortress Mountain Formation consists of a series of discontinuous exposures in the Castle Mountain area (fig. 2; Patton and Tailleur, 1964). This 3,000-m-thick section is considerably thicker than any other known outcrop of the formation and is interpreted to grade from basin floor(?) to slope facies up through fan delta, alluvial fan, and braided fluvial facies (Molenaar and others, 1988; Crowder, 1987).

The Nanushuk Formation records deposition in marine shelf, deltaic, and fluvial environments (Ahlbrandt, 1979; Huffman, 1985; LePain and others, 2008). Seismic data clearly indicate that Nanushuk topsets transition basinward (to the northeast) into clinoforms of the Torok Formation (Molenaar, 1988; Houseknecht and Schenk, 2001). In the east-central foothills, where the samples for this study were collected, the Nanushuk is approximately 1,600 m thick (Patton and Tailleur, 1964) and is subdivided into a marine lower part and a dominantly nonmarine upper part (fig. 3; Mull and others, 2003).

Regionally, the Fortress Mountain formation rapidly fines northward and locally grades into rocks assigned to the lower Torok Formation (Patton and Tailleur, 1964; Molenaar and others, 1988; fig. 3). However, at Castle Mountain the upper $350 \mathrm{~m}$ of section includes the most proximal nonmarine facies interpreted as alluvial fan and braided fluvial. The northerly equivalent of this nonmarine succession is not known and it remains possible that it graded northward into the marine facies of the lower Nanushuk. The uncertain relationship between the two units is schematically illustrated in figure 4 .

\section{Sandstone Composition}

In hand sample, sandstones of the Nanushuk Formation are often lighter colored and appear less lithic rich than darker greenish-gray-weathering Fortress Mountain Formation sandstones. This qualitative observation is borne out by regional petrographic data that indicate that Nanushuk samples from the central and eastern foothills average about 58 percent total quartz (Bartsch-Winkler and Huffman, 1988), whereas Fortress Mountain samples average only 32 percent quartz in the east-central outcrop belt (Molenaar and others, 1988). An additional notable difference documented in these studies is captured in the metamorphic lithics, which average 15 percent for the Nanushuk samples as compared to only 1 percent for Fortress Mountain samples. This stark difference was also noted by Johnsson and Sokol (2000), who documented as much as 30 percent metamorphic lithic fragments in the easternmost exposures of the Nanushuk Formation.

\section{Biostratigraphy}

The Fortress Mountain Formation is generally ascribed an Aptian(?) to early Albian age, whereas the Nanushuk Formation is regarded as middle Albian to Cenomanian (fig. 3). These assignments largely reflect detailed megafossil work done by the USGS in the 1950s and 1960s, most notably Imlay (1961). The shallow marine Nanushuk Formation has generally yielded a more diverse fauna and the biostratigraphic range can be considered more robust than the Fortress Mountain Formation. The majority of the biostratigraphic control for the Fortress Mountain Formation came from the lower third of the unit (Patton and Tailleur, 1964), leaving the upper limit of the formation in question.

Bivalves identified as similar to Inoceramus anglicus and Inoceramus altifluminis were reported from both the Fortress Mountain and Nanushuk Formations by Imlay (1961). In Alberta and British Columbia, these species were generally regarded as no older than middle Albian (McLearn, 1945). On the basis of the entire fossil assemblage from the Fortress Mountain Formation, particularly ammonite specimens, Imlay (1961) favored an interpretation that these Inoceramids must have ranged down into the early Albian in northern Alaska. More recently, Kelley (1990) reported additional specimens of I. anglicus from the Fortress Mountain Formation at Hoary Marmot Mountain (informal name; fig. 2). He interpreted an age no older than middle Albian and concluded the exposure was likely coeval with the lower part of the Nanushuk Formation.

Palynological and foraminiferal data generally offer limited biostratigraphic resolution for any of the Fortress, Nanushuk, or Torok Formations, and typically yield a significant number of “Aptian-Albian” or “Lower Cretaceous undifferentiated” age assignments (unpublished DGGS micropaleontology reports). However, there is a general observation that can be gleaned from the subset of samples that do preserve abundant age-diagnostic microfossils: the Fortress Mountain Formation samples do not appear to produce ages younger than Aptian to early Albian and the Nanushuk Formation in the central foothills does not yield ages older than middle to late Albian (written commun., M. Mickey, 2006; LePain and others, 2008). 


\section{NEW DATA}

As outlined in the preceding sections, existing constraints have proven inadequate to definitively assess the stratigraphic relationship between the Fortress Mountain and Nanushuk Formations. The following new data attempts to address the question by focusing on the provenance of the two units, specifically the U-Pb ages of detrital zircons.

\section{Detrital Zircon Geochronology}

Zircon is a common heavy mineral in most siliciclastic systems and is highly resistant to weathering and diagenesis (Fedo and others, 2003). Recent advances in analytical technology have allowed for the rapid acquisition of a large number of U-Pb ages from individual detrital zircons (Gehrels and others, 2006). The addition of this geochronologic component is revolutionizing studies of sedimentary provenance, particularly regional paleogeographic and tectonic studies (Gillis and others, 2005; Dickinson and Gehrels, 2003).

\section{Sample Selection and Methods}

In order to assess the population of detrital zircon ages from each formation, samples were selected from some of the thicker, more continuous exposures in the foothills. In the case of the Fortress Mountain Formation, three samples were selected from the type section at Castle Mountain, one from the lower and two from the upper part of the formation (figs. 2 and 4; table 1). This section is particularly appropriate as it likely contains the stratigraphically highest Fortress Mountain Formation exposed anywhere in the foothills. Two Nanushuk Formation samples were analyzed from well-exposed bluffs where the Siksikpuk River cuts across the Tuktu escarpment area; one sample is from the very base of the formation, the other from upper Nanushuk on Gunsight Mountain (figs. 2 and 4; table 1).

Zircons were separated at the Apatite-to-Zircon, Inc. laboratory using heavy liquid and magnetic separation techniques. Grains were mounted in epoxy and polished to expose grain interiors for analysis. One-hundred grains were selected at random and dated for each sample, a number commonly sought by most workers and one that reduces the probability of missing any given provenance components to < 5 percent (Dodson and others, 1988). Uranium, thorium, and lead isotope data were collected at the Washington State University Geoanalytical Laboratory on a ThermoFinnigan Element2 magnetic sector double-focusing ICP-MS (inductively coupled plasma-mass spectrometer). Each grain underwent laser ablation using a New Wave Research UP-213 system. See Chang and others (2006) for additional details regarding laboratory procedures such as standards and error corrections.

Table 1. Sample location information; note map number that refers to sample notation in figure 4.

\begin{tabular}{|c|c|c|c|}
\hline \multirow[b]{2}{*}{$\begin{array}{l}\text { Sample } \\
\text { Number }\end{array}$} & \multicolumn{3}{|c|}{ LOCATION } \\
\hline & Map \# & Description & Latitude / Longitude \\
\hline 05ASD053 & (1) & $\begin{array}{l}\text { Gunsight Mountain } \\
\text { Top of Nanushuk Fm. }\end{array}$ & N 68.71775 W 151.83504 \\
\hline 05WKW082 & $(2)$ & $\begin{array}{l}\text { Siksikpuk River } \\
\text { Base of Nanushuk Fm. }\end{array}$ & N 68.72206 W 151.88918 \\
\hline 02MAW009 & (3) & $\begin{array}{l}\text { Castle Mountain summit } \\
\text { Top of Fortress Mountain Fm. }\end{array}$ & N 68.56649 W 152.58198 \\
\hline 02MAW020 & (4) & $\begin{array}{l}\text { Castle Mountain base } \\
\text { upper Fortress Mountain Fm. }\end{array}$ & N 68.56365 W 152.60785 \\
\hline
\end{tabular}




\section{Detrital zircon populations}

Appendix C-1 includes isotopic ratio and age data for 500 individual U-Pb zircon analyses. Only one grain from sample 02MAW020 produced strongly discordant data and was rejected. For ages up to $1000 \mathrm{Ma}$, the ${ }^{206} \mathrm{~Pb} /{ }^{238} \mathrm{U}$ age is selected as the most precise; those greater than $1000 \mathrm{Ma}$ are taken from the ${ }^{206} \mathrm{~Pb} /{ }^{207} \mathrm{~Pb}$ ages (see Gehrels and others, 2006). The age distribution data for each of the five samples are plotted in a histogram format and cumulative probability curves (figs. 5-9). Histograms illustrate the number of ages that fall into each 50 Ma bin. Cumulative probability curves, which are a common method for displaying detrital zircon data, represent the normalized sum of probability distributions for all analyses from a sample. Age peaks are only considered statistically significant if defined by several analyses. All plots were created using Isoplot/Ex v. 3.32 (Ludwig, 2005).

\section{DISCUSSION}

The detrital zircon data reveal statistically significant differences between the two formations. This is best illustrated by comparing selected groups of grain ages (table 2, figs. 10 and 11). All three Fortress Mountain Formation samples include abundant Permian grains (10-19 percent), whereas the Nanushuk samples yielded only one Permian grain between both samples. Typically the parent lithology of individual zircons is difficult to assess. However, in the case of the Permian age spike, U-Pb zircon ages from igneous clasts within the Fortress Mountain Formation (Wartes and others, 2006) indicate the detrital population observed in this study was derived from an unknown tonalitic-dacitic igneous complex.

Late Neoproterozoic to Cambrian ages (500-665 Ma) form a prominent peak in both Nanushuk samples (average 23 percent) but are much less abundant, on average, in the Fortress Mountain samples (7 percent). Nanushuk samples also contain a discrete pulse of early Neoproterozoic ages (850-950 Ma) that is much less common in the Fortress Mountain samples. Similarly, Mesoproterozoic ages ( 1000-1300 Ma) form prominent peaks in both Nanushuk samples (average 20 percent), while the Fortress Mountain samples include a very weak record of this provenance (average 5 percent). Finally, although the Nanushuk Formation samples contain significantly larger proportion of Precambrian grains, the Fortress Mountain samples average almost three times more early Proterozoic grain ages (Orosirian period 1800-2050 Ma).

If the Fortress Mountain and Nanushuk Formations were in part correlative, it seems probable that the uppermost Fortress Mountain sample (02MAW009) would have been most similar to the basal Nanushuk sample (05WKW082). In fact, these two samples produced some of the starkest contrasts in several groupings of detrital grain ages (table 2; figs. 10 and 11). The two formations clearly have a different provenance for zircons and the

Table 2. Comparison of significant detrital-age groupings highlighting noteworthy differences between the Nanushuk and the Fortress Mountain Formations. Age groupings are listed as numbers of ages within each "bin”, although since 100 grains were dated for each sample, these numbers are effectively percentages as well.

\begin{tabular}{|c|c|c|c|c|c|c|}
\hline \multirow[b]{2}{*}{ Sample No. } & \multicolumn{6}{|c|}{ SIGNIFICANT GROUPINGS OF DETRITAL AGES } \\
\hline & 251-299 $\mathrm{Ma}^{\mathrm{a}}$ & $500-665 \mathrm{Ma}^{\mathrm{b}}$ & $850-950 \mathrm{Ma}^{\mathrm{c}}$ & $1.00-1.35 \mathrm{Ga}^{\mathrm{d}}$ & $1.80-2.05 \mathrm{Ga}^{\mathrm{e}}$ & $>542 \mathrm{Ma}$ \\
\hline \multicolumn{7}{|c|}{ NANUSHUK FORMATION } \\
\hline 05ASD053 & 1 & 14 & 12 & 24 & 6 & 76 \\
\hline $05 W K W 082$ & 0 & 32 & 14 & 16 & 4 & 82 \\
\hline AVERAGE & $0.5 \%$ & $23 \%$ & $13 \%$ & $20 \%$ & $5 \%$ & $79 \%$ \\
\hline \multicolumn{7}{|c|}{ FORTRESS MOUNTAIN FORMATION } \\
\hline 02MAW009 & 19 & 2 & 5 & 4 & 10 & 40 \\
\hline 02MAW020 & 18 & 14 & 3 & 7 & 13 & 58 \\
\hline 02MAW006 & 10 & 5 & 3 & 4 & 20 & 54 \\
\hline AVERAGE & $16 \%$ & $7 \%$ & $4 \%$ & $5 \%$ & $14 \%$ & $51 \%$ \\
\hline $\begin{array}{l}{ }^{\mathrm{a}} \text { Permian period, based o } \\
{ }^{\mathrm{b}} \text { Globally significant oro } \\
{ }^{\mathrm{c}} \text { Part of the early Neopro } \\
{ }^{\mathrm{d}} \text { Globally significant oro } \\
{ }^{\mathrm{e}} \text { Orosirian period of the }\end{array}$ & $\begin{array}{l}\text { timescale of Ogg } \\
\text { genic episode spann } \\
\text { erozoic } \\
\text { genic episode in the } \\
\text { aleoproteroic, base }\end{array}$ & $\begin{array}{l}\text { g04) } \\
\text { the late Neoproter } \\
\text { esoproterozoic (e.g } \\
\text { n timescale of Ogg }\end{array}$ & $\begin{array}{l}\text { oic - Cambrian (e.g } \\
\text { YcLelland and other } \\
004 \text { ) }\end{array}$ & $\begin{array}{l}\text { Murphy and Nance, } 1 \\
\text { 1996) }\end{array}$ & 91) & \\
\hline
\end{tabular}



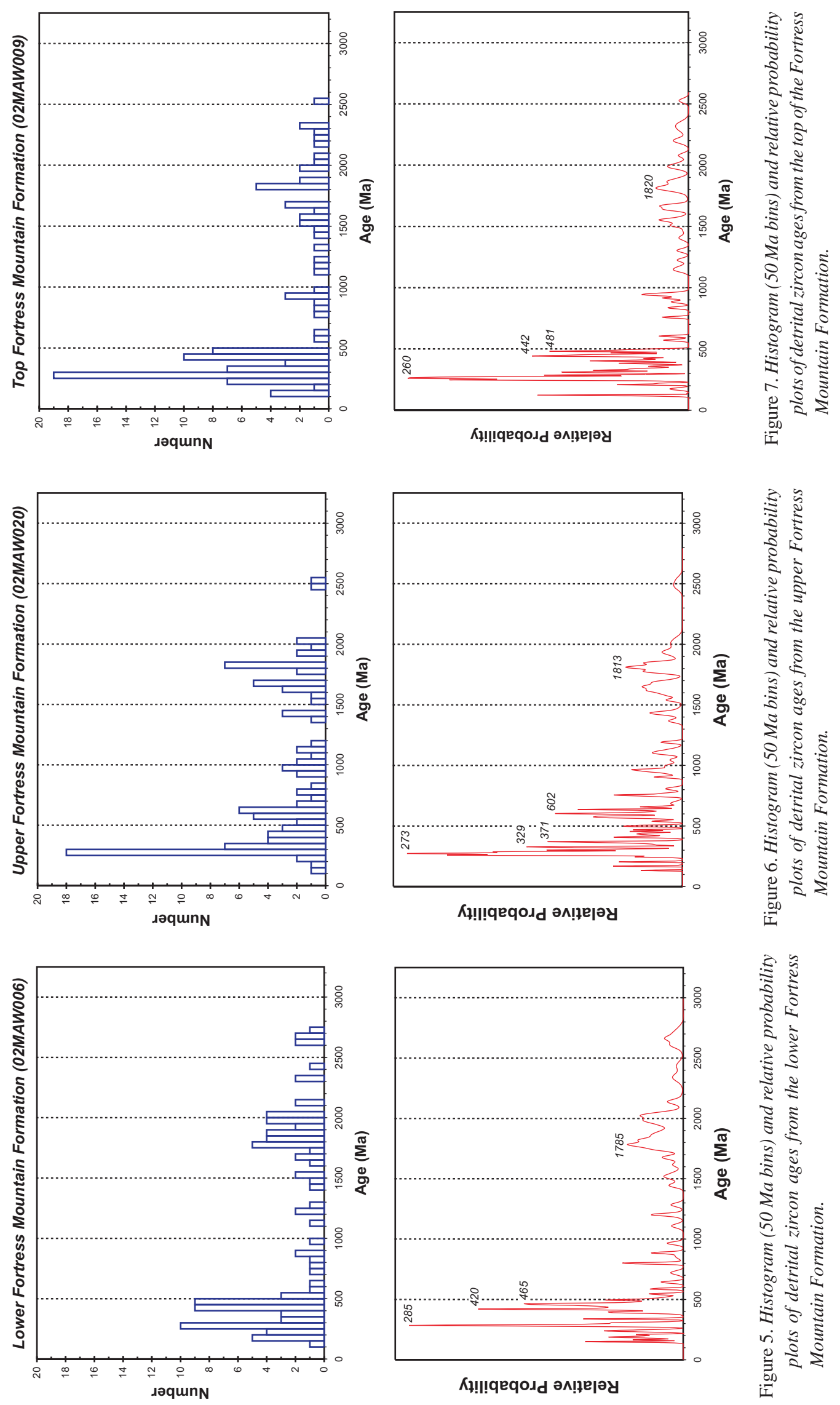

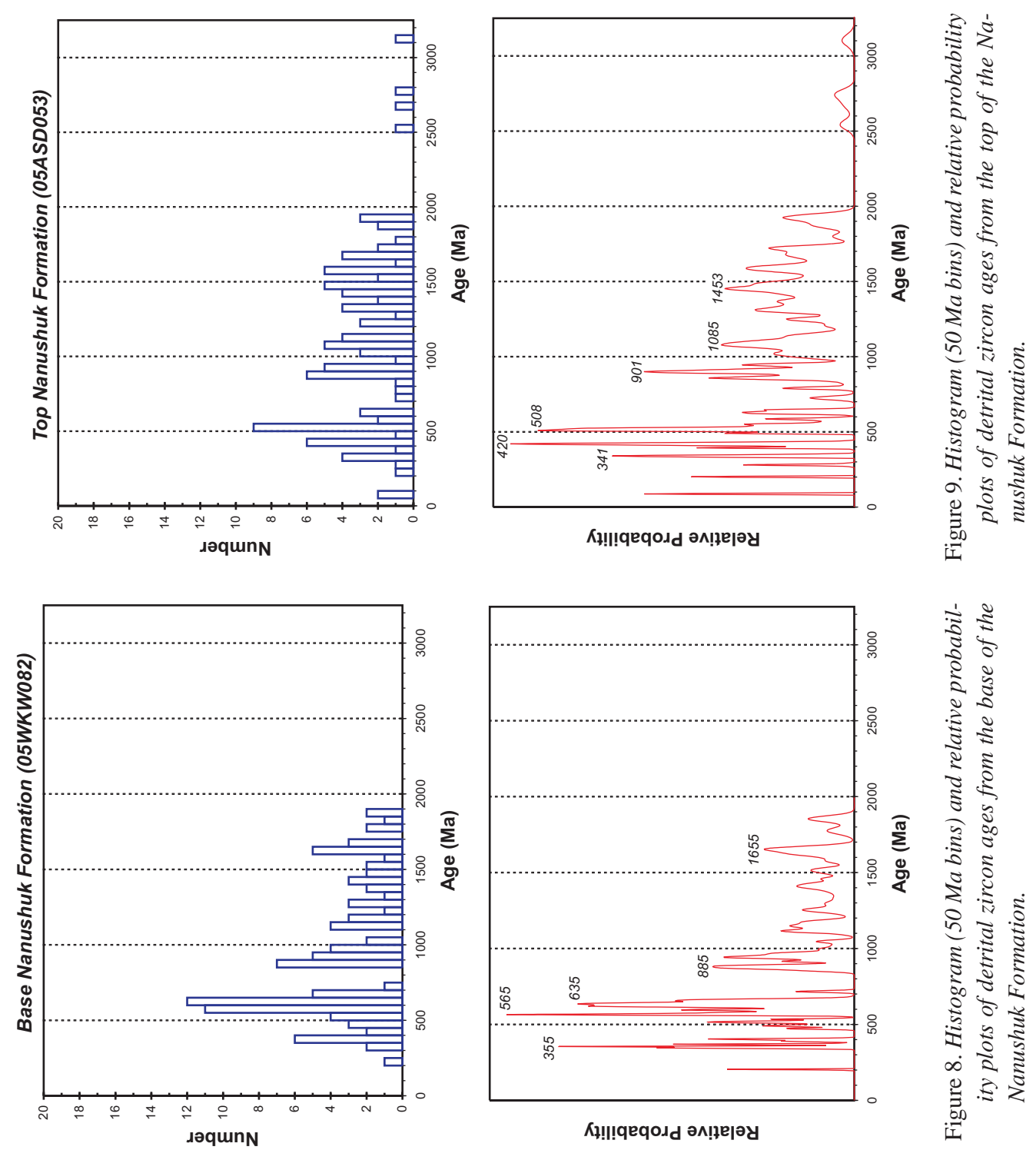

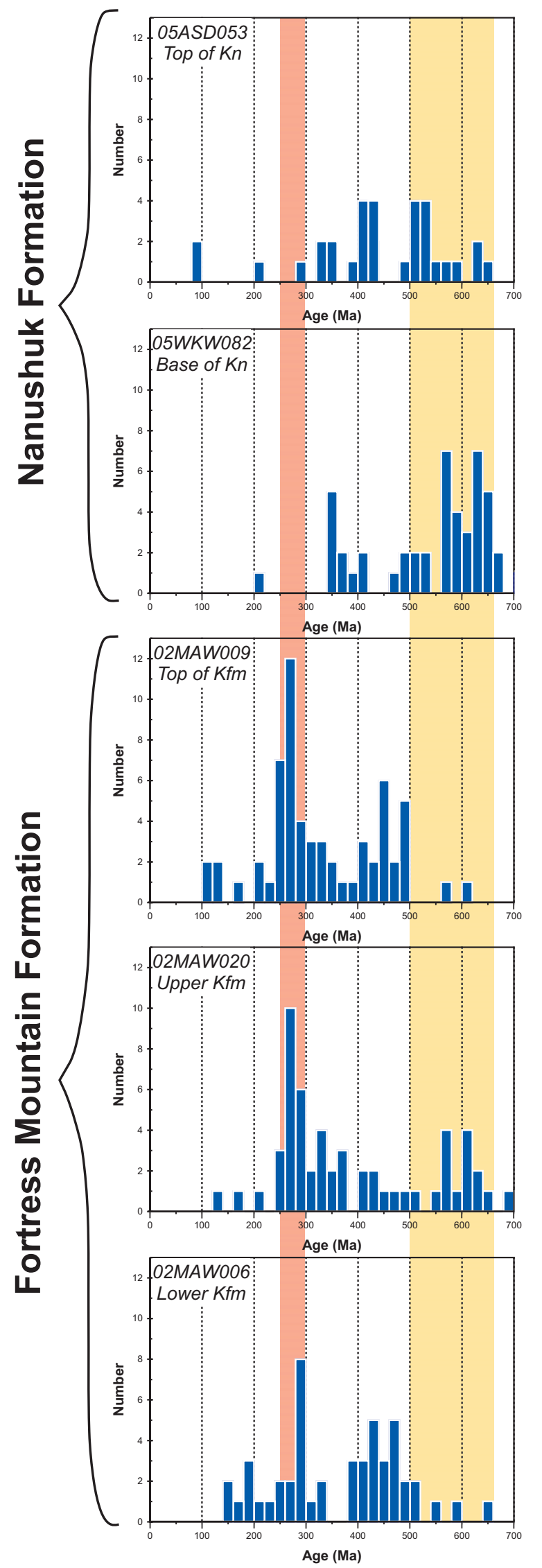

Permian ages

( 251 - $299 \mathrm{Ma})$

late Neoproterozoic - Cambrian "Pan-African" ages ( 500 - $665 \mathrm{Ma})$

Figure 10. Histograms (20 Ma bins) depicting a subset of grain age populations (0-700 Ma). Samples are stacked in interpreted stratigraphic order. Highlighted groupings illustrate the significant differences between Fortress Mountain and Nanushuk Formation samples (see also table 2). "Pan-African" refers to a globally significant orogenic episode (Murphy and Nance, 1991).

balance of these results favors an interpretation that the two units do not represent parts of a single clastic wedge.

Very little $\mathrm{U}-\mathrm{Pb}$ zircon geochronologic data exists for the Brooks Range and precise correlations between these detrital ages and specific units in the fold-and-thrust belt is premature and beyond the scope of this paper. Instead, the more salient, first order result from this study is that the Fortress Mountain and Nanushuk Formations were clearly tapping unique and different source areas and represent discrete phases in the unroofing sequence. This agrees with existing conventional petrographic point-count data noted earlier, which indicated clear differences in framework grain composition between the two formations (Bartsch-Winkler and Huffman, 1988; Molenaar and others, 1988). However, in some respects, the zircon data provide a more robust and quantitative comparison of the two units. It has long been recognized that sandstone mineralogy can be strongly influenced by transport distance (Pettijohn, 1957), particularly the labile components (Mack, 1978) that are abundant in both units. Given the geographic separation of the Fortress Mountain and Nanushuk outcrop belts, it remains possible that the observed differences were simply a function of transport biases. In contrast, durable zircons are unlikely to undergo significant weathering or fractionation along a depositional profile (Morton and Smale, 1991).

Ultimately, these provenance differences have stratigraphic implications and suggest the youngest exposed Fortress Mountain Formation is not correlative with the basal Nanushuk Formation. This interpretation is consistent with most depictions of Cretaceous stratigraphy, which show a tongue of the Torok Formation separating the sandstone-rich Fortress Mountain and Nanushuk sequences (Mull and others, 2003; figs. 3 and 12). The uppermost Fortress Mountain Formation at Castle Mountain records alluvial fan and braided fluvial deposition (Molenaar and others, 1988; Crowder, 1987). Thus, if a succession of Torok mudstones originally overlay this interval, it would represent a transgressive sequence (fig. 12b). This hypothesis is difficult to evaluate due 

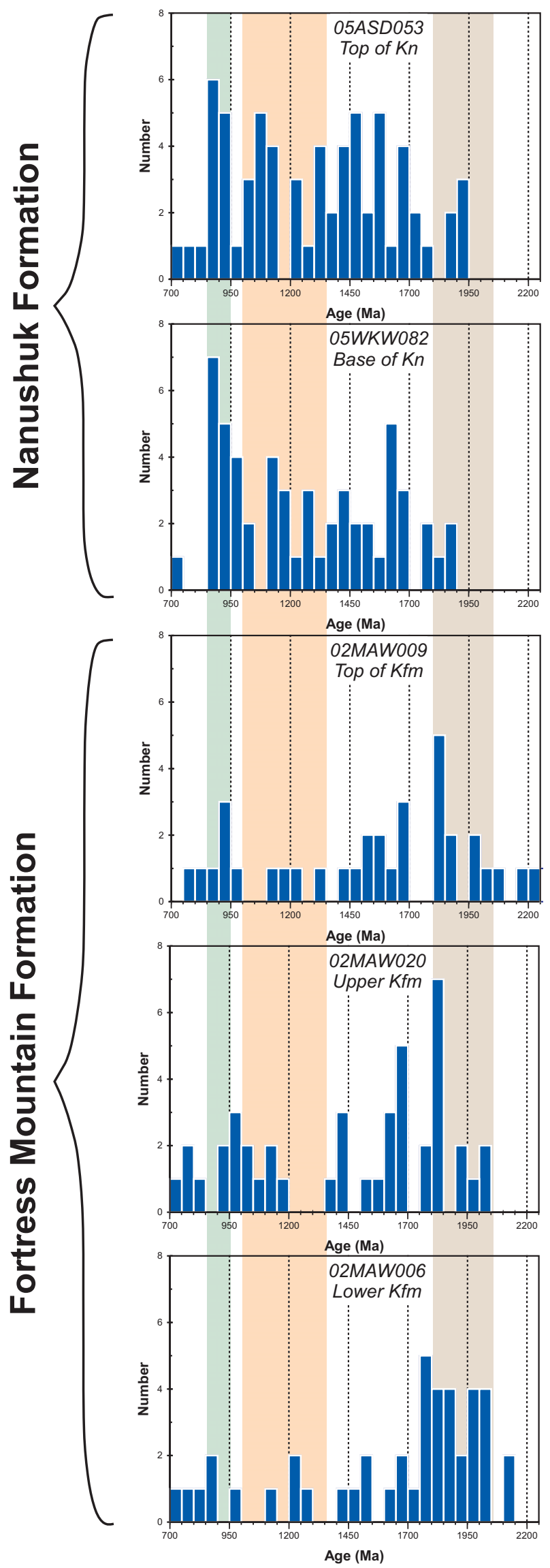

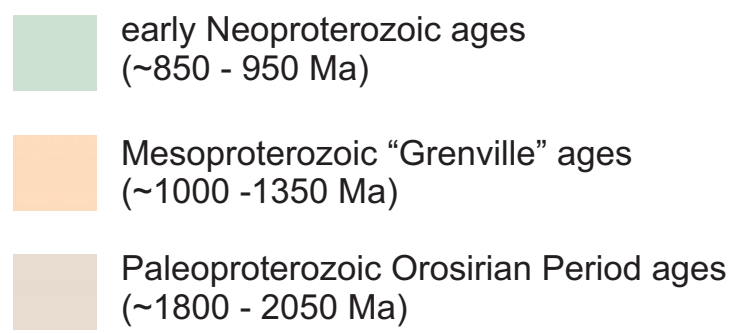

Figure 11. Histograms (50 Ma bins) depicting a subset of grain age populations (700-2250 Ma). Samples are stacked in interpreted stratigraphic order. Highlighted groupings illustrate the significant differences between Fortress Mountain and Nanushuk Formation samples (see also table 2). "Grenville” refers to a globally significant orogenic episode (McLelland and others, 1996); Orosirian is a Mesoproterozoic period (Ogg, 2004).

to the lack of exposed formation tops in Fortress Mountain exposures (fig. 12a; see also figure 4a of Bird and Molenaar, 1992). However, a few regional observations have cited evidence for an upward deepening at the top of the Fortress Mountain Formation. For example, in the Ekakevik Mountain area (fig. 1), Hunter and Fox (1976) noted that the formation generally fines upward and, where best exposed, the top of the formation was characterized by transgressive shallow marine facies overlying nonmarine conglomerate. Farther west, between Poko and Igloo mountains (fig. 1), Mull (1985) inferred a gradational contact between the Fortress Mountain Formation and overlying fine-grained facies of the Torok Formation.

A major flood back of Torok slope facies over nonmarine-marginal marine Fortress Mountain Formation was recently recognized in the Siksikpuk River area (labeled as Kfm-Kto contact on fig. 2; Houseknecht and others, 2007; Peapples and others, 2007). However, this section is here interpreted as relatively low in the composite Fortress Mountain succession (Patton and Tailleur, 1964), suggesting that the transgressive event is intra-Fortress Mountain, rather than marking the regional top of the formation. It is also possible there is regional variation in the position of the top of the Fortress Mountain Formation and that flooding of the Torok Formation across the Fortress Mountain Formation was diachronous locally, varying according to paleotopography across the complex orogenic wedge (Wartes and Swenson, 2005). Similarly complex relationships are known from the better-studied Upper Cretaceous foreland basin strata of the Western Interior Seaway (Krystinik and DeJarnett, 1995).

Existing data do not unequivocally rule out a scenario whereby now-eroded sections of the Fortress Mountain Formation once existed above Castle Mountain and formed part of a unified prograding clastic wedge that 
graded northward into the lower Nanushuk deltas (fig. 12c; see also figure 25.3c in Molenaar, 1988). However, if such a section existed, then a substantial upsection change in provenance would be required within the uppermost proximal Fortress Mountain Formation. Based on available data (including that presented here), it seems more probable that the Fortress Mountain and Nanushuk Formations are regionally separated by an intervening tongue of the Torok Formation (fig. 12b), possibly recording a basin-scale change in the balance between sediment supply and newly created accommodation.

The Torok Formation can be generically subdivided into lower and upper parts, roughly corresponding to proximal Fortress Mountain and Nanushuk Formations, respectively (Mull and others, 2003; fig. 3). If a tongue of Torok separates these two progradational sequences (fig. 12b) —an interpretation that is favored here-then it may prove useful to consider a tripartite genetic subdivision of the formation (fig. 13). It is difficult to evaluate this proposed subdivision in the outcrop belt where distinctions between lower, middle, and upper parts of the formation are hampered by: (1) inadequate biostratigraphic resolution, (2) non-unique, fine-grained facies, (3) discontinuous exposures, and (4) complex structure (Patton and Tailleur, 1964; Mull, 1985; Molenaar and others, 1988; Houseknecht and Schenk, 2007; Houseknecht and others, 2007). Regional seismic and well data indicate that an older succession of Brookian rocks exists beneath the Nanushuk-related Torok clinoforms (Molenaar, 1988). In the northern foothills, Houseknecht and Schenk (2001) document that this older Torok "foredeep wedge" was derived from the west and traced individual Torok clinoforms into Nanushuk topsets. However, this wedge continues to thicken dramatically southward, probably including southerly sourced Fortress Mountain-related lower(?) Torok facies (Cole and others, 1997; Molenaar, 1988). Regardless, in light of the strong differences in detrital zircon ages within the proximal Fortress Mountain and Nanushuk Formations, it seems likely that the affinity of isolated Torok samples could be reliably assessed with the technique outlined in this study.

The new provenance data presented here confirm that the Fortress Mountain and
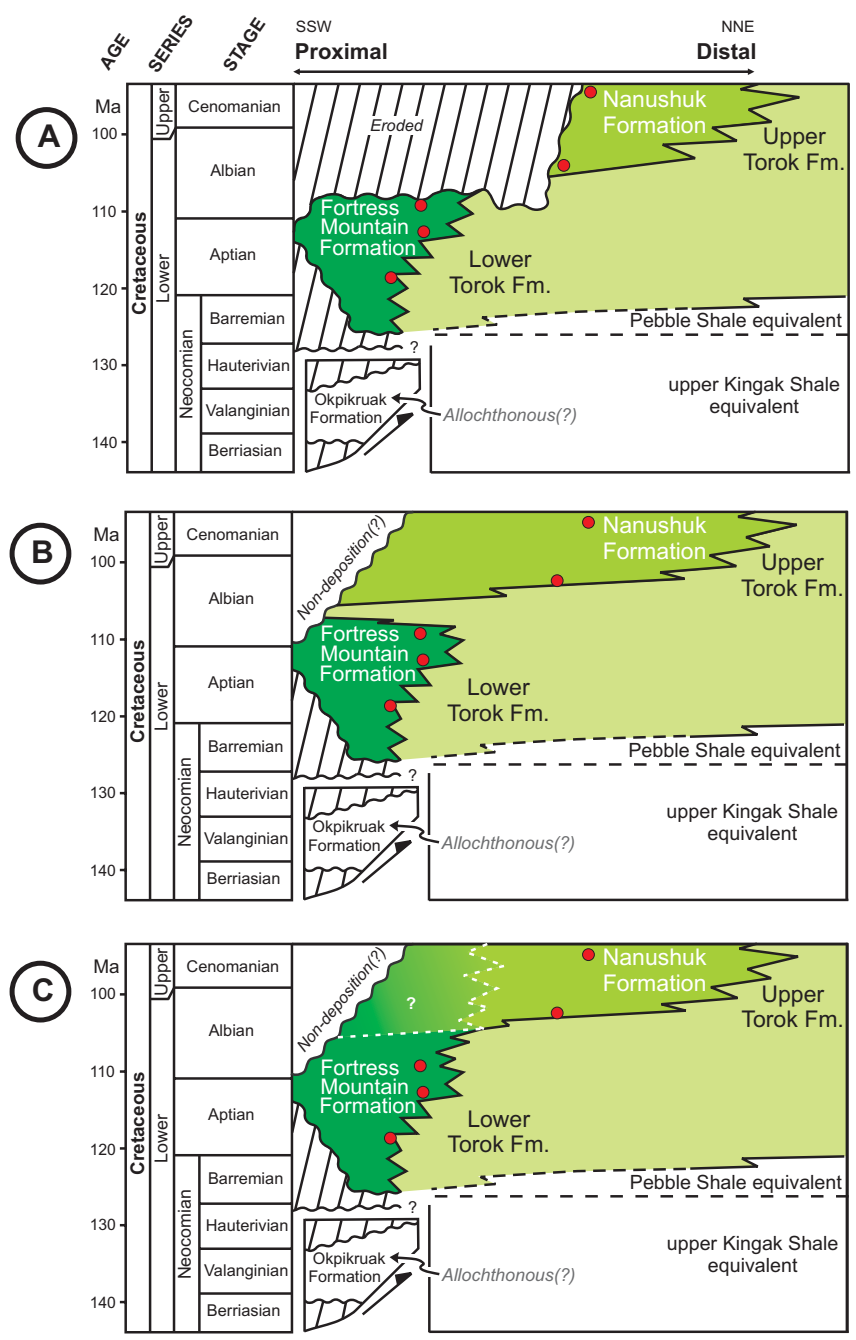

Figure 12. Chronostratigraphic diagrams illustrating relationships between the Fortress Mountain, Nanushuk, and Torok Formations discussed in the text. Approximate sample positions shown by red dots. (A) Depiction of the observed spatial context of Fortress Mountain and Nanushuk exposures, highlighting the ambiguity of proposed stratigraphic correlations between the two units. This diagram contrasts with the common schematic representation of Early Cretaceous stratigraphy (Mull and others, 2003; fig. 3) and emphasizes that the top of the Fortress Mountain Formation is a Holocene erosion surface and that the Nanushuk Formation cannot be demonstrated to overlie the Fortress Mountain Formation based on field evidence alone. On the basis of the available constraints discussed in the text, this figure interprets the exposed Fortress Mountain Formation as entirely older than the Nanushuk Formation in this area. (B \& C) Portrayal of two possible stratigraphic scenarios as they would have appeared at the close of Nanushuk deposition: (B) proposes a retrogradational tongue of Torok separated the Fortress Mountain and Nanushuk Formations (model favored in this study), while (C) illustrates a model where the Fortress Mountain and Nanushuk Formations represent a continuous northward-prograding clastic wedge (see also figure 25.3c in Molenaar, 1988). 


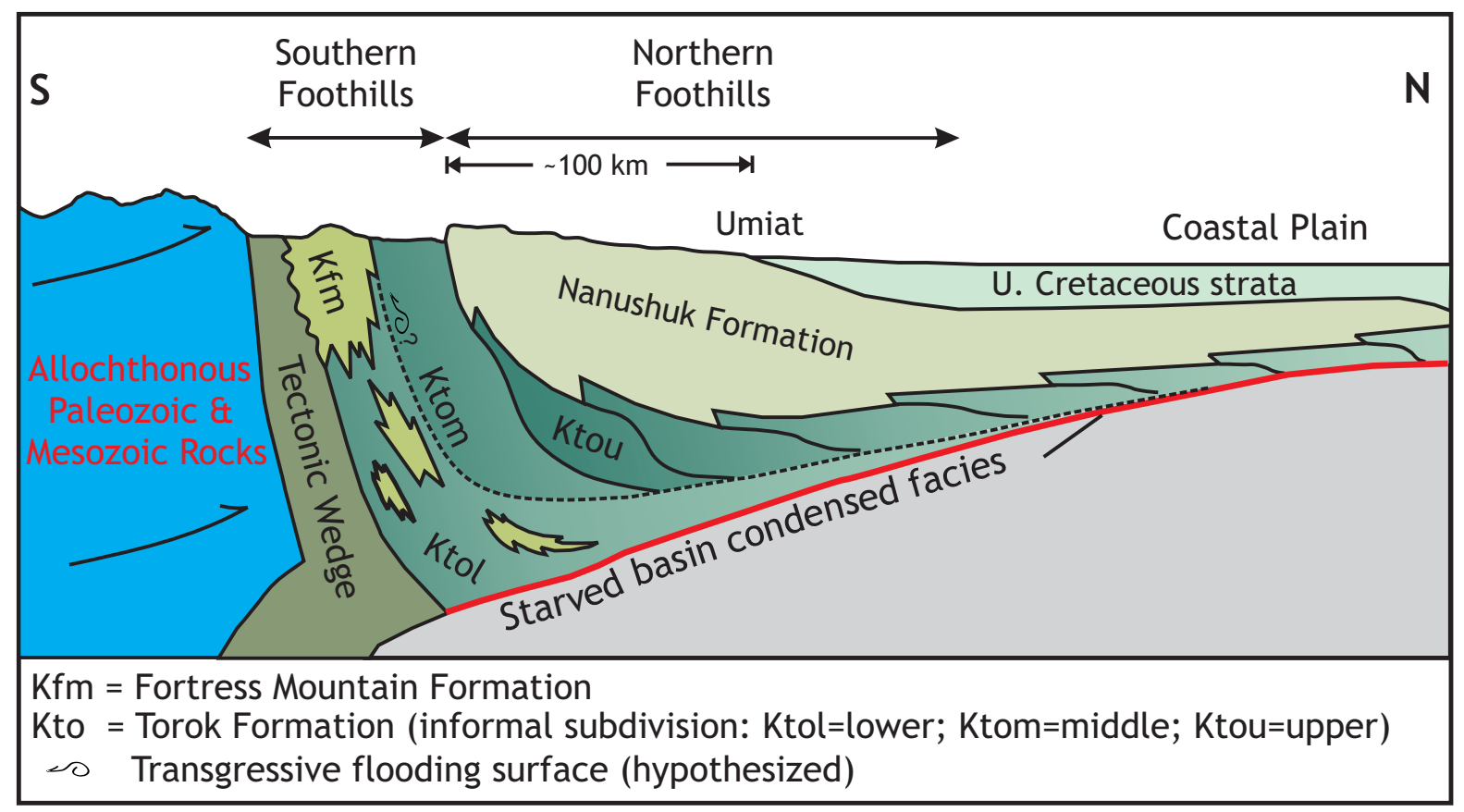

Figure 13. Schematic cross section of the Colville Basin (modified from Mull, 1985, and Houseknecht and Schenk, 2001). The middle Torok is speculated to be a retrogradational package separating the Fortress Mountain and Nanushuk Formations.

Nanushuk Formations were clearly derived from different sources. Provided the two units both record unroofing of the nearby ancestral Brooks Range, it follows that the exposed Fortress Mountain Formation represents an entirely older depositional system than the Nanushuk topsets (as shown in fig. 12a). However, it remains possible that the two units are partly coeval and that the detrital zircon data reflects two different major sediment dispersal systems - transverse, Brooks Range-derived Fortress Mountain Formation and axially fed Nanushuk facies tapping a different source region to the west. Even in better-studied foreland basins, identifying the relative roles of axial versus transverse systems is difficult (Clevis and others, 2004). Farther north, in central NPRA (fig. 1), seismically mapped shelf margins indicate the Nanushuk-Torok depositional system is fed principally out of the west (Molenaar, 1988; Houseknecht and Schenk, 2001). However, the origin of Nanushuk topsets in the area sampled in this study were most likely sourced from transverse, north-flowing rivers as indicated by paleocurrent data as well as contrasting deltaic style and provenance relative to the demonstrably western-sourced axial deltaic system (Huffman and others, 1988; Molenaar, 1988; LePain and others, in press).

The focus of this paper has been the stratigraphic implications of a modest new detrital zircon data set. Future papers will examine the potential sources of various zircon age populations and the broader tectonic implications of these data. However, it is worth noting that the marked change in provenance outlined in this study occurred at approximately the early to middle Albian boundary, a time characterized by significant tectonic events in the Brooks Range hinterland (Vogl, 2002). In other words, the provenance changes may reflect discrete tectonicallydriven exhumation and orogen-wide reorganization of drainages.

\section{CONCLUSIONS}

New detrital zircon age data indicate the Fortress Mountain and Nanushuk Formations in the central Brooks Range foothills were sourced from unique and different provenances. Significantly different populations of grain ages suggest the Fortress Mountain and Nanushuk depositional systems were not part of a unified north-northeasterly prograding clastic wedge. Instead, the youngest exposed Fortress Mountain Formation is here interpreted to be entirely older than the Nanushuk Formation. Based on available data, it is inferred that the Fortress Mountain and Nanushuk Formations are separated by a transgressive tongue of the Torok Formation, although more data are needed to definitively reject alternate hypotheses. In particular, additional subsurface information will be required to document stratigraphic relationships that are presently ambiguous. 


\section{ACKNOWLEDGMENTS}

The impetus for this study came from a number of outcrop discussions with A. Carroll, who, unbiased by any North Slope geological dogma, posed a number of insightful questions regarding established Brookian stratigraphic relationships, including, “Are you sure the Fortress Mountain and Nanushuk Formations aren’t, in part, correlative?” The ideas presented here also benefited from numerous discussions with D. LePain, R. Gillis, T. Moore, P. Decker, G. Mull, R. Reifenstuhl, R. Swenson, W. Wallace, D. Houseknecht, and P. O’Sullivan. A version of figure 13 was kindly provided by D. LePain. Funding for part of the original work in the Castle Mountain area was generously supplied to the University of Wisconsin by Anadarko Petroleum Corporation. DGGS studies in the foothills are supported by industry contributions from Anadarko, FEX, BG Alaska, Chevron, Petro-Canada, Pioneer Natural Resources, ENI, Shell, and ConocoPhillips. Funding for DGGS geologic mapping in the Siksikpuk River area was provided by the state of Alaska and the U.S. Geological Survey National Cooperative Geologic Mapping Program (award numbers 04HQAG0061 and 05HQAG0025). This paper benefitted from constructive review comments by Bob Gillis.

\section{REFERENCES}

Ahlbrandt, T.S., ed., 1979, Preliminary geologic, petrologic, and paleontologic results of the study of Nanushuk Group rocks, North Slope, Alaska: U.S. Geological Survey Circular 794, 163 p.

Bartsch-Winkler, S., and Huffman, A.C., Jr., 1988, Sandstone petrography of the Nanushuk Group and Torok Formation, in Gryc, George, ed., Geology and exploration of the National Petroleum Reserve in Alaska, 1974 to 1982: U.S. Geological Survey Professional Paper 1399, p. 801-831.

Bird, K.J., and Molenaar, C.M., 1992, The North Slope foreland basin, Alaska, in Macqueen, R.W., and Leckie, D.A., eds., Foreland basins and fold belts: AAPG Memoir 55, p. 363-393.

Chang, Z., Vervoort, J.D., McClelland, W.C., and Knaack, C., 2006, U-Pb dating of zircon by LA-ICP-MS: Geochemistry, Geophysics, Geosystems, v. 7, no. 5, Q05009.

Clevis, Q., DeBoer, P.L., and Nijman, W., 2004, Differentiating the effect of episodic tectonism and eustatic sea-level fluctuations in foreland basins filled by alluvial fans and axial deltaic systems: insights from a threedimensional stratigraphic forward model: Sedimentology, v. 51, p. 809-835.

Cole, F.E., Bird, K.J., Toro, J., Roure, F., O’Sullivan, P.B., Pawlewicz, M.J., and Howell, D.G., 1997, An integrated model for the frontal Brooks Range and Colville Basin 250 km west of the Trans-Alaska Crustal Transect: Journal of Geophysical Research, v. 102, p. 20,685-20,708.

Crowder, R.K., 1987, Cretaceous basin to shelf transition in northern Alaska; deposition of the Fortress Mountain Formation, in Tailleur, I.L., and Weimer, P., eds., Alaskan North Slope geology: Pacific Section, SEPM, Bakersfield, CA, v. 50, p. 449-458.

—Deposition of the Fortress Mountain Formation, in Mull, C.G., and Adams, K.E., eds., Dalton Highway, Yukon River to Prudhoe Bay, Alaska: Alaska Division of Geological \& Geophysical Surveys Guidebook 7, v. 2, p. 293-301.

Detterman, R.L., 1956, New and redefined nomenclature of Nanushuk Group: AAPG Bulletin, v. 40, p. 233244.

Dickinson, W.R., and Gehrels, G.E., 2003, U-Pb ages of detrital zircons from Permian and Jurassic eolian sandstones of the Colorado Plateau, USA; paleogeographic implications: Sedimentary Geology, v. 163, p. 29-66.

Dodson M.H., Compston, W., Williams, I.S., and Wilson, J.F., 1988, A search for ancient detrital zircons in Zimbabwean sediments: Journal of the Geological Society of London, v. 145, p. 977-983.

Fedo, C.M., Sircombe, K.N., and Rainbird, R.H., 2003, Detrital zircon analysis of the sedimentary record: Reviews in Mineralogy and Geochemistry, v. 53, p. 277-303.

Gehrels, G.E., Valencia, V., and Pullen, A., 2006, Detrital zircon geochronology by laser-ablation multicollector ICPMS at the Arizona Laser-Chron Center, in Olszewski, T., and Huff, W., eds., Geochronology; Emerging opportunities: Philadelphia, Pennsylvania, Paleontological Society Short Course, p. 1-10.

Gillis, R.J., Gehrels, G.E., Ruiz, J., and de Dios Gonzalez, L.A.F., 2005, Detrital zircon provenance of Cambrian-Ordovician and Carboniferous strata of the Oaxaca terrane, southern Mexico: Sedimentary Geology, v. 182, p. 87-100.

Houseknecht, D.W, and Schenk, C.J., 2001, Depositional sequences and facies in the Torok Formation, National Petroleum Reserve-Alaska (NPRA), in Houseknecht, D.W., ed., NPRA Core Workshop; Petroleum Plays and Systems in the National Petroleum Reserve Alaska: SEPM Core Workshop (June 2001), no. 21,, p. 179-199. 
Houseknecht, D.W, and Schenk, C.J., 2007, Outcrops of turbidite channel facies in the Torok Formation; reservoir analogs for the Alaska North Slope, in Nilsen, T., Shew, R.D., Steffens, G.S., and Studlick, J.R.J., eds., An Atlas of Deepwater Outcrops; Models and Analogs: American Association of Petroleum Geologists Studies in Geology v. 56, p. 373-377.

Houseknecht, D.W., and Bird, K.J., 2006, Oil and gas resources of the Arctic Alaska petroleum province: U.S. Geological Survey Professional Paper 1732-A, 11 p.

Houseknecht, D.W., Schenk, C.J., and Wartes, M.A., 2007, Sedimentology and sequence stratigraphy of the Lower Cretaceous Fortress Mountain and Torok Formations exposed along the Siksikpuk River, north-central Alaska, in Haeussler, P.J., and Galloway, J.P., eds., Studies by the U.S. Geological Survey in Alaska, 2006: U.S. Geological Survey Professional Paper 1739-D, 27 p., 1 plate.

Huffman, A.C., Jr., ed., 1985, Geology of the Nanushuk Group and related rocks, North Slope, Alaska: U.S. Geological Survey Bulletin 1614, 129 p.

Huffman, A.C., Jr., Ahlbrandt, T.S., and Bartsch-Winkler, Susan, 1988, Sedimentology of the Nanushuk Group, North Slope, in Gryc, George, ed., Geology and exploration of the National Petroleum Reserve in Alaska, 1974 to 1982: U.S. Geological Survey Professional Paper 1399, p. 281-298.

Hunter, R.E., and Fox, J.E., 1976, Interpretation of depositional environments in the Fortress Mountain Formation, central Arctic Slope: U.S. Geological Survey Circular 733, p. 30-31.

Imlay, R.W., 1961, Characteristic Lower Cretaceous megafossils from northern Alaska: U.S. Geological Survey Professional Paper 335, 74 p.

Johnsson, M.J., and Sokol, N.K., 2000, Stratigraphic variation in petrographic composition of Nanushuk Group sandstones at Slope Mountain, North Slope, Alaska, in Kelley, K.D., and Gough, L.P., eds., Geologic studies in Alaska by the U.S. Geological Survey, 1998: U.S. Geological Survey Professional Paper 1615, p. 83-100.

Kelley, J.S., 1990, Generalized geologic map of the Chandler Lake Quadrangle, north-central Alaska: U.S. Geological Survey Miscellaneous Field Studies Map 2144A, 1 sheet, 19 p.

Krystinik, L.F., and DeJarnett, B., 1995, Lateral variability of sequence stratigraphic framework in the Campanian and Early Maastrichtian of the Western Interior Seaway, in Van Wagoner, J.C., and Bertram, G.T., eds., Sequence stratigraphy of foreland basin deposits; Outcrop and subsurface examples from the Cretaceous of North America: American Association of Petroleum Geologists Memoir, no. 64, p. 11-26.

LePain, D.L., McCarthy, P.J., and Kirkham, R., 2008, Sedimentology and sequence stratigraphy of the Nanushuk Formation in the central Brooks Range foothills, northern Alaska: Alaska Division of Geological \& Geophysical Surveys Report of Investigation, in press.

Ludwig, K.R., 2005, Isoplot/EX rev. 3.32; A geochronological toolkit for Microsoft Excel: Berkeley Geochronology Center Special Publication 4.

Mack, G.H., 1978, The survivability of labile light-mineral grains in fluvial, aeolian, and littoral marine environments; the Permian Cutler and Cedar Mesa formations, Moab, Utah: Sedimentology, v. 25, no. 5, p. 587-603.

McLearn, F.H., 1945, Revision of the Lower Cretaceous of the western interior of Canada: Geological Survey of Canada Paper 44-17 (2nd ed.), 14 p., 2 tables, 12 plates.

McLelland, J., Daly, J.S., and McLelland, J.M., 1996, The Grenville Orogenic Cycle (ca. 1350-1000 Ma); an Adirondack perspective: Tectonophysics, v. 265, p. 1-28.

Molenaar, C.M., 1988, Depositional history and seismic stratigraphy of Lower Cretaceous rock in the National Petroleum Reserve in Alaska and adjacent areas, in Gryc, G., editor, Geology and exploration of the National Petroleum Reserve in Alaska, 1974-1982: U.S. Geological Survey Professional Paper 1399, p. 593-621.

Molenaar, C.M., Egbert, R.M., and Krystinik, L.F., 1988, Depositional facies, petrography, and reservoir potential of the Fortress Mountain Formation (Lower Cretaceous), central North Slope, Alaska, in Gryc, G., ed., Geology and Exploration of the National Petroleum Reserve in Alaska, 1974-1982: U.S. Geological Survey Professional Paper 1399, p. 257-280.

Moore, T.E., Wallace, W.K., Bird, K.J., Karl, S.M., Mull, C.G., and Dillon, J.T., 1994, Geology of northern Alaska, in Plafker, G., and Berg, H.C., eds., The Geology of North America, v. G-1, The Geology of Alaska: Boulder, CO, Geological Society of America, p. 49-140.

Moore, T.E., Potter, C.J., O’Sullivan, P.B., Shelton, K.L., and Underwood, M.B., 2004, Two stages of deformation and fluid generation for the central Brooks Range fold and thrust belt, northern Alaska, in Swennen, R.A.J., Roure, Francois, and Granath, J.W., eds., Deformation, fluid flow, and reservoir appraisal in foreland fold and thrust belts: AAPG Hedberg Series, no. 1, p. 157-186. 
Morton, A.C., and Smale, D., 1991, The effects of transport and weathering on heavy minerals from the Cascade River, New Zealand: Sedimentary Geology, v. 68, p. 117-123.

Mull, C.G., 1985, Cretaceous tectonics, depositional cycles, and the Nanushuk Group, Brooks Range and Arctic Slope, Alaska, in Huffman, A.C., ed., Geology of the Nanushuk Group and related rocks, North Slope, Alaska: U.S. Geological Survey Bulletin 1614, p. 7-36.

Mull, C.G, Houseknecht, D.W., and Bird, K.J., 2003, Revised Cretaceous and Tertiary stratigraphic nomenclature in the Colville Basin, northern Alaska: U.S. Geological Survey Professional Paper 1673, 51 p.

Murphy, J.B., and Nance, R.D., 1991, Supercontinent model for the contrasting character of Late Proterozoic orogenic belts: Geology, v. 19, p. 469-472.

Ogg, J.G., 2004, Status of divisions of the International Geologic Time Scale: Lethaia, v. 37, p. $183-199$.

Patton, W.W., and Tailleur, I.L., 1964, Geology of the Killik-Itkillik region, Alaska: U.S. Geological Survey Professional Paper 303G, p. 409-500.

Peapples, P.R., Wallace, W.K., Wartes, M.A., Swenson, R., Mull, C.G., Dumoulin, J.A., Harris, E.E., Finzel, E.S., Reifenstuhl, R.R., and Loveland, A.L., 2007, Geologic map of the Siksikpuk River area, Brooks Range northern foothills, Alaska: Alaska Division of Geological \& Geophysical Surveys Preliminary Interpretive Report 2007-1, 1 sheet, scale 1:63,360.

Pettijohn, F.J., 1957, Sedimentary Rocks: 2nd ed., New York, Harper and Bros., 718 p.

Vogl, J.J., 2002, Late-orogenic backfolding and extension in the Brooks Range collisional orogen, northern Alaska: Journal of Structural Geology, v. 24, p. 1,753-1,776.

Wallace, W.K., Duncan, A.S. Peapples, P.R., Swenson, R.F., Wartes, M.A., O’Sullivan, P.B., and Finzel, E.S., 2006, Geometry and evolution of the frontal part of an orogenic wedge, central Brooks Range Foothills, Alaska: Geological Society of America Abstracts with Program, v. 38, no. 5, p. 24.

Wartes, M.A., 2008, Measured section and facies analysis of the Lower Cretaceous Fortress Mountain Formation, Atigun Syncline, northern Alaska, in Wartes, M.A., and Decker, P.L., eds, Preliminary results of recent geologic field investigations in the Brooks Range foothills and North Slope, Alaska: Alaska Division of Geological \& Geophysical Surveys Preliminary Interpretive Report 2008-1, p. 11-24, 1 sheet.

Wartes, M.A., and Swenson, R.F., 2005, New constraints on the structural and stratigraphic development of the proximal Colville foreland basin; Implications for burial history and oil and gas exploration in the central Brooks Range foothills, northern Alaska, in GSA, Cordilleran Section, 101st annual meeting: AAPG, Pacific Section, 80th annual meeting, Abstracts with Programs, v. 37, no. 4, p. 92-93.

Wartes, M.A., O’Sullivan, P.B., and Carroll, A.R., 2006, Enigmatic Permian U-Pb zircon ages from igneous clasts found in mid-Cretaceous deposits of the Colville Foreland Basin, northern Alaska: Geological Society of America Abstracts with Programs, v. 38, no. 5, p. 89. 
This page has intentionally been left blank. 


\title{
MEASURED SECTIONS AND PRELIMINARY INTERPRETATIONS OF THE NANUSHUK FORMATION EXPOSED ALONG THE COLVILLE RIVER NEAR THE CONFLUENCES WITH THE AWUNA AND KILLIK RIVERS
}

\author{
by \\ David L. LePain ${ }^{1}$, Paul L. Decker², and Marwan A. Wartes ${ }^{1}$
}

\section{INTRODUCTION}

On the south-central North Slope (fig. 1), the Torok and Nanushuk Formations (revised nomenclature of Mull and others, 2003; fig. 2) constitute a mid-Cretaceous clastic wedge that locally exceeds 5,000 $\mathrm{m}$ in thickness (Bird and Andrews, 1979). Deep-water shales and sandstones of the upper Torok Formation, deposited in basinal, slope, and outer-shelf settings, grade up-section and landward (toward the southwest) to shelf, shorezone (shoreface and delta-front), and nonmarine strata of the Nanushuk Formation.

The Alaska Division of Geological \& Geophysical Surveys (DGGS) has led a multiyear, outcrop-based investigation of the sequence stratigraphy and reservoir potential of these units, focusing particularly on the better exposed Nanushuk Formation. This work resulted in numerous detailed measured sections throughout the central and east-central Brooks Range foothills (fig. 1) and greatly improves our understanding of this depositional system (LePain and others, 2008).

During the 2004 and 2005 field seasons, reconnaissance evaluations of Nanushuk exposures were undertaken along the Colville River, near the southern boundary of the National Petroleum Reserve-Alaska (fig. 1). The focus of the effort was to collect preliminary facies observations and assess potential candidates for future detailed measured sections. In 2006, twelve days were spent at three main exposures, resulting in several detailed measured sections addressed in this report.

Sheet D-1 illustrates the location of the three principal outcrops discussed here and includes a preliminary interpretation of a composite seismic line placing the surface outcrops in stratigraphic context within the Nanushuk-Torok depositional system. Within the limits of our ability to tie these outcrops to the regional grid of public seismic data (Miller and others, 2000), we interpret all three exposures as grossly time-equivalent, marking the lower to middle portion of the Nanushuk Formation in this area (see cyan horizon, Sheet D-1). However, the east- and northeast-prograding Torok-Nanushuk depositional system is highly time transgressive, and regional interpretation of this seismic horizon suggests it corresponds roughly to the early part of the latter third of Nanushuk depositional time.

\section{MAIN OBSERVATIONS AND INTERPRETATIONS}

\section{Western Horseshoe Bend}

Sheet D-2 summarizes a well exposed Nanushuk section just north of the Tuktu Escarpment on the north side of the Colville River, $14.5 \mathrm{~km}$ straight-line distance to the southwest (53 km upstream river distance) of the confluence with the Awuna River. The low structural dip of this long exposure allowed for three separate sections to be measured, capturing the clearly visible lateral stratigraphic variations. The lower part of the section includes a thick $(\sim 3 \mathrm{~m})$ coal seam that splits into two thinner seams separated by a sandstone unit interpreted as a crevasse channel fill. The coaly section is overlain by a prominent series of downlapping deltaic foresets, interpreted as a bayhead delta (see photos in Sheet D-2). This delta was possibly sourced by a channelized system analogous to the crevasse fill that locally cut across the lower delta plain mire and filled a semi-protected interdistributary bay. Further upsection, an upward-coarsening, upward-thickening sandstone unit with well developed hummocky cross-stratification suggests a transgressive deepening or lateral facies shift to fully marine lower or middle shoreface settings.

\section{Eastern Horseshoe Bend}

Sheet D-3 shows the longest section measured in this study ( 450 m), exposed on the north side of the Colville River about $3 \mathrm{~km}$ straight-line distance to the northeast (11 km downstream river distance) of the western horseshoe

${ }^{1}$ Alaska Division of Geological \& Geophysical Surveys, 3354 College Rd., Fairbanks, Alaska 99709-3707

Email for David L. LePain: dave.lepain@alaska.gov

${ }^{2}$ Alaska Division of Oil \& Gas, 550 W. 7th Ave., Suite 800, Anchorage, Alaska 99501-3560 


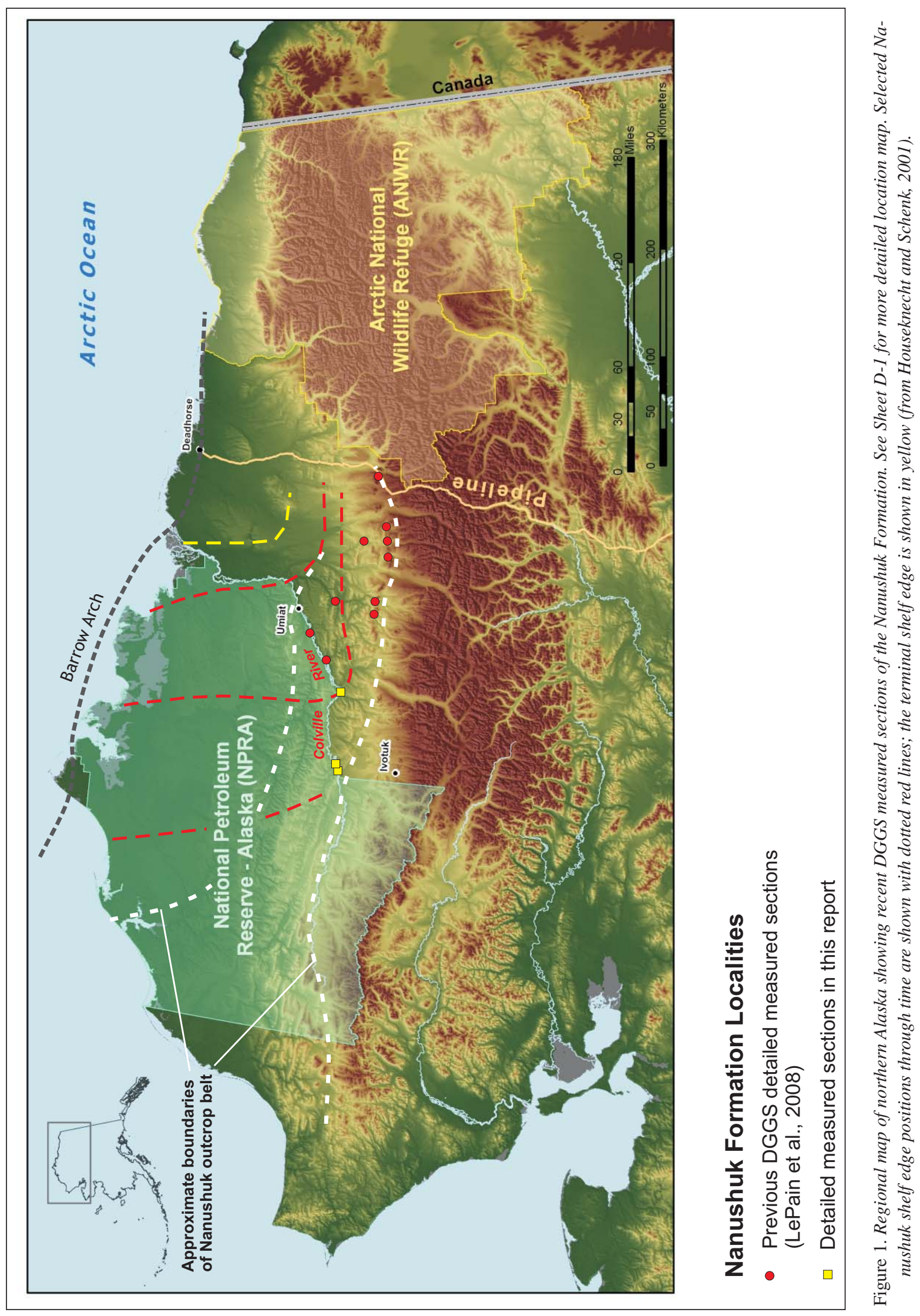


bend discussed above. The section dips moderately toward the north-northeast, and its base lies an estimated 1,000 $\mathrm{m}$ stratigraphically above the exposures at the western horseshoe bend. The outcrop exhibits repetitive parasequence scale cyclicity and interpreted facies associations ranging from coastal plain-bayfill to shoreface-delta front to shelf settings below fair-weather wave base. Appendix D-1 contains additional observations excerpted from field notes, too numerous to include on Sheet D-3, regarding grain size, sedimentary structures, trace fossils, hydrocarbon staining, sample specifics, and other details tied to specific stratigraphic positions within this measured section.

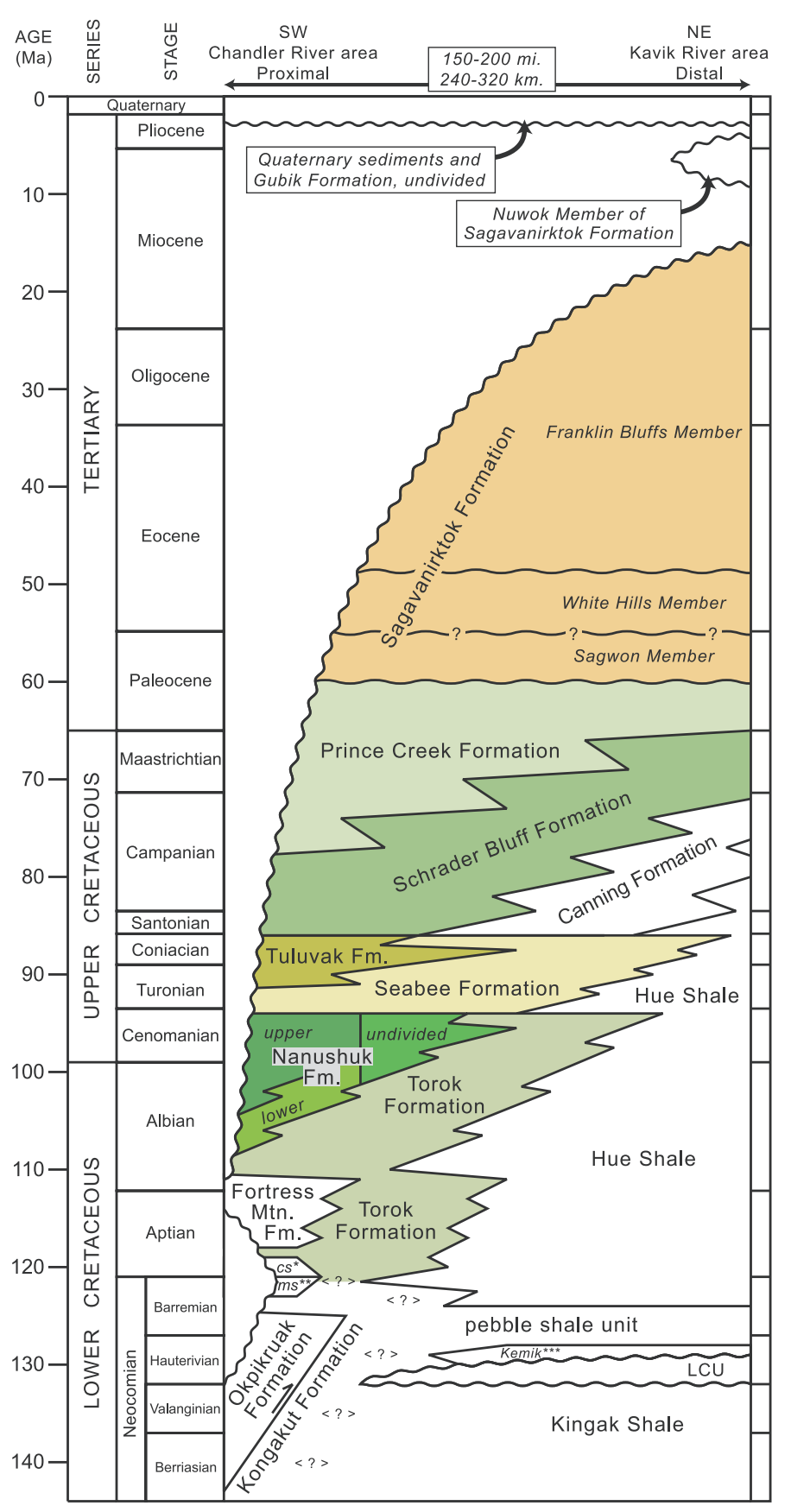

Figure 2. Chronostratigraphic column showing revised Cretaceous and Tertiary stratigraphic nomenclature of Mull and others (2003). cs* = cobblestone sandstone (informal unit) of Fortress Mountain Formation; $\mathrm{ms}^{* *}=$ manganiferous shale unit (informal).
A possible growth fault was interpreted in the western portion of the long exposure; bed tracing suggests the feature would project into the upper portion of the measured section transect. A notable stratal geometry exhibited in this long outcrop is the proximal (westward) pinchout of shorezone sand bodies, which may have important implications for forming stratigraphically trapped Nanushuk reservoirs. We speculate that this pinchout may relate to transgressive ravinement at high-order flooding surfaces, and/or to lateral differences in sand accommodation driven by greater compaction of progressively-finer-grained, more distal sediments.

\section{Killik Bend}

Sheet D-4 summarizes a $\sim 160 \mathrm{~m}$ section of Nanushuk Formation exposed along the Colville River near the confluence with the Killik River, well downstream and approximately 41 miles due east of the eastern horseshoe bend section described above. The top of the section is in the hinge of a conspicuous, relatively tight syncline at the southeast end of the outcrop. Similar to the eastern horseshoe bend, this exposure includes parasequences recording high-frequency oscillation between coastal plain/nonmarine and delta front/shoreface facies. Thin coals and carbonaceous mudstones, locally featuring pedogenic structures, are repetitively associated with marine facies as indicated by pelecypods, starfish, and marine trace fossils. The ichnofossil assemblage is diverse in places, including Rosselia, Rhizocorallium, Gyrochorte, Planolites, and possible Thalassinoides. Appendix D-2 contains detailed observations excerpted from field notes, too numerous to include on Sheet D-4, tied to specific stratigraphic positions within this measured section. 


\section{SUMMARY}

The purpose of this short report is to release our basic measured section data from along the Colville River and offer preliminary facies interpretations. All three localities exhibit lateral and vertical facies complexity typical of deltaic systems (fig. 3). Preliminary conclusions suggest a different depositional style than coeval deltaic systems documented in our earlier work to the east (LePain and others, 2008). The new sections along the Colville River record considerably more high-frequency, parasequence-scale fluctuations ranging from outer shoreface to alluvial facies. This vertical variability in facies tracts is encouraging as it allows for more consistent tracking of shoreline migration and hence sequence stratigraphic interpretations. Based on facies analysis, these exposures appear to reflect the development of river-dominated deltas. This contrasts with the more pervasive wave influence observed to the east (for example, LePain and others, 2008). In general, our facies observations and interpretations agree with prior USGS work (for example, Huffman and others, 1981). In particular, our preliminary conclusions regarding regional differences in deltaic style were suggested in earlier stratigraphic studies comparing the Nanushuk Formation in the western and central foothills (for example, Ahlbrandt, 1979; Huffman and others, 1988).

\section{FUTURE WORK}

The Nanushuk Formation is locally prospective as a reservoir objective throughout much of the western North Slope and in the central and western Brooks Range foothills. In light of this importance, DGGS anticipates continuing field-based sedimentologic and stratigraphic studies of the Nanushuk Formation. In particular, we hope to extend westward the level of detailed observations captured in the east-central foothills (LePain and others, in press). In collaboration with the Division of Oil \& Gas, additional future work will seek to extend our outcrop analysis into the subsurface, integrating additional publicly available two-dimensional (2-D) seismic data and nearby well control (for example, East Kurupa 1, West Kurupa 1, Knifeblade 1/1A, Sheet D-1).

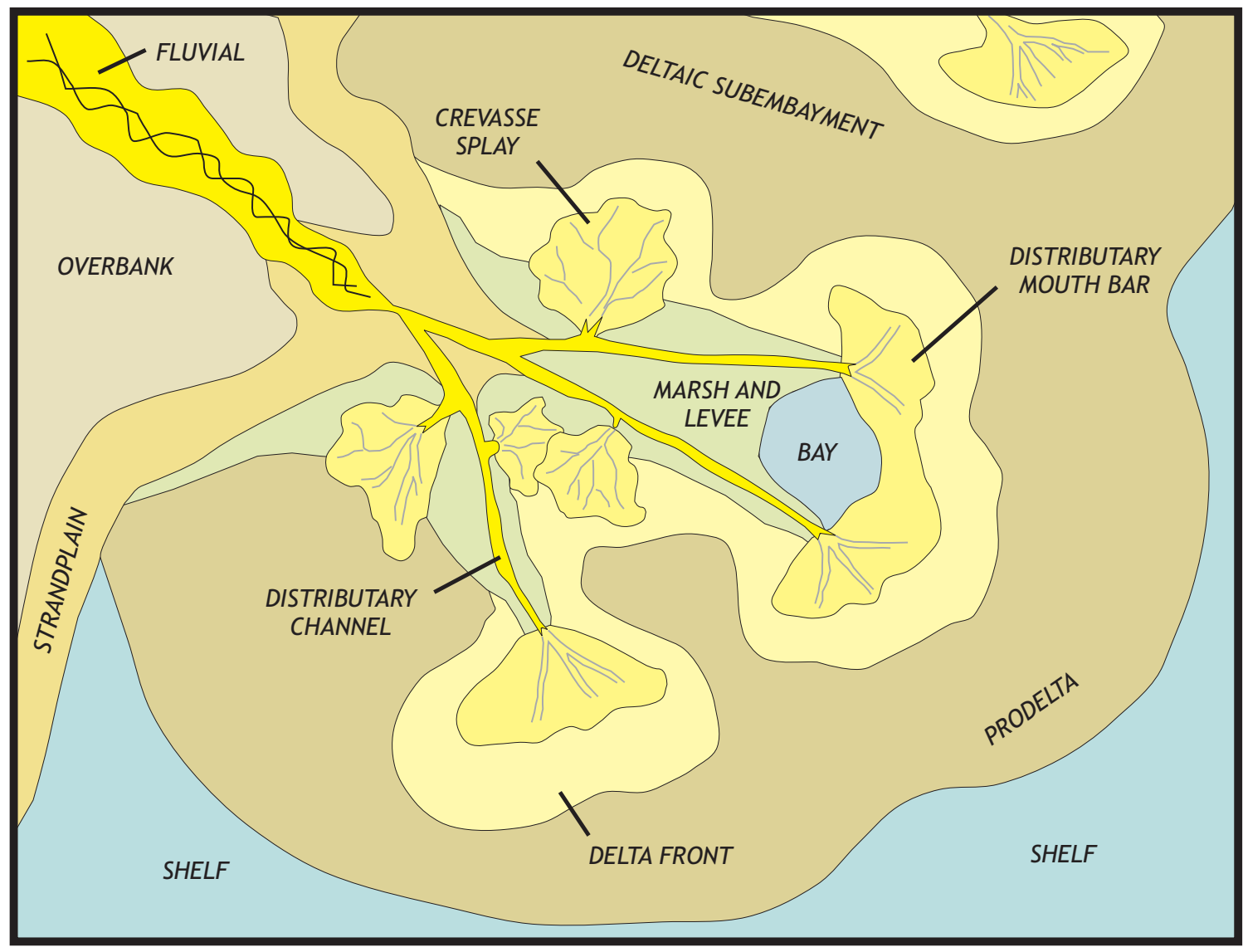

Figure 3. Schematic diagram of a deltaic depositional system and common facies observed in the Nanushuk Formation (modified from Huffman and others, 1985). 


\section{ACKNOWLEDGMENTS}

Fieldwork was supported through a combination of state budget sources and substantial contributions from companies and individuals involved in the Alaska oil and gas industry. During 2005, 2006, and 2007 industry sponsors included Anadarko Petroleum Corp., BG Alaska, Chevron, ConocoPhillips Alaska, Inc., ENI, Petro-Canada, Pioneer Natural Resources, Repsol YPF Exploration and Production Co., Shell International Exploration and Production Co., and Talisman Energy, Inc. This paper benefitted from discussions with P. McCarthy, C.G. Mull, and D. Schafer; R. Reifenstuhl provided a helpful review.

\section{REFERENCES}

Ahlbrandt, T.S., ed., 1979, Preliminary geologic, petrologic, and paleontologic results of the study of Nanushuk Formation rocks, North Slope, Alaska: U.S. Geological Survey Circular 794, 163 p.

Bird, K.J., and Andrews, J., 1979, Subsurface studies of the Nanushuk Formation, North Slope, Alaska, in Ahlbrandt, T.S., ed., Preliminary geologic, petrologic, and paleontologic results of the study of Nanushuk Formation rocks, North Slope, Alaska: U.S. Geological Survey Circular 794, p. 32-41.

Houseknecht, D.W., and Schenk, C.J., 2001, Depositional sequences and facies in the Torok Formation, National Petroleum Reserve-Alaska (NPRA), in Houseknecht, D.W., ed., NPRA Core Workshop Petroleum Plays and Systems in the National Petroleum Reserve-Alaska: SEPM Core Workshop No. 21, p. 179-199.

Huffman, A.C., Jr., Ahlbrandt, T.S., Pasternack, Ira, Stricker, G.D., Bartsch-Winkler, Susan, Fox, J.E., May, F.E., Scott, R.A., and Materna, W.L., 1981, Measured sections in the Cretaceous Nanushuk and Colville Groups undivided, central North Slope, Alaska: U.S. Geological Survey Open-File Report 81-177.

Huffman, A.C., Jr., Ahlbrandt, T.S., Pasternack, Ira, Stricker, G.D., and Fox, J.E., 1985, Depositional and sedimentologic factors affecting the reservoir potential of the Cretaceous Nanushuk Group, central North Slope, Alaska, in Huffman, A.C., ed., Geology of the Nanushuk Group and related rocks, North Slope, Alaska: U.S. Geological Survey Bulletin 1614, p. 61-74.

Huffman, A.C., Jr., Ahlbrandt, T.S., and Bartsch-Winkler, Susan, 1988, Sedimentology of the Nanushuk Group, North Slope, Alaska, in Gryc, G., ed., Geology and exploration of the National Petroleum Reserve in Alaska, 1974-1982: U.S. Geological Survey Professional Paper 1399, p. 281-298.

LePain, D.L., McCarthy, P.J., and Kirkham, R., 2008, Sedimentology and sequence stratigraphy of the Nanushuk Formation in the central Brooks Range foothills, northern Alaska: Alaska Division of Geological \& Geophysical Surveys Report of Investigations, in press.

Miller, J.J., Agena, W.F., Lee, M.W., Zihlman, F.N., Grow, J.A., Taylor, D.J., Killgore, M., and Oliver, H.L., 2000, Regional seismic lines reprocessed using post-stack processing techniques: National Petroleum Reserve-Alaska: U.S. Geological Survey Open-File Report 00-286 (CD-ROM). http://pubs.usgs.gov/of/2000/ ofr-00-0286/22RLINES.HTM

Mull, C.G., Houseknecht, D.W., and Bird, K.J., 2003, Revised Cretaceous and Tertiary stratigraphic nomenclature in the Colville basin, Northern Alaska: U.S. Geological Survey Professional Paper 1673, 51 p. 
This page has intentionally been left blank. 


\title{
GEOCHEMISTRY OF THE AUPUK GAS SEEP ALONG THE COLVILLE RIVER-EVIDENCE FOR A THERMOGENIC ORIGIN
}

\author{
by
}

\author{
Paul L. Decker ${ }^{1}$ and Marwan A. Wartes ${ }^{2}$
}

\section{INTRODUCTION}

The Brooks Range Foothills of Alaska's North Slope are generally considered gas prone with mean estimates of undiscovered, technically recoverable natural gas reported in the tens of trillions of cubic feet (Houseknecht and Bird, 2006; Garrity and others, 2005; Bird and Houseknecht, 2002; Schuenemeyer, 1999). Despite the large size of this assessed resource, the province remains underexplored and more data are required to evaluate details of the gas component of the petroleum system (for example, Nelson and others, 2006; Burruss and others, 2003).

This report summarizes new data from the Aupuk gas seep along the Colville River (Ikpikpuk River Quadrangle; fig. 1). The gas seep was discovered by a U.S. Navy geological field party in 1945 near Kakvuiyat Bend upstream of the confluence of Aupuk Creek with the Colville River (figs. 1 and 2). The area was revisited in 1946, 1947, and 1950 by U.S. Geological Survey (USGS) field parties (Chapman and others, 1964). Compositional data from samples analyzed in 1946 were reported by Chapman and others (1964) and indicated the seep was dominated by methane, although available technology did not allow them to assess whether the gas was biogenic or thermogenic.

During recent stratigraphic investigations of the Albian-Cenomanian Nanushuk Formation (LePain and others, 2008, this volume), we were able relocate the still active seep and sample it for modern geochemical analyses. Three gas samples were collected from the seep during 2005 and 2006 and analyzed for both molecular composition and stable isotopic data.

\section{SEEP DESCRIPTION AND SAMPLE COLLECTION}

The seep is located in a small meander scar lake shown in figure 2. Rubbly exposures of Nanushuk Formation sandstone form the moderately steep slope immediately south of the seep. During the first visit in 2005, gas bubbles emanated from a single point in water less than $60 \mathrm{~cm}$ deep on the south side of the lake, approximately $12 \mathrm{~m}$ from

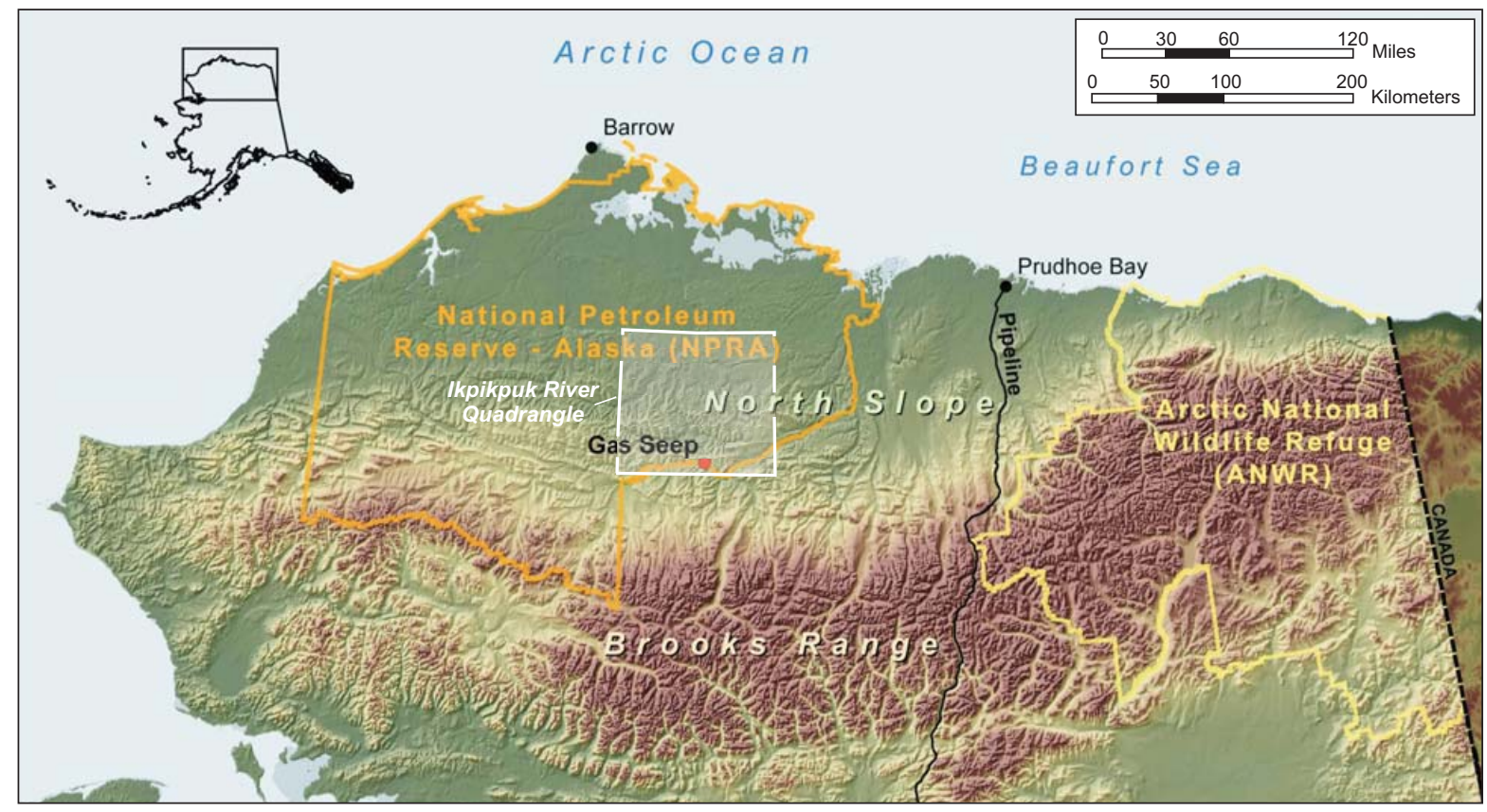

Figure 1. Regional map of northern Alaska showing location of the Aupuk gas seep. See figure 2 for more detailed map and coordinates.

${ }^{1}$ Alaska Division of Oil \& Gas, 550 W. 7th Ave., Suite 800, Anchorage, Alaska 99501-3560

Email for Paul L. Decker: paul.decker@alaska.gov

${ }^{2}$ Alaska Division of Geological \& Geophysical Surveys, 3354 College Rd., Fairbanks, Alaska 99709-3707 


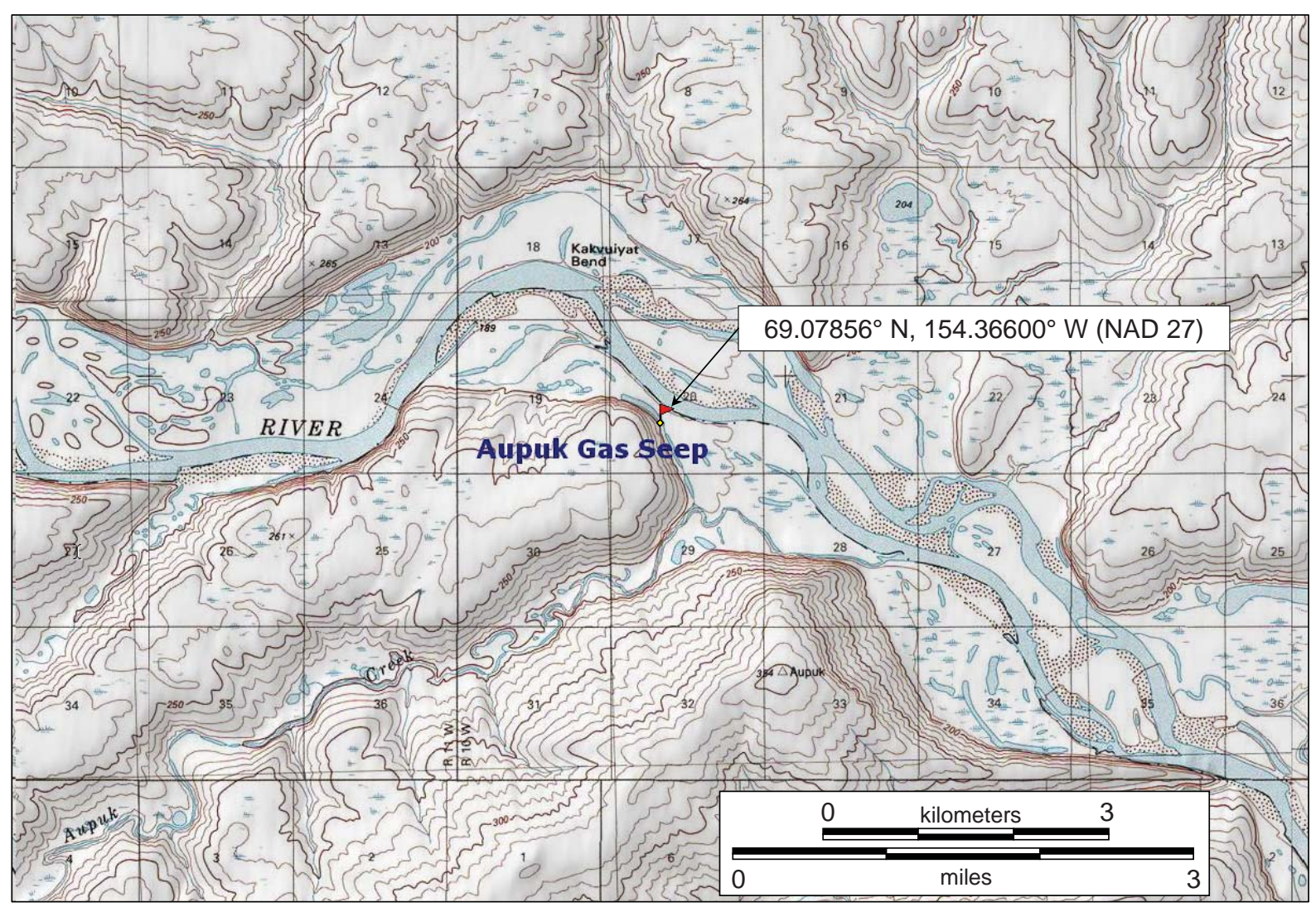

Figure 2. Location of the Aupuk gas seep sampled during the 2005 and 2006 field seasons, between Kakvuiyat Bend and the confluence of Aupuk Creek on the Colville River.

the southeast end (fig. 3). Bubbles rose from the lake bottom in continuous streams lasting 2-3 seconds with no more than 15 seconds between subsequent episodes ${ }^{3}$. In 2006, the seep was far more active, with approximately 20 bubble streams observed within a $\sim 15 \mathrm{~m}$ radius, a level of activity analogous to that observed in the early USGS investigations (Chapman and others, 1964). The 2006 samples were collected from what appeared to be the same vent as the 2005 sample. All samples were collected by allowing the bubbles to displace approximately $200 \mathrm{ml}$ of water from an inverted $250 \mathrm{ml}$ I-Chem amber glass sample bottle (fig. 3d).

The 2005 sample was analyzed for composition at CoreLab in Calgary, Alberta, then forwarded to the Department of Earth and Ocean Sciences at the University of Victoria in Victoria, British Columbia, for methane isotope analysis. Two additional gas samples were collected in 2006 and analyzed at Intertek Westport Technology Center, Houston, Texas.

\section{COMPOSITION AND METHANE ISOTOPIC ANALYSIS}

Table 1 presents results for all known analyses of the Aupuk gas seep, including data from 1946 reported in Chapman and others (1964). Because of known or suspected air leakage into their samples, Chapman and others (1964) reported the gas composition in two columns: column A gives the composition on a dry basis but including air, and column B gives results on a dry, air-free basis. No specific explanation is given for how the air-free results were derived, but the nitrogen, oxygen, and argon values in column B appear to have been recalculated by assuming all the oxygen in column $\mathrm{A}$ was due to air leakage, and adjusting the nitrogen and argon values in direct proportion to their ratios with oxygen in air. In any event, their compositions range from approximately 95 percent methane (including air, column A) to approximately 99 percent methane (on a dry, air-free basis, column B), with traces of nitrogen, carbon dioxide, argon, and heavier gas species.

\footnotetext{
${ }^{3}$ See 19-second QuickTime movie clip illustrating the nature and rate of gas seepage during the 2005 visit $<$ http://www.dggs.dnr.state.ak.us/pubs/pubs?reqtype=citation\&ID $=16084>$.
} 

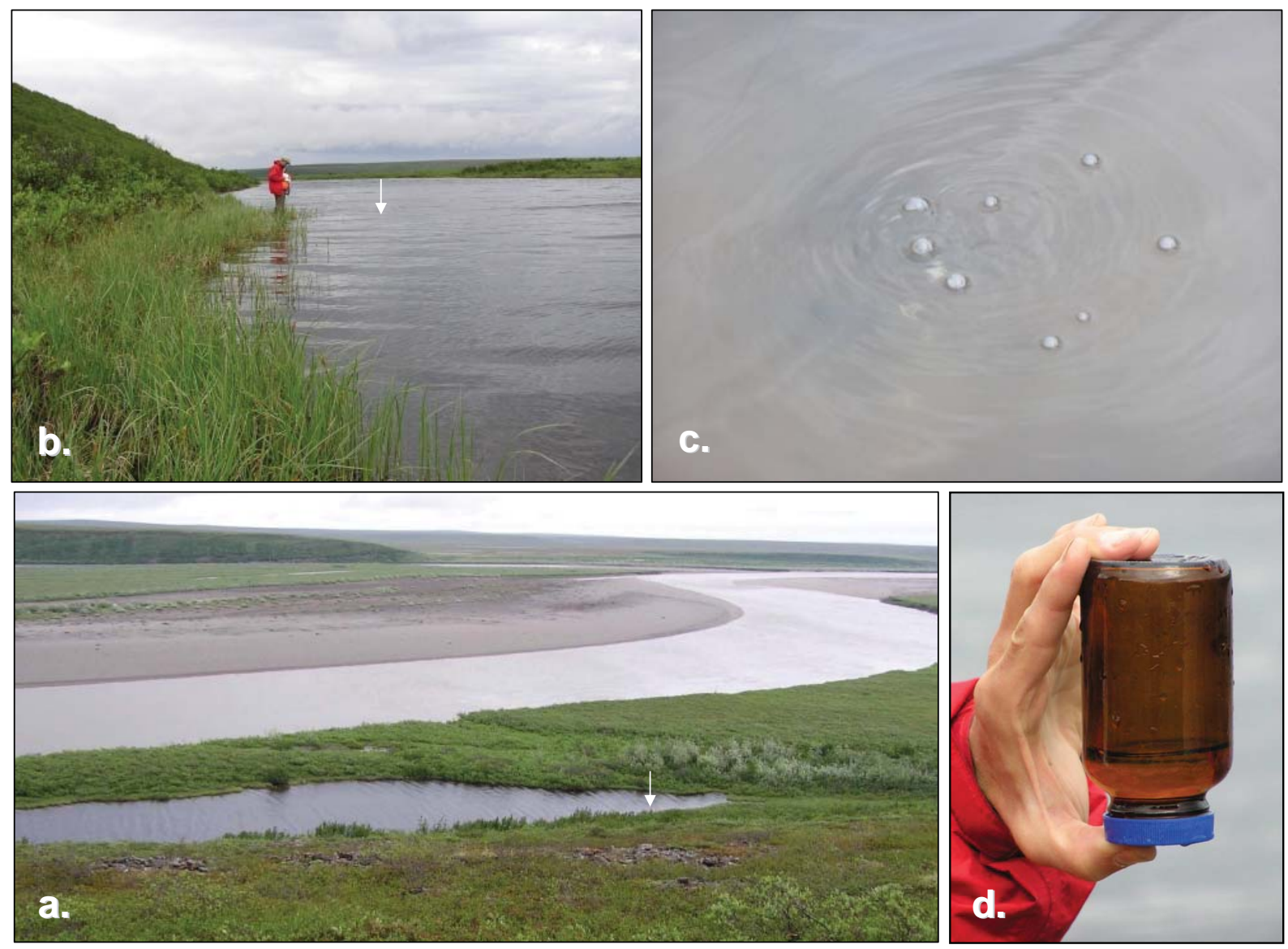

Figure 3. Field photos of the Aupuk gas seep near Kakvuiyat Bend on the Colville River. (a) View to northeast of small meander scar lake immediately south of Colville River. (b) View to northwest at sample location on south shore of lake. During the 2005 visit, the gas bubbles emanated from a single point in water less than $60 \mathrm{~cm}$ deep near the south side of the lake approximately $12 \mathrm{~m}$ from the southeast end [arrows in (a) and (b)]. In 2006, numerous bubble streams were active within a radius of approximately $15 \mathrm{~m}$ from sample location. Gas samples were collected by allowing bubble stream (c) to displace approximately $200 \mathrm{ml}$ of water from an inverted $250 \mathrm{ml}$ I-Chem amber glass sample bottle (d).

Similar to other analyses of gas in the Brooks Range Foothills (Burruss and others, 2003), data from the Aupuk seep indicate a very dry gas, containing mostly methane with negligible ethane and heavier hydrocarbons (table 1). However, all three of our recent samples yielded significantly higher nitrogen content than gas sampled from the same seep in 1946 (table 1). The reason for the high nitrogen content is not clear. Most natural gases from the North Slope contain less than 4 mole percent nitrogen (Burruss and others, 2003), and air contamination is blamed for higher nitrogen content in some cases. However, the ratio of nitrogen to oxygen in sample 05PD034 (235:1) is orders of magnitude higher than the ratio in air (3.25:1), so only a small fraction of the nitrogen can be readily explained by air leakage alone. Sample 06PD004a yielded a much lower methane and much higher nitrogen content than any of the other compositional analyses from this seep (table 1), and is believed to have been contaminated by air. However, the results for the 2006 analyses did not distinguish between oxygen and argon, making it impossible to calculate the nitrogen:oxygen ratio to establish air contamination.

Isotope analysis of the nearly 87 percent methane fraction in sample 05 PD034 yielded a $\delta 13$ carbon ratio of -39.3 per mil, and $\delta$ deuterium ratio of -195 per mil (table 1). These data are plotted on the natural gas characterization plot (fig. 4; format after Schoell, 1983), and indicate the Aupuk gas seep is clearly thermogenic rather than biogenic in origin, and appears to be a condensate- or oil-associated product generated at oil-window maturity. The 2006 samples were not analyzed for deuterium isotopes, although the two additional carbon isotopic measurements were nearly identical to the 2005 sample (table 1) and appear to be representative of actual current seepage. 


\section{DISCUSSION AND CONCLUSIONS}

The presence of a surface gas seep suggests there is a slowly leaking, thermogenic gas accumulation reservoired in Nanushuk Formation sandstones at depth. The source of this gas is difficult to assess because natural gases do not contain the large, complex biomarker molecules that allow liquid hydrocarbons to be tied back to their specific source rocks. On the basis of its apparent oil-window thermal maturity, it is speculated that the Aupuk seep is probably sourced from gas-prone terrestrial kerogen in the Torok Formation. If migration occurred early in the burial history, then the gas could also be a relict charge from several deeper source rocks that are likely now at much higher maturation levels. These include the Lower Cretaceous gamma ray zone (GRZ, also known as highly radioactive zone, HRZ) and/or pebble shale unit, Jurassic Kingak Formation, and Triassic Shublik Formation, and perhaps other intervals. Finally, given the possibility that polyphase deformation affected this area (O'Sullivan and others, 1997; Finzel and others, 2003), the Aupuk seep could reflect an accumulation of re-migrated hydrocarbons from an earlier episode of trapping.

The trapping mechanism and timing of hydrocarbon migration for the Aupuk gas is unknown, although consideration of local and regional data offers some constraints. Chapman and others (1964) noted that the seep was located near the east end of the Aupuk anticline (fig. 5). The position of the seep near the axis of the structure, as well as evidence for local faulting, support the hypothesis that the gas is leaking from a structurally trapped accumulation. Subsequent mapping in the southern Ikpikpuk Quadrangle by Mull and others (2005) reported additional strike and dip data, further constraining the nature of the Aupuk anticline (fig. 5). Most wells targeting the Nanushuk Formation in the foothills were drilled on structural highs (Mull, 1989) and all the Nanushuk foothills gas discoveries (undeveloped) are reported to be trapped in structural closures (Meade, Square Lake, Wolf Creek, East Umiat, Gubik, and East Kurupa are summarized in Kumar and others [2002]; Oumalik is described in Robinson [1956] and Schindler [1988]).

The timing for the development of this and other folds in the foothills belt could be either mid-Cretaceous (Albian-Cenomanian) or Paleocene. Timing the formation of structural traps in this area is significant because the younger deformation event postdates the principal mid- to Late Cretaceous phase of hydrocarbon generation suggested by burial and thermal history modeling (Burns and others, 2002). In assessing structural plays within NPRA, Potter and Moore (2003) interpreted all of the folding within the Nanushuk belt to reflect deformation at approximately $60 \mathrm{Ma}$, an episode that is widely recorded by apatite fission track data (Moore and others, 2004; O'Sullivan and others, 1997). However, the presence of an earlier phase of mid-Cretaceous folding cannot be ruled out. In fact, there are select fission track data from the central Brooks Range foothills, south of the Nanushuk outcrop belt, that preserve evidence for cooling at 90-110 Ma (Duncan and others, 2006; Cole and others, 1997; O'Sullivan and others, 1997). It is possible that this mid-Cretaceous cooling event affected Nanushuk rocks, but that subsequent burial reset the apatite thermochronometer, potentially erasing any record of pre-60 Ma cooling events (uplift and folding).

The Kurupa anticline (south of the Awuna syncline shown in fig. 5) is approximately $21 \mathrm{~km}$ south of the Aupuk seep and houses the undeveloped East Kurupa gas accumulation within the Torok and/or Fortress Mountain Formations (Kumar and others, 2002). In a study of the thermal maturity of the Torok and Nanushuk Formations involved in this fold, Bird and Pawlewicz (2006) concluded from vitrinite data that folding likely occurred prior to maximum burial, presumably in the mid-Cretaceous. On the basis of seismic and field evidence, other workers have also suggested portions of the Nanushuk Formation were influenced by mid-Cretaceous folding (Wallace, 2003; Finzel and others, 2003; Mull and others, 2000; Cole and others, 1997, Detterman and others, 1963). If additional new data confirm an episode of mid-Cretaceous folding, it would increase the probability of structurally trapped oil and gas accumulations across the Brooks Range Foothills.

\section{ACKNOWLEDGMENTS}

Fieldwork was supported through a combination of State of Alaska budget sources, federal funding distributed through the USGS STATEMAP program, and by substantial contributions from companies and individuals involved in the Alaska oil and gas industry. During 2005, 2006, and 2007, industry sponsors included Anadarko Petroleum Corp., BG Alaska, Chevron, ConocoPhillips Alaska, Inc., Eni Petroleum, Petro-Canada, Pioneer Natural Resources, Repsol YPF Exploration and Production Co., Shell International Exploration and Production Co., and FEX/Talisman Energy, Inc. Petro-Canada graciously paid for and oversaw shipping and analyses for the 2005 Aupuk gas seep sample. This paper benefitted from discussions with D.L. LePain, C.G. Mull, J.G. Clough, and R.F. Swenson as well as a helpful review by G.C. Wilson. 


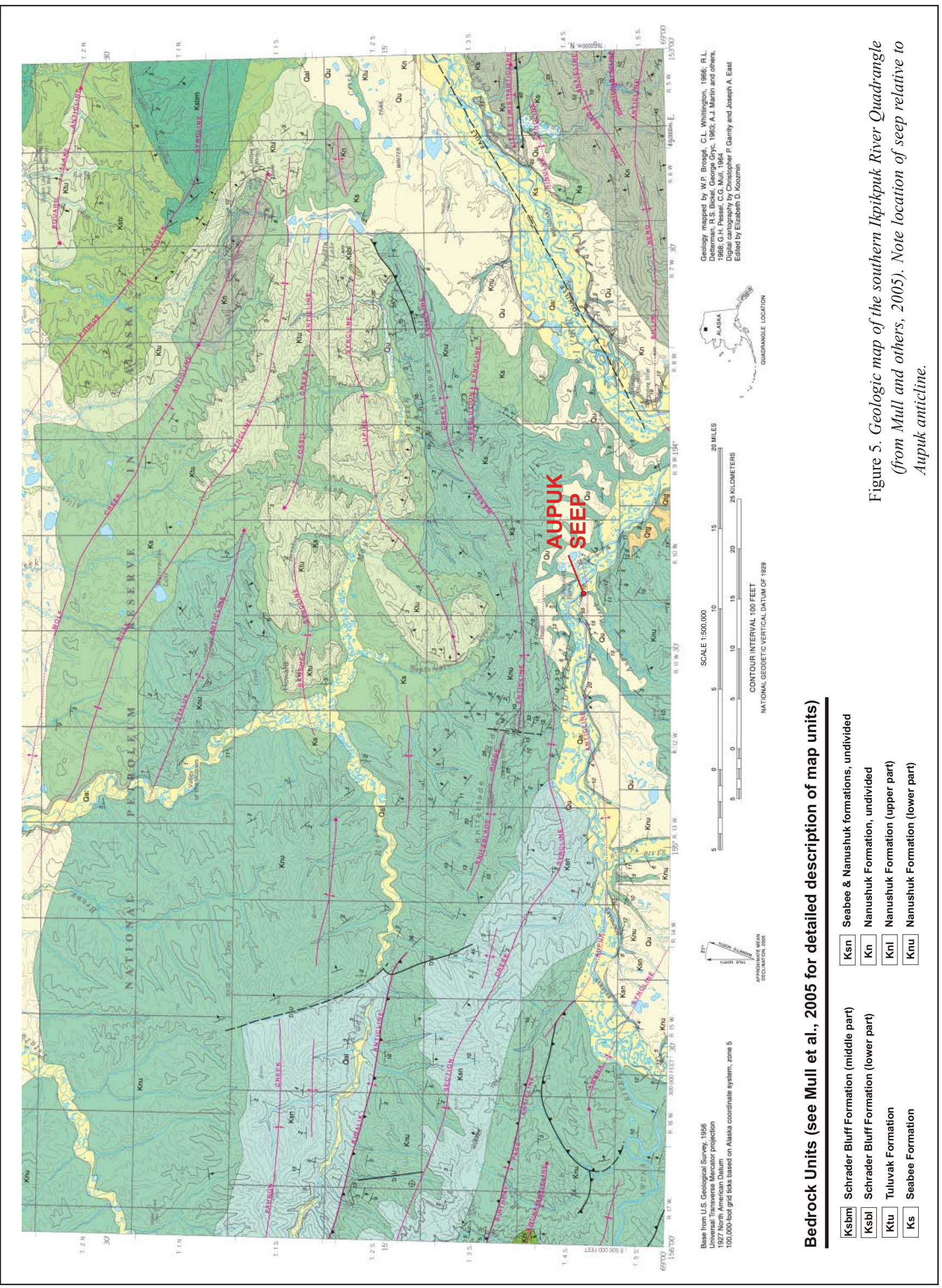




\section{REFERENCES}

Bird, K.J., and Houseknecht, D.W., 2002, U.S. Geological Survey 2002 petroleum resource assessment of the National Petroleum Reserve in Alaska (NPRA): Play maps and technically recoverable resource estimates: U.S. Geological Survey Open-File Report 2002-207, 18 p.

Bird, K.J., and Pawlewicz, M.J., 2006, Thermal maturity and timing of deformation in the foreland basin at Kurupa Anticline, Brooks Range Foothills, Alaska: GSA Cordilleran Section, Abstracts with Programs, v. 38, no. 5, p. 87.

Burruss, R.C., Lillis, P.G., and Collett, T.S., 2003, Geochemistry of natural gas, North Slope, Alaska: Implications for gas resources, NPRA: U.S. Geological Survey Open-File Report 03-341, online publication <http://pubs. usgs.gov/of/2003/of03-041/>.

Burns, W.M., Hayba, D.O., Houseknecht, D.W., and Rowan, E.L., 2002, Timing of hydrocarbon generation in the National Petroleum Reserve-Alaska (NPRA) from burial and thermal history modeling: American Association of Petroleum Geologists Pacific Section and Society of Petroleum Engineers Western Region, Joint Technical Conference Program and Abstracts, p. 66.

Chapman, R.M., Detterman, R.L., and Mangus, M.D., 1964, Geology of the Killik-Etivluk Rivers region, Alaska, U.S. Geological Survey Professional Paper 303-F, p. 325-407, 8 sheets.

Cole, F.E., Bird, K.J., Toro, J., Roure, F., O’Sullivan, P.B., Pawlewicz, M.J., and Howell, D.G., 1997, An integrated model for the frontal Brooks Range and Colville Basin $250 \mathrm{~km}$ west of the Trans-Alaska Crustal Transect: Journal of Geophysical Research, v. 102, p. 20,685-20,708.

Detterman, R.L., Bickel, R.S., and Gryc, George, 1963, Geology of the Chandler River region, Alaska: U.S. Geological Survey Professional Paper 303-E, p. 233-324, 16 sheets, scale 1:125,000.

Duncan, A.S., Hanks, C.L., Wallace, W.K., O’Sullivan, P.B., and Parris, T.M., 2006, Evolution and timing of fractures and related map-scale structures of the central Brooks Range fold-and-thrust belt, northern Alaska: Geological Society of America Abstracts with Programs, v. 38, no. 5, p. 89.

Finzel, E.S., McCarthy, P.J., and Wallace, W.K., 2003, Facies architecture and syntectonic fold geometry of fluvial conglomerate in the Cretaceous Nanushuk Formation, Brooks Range foothills, Alaska: AAPG Pacific Section, Abstracts with Programs, volume and page numbers unavailable.

Garrity, C.P., Houseknecht, D.W., Bird, K.J., Potter, C.J., Moore, T.E., Nelson, P.H., and Schenk, C.J., 2005, U.S. Geological Survey 2005 oil and gas resources assessment of the central North Slope, Alaska: Play maps and results: U.S. Geological Survey Open-File Report 2005-1182, 29 p.

Houseknecht, D.W., and Bird, K.J., 2006, Oil and gas resources of the Arctic Alaska petroleum province: U.S. Geological Survey Professional Paper 1732-A, 11 p.

Kumar, N., Bird, K.J., Nelson, P.H., Grow, J.A., and Evans, K.R., 2002, A digital atlas of hydrocarbon accumulations within and adjacent to the National Petroleum Reserve-Alaska (NPRA): U.S. Geological Survey OpenFile Report 02-71, 80 p.

LePain, D.L., Decker, P.L., and Wartes, M.A., 2008, Measured sections and preliminary interpretations of the Nanushuk Formation exposed along the Colville River near the confluences with the Awuna and Killik rivers, in Wartes, M.A., and Decker, Paul, eds., Preliminary results of recent geologic field investigations in the Brooks Range foothills and North Slope, Alaska: Alaska Division of Geological \& Geophysical Surveys Preliminary Interpretive Report 2008-1, p. 41-45, 4 sheets.

Moore, T.E., Potter, C.J., O’Sullivan, P.B., Shelton, K.L., and Underwood, M.B., 2004, Two stages of deformation and fluid migration in the west-central Brooks Range fold and thrust belt, northern Alaska, in Swennen, R., Roure, F., and Granath, J.W., eds., Deformation, fluid flow, and reservoir appraisal in foreland fold and thrust belts: American Association of Petroleum Geologists Hedberg series, no. 1, p. 157-186.

Mull, C.G., 1989, History of oil exploration on the Arctic Slope, in Mull, C.G., and Adams, K.E., eds., Dalton Highway, Yukon River to Prudhoe Bay, Alaska: Division of Geological \& Geophysical Surveys Guidebook 7, p. 133-140.

Mull, C.G., Harris, E.E., Reifenstuhl, R.R., and Moore, T.E., 2000, Geologic map of the Coke Basin-Kukpowruk River area, DeLong Mountains D-2 and D-3 quadrangles, northwestern Alaska: Alaska Division of Geological \& Geophysical Surveys Report of Investigations 2000-2, 1 sheet, scale 1:63,360.

Mull, C.G., Houseknecht, D.W., Pessel, G.H., and Garrity, C.P., 2005, Geologic map of the Ikpikpuk River Quadrangle, Alaska: U.S. Geological Survey Scientific Investigations Map 2817-B, 1 sheet. 
Nelson, P.H., Bird, K.J., Houseknecht, D.W., Potter, C.J., and Moore, T.E., 2006, Potential tight gas resources in a frontier province-Jurassic through Tertiary strata beneath the Brooks Range foothills, Arctic Alaska: U.S. Geological Survey Open File Report 2006-1172, version 1.0, 2 sheets.

O'Sullivan, P.B., Murphy, J.M., and Blythe, A.E., 1997, Late Mesozoic and Cenozoic thermotectonic evolution of the central Brooks Range and adjacent North Slope foreland basin, Alaska - including fission track results from the Trans-Alaska Crustal Transect (TACT): Journal of Geophysical Research, v. 102, p. 20,821-20,845.

Potter, C.J., and Moore, T.E., 2003, Brookian structural plays in the National Petroleum Reserve, Alaska: U.S. Geological Survey Open-File Report 03-266, 49 p.

Robinson, F.M., 1956, Core tests and test wells, Oumalik area, Alaska: U.S. Geological Survey Professional Paper 305-A, 70 p., 6 sheets.

Schoell, M. 1983, Genetic characterization of natural gases: American Association of Petroleum Geologists Bulletin, v. 67, p. 2225-2238.

Schindler, J.F., 1988, History of exploration in the National Petroleum Reserve in Alaska, with emphasis on the period from 1975 to 1982, in Gryc, George, ed., Geology and exploration of the National Petroleum Reserve in Alaska, 1974-1982: U.S. Geological Survey Professional Paper 1399, 940 p., 58 sheets.

Schuenemeyer, J.H., 1999, Chapter RS, Assessment results, in the oil and gas resource potential of the 1002 Area, Arctic National Wildlife Refuge, Alaska, by ANWR Assessment Team: U.S. Geological Survey Open-File Report 98-34, 2 disks, 12 p., online at $<$ http://energy.cr.usgs.gov/OF98-34/>.

Wallace, W.K., 2003, Geometry and evolution of detachment folds in deformed foreland basin deposits of the Brooks Range Foothills, northern Alaska, abs., in Chidsey, T.C., Jr., ed., 2003 AAPG annual convention with SEPM: Annual Meeting Expanded Abstracts-American Association of Petroleum Geologists, vol.12, p.177. 


\title{
STRATIGRAPHIC AND STRUCTURAL INVESTIGATIONS IN THE IVISHAK RIVER AND GILEAD CREEK AREAS: PROGRESS DURING 2007
}

\author{
by \\ P.L. Decker ${ }^{1}$, M.A. Wartes ${ }^{2}$, W.K. Wallace ${ }^{3}$, D.W. Houseknecht ${ }^{4}$, \\ C.J. Schenk ${ }^{5}$, R.J. Gillis ${ }^{2}$, and J. Mongrain ${ }^{3}$
}

\begin{abstract}
Contractional deformation of foreland basin deposits adjacent to the northeast-southwest-trending mountain front in the east-central Brooks Range foothills exposes rock units of Albian to Late Cretaceous age that are largely concealed in the subsurface to the west and removed by erosion to the east. The informally named Gilead sandstone and overlying units in this area provide valuable insights into depositional systems active during the early and middle phases of foreland basin evolution, as well as an opportunity to study their responses to subsequent Brookian deformation. Systematic traverses of the Ivishak River, Gilead syncline, and Gilead Creek yield ubiquitous evidence of sediment gravity flow depositional processes in both the highly amalgamated sandstones and the intervening, finer-grained and thinner-bedded intervals throughout the Gilead sandstone, Seabee-equivalent strata, and the overlying Canning Formation. The amalgamated sandstone facies association of the Gilead succession contains many characteristics of hyperpycnal flow deposits, and submarine channels are locally preserved. Much of the unit may represent east- or northeast-flowing axial foredeep channel belt deposits. Sediment gravity flow sandstones in the upper parts of the Gilead unit that contain possible wave-influenced sedimentary structures may have been deposited south of the foredeep in shallower orogenic wedge-top, upper slope, or ramp settings. The Gilead sandstone has previously been interpreted to belong to a far-traveled allochthon, but we have found no compelling structural evidence to support this interpretation. Instead, observations appear consistent with lower Brookian strata at Gilead syncline forming the passive roof of a triangle zone duplex containing structurally thickened Valanginian and older strata. The Gilead sandstone itself is more strongly deformed on strike to the west at the Ivishak River. Transverse tear and rotational faults may account for the alongstrike compartmentalization of deformation. These preliminary interpretations require further scrutiny and the incorporation of pending analytical results from samples collected during these investigations.
\end{abstract}

\section{INTRODUCTION}

Reconnaissance during the 2007 field season addressed stratigraphic and structural uncertainties in the Ivishak River-Gilead Creek area (figs. 1-3) in preparation for detailed geologic mapping in this part of the Foothills belt during 2008 and subsequent years. These drainages are located on the northeast-southwest-trending edge of the northeastern Brooks Range salient where rocks of the lower and middle Brookian sequence that are restricted to the subsurface in most of the Foothills have been brought to the surface. This presents a unique opportunity to study the evolution of the foreland basin, and provides direct insight into the Foothills petroleum system in the adjacent subsurface.

An inherent challenge to understanding the Brookian foreland basin sequence is that the nomenclature, organization, thickness, depositional environments, and lithostratigraphy of the succession in any given area may be very different than the stratigraphic equivalents elsewhere in the basin (for example, Molenaar and others, 1986; Decker, 2007). The Ivishak River-Gilead Creek outcrop belt presents a conundrum analogous to trying to solve a system of equations with too many variables: the Brookian sequence differs dramatically from other areas, but because of obvious structural complications, the original stratigraphic succession has never been fully reconstructed. Conversely, the complete structural picture remains elusive, and thus difficult to filter out, because the original stratigraphy is not adequately understood.

\footnotetext{
${ }^{1}$ Alaska Division of Oil \& Gas, 550 W. 7th Ave., Suite 800, Anchorage, Alaska 99501-3560

Email for Paul L. Decker: paul.decker@alaska.gov

${ }^{2}$ Alaska Division of Geological \& Geophysical Surveys, 3354 College Rd., Fairbanks, Alaska 99709-3707

${ }^{3}$ University of Alaska, Department of Geology \& Geophysics, P.O. Box 757320, Fairbanks, Alaska 99775-7320

${ }^{4}$ U.S. Geological Survey, 956 National Center, Reston, Virginia 20192

${ }^{5}$ U.S. Geological Survey, Box 25046 Denver Federal Center, Denver, Colorado 80225
} 

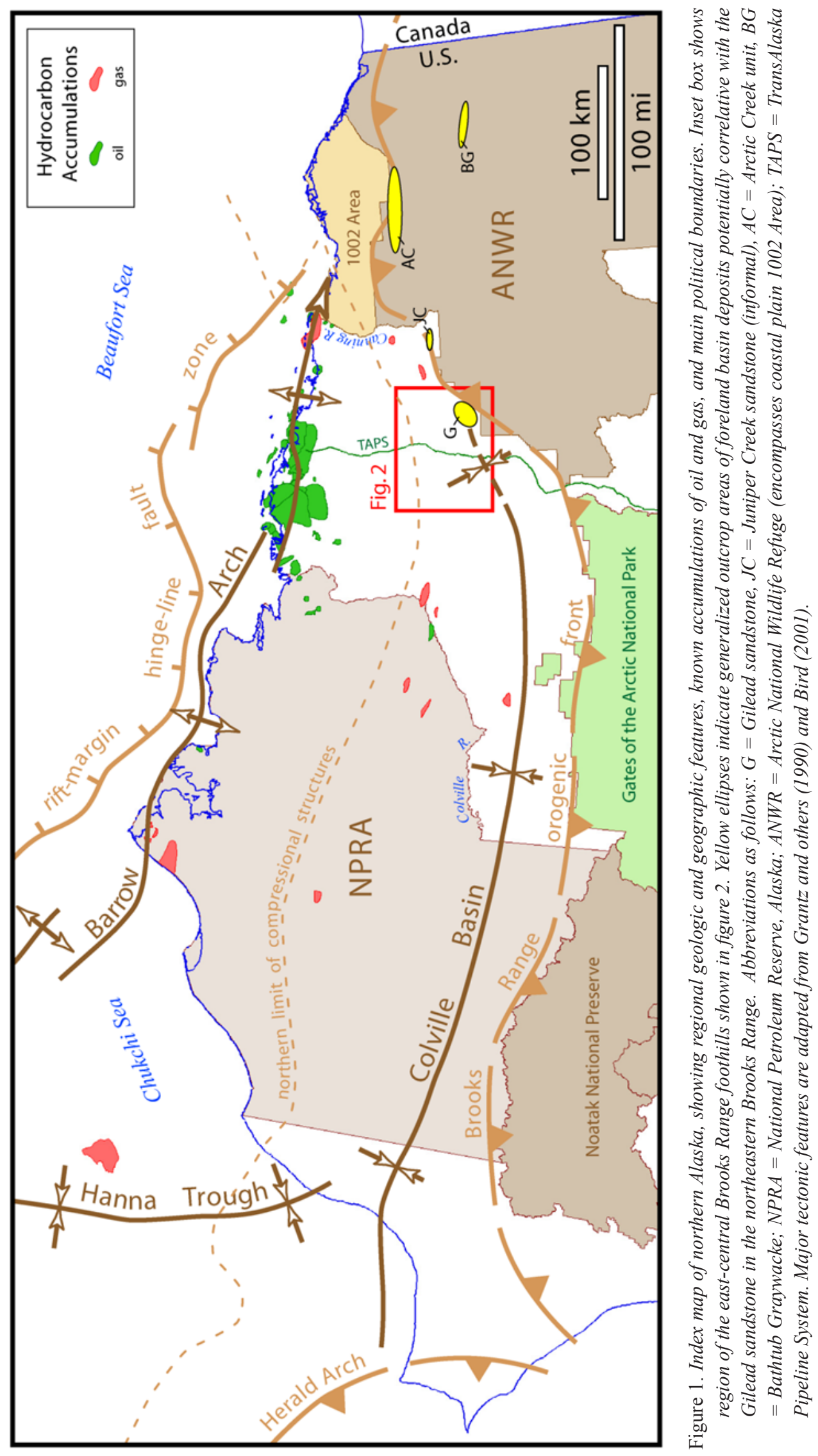


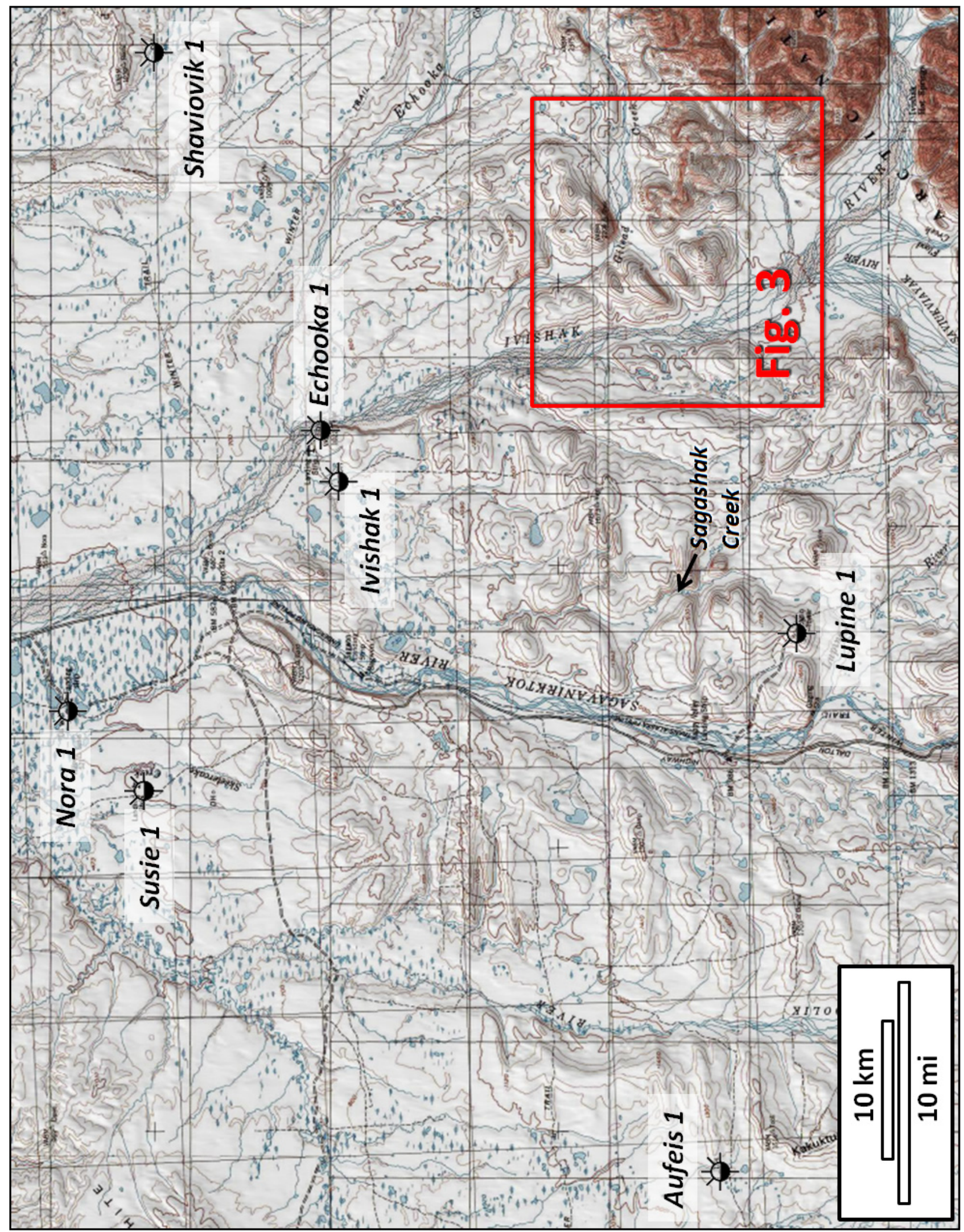

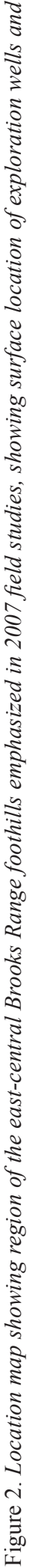

$\therefore \frac{\pi}{2}$

छ

$\stackrel{8}{8}$

क.

s

๑)

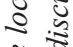

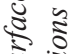

कर

है:

离

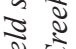

$\hat{\sigma}$

ป ن

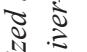

8

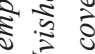

ปิ

8 5

5 ธิ

¿े है

के के

今े ซั

उ

บ

ป $\cong$

$\approx 2$

$0 \div$

के के

प

$\Rightarrow$ s.

के के

क

$\div$

5

రू

i

ะ ะ 
In their early mapping of the area, Keller and others (1961) assigned all Cretaceous rocks to the Ignek Formation. They differentiated two members mainly on the basis of pyroclastic content. They tentatively considered the units Lower and Upper Cretaceous in age, and speculated that they were separated by an unconformity. They viewed the lower member's siltstone, shale, and subgraywacke as partially equivalent to rocks now assigned to the Nanushuk and Torok Formations (fig. 4), and the upper member's pyroclastic (tuffaceous) shale and lesser sandstone and siltstone as partially equivalent to the Colville Group. The Ignek Formation was abandoned by Detterman and others (1975), and the encompassing term "Colville Group" was abandoned by Mull and others (2003). In the current formal nomenclature, Upper Cretaceous rocks of Keller and others' (1961) upper member would ideally be divided into the upper Hue Shale, Seabee, Canning, Schrader Bluff, and perhaps Prince Creek Formations (fig. 4). In the field, however, these units can be difficult to distinguish reliably because of structural complication and limited exposures that lack stratigraphic context. Much of the Lower to Upper Cretaceous section in the study area is dominated by deepwater turbidites and other sediment gravity flow deposits. Lithologically

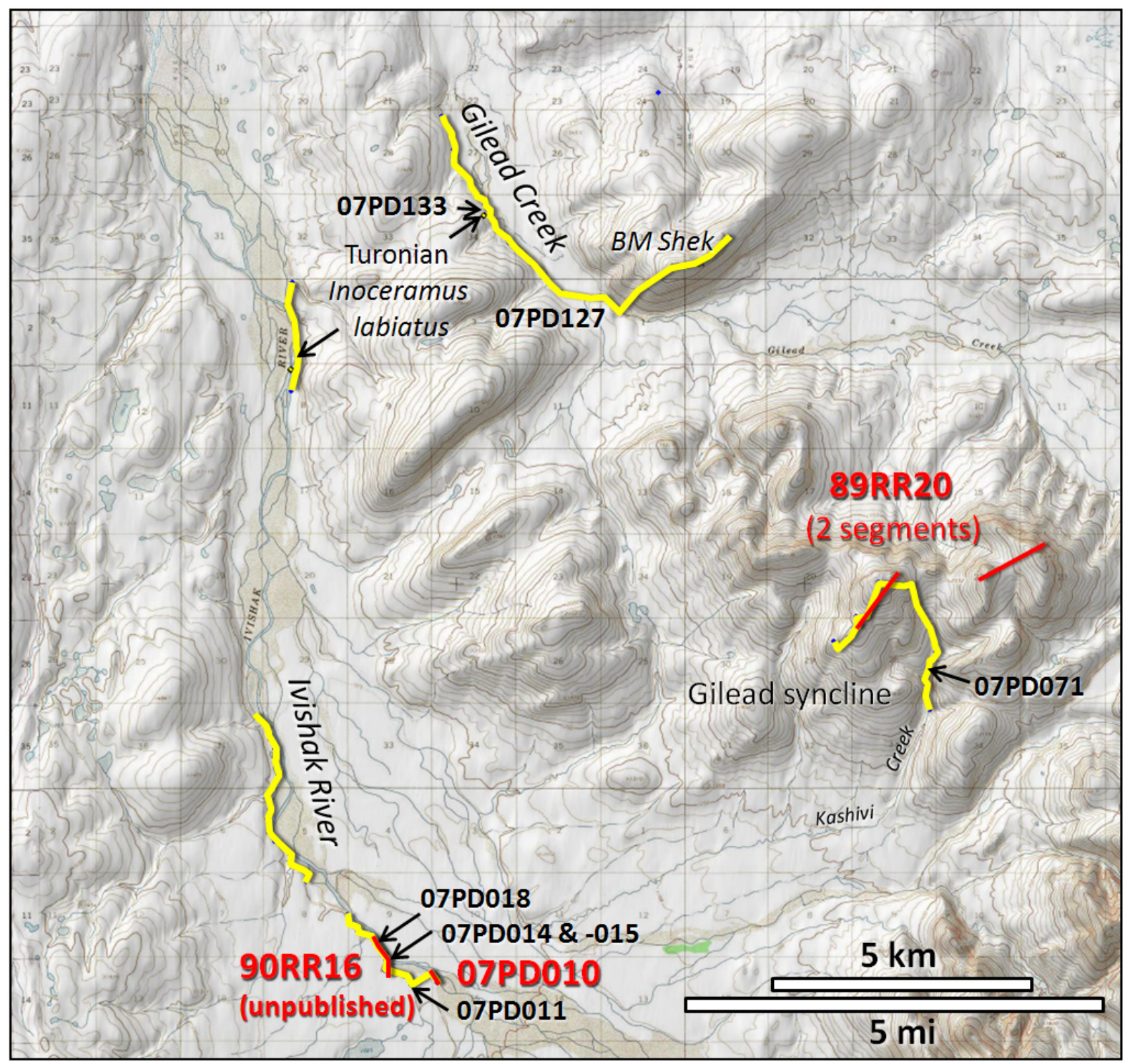

Figure 3. Location map showing detailed 2007 season foot traverses through Gilead sandstone and associated Upper Cretaceous rocks (yellow lines), measured sections of the Gilead sandstone (red lines and labels), including 2007 Ivishak River section 07PD010 (see Sheet F-1), Gilead syncline section 89RR20, and unpublished Ivishak River section 90RR16 (Reifenstuhl, 1989; 1991), and other locations referred to in text. Adapted from 1:63,360-scale USGS topographic coverage. 
distinct intervals are commonly either abruptly interleaved by complex structures or appear to change gradationally from one to another, without clear formation boundaries. There is an overall northward younging trend along these stream drainages, but thrusting and folding complicate this broader pattern.

Reifenstuhl (1989) applied the informal name "Gilead Creek sandstone," later shortened to "Gilead sandstone" (Reifenstuhl, 1991), to a clastic succession at least $850 \mathrm{~m}$ thick in the Gilead Creek-Ivishak River area (figs. 2 and 3 ) that he reported as Albian to Cenomanian in age. This informal unit encompasses much of the interval formerly assigned by Keller and others (1961) to the Ignek Formation lower member. The Gilead sandstone is problematic from a mapping standpoint because its upper contact with overlying strata has never been defined. The Gilead sandstone has also remained poorly understood from a genetic perspective, for several reasons. The age and sequence stratigraphic nature of the undefined upper contact are not well constrained. Additionally, opinions vary

Figure 4. Chronostratigraphic column for the Colville basin, northern Alaska, from Mull and others (2003). The informally named Gilead sandstone (not shown in figure) includes hundreds of meters of Albian-Cenomanian strata, and is thus at least partially age-equivalent to the Torok and Nanushuk Formations. However, as discussed in text, the Gilead unit's upper and lower contacts are poorly defined, both chronostratigraphically and lithostratigraphically. Depositional environment and paleobathymetric interpretations also remain uncertain for much of the unit, making it difficult to represent in this context. Refer to original figure (Mull and others, 2003, fig. 3) for additional explanation.

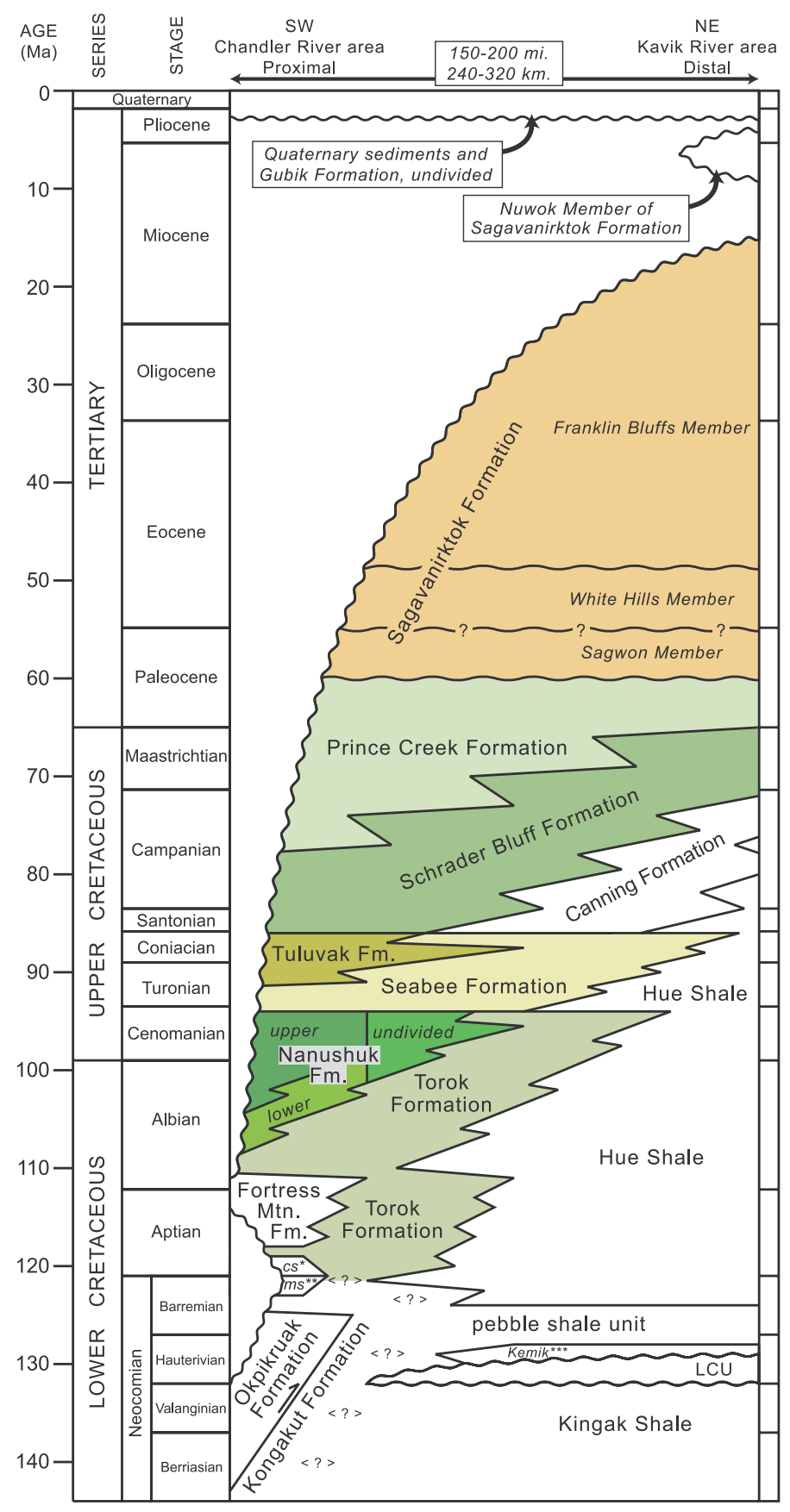


considerably regarding the range of water depths and depositional environments represented (Molenaar and others, 1984; Huffman and others, 1985; Pessel and others, 1990; Reifenstuhl, 1991; Schenk and Bird, 1993; LePain and Kirkham, 2002), making it difficult to interpret the paleogeographic setting of the Gilead sandstone within the foreland basin. Furthermore, there is almost certainly a detachment surface of some sort at the base of the Gilead sandstone at Gilead syncline (Reifenstuhl, 1989, 1991; Pessel and others, 1990), but it is uncertain whether the unit is essentially autochthonous (and thus, in its depositional context relative to the surrounding stratigraphic succession), or whether it is part of an allochthonous thrust or gravity-glide sheet that was transported from well to the south (for example, C.G. Mull, oral commun., 2007). The base of the sandy Albian-Cenomanian section at Gilead syncline is universally covered by rubble or vegetation, but it lies anomalously close to the deformed, underlying Kingak Shale. This leaves little room for the normal upper Beaufortian to lowermost Brookian stratigraphic succession of the North Slope autochthon and parautochthon (for example, Kemik Formation, pebble shale unit, and gamma-ray zone [GRZ] or basal Brookian mudstone). Finally, the Gilead unit is not present in coherent exposures of Neocomian through Upper Cretaceous stratigraphic strata just $19 \mathrm{~km}$ to the northeast on the Echooka River. These enduring enigmas are partly attributable to discontinuous frost-shattered exposures and structural dismemberment of the stratigraphic section. They highlight the need for better stratigraphic and structural models, constrained by detailed mapping that integrates additional field observations, refined age control, and petrographic study.

Our 2007 field investigations have not resolved these issues, but systematic foot traverses along the wellexposed reaches of the Ivishak River, Gilead Creek, and at Gilead syncline (fig. 3) generated numerous detailed observations that have already materially advanced our understanding of this complex area. This report discusses preliminary findings from field studies regarding the sedimentology, stratigraphy, and stacking architecture of the Gilead sandstone, and speculates on its depositional process and setting, and its relationship to overlying Upper Cretaceous rocks. It also documents key aspects of the structural geology that are crucial to predicting subsurface geometries and interpreting the basin evolution and hydrocarbon potential in this part of the North Slope Foothills. The descriptions, hypotheses, and tentative conclusions offered here are subject to change pending the results of ongoing analytical studies, future field investigations, and further refinement of interpretations.

\section{DESCRIPTION AND INTERPRETATION OF THE GILEAD SANDSTONE}

Reifenstuhl (1991) described the Gilead sandstone as "dominated by typically medium- to dark-gray, fine- to coarse-grained, subangular, moderately sorted litharenite, which weathers dark gray and orange-brown." We observe considerable variation in the color, composition, and texture of the unit, particularly in the upper portions. In hand specimens, the darker gray, compositionally and texturally immature sandstones are commonly described as graywacke or subgraywacke. The unit alternates between two major facies associations that tend to occur in discrete intervals tens of meters thick. As end members, these associations consist of either (1) medium- to massive-bedded (beds $10 \mathrm{~cm}$ to $>1 \mathrm{~m}$ thick) sandstone with very little interbedded siltstone and shale, or (2) very thin-bedded (beds $1-3 \mathrm{~cm}$ thick) to ripple-laminated mixtures of very fine sandstone, siltstone, and shale. The least structurally disrupted, and perhaps most complete section of the Gilead sandstone, is at Gilead syncline, where nearly $850 \mathrm{~m}$ of gently to moderately dipping sandstone, siltstone, lesser shale, and thick covered intervals were measured by Reifenstuhl $(1989,1991)$. Exposures of the unit on the Ivishak River extend over a distance of approximately 13 $\mathrm{km}$ from south to north, but are mainly steeply dipping to overturned, and the amount of structural repetition by folding and faulting is difficult to determine. We have not yet estimated the stratigraphic thickness represented there. An unpublished 254-m-thick section was measured previously on the Ivishak River (Reifenstuhl, 1991), but it clearly encompasses only a minor fraction of the structurally complex exposures along the Ivishak River, and represents an uncertain portion of the Gilead interval.

\section{Stratigraphy of the Ivishak River Transect}

Stratigraphic and structural measurements and observations were collected along three foot traverses with a combined length of $8.8 \mathrm{~km}$ that represent nearly all of the exposed bedrock on this stretch of the Ivishak River (fig. 3). We measured a $160 \mathrm{~m}$ section of what appears to be the lower part of the Gilead sandstone at the south end of this transect, making detailed observations on grain size, bed thickness, sedimentary structures, paleocurrent indicators, composition, and stacking patterns, and collecting samples for petrography, micropaleontology, porosity and permeability, fission track thermochronology, and detrital zircon geochronology. Analytical results for these samples are not yet available. The measured section extends northward from station 07PD010 on the west side of the river a short distance downstream of the Saviukviayak River confluence (figs. 2 and 3), where nearly vertical sandstone beds are well exposed on a low, current-scoured bench that rises just above river level (fig. 5a). 
A preliminary version of the measured section is presented in Sheet F-1 of this report, which will be supplemented with analytical data and interpretations as they become available.

The Gilead sandstone in this measured section is dominated by 40-50-m-thick intervals of resistant, well sorted, lower to upper very fine-grained sandstone with little interbedded siltstone or shale, alternating with 5-30-m-thick intervals of recessive cover and very fine-grained, thin-bedded sandstones and siltstones. Lower to upper fine-grained sandstone is common and medium grains are locally abundant in moderately to poorly sorted portions of some beds. Sandstone beds with overall medium grain size are rare at this location, though they are common in some other Gilead outcrops. Sandstones from the measured section weather mostly medium gray, with local rusty-weathering beds and lenses, and are medium to dark olive-gray on freshly broken surfaces. Petrographic thin sections from this location are not yet available, but the sandstones appear in hand specimen to consist of subrounded to angular quartz with abundant dark lithic fragments, and less than 5 percent yellow-orange limonitic fragments, consistent
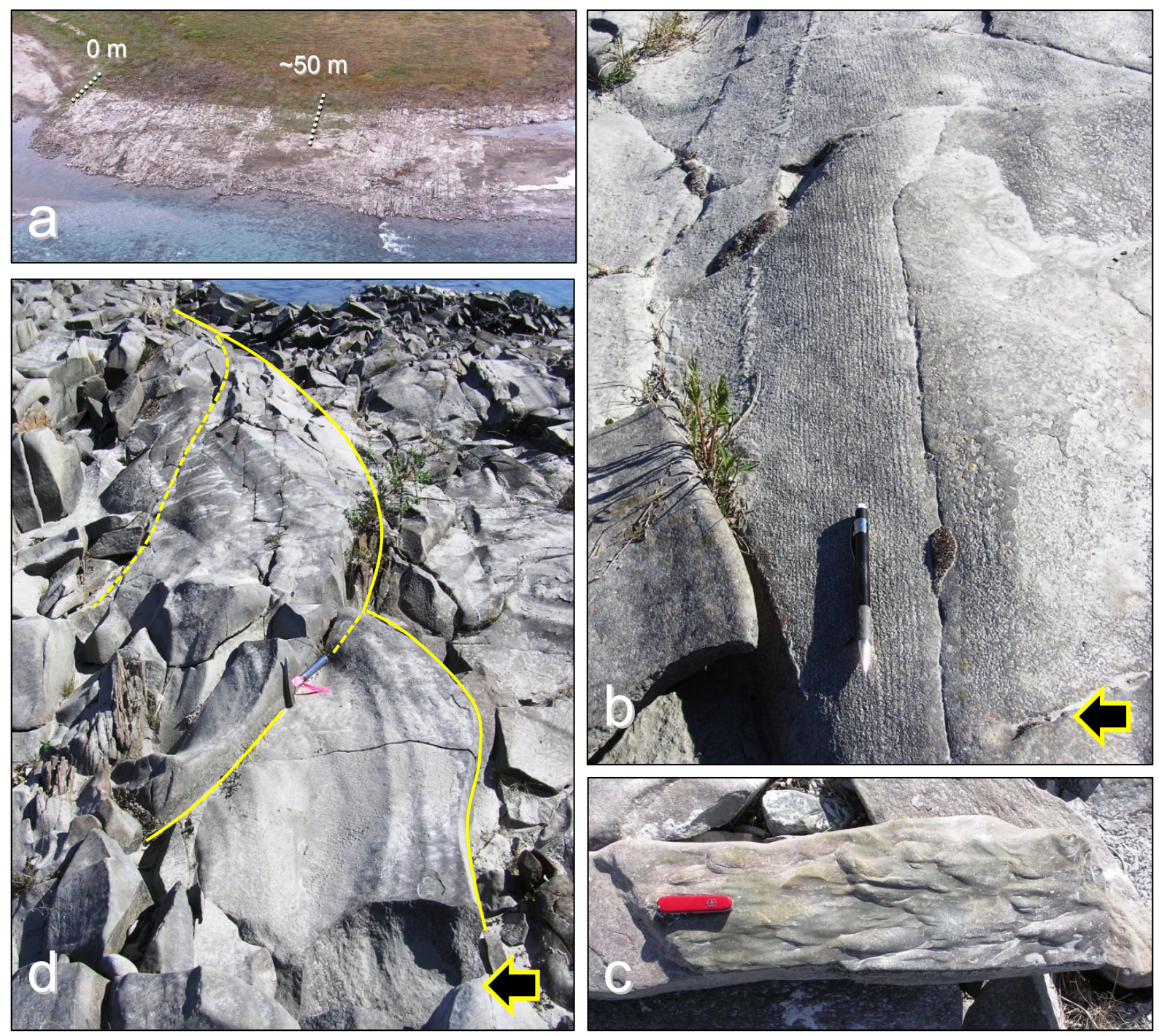

Figure 5. Photos of measured section of lower Gilead sandstone at station 07PD010 on the west bank of the Ivishak River (location labeled in fig. 3). (a) Aerial overview looking west-southwest at the lower two-thirds of the section. (b) Upper flow regime planar lamination is common, as in this example from approximately $8 \mathrm{~m}$ above the base of the measured section. Stratigraphic up direction is to left (north) as indicated by arrow. (c) Flute casts (in float at approximately $80 \mathrm{~m}$ in section) are uncommon in the measured section, though they occur occasionally throughout the Gilead sandstone. (d) Complex of large scale cut-and-fill structures with compound curviplanar and planar-laminated fill at approximately 10-12 $\mathrm{m}$ in section. Largest scours are nearly $1 \mathrm{~m}$ deep by $5 \mathrm{~m}$ wide. Stratigraphic up direction is to left (north) as indicated by arrow. 
with the litharenite designation applied to the Gilead sandstone by Reifenstuhl $(1989,1991)$. Metamorphic rock fragments, especially of micaceous phyllite(?) detritus, are locally abundant along the Ivishak River transect, and are most conspicuous in coarse to very coarse sandstone beds that crop out north of the measured section. The sandstones of this measured section are well indurated and appear silicified, suggesting paleo-burial at substantial depth corresponding to paleotemperatures exceeding $80-100^{\circ} \mathrm{C}$ (Worden and Burley, 2003). This is consistent with paleotemperatures $>110^{\circ} \mathrm{C}$ indicated by fission track analyses (O'Sullivan, 1991), and with vitrinite reflectance values in the 1.0-2.3 percent range (Reifenstuhl, 1991) reported from Gilead syncline.

As described and illustrated on Sheet F-1, Gilead sandstone beds are typically decimeters to more than a meter thick, commonly amalgamated from multiple flow events, and they contain current-generated sedimentary structures and other features associated with full or partial Bouma successions. Stratigraphic up direction is commonly indicated by an incredibly diverse suite of load casts developed at the base of many structureless or convolute-bedded (Ta) sandstone beds. Loads vary from millimeter to decimeter scale, and include a broad range of forms that can be described as rounded-bulbous, linear-parallel, curvilinear-radial, or puckered, and in some instances, appear to transition between flute-shaped loads and loaded flutes. Grooves and flutes (fig. 5c) are more common in other outcrops than in this measured section, and are valuable indicators of stratigraphic younging direction. Upper flow regime planar lamination ( $\mathrm{Tb}$ facies, fig. $5 \mathrm{~b}$ ) with common parting lineation normally overlies the basal massive or convolute sandstones, and locally grades upward into low-angle trough cross-stratification. The latter is typically preserved as rusty-weathering remnant lenses at gently curved scoured amalgamation surfaces between higher energy sands. Large scour-and-fill features, up to $1 \mathrm{~m}$ deep and $5 \mathrm{~m}$ wide, are locally abundant and nested, for example, from 10 to $13 \mathrm{~m}$ in the measured section (fig. 5d). These and other, more cryptic amalgamation surfaces locally modify the normal Bouma sequence. This has generated amalgamated sandstones with reversed or complicated stacking architectures, for example, Tab-a-abc, where hyphens represent amalgamation or the resumption of higher energy flow. In many instances, it is unclear whether the amalgamation reflects erosion of fine-grained material, or if the event frequency was high enough to prevent the accumulation of mudstone.

Packages of current-ripple-laminated (Tc) sandstone ranging from a few centimeters to a decimeter or more in thickness are present at the tops of numerous beds in the amalgamated sandstone facies. Similar ripple-laminated units account for nearly all of the thin-bedded sands in recessive-weathering intervals. Ripple asymmetry indicates predominant paleocurrent flow was to the east or northeast. Locally, these rippled caps are overlain by thinner beds of lower flow regime planar-laminated (Td) siltstone. True shale is rarely preserved as very thin hemipelagic drapes (Te facies) above the laminated siltstone and below the overlying unit. Bedforms generated by either fair weather or storm waves are absent entirely from the measured section, but they may be present farther north in the central traverse segment on the Ivishak River (fig. 3). Trace fossils are rare on the Ivishak River transect, restricted to isolated occurrences of nondescript Planolites on beds that also contain groove casts. This suggests the burrowing organisms may have been transported into the depositional environment by turbidity currents along with woody debris and other detritus.

In measured section 07PD010, the mostly amalgamated sandstone facies association is present in three main packages, and constitutes approximately 60 percent of the $160 \mathrm{~m}$ section; the thin-bedded to ripple-laminated finegrained association accounts for the other 40 percent. It is our impression that this ratio is fairly representative of the Gilead sandstone as a whole. Both upward-coarsening/thickening and upward-fining/thinning stacking patterns are observed, and in some instances, beds of highly variable thickness are developed with no discernable grain size or thickness trend, as shown in figure 6 from a sandy interval north of the measured section at station 07PD018. The bases of sand-rich cycles are either abrupt or gradational, but their tops are characteristically sharp.

Sandstone beds in some Gilead exposures reach thicknesses of several meters with only rare ripple-laminated partings to indicate episodes of lower energy flow between high energy depositional phases. An example is the 3.5 -m-thick bed shown in figure 6, consisting mostly of massive to faintly planar laminated sandstone with a single internal parting surface defined by ripple lamination. The upper $15-18 \mathrm{~cm}$ is current-ripple laminated to lower flow regime planar laminated sandy siltstone with abundant woody impressions. This anomalously thick sandstone bed is interpreted to record deposition from sustained, mainly high energy flow during a single major event, perhaps a large flood in the provenance area.

Where exposed, the recessive, thin-bedded and ripple-laminated facies association consists largely of rusty reddish brown- and iridescent purple-weathering lower very fine-grained sandstone, siltstone, and shale (fig. 7b). These are typically arranged in laminated to thin $(<1-10 \mathrm{~cm}$ thick), upward fining and thinning graded beds characteristic of classical turbidites. Some recessive intervals contain sporadic 1-5-mm-thick bentonite laminae. Ash beds and dispersed tuffaceous material became increasingly abundant in northern Alaska during Cenomanian time, which suggests these exposures may belong to the upper part of the Gilead succession. Intervals of highly 

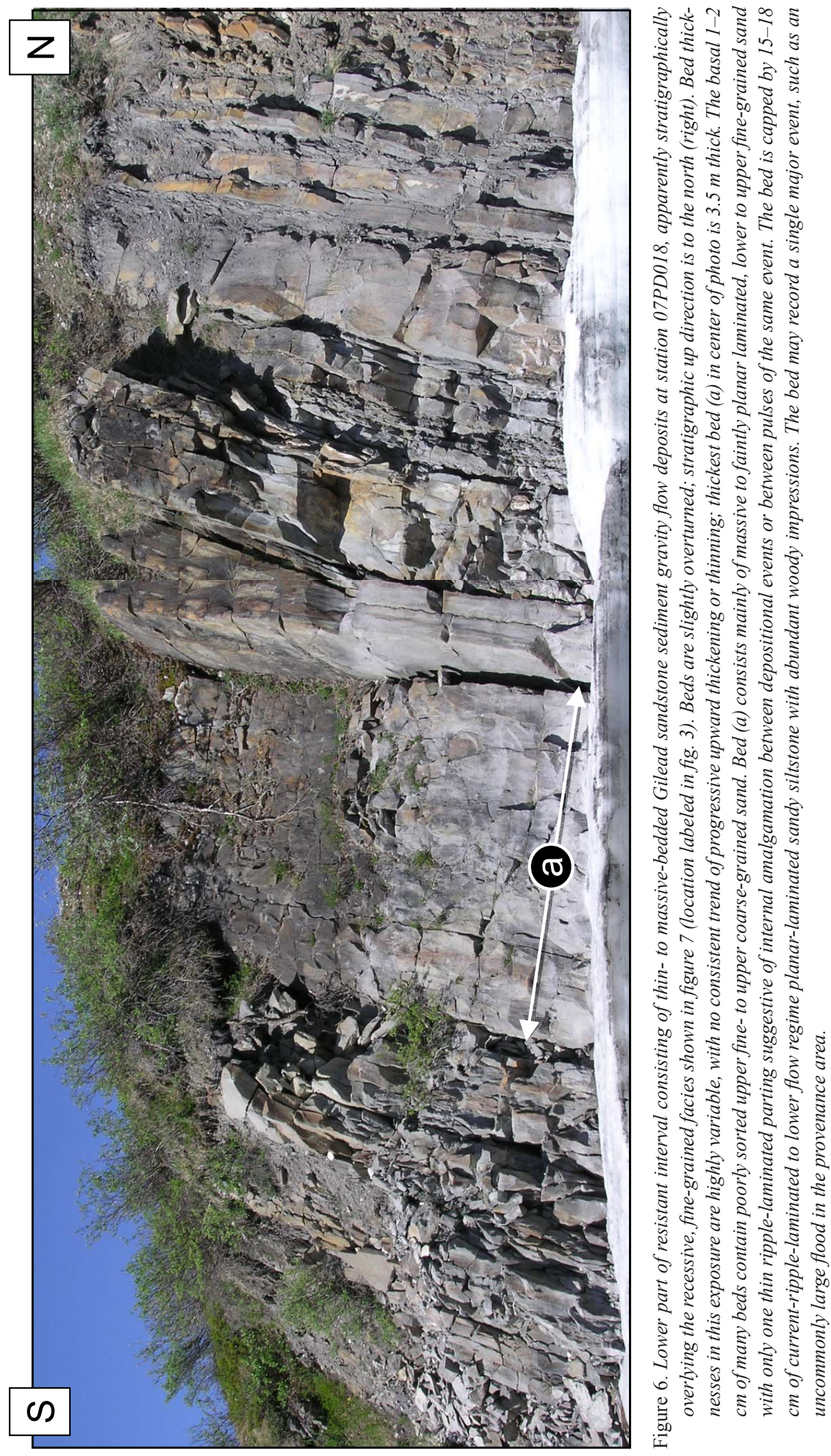

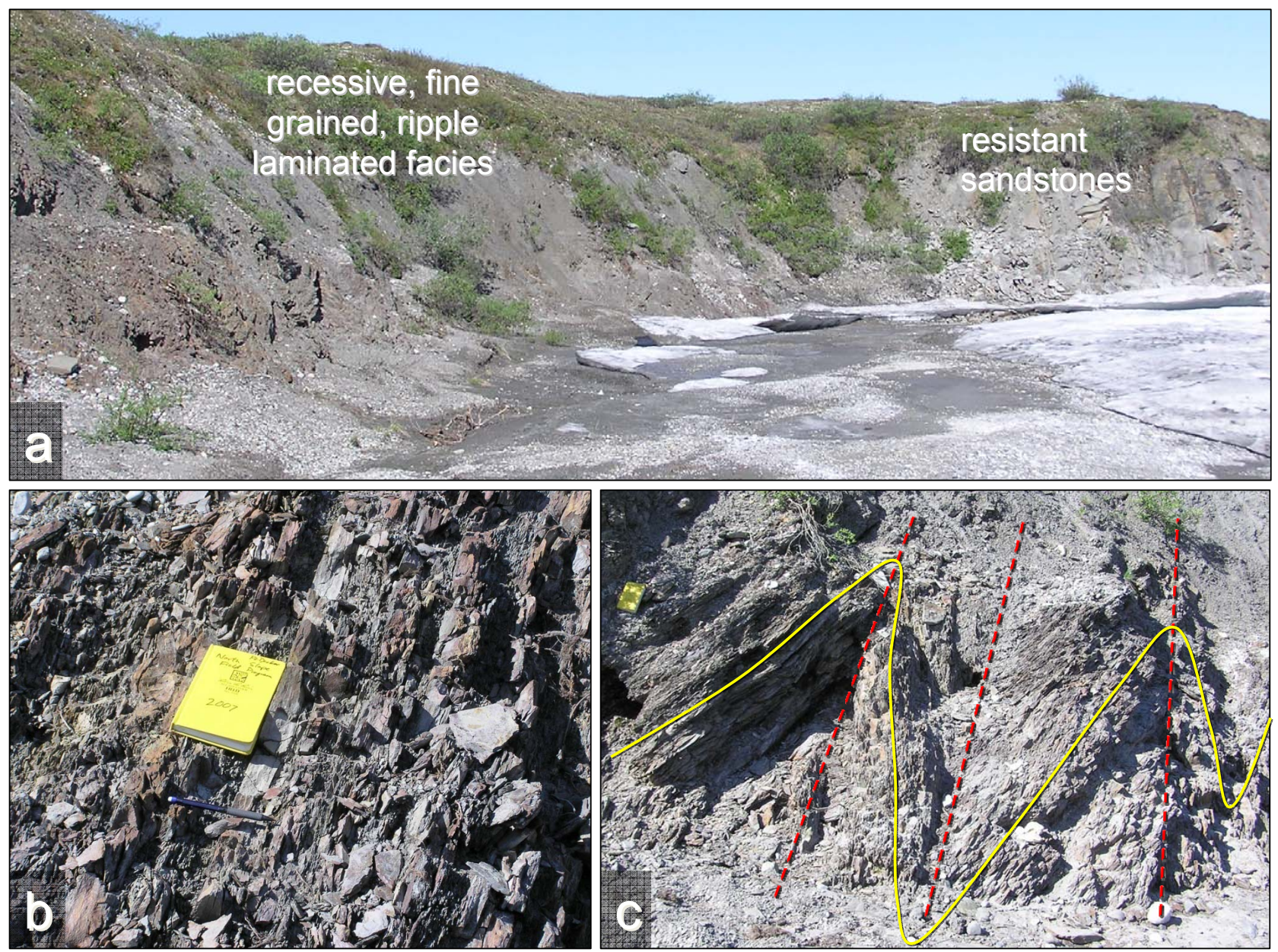

Figure 7. Steeply dipping, locally tightly folded, fine-grained sandstone and siltstone ripple-laminated facies of the Gilead sandstone on the Ivishak River at station 07PD018 (location labeled in fig. 3). (a) Outcrop overview looking northwest shows recessive bank outcrops visible in close-up photos. Overall stratigraphic up direction is to the right (north). The overlying light gray resistant sandstone interval at right is shown in fig. 6. (b) View to west of characteristic rusty reddish-brown to iridescent ripple-laminated beds; flat bed bottoms and rippled tops indicate beds are overturned, with stratigraphic up to the north (to right). (c) View to west of tight, north-verging chevron folds in sandy siltstones. Field notebook in shade at left for scale. These incompetent, fine-grained intervals localize deformation, recording much higher internal strain than the adjacent competent, sand-rich intervals that have experienced the same amount of tectonic shortening. Figure 12 shows area immediately south (left) of these exposures.

bentonitic, organic fissile shales are also present in the central and northern parts of the Ivishak River transect; in the absence of age control to the contrary, we assume those shales are somewhat younger Late Cretaceous in age, and do not consider them part of the Gilead succession. We await biostratigraphic and radiometric results from 2007 samples to further evaluate the ages of these intervals.

\section{Stratigraphy of the Gilead Syncline and Gilead Creek Traverses}

A traverse $5 \mathrm{~km}$ long beginning at the Kingak Formation on Kashivi Creek to the uppermost horizons in the hinge of the openly folded Gilead syncline (fig. 3) permitted investigation of the most continuous and least deformed stratigraphic section of Gilead sandstone. A second traverse began in Gilead sandstone on the ridgeline occupied by benchmark Shek and continued $8 \mathrm{~km}$ northward, following Gilead Creek through highly folded and thrust-faulted Gilead and Upper Cretaceous sandstones and mudstones, ending in Canning Formation (fig. 3). Several tight folds and probable faults exist between these two traverses, and it is unclear how to correlate between them due to the absence of good marker beds. Additional foot traverses near the east end of Gilead syncline focused primarily on structural relationships near the basal Brookian contact. 
The Gilead syncline traverse begins on Kashivi Creek (fig. 3; Keller and others, 1961) at an outcrop near the top of the Kingak Formation, where splintery, dark gray, micaceous, silty shales with sideritic concretionary horizons are highly deformed by north-vergent, moderately west plunging angular folds. Prior sampling in this outcrop has yielded Valanginian foraminifera and Kimmeridgian to Valanginian palynomorphs, making this shale largely timeequivalent to the Miluveach Formation of subsurface usage (Carman and Hardwick, 1983). An estimated $50 \mathrm{~m}$ of cover separates this Kingak outcrop from an exposure containing a few meters of nearly undeformed, micaceous, rusty-weathering and iridescent mudstone with thin interbeds of planar- and ripple-laminated siltstone and lower very fine sandstone; the age of these fine-grained clastic beds is uncertain. They appear similar to the fine-grained recessive intervals present elsewhere within the Gilead sandstone, and are tentatively assumed to be Brookian deposits that forecast the deposition of the overlying thicker and coarser-grained beds. Further constraints on the age of this interval may emerge from biostratigraphic analyses of 2007 samples.

The base of the more continuous Gilead sandstone exposures is in largely amalgamated, thin- to massive-bedded upper very fine to lower fine-grained quartzose, lithic, micaceous sandstones that closely resemble those on the Ivishak River except in their weathering character. These outcrops are typically extensively lichen-covered and badly frost-shattered, but they contain many of the load casts, convolutions, grooves, flutes, and partial Bouma intervals (Ta, Tab, Tabc, etc.) described from the Ivishak River transect.

Rare ammonites have been found as float from the lower part of the succession at Gilead syncline. One collected during a previous field season is tentatively assigned to the genus Gastroplites (fig. 8), of probable Albian age (R. Blodgett, oral commun., 2006). This cast, along with a similar but smaller and more fragmentary ammonite impression found in 2007, will be submitted by DGGS for more specific identification. If trace fossils exist at all in the Gilead syncline section, they are even rarer than in Ivishak River outcrops. We noted no traces in our two-day traverse.

Although the Gilead unit has been described previously as mainly non-channelized (Reifenstuhl, 1989; 1991; Pessel and others, 1990), we identified a sizeable submarine channel in the lower part of the succession on Kashivi Creek (fig. 9). The channel margin truncates at least $2 \mathrm{~m}$ of dark gray mudstones on a stair-stepped surface. The lowest exposed channel-filling unit (possible thalweg deposit) consists of blocky sandstone beds with thin, finergrained interbeds. Sandstone beds encased in mudstone farther up the channel margin appear rotated by slumping into the channel. Higher in the channel-fill succession, apparent angular discordance between beds suggests a second, slightly younger thalweg, though this merits confirmation by closer examination.

Sedimentary features interpreted to represent shelfal or shallower settings have been described previously from the middle to upper part of the section at Gilead syncline (LePain and Kirkham, 2002), including hummocky and trough cross-stratification and climbing ripples (Reifenstuhl, 1989; 1991). In our traverse of the syncline, possible

Figure 8. Ammonite cast collected during previous field season as float from the lower part of the Gilead succession at Gilead syncline. Tentatively identified to the genus level as Gastroplites, it is probably of Albian age. More specific identification is planned on this and a smaller ammonite fragment impression found during 2007 in float of submarine channel fill at location of figure 9 .

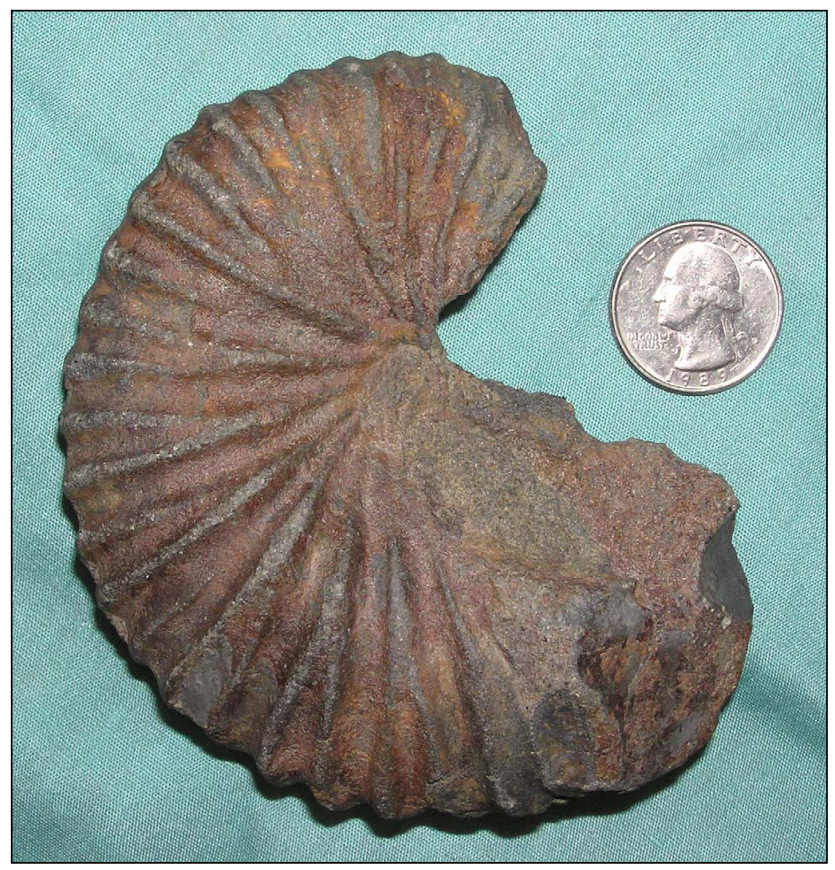



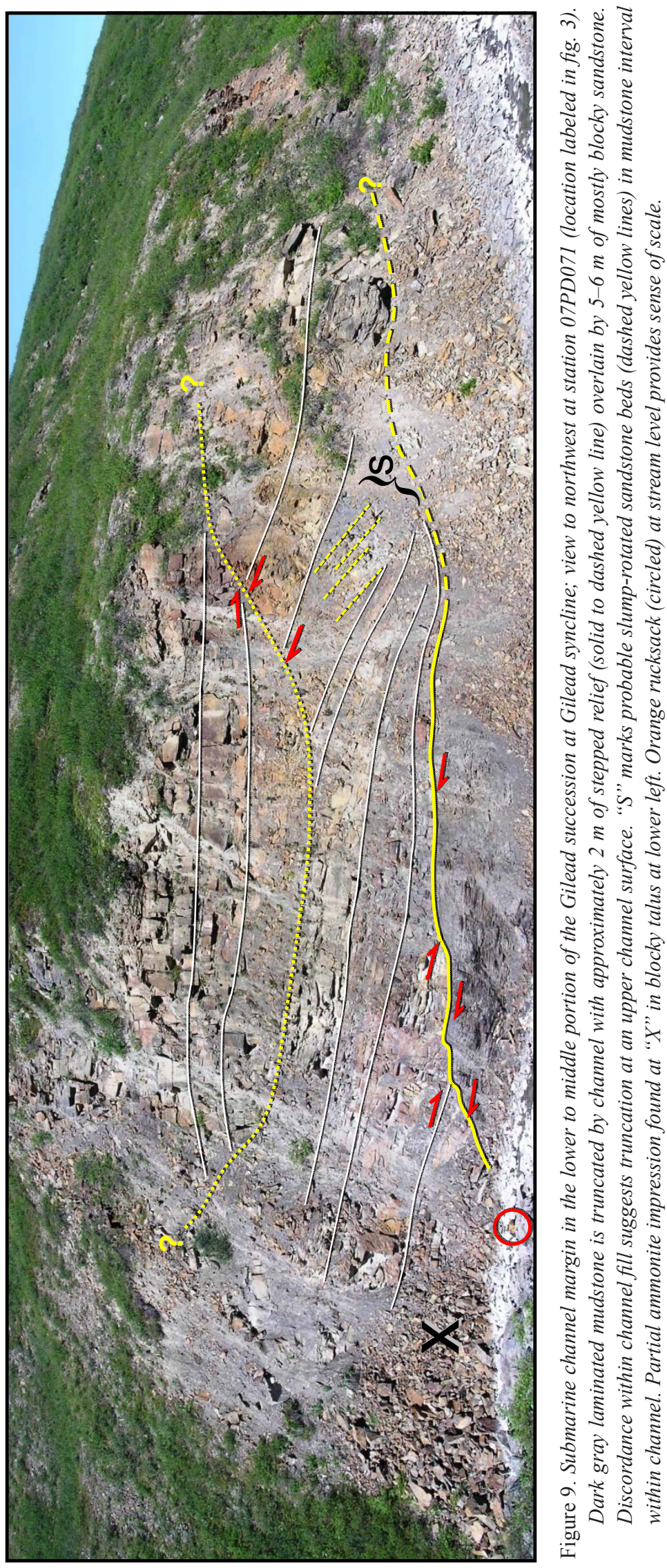
hummocky beds were few, scattered, and nowhere positively identified. One of the thickest ledge-forming packages of the amalgamated sandstone facies contains a sandstone bed $5 \mathrm{~m}$ thick made up entirely of east-prograding climbing ripples. Higher in the section, we located several examples of probable trough cross-bedding, and a few of apparent swaley cross-stratification (fig. 10). However, by themselves, trough cross-bedding and climbing ripple lamination are not diagnostic of shallow water conditions, as they occur in a range of environments including fluvial, shelfal, and deepwater settings, and are mostly indicators of current strength, grain size, and sediment supply. Furthermore, in the Gilead sandstone, these possible wave-influenced sedimentary structures are everywhere closely affiliated with features such as loads, grooves, flutes, and Bouma-like successions characteristic of sediment gravity flow deposits.

North of Gilead syncline, the Gilead Creek traverse extended the documented distribution of many of the same characteristics described along the Ivishak River and at Gilead syncline. For example, at the southeast end of the traverse on the ridge topped by benchmark Shek, the Gilead comprises numerous benches of upper fine- to lower medium-grained, medium greenish-gray-weathering amalgamated sandstone rich in metamorphic lithic clasts. White mica and conspicuous phyllite fragments appear to be important framework constituents of the coarser beds. Abundant lichen cover and frost shattering obscures many sedimentary structures, but massive, planar-parallel, and ripple-laminated (Bouma Ta-Tb-Tc) intervals are evident in the amalgamated sandstones, as well as a few probable
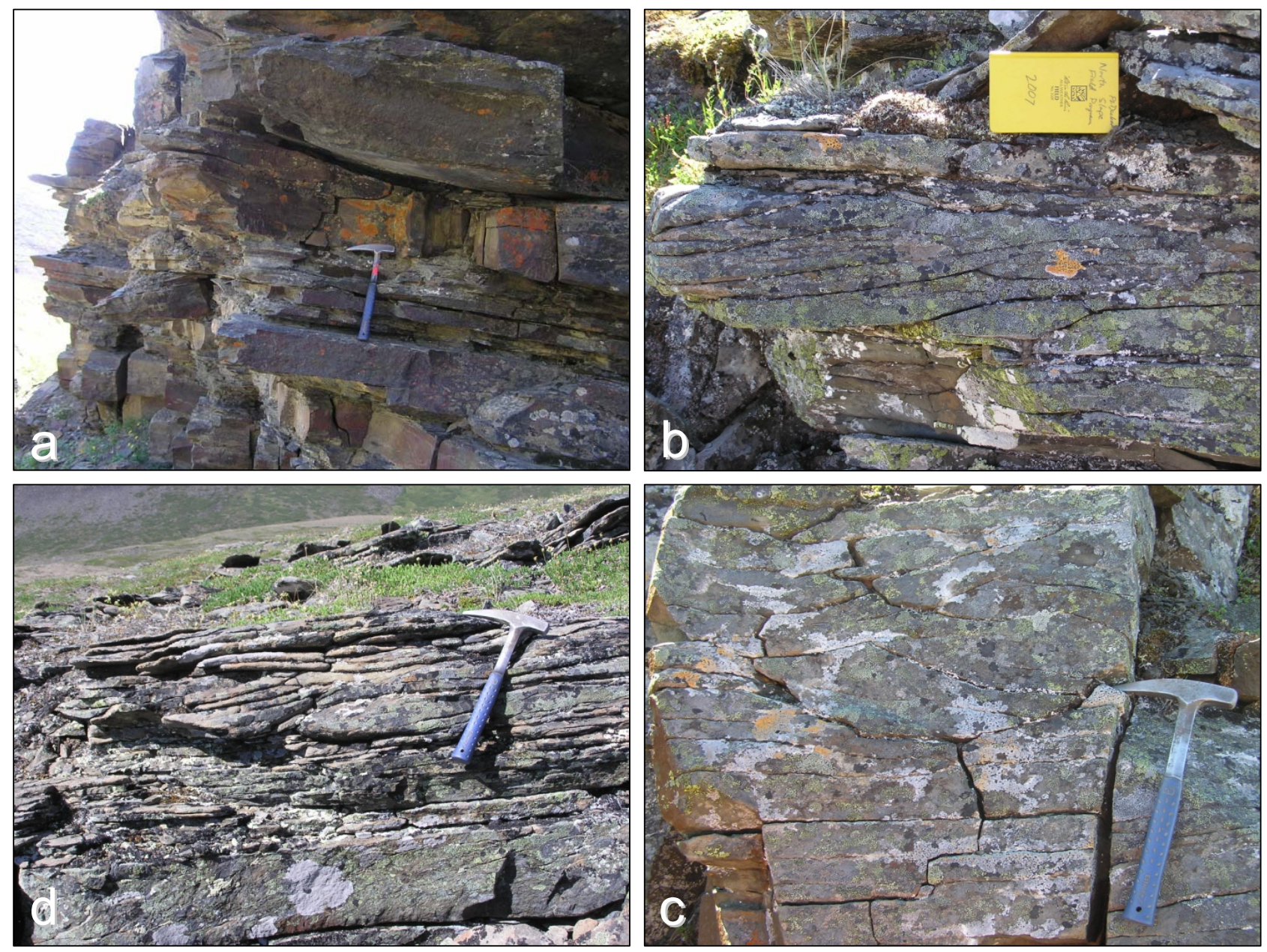

Figure 10. The middle and upper portions of the Gilead sandstone at Gilead syncline host occasional features that can be construed as evidence of wave reworking of sands that nearby features (not necessarily present in photos) indicate were most likely deposited from sediment gravity flows. (a) Medium bed with flat base at hammer head and convex-upper surface may contain large-scale hummocky bedforms with wavelengths of 2.5-3 m, but it is interbedded with sandstones marked by load casts, scour and fill features, planar-laminated beds, and current-ripple-laminated caps consistent with sediment gravity flow deposition. (b-d) Possible trough cross-beds and possible swaley cross-stratification immediately left of hammer in (d). 
trough cross-beds. North of this ridge, Gilead Creek appears to flow mostly down-section through alternating cycles of medium- to thick-bedded sandstones and thinner-bedded turbidites, including substantial covered intervals. It is our impression that the ridge-forming, amalgamated sandy packages become thinner, and that the recessive, heterolithic, thin- to medium-bedded sandstone and mudstone packages become thicker and represent more of the section northwest of benchmark Shek than to the south in Gilead syncline. This requires more quantitative evaluation since it may relate significantly to the north-south lateral continuity of the Gilead unit.

\section{Stratigraphic Interpretations and Working Depositional Model}

Molenaar and others (1984) interpreted the Gilead syncline section as consisting mainly of deep water turbidites. Huffman and others (1985, p. 68) interpreted a broader spectrum of depositional settings, and described the stratigraphic section as constituting a thick deep-marine turbidite sequence overlain by thick shallow-marine deposits with a thin fluvial section at the top; like Keller and others (1961), they interpreted it as largely Nanushuk-equivalent. Reifenstuhl (1991) inferred a middle shelf setting dominated by single-event processes such as storm-surge ebb flow and turbidity currents. Schenk and Bird (1993) concurred with Molenaar and others (1984) that the unit consists mainly of turbidites, and speculated that it probably represents lowstand fan deposition from one or more depositional sequences. We agree that the sand-rich cycles record some sort of event deposition, but are not convinced that they include shallow-marine to nonmarine deposits, though we locally observe a few instances of possible wave-related or combined-flow sedimentary structures. We refrain here from using the term "turbidites" to describe the thicker bedded, amalgamated sandstone facies intervals to avoid confusion with classical thin-bedded, unidirectionally graded turbidites. The term is more appropriately used to describe the recessive, much thinner bedded to ripple-laminated sandy siltstone to mudstone facies of the Gilead unit.

We find ubiquitous evidence for sediment gravity flow as the dominant agent of deposition throughout the Gilead sandstone, namely the partial Bouma-like successions and associated tractional and dewatering features. In the amalgamated facies association, we interpret internally structureless sandstones to represent rapidly emplaced, frictionally-frozen slurries. The overlying upper flow regime planar lamination records the reworking of such slurry beds and deposition from the traction carpet. Loaded bases and convolutions testify to rapid compactional dewatering accompanying sudden deposition. Waning flow velocity produces the upper flow regime current ripples and lower flow regime planar laminated siltstones in the late stages of flow events. The high degree of amalgamation of high energy $\mathrm{Ta}$ and $\mathrm{Tb}$ sandstone beds suggests either very frequent or sustained, possibly surging flow events rather than occasional turbidity currents produced by slope failure as the depositional process for the sand-rich facies association.

The presence of both upward-coarsening/thickening and upward-fining/thinning trends could indicate that the depositional environment was subject to progradational and retrogradational fluctuations, or it might simply reflect aggradation accompanied by lateral migration of a sand-prone channel belt. Clearly, the channelized succession incised into fine-grained facies on Kashivi Creek at Gilead syncline (fig. 9) locally provides unequivocal evidence of sandy submarine channel systems.

We consider it plausible that some of these sands represent hyperpycnites, that is, high-density sediment gravity flow deposits fed by sustained, fluctuating to quasi-steady flows with a high freshwater component that evolve from sediment-laden fluvial systems debouching into the subaqueous environment (Mulder and Syvitski, 1995). Hyperpycnal flow deposits have been recognized in association with deepwater lowstand systems, particularly where connected to shelf-edge deltas or narrow shelves (for example, Plink-Björklund and others, 2002; Petter and Steel, 2006), but they have also been described in flood-dominated deltaic environments (Mutti and others, 2003) and prodelta settings subject to storm wave reworking (Myrow and others, 2002). The near absence of trace fossils and paucity of megafossils indicates an environment hostile to marine organisms. Low salinity and high suspended sediment concentrations are two of the most common stress factors invoked to explain such conditions and both are characteristic of environments dominated by hyperpycnal flow. The presence of consistently oriented climbing ripples throughout a bed $5 \mathrm{~m}$ thick, clear evidence of a persistent current and very high sediment load, is also characteristic of hyperpycnite deposits (Mulder and others, 2003).

The lateral continuity and correlatability of the Gilead sandstone as a genetic unit remains a matter of speculation. It appears to be largely age-equivalent to parts of the Albian-Cenomanian-aged Torok and Nanushuk Formations. The Gilead name has been applied only in the Gilead Creek-Ivishak River area, but the succession closely resembles much of the Arctic Creek unit and Bathtub Graywacke in the Arctic National Wildlife Refuge (Molenaar and others, 1987; Detterman and others, 1975; Decker and others, 1988; Robinson and others, 1989; Mull and Decker, 1993) and the informally named Juniper Creek sandstone in the Kavik River area (Wartes and others, 2007). As shown in figure 1, the Bathtub Graywacke lies at nearly the same latitude as Gilead syncline. 
The Arctic Creek unit and Juniper Creek sandstone are considered to have been thrust northward to their present positions along a more northerly trend; structural restorations are loosely constrained, but it is possible that these units would restore to approximately this same latitude.

Lithologically, Gilead sandstones are also similar to isolated ridgeline outcrops visited near the Lupine River in 2007 some $20 \mathrm{~km}$ west of the Ivishak River. Figure 11 shows a comparison of our $160 \mathrm{~m}$ measured section with the well logs from the base of the sand-prone lower Brookian interval in the Lupine Unit 1 well. It is immediately clear that the thicknesses of the alternating sand-dominated and finer-grained cycles are of the same order in both sections. Furthermore, we interpret a close correspondence in the positions of upward-coarsening and upwardfining successions and note the possible correlation of certain surfaces within these larger cycles. These striking similarities in stratigraphic architecture argue that the Gilead sandstone is, at a minimum, a good analogue for the lower Brookian sand-prone interval in this well and adjacent areas of the foothills, and may actually be directly correlatable across the $24 \mathrm{~km}$ east-west distance between the well and the outcrop section.

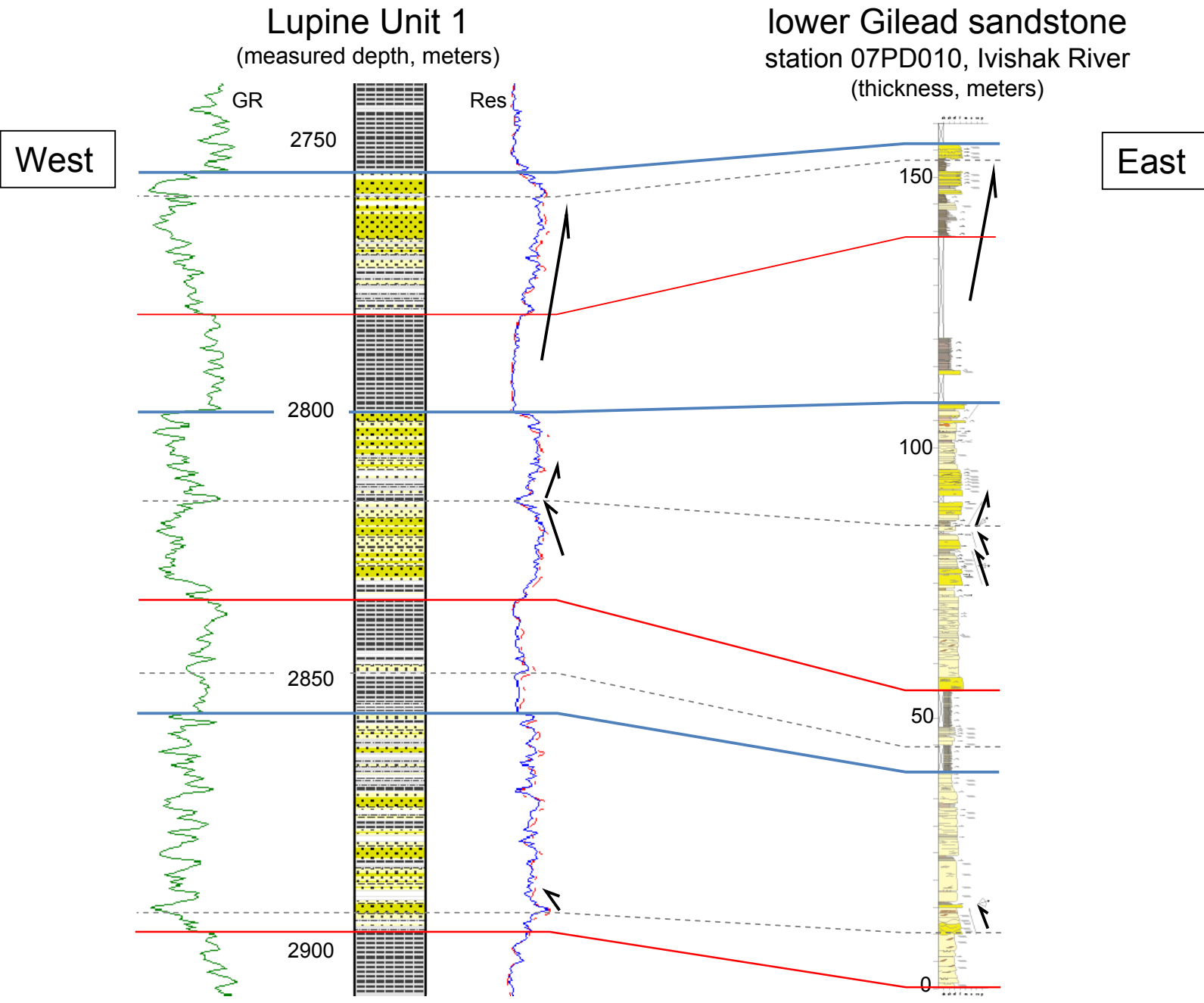

Figure 11. Comparison of the stacking architecture of the lowermost exposures (probable basal portion) of the Gilead sandstone on the Ivishak River with the basal part of the sand-prone lower Brookian interval (approximately 9,000-9,500' MD) in the Lupine Unit 1 well $24 \mathrm{~km}$ to the west. Alternating large-scale, sand-rich, and finer-grained cycles are of similar thicknesses, and internal cycles and surfaces interpreted from grain size and bed thickness variations suggest these may be time-equivalent units despite the distance between locations. If so, these variations would likely reflect major changes in the sediment source area that influenced sediment supply or hydraulic regime across a significant part of the basin. Paleocurrent observations from the Ivishak River measured section indicate relatively consistent flow to the east or northeast, in keeping with axial flow within the foreland basin, and further explaining the potential for correlations between these two occurrences. See figures 2 and 3 for locations. 
As mentioned above (and discussed in more detail later in this report), the Gilead sandstone was tectonically shortened and imbricated, and at least locally detached from the underlying Kingak Shale, but these facts do not require that it belongs to a far-traveled thrust or gravitational glide sheet. If it resides relatively close to its depositional location, it would appear to have a restricted north-south lateral extent, as the unit disappears entirely between benchmark Shek north of Gilead Creek and the long exposures of Neocomian through Upper Cretaceous strata along the Echooka River $19 \mathrm{~km}$ to the northeast (figs. 2 and 3).

The observations described above are mostly consistent with a model for the Gilead sandstone involving deposition by west-east-flowing currents, possibly largely in a submarine channel belt with restricted north-south dimension in the foreland basin's axial trough, and perhaps partly in shallower shelfal, slope, or ramp environments south of the foredeep. The southern basin margin may well have been a complex, tectonically active slope or orogenic wedge-top setting during deposition of the Gilead unit, locally subject to periodic or progressive shoaling above growing contractional structures. This offers one explanation of the possible reworking of sediment gravity flow deposits by wave energy in the upper part of the Gilead succession, though other, equally plausible explanations may emerge with further study. We tentatively view the Oligocene-Miocene Puchkirchen Formation of the Austrian molasse foreland basin (De Ruig and Hubbard, 2006) as a potential analogue for the Gilead depositional system. Prior to the interpretation of recent 3D seismic data, the Puchkirchen had been modeled as a simple series of lobate submarine fans. New mapping using high-resolution data shows that its dominant element is a low-sinuosity, axially confined channel belt $3-5 \mathrm{~km}$ wide and more than $100 \mathrm{~km}$ long. Such a long, narrow west-east-flowing axial channel belt system, along with slope fans on the southern basin margin, may have united the lower Brookian sand-rich successions in the Lupine Unit 1, Gilead syncline, Juniper Creek, Arctic Creek, and Bathtub Ridge areas, and would help explain their absence by pinchout just north of the basin axis (Molenaar, 1983).

\section{RELATIONSHIP OF GILEAD SANDSTONE TO UPPER CRETACEOUS UNITS}

As stated previously, a fundamental characteristic of the Brookian sequence is that it differs substantially from one part of the basin to another. This sets up a problem in areas that are both structurally complex and isolated from time-equivalent strata (such as the Ivishak River-Gilead Creek outcrop belt) that makes it difficult to unravel either the original depositional succession or develop a robust structural understanding.

In this part of the foothills, Albian through lower Campanian rocks are dominated by deepwater turbidites and other sediment gravity flow deposits, and formation identifications on the basis of field criteria can be highly speculative in isolated outcrops. It is harder still to piece together (with confidence) the complete original stratigraphic succession where such inherently similar units are dismembered and rearranged by structures that are themselves only partially exposed. For these reasons, it remains unclear how the top of the Gilead unit should be defined, either lithologically or in terms of precise geologic age.

Biostratigraphic constraints on the upper Gilead contact are sparse, and in some cases, may be conflicting. The youngest preserved strata from the core of Gilead syncline are of Cenomanian or younger age, based on a single specimen of the bivalve Inoceramus dunveganensis (Reifenstuhl, 1991), but these beds do not necessarily represent the depositional top of the succession. The Turonian bivalve Inoceramus (Mytiloides) labiatus (Molenaar and others, 1984) has been identified in sandstone outcrops of the northern Ivishak River traverse and along strike to the northeast on Gilead Creek (fig. 3; Reifenstuhl, 1991), but it is not clear whether these Turonian strata are mappably distinct from the Gilead sandstone as described to date. Further complicating this question is the fact that the collection location on the Ivishak River is also the recorded site of a bivalve identified as Inoceramus anglicus (Woods) of middle to late Albian age (Miller, 1982). This may be a different interpretation of the same fossil as the Turonian Inoceramid later reported from the same location by Molenaar and others (1984).

In the Brookian sequence, abundant pyroclastic content, both as discrete bentonite horizons and as dispersed tuffaceous debris, has long been recognized as characteristic of Cenomanian and younger Cretaceous strata (for example, Whittington, 1956). Thus, lacking biostratigraphic control to the contrary, Gilead beds containing bentonite laminae are inferred to be from the upper part of the succession. More work is needed to determine if an objective bentonite content threshold separates upper Gilead intervals from the Seabee or Canning Formations. Bentonite-rich, fissile, organic shale intervals are present among the sandier sections at several locations along both the Ivishak River and Gilead Creek traverses. They likely reflect relatively widespread (correlatable) transgressive to maximum flooding episodes, and it is hoped they will yield biostratigraphic control that may further define the ages of the adjacent sandstones and help reconstruct the larger mid- to Upper Cretaceous stratigraphic sequence. We also collected samples from a number of tuffs and bentonites in the hope that they will yield crystals dateable by $\mathrm{Ar} / \mathrm{Ar}$ or $\mathrm{U} / \mathrm{Pb}$ geochronology. 
At the south end of a series of outcrops beginning at station 07PD018 on the Ivishak River (fig. 12), an upright, gently dipping section of bentonitic mudstone on the south side of a small gully probably represents either Upper Cretaceous Seabee or Canning Formation. These beds are medium gray, popcorn-weathering, and contain large siderite concretions and concretionary bedding. On the other side of the gully just a few meters to the north lies an overturned section of contorted, rusty brown weathering, fine-grained Gilead facies that contains only sporadic, very thin bentonite laminae (figs. 7 and 12). The contact between these two lithologically contrasting units at or near the gully is not well exposed. During fieldwork, we inferred a fault contact at the gully. We look forward to re-examining this outcrop to evaluate whether it could instead contain a (local?) angular unconformity between these different rock units. Either way, this exposure is an example of the close juxtapositions of tuffaceous and less bentonitic strata that may have inspired Keller and others (1961) to hypothesize the existence of a mid-Cretaceous unconformity in this area.

Given current information, it appears possible that the Gilead succession may encompass both Albian-Cenomanian (Torok-equivalent) and Cenomanian-Turonian (Seabee-equivalent) deepwater deposits without a sharp lithologic break in the sandstones or the well-developed condensed shale that separates strata of these ages to the northwest, such as in wells in the Tarn-Meltwater area and in outcrops near Umiat. Albian to Turonian deepwater sediments in those areas were delivered from the west, having been transported first across the broad shelfal platform constructed by the eastward prograding Torok-Nanushuk depositional system. At the toe of that broad shelf platform, sediment supply was highly sensitive to being shut off by relative sea level rise; this is recorded by the condensed section at the base of the Seabee Formation in that area (the Shale Wall facies in the sense of Houseknecht and Schenk [2005] and adopted by Decker [2007]). In contrast, the Gilead study area lies far to the east of the north-south-trending segment of the final Nanushuk shelf margin. Little is directly known about the width of the shelf attached to the orogen to the south, but we speculate that the Gilead area may have been either at or just south of the basin axis during mid-Cretaceous time, with a relatively direct connection to the actively eroding orogenic belt. This may have ensured that the Gilead area had a more consistent supply of sandy sediment than the Tarn-Meltwater area during the major Cenomanian flooding event, and may have sustained nearly continuous deepwater sand deposition without the well-developed basal Seabee Formation condensed section that exists north of the foredeep axis. This scenario would be consistent with the top of the Gilead unit being a gradational contact.

Until the upper contact is better defined, it will be challenging to use the Gilead sandstone as a map unit in areas where it is associated with Turonian Seabee-equivalent and younger rocks. We hope that samples collected in 2007 will yield critical biostratigraphic or radiometric control that can be integrated with detailed petrography to develop robust criteria for distinguishing these units in the field.

\section{STRUCTURAL STYLE AND DEFORMATION HISTORY}

The topographic and structural grain of this area trends northeast-southwest. Not surprisingly, important changes in structural style and stratigraphy are observed in progressing across the grain toward the foreland from south to north along our traverses. A full interpretation of the structural observations and measurements collected along the 2007 traverses of the Ivishak River, Gilead syncline, and Gilead Creek is beyond the scope of this report. Nevertheless, the following section summarizes key structural characteristics observed on these traverses, and considers their implications for unraveling the stratigraphic record and documenting the regional deformation history.

\section{Structure of the Ivishak River Transect}

Bedding attitudes vary widely along the Ivishak River, but much of the section in the three segments of our 8.8 $\mathrm{km}$ traverse is subvertical to overturned. Though the succession becomes younger to the north in the broadest sense, common dip reversals and probable thrust imbrication make it crucial to determine the stratigraphic up direction at each outcrop. The southern portions of the Ivishak River transect include long exposures of strongly overturned beds with stratigraphic top to the north, locally rotated by more than $160^{\circ}$, resulting in overturned southward dips of less than $30^{\circ}$. These long stretches of overturned beds alternate with short exposures of upright, gently-dipping beds on the south limbs of anticlines whose axial surfaces dip to the south (fig. 13). Most fold axes plunge gently to the west, consistent with greater uplift in the nearby Echooka anticlinorium (Meigs and Imm, 1995) and other portions of the Brooks Range salient to the east.

The southern Ivishak River segment (fig. 3) contains mostly tight, asymmetric to overturned folds with south-dipping axial surfaces. They are readily observed at the outcrop scale and are reconstructed from bedding orientations at larger scales. Thrust faults are localized in the overturned limb of some, if not most, of the over- 

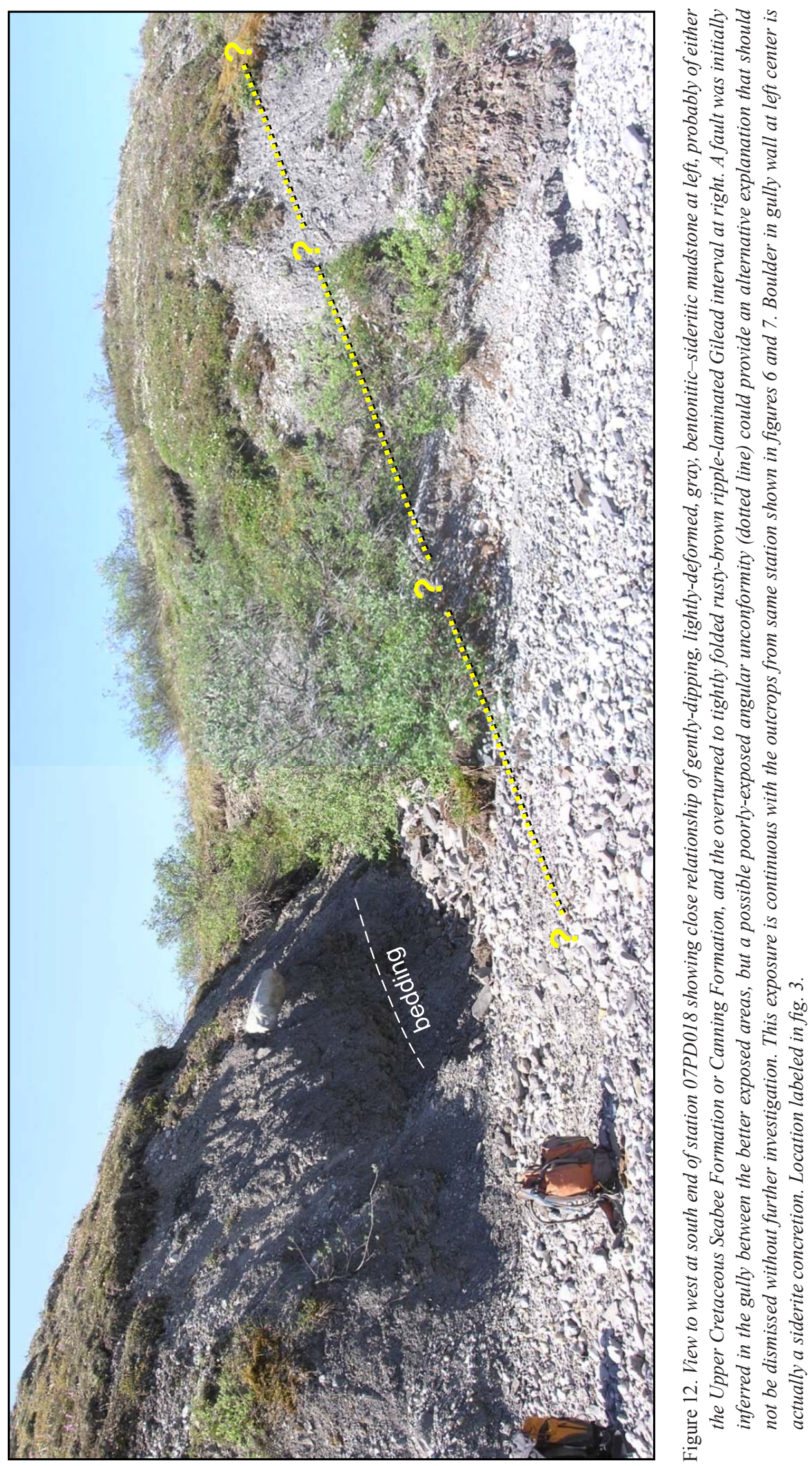
turned folds. Observed structural styles are clearly related to the mechanical strength of various units. Competent, massive-bedded sandstones form folds that are rounded and concentric at the outcrop scale, whereas incompetent very thin-bedded sandstones and mudstones commonly form chevron folds. Some folds record higher strains, becoming recumbent and even entirely inverted (downward facing).

Figure 14 illustrates a spectacular example of an outcrop-scale synformal anticline juxtaposed by faulting with a much more readily explained pair of overturned chevron folds. We interpret this set of structures in terms of a deformational sequence that may involve two distinct contractional events, or may simply reflect a change in deformational behavior with progressive shortening (fig. 15). An early phase (arbitrarily called D1 for discussion purposes) is hypothesized to have involved low-angle thrust faulting of a nearly isoclinal, recumbent, outcropscale anticline in the hangingwall above a ramp, marked by cutoff of beds in the footwall. During a subsequent deformational phase (D2, perhaps a continuation of the same event), the area of this outcrop-scale structure is hypothesized to have become the overturned limb of a lower order (much larger) north-vergent fold, rotating the earlier formed recumbent anticline through an additional $90^{\circ}$ or more, making it a downward-facing (completely inverted) fold. Shortening accompanying formation of the larger fold generated parasitic chevron-style folds in which bedding in the short limb is returned to an upright orientation, but bedding elsewhere remains overturned. The asymmetry of these chevron folds is consistent with the flexural-slip shear couple expected in the overturned limb of the larger fold.

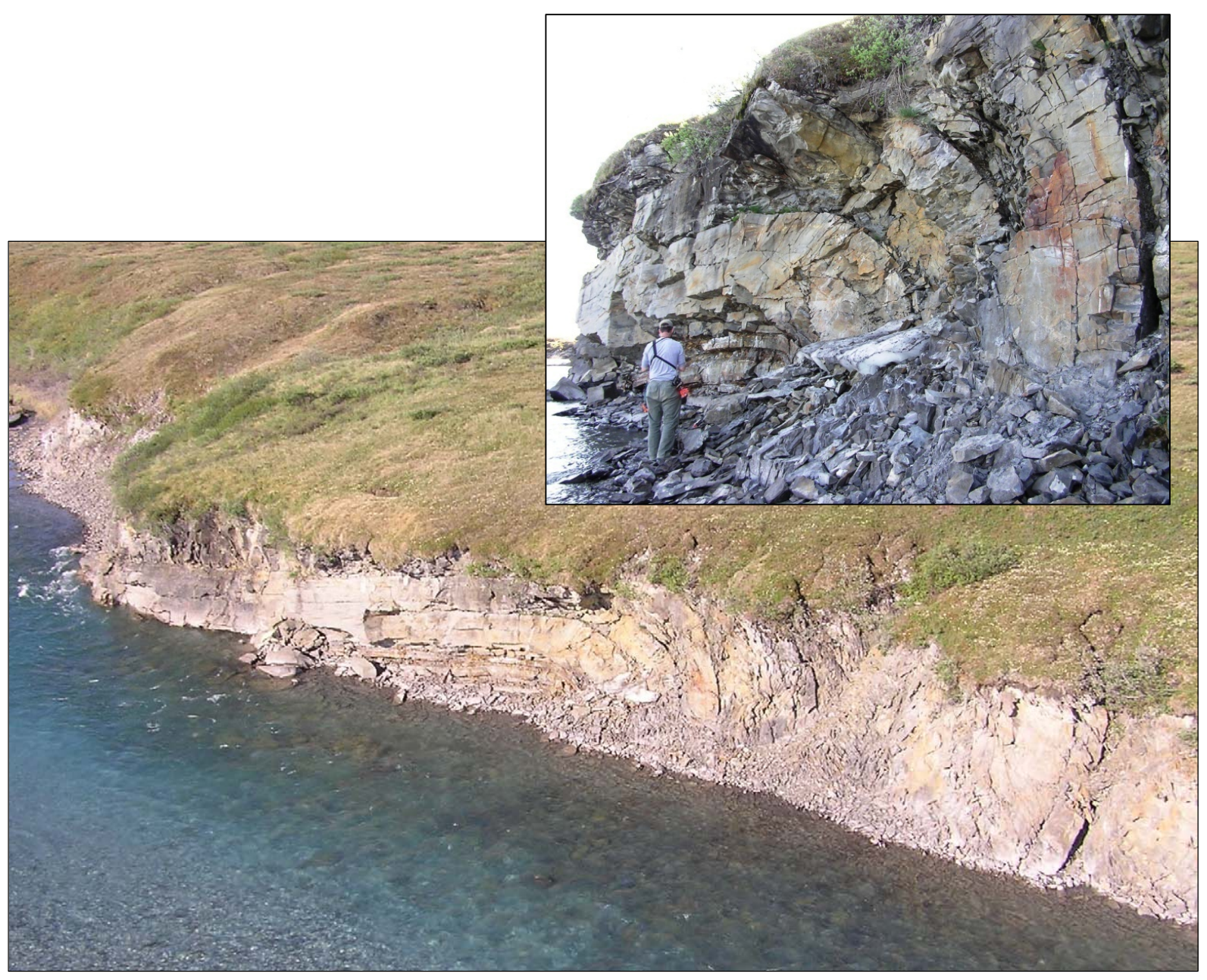

Figure 13. Overturned anticline with south-dipping axial surface in Gilead sandstone at stations 07PD014 and-015 on Ivishak River approximately $0.5 \mathrm{~km}$ northwest of the synformal anticline shown in fig. 14. This view to the west-southwest is nearly parallel to the anticlinal axis, which plunges approximately 15 degrees to azimuth 245 . The upright limb at left exposes much less section than the steep, overturned limb at right, which becomes progressively more overturned and thrust-faulted slightly farther north. Location labeled in figure 3. 

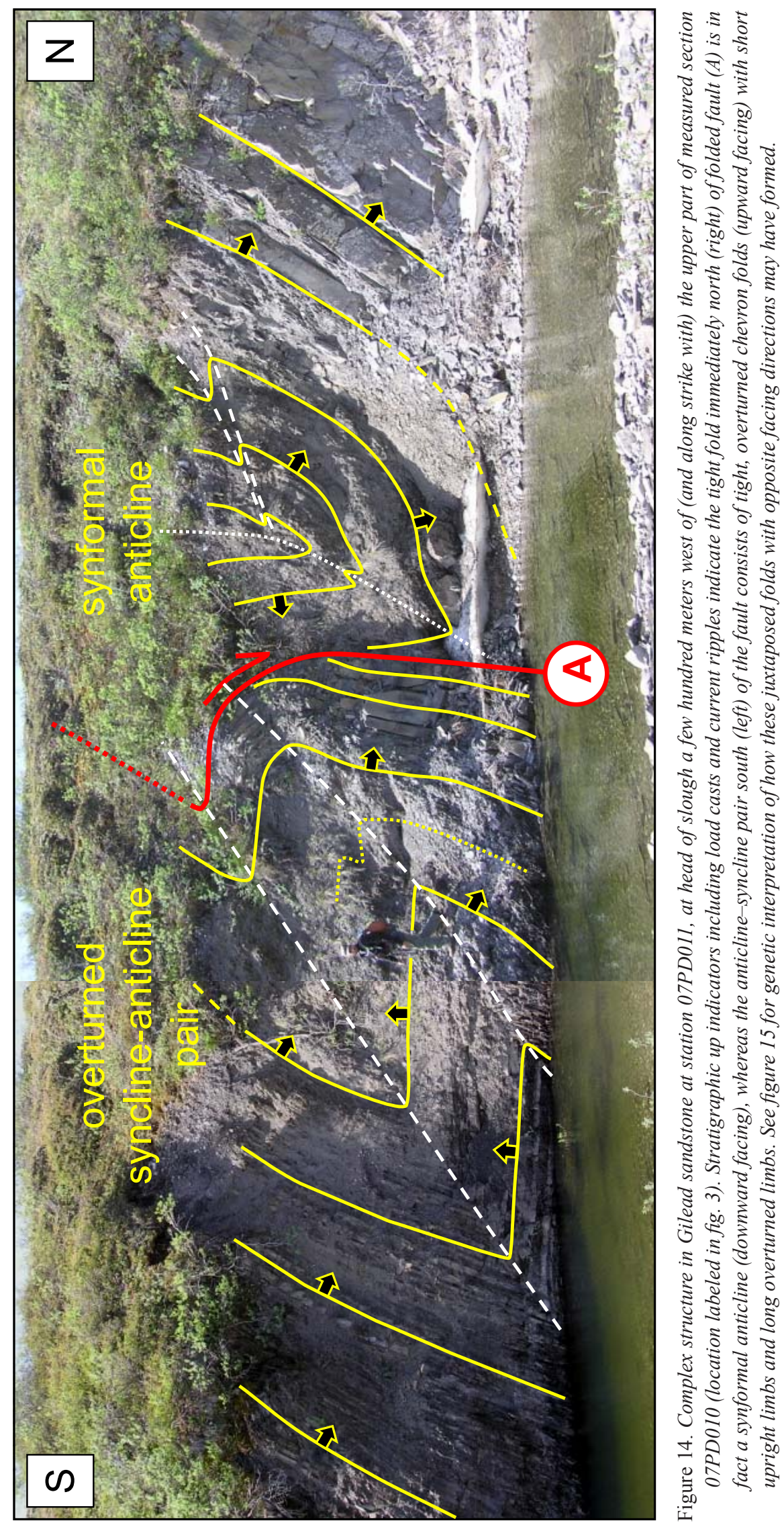


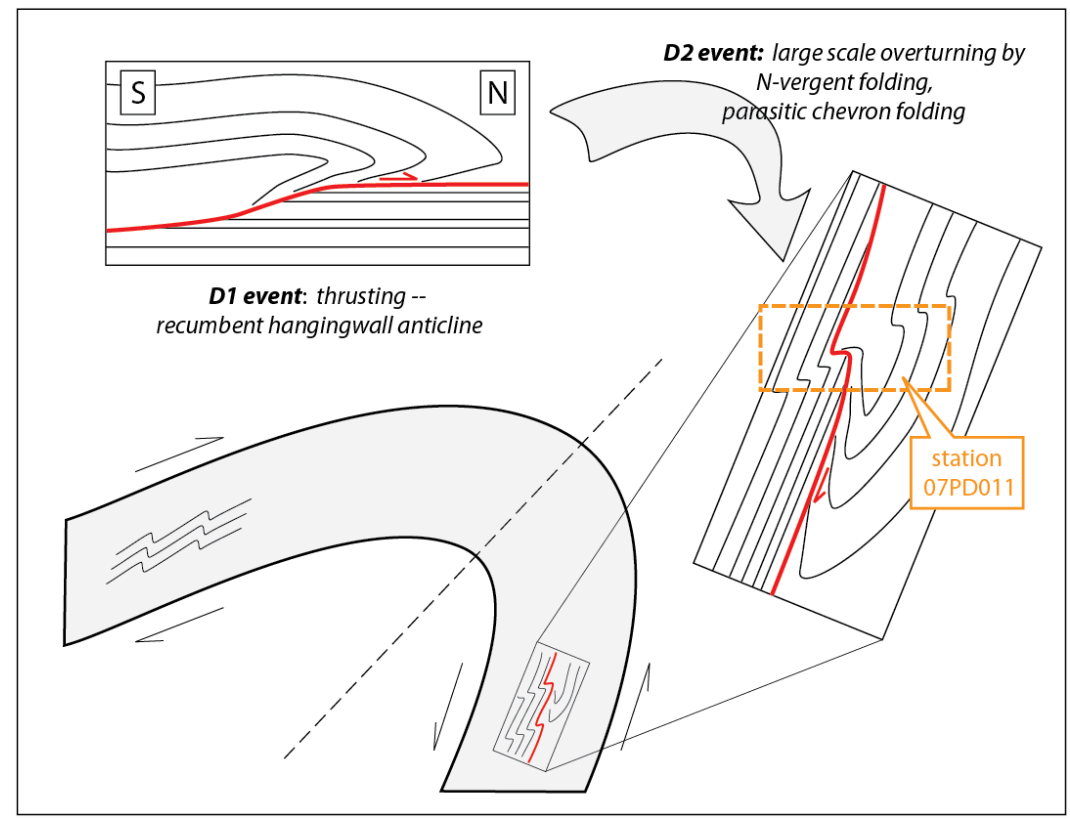

Figure 15. Structural hypothesis for development of synformal anticline, thrust, and overturned chevron folds in the Gilead sandstone on the Ivishak River at station 07PD011 (fig. 14). North-directed thrusting with development of a recumbent hangingwall anticline and footwall cutoff occurred during an early deformational phase (D1). During a second phase of deformation (D2), this location may have become the overturned limb of a large-scale north-vergent fold, in which parasitic drag fold geometries are characterized by long overturned limbs and short upright limbs. Apatite fission track analyses by O'Sullivan (1991) recognized as many as three Tertiary uplift events in this area with approximate ages of $60 \mathrm{Ma}$ (Paleocene), $45 \mathrm{Ma}$ (Eocene), and $35 \mathrm{Ma}$ (Oligocene). Further thermochronologic analyses on 2007 samples may help tie the phases of deformation described here to datable events.

On the basis of apatite fission track analyses in the Gilead area, O'Sullivan (1991) recognized three cooling events with approximate ages of $60 \mathrm{Ma}$ (Paleocene), $45 \mathrm{Ma}$ (Eocene), and $35 \mathrm{Ma}$ (Oligocene). These cooling events have subsequently been recognized across much of the northeastern Brooks Range (O'Sullivan and others, 1993; O'Sullivan, 1996), and are interpreted to reflect uplift and erosional unroofing accompanying major phases of Tertiary contractional reactivation. We collected samples in 2007 for further thermochronologic study that may help link the structural phases interpreted in outcrop to datable cooling events.

A nearly vertical fault that strikes northwest-southeast with slickenlines plunging $5^{\circ}$ southeast cuts measured section 07PD010 on the Ivishak River, offsetting the subvertical beds in a left-lateral sense by $5.3 \mathrm{~m}$. This is a fairly minor fault, but when combined with observations of dip reversal, misaligned or terminating fold hinges, and other structural discordances between outcrops on opposite sides of the river, it seems probable that this northwest-trending stretch of the river is controlled by a larger tear fault of similar orientation, allowing compartmentalization of shortening, with differences in structure east and west of the Ivishak River.

Slightly farther north in the central segment of the Ivishak River transect (fig. 3), beds are mostly upright and south dipping, becoming older to the north, the reverse of the overall northward-younging trend. Mostly northvergent structures are developed at a variety of scales, including thrust faults and open to tight folds with long upright limbs and short overturned forelimbs. In the overturned forelimb of a significant anticline near the south end, beds are locally strongly overturned with south-southeast dip as low as $29^{\circ}$. Near the middle of this segment is a symmetric to slightly south-vergent anticline-syncline pair with low to moderate dip angles and gentle plunge to the west or southwest. A south-dipping thrust cuts the north end of the central segment, carrying Gilead- or Seabee-equivalent sandstones with strong oil odor in the overturned limb of a hangingwall anticline, emplacing it above fissile to subfissile bentonitic shale, likely of the Canning Formation. This fault probably continues to 
the west-southwest through the prominent saddle between two rounded hilltops slightly lower than $460 \mathrm{~m}(1500$ $\mathrm{ft}$ ) elevation, and is interpreted to project northeast of the Ivishak River into the uplands west of Gilead syncline (figs. 3 and 16).

The northern segment of the Ivishak River traverse (fig. 3) comprises a mainly upright, south-dipping panel of Gilead sandstone and/or Seabee-equivalent sandstone and organic, bentonitic shale with locally strong oil odor. North-vergent asymmetric to overturned and locally isoclinal outcrop-scale folds and thrust-faults are common. In one area of particularly intense folding, medium- and thick-bedded sandstones are thrust-imbricated, detached from, and disharmonically folded relative to the subjacent chevron-folded laminated mudstones. Some of these are isoclinal folds whose axial surfaces have been refolded into open folds, consistent with two stages of deformation. In a gully at the north end of the northern traverse, thin-bedded sandstone, siltstone, and shale beds of probable Canning Formation are deformed into complex folds with non-linear axes. We interpret this northernmost outcrop as being in the footwall of a thrust that cores the long Aufeis anticline (Mull and Adams, 1989, p. 121-123) penetrated by the Aufeis Unit 1 well some $60 \mathrm{~km}$ to the west (fig. 3). This places the northern Ivishak River traverse on strike structurally with the lower part of the Turonian to Campanian aged Sagashak Creek section in the south limb of the Aufeis anticline, discussed by LePain and others in a separate chapter of this report.

\section{Structure of the Gilead syncline and Gilead Creek traverses}

The upland area south of the west-flowing upper reaches of Gilead Creek (fig. 3) encompasses several folds in addition to Gilead syncline, the major structure in the area. Partial remapping of these structures in 2007 was conducted (primarily by Wallace) both in the field and from aerial photography (fig. 16). Gilead syncline preserves the southernmost exposures of the Brookian sequence in this area of the mountain front; Brookian strata have been uplifted and eroded above the Echooka anticlinorium to the southeast. Gilead syncline is an open, southwestplunging "thumbprint" syncline, measuring approximately $3-4 \mathrm{~km}$ in width and $6 \mathrm{~km}$ in length, defined by the thick succession of resistant Gilead sandstone. To the northwest, between Gilead syncline and Gilead Creek lies a train of several smaller, narrow anticlines and wider synclines. They dominantly plunge to the southwest, but locally exhibit more gentle plunge to the northeast. We correlate the resistant sandstone packages exposed in these northern folds with several of the major benches from the lower and middle parts of the unit in Gilead syncline. We recognize a probable north-directed thrust fault with apparently limited displacement between Gilead syncline and the northern train of folds. This fault was mapped locally by Pessel and others (1990), and we tentatively extend its trace to the southwest toward the Ivishak River, where it may connect with the thrust described in the previous section at the north end of the central segment of the Ivishak River traverse.

Pessel and others (1990) mapped a series of gently-dipping thrusts parallel or near-parallel to bedding and with arcuate surface traces within and at the base of the succession. They drew these as top-to-south faults on their cross section, which can be interpreted as either backthrusts or out-of-syncline thrusts. Reifenstuhl (1991) interpreted thrust duplication of the upper part of the succession at one of these faults on Kashivi Creek. Although it is possible that such faults may be present in the area, we have a different impression of the Kashivi Creek fault. We interpret it as one of several steeply dipping transverse or rotational faults with fairly linear, north- and northwest-trending traces that we recognize in the area from the offset of fold hinges and resistant sandstone units. These transverse faults compartmentalize deformation within the fold train, allowing structures on either side to contract quasi-independently of each other. Two of the best-developed examples have greater map-view offset on one limb than the other. Slickenlines have not been observed on the transverse faults at Gilead syncline, and it is unclear whether they are dominated by strike-slip, dip-slip, or sub-equal amounts of both.

Without question, there are major along-strike differences in the style and magnitude of shortening within the Gilead succession. For example, the dominantly overturned section of the southern Ivishak River traverse trends into or is juxtaposed against the upright folds of the Gilead syncline area. Exposures are poor and discontinuous in the intervening low terrain, but a system of tear faults offers an attractive explanation for these differences.

As described in the introduction, there has been long-running (though mostly unpublished) discussion of whether the Gilead unit is allochthonous or parautochthonous. This question has significant subsurface implications and major bearing on paleogeographic reconstructions. The covered contact between the Gilead sandstone and the more deformed underlying Kingak Shale has been mapped as a thrust (Pessel and others, 1990; Reifenstuhl, 1989; 1991), despite the fact that it appears to consist of Albian strata overlying Valanginian-aged rocks with the apparent omission of several Lower Cretaceous units between the Gilead sandstone and the Kingak Shale. These missing units include the gamma ray zone (GRZ) of the lower Hue Shale, the pebble shale unit, the Kemik Formation, and any surface correlatable with the Lower Cretaceous unconformity (LCU); this stratigraphic interval ranges from an estimated $90 \mathrm{~m}$ to $210 \mathrm{~m}$ thick in the nearest wells. Except at decollements or in triangle zones, where 


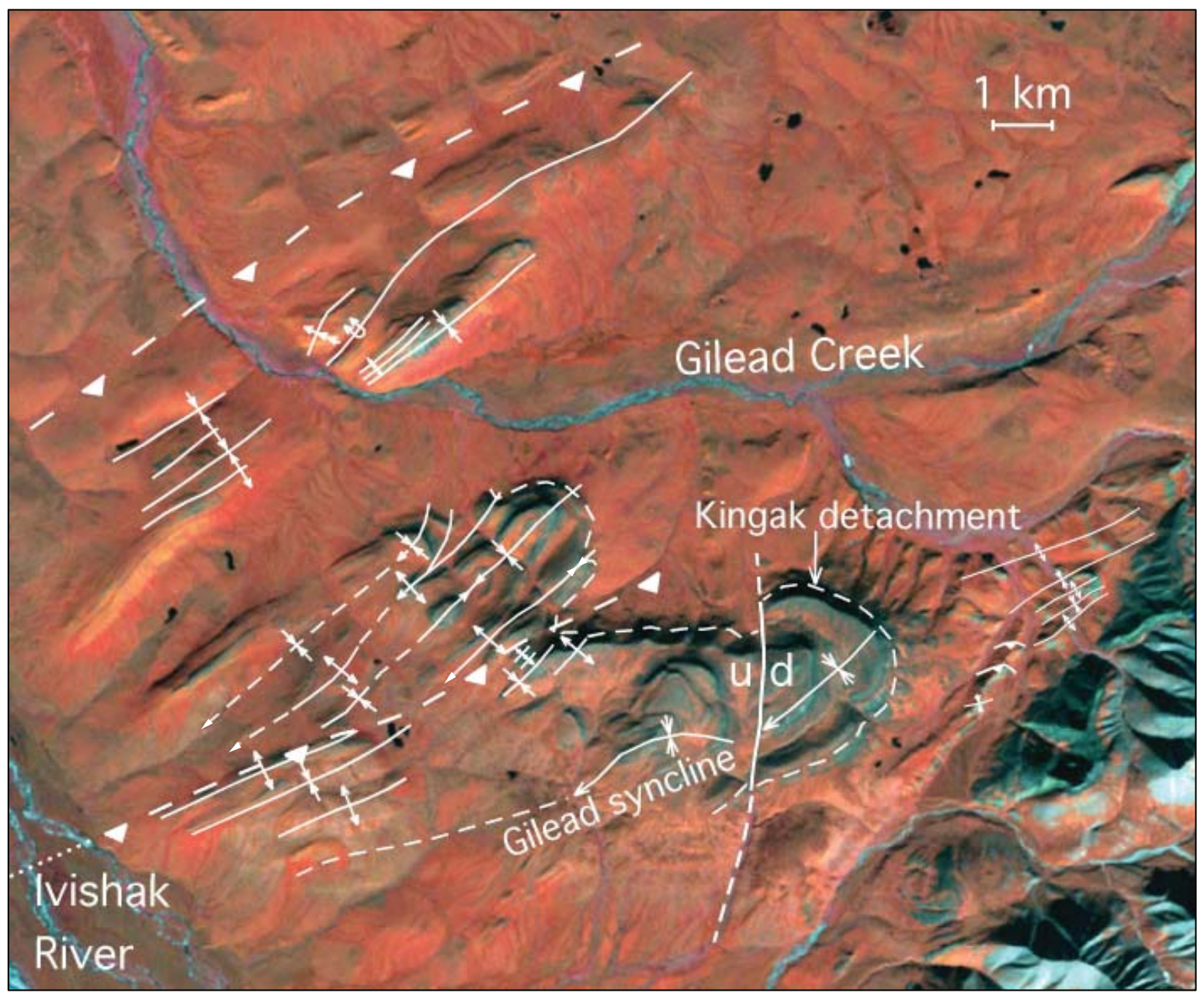

Figure 16. Simplified preliminary remapping in the Gilead syncline-Gilead Creek area from aerial photo interpretation and foot traverses conducted during 2007.

younger rocks in the passive roof of a backthrust may directly overlie older beds of the imbricated horses below, younger-over-older thrusting is unusual, and generally requires that the thrust fault cuts downsection across rocks that were previously folded or faulted to result in omission of section rather than the usual thrust repetition. This multi-stage scenario is conceivable at Gilead, but is not required to explain both the deformation in the Kingak Formation or the apparent omission of section at the contact.

The angular folds and shear fractures present in the Kingak Formation on Kashivi Creek are entirely consistent with the types of structures to be expected in this part of the mechanical stratigraphy, whether or not there is a fault of significant displacement between the Kingak and the Gilead. As an incompetent mudstone subjected to shortening along with the thick overlying succession of competent Gilead sandstone, it undergoes mostly outcrop-scale ductile flow, with folding and faulting of the brittle concretionary beds within it. Mechanical detachment of the Gilead unit from the underlying Kingak Shale (fig. 16) would be expected, whether the Gilead is a far-traveled allochthon, or simply the passive foreland-dipping roof of a north-vergent, west-plunging duplex created by the imbrication of underlying units. We confirm that the Triassic and Jurassic section structurally below and to the east of Gilead syncline is shortened by thrust-broken north-vergent folds (Meigs and Imm, 1995) with smaller wavelength and amplitude than the folds in the overlying Gilead sandstone (fig. 16).

Theoretically, the younger-over-older relationship and omission of section at Gilead syncline could also be explained with structural models involving (low-angle) normal faulting (Schenk and Bird, 1993) or top-to-north gravity gliding (C.G. Mull, oral commun., 2007). Large-magnitude Early to mid-Cretaceous extension of the overthickened orogen along shallow dipping, top-to-south normal faults has been documented in the southern Brooks Range (for example, Miller and Hudson, 1991; Blythe and others, 1996; Vogl, 2002; Vogl and others, 2002), but 
younger, top-to-north extensional collapse that could account for normal displacement of the Gilead succession on the north edge of the range has never been recognized.

Alternatively, the missing Lower Cretaceous units could be absent due to local non-deposition or may have been removed by erosion (Schenk and Bird, 1993) or mass wasting before deposition of the Gilead sandstone. The paleogeography of the Gilead area during that time is uncertain but it is sufficiently far south that it may have been too distal to experience laterally persistent deposition of the Kemik sands derived from the Barrow Arch rift margin to the north. Alternatively, the area might have been a bald subaerial high lacking accommodation space, or a bald bathymetric high, isolated from sandy sediment supply during Neocomian time. At nearly the same latitude, the Lupine Unit 1 well is the nearest and most relevant source of subsurface control. Overpressure prevented the acquisition of wireline logs across the lowermost Brookian to Kingak interval in the lower part of the well, where biostratigraphic data suggest the section is imbricated by thrust faults. However, mudlog data provide no evidence of a Kemik Sandstone interval in the well. Cuttings samples of fissile shales may be GRZ-equivalent, and numerous descriptions of floating sand grains and several instances of rounded pebbles may represent fault repetition of the pebble shale unit and/or a surface correlative to the LCU. In short, the Lupine well data support the argument that the Kemik sandstone may be absent at Gilead syncline due to non-deposition rather than because of faulting, but it offers no compelling explanation for the absence of the other Lower Cretaceous units there. Additionally, tentative correlations between the lower Gilead outcrop belt on the Ivishak River and the lower Brookian interval in the Lupine well (fig. 11) suggest that either the Gilead outcrop belt is not highly allochthonous, or that the allochthon extends at least as far west as the Lupine well.

To the north on the Gilead Creek traverse, shortening within the Gilead interval and associated Upper Cretaceous units appears to be greater than at Gilead syncline, with tighter asymmetric folds having steep to locally overturned limbs. The central part of this traverse is on strike with the northern segment of the Ivishak River transect approximately $5 \mathrm{~km}$ to the southwest, and is believed to correlate structurally to the Aufeis anticline.

Most of the section on the Gilead Creek traverse is right-side up and south dipping, yet overall, the section youngs northward from Gilead sandstone into north-dipping, progressively less-deformed Canning and Schrader Bluff Formations. This geometry is consistent with a series of south-dipping, north-vergent thrusts in the older strata, which either breach the surface or merge with a hypothetical north-dipping backthrust lying beneath the Upper Cretaceous units. The north dip of the younger strata may reflect deeply rooted folding, or might reflect a northward-tapering triangle zone within the Brookian sequence.

Beds are locally steeply overturned in the thrusted forelimb of a north-vergent anticline at station 07PD127 in the southern part of the traverse (fig. 17). This is the perhaps the best-exposed thrust fault we have encountered in the study area. The amount of offset is uncertain, but Gilead succession rocks make up both sides of the fault. It exhibits a substantial damage zone consisting of shredded sandstone and finer-grained lithologies from both the overturned hangingwall and upright footwall beds. A large, lozenge-shaped shear boudin in the gouge zone has tails and internal shear fractures consistent with top-to-north transport. Interestingly, a minor thrust-faulted kink fold in the overturned limb a few meters south of the major thrust is consistent with the opposite sense of shear. It is interpreted as a probable parasitic drag structure generated by the flexural slip shear couple expected for the overturned limb. It is analogous to the folds with short upright limbs that are present in the overturned limbs of larger folds in the "D2" phase described earlier, but it is unclear whether it is of the same age.

Both north- and south-vergent asymmetric folds are present on Gilead Creek. North of the location where Reifenstuhl (1991) reported the collection of the Turonian bivalve Inoceramus labiatus (station 07PD133, fig. 3), axial planes dip mainly to the northwest, and folds appear to be southeast-vergent (fig. 18). Whether this reversal in axial planar dip is accompanied by one or more northwest-dipping (southeast-vergent) backthrusts is not clear.

\section{SUMMARY AND CONCLUSIONS}

The Gilead sandstone in the study area is dominated by alternating facies developed in units tens of meters thick. These alternating cycles consist of (1) very sand-rich, medium to massive bedded, highly amalgamated intervals interpreted as hyperpycnites or other high-density sediment gravity flow deposits, and (2) very thin bedded, current-ripple-laminated intervals consisting of more classical turbidites. The fine-grained facies appears to constitute a significant percentage of the unit's overall stratigraphic thickness, suggesting broader terms such as "Gilead unit" or "Gilead succession" may be more appropriate when referring to the interval in its entirety. Transitions between these contrasting lithologies are variable, including gradual upward-coarsening and -thickening progradational cycles, upward-fining and -thinning retrogradational cycles, and sharp-based and sharp-topped intervals that appear to record either abrupt avulsion events or changes in sediment supply within the provenance area. 
The upper contact of the Gilead sandstone is not defined, and hence, the unit's complete stratigraphic thickness remains unknown. The nature of the stratigraphic section between the Cenomanian upper Gilead and Campanian Canning Formation is difficult to reconstruct with confidence. This part of the section is eroded at Gilead syncline, and where Turonian rocks and younger beds are present on the Ivishak River and Gilead Creek, the problem remains challenging because of structural dismemberment, common dip reversals, and to date, insufficient robust biostratigraphic and chronostratigraphic age control. The Gilead sandstone at Gilead syncline is far less deformed than on the Ivishak River; steeply dipping tear and rotational faults recognized in 2007 were mapped previously as thrust faults (Pessel and others, 1990; Reifenstuhl, 1989; 1991), but we concur with the correlation of units that was used by Reifenstuhl to offset the measured section at one of these faults $(1989 ; 1991)$. However, because no contact is preserved with a lithologically distinct overlying succession, the $850 \mathrm{~m}$ thickness measured there (Reifenstuhl, 1989) represents a minimum thickness.

Compositional and textural changes appear gradational from Albian strata of the lower Gilead into sandstones that are of probable Turonian age and thus laterally equivalent to the Seabee Formation. Depositional processes are dominated by sediment gravity flow throughout. At this point, we tentatively reconcile these observations as consistent with a depositional model that involves nearly continuous Early to Late Cretaceous sand deposition in a west-to-east flowing axial channel belt system, and perhaps in shallower environments toward the southern

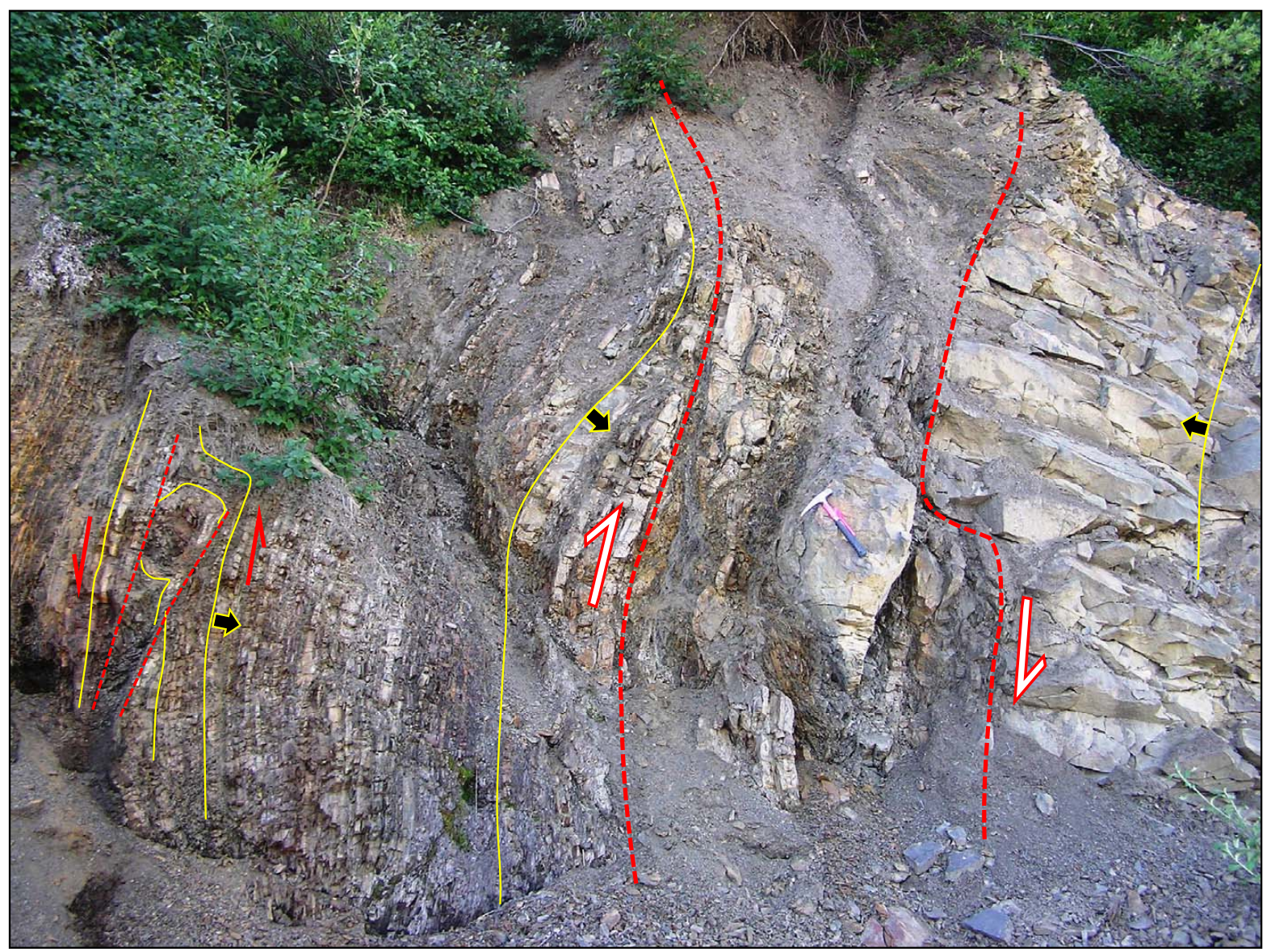

Figure 17. View to west of recessive, fine-grained, thin-bedded facies in the overturned forelimb of a north-vergent anticline thrust over upright thick- to massive-bedded Gilead sandstone on Gilead Creek at station 07PD127 (location labeled in fig. 3). Small arrows indicate stratigraphic up direction. Hammer rests on lozenge-shaped shear boudin derived from the footwall within thick damage zone approximated by dashed red lines in which shear indicators are consistent with top-tonorth displacement indicated by half-arrows. Thin beds at left contain a minor, faulted kink fold that reflects the opposite sense of shear. This may be a parasitic drag structure generated by the flexural slip-shear couple in the overturned forelimb, directly analogous to the D-2 folds interpreted in fig. 15 from structures on the Ivishak River. 


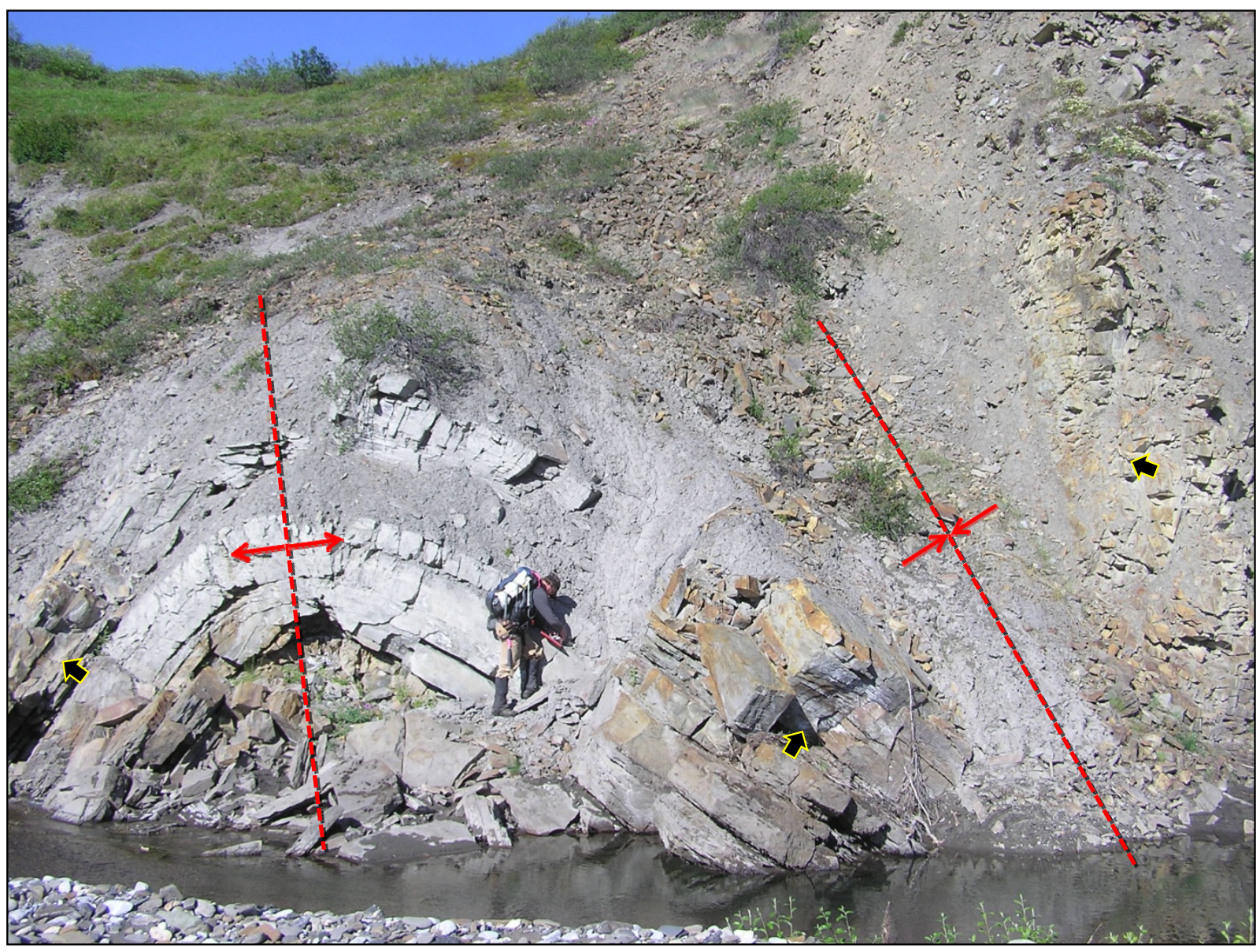

Figure 18. View to west of south-vergent asymmetric, concentric anticline-syncline pair in upright Gilead-like sandstones and mudstones at station 07PD133. Small arrows indicate stratigraphic up direction; red lines and arrows approximate axial traces of folds. This is very near the collection site of the Turonian bivalve Inoceramus labiatus reported by Reifenstuhl (1991), consistent with a possible transitional or interfingering boundary between the upper Gilead sandstone and Turonian strata mapped elsewhere as Seabee Formation. See fig. 3 for location.

margin of the Colville foreland basin. The prominent Cenomanian-Turonian condensed section known from north of the foredeep axis in the Umiat and Tarn-Meltwater areas may be poorly developed or missing in this southern setting nearer the orogenic front, where sediment supply may have been less restricted by sea level rise. Comparison of outcrop stacking architecture with logs from the Lupine Unit 1 well suggest the Gilead sandstone is, at a minimum, a good analogue for interpreting the lower Brookian sequence sandstones of the gas-prone Foothills province in the subsurface. It may, in fact, be highly correlatable in an east-west direction to potential subsurface reservoirs. We remain uncertain as to the range of water depths represented by some of these deposits, and their setting relative to shelf-clinoform, orogenic wedge-top, or ramp models of the basin's southern margin. We have found no compelling evidence of a mid-Cretaceous unconformity hypothesized by Keller and others (1961), but the relationship between the Gilead succession and a much less deformed tuffaceous mudstone of probable Upper Cretaceous age at one location could be explained either by structure or by an angular unconformity, and requires further investigation.

Structural style and the amount of shortening with the Gilead sandstone and adjacent units vary dramatically along strike between the southern traverse segments on the Ivishak River and Gilead syncline. The southern segment of the Ivishak River transect is intensely folded and thrust faulted, dominated by long stretches of vertical to strongly overturned beds separated by short intervals of upright, gently-dipping strata. In contrast, at Gilead syncline, the unit is folded into a broad, upright syncline, probably in the passive roof of an underlying duplex in Jurassic and Triassic units. 
The northern segments of the Ivishak River and Gilead Creek traverses are also complexly shortened by open to tight folds and thrusts, but this structural belt is dominated by south-dipping beds with only local overturning. Much of this northern trend is considered an eastward continuation of the Aufeis anticline, which has been deflected, more severely shortened, and structurally elevated as it approaches the northeastern salient of the Brooks Range. The predominant south dip of beds in this northern belt probably reflects the presence of south-dipping, north-vergent thrusts at depth. Rocks of apparent Gilead affinity, including probable Seabee-equivalent Turonian strata, are internally deformed in this belt and may be thrust over younger Canning Formation along its northern edge on both drainages. Toward the northern end of the Gilead Creek traverse, deformation dies out in moderately to gently northward-dipping Upper Cretaceous sandstones and mudstones of the Canning and Schrader Bluff formations, possibly in the roof of a north-tapering triangle zone.

\section{ACKNOWLEDGMENTS}

In addition to State and Federal funding through the Alaska Division of Geological \& Geophysical Surveys, the Alaska Division of Oil and Gas, and the U.S. Geological Survey, 2007 field studies were supported by energy industry contributors Anadarko Petroleum, BG Alaska E\&P, Chevron, ConocoPhillips, Eni Petroleum, FEX, Petro-Canada, Pioneer Natural Resources, and Shell E\&P. We also thank the numerous geoscientists from these companies who shared their time and technical opinions with us in the field. Outcrop-based discussions with these and other colleagues have helped shape many of the ideas presented here. Finally, the authors thank Bob Swenson for suggesting improvements to the manuscript in his technical review.

\section{REFERENCES}

Bird, K.J., 2001, Alaska; A twenty-first-century petroleum province, in Downey, M.W., Threet, J.C., and Morgan, W.A., eds., Petroleum provinces of the twenty-first century: American Association of Petroleum Geologists Memoir 74, p. 137-165.

Blythe, A.E., Bird, J.M., and Omar, G., 1996, Deformational history of the central Brooks Range, Alaska; Results from fission-track and ${ }^{40} \mathrm{Ar} /{ }^{39} \mathrm{Ar}$ analyses: Tectonics, v. 15, p. 440-455.

Carman, G.J., and Hardwick, P., 1983, Geology and regional setting of Kuparuk oil field, Alaska: American Association of Petroleum Geologists Bulletin v. 67, p. 1,014-1,031.

Decker, J., Camber, W., Vandergon, M.A., and Crowder, R.K., 1988, Arctic Creek facies, Arctic National Wildlife Refuge, northeastern Alaska: American Association of Petroleum Geologists Bulletin, v. 73, p. 176-177.

Decker, P.L., 2007, Brookian sequence stratigraphic correlations, Umiat Field to Milne Point Field, west-central North Slope, Alaska: Alaska Division of Geological \& Geophysical Surveys Preliminary Interpretive Report 2007-2, 19 p., 1 sheet.

Detterman, R.L., Reiser, H.N., Brosgé, W.P., and Dutro, J.T., 1975, Post-Carboniferous stratigraphy, northeastern Alaska: U.S. Geological Survey Professional Paper 886, 46 p.

De Ruig, M.J., and Hubbard, S.M., 2006, Seismic facies and reservoir characteristics of a deep-marine channel belt in the Molasse foreland basin, Puchkirchen Formation, Austria: American Association of Petroleum Geologists Bulletin, v. 90, p. 735-752.

Grantz, A., May, S.D., and Hart, P.E., 1990, Geology of the Arctic continental margin of Alaska, in Grantz, A., Johnson, L., and Sweeney, J.F., eds., The geology of North America, the Arctic Ocean region: Geological Society of America, Boulder, Colorado, v. L, p. 257-287.

Houseknecht, D.W., and Schenk, C.J., 2005, Sedimentology and sequence stratigraphy of the Cretaceous Nanushuk, Seabee, and Tuluvak Formations exposed on Umiat Mountain, north-central Alaska, in Haeussler, P., and Galloway, J.P., eds., Studies by the U.S. Geological Survey in Alaska, 2004: U.S. Geological Survey Professional Paper 1709B, 18 p., 1 plate.

Huffman, A.C., Jr., Ahlbrandt. T.S., Pasternack, I., Stricker, G.D., and Fox, J.E., 1985, Depositional and sedimentologic factors affecting the reservoir potential of the Cretaceous Nanushuk Group, central North Slope, Alaska, in Huffman, A.C., ed., Geology of the Nanushuk Group and related rocks, North Slope, Alaska: U.S. Geological Survey Bulletin 1614, p. 61-74.

Keller, A.S., Morris, R.H., and Detterman, R.L, 1961, Geology of the Shaviovik and Sagavanirktok Rivers Region, Alaska: U.S. Geological Survey Professional Paper 303-D, p. 169-222, 5 plates.

LePain, D.L., and Kirkham, R., 2002, Shoreline to basin transition(?) in Albian-Cenomanian strata east of the Sagavanirktok River, Brooks Range Foothills, Alaska [abs]: Pacific Section, American Association of Petroleum Geologists, and Western Region, Society of Petroleum Engineers Joint Technical Conference Program and Abstracts, p. 87-88. 
LePain, D.L., Kirkham, Russell, Gillis, R.J., and Mongrain, Jacob, 2008, Turonian-Campanian strata east of the Trans-Alaska Pipeline corridor, North Slope foothills, Alaska: Progress during the 2001-02 and 2007 field seasons, in Wartes, M.A., and Decker, P.L., eds, Preliminary results of recent geologic field investigations in the Brooks Range foothills and North Slope, Alaska: Alaska Division of Geological \& Geophysical Surveys Preliminary Interpretive Report 2008-1, p. 85-134.

Meigs, A.J., and Imm, T.A., 1995, Geometry and deformation of a duplex and its roof layer; Observations from the Echooka Anticlinorium, northeastern Brooks Range, Alaska, in Combellick, R.A., and Tannian F., eds., Short notes on Alaska Geology: Alaska Division of Geological \& Geophysical Surveys Professional Report 117, p. 19-31.

Miller, E.L., and Hudson, T.L., 1991, Mid-Cretaceous extensional fragmentation of a Jurassic-Early Cretaceous compressional orogen, Alaska: Tectonics, v. 10, p. 781-796.

Miller, J., 1982, Report on referred fossils: U.S. Geological Survey Alaska Paleontological Database, field locality no. 82AMK-22N, online reference http://AlaskaFossil.org.

Molenaar, C.M., 1983, Depositional relations of Cretaceous and Lower Tertiary rocks, northeastern Alaska: American Association of Petroleum Geologists Bulletin, v. 67, p. 1,066-1,080.

Molenaar, C.M., Bird, K.J., and Collett, T.S., 1986, Regional correlation sections across the North Slope of Alaska: U.S. Geological Survey Miscellaneous Field Studies 1907, 1 sheet.

Molenaar, C.M., Bird, K.J., and Kirk, A.R., 1987, Cretaceous and Tertiary stratigraphy of northeastern Alaska, in Tailleur, I., and Weimer, P., eds., Alaskan North Slope Geology, Bakersfield, California, Pacific Section, Society of Economic Paleontologists and Mineralogists and Alaska Geological Society, v. 1, p. 513-528.

Molenaar, C.M., Kirk, A.R., Magoon, L.B., and Huffman, A.C., 1984, Twenty-two measured sections of Cretaceous-Lower Tertiary rocks, eastern North Slope, Alaska: U.S. Geological Survey Open-file Report 84-695, 21 p., 4 sheets.

Mulder, T., and Syvitski, J.P.M., 1995, Turbidity currents generated at river mouths during exceptional discharges to the world oceans: Journal of Geology, v. 103, p. 285-299.

Mulder, T., Syvitski, J.P.M, Migeon, S., Faugeres, J.C., and Savoye, B., 2003, Marine hyperpycnal flows: initiation, behavior and related deposits; A review: Marine and Petroleum Geology, v. 20, no. 6-8, p. 861-882.

Mull, C.G., and Adams, K.E., 1989, Dalton Highway, Yukon River to Prudhoe Bay, Alaska: Alaska Division of Geological \& Geophysical Surveys Guidebook 7, v. 1, 155 p.

Mull, C.G., and Decker, J., 1993, Organic-rich shale and bentonite in the Arctic Creek unit, Arctic National Wildlife Refuge; Implications for stratigraphic and structural interpretations, in Solie, D.N., and Tannian, F., eds., Short Notes on Alaskan Geology 1993: Alaska Division of Geological \& Geophysical Surveys Professional Report 113, p. 41-49.

Mull, C.G., Houseknecht, D.W., and Bird, K.J., 2003, Revised Cretaceous and Tertiary stratigraphic nomenclature in the Colville Basin, northern Alaska: U.S. Geological Survey Professional Paper 1673, 51 p.

Mutti, E., Tinterri, R., Benevelli, G., di Biase, D., and Cavanna, G., 2003, Deltaic, mixed and turbidite sedimentation of ancient foreland basins: Marine and Petroleum Geology, v. 20, p. 733-755.

Myrow, P.M., Fischer, W., and Goodge, J.W., 2002, Wave-modified turbidites: combined-flow shoreline and shelf deposits, Cambrian, Antarctica: Journal of Sedimentary Research, v. 72, p. 641-656.

O’Sullivan, P.B., 1991, Preliminary results of 25 apatite fission track analyses of samples from the Gilead Creek region, North Slope of Alaska: Alaska Division of Geological \& Geophysical Surveys Public-Data File 91$21 \mathrm{C}, 40 \mathrm{p}$.

1996, Late Mesozoic and Cenozoic thermotectonic evolution of the Colville basin, North Slope, Alaska, in Johnsson, M.J., and Howell, D.G., eds., Thermal evolution of sedimentary basins in Alaska: U.S. Geological Survey Bulletin 2142, p. 45-79.

O’Sullivan, P.B., Green, P.F., Bergman, S.C., Decker, J., Duddy, I.R., Gleadow, A.J.W., and Turner, D.L., 1993, Multiple phases of Tertiary uplift and erosion in the Arctic National Wildlife Refuge, Alaska, revealed by apatite fission track analysis: American Association of Petroleum Geologists Bulletin v. 77, p. 359-385.

Pessel, G.H., Robinson, M.S., Clough, J.G., Imm, T.A., Reifenstuhl, R.R., Ryherd, T.J., Myers, M.D., and Mull, C.G., 1990, Preliminary geologic map of the Gilead Creek area, Sagavanirktok A-2 Quadrangle, Arctic Foothills, Alaska: Alaska Division of Geological \& Geophysical Surveys Public-Data File 90-18, 7 p., 1 sheet.

Petter, A.L., and Steel, R.J., 2006, High-latitude recipe for sand delivery to the deepwater via hyperpycnal flow; A greenhouse example from the Early Eocene, Central Spitsbergen Basin [abs]: American Association of Petroleum Geologists Bulletin, v. 90, Annual Meeting Program Abstracts (http://www.searchanddiscovery. net/documents/2006/06088houston_abs/abstracts/petter.htm). 
Plink-Björklund, P., Steel, R., Clark, B., Pontén, A., and Sjögren, L., 2002, Hyperpycnal flow turbidites as an indicator for sequence boundary in slope turbidite systems of Spitsbergen Central Basin [abs]: American Association of Petroleum Geologists Bulletin, v. 86, Annual Meeting Program Abstracts (http://www.searchanddiscovery. net/documents/abstracts/annual2002/DATA/2002/13ANNUAL/SHORT/43245.pdf).

Reifenstuhl, R.R., 1989, Measured stratigraphic section of the Gilead Creek sandstone, northeastern Alaska, ANWR: Alaska Division of Geological \& Geophysical Surveys Public-Data File 89-26B 16 p., 1 sheet.

1991, Gilead sandstone, northeastern Brooks Range, Alaska: An Albian to Cenomanian marine clastic succession, in Reger, R.D., ed., Short Notes on Alaskan Geology 1991: Alaska Division of Geological \& Geophysical Surveys Professional Report 111, p. 69-76.

Robinson, M.S., Decker, J.E., Clough, J.G., Reifenstuhl, R.R., Bakke, A.A., Dillon, J.T., Combellick, R.A., and Rawlinson, S.E., 1989, Geology of the Sadlerochit and Shublik Mountains, Arctic National Wildlife Refuge, northeastern Alaska: Alaska Division of Geological \& Geophysical Surveys Professional Report 100, 1 sheet, scale $1: 63,360$.

Schenk, C.J., and Bird, K.J., 1993, Depositional sequences in Lower Cretaceous rocks, Atigun syncline and Slope Mountain areas, Alaskan North Slope, in Dusel-Bacon, C., and Till, A.B., eds., Geologic studies in Alaska by the U.S. Geological Survey, 1992: U.S. Geological Survey Bulletin 2068, p. 48-58.

Vogl, J.J., 2002, Late-orogenic backfolding and extension in the Brooks Range collisional orogen, northern Alaska: Journal of Structural Geology, v. 24, p. 1,753-1,776.

Vogl, J.J., Calvert, A.T., and Gans, P.B., 2002, Mechanisms and timing of exhumation of collision-related metamorphic rocks, southern Brooks Range, Alaska; Insights from ${ }^{40} \mathrm{Ar}^{39} \mathrm{Ar}$ thermochronology: Tectonics, v. 21, p. 2-1-2-17.

Wartes, M.A., Loveland, A.M., Wallace, W.K., Gillis, R., Peapples, P.R., Reifenstuhl, R.R., and Mull, C.G., 2007, Geology of the Kavik River area, east-central North Slope, Alaska; Preliminary Results of the 2006 STATEMAP project [abs.]: Alaska Geological Society Annual Technical Conference Abstracts.

Whittington, C.L., 1956, Revised stratigraphic nomenclature of Colville Group, in Gryc, G., and others, Mesozoic sequence in Colville River region, northern Alaska: American Association of Petroleum Geologists Bulletin v. 40, p. 244-253.

Worden, R.H., and Burley, S.D., 2003, Introduction, in Burley, S.D., and Worden, R.H., eds., Sandstone diagenesis; Ancient and recent: Malden, Massachusetts, Blackwell Publishing, 649 p. 
This page has intentionally been left blank. 


\title{
TURONIAN-CAMPANIAN STRATA EAST OF THE TRANS-ALASKA PIPELINE CORRIDOR, NORTH SLOPE FOOTHILLS, ALASKA: PROGRESS DURING THE 2001-02 AND 2007 FIELD SEASONS
}

\author{
by \\ David L. LePain ${ }^{1}$, Russell Kirkham², Robert Gillis', and Jacob Mongrain ${ }^{3}$
}

\begin{abstract}
Lower Turonian through Campanian strata are discontinuously exposed along an unnamed drainage approximately $6 \mathrm{~km}$ east of the Sagavanirktok River, in the Sagavanirktok Quadrangle, in the foothills north of the Brooks Range. In spite of some outcrop-scale deformation, this succession is viewed as a relatively continuous and unbroken succession deposited basinward (east and north) of the terminal Nanushuk shelf edge. South-dipping exposures of sandstone, siltstone, and tuff are separated by long tundra-covered intervals inferred to be underlain by finer-grained lithologies. Field studies by DGGS in 2001, 2002, and 2007 document the depositional setting of this succession and provide a framework for more detailed facies analysis and bedrock geological mapping in the area.

Lower Turonian strata at the northwest end of the succession consist dominantly of shale with 18-30m-thick packages of interbedded mudstone and sandstone recording deposition as sandstone lobes in basin floor settings. This part of the succession is tentatively correlated with Seabee Formation west of the TransAlaska pipeline corridor. Santonian to lower Campanian strata in the middle of the succession also consist dominantly of shaly lithologies interrupted by 25-60-m-thick packages of interbedded mudstone, sandstone, minor conglomerate, and silicified tuff deposited as sandstone lobes and overbank deposits (levees) and submarine ashfalls in proximal basin to lower slope settings. Campanian strata near the south end of the trend includes interbedded siltstone and sandstone deposited in slope and outer-shelf settings, below storm wave-base. Campanian strata at the southeast end of the trend consists of siltstone and sandstone in a series of stacked offshore-shoreface parasequences. Collectively, these rocks record the eastward progradation of Upper Cretaceous basin floor-slope-shelf depositional systems beyond the terminal Nanushuk (Cenomanian) shelf edge. A composite thickness of 2,460 m is estimated for this Upper Cretaceous succession.
\end{abstract}

\section{INTRODUCTION}

During the summers of 2001 and 2002 the Alaska Division of Geological \& Geophysical Surveys (DGGS) conducted detailed stratigraphic investigations of upper Cretaceous strata exposed along an unnamed drainage between the Sagavanirktok and Ivishak rivers, in Township 3 South, Range 15 East, sections 17, 20, 21, 27, and 28, Sagavanirktok A-3 Quadrangle (figs. 1-3). By virtue of its position between two named rivers, this drainage has been informally referred to as Sagashak Creek. DGGS revisited many of these exposures during the 2007 field season to refine interpretations of the depositional setting and to clarify correlations with coeval shelf strata exposed west of the Trans-Alaska pipeline corridor. Available unpublished geological mapping and biostratigraphic data suggest a relatively unbroken south-dipping succession of lower Turonian to Campanian age strata on the south flank of the Aufeis anticline (fig. 4; Mull, unpublished data). Publicly available seismic data indicate this succession is situated basinward of the terminal Cenomanian Nanushuk shelf edge (Houseknecht and Schenk, 2001; 2004). The uniqueness of this long, discontinuous section necessitates that the following discussion include our station-by-station observations on the facies and sedimentology of each outcrop. We hope that this level of documentation will allow interested workers to locate and revisit specific parts of the section. In the near future, DGGS intends to synthesize available surface and subsurface data to arrive at an integrated picture of the Upper Cretaceous stratigraphic evolution.

Many exposures along this trend include examples of small-scale folding and thrust faulting, and one exposure includes complex disharmonic folds in a thinly interbedded succession of shale, sandstone, and tuff. These complications, combined with long tundra-covered intervals, precluded measurement of a single continuous stratigraphic section. Instead, our approach was to measure detailed sections where exposure quality permitted, obtain general descriptions for rubbly exposures unsuitable for measuring, obtain relatively accurate geographic coordinates for the base and top of each measured section and the central point of each rubblecrop using a handheld global positional unit, and to reconstruct the larger succession from the resulting dataset. Using this approach we calculated

${ }^{1}$ Alaska Division of Geological \& Geophysical Surveys, 3354 College Rd., Fairbanks, Alaska 99709-3707

Email for David L. LePain: dave.lepain@alaska.gov

${ }^{2}$ Alaska Division of Mining, Land \& Water, 550 W. 7th Ave., Suite 900D, Anchorage, Alaska 99501-3577

${ }^{3}$ University of Alaska, Department of Geology \& Geophysics, P.O. Box 757320, Fairbanks, Alaska 99775-7320 


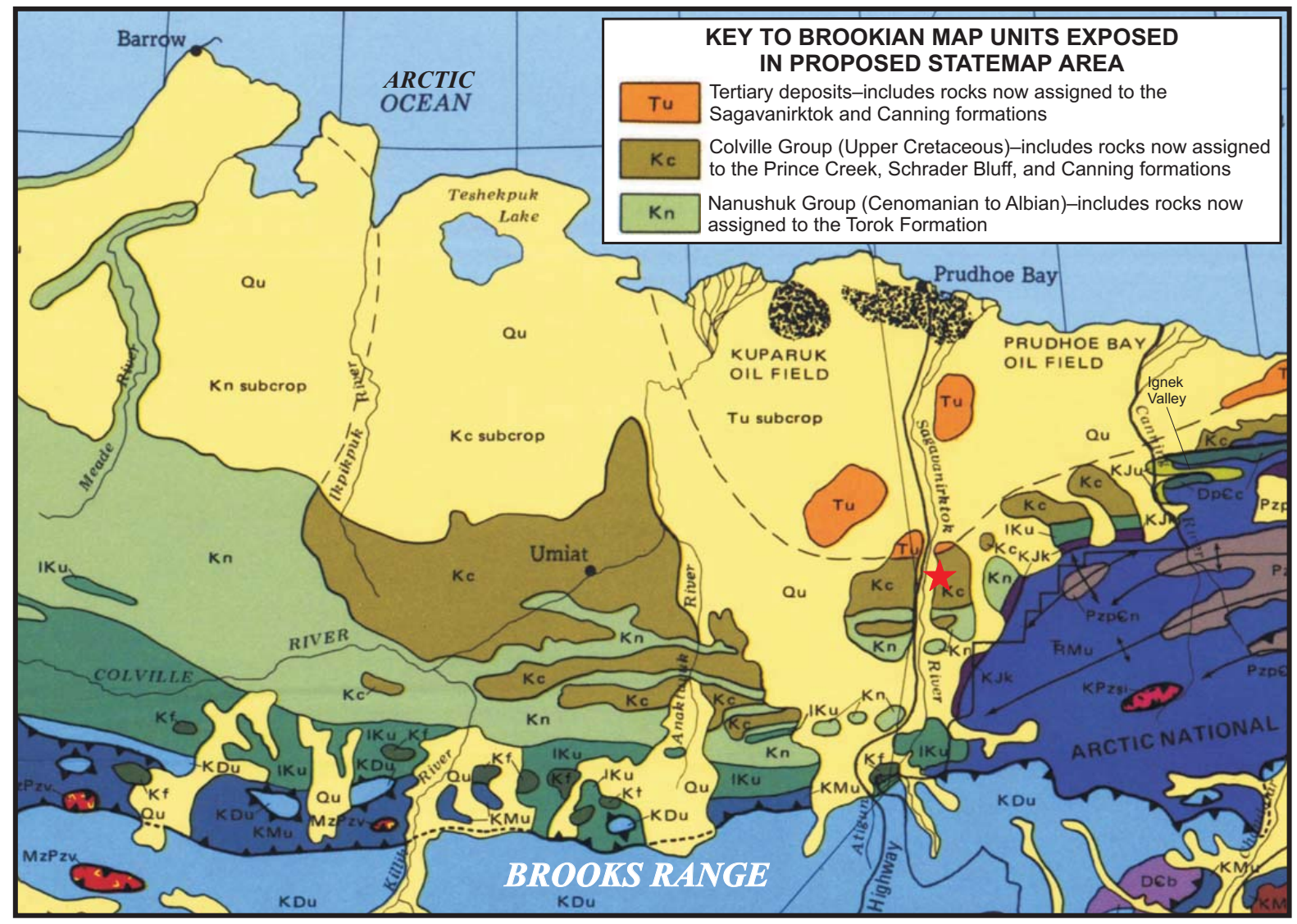

Figure 1. Generalized geologic map of the central North Slope. The red star shows the approximate location of the upper Cretaceous succession addressed in this report. The succession is located along the northeast side of an unnamed tributary drainage to the Sagavanirktok River. The southeastern end of this drainage is located midway between the Sagavanirktok and Ivishak rivers, which led to the informal name of Sagashak Creek. Map modified from Mull and Harris (1989).

a total stratigraphic thickness (station 045 to station 022; fig. 2) of 2,450 m. Given the potential errors inherent in our methodology, and uncertainty associated with structural complications, this estimate should be viewed only as a rough approximation of the true stratigraphic thickness of lower Turonian-Campanian strata in the area.

In the following section we present descriptions and interpretations of all major and most minor exposures along this trend. Figure 4 shows the locations of stations reexamined during the 2007 field season; the two southernmost stations shown on fig. 2 were not revisited. Latitude and longitude information is shown in table 1 . The degree of bioturbation is classified using Droser and Bottjer's (1986) ichnofabric index. The ichnofabric index is defined as follows: II1—unbioturbated; II2—up to 10 percent of original bedding disturbed; II3—approximately 10-40 percent of original bedding disturbed, burrows are typically isolated; II4—approximately 40-60 percent of bedding is disturbed, but last remnants are visible; II5—-bedding is completely disturbed, but discrete burrows are recognizable; II6-bedding nearly or completely homogenized. Outcrop gamma logs were acquired at selected exposures along this transect during 2007 using an Exploranium GR-320 enviSPEC gamma ray spectrometer. Gamma logs (total counts) are presented on the left side of the measured sections shown in this report (figs. 5, 7, 9, and 13).

\section{STATION DESCRIPTIONS AND INTERPRETATIONS}

\section{Station 07DL045 (01DL11)}

\section{DESCRIPTION}

Station 045 is located at the northwest end of the transect and consists of $23 \mathrm{~m}$ of interbedded sandstone, mudstone (argillaceous siltstone and siltstone), and minor clay shale (figs. 2, 4, and 5). Bedding dips 58 degrees toward the south-southeast. Tundra cover immediately north of the exposure suggests underlying strata consist of recessive-weathering mudstone and shale. At least one outcrop-scale syncline is present at the south end of the 


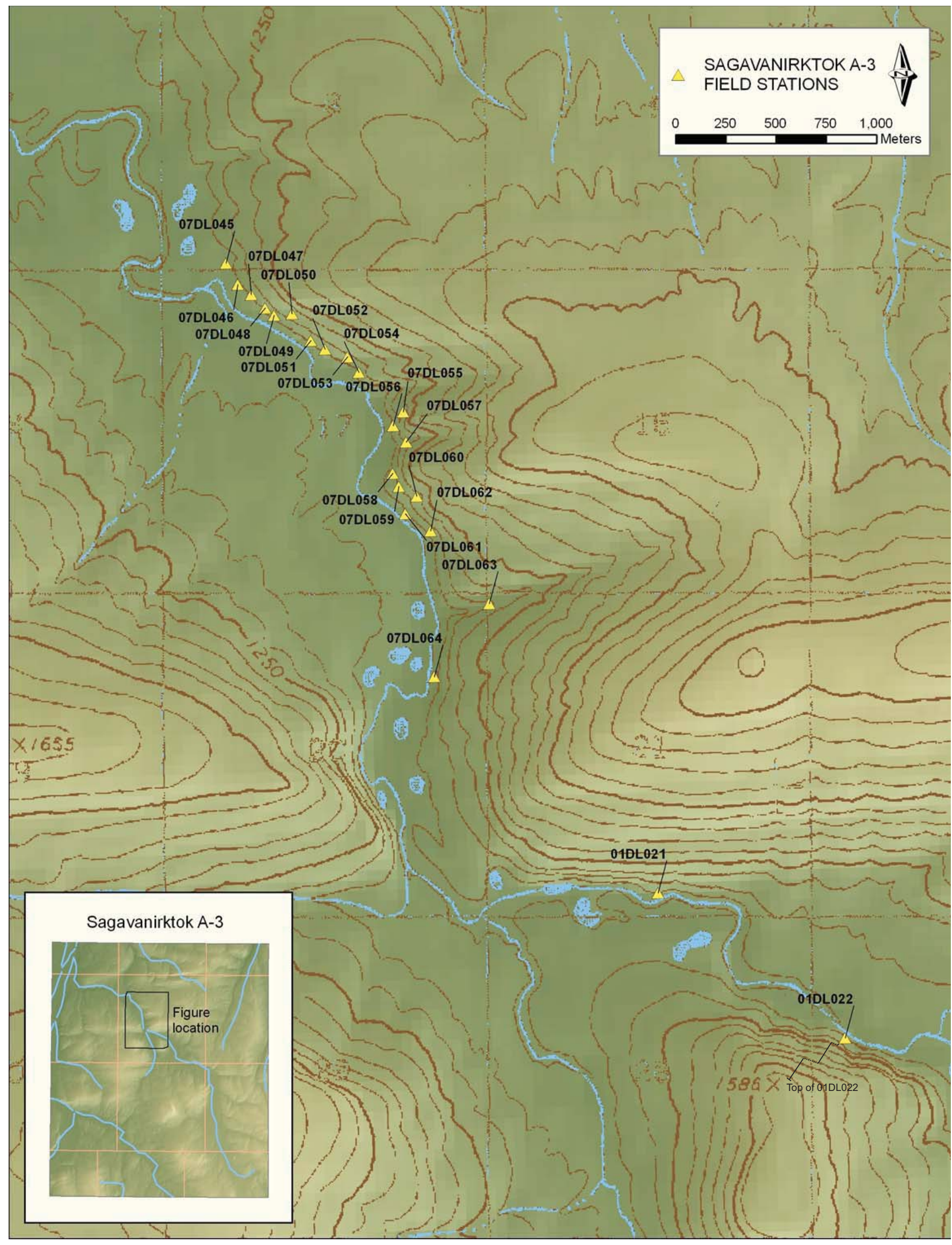

Figure 2. The portion of the Sagavanirktok A-3 1:63,360-scale topographic map that Sagashak Creek and the exposures of upper Cretaceous strata addressed in this report. Outcrop and rubblecrop are designated by station numbers that include the year (07 or 01), geologist's initials (DL), and a sequential number. The northwest end of this trend corresponds to station 07DL045, which is located at the base of a relatively coherent southeast- to south-dipping succession of deep-water through shoreface deposits. The succession ranges in age from Turonian at the northwest end to late Campanian at the southeast end. 
Table 1. Table summarizing station locations, available biostratigraphic control, and formation assignments

\begin{tabular}{|c|c|c|c|c|c|}
\hline Station & Latitude & Longitude & Age & $\begin{array}{l}\text { Formation } \\
\text { Assignment }\end{array}$ & Comments \\
\hline 07DL045 & 69.18997 & 148.56877 & Turonian-Coniacian $^{1}$ & Seabee & $\begin{array}{l}\text { Probably early Turonian; } \\
\text { sample collected at this station }\end{array}$ \\
\hline 07DL046 & 69.18902 & 148.56728 & early Turonian & Seabee & $\begin{array}{l}\text { Age assigned by relative } \\
\text { stratigraphic position }\end{array}$ \\
\hline 07DL047 & 69.18856 & 148.5656 & early Turonian & Seabee & $\begin{array}{l}\text { Age assigned by relative } \\
\text { stratigraphic position }\end{array}$ \\
\hline 07DL048 & 69.18797 & 148.56387 & early Turonian & Seabee & $\begin{array}{l}\text { Age assigned by relative } \\
\text { stratigraphic position }\end{array}$ \\
\hline 07DL049 & 69.18763 & 148.56273 & early Turonian & Seabee & $\begin{array}{l}\text { Age assigned by relative } \\
\text { stratigraphic position }\end{array}$ \\
\hline 07DL050 & 69.18771 & 148.56052 & early Turonian & Seabee & $\begin{array}{l}\text { Age assigned by relative } \\
\text { stratigraphic position }\end{array}$ \\
\hline 07DL051 & 69.1865 & 148.55815 & early Turonian ${ }^{2}$ & Seabee & $\begin{array}{l}\text { Sample collected at this } \\
\text { station }\end{array}$ \\
\hline 07DL052 & 69.18613 & 148.55637 & Turonian & Seabee & $\begin{array}{l}\text { Age assigned by relative } \\
\text { stratigraphic position }\end{array}$ \\
\hline 07DL053 & 69.18578 & 148.55354 & Turonian & Seabee & $\begin{array}{l}\text { Age assigned by relative } \\
\text { stratigraphic position }\end{array}$ \\
\hline 07DL054 & 69.18509 & 148.55215 & $\begin{array}{l}\text { Late Albian to early } \\
\text { Turonian }{ }^{3} \text {; middle } \\
\text { Albian to early } \\
\text { Santonian }{ }^{4} \text {; Santonian } \\
\text { to Campanian } \\
\text { Santonian }^{6}\end{array}$ & $\begin{array}{l}\text { Seabee to } 66 \mathrm{~m} \text {; } \\
\text { Canning above } 66 \\
\text { m }\end{array}$ & $\begin{array}{l}0-66 \mathrm{~m} \text { in measured section } \\
\text { 07DL054 is considered } \\
\text { Turonian; above } 66 \mathrm{~m} \text { is } \\
\text { considered Santonian }\end{array}$ \\
\hline 07DL055 & 69.18333 & 148.54654 & $\begin{array}{l}\text { Middle Santonian to } \\
\text { early Campanian }\end{array}$ & Canning & $\begin{array}{l}\text { Age assigned by relative } \\
\text { stratigraphic position }\end{array}$ \\
\hline 07DL056 & 69.18271 & 148.54785 & $\begin{array}{l}\text { Middle Santonian to } \\
\text { early Campanian }\end{array}$ & Canning & $\begin{array}{l}\text { Sample collected at this } \\
\text { station }\end{array}$ \\
\hline 07DL057 & 69.18198 & 148.54623 & Campanian ${ }^{6,7}$ & Canning & $\begin{array}{l}\text { Age assigned by relative } \\
\text { stratigraphic position }\end{array}$ \\
\hline 07DL058 & 69.18057 & 148.54991 & Campanian $^{6,7}$ & Canning & $\begin{array}{l}\text { Age assigned by relative } \\
\text { stratigraphic position }\end{array}$ \\
\hline 07DL059 & 69.18 & 148.54715 & Campanian $^{6,7}$ & Canning & $\begin{array}{l}\text { Age assigned by relative } \\
\text { stratigraphic position }\end{array}$ \\
\hline 07DL060 & 69.17956 & 148.54491 & $\begin{array}{l}\text { Middle to late } \\
\text { Campanian }\end{array}$ & Canning & $\begin{array}{l}\text { Age assigned by relative } \\
\text { stratigraphic position }\end{array}$ \\
\hline 07DL061 & 69.17878 & 148.5463 & Late Campanian $^{7}$ & Canning & $\begin{array}{l}\text { Sample collected at this } \\
\text { station }\end{array}$ \\
\hline 07DL062 & 69.17801 & 148.54317 & Late Campanian ${ }^{7}$ & Canning & $\begin{array}{l}\text { Age assigned by relative } \\
\text { stratigraphic position }\end{array}$ \\
\hline 07DL063 & 69.17477 & 148.53581 & Late Campanian ${ }^{7}$ & $\begin{array}{l}\text { Canning or } \\
\text { Schrader Bluff }\end{array}$ & $\begin{array}{l}\text { Age assigned by relative } \\
\text { stratigraphic position }\end{array}$ \\
\hline 07DL064 & 69.17152 & 148.54272 & $\begin{array}{l}\text { Late Campanian } \\
\text { Campanian }^{8}\end{array}$ & Schrader Bluff & $\begin{array}{l}\text { Age assigned by relative } \\
\text { stratigraphic position }\end{array}$ \\
\hline 01DL021 & 69.162467 & 148.52 & $\begin{array}{l}\text { Late Campanian"; } \\
\text { Campanian }^{8}\end{array}$ & Schrader Bluff & $\begin{array}{l}\text { Probably late Campanian. Age } \\
\text { assigned by relative } \\
\text { stratigraphic position }\end{array}$ \\
\hline 01DL022 & 69.15538 & 148.49132 & Campanian $^{8}$ & Schrader Bluff & $\begin{array}{l}\text { Sample collected at this } \\
\text { station }\end{array}$ \\
\hline
\end{tabular}

\footnotetext{
${ }^{1}$ Turonian-Coniacian paly (Mull, unpublished data)

${ }^{2}$ Age based on Mytiloides labiatus (Mull, unpublished data).

${ }^{3}$ Composite palynologic sample between 45-58 m in measured section 07DL054 (Zippi report for DGGS, August 29, 2004).

${ }^{4}$ Palynologic sample at $84 \mathrm{~m}$ in measured section 07DL054 (Zippi report for DGGS, August 29, 2004).

${ }^{5}$ Composite palynologic sample between 85-91 m in measured section 07DL054 (Micropaleo Consultants, Inc., report for DGGS, January 2003).

${ }^{6}$ Age based on Sphenoceramus patootensis collected near station 056 (Mull, unpublished data).

${ }^{7}$ Palynologic sample between 6-10 m in measured section 07DL061 (Zippi report for DGGS, August 29, 2004).

${ }^{8}$ Campanian megafossils at station 01DL022 (Mull, unpublished data).
} 


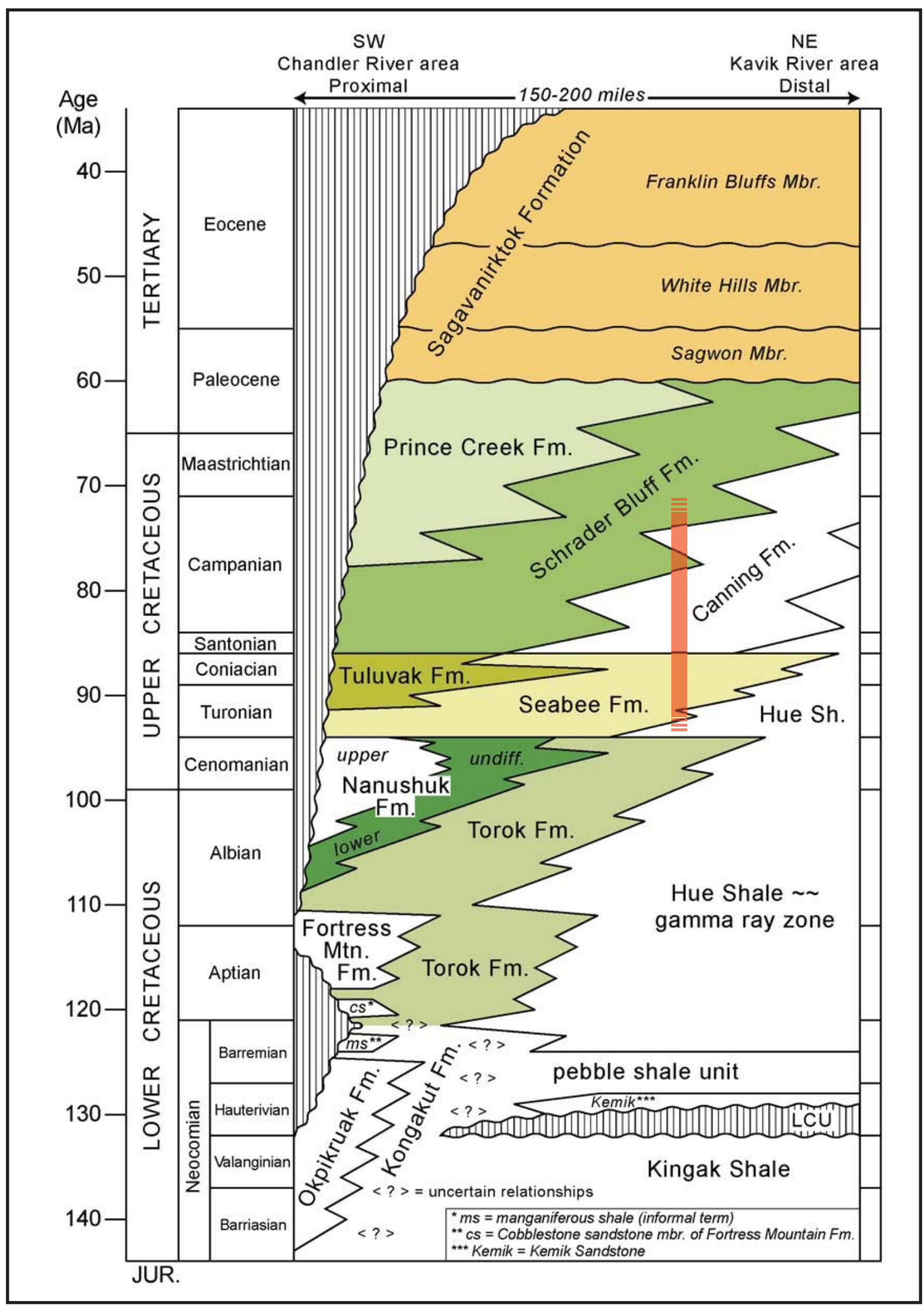

Mull and others (2003)

Figure 3. Generalized stratigraphic column showing Beaufortian and Brookian sequences in the central North Slope. The vertical red bar shows the approximate stratigraphic range of the succession addressed in this report. 
exposure. The top of the measured section shown in figure 5 corresponds to the north limb of this structure. An additional 50 to $100 \mathrm{~m}$ of interbedded sandstone and mudstone are poorly exposed immediately south of the fold (station 046).

The ages of these rocks are constrained by microfossil and macrofossil samples (Mull, unpublished data). Palynomorphs from this location suggest a Turonian to Coniacian age. The early Turonian bivalve Mytiloides labiatus is present up-section toward the southeast, in sandstones at station 051 (fig. 2). These data suggest the rocks at station 045 are lower Turonian.

Sandstones are well indurated to friable, light gray to buff weathering, medium gray on fresh surfaces, and very fine to fine grained. Some indurated beds are cemented with calcite and cut by calcite-filled veins (fig. 6a). Bed thicknesses range from a few centimeters to nearly one meter and contacts are typically planar and parallel. Sandstone is present as single beds up to $20 \mathrm{~cm}$ thick bounded by mudstone; amalgamated beds (sand-on-sand contacts) up to $60 \mathrm{~cm}$ thick form bedsets up to $2 \mathrm{~m}$ thick (fig. 6b). Discontinuous mudstones a few centimeters thick are present in some bedsets, demonstrating incomplete amalgamation locally. Fresh sandstone surfaces in the upper half of the exposure have a strong hydrocarbon odor.

Sedimentary structures are difficult to see throughout most of the exposure and most beds appear internally massive. Mudstone rip-up clast impressions (fig. 6c) and sole markings, including linear groove and load-enhanced flute casts, are present on the bases of some sandstone beds. Normal size grading is present in a few beds in the lower $14 \mathrm{~m}$ of the succession and some beds throughout the exposure include plane-parallel lamination and equivocal examples of small-scale trough cross-bedding and ripple bedforms. The distribution of these structures suggests Bouma $\mathrm{Ta}, \mathrm{Tb}$, and Tbc beds. Scour surfaces within sandstone bedsets are common and locally overlain by scattered sideritized(?) mudstone clasts, marking amalgamation surfaces. Trace fossils have not been recognized (II1; ichnofabric index of Droser and Bottjer, 1986). Mudstones are poorly exposed and their sedimentary structures are not visible.

\section{INTERPRETATION}

Bouma Ta, Tb, and Tbc beds and associated sole markings suggest deposition from turbidity currents (facies $\mathrm{D}$ or E of Mutti and Ricci Lucchi, 1978; Weimer and Slatt, 2007). Massive beds represent either lags from energetic flows that transported finer material to more distal settings (favored interpretation; Pickering and others, 1986; Mutti and Normark, 1987) or rapid deposition from flows carrying a limited range of grain sizes. Mudstone rip-up clast impressions and flute and groove casts are all consistent with deposition from turbulent flows.

Publicly available subsurface data suggest deposition basinward (east and north) of the terminal Nanushuk shelf edge (Molenaar and others, 1986; Houseknecht and Schenk, 2001; 2004). Parallel and laterally continuous seismic reflections characterize probable Turonian strata, suggesting deposition in a basin floor setting (Decker, oral commun.). We tentatively suggest the succession represents two overlapping sandstone lobes separated by $4.5 \mathrm{~m}$ of mudstone. The two sandstone packages could represent shingled lobe deposits, with the younger lobe offset laterally (compensation bedding).

Available biostratigraphic data suggest correlation with the Seabee Formation west of the Trans-Alaska pipeline corridor.

\section{Station 07DL046 \\ DESCRIPTION}

Station 046 is located on the north side of the synform noted at station 045 (figs. 2 and 4). Approximately 50 to $100 \mathrm{~m}$ of interbedded sandstone and mudstone are poorly exposed at this station. The distribution of rubblecrop and sandstone slabs in float suggest bedding dips toward the south-southeast, comparable to bedding on the north limb of the synform. Stratigraphic up is toward the north.

Sandstones are well indurated, light buff weathering and light gray on fresh surfaces, and very fine to fine grained. Light gray to gray translucent grains of chert and quartz are the dominant framework grains in hand sample, whereas black chert is a conspicuous but minor component. Bed geometry appears similar to sandstones at station 045. Mudstone rip-up clast impressions are common. Sandstones appear internally massive and mudstone is only visible as float in holes dug by animals.

\section{INTERPRETATION}

Interpretation of the depositional setting is not possible given the exposure quality. Available biostratigraphic data suggest correlation with the Seabee Formation west of the Trans-Alaska pipeline corridor. 


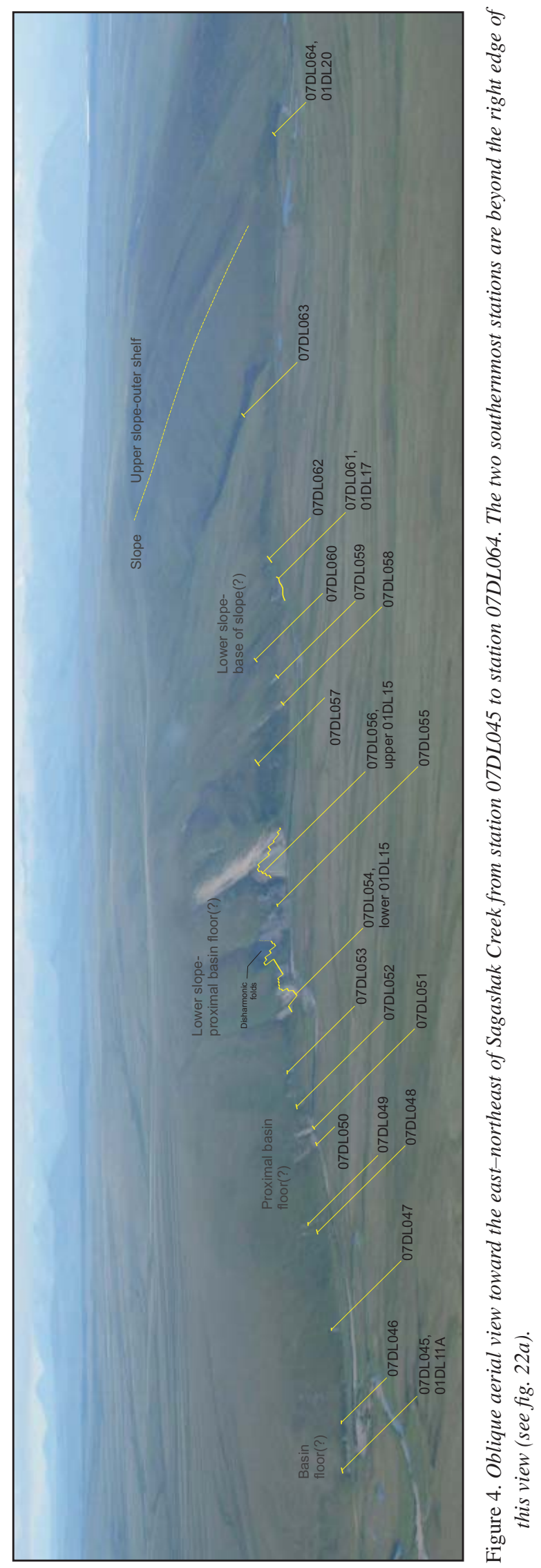




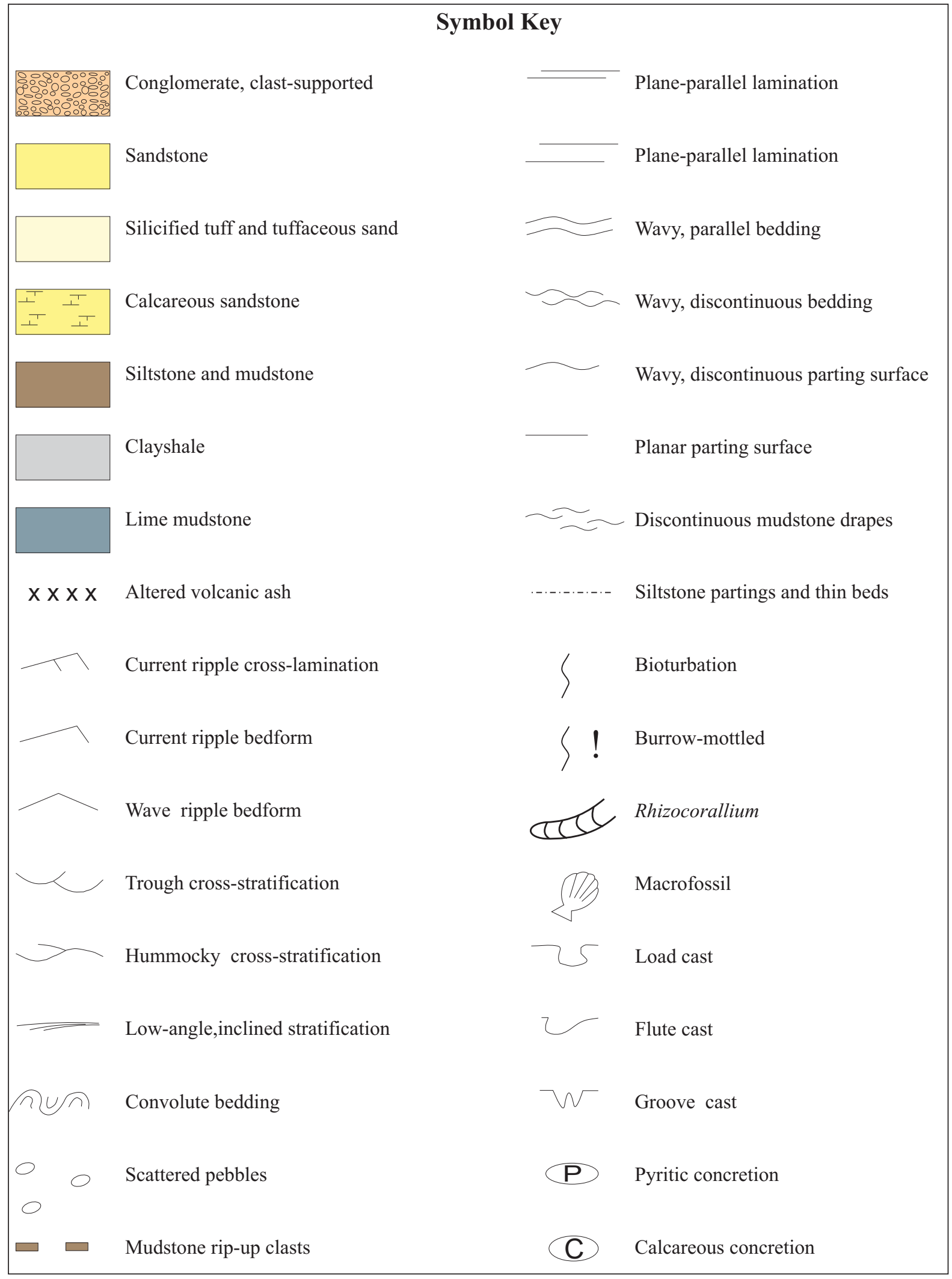

Figure 5. Measured stratigraphic section through Turonian turbidites and associated hemipelagic deposits of the distal Seabee Formation at station 07DL045. 
07DL045

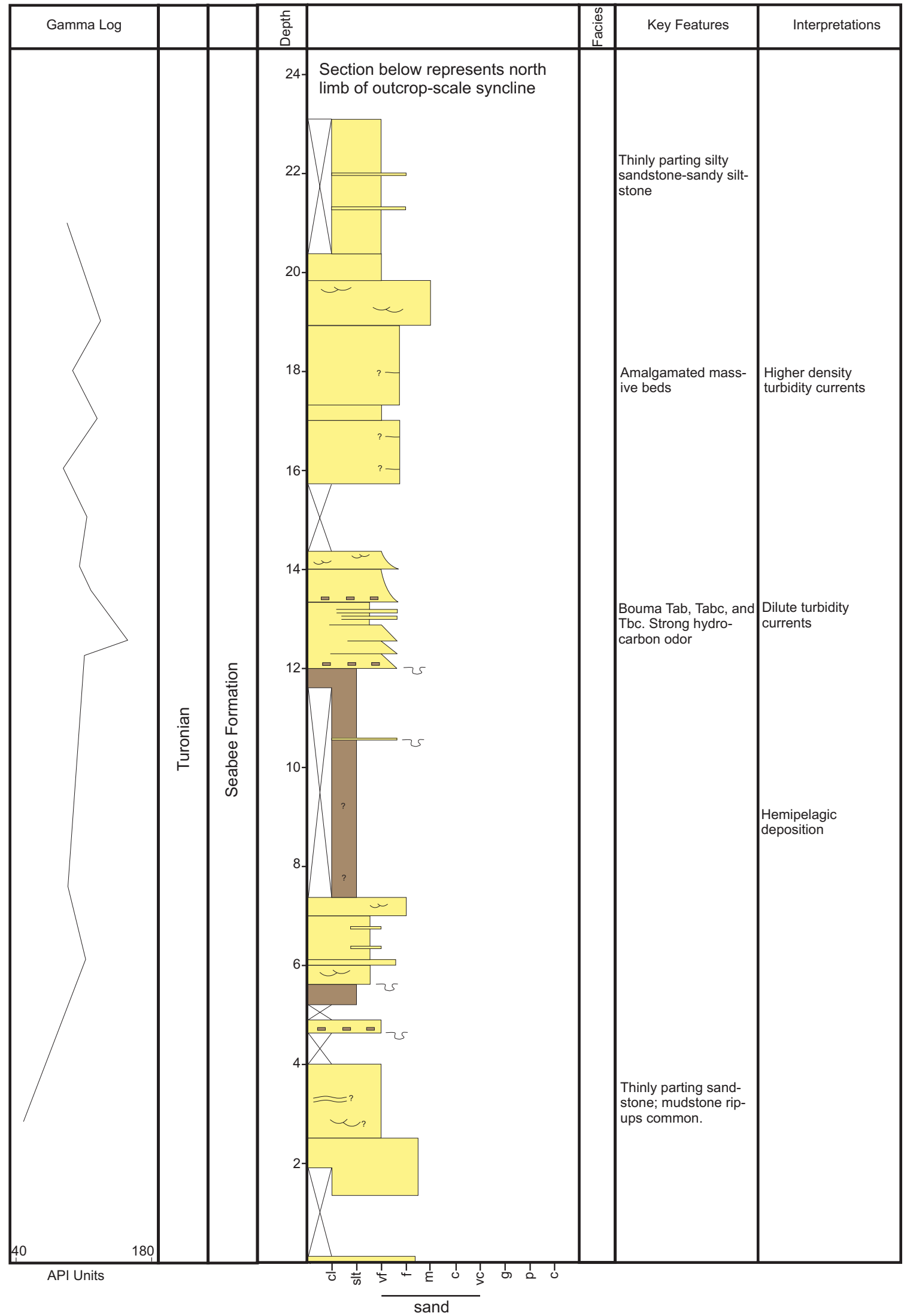

Figure 5. Measured stratigraphic section through Turonian turbidites and associated hemipelagic deposits of the distal Seabee Formation at station 07DL045. 


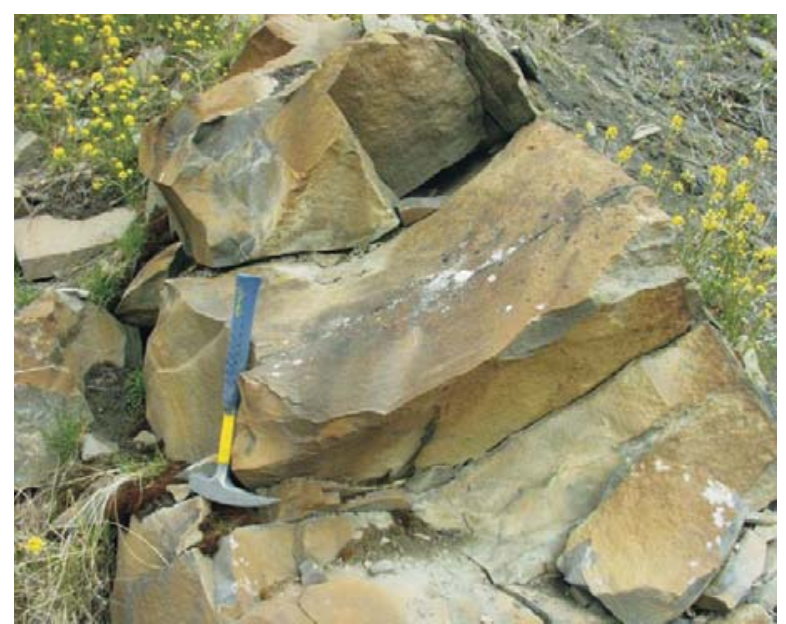

A.

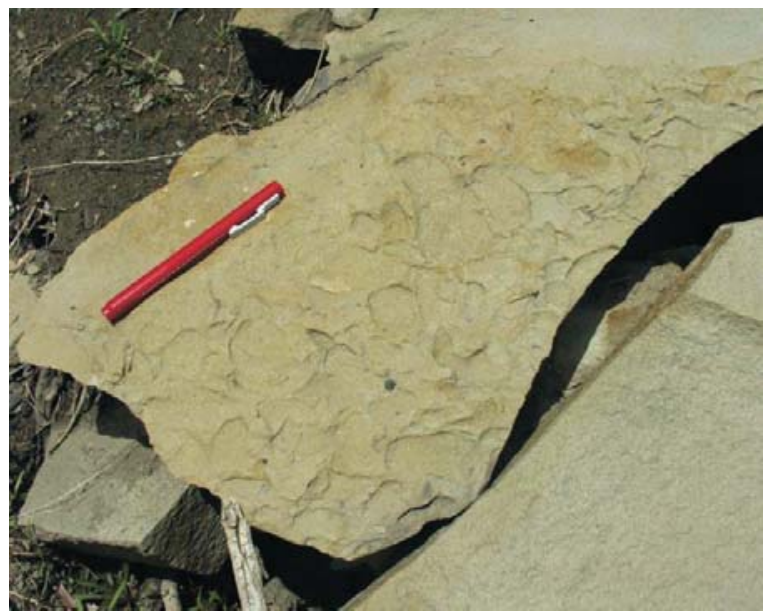

C.

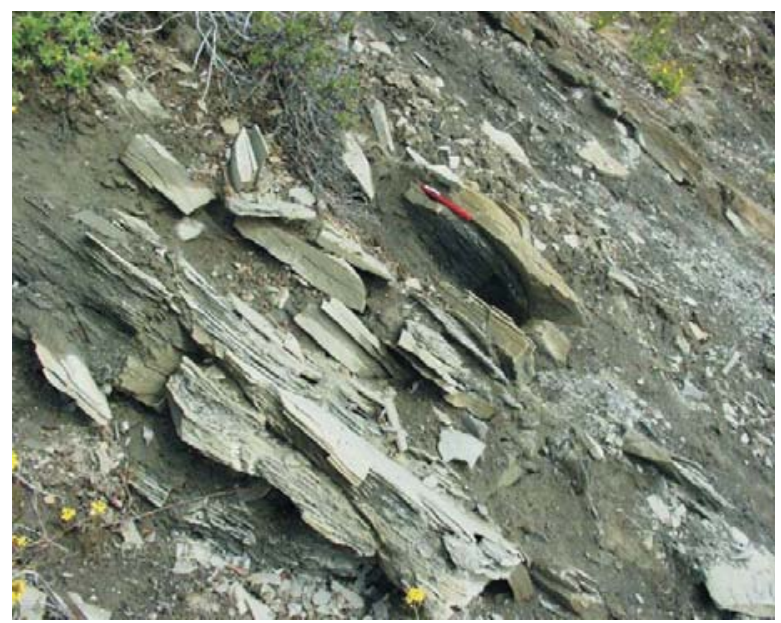

B.

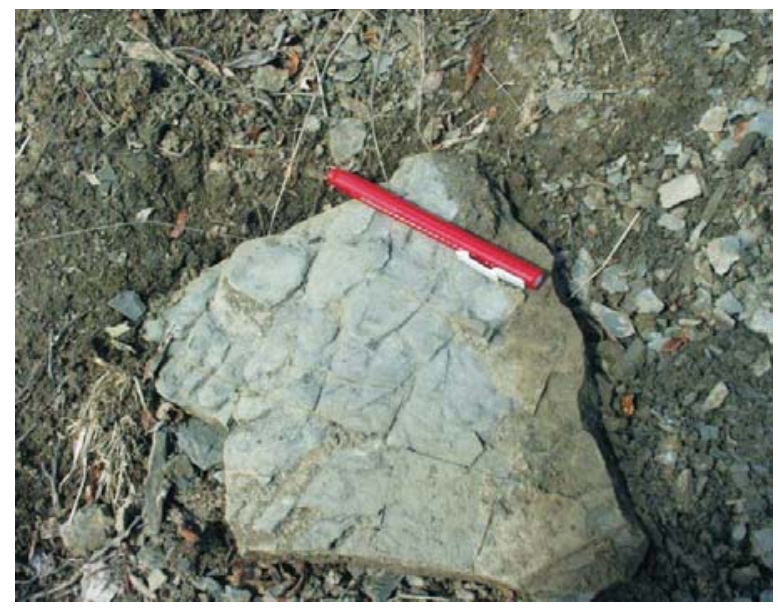

D.

Figure 6. Photographs of sedimentary features in the distal Seabee Formation at station 07DL045. (A) Calcite-cemented sandstone from 1.7-2.6 $\mathrm{m}$. Note the calcite-filled vein immediately to the right of the hammer handle. (B) Thinly parting sandstone in amalgamated beds between 16 and $18 \mathrm{~m}$. (C) Molds of mudstone rip-up clasts preserved on the underside of a sandstone bed at $12 \mathrm{~m}$. (D) Load-enhanced flute casts in float.

\section{Station 07DL047}

\section{DESCRIPTION}

Station 047 (figs. 2 and 4) consists of a coherent line of sandstone rubble that extends from river level up-slope 20 to $30 \mathrm{~m}$ toward the northeast. The station is not visible from the air as a rubble-covered ridgeline. Bedding appears to dip 40 degrees toward the northwest, but stratigraphic facing direction is unclear. The sandstone bed or bedset weathering out of the slope at this location is approximately $1.5 \mathrm{~m}$ thick, is brown weathering, light gray on fresh surfaces, and very fine to fine grained. The lower 1.0-1.3 $\mathrm{m}$ of the rubblecrop have a frost-shattered appearance and parting surfaces are wavy to irregular shaped. The uppermost $20-50 \mathrm{~cm}$ of the rubblecrop is characterized by thin flaggy parting, possibly reflecting thinner horizontal bedding. Load casts and equivocal current ripple bedforms are present in float.

\section{INTERPRETATION}

Features recognized at station 047 are similar to those described at station 045 and are similarly interpreted. The absence of a visible line of rubble from the air away from the river suggests a lenticular sand body geometry. Available biostratigraphic data suggest correlation with the Seabee Formation west of the Trans-Alaska pipeline corridor. 


\section{Stations 07DL048 and 07DL049 \\ DESCRIPTION}

Stations 048 and 049 are separated by 30 to $40 \mathrm{~m}$ of tundra cover (figs. 2 and 4). Both stations consist of rubblecrop 2-3 m thick. Bedding at both stations is estimated to dip 70 degrees toward the southeast. Stratigraphic facing direction is inferred to be south, but is questionable. Sandstone at station 048 is well indurated, light gray to orange-brown weathering, light to medium gray on fresh surfaces, and very fine to fine grained. Some rocks appear green-gray on fresh surfaces. Parting character suggests wavy continuous beds; bed thickness is unknown. Scattered mudstone rip-up clasts up to a few millimeters long are present in the sandstones. Load-enhanced flute casts are present on sandstone slabs in float, indicating the presence of shaly interbeds (fig. 6d).

Sandstone at station 049 is well indurated, buff to brown weathering, light gray on fresh surfaces, and fine grained. Parting character is irregular and sandstone breaks easily in small chips and irregular pieces. Mudstone rip-up impressions up to a few centimeters long are common in sandstone float.

\section{INTERPRETATION}

Features similar to those described at station 045 suggest similar depositional processes. Available biostratigraphic data suggest correlation with the Seabee Formation west of the Trans-Alaska pipeline corridor.

\section{Station 07DL050 \\ DESCRIPTION}

Station 050 is the next rubblecrop southeast of station 049 (figs. 2 and 4). Approximately 2-4 m of well indurated, rusty red-brown weathering sandstone is exposed. Bedding dips 34 degrees toward the northwest, but definitive way-up indicators have not been found in place. On fresh surfaces sandstones are medium to dark gray, very fine grained, and locally have a sulfurous odor. Bedding character is difficult to assess; some slabs in rubble are bounded by gently curving, irregular fracture surfaces, and other parts of the exposure appear more or less in place and display a thin, wavy parting character. No size grading or sedimentary structures have been recognized. Fracture and parting character suggest the presence of internally massive medium-bedded and thin, wavy-bedded sandstones. Chippy siltstone and lower very-fine-grained sandstone are present as float in recessive-weathering intervals within the rubblecrop. Similar chippy siltstone and small pieces of very-fine-grained sandstone are present as float approximately 15-20 m southeast of the exposure.

\section{INTERPRETATION}

Deposition in a deep-water setting is inferred based on regional context (Molenaar and others, 1986; Houseknecht and Schenk, 2004). More detailed interpretation is not possible given the exposure quality. Available biostratigraphic data suggest correlation with the Seabee Formation west of the Trans-Alaska pipeline corridor.

\section{Station 07DL051 \\ DESCRIPTION}

Station 051 is the first significant intact outcrop southeast of stations 045 and 046, and consists of $18 \mathrm{~m}$ of relatively well-exposed shale, siltstone, and sandstone (figs. 2, 4, and 7). Rubble of red-orange weathering veryfine- to fine-grained sandstone extends approximately $12 \mathrm{~m}$ below the base of the exposure toward the northwest, and shale and very-fine- to fine-grained sandstone are poorly exposed immediately south of the exposure. Beds dip 60 degrees toward the south and sole markings indicate the section is not overturned. In contrast, sole markings on sandstones thought to be in place immediately southeast of the exposure suggest bedding is overturned and that the southeast end of the exposure at station 051 represents the upright limb of a syncline.

The age of this succession is constrained by well-preserved impressions of the early Turonian bivalve Mytiloides labiatus (fig. 8a).

The lower $9 \mathrm{~m}$ at station 051 consists of discontinuously exposed light green-gray weathering fissile clay shale and olive-gray weathering chippy siltstone with minor interbedded rusty red-brown and yellow weathering, very-fine- to fine-grained sandstone (fig. 8b). Siltstone is locally red-brown stained with millimeter-scale laminae visible on fresh surfaces. Sandstone beds range from a few centimeters to decimeters thick. Sedimentary structures include small bulbous load casts (fig. 8c) and current ripple cross-lamination suggestive of Bouma Tc beds. Some beds are plane-parallel laminated (Bouma $\mathrm{Tb}$ ). At least one 1-m-thick bedset of very-fine-grained sandstone with irregular parting surfaces suggestive of small-scale trough cross-bedding is present. Many beds have a bioturbated appearance (fig. 8d). 
07DL051

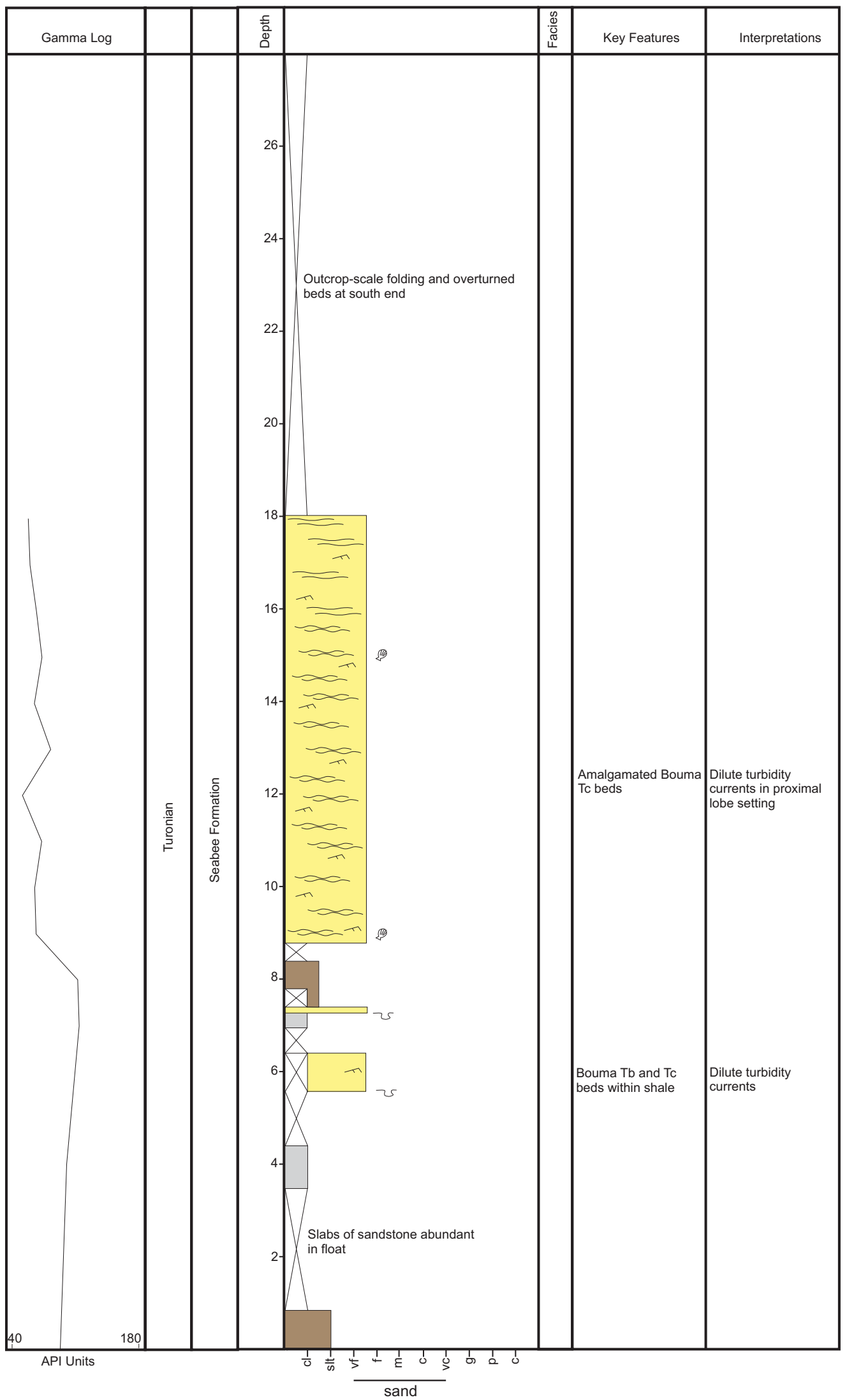

Figure 7. Measured stratigraphic section through Turonian turbidites of the distal Seabee Formation at station 07DL051. See figure 5 (p. 92) for symbol key. 

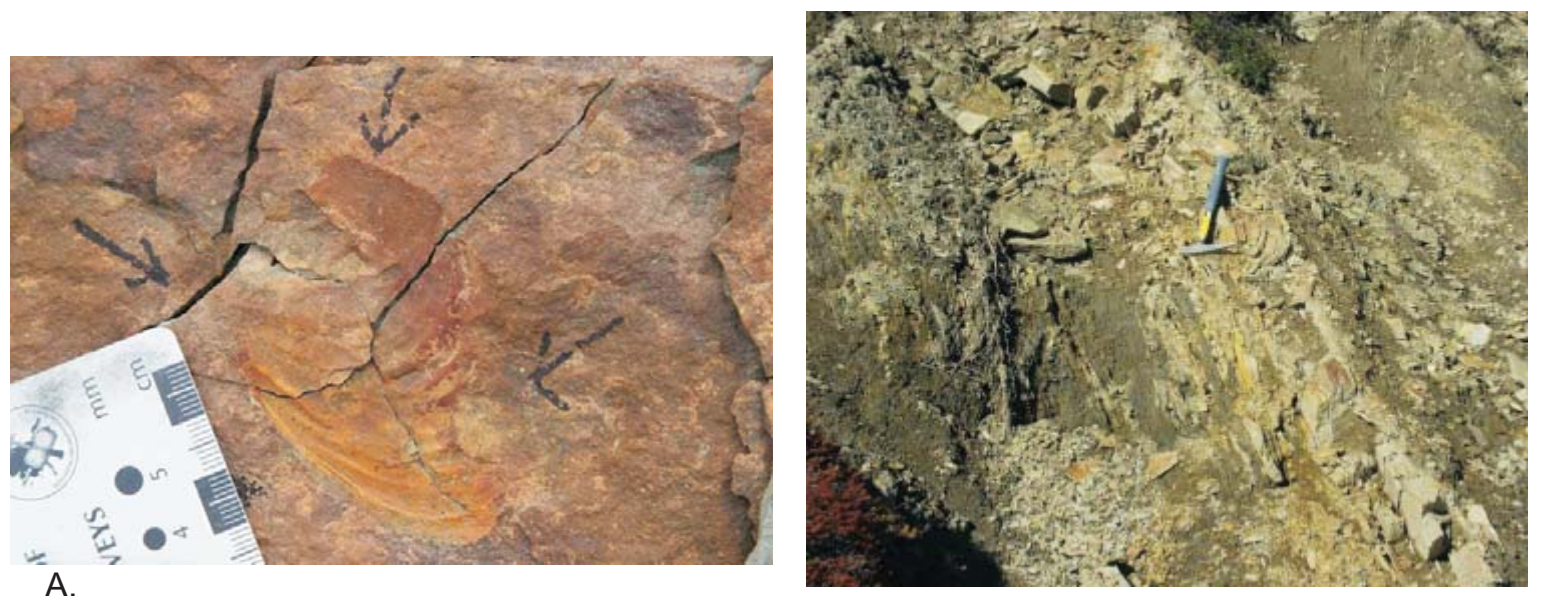

B.

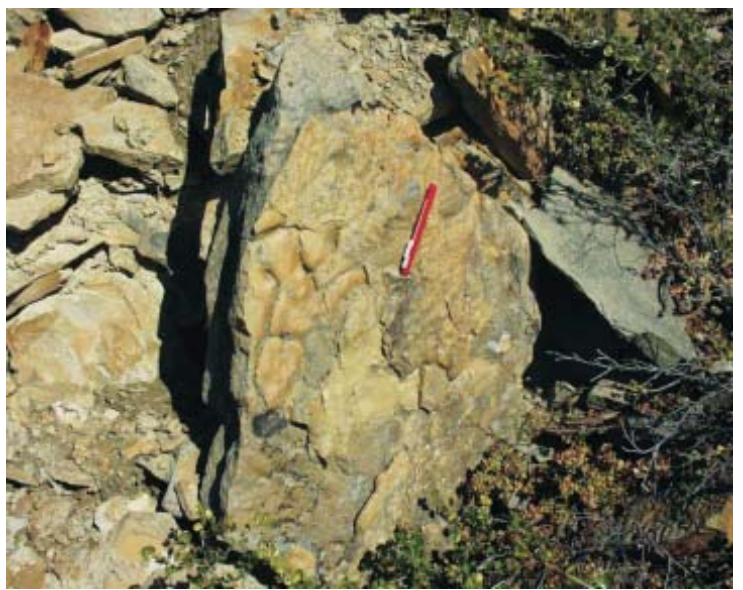

C.

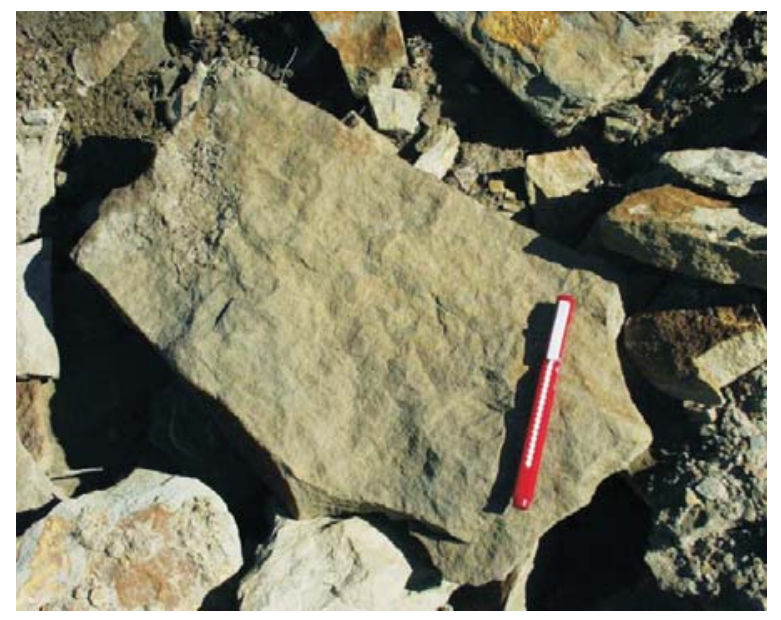

D.
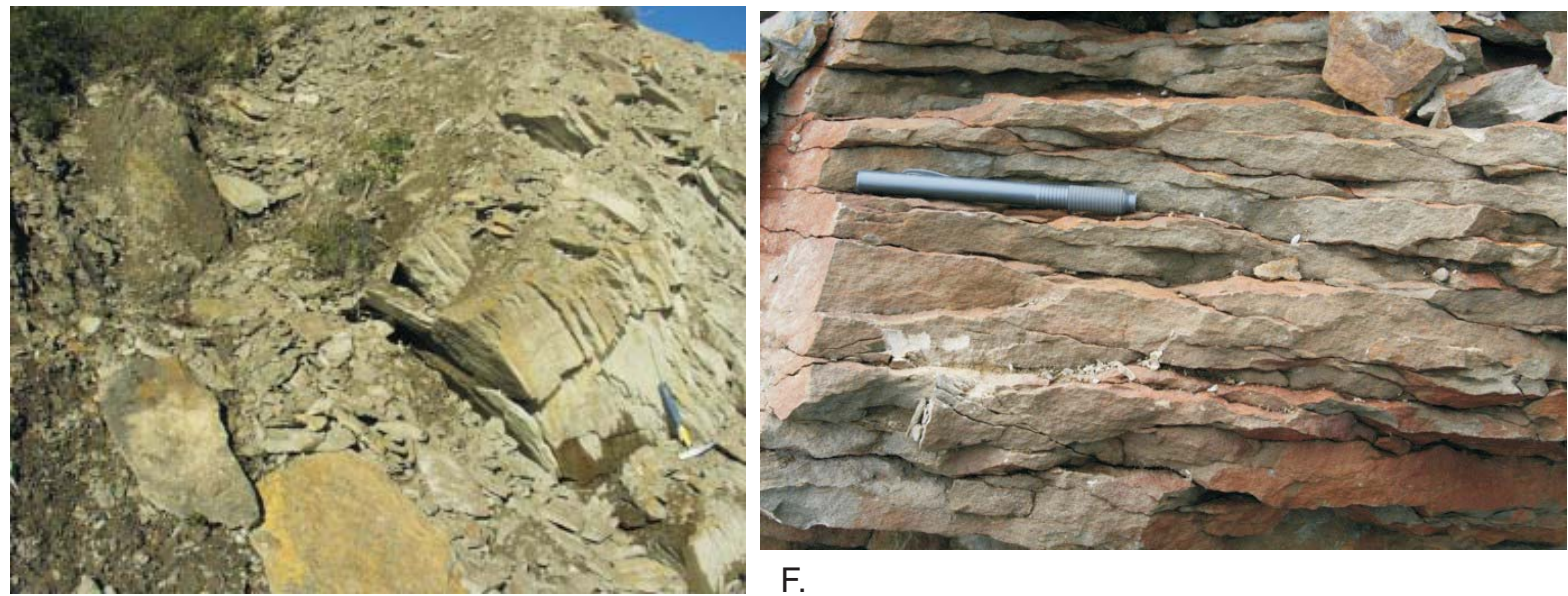

$\mathrm{F}$.

E.

Figure 8 (A-F). Photographs of sedimentary features through Turonian turbidites and associated hemipelagic deposits of the distal Seabee Formation at station 07DL051. (A) Impression of early Turonian clam Mytiloides labiatus in iron-stained sandstone at $9 \mathrm{~m}$. (B) Thinly interbedded very-fine-grained sandstone and silty claystone at $6 \mathrm{~m}$. (C) Load casts on the underside of a sandstone bed above $18 \mathrm{~m}$. The orientation of this bed suggests the presence of an outcrop-scale fold and vertical to overturned beds on the southeast limb. Measured section 07DL051 was measured on the northwest limb. (D) Bioturbated appearance of sandstone on an irregular parting surface. (E) Contact between amalgamated sandstone beds and siltstone at $8.7 \mathrm{~m}$. (F) Thin, discontinuous sandstone beds at $10 \mathrm{~m}$. 


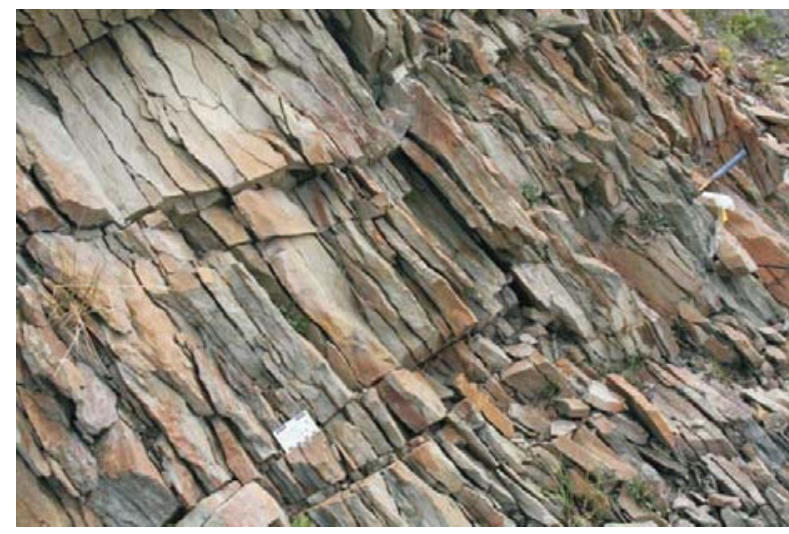

G.

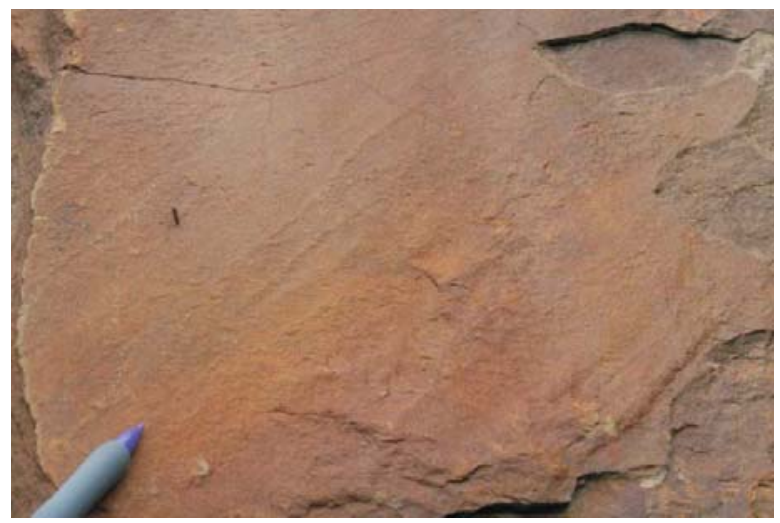

I.

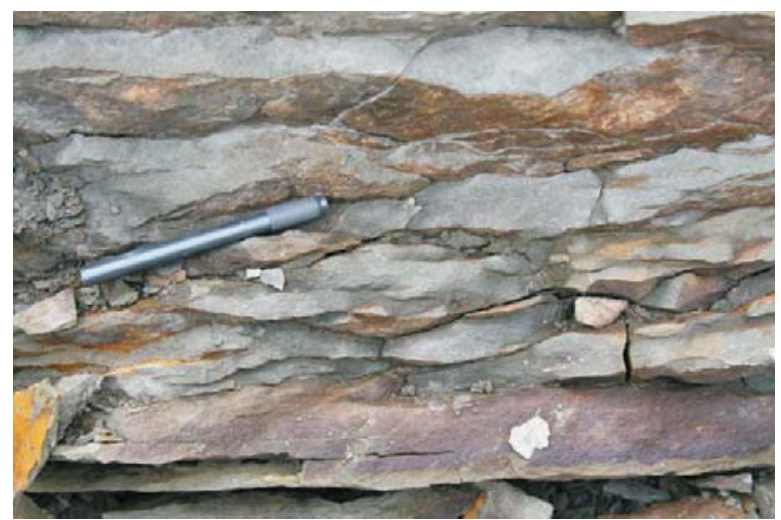

H.

Figure 8 (G-I). Photographs of sedimentary features through Turonian turbidites and associated hemipelagic deposits of the distal Seabee Formation at station 07DL051. (G) Slightly thicker, discontinuous sandstone beds near $16 \mathrm{~m}$. The lower edge of the white scale is graduated in centimeters and the top edge in inches. (H) Concave-up surfaces overlain by concave-up gently dipping foreset laminae of small-scale trough cross beds near 16 m. (I) Parting lineation visible on sandstone parting surface in float.

The upper $9 \mathrm{~m}$ consists entirely of an amalgamated succession of red-brown weathering very-fine- to finegrained sandstone. The contact with underlying shale is sharp (fig. 8e) and linear groove and prod marks are visible on the underside of the basal sand bed. Sandstone is light to medium gray on fresh surfaces, which give off faint hydrocarbon and sulfur odors. Parting surfaces typically have a burrow-churned, disrupted appearance (fig. 8a). Bedding is discontinuous and ranges from 0.5 to $5 \mathrm{~cm}$ near the base (fig. 8f) and gradually thickens upward to 5 to $7 \mathrm{~cm}$ near the top (fig. 8g). Faint, gently-dipping to concave-up laminae are visible locally and concave-up parting surfaces are common, both of which suggest small-scale trough cross-bedding in sets up to $10 \mathrm{~cm}$ thick (fig. 8h). Parting planes throughout the amalgamated succession are coated with a red-brown sub-millimeter-thick film. The film is either an exceedingly thin clay drape or, more likely, an oxide coating of some sort. Lineations (fig. 8i) and minor sideritized(?) mudstone rip-up clasts are present on parting surfaces throughout the sand body; rip-up clast impressions up to $5 \mathrm{~cm}$ across are abundant throughout the upper few meters of the sand body. Well-preserved unbroken bivalve impressions of Mytiloides labiatus are present on scattered parting surfaces as concave-upward depressions (fig. 8a). If these occurrences represent impressions of disarticulated valves, the valves were deposited in the hydrodynamically-unstable concave-side-up position. Casts of the complete clam (both valves articulated as in life) have not been found. Freshly broken pieces of sandstone have faint hydrocarbon and sulfur odors.

\section{INTERPRETATION}

The lower $9 \mathrm{~m}$ records deposition in a low-energy setting that was interrupted intermittently by dilute turbidity currents depositing Bouma Tb and Tc beds on the distal fringe of a sandstone lobe (lobe fringe in the sense of Mutti and Normark, 1987). Rip-up clasts and small-scale trough cross-bedding suggest that sandstone in the upper $9 \mathrm{~m}$ was deposited from turbulent flows involving traction transport of very-fine- to fine-grained sandy bedload and development of small-scale three-dimensional bedforms. The apparent absence of laterally continuous beds makes recognition of individual turbidite event beds difficult, and highlights the presence of intersecting scour features throughout the sand body. This part of the succession is tentatively interpreted as the depositional products of a series of dilute turbidity currents that deposited a series of Bouma Tc beds. Each event involved enough turbulent 
scour in the head of the flow to remove finer-grained deposits, resulting in amalgamated Tc beds. The churned, disrupted appearance of most parting surfaces suggests the presence of a burrowing fauna. However, common undisturbed (or minimally disturbed) lamination indicates not all beds were subjected to the disrupting activities of burrowing organisms.

Characteristics described above for the upper 9-m-thick sandstone body are consistent with deposition as channel-lobe transition or proximal lobe deposits (Mutti and Normark, 1987), possibly in a channelized setting. Subsurface control (Decker, written commun.; Molenaar and others, 1986) suggests deposition in a basin floor position, which is consistent with sandstone lobe deposition.

The presence of well-preserved disarticulated clam shells in the hydrodynamically-unstable concave-up position in a deep-water succession seems problematic. Although M. labiatus shells can be thick-walled and robust (Will Elder, written commun.), significant transport as bedload should have resulted in significant abrasion and some breakage, yet the valve impressions in these rocks do not clearly show these signs. It is possible that disarticulated shells were rafted to the depositional site on the underside of seasonal ice flows that formed in nearshore locations where the shells were incorporated in the base of ice. Subsequent seasonal warming allowed ice flows to break up and carry their entrained load, including the occasional clam shell, seaward to deeper water. A concave-up resting position might be expected for valves that settled through a low-energy water column. The presence of seasonal ice is reasonable given the 75 to 85 degrees north latitude of northern Alaska during the Late Cretaceous (Spicer and others, 1992).

Available biostratigraphic data suggest correlation with the Seabee Formation west of the Trans-Alaska pipeline corridor.

\section{Station 07DL052 \\ DESCRIPTION}

Station 052 is an inconspicuous rubbly exposure east-southeast of station 051 (figs. 2 and 4). Rubblecrop on the west side of the location includes approximately $10 \mathrm{~m}$ of light gray to light brown weathering very-fine- to fine-grained sandstone. Rusty red-brown weathering sandstone is present locally. Load casts are common. Wavy discontinuous internal surfaces visible on some pieces of float are suggestive of current ripple cross-lamination or small-scale trough cross-bedding. Silty claystone is present as float 25 to $30 \mathrm{~m}$ east-southeast of the sandstone rubble, where tundra vegetation is absent. A possible ash consisting of yellow weathering clayey material is intermixed with the silty claystone float.

\section{INTERPRETATION}

The presence of load casts and possible current ripple cross-lamination are consistent with deposition as Bouma Tc beds from dilute turbidity currents. The silty claystone in float 25 to $30 \mathrm{~m}$ above the sandy rubblecrop records background hemipelagic sedimentation. More detailed interpretation is not possible given the limited exposure. Regional constraints suggest deposition in a deep-water setting (Molenaar and others, 1986; Houseknecht and Schenk, 2004).

Available biostratigraphic data suggest correlation with the Seabee Formation west of the Trans-Alaska pipeline corridor.

\section{Station 07DL053 \\ DESCRIPTION}

Station 053 consists of approximately $3 \mathrm{~m}$ of rusty brown weathering very-fine-grained sandstone or coarse siltstone (figs. 2 and 4). Bedding is thin, wavy, and discontinuous.

\section{INTERPRETATION}

Such limited exposure precludes environmental interpretation. Nearby seismic data suggest deposition in a deep-water setting (Molenaar and others, 1986). Available biostratigraphic data suggest correlation with the Seabee Formation west of the Trans-Alaska pipeline corridor.

\section{Station 07DL054 \\ Description}

Station 054 spans two prominent east-west-trending ridges (figs. 2, 4, and 9). Complex disharmonic folds in a succession of thinly interbedded shale, sandstone, and silicified tuff are exposed on the north-facing slope of the southern ridge. Bedding on the north side of the exposure dips 48 degrees toward the south. 
The age of the succession is bracketed by an early Turonian bivalve Mytiloides labiatus at station 051 and a Santonian bivalve Sphenoceramus near station 056 (Mull, unpublished data). A palynologic sample collected near $28 \mathrm{~m}$ yielded an early Turonian? age, and a composite palynologic sample collected between 84 and $90 \mathrm{~m}$ yielded an early Santonian age (fig. 9; LePain, unpublished data). The age of the succession most likely ranges from late Turonian to Santonian.

The lower two-thirds of the exposure consists of thinly interbedded silty shale, siltstone, and sandstone $66 \mathrm{~m}$ thick (fig. 10a). Sandstone is buff to light gray weathering, medium gray on fresh surfaces, and very fine to fine grained. Bedding in sandstone ranges from less than $1 \mathrm{~cm}$ to $80 \mathrm{~cm}$, but thickness is commonly $2-20 \mathrm{~cm}$. Most sandstone beds are present as single event beds; amalgamated beds are present, but not abundant. Detrital white mica is a minor $(>1 \%)$, but distinctive component in sandstone. Interbedded silty shale and siltstone ranges from a few centimeters to $8 \mathrm{~m}$ thick, is dark to medium gray weathering, and displays a characteristic chippy parting. Sandstones near the top of the lower two-thirds of the exposure, on the north side of the gully below the disharmonic folds (fig. 10b), are visibly hydrocarbon stained and have a strong hydrocarbon odor.

A limited variety of sedimentary structures have been recognized in this part of the succession and, most commonly, sandstone beds appear internally massive. Normal size grading has only been recognized in the lower few meters of the succession, where it is associated with plane-parallel lamination and ripple cross-lamination and forms the base of Bouma Tabc and Tac beds. Elsewhere in the exposure, plane-parallel and ripple cross-lamination are associated with Bouma Tb, Tbc, and Tc beds. Sole markings, including load and groove casts (fig. 10c), are common throughout the succession. Flute casts are present but not common. Parting lineations are visible on many bed tops and some appear to be related to linear sole markings present on the underside of overlying sandstone beds in which scour during the formative event stripped away intervening mudstones and cut into the lower sand (fig. 10d). Discoid mudstone rip-up clasts (or empty molds of rip-up clasts) are common on parting surfaces (fig. 10e); rip-up clasts range from less than $1 \mathrm{~cm}$ to $15 \mathrm{~cm}$ (fig. 10f).

The upper third of the exposure, including the folded strata mentioned above, consists of approximately $31 \mathrm{~m}$ of slightly silty clay shale with thinly interbedded siltstone, sandstone, silicified tuff, and minor lime mudstone (fig. 9). The upper $18 \mathrm{~m}$ of this succession is complexly folded (fig. 10g); folding does not involve underlying or overlying strata. Shale weathers light to medium gray, is dark chocolate brown on fresh surfaces, appears organicrich (fig. 10h), and commonly displays a papery fissility. Siltstone is present as discrete interbeds $1-4 \mathrm{~cm}$ thick and accounts for the bulk of at least one coarsening-upward succession (74-76 m on fig. 9). Sandstone weathers brown to light gray, is lower very fine grained, in beds ranging from $>1 \mathrm{~cm}$ to $15 \mathrm{~cm}$, and is typically plane-parallel laminated (Bouma Tb beds). Tuff beds are medium gray to dark red-brown weathering, are dark gray to brown on fresh surfaces, typically plane-parallel laminated, in beds ranging from $>1 \mathrm{~cm}$ to $15 \mathrm{~cm}$ thick, and silicified (fig. 10i). The weathered surfaces of some tuff beds have a discontinuous coating of a yellow-white precipitate (gypsum?). All tuff beds have strong hydrocarbon odors. Altered volcanic ash (bentonite) layers up to $2 \mathrm{~cm}$ thick are common (fig. 10j).

\section{INTERPRETATION}

Thinly interbedded sandstone and siltstone in the lower two-thirds of the succession resemble facies D turbidites of Mutti and Ricci Lucchi (1978) and are interpreted as the products of dilute turbidity currents in a proximal(?) basin floor or lower slope setting. The thin-bedded nature of most sandstones and the minor presence of amalgamated sandstone beds is consistent with deposition as the distal part of a sandstone lobe (lobe fringe) or channel levee.

Finer-grained facies in the upper third of the succession are interpreted as a condensed section recording deposition in a sediment-starved setting, either in a lower slope or basinal position. The abrupt decrease in grain size above $66 \mathrm{~m}$ (fig. 9) suggests correlation with a prominent flooding surface on the shelf to the west that may correspond to the top of the Tuluvak Formation (fig. 3). Tuff beds originated from airfall ash that settled through the water column (submarine ashfall). We suggest the folded section above $84.8 \mathrm{~m}$ (fig. 9) corresponds, at least in part, to a maximum flooding zone, and that folding is the result of mass wasting of slope sediment (facies $\mathrm{F}$ of Mutti and Ricci Lucchi, 1978). We tentatively correlate the lower $66 \mathrm{~m}$ of strata at station 054 with the Turonian Seabee Formation west of the Trans-Alaska pipeline corridor. Beds above $66 \mathrm{~m}$ are considered part of the Canning Formation (for example, turbidite sandstone facies of Molenaar and others, 1987; 1986). 
07DL054

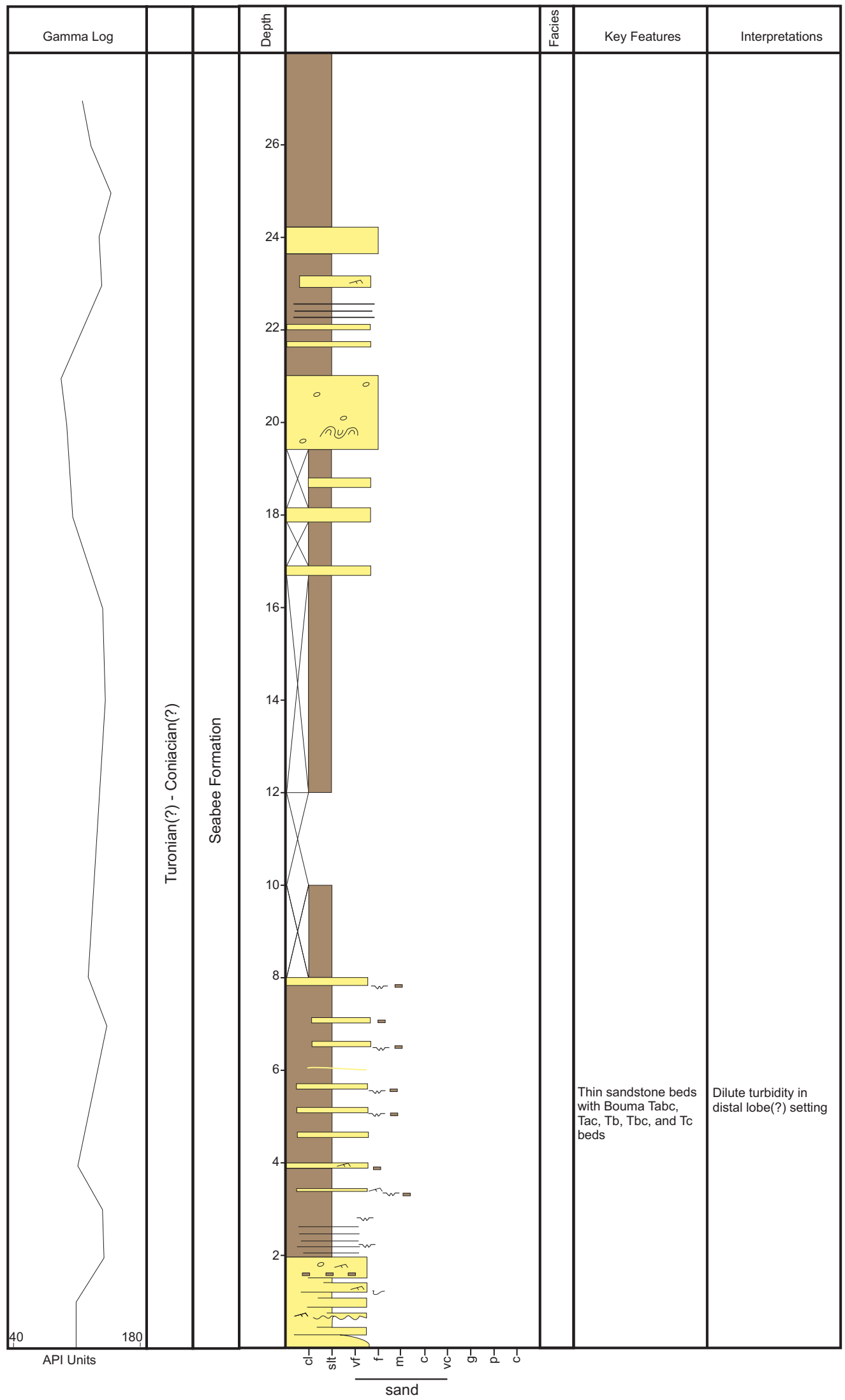

Figure 9. Measured stratigraphic section through turbidites and associated hemipelagic deposits of the distal Seabee and Canning Formations. Organic-rich clayshale and silicified tuffs above 50 m may represent a tongue of the Hue Shale. See figure 5 (p. 92) for symbol key. 


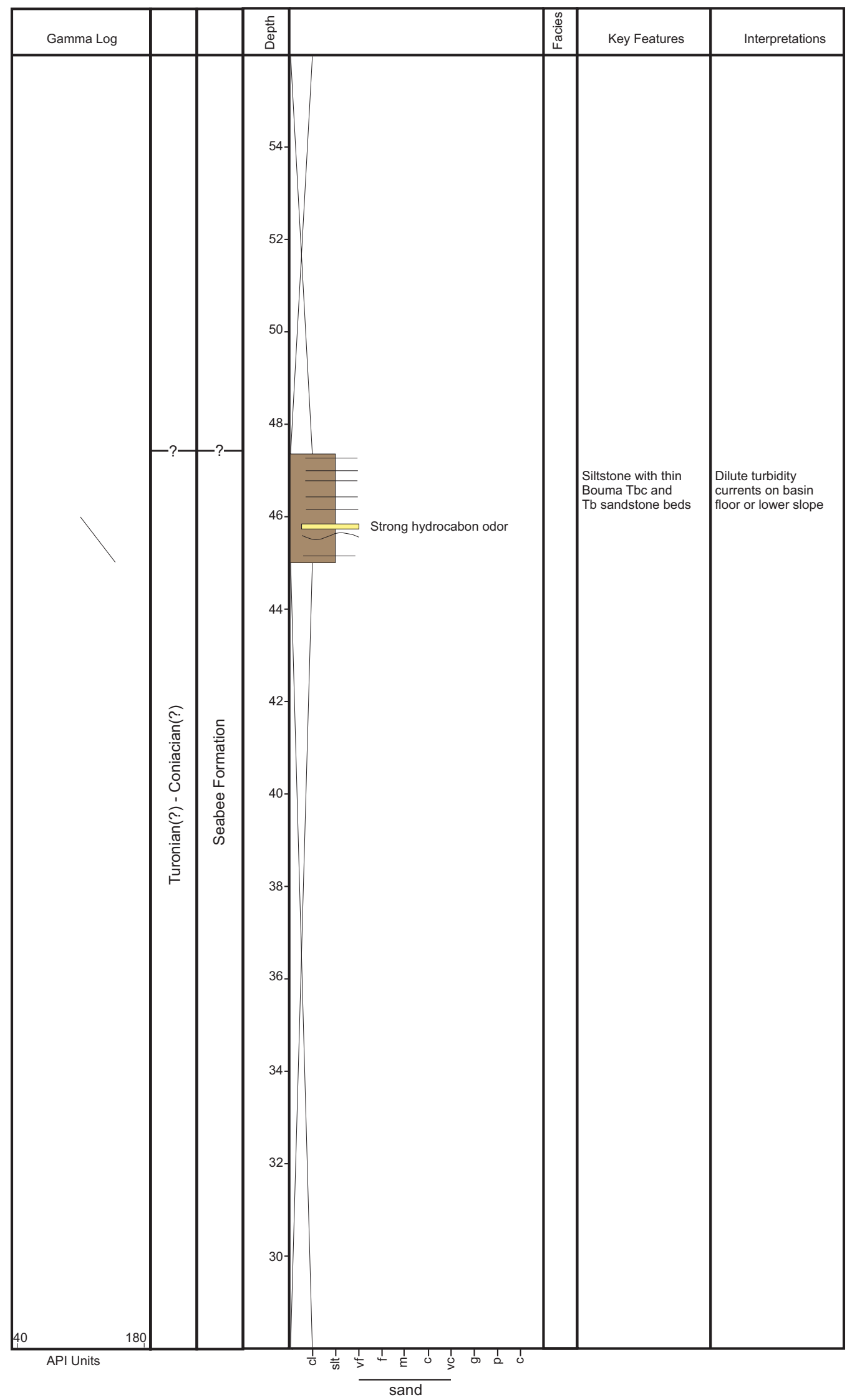

Figure 9. (continued) Measured stratigraphic section through turbidites and associated hemipelagic deposits of the distal Seabee and Canning Formations. Organic-rich clayshale and silicified tuffs above 50 m may represent a tongue of the Hue Shale. See figure 5 (p. 92) for symbol key. 


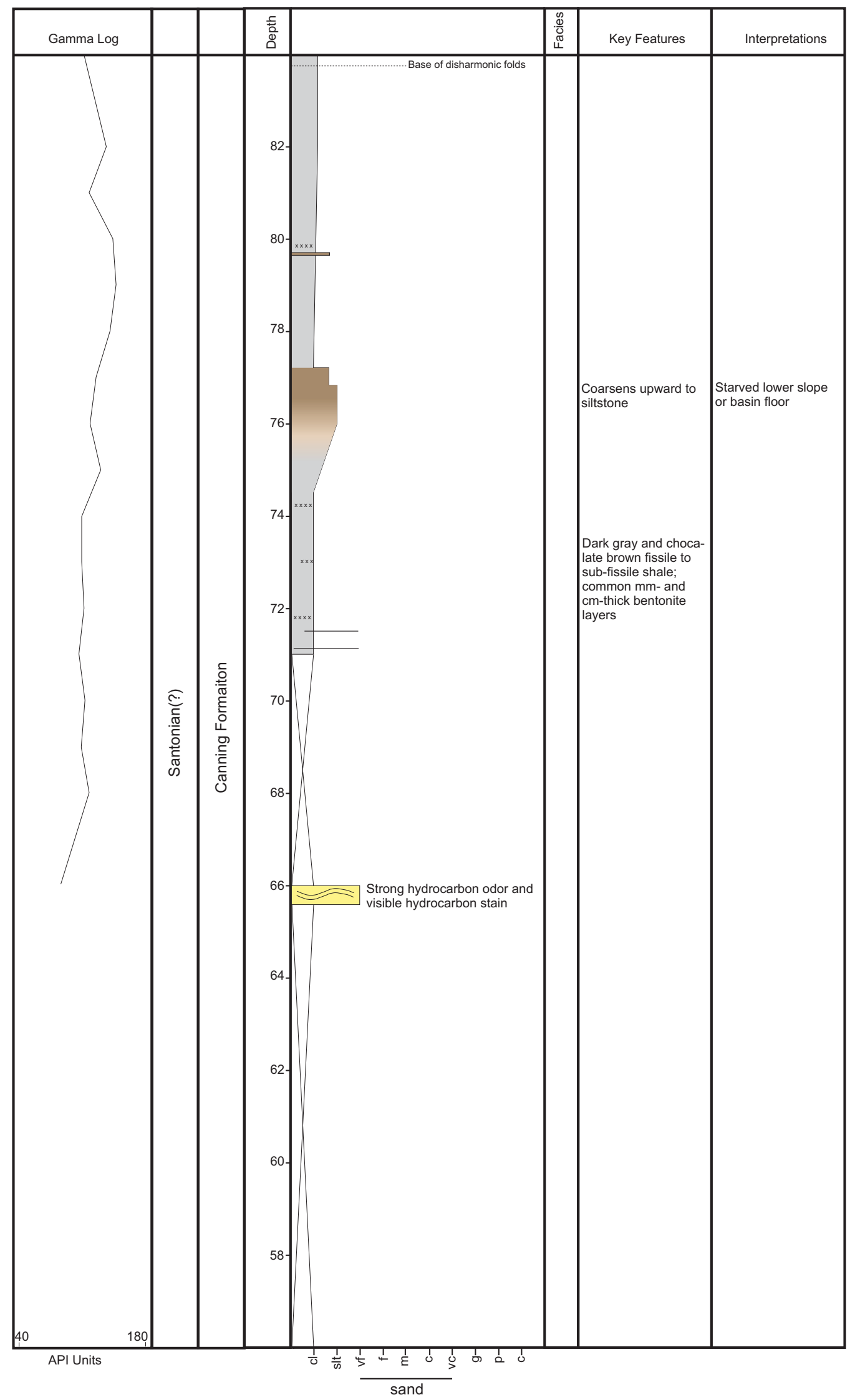

Figure 9. (continued) Measured stratigraphic section through turbidites and associated hemipelagic deposits of the distal Seabee and Canning Formations. Organic-rich clayshale and silicified tuffs above $50 \mathrm{~m}$ may represent a tongue of the Hue Shale. See figure 5 (p. 92) for symbol key. 


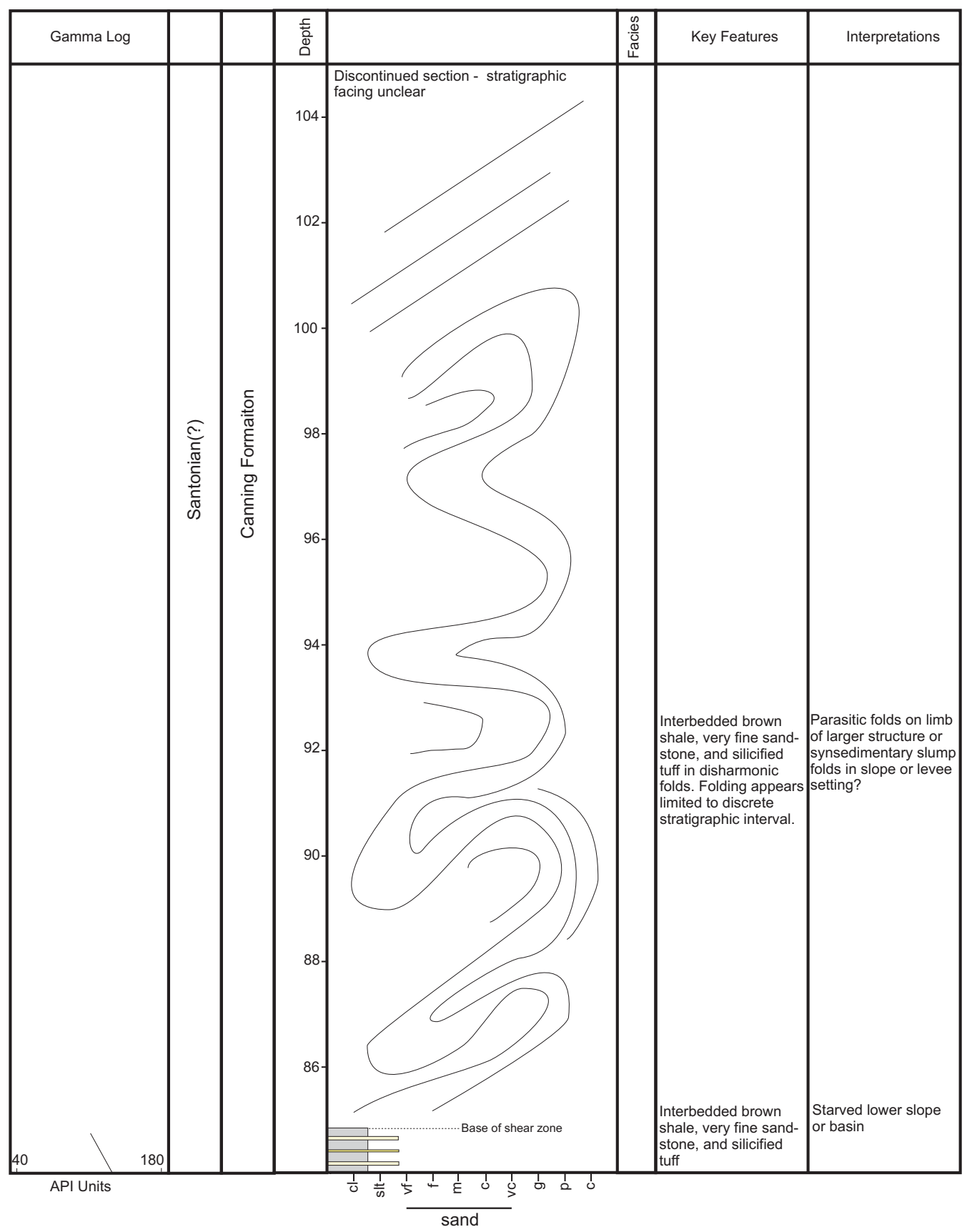

Figure 9. (continued) Measured stratigraphic section through turbidites and associated hemipelagic deposits of the distal Seabee and Canning Formations. Organic-rich clayshale and silicified tuffs above 50 m may represent a tongue of the Hue Shale. See figure 5 (p. 92) for symbol key. 

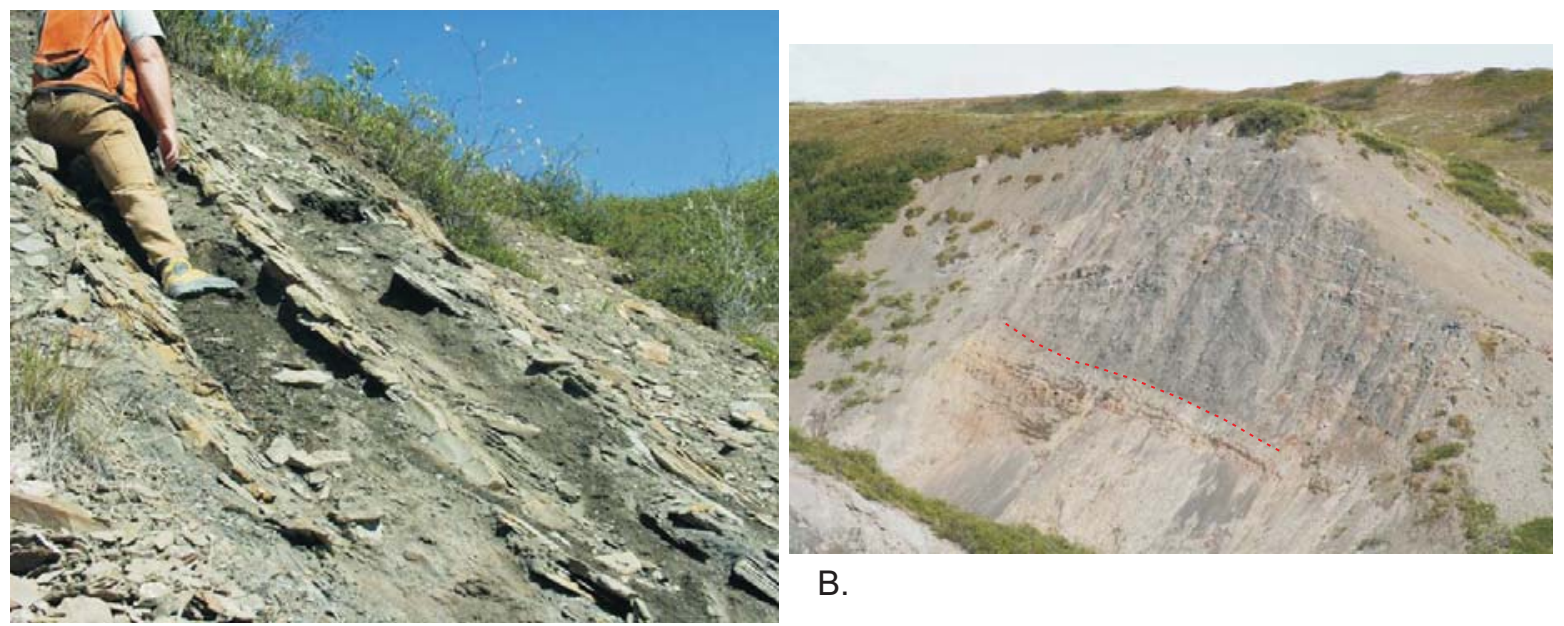

B.

A.

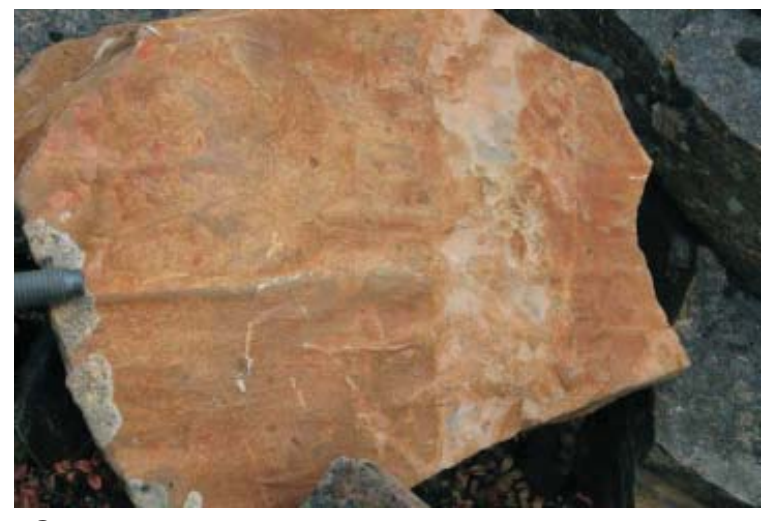

C.

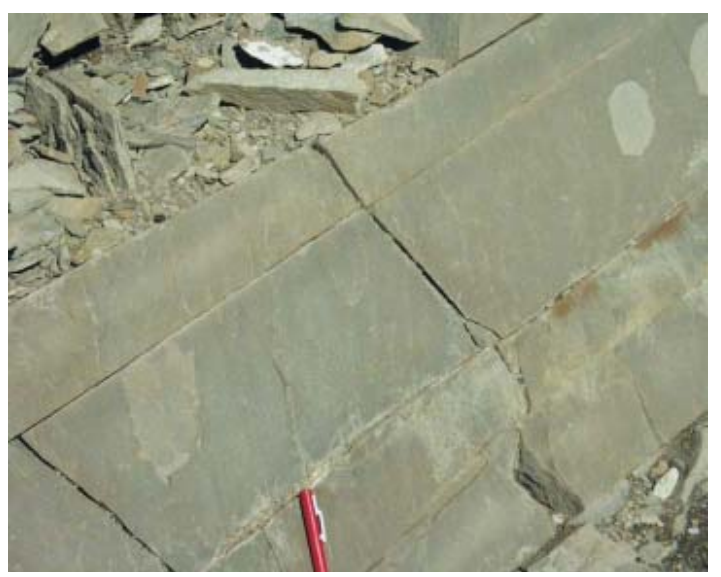

D.
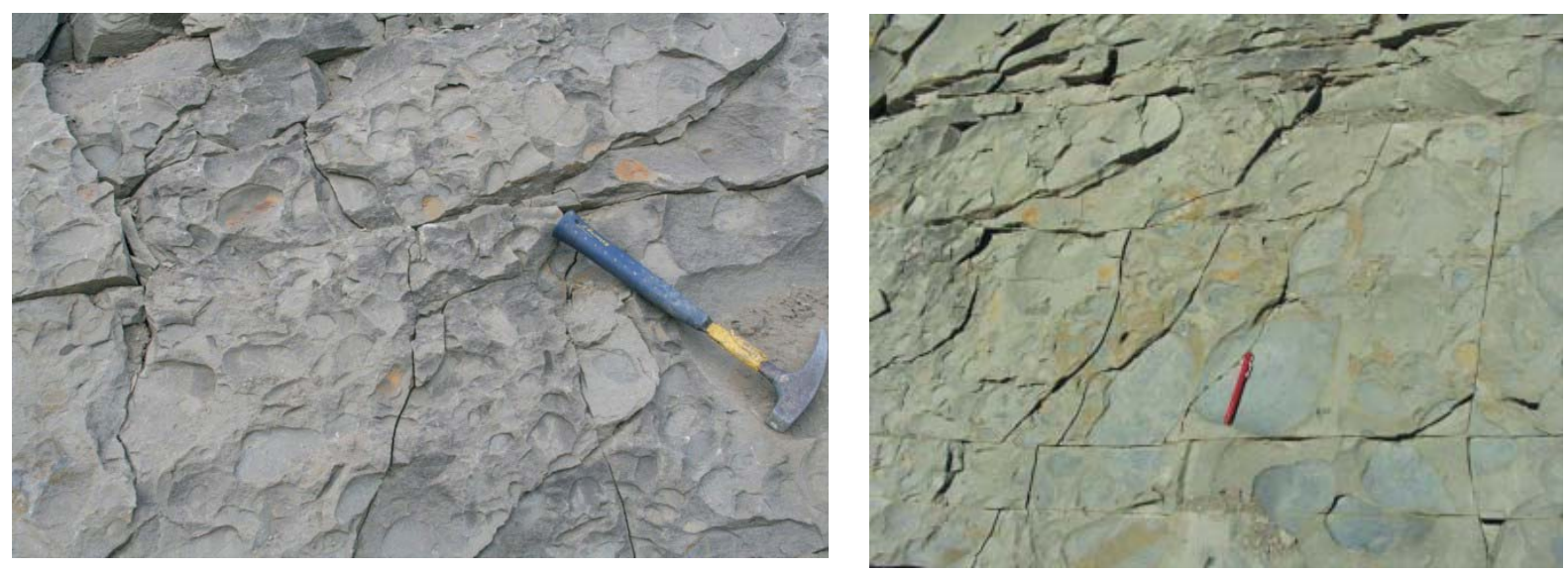

E.

F.

Figure 10 (A-F). Photographs of sedimentary features in turbidites of the distal Seabee and Canning Formations at station 07DL054. (A) Thinly interbedded siltstone, silty shale, and very-fine-grained sandstone. (B) Aerial view toward the east-southeast of disharmonic folds in interbedded clayshale, very-fine-grained sandstone, and silicified tuff between 85 and $104 \mathrm{~m}$. (C) Linear groove cast on sandstone bed near $6 \mathrm{~m}$. (D) Faintly visible flute casts preserved on the upper surface of a sandstone bed at $2 \mathrm{~m}$. These casts were associated with an overlying sandstone bed. Scour at the base of the flow that transported the sand in the overlying bed cut through an intervening thin mudstone bed and into the uppermost portion of the sandstone bed shown here. (E-F) Impressions of mudstone rip-up clasts on a parting surface in a sandstone bed at $20 \mathrm{~m}$. 


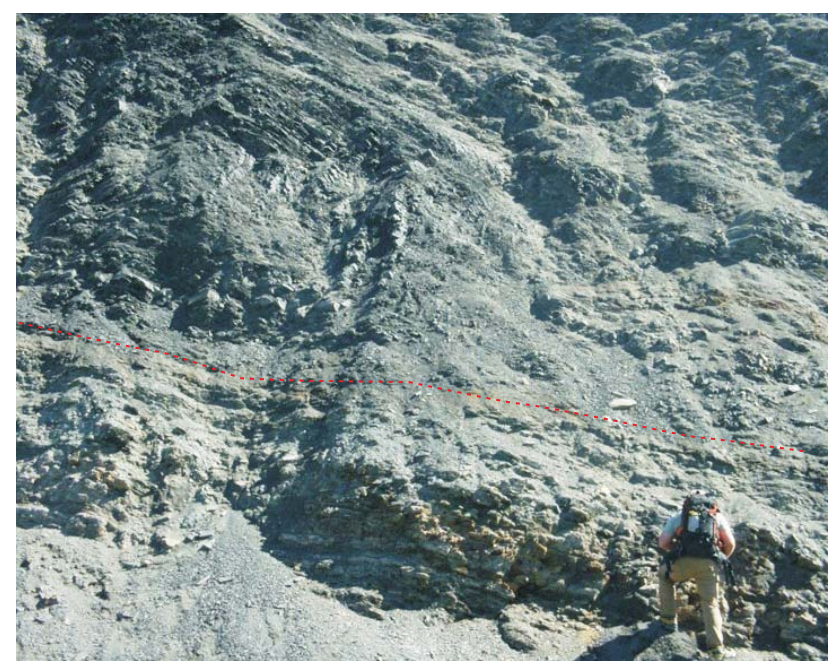

G.

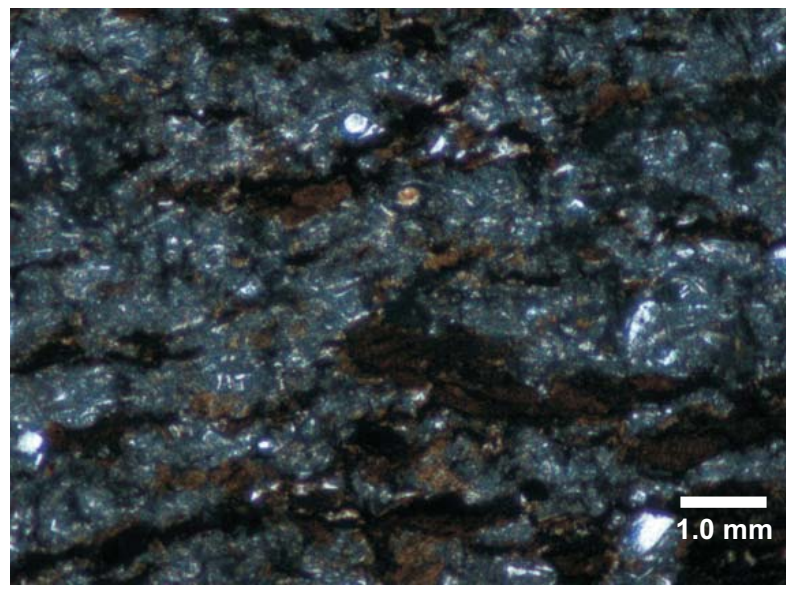

I.

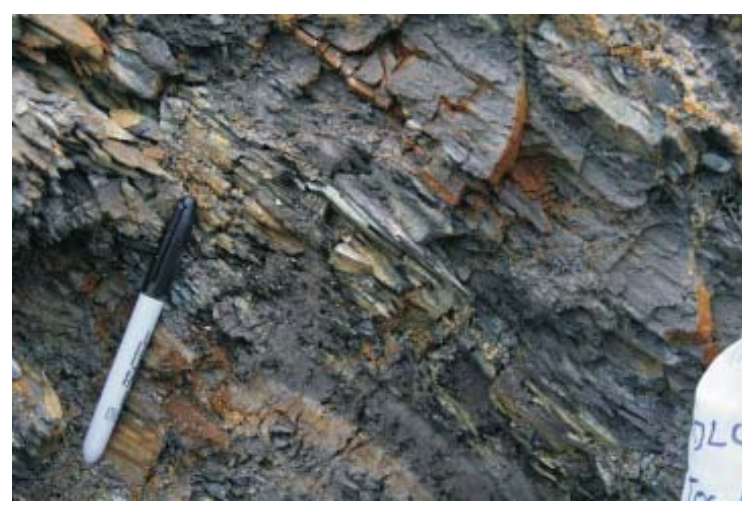

$\mathrm{H}$.

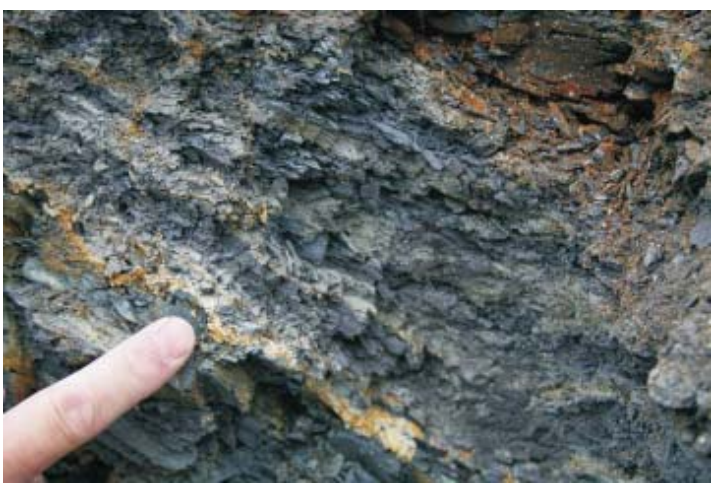

J.

Figure 10 (G-J). Photographs of sedimentary features in turbidites of the distal Seabee and Canning Formations at station 07DL054. (G) Contact between gently dipping interbedded clay shale, very-fine-grained sandstone, and silicified tuffs below and complex folds in overlying strata. The same lithologies comprise the folded package as in the gently dipping succession below. (H) Chocolate brown weathering clayshale at $73 \mathrm{~m}$. (I) Photomicrograph of silicified tuff at $85 \mathrm{~m}$. Some of the dark brown and black opaque material is hydrocarbon. (J) Altered tephra layer at $74.2 \mathrm{~m}$. This is one of many millimeter- to centimeter-thick tephra beds in the upper third of this exposure. Tephras were not observed below $50 \mathrm{~m}$, due to either their absence or to poor exposure.

\section{Station 07DL055}

\section{DESCRIPTION}

Station 055 is located on the north side of the next tributary side valley south of station 054 , immediately east of the main drainage (figs. 2 and 4). Slumped tundra vegetation has exposed approximately 0.5 m of thinly interlaminated siltstone and lower very-fine-grained sandstone. Siltstone is rusty red-brown weathering and dark gray on fresh surfaces and sandstone is present as millimeter-thick laminae.

\section{INTERPRETATION}

Interpretation is not possible given the limited exposure. Available data suggest strata at this location belong to the Canning Formation. 


\section{Station 07DL056 \\ DESCRIPTION}

Station 056 is located at the west end of a prominent east-west-trending ridge characterized by distinctive orange, buff, and light gray weathering float along the ridge crest, north and south flanks, and as talus and steeply south-dipping exposures where the ridge is cut by the main drainage (figs. 2 and 4). Approximately $32 \mathrm{~m}$ of interbedded tuffaceous sandstone, silicified tuff, and slightly silty shale are exposed at the west end of the ridge (figs. 11 and 12a). Two prominent resistant sandstone and tuffaceous packages separated by a thick recessive-weathering interval, dip 48 degrees toward the south. Contact relations between the lower resistant package and underlying strata are poorly known due to talus cover (fig. 12a).

The age of the succession at station 056 is constrained by the Santonian bivalve Sphenoceramus collected near station 056 (Mull, unpublished data) and late Campanian palynomorphs at overlying station 061 (LePain, unpublished data). The age of the succession is probably Santonian to early Campanian.

The lower third of the exposure consists of interbedded shale, tuff, tuffaceous sandstone (reworked tuff?), and minor lime mudstone (figs. 11, 12a, and 12b). Shale is slightly silty, brown to yellow-brown weathering, chocolate brown in fresh cuts, fissile, organic rich(?), and includes few bentonitic layers. Tuff and tuffaceous sandstone are buff to orange weathering, plane-parallel laminated, and locally include well-developed ripple cross-lamination (tuffaceous sandstone). Bed thickness ranges from 1 to $40 \mathrm{~cm}$; thicker beds locally display shard-like fracture patterns. In thin-section, tuffs include needle- and rectangular-shaped crystals within a felted groundmass (fig. 12c). Soft-sediment slump folds are present locally.

The middle third consists of $10 \mathrm{~m}$ of poorly exposed brown weathering sub-fissile shale (figs. 11 and $12 \mathrm{a}$ ). Tuff and tuffaceous sandstone are present in float and it is unclear if these lithologies are present interbedded in the shale.

The upper third consists of rusty brown weathering, sub-fissile silty shale with interbedded buff and orange-buff weathering tuff and tuffaceous sandstone, and minor lime mudstone (figs. 11 and 12d). Shale is similar in appearance to shale encountered in the lower and middle thirds of the exposure. Bedding in tuff, tuffaceous sandstone, and limestone ranges from a few centimeters to $20 \mathrm{~cm}$ thick. Tuff and sandstone appear organized in bedsets up to $70 \mathrm{~cm}$ thick that cap coarsening(?)-upward packages up to $2.5 \mathrm{~m}$ thick. Whitish-yellow bentonite beds up to 15 $\mathrm{cm}$ thick are interbedded within the silty shale. Lime mudstone is a minor component that weathers rusty brown, is dark brown on fresh surfaces, and has a distinct hydrocarbon odor.

\section{INTERPRETATION}

Organic-rich(?) brown shale suggests deposition in a deep-water setting below the oxygen minimum layer. Interbedded tuffs and bentonites originated from volcanic eruptions as airfall deposits that settled through the water column (submarine ashfalls). Ripple cross-laminae indicate that some tuffs were reworked during or after deposition on the sea floor. Meter-scale coarsening-upward successions could record deposition on levees marginal to active channels and, if correctly interpreted, indicate at least some reworking. Minor but conspicuous smallscale slump folds in tuffs are consistent with deposition in levee or slope settings. Given available data, choosing between these possibilities is not possible.

Strata at this station are assigned to the Canning Formation. Based on the resistant tuffaceous character and the likely Santonian-early Campanian age, strata at this location are tentatively correlated with the Barrow Trail Member (Schrader Bluff Formation) of former usage, which is exposed in the Umiat Quadrangle west of the Trans-Alaska pipeline corridor (Whittington, 1956). The age-diagnostic inoceramid Sphenoceramus (Santonian) was collected down-section (northwest) between stations 55 and 56. Sphenoceramus is common in the Barrow Trail Member in outcrop to the west (Brosgé and Whittington, 1966, p. 547). Other megafossils from the Barrow Trail Member indicate a middle Santonian to early Campanian age (Brosgé and Whittington, 1966).

Wartes (oral commun.) suggested correlating silicified tuffaceous strata at station 056 with the middle part of the Hue Shale, which was described in outcrop (south side of Ignek Valley) and recognized in core from the West Staines 18-9-23 well (south of Point Thomson; Molenaar and others, 1987, p. 521; fig. 1). Palynological data from the West Staines well indicate a Santonian-Campanian age (Molenaar and others, 1987).

\section{Station 07DL057 \\ DESCRIPTION}

Station 057 is an inconspicuous tundra-covered slope with float of chippy shale and siltstone between grass tussocks (figs. 2 and 4). 
07DL056

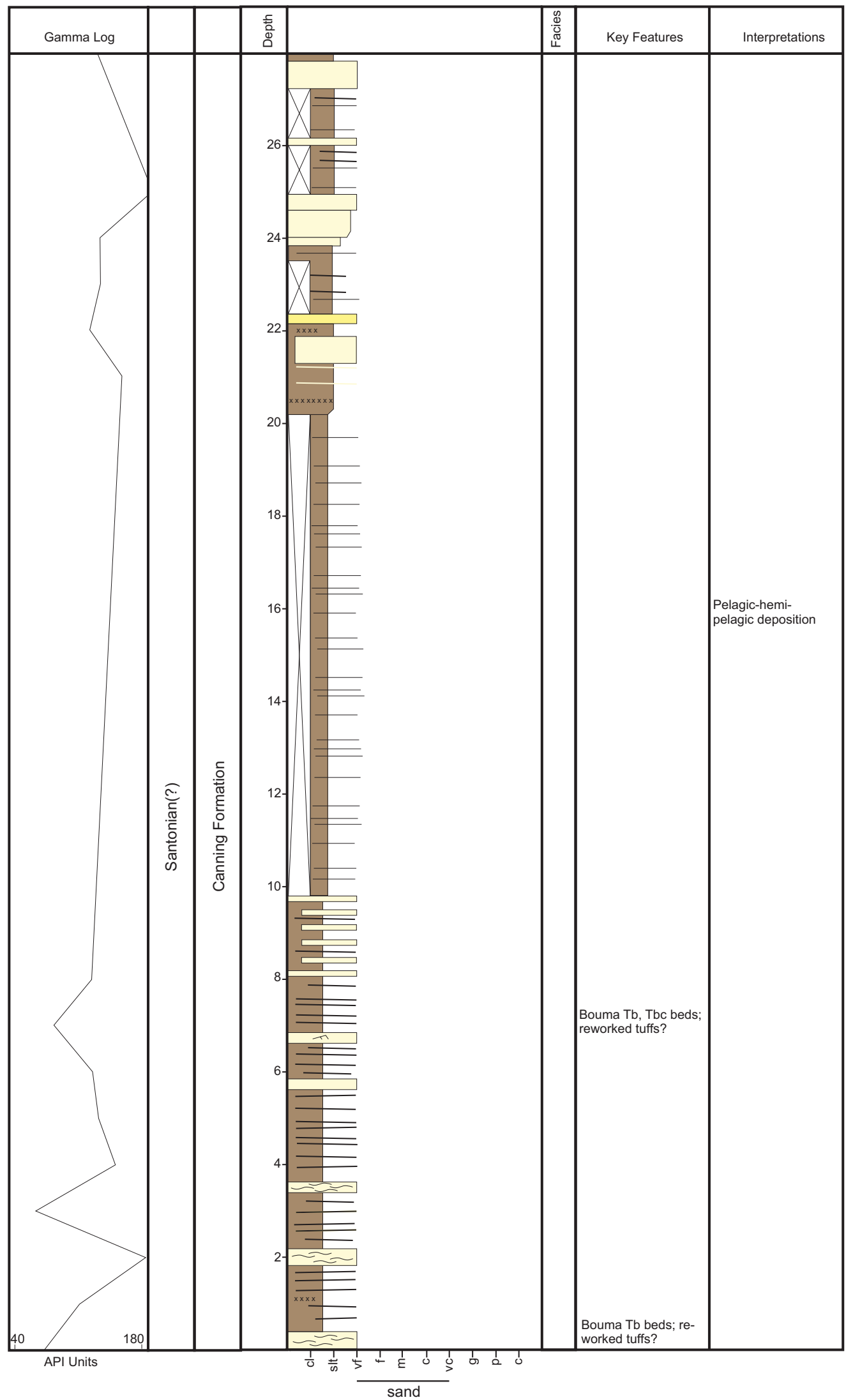

Figure 11. Measured stratigraphic section through probable Santonian age distal turbidites and associated hemipelagic deposits of the Canning Formation at station 07DL056. See figure 5 (p. 92) for symbol key. 


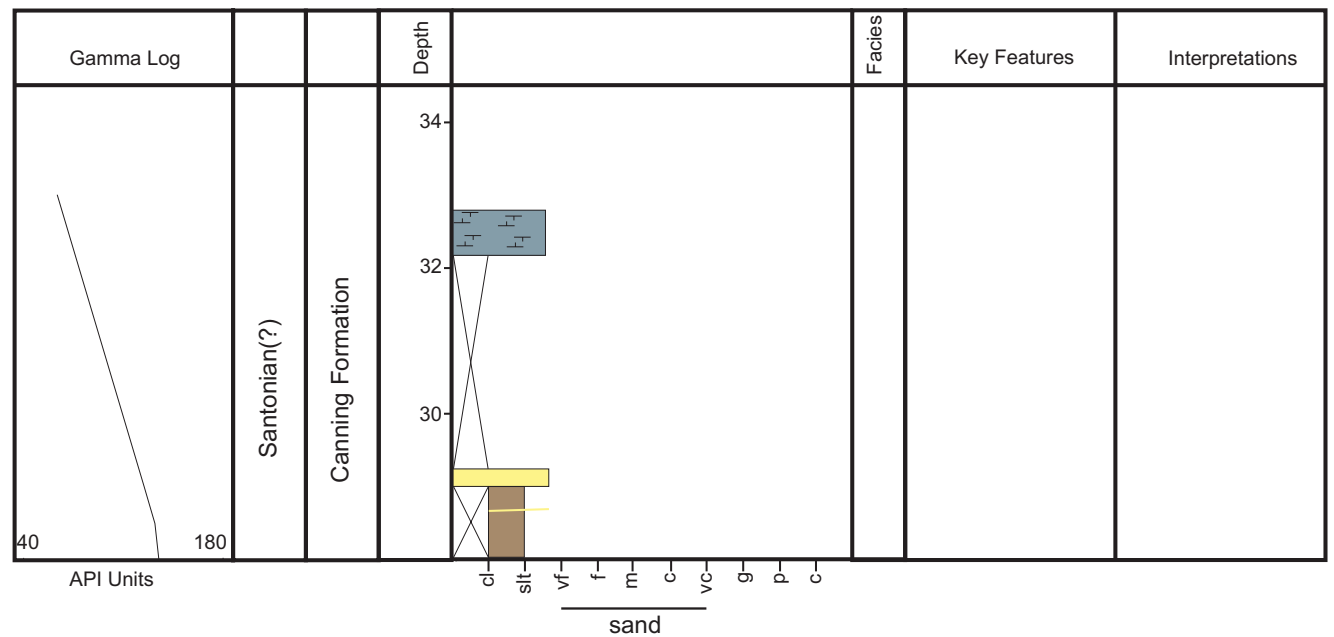

Figure 11. (continued) Measured stratigraphic section through probable Santonian age distal turbidites and associated hemipelagic deposits of the Canning Formation at station 07DL056. See figure 5 (p. 92) for symbol key.

\section{INTERPRETATION}

Interpretation is not possible given the limited exposure.

\section{Station 07DL058}

\section{DESCRIPTION}

Station 058 is the first prominent east-west-trending ridge south of station 056 (figs. 2 and 4) and consists of approximately $3 \mathrm{~m}$ of amalgamated buff to light gray weathering very-fine- to fine-grained sandstone. Beds dip 26 degrees toward the southwest and are 15-50 cm thick in the lower $2 \mathrm{~m}$ and 1-5 cm thick in the upper meter. Common concave-up scour surfaces are overlain by gently-dipping laminae. Small-scale trough cross-bedding is visible locally (Bouma Tc?) as are low-relief asymmetric current-ripple bedforms. Bedform crestlines are discontinuous and parallel, and the lee face associated with one bedform dips toward 155 degrees (corrected for tectonic tilt). Mudstone rip-up impressions are common and typically concentrated along cryptic scour surfaces. Load casts are prominent features on the underside of some sandstone beds (fig. 12e), yet interbedded mudstone is not evident. White mica is a prominent, but minor, component of these sandstones and small carbonaceous plant fragments are present on some bed surfaces.

\section{INTERPRETATION}

Features observed in sandstone at this location could form in a variety of shallow- and deep-water settings. Given the stratigraphic position of these strata above basin-floor or slope deposits at station 056 and below probable slope facies at station 063 (described below), a depositional setting basinward of the coeval shelf edge is likely.

\section{Station 07DL059}

\section{DESCRIPTION}

Station 059 (figs. 2 and 4) consists of a stream of float approximately $8 \mathrm{~m}$ wide with about $30 \mathrm{~cm}$ of thin flaggy parting sandstone in place (fig. 12f). Sandstone is light gray to buff weathering, lighter gray on fresh surfaces, and coarse grained. A shallow excavation exposed thinly interbedded sandstone and siltstone. Plane-parallel lamination (Bouma $\mathrm{Tb}$ ) is common in sandstones and one thin sandstone bed within the excavation included small groove casts on its basal surface. Parting lineation is common on sandstones in float.

\section{INTERPRETATION}

Parting lineation and plane-parallel lamination are consistent with deposition from dilute turbidity currents under upper flow-regime plane-bed conditions as Bouma Tb beds. A deep-water depositional setting is inferred by the stratigraphic context of this exposure below interpreted slope strata and above interpreted slope to basin-floor deposits. Assigning this exposure to a deep-water architectural element (in the sense of Mutti and Normark, 1987) 


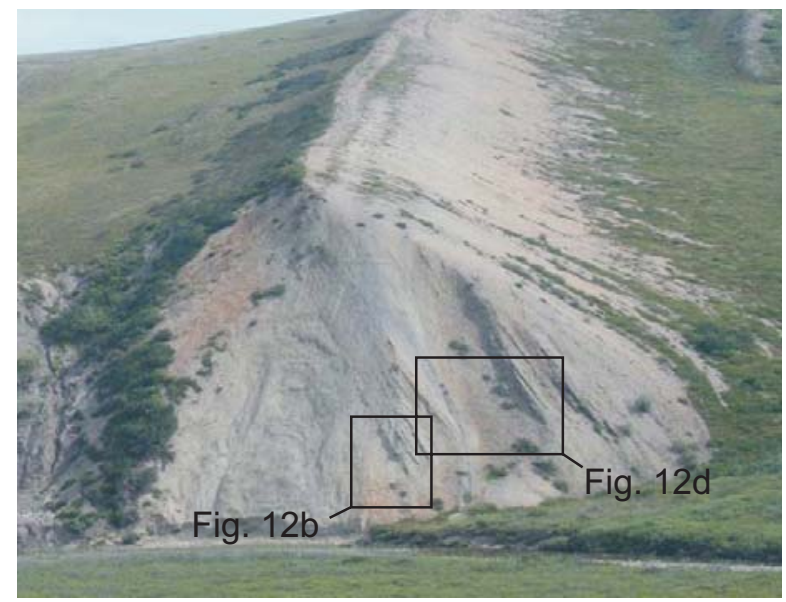

A.

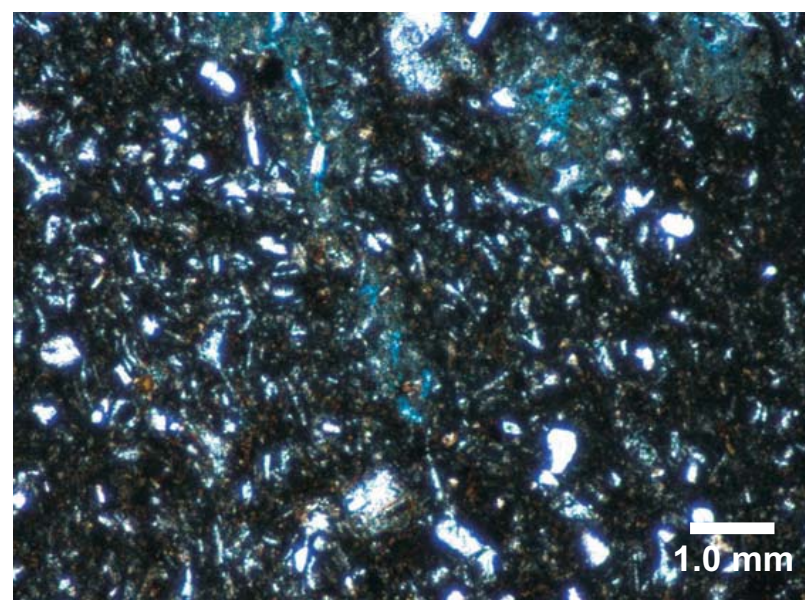

C.

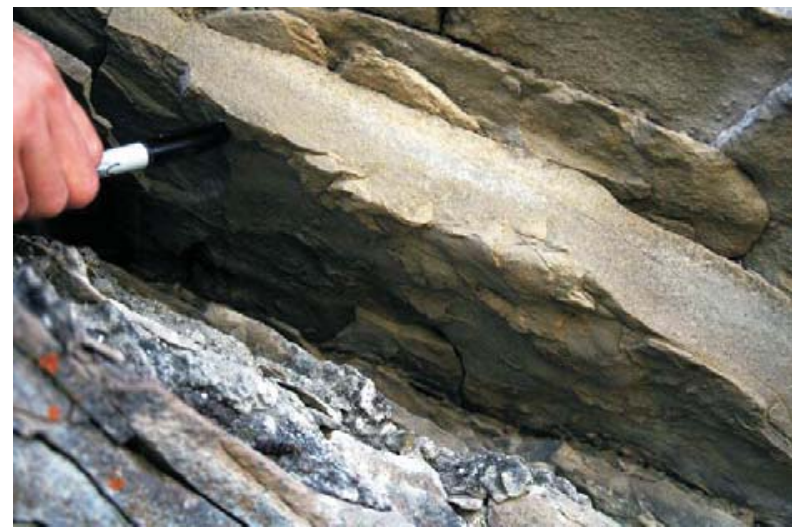

E.

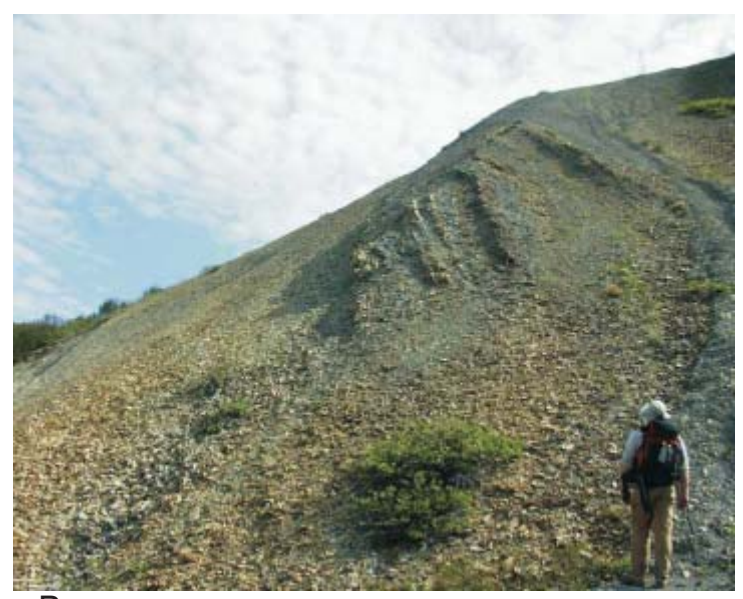

B.

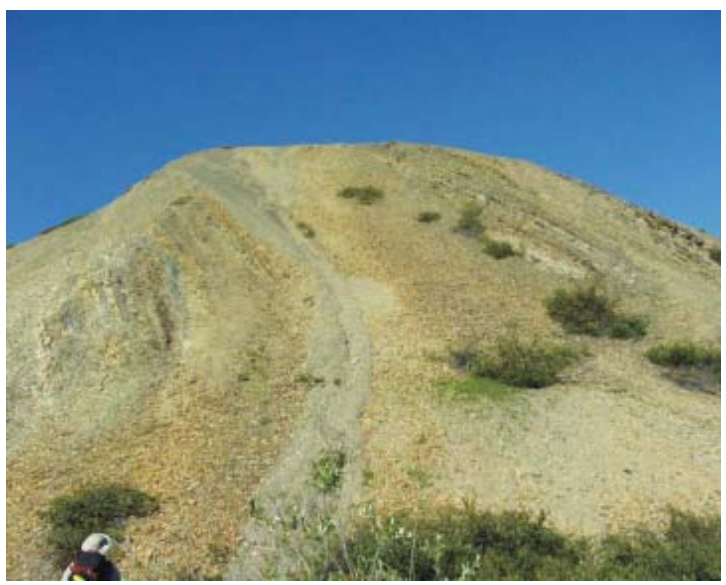

D.

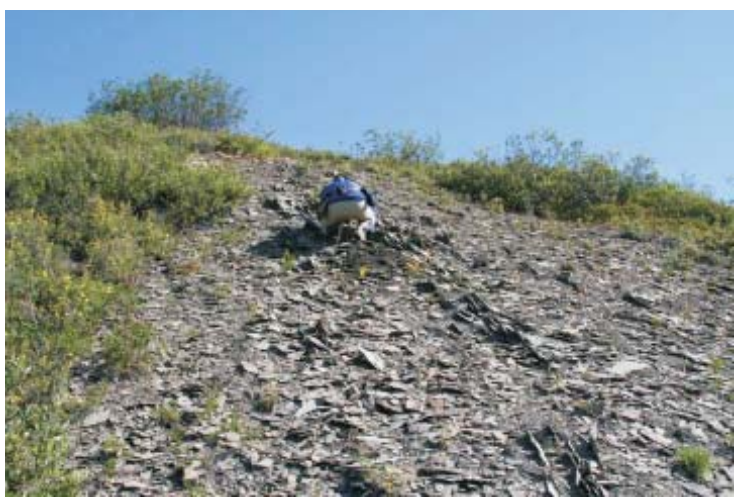

F.

Figure 12. Photographs of sedimentary features in probable Santonian strata of the Canning Formation at stations 07DL056, 07DL058, and 07DL059. (A) Aerial view toward the northeast showing rubblecrop and exposures of tuffaceous(?) sandstones and interbedded silty clayshale and tephra at station 07DL056. Abundant volcanigenic material in these rocks imparts the light buff to orange-brown color typical of sandstones at this station. (B) Outcrop of thin-bedded sandstone and interbedded silty clayshale and tephra in the lower $10 \mathrm{~m}$ of the measured section at 07DL056. (C) Photomicrograph of silicified tuff at approximately $9 \mathrm{~m}$ in the measured section at 07DL056. (D) Outcrop of interbedded thin-bedded sandstone and silty clayshale in the upper third of the measured section at station 07DL056. (E) Load casts on the underside of a sandstone bed in rubblecrop at station 07DL058. (F) Thin flaggy parting sandstone in rubblecrop at station 07DL059. 
is not possible given the limited exposure. Coarse-grained sandstone represents a significant grain size increase over the very-fine- to fine-grained sandstones down-section. Whatever depositional element these rocks are part of, significantly coarser sediment was being supplied to the depositional system, possibly from nearby shelf-edge (late highstand or lowstand) deltas. Taken in the context of station 061, coarse-grained sandstones at this location are interpreted as late highstand deposits.

\section{Station 07DL060 \\ DESCRIPTION}

Station 060 (figs. 2 and 4) consists of a few meters of buff weathering medium-grained sandstone that barely protrudes from the tundra cover. Bedding dips 55 degrees toward the south.

\section{INTERPRETATION}

Interpretation is not possible given the limited extent of exposure. Whatever depositional element these rocks are part of, as at the previous station, significantly coarser sediment was being supplied to the depositional system, possibly from nearby shelf-edge (late highstand?) deltas.

\section{Station 07DL061}

\section{DESCRIPTION}

Station 061 is a prominent exposure near river level consisting of $60 \mathrm{~m}$ of interbedded siltstone, sandstone, and minor conglomerate dipping 43 degrees toward the south (figs. 2, 4, 13, and 14a).The lower half is continuously exposed, whereas the upper half is mostly covered interval with localized exposures of resistant sandstone and conglomerate.

The age of this succession is constrained by microfossils. A probable Turonian to Santonian age range is suggested by foraminifera and a late Campanian age is indicated by palynomorphs. The age of the section is probably Campanian.

The lower $25 \mathrm{~m}$ consists of interbedded sandstone and siltstone organized in a series of prominent coarsening- and thickening-upward (CU-TU) cycles approximately 1.5-4 m thick (figs. 13 and 14b). Sandstones are buff weathering, medium to light gray on fresh surfaces, and very fine to fine grained. Siltstone is light gray weathering, medium to dark gray on fresh surfaces, and parts in small platy pieces. Bed thickness ranges from $>3 \mathrm{~cm}$ in siltstone and sandstone near the base of CU-TU cycles to $25 \mathrm{~cm}$ in sandstone near the top. Thin silty partings separate sandstone beds at the top of some CU-TU cycles, whereas amalgamated sandstones cap others. Sole markings are common and include bulbous-shaped load casts and flute casts (figs. 14c and 14d). Flute casts commonly appear load-enhanced. Mudstone rip-up clasts are common on some bed surfaces. Bouma Tabc, Tb, and Tbc beds are common. Where present, the Ta division of beds is subtle (fig. 14e). Small- to moderate-scale two- and three-dimensional (linguoid) current ripple bedforms cover some bed surfaces (wavelength $10-20 \mathrm{~cm}$ and amplitude 1-3 cm) (figs. 14f and 14g). Terrestrial plant material is common in sandstones and occurs as streaks of finely divided plant material concentrated in selected laminae, as finely divided carbonaceous remains scattered on bed surfaces, concentrated as "coffee grounds" in the lee of current ripple bedforms (fig. 14h), and as large impressions of woody and leafy material densely covering some bed surfaces (fig. 14i). Trace fossils appear absent throughout the succession. At least one sandstone bed is cut by a small-scale, northwest-vergent thrust fault (fig. 14j).

The upper $35 \mathrm{~m}$ is a poorly exposed succession of siltstone with resistant thinly to thickly interbedded veryfine- to coarse-grained sandstone and pebble conglomerate. Siltstone successions range from 3 to $8.5 \mathrm{~m}$ thick and, where exposed, include chippy light- to medium-gray weathering material that is dark gray on fresh surfaces. Sandstone is orange-brown, light brown, and buff-weathering and light brown or gray on fresh surfaces. White and aquamarine colored grains of chert are distinctive framework components when viewed on fresh surfaces. Load and flute casts are common on the base of sandstone beds and provide robust way-up indicators (fig. 14k). Sandstones commonly appear massive and size grading has not been recognized. Concave-up surfaces suggestive of trough cross-bedding and current ripple cross-lamination are prominent locally. Parting lineations and finely divided organic debris are present on many bed surfaces.

Two thin but prominent conglomerate beds, each up to $40 \mathrm{~cm}$ thick, are separated by a medium- to coarsegrained sandstone bed $50 \mathrm{~cm}$ thick (fig. 14l). Conglomerates are poorly sorted, clast-supported, polymictic, and include tightly packed matrix material of fine- to coarse-grained sandstone. Clasts include extrabasinal and intrabasinal varieties. Extrabasinal clasts are up to $7 \mathrm{~cm}$ in apparent long dimension, are dominantly equant shaped, and include black, gray, and white chert, cherty(?) argillite, and white vein quartz. Intrabasinal clasts up to $14 \mathrm{~cm}$ in apparent long dimension are dominantly disc-shaped and overwhelmingly consist of orange weathering sideritized(?) mudstone. Disc-shaped clasts commonly display bed-parallel to weak imbricate fabrics (fig. $14 \mathrm{~m}$ ). The 


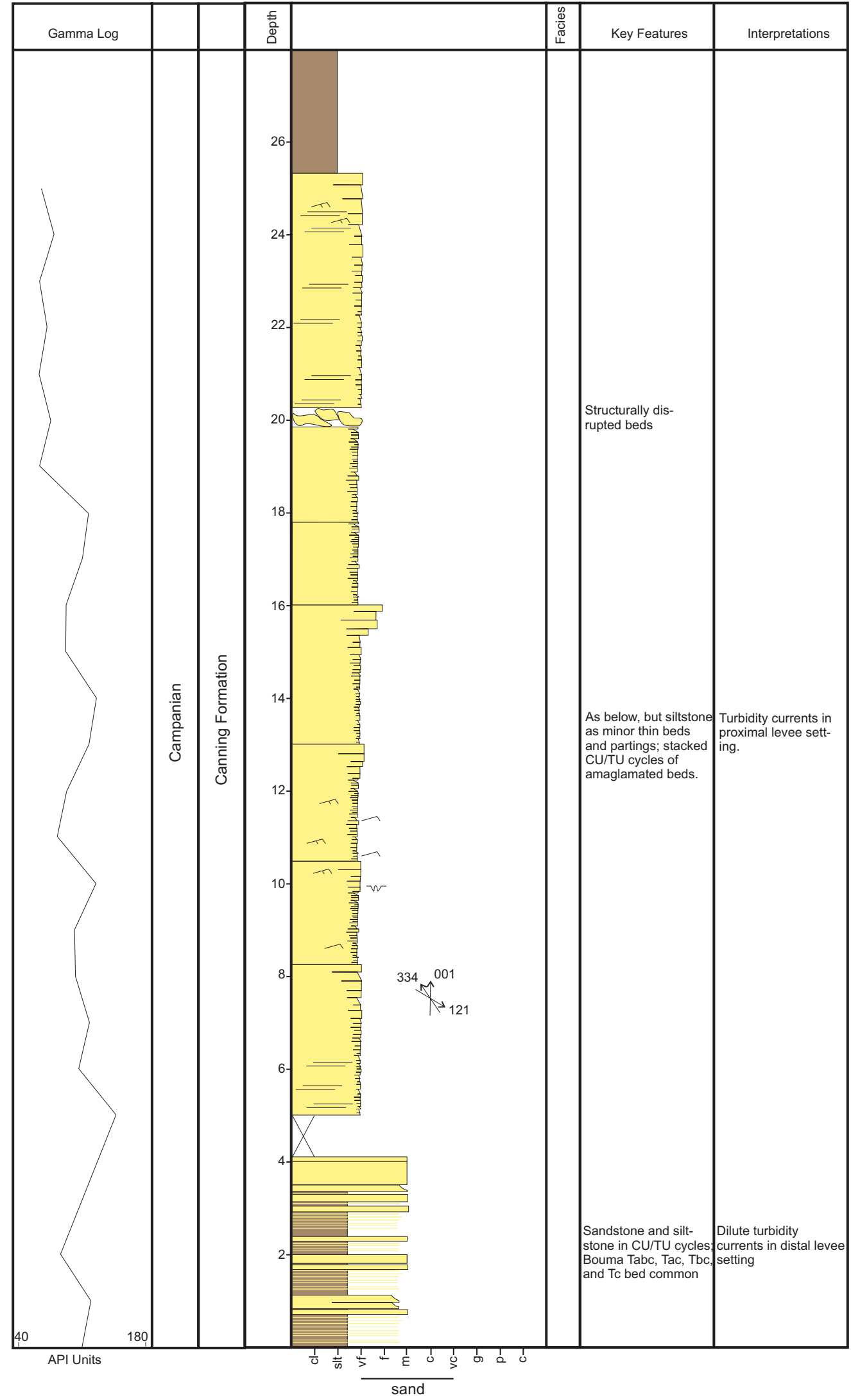

Figure 13. Measured stratigraphic section through Campanian age base-of-slope to proximal basin-floor turbidites and associated deposits of the Canning Formation at station 07DL061. See figure 5 (p. 92) for symbol key. 


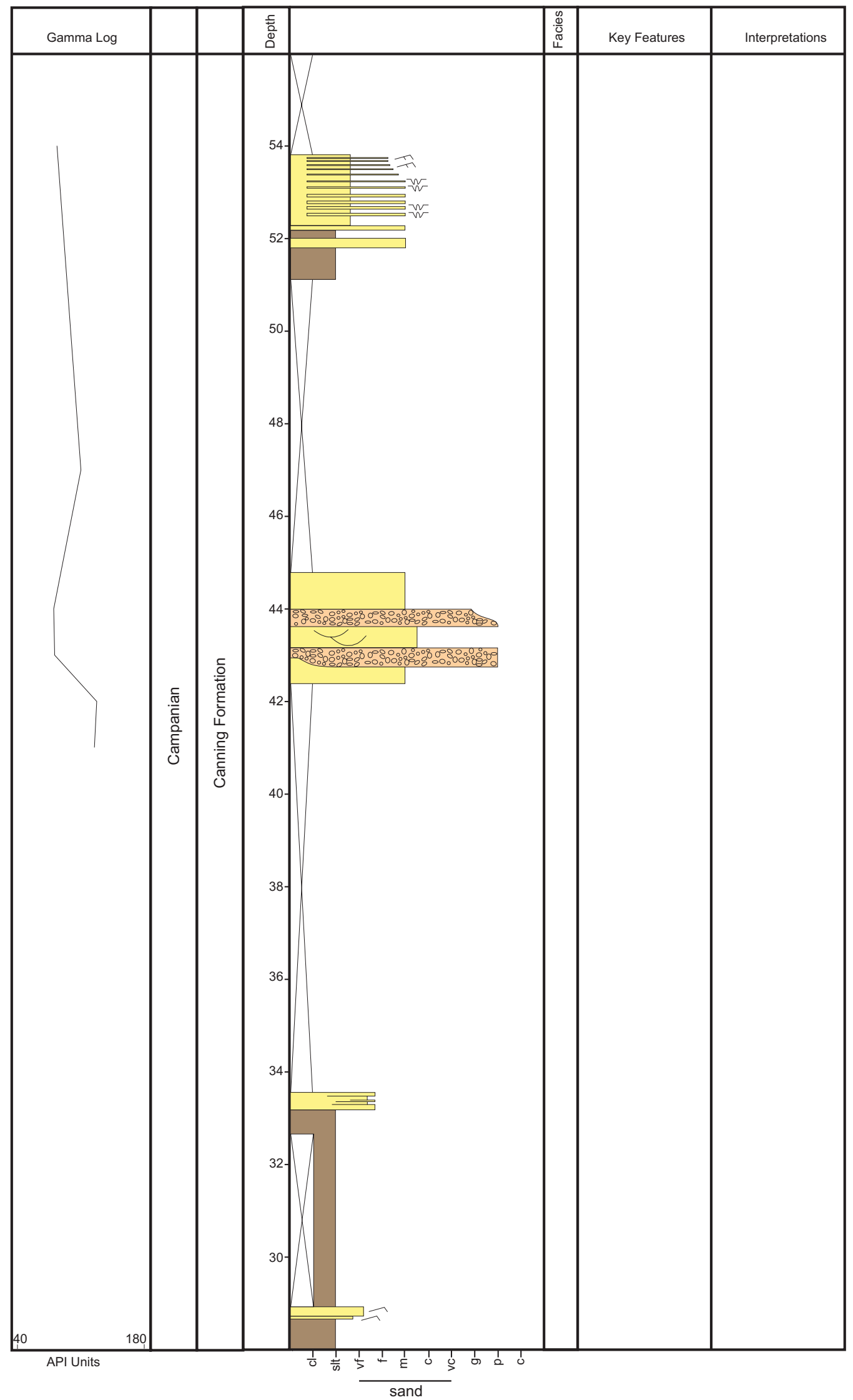

Figure 13. (continued) Measured stratigraphic section through Campanian age base-of-slope to proximal basin-floor turbidites and associated deposits of the Canning Formation at station 07DL061. See figure 5 (p. 92) for symbol key. 


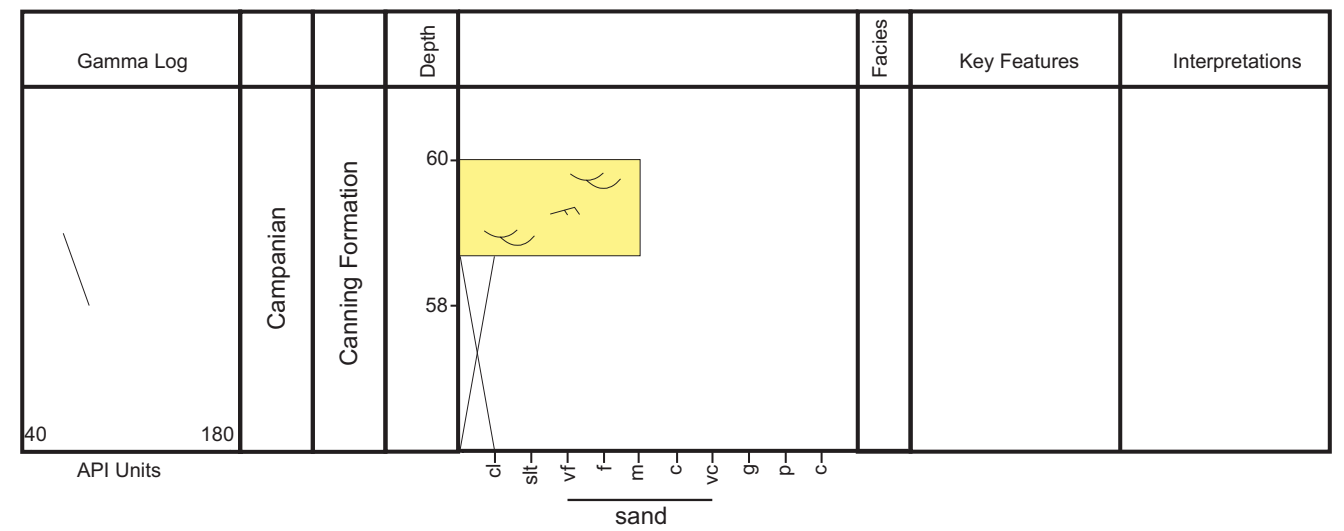

Figure 13. (continued) Measured stratigraphic section through Campanian age base-of-slope to proximal basin-floor turbidites and associated deposits of the Canning Formation at station 07DL061. See figure 5 (p. 92) for symbol key.

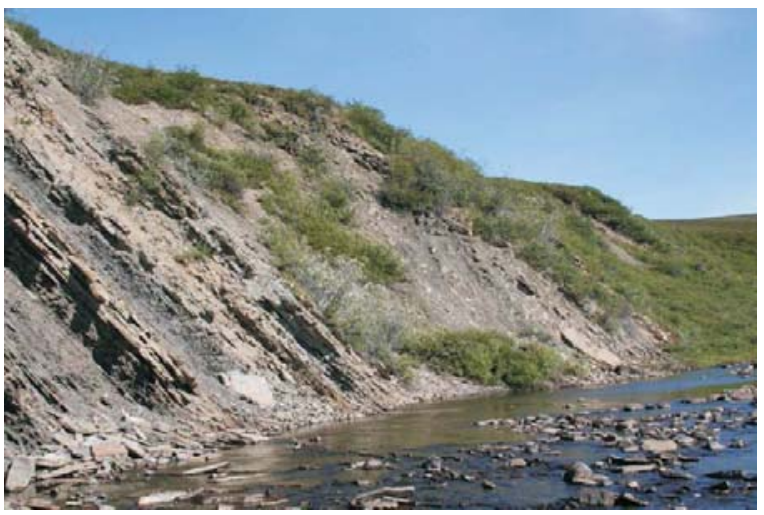

A.

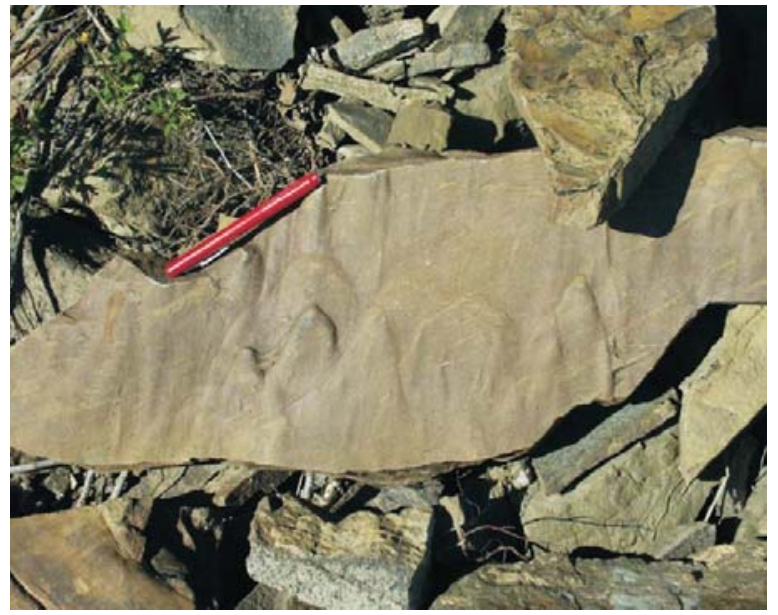

C.

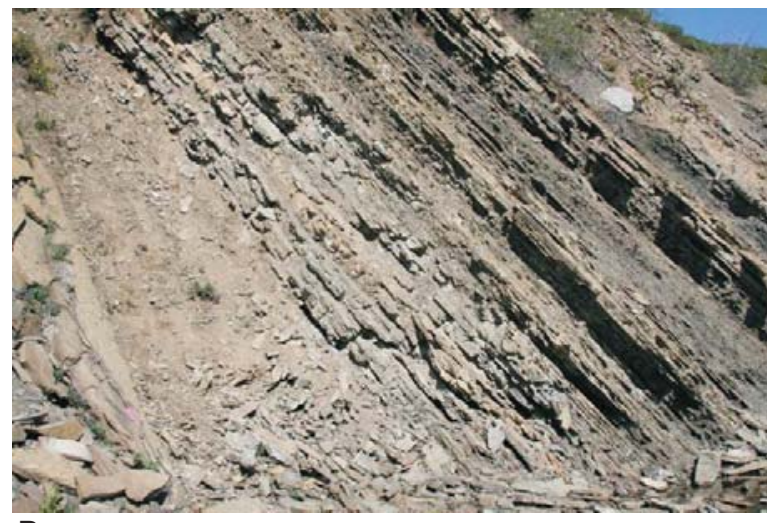

B.

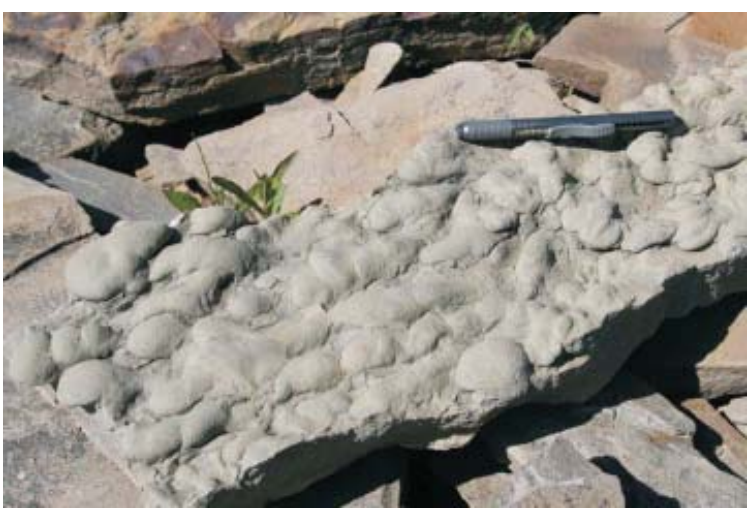

D.

Figure 14 (A-D). Photographs of sedimentary features in Campanian strata of the Canning Formation at station 07DL061. (A) View toward the east-southeast showing interbedded sandstone and mudstone between 16 and $25 \mathrm{~m}$ of the measured section (left half of photograph); the partially vegetated slope in the middle distance corresponds to 25-42 $\mathrm{m}$ in the measured section; the resistant beds in right third of the image are sandstone and conglomerates between 42.5 and $60 \mathrm{~m}$.

(B) Interbedded sandstone and siltstone between 2 and $10 \mathrm{~m}$ showing meter-scale coarsening-and thickening-upward cycles interpreted as levee deposits marginal to a submarine channel. (C) Flute casts on a piece of sandstone float near $8 \mathrm{~m}$. (D) Bulbous load casts in float in the lower $4 \mathrm{~m}$ of the measured section. 


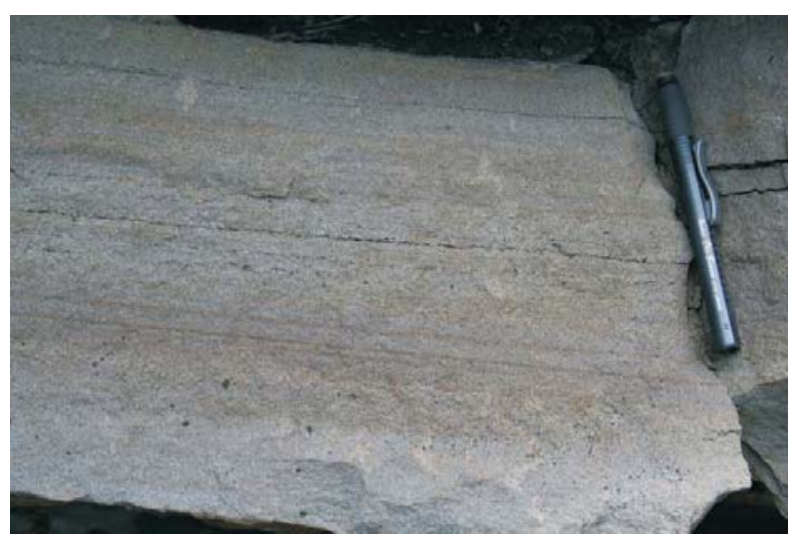

E.

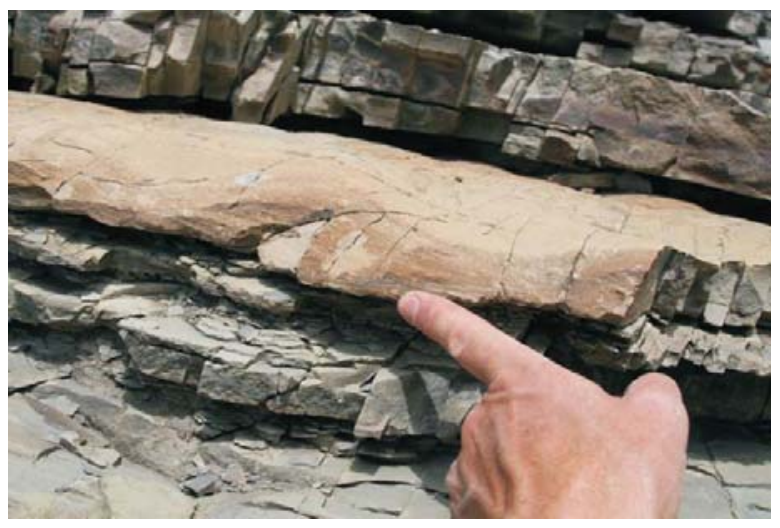

G.
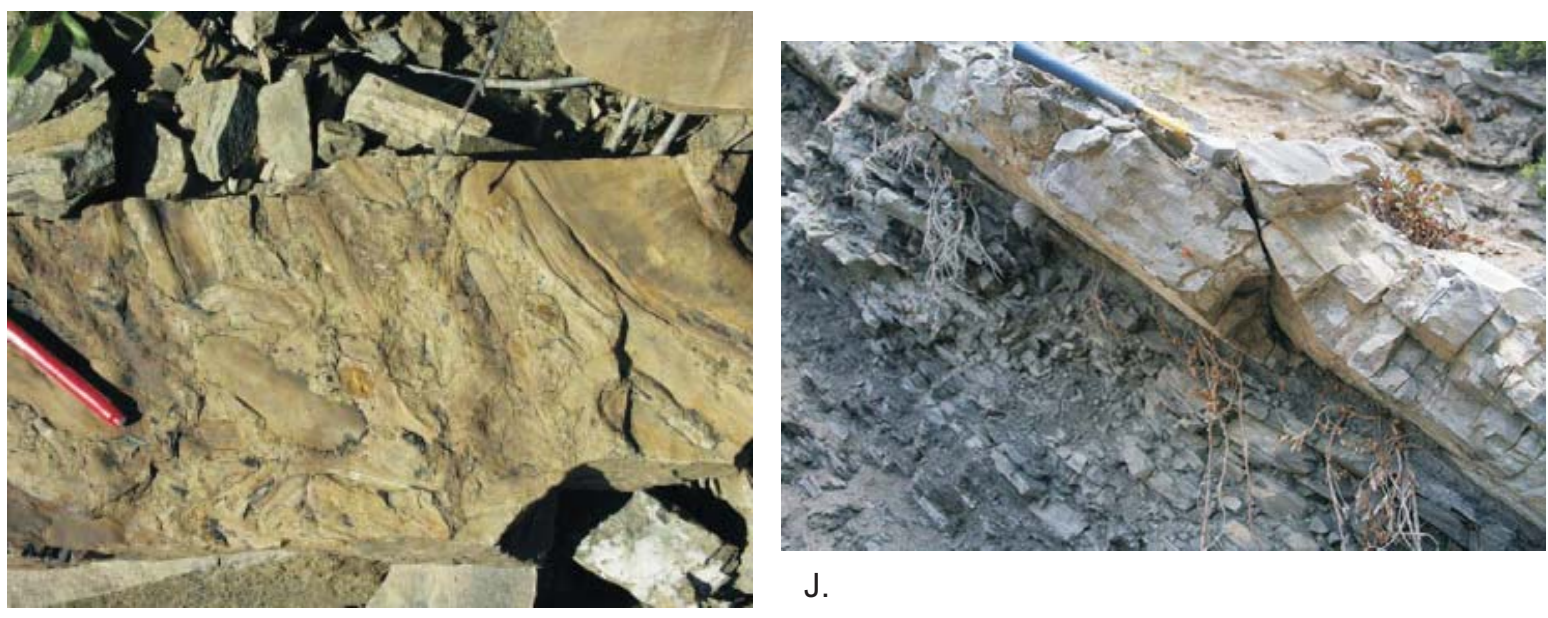

J.

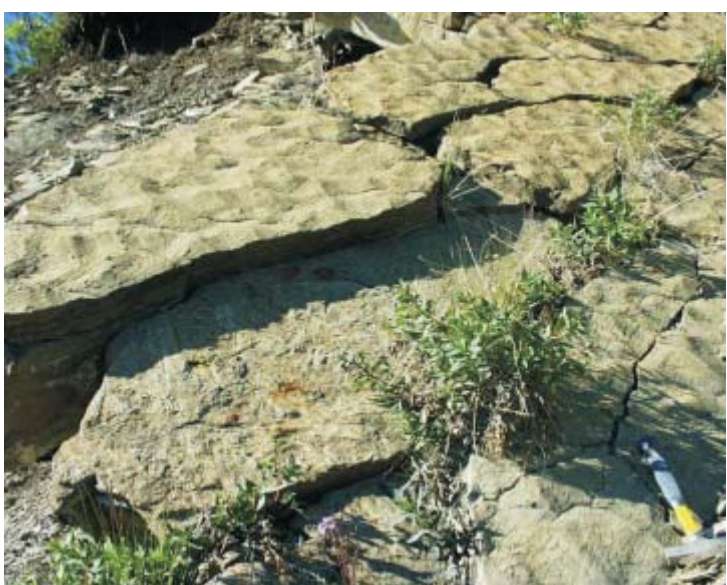

F.

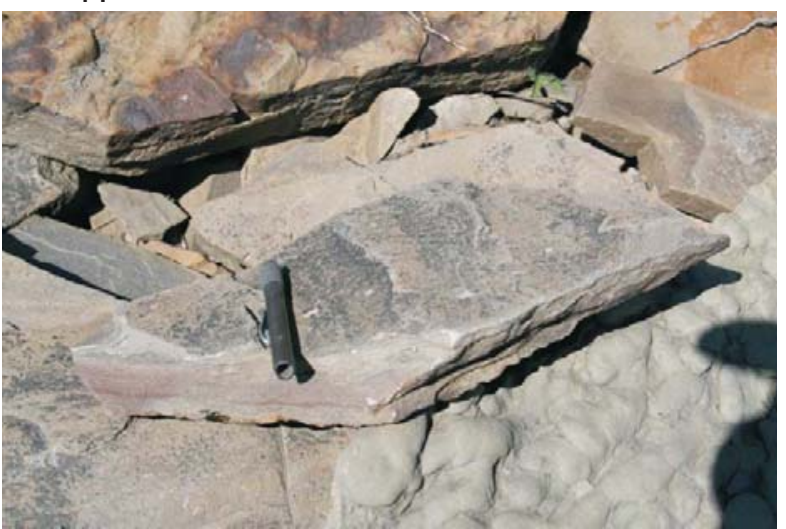

$\mathrm{H}$.

I.

Figure 14 (E-J). Photographs of sedimentary features in Campanian strata of the Canning Formation at station $07 D L 061$.

(E) Bouma Tab bed at $6 \mathrm{~m}$. (F-H) Small-scale three-dimensional to slightly sinuous-crested two-dimensional ripple bedforms on sandstone bed surfaces between 8 and $12 \mathrm{~m}$. (I) Large woody and leafy plant impressions on bed surface between 3 and $4 \mathrm{~m}$. (J) Small-scale thrust fault at $20 \mathrm{~m}$. 


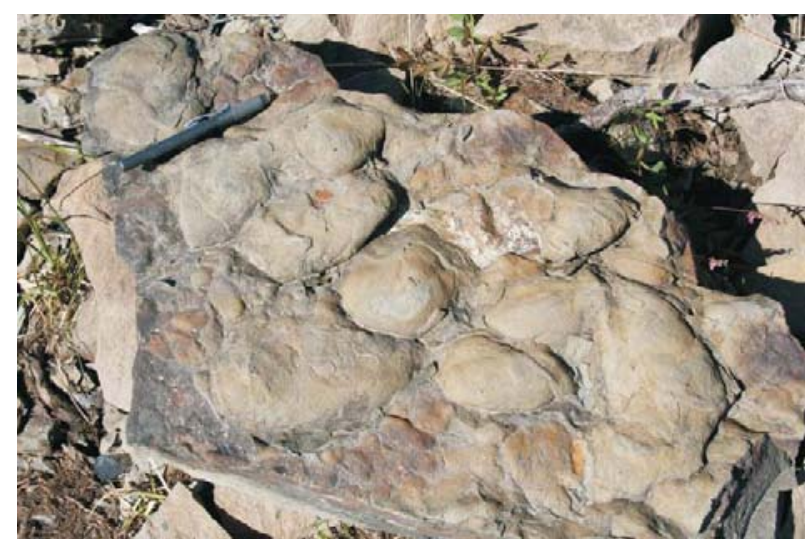

$\mathrm{K}$.

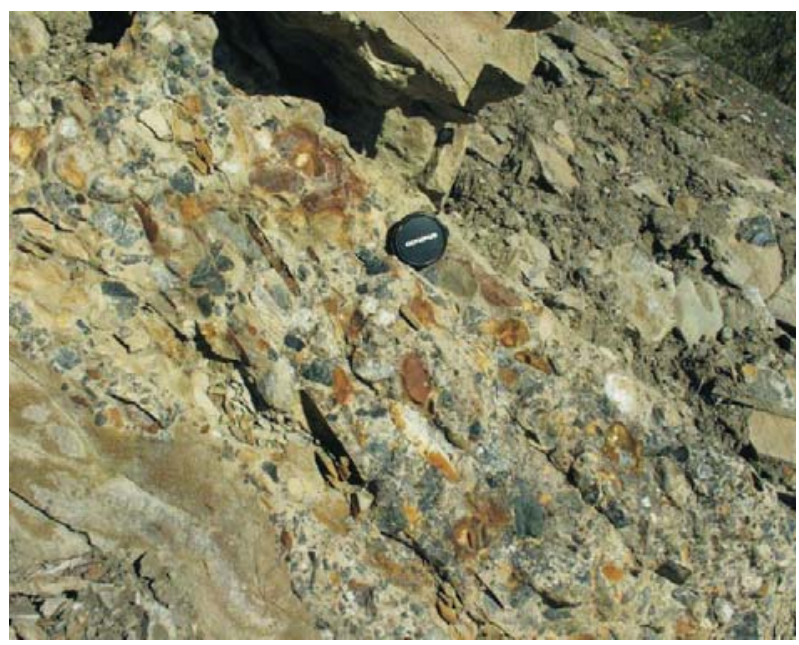

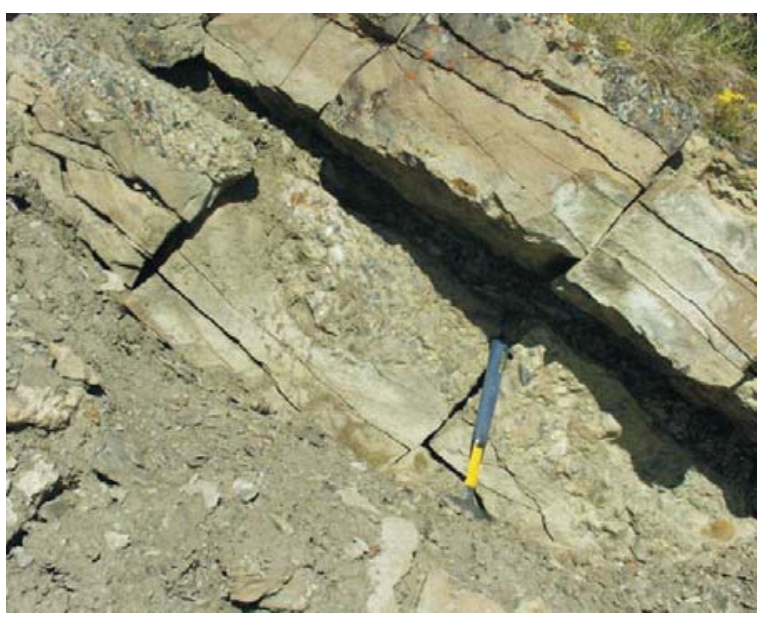

L.

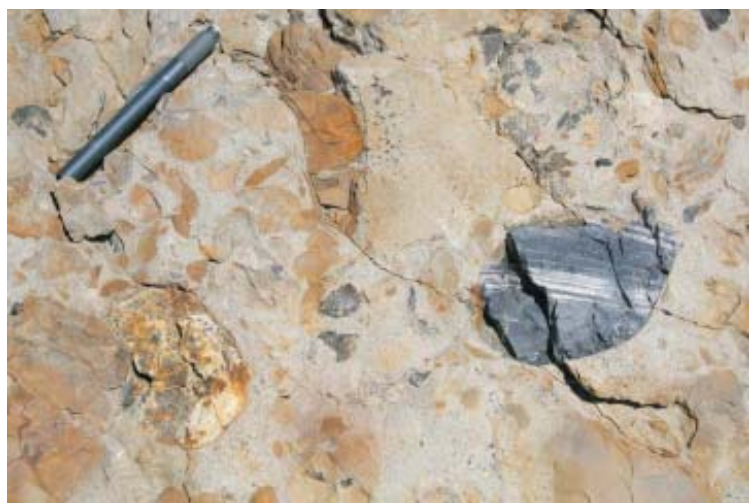

N.

M.

Figure 14 (K-N). Photographs of sedimentary features in Campanian strata of the Canning Formation at station 07DL061. (K) Load casts on underside of sandstone bed in float in the upper $35 \mathrm{~m}$ of the measured section. Load casts are common in this part of the succession. (L) Two poorly-sorted, clast-supported pebble conglomerate beds. The hammer handle rests on the lower bed at $43 \mathrm{~m}$. The base of the upper bed is visible in the upper right corner of the photograph. (M) Clast fabric in bed at $43 \mathrm{~m}$. Note preferred alignment of discoid clasts. Disc-shaped clasts are most commonly sideritized mudstone rip-ups. (N) Clasts of sideritized mudstone (orange), cherty(?) argillite (black clast with white laminae), and rare silicified tuff clasts that are outwardly similar to tuffs at station 07DL054 (84-85 m).

clast population includes rare tuff or brown shale clasts (fig. 14n) similar to lithologies encountered at stations 054 and 056. The contact between conglomerates and underlying sandstones is sharp and erosive, with up to $20 \mathrm{~cm}$ of erosional relief. Both conglomerate beds can be traced up the slope toward the east approximately $15 \mathrm{~m}$ until the beds become concealed by tundra cover.

\section{INTERPRETATION}

Thinly interbedded sandstone and siltstone, organized in prominent thickening- and coarsening-upward cycles, resemble levee deposits described by Mutti and Normark (1987) and Weimer and Slatt (2007) and are similarly interpreted. The abrupt change from interbedded sandstone and siltstone in the lower part of the exposure to poorly exposed siltstone with few interbeds and bedsets of sandstone and conglomerate suggest a fundamental change in the depositional pattern, which can be interpreted in several different ways. This part of the succession could record deposition in a channelized or gullied lower slope setting, or deposition in a channelized lobe setting. The low sandstone content argues against the latter setting. The abrupt introduction of conglomeratic material suggests 
deposition during a lowstand of relative sea level.

Available biostratigraphic data suggest correlation with the Schrader Bluff Formation west of the Trans-Alaska pipeline corridor.

\section{Station 07DL062 \\ DESCRIPTION}

Station 062 is a small, inconspicuous exposure a short distance southeast of station 061 (figs. 2 and 4). Approximately $1 \mathrm{~m}$ of rubblecrop is present, consisting of buff weathering, very-fine- to fine-grained sandstone. Bed thickness is difficult to assess, but slabs in float include plane-parallel lamination and current ripple cross-lamination (Bouma $\mathrm{Tb}$ and $\mathrm{Tbc}$ ). Some bed surfaces in float include small three-dimensional ripple bedforms (Bouma Tc) and mudstone rip-up clast impressions. Many clast impressions are lined with orange weathering material that resembles sideritized mudstone.

\section{INTERPRETATION}

The suite of features recognized in sandstones at this location suggest deposition from waning flows capable of transporting platy rip-up clasts in addition to fine-grained sand. Plane-parallel lamination and current ripple cross-lamination suggest deposition from waning flows that included an initial upper flow-regime plane bed phase (Bouma Tb). Additional interpretation is not possible given extremely limited exposure.

\section{Station 07DL063 \\ DESCRIPTION}

Station 063 corresponds to a prominent east-northeast-trending tributary valley on the east side of the drainage (figs. 2 and 4). Approximately $35 \mathrm{~m}$ of thinly bedded sandstone and siltstone are exposed on the south wall of the valley and dip 46 degrees toward the southeast (fig. 15). Sandstone is light to medium gray weathering, medium to dark gray on fresh surfaces, very fine grained, and in beds ranging from a few millimeters to $20 \mathrm{~cm}$ thick. Most beds are less than $4 \mathrm{~cm}$ thick (fig. 16a). Siltstone is medium gray to brown weathering and present as thin papery partings separating sandstone beds and as thicker (up to $1 \mathrm{~cm}$ ) caps to sandstones. One or two beds of orange weathering calcareous siltstone up to $20 \mathrm{~cm}$ thick are present in the succession (fig. 16b). Beds are continuous and of uniform thickness laterally, giving the outcrop a monotonous appearance (fig. 16a). Most sandstone beds include a basal graded layer overlain by plane-parallel lamination which, in turn, either grades upward to siltstone or is sharply overlain by siltstone (figs. 16c and 16d). These lithologies and structures combine to form Bouma Tabd, Tab, Tbd, and Tb beds. No sole markings or trace fossils have been found in rocks at this location.

\section{INTERPRETATION}

Bed thickness and character combined with common partial Bouma sequences suggest deposition from dilute turbidity currents in an unconfined setting. The undisturbed condition of bedding suggests deposition below the oxygen minimum layer, possibly in a slope setting. The absence of clay and the overall silty-sandy character of this exposure are consistent with deposition in a shelf-edge proximal slope setting. This interpretation is consistent with the overall stratigraphic context of this exposure, with interpreted lower slope to basin-floor deposits down-section to the northwest and bioturbated upper slope to outer-shelf strata up-section to the southeast (described below).

\section{Station 07DL064 \\ DESCRIPTION}

Approximately $20 \mathrm{~m}$ of continuously exposed, thinly bedded, very-fine-grained sandstone and coarse siltstone are exposed along the east side of the main drainage, immediately downstream of a prominent westward bend in the river (figs. 2, 4, and 17). Beds dip 66 degrees toward the south near the north end of the exposure (fig. 18a) and dips shoal to 20 degrees or less toward the middle and south end of the exposure (fig. 18b). Some structural disruption is evident at the north end of the exposure in the form of either a tight fold (unlikely) or a bed-parallel thrust fault of minor displacement (likely; fig. 18c).

The ages of these rocks are constrained by stratigraphic position between Campanian age beds (late Campanian palynomorphs down-section at station 07DL061 and Campanian megafossils up-section at 01DL22 ).

Sandstones and siltstones are light gray weathering, medium-gray on fresh surfaces, in beds 1 to $15 \mathrm{~cm}$ thick. In the lower third of the exposure, thicker beds are grouped in bedsets within which beds are amalgamated or separated only by thin siltstone partings. Less thickness variation in bedding in the upper two-thirds of the ex- 
07DL63

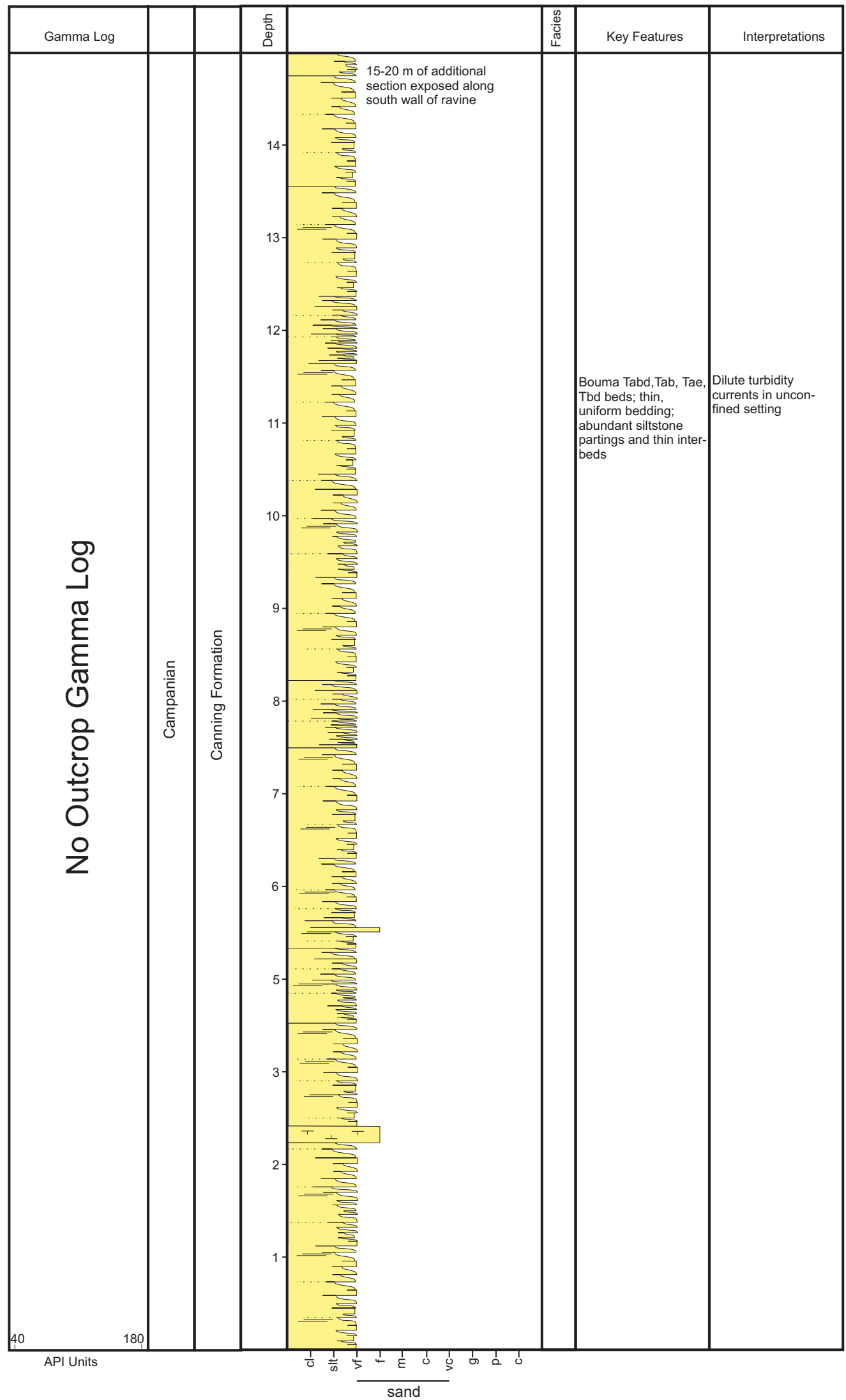

Figure 15. Measured stratigraphic section through Campanian age thin-bedded turbidites and associated hemipelagic siltstones of the Canning Formation at station 07DL063. See figure 5 (p. 92) for symbol key. 


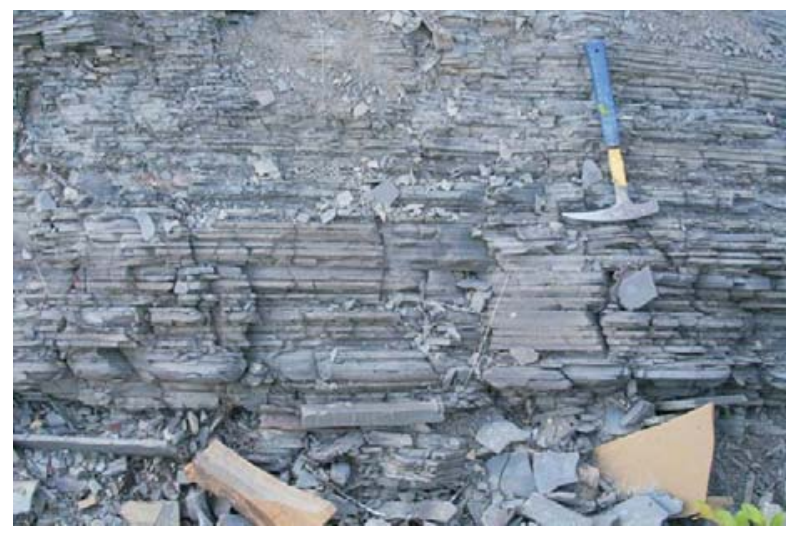

A.

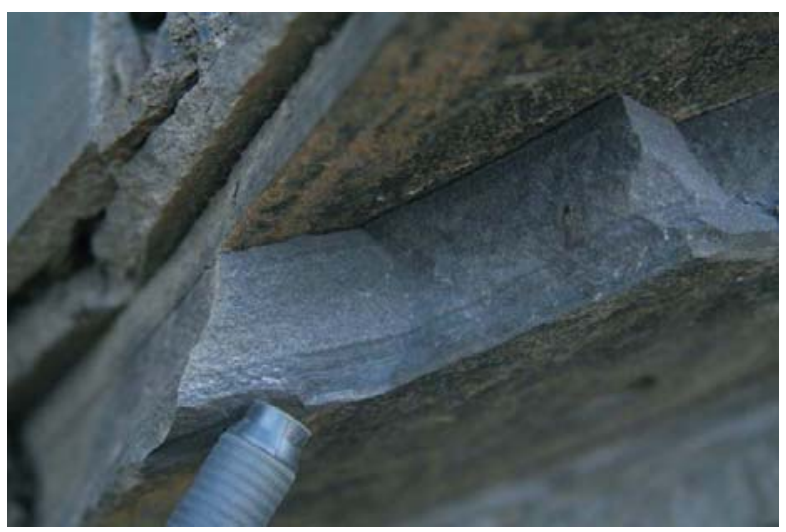

C.

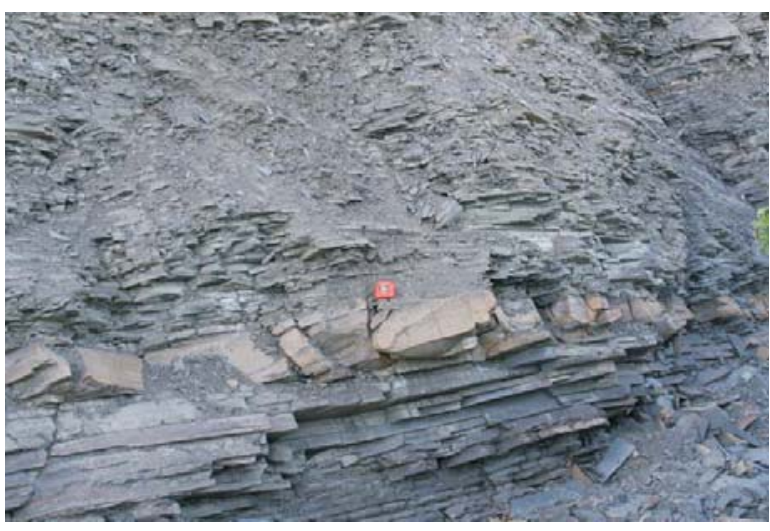

B.

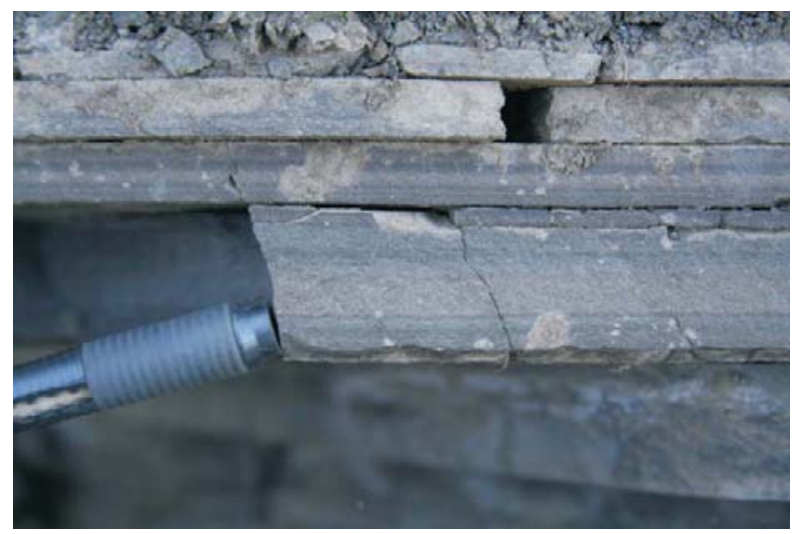

D.

Figure 16. Photographs of sedimentary features in Campanian turbidites of the Canning Formation at station $07 D L 063$. (A) Thin-bedded, very-fine-grained sandstone in the lower $4 \mathrm{~m}$ of the measured section. (B) Calcareous siltstone (orangebrown bed below tape measure) interbedded with very-fine-grained sandstone and siltstone. (C-D) Subtle Bouma Tabe and Tae sequences are visible.

posure gives the succession a more monotonous appearance. Beds are laterally continuous throughout the extent of their length in outcrop. Bioturbated beds (II3-4) occur interbedded with unbioturbated or sparsely bioturbated beds throughout the exposure, but the overall degree of bioturbation increases up-section toward the southeast (II3-4 throughout; fig. 18d). Scattered black chert pebbles floating in a sandstone matrix (fig. 18f) and remnants of ripple cross-lamination (fig. 18e) are common near the south end of the exposure. Small plant fragments litter the surface of many beds throughout the succession.

\section{INTERPRETATION}

Features described above suggest deposition in shallower water than strata exposed down-section (northwest), possibly in an upper slope to outer-shelf setting. The change in bioturbation from the base of the section toward the top can be explained by an increasing recurrence interval for episodic flow events up-section (associated with transgression?), thereby allowing more time between events for burrowing organisms to disrupt primary sedimentary structures. Available biostratigraphic data suggest correlation with shallower water strata of the Schrader Bluff Formation west of the Trans-Alaska pipeline corridor.

\section{Station 01DL021 \\ DESCRIPTION}

Station 021 is located on the north side of a prominent east-west-trending stretch of the river and includes approximately $6 \mathrm{~m}$ of sandstone (fig. 2 and 19). Sandstone is light greenish gray weathering, light gray on fresh surfaces, and fine grained. Beds range from 2 to $10 \mathrm{~cm}$ thick and are wavy, non-parallel, and laterally discontinuous in outcrop (fig. 20a). Discontinuous silty partings separate some beds and plant fragments are common on many 


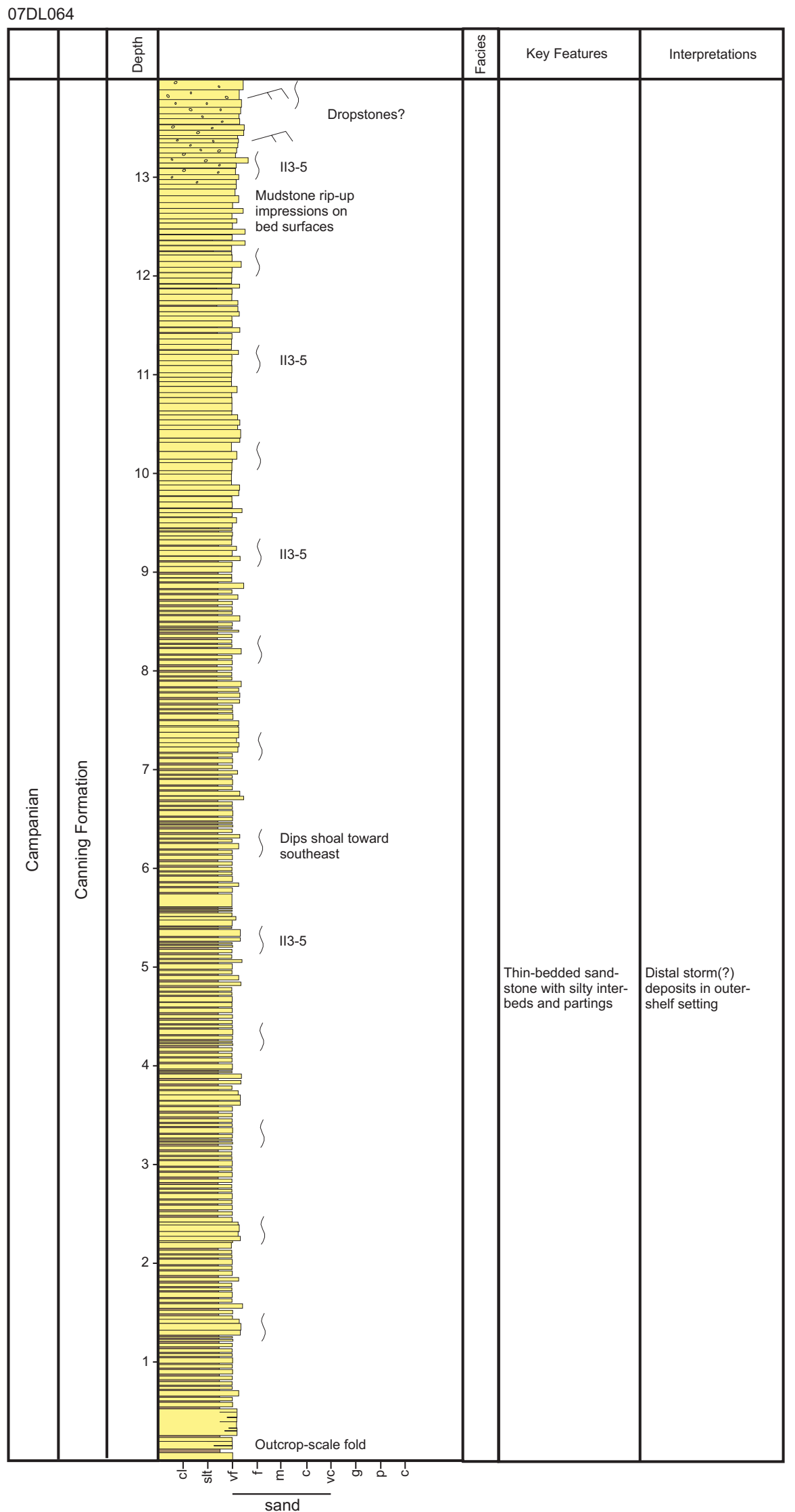

Figure 17. Measured stratigraphic section through probable Campanian age thin-bedded upper-slope to outer-shelf deposits transitional between the Canning and Schrader Bluff Formations. See figure 5 (p. 92) for symbol key. 


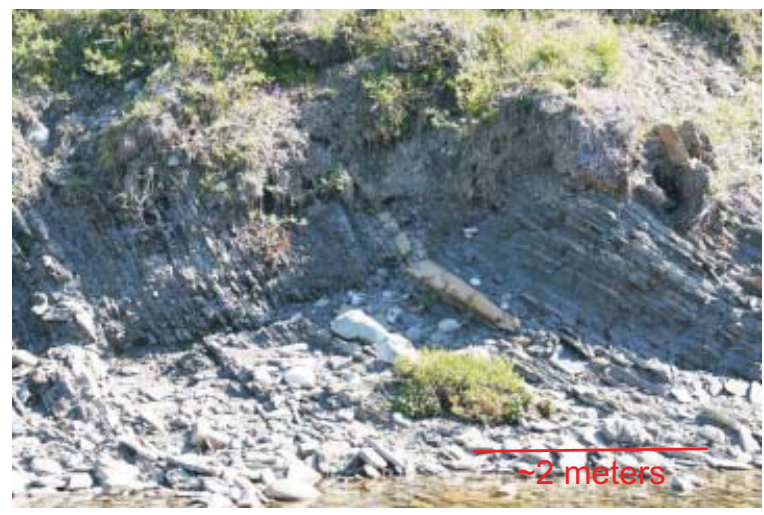

A.

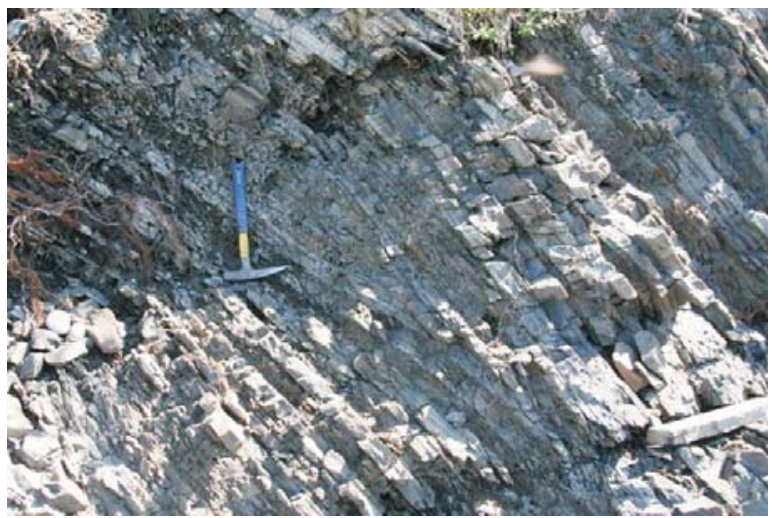

C.

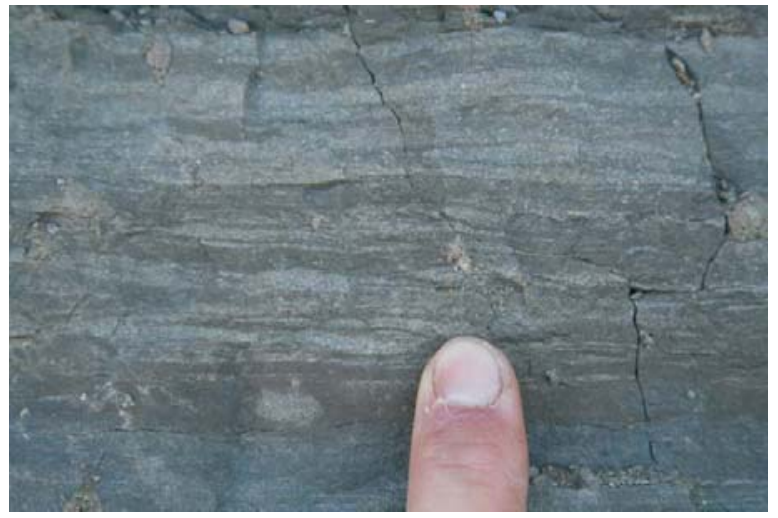

E.

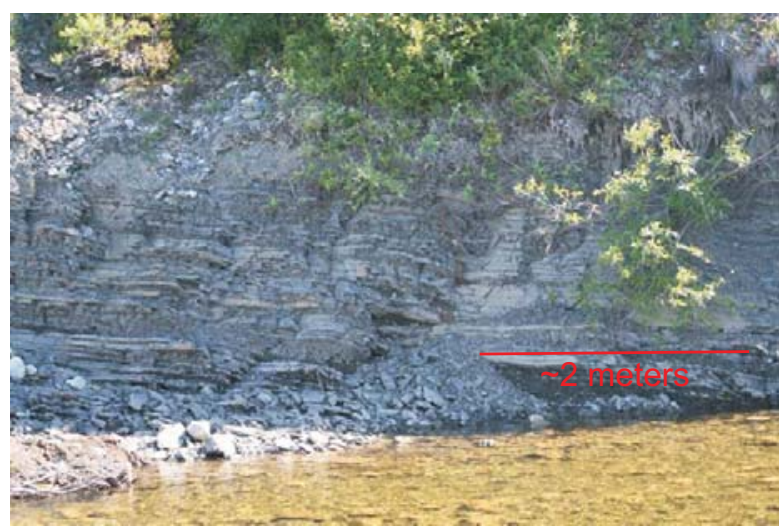

B.

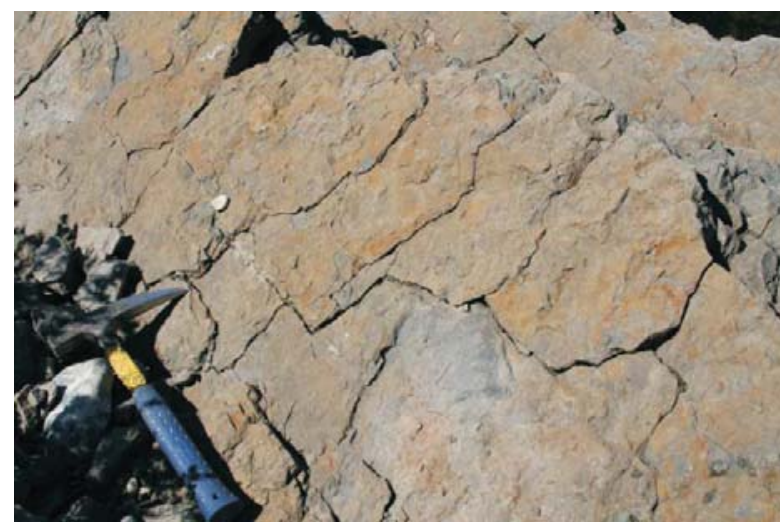

D.

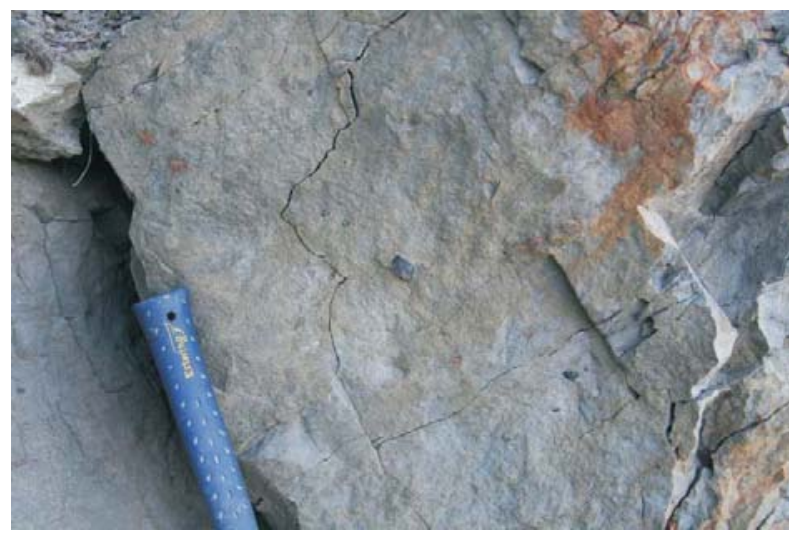

F.

Figure 18. Photographs of sedimentary features in probable Campanian strata transitional between the Canning and Schrader Bluff Formations at station 07DL063. (A) Thinly interbedded siltstone and very-fine-grained sandstone at the northwest end of the station (1-4 $\mathrm{m}$ in measured section shown in fig. 17) dipping up to 66 degrees toward the south. (B) Gently southdipping interbedded siltstone and very-fine-grained sandstone in the central part of the exposure (7-9 $\mathrm{m}$ in the measured section shown in fig. 17). (C) Bed-scale thrust(?) fault at $0.5 \mathrm{~m}$. (D) Bioturbated very-fine-grained sandstone at $13 \mathrm{~m}$. (E) Floating chert pebbles in sandstone at $13.5 \mathrm{~m}$. (F) Starved ripple cross-lamination in very-fine-grained sandstone at southeast end of exposure $(14 \mathrm{~m})$. 
01DL021

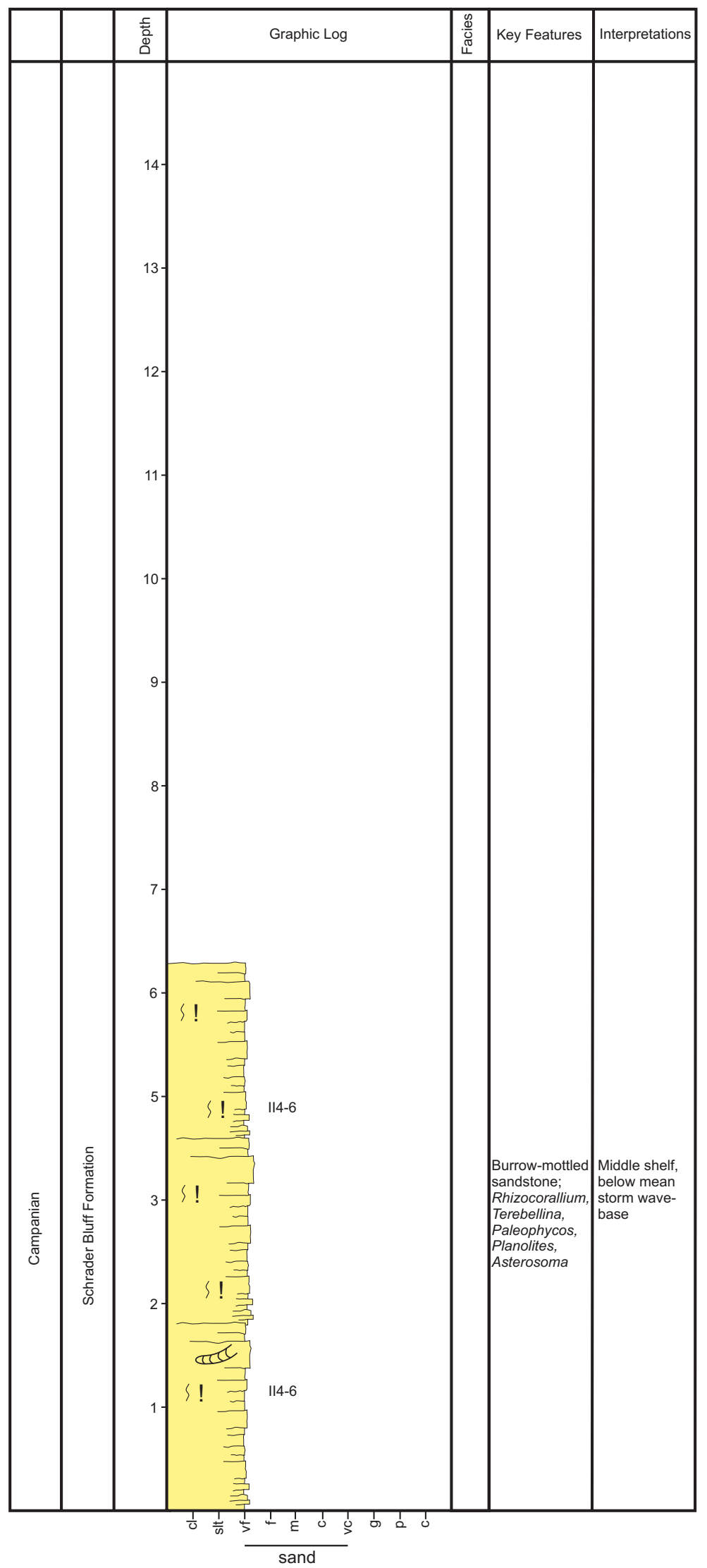

Figure 19. Measured stratigraphic section through Campanian age shelf deposits of the Schrader Bluff Formation at station 01DL021. See figure 5 (p. 92) for symbol key. 
bed surfaces (fig. 20b). Beds are burrow mottled (II4-6) and only isolated remnants of ripple cross-lamination are preserved. Trace fossils of the distal Cruziana ichnofacies are present, including Rhizocorallium, Planolites, Paleophycos, Schaubcylindrichnus, and Asterosoma (figs. 20c-e). At least one sandstone bed includes abundant small circular traces up to $1 \mathrm{~mm}$ in diameter filled with dark gray material that resembles Anconichnus (or Helminthopsis?). A single specimen of the bivalve Solecurtis? chapmani (wide ranging in time) was found in float.

\section{INTERPRETATION}

Moderate to highly bioturbated sandstone, the general lack of siltstone and shale, and a relatively diverse trace-fossil assemblage belonging to the Cruziana ichnofacies are suggestive of deposition in well-oxygenated water, possibly in a lower shoreface setting. An offshore shelf setting is possible and sand may have been transported offshore by fluvial flood-generated hyperpycnal flows (Mulder and Syvitski, 1995; Myrow and others, 2002) discharging from river mouths up depositional dip, or by storm-surge ebb flows (Swift and others, 1985). The succession could represent the distal part of a low-energy shoreface succession, which is consistent with a shelf setting below mean storm wave-base. Alternatively, the succession could record deposition in a shelf setting above storm wave-base, but in an area where the recurrence interval between major storms was long. Available biostratigraphic data suggest correlation with shallower water strata of the Schrader Bluff Formation west of the Trans-Alaska pipeline corridor.

\section{Station 022}

\section{DESCRIPTION}

Station 022 is located at the southeast end of the trend, on the southwest side of the drainage (figs. 2, and 22a). Approximately $142 \mathrm{~m}$ of discontinuously exposed siltstone and sandstone are present on a north-facing slope that corresponds to the north limb of a syncline (fig. 21). The exposure starts at river level and extends up-slope to the southwest (figs. 2 and 22b). Nondescript rubble extends from the top of the slope (fig. 2, top of measured section 01DL022) southward to the axis of the syncline. The succession described here does not include the rubble south of the measured section. Beds dip 10 degrees toward the south.

The age of this succession is constrained by early Maastrichtian to late Campanian palynomorphs collected from near the base (LePain, unpublished data) and by Campanian megafossils collected near the top (Mull, unpublished data). The succession is probably late Campanian.

The lower 13-16 m consists of thin-bedded, silty, very-fine-grained sandstone to coarse, sandy siltstone (fig. 22b). Silty sandstone is light gray weathering and medium gray on fresh surfaces. Beds are wavy and discontinuous, and range from $>1$ to $15 \mathrm{~cm}$ thick. Ferruginous ovoid-shaped concretions up to $2 \mathrm{~cm}$ in maximum diameter are common in float. Rocks have a bioturbated appearance (II3-4?) and curvilinear trace fossils are common on bed surfaces, and some pieces of float include Terebellina? (or Schaubcylindrichnus).

The lower 13-16 m extends up to a prominent break in slope, above which the slope is shallower and underlain by dark gray weathering siltstone that extends up-section to at least $50 \mathrm{~m}$ (figs. 21 and 22c). Few bedsets of red-brown to gray weathering, lower, very-fine-grained sandstone form inconspicuous resistant ledges up to 1 $\mathrm{m}$ thick within the siltstone (figs. 22d-e). Sandstones include pyritic(?) concretions up to $1 \mathrm{~cm}$ in diameter and have a crumbly, burrowed-mottled (II4-5) appearance. Trace fossils resembling Terebellina or Paleophycos are present locally.

The upper $67 \mathrm{~m}$ consists of discontinuously exposed sandstone. The lower $2.4 \mathrm{~m}$ (75.1 to $77.5 \mathrm{~m}$ on fig. 21) consists of light gray weathering, locally rusty-brown weathering, very-fine- to fine-grained sandstone. Bed thickness and geometry are difficult to determine due to uniform grain size and nearly uniform weathering character; beds have an irregular parting character and an overall appearance suggestive of a moderate degree of bioturbation (II3-4?; fig. 22f). Terebellina or Paleophycos are the only recognizable trace fossils. Scattered orange-brown weathering, concretion-like cemented sandstone masses up to $2 \mathrm{~cm}$ in diameter may be burrow-fills of unknown affinity. Isolated remnants of sparsely bioturbated low-angle convex-upward laminae are present locally.

Discontinuously exposed sandstone from $114 \mathrm{~m}$ to $142 \mathrm{~m}$ is light gray to buff weathering and upper very fine to fine grained. Grain size appears to coarsen slightly from the base to the top of this interval. Most of this interval appears moderately bioturbated (II3) with scattered sparsely bioturbated (II1-2) beds 5-15 cm thick (fig. 22g). Discrete trace fossils are not recognizable. Pyritic(?) concretions up to a few centimeters in diameter are common. Concave-up surfaces scattered throughout are suggestive of small- to moderate-scale trough cross-bedding. Wave-ripple bedforms (fig. 22h) and possible hummocky cross-stratification are present locally. A distinctive pitted or honeycombed weathering pattern characterizes discrete intervals. The origin of this weathering pattern is unknown - it may be the result of a bioturbation fabric. Sparsely bioturbated plane-parallel lamination is common in the upper $8 \mathrm{~m}$ of the exposure (fig. 22i). Float at the top of the exposure includes impressions of an articulated pelecypod that came to rest with valves wide open. 


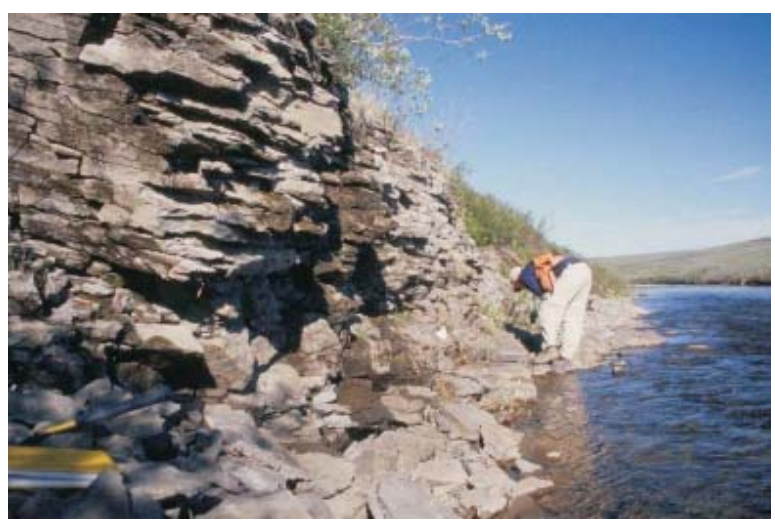

A.

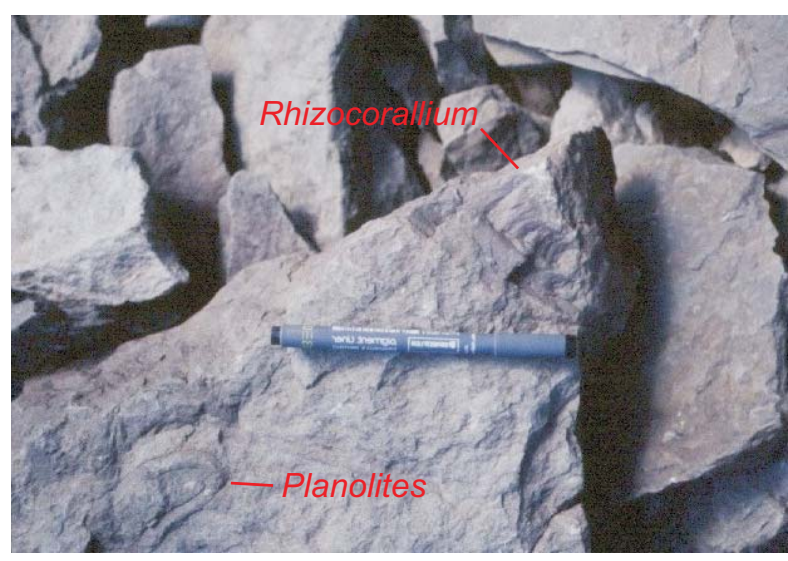

C.

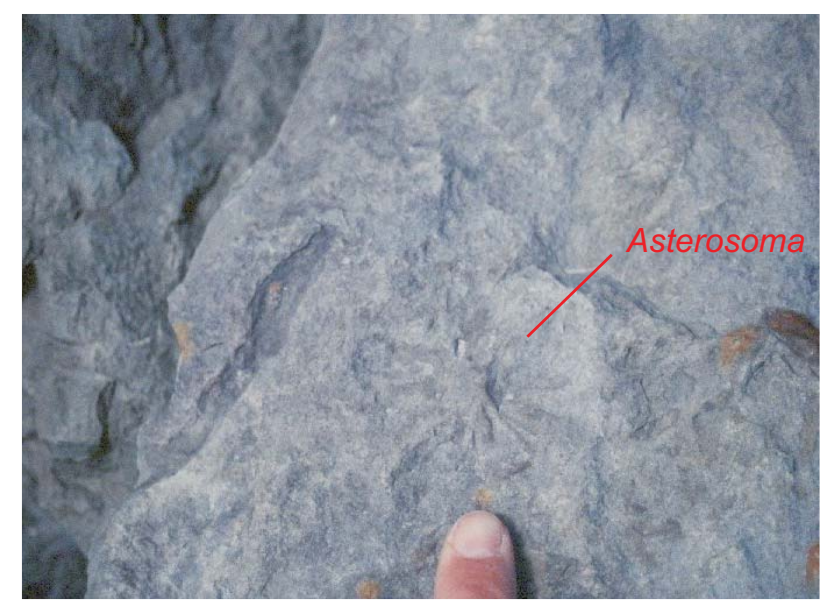

E.

Figure 20. Photographs of sedimentary features in Campanian age shelf deposits of the Schrader Bluff Formation at station 01DL021. (A) Thin, wavy bedded, bioturbated, very-fine-grained sandstone from 0-3 m. (B) Plant fragments on parting surface in bioturbated very-fine-grained sandstone at $3 \mathrm{~m}$. (C) Planolites and part of a Rhizocorallium trace at $1.6 \mathrm{~m}$. (D) Schaubcylindrichnus burrows in very-fine-grained sandstone at $3 \mathrm{~m}$. (E) Asterosoma trace in argillaceous very-finegrained sandstone at $2.5 \mathrm{~m}$.

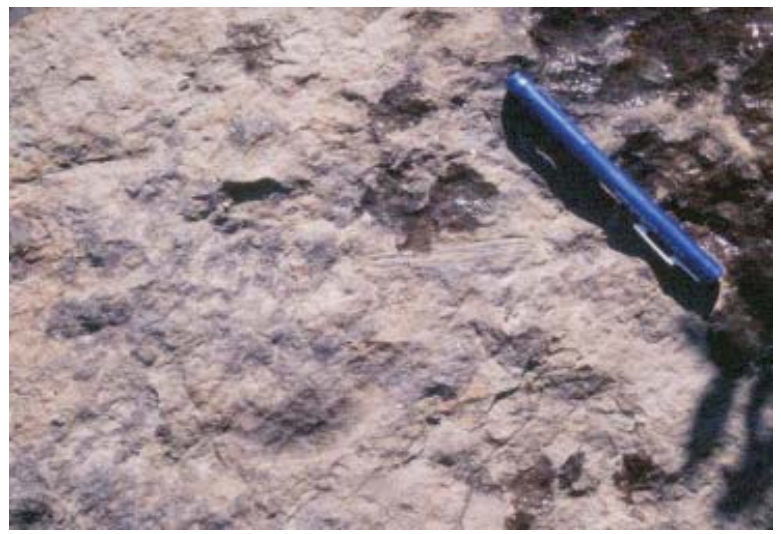

B.

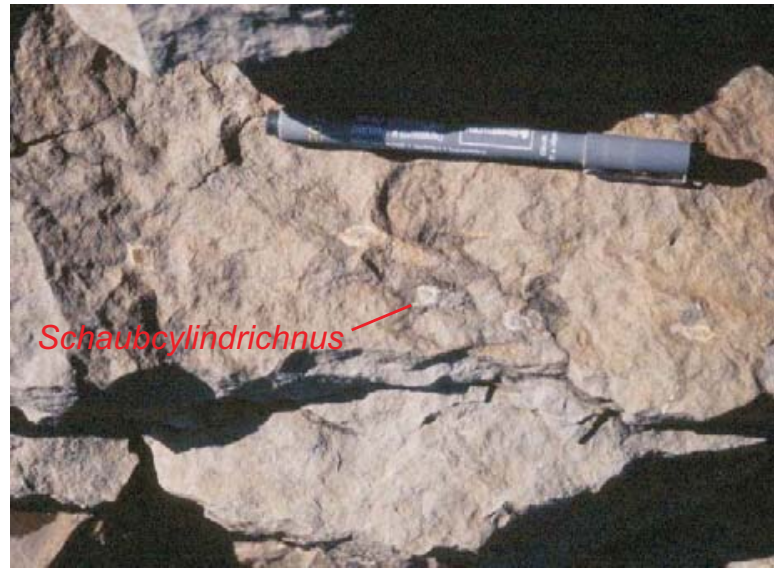

D. 


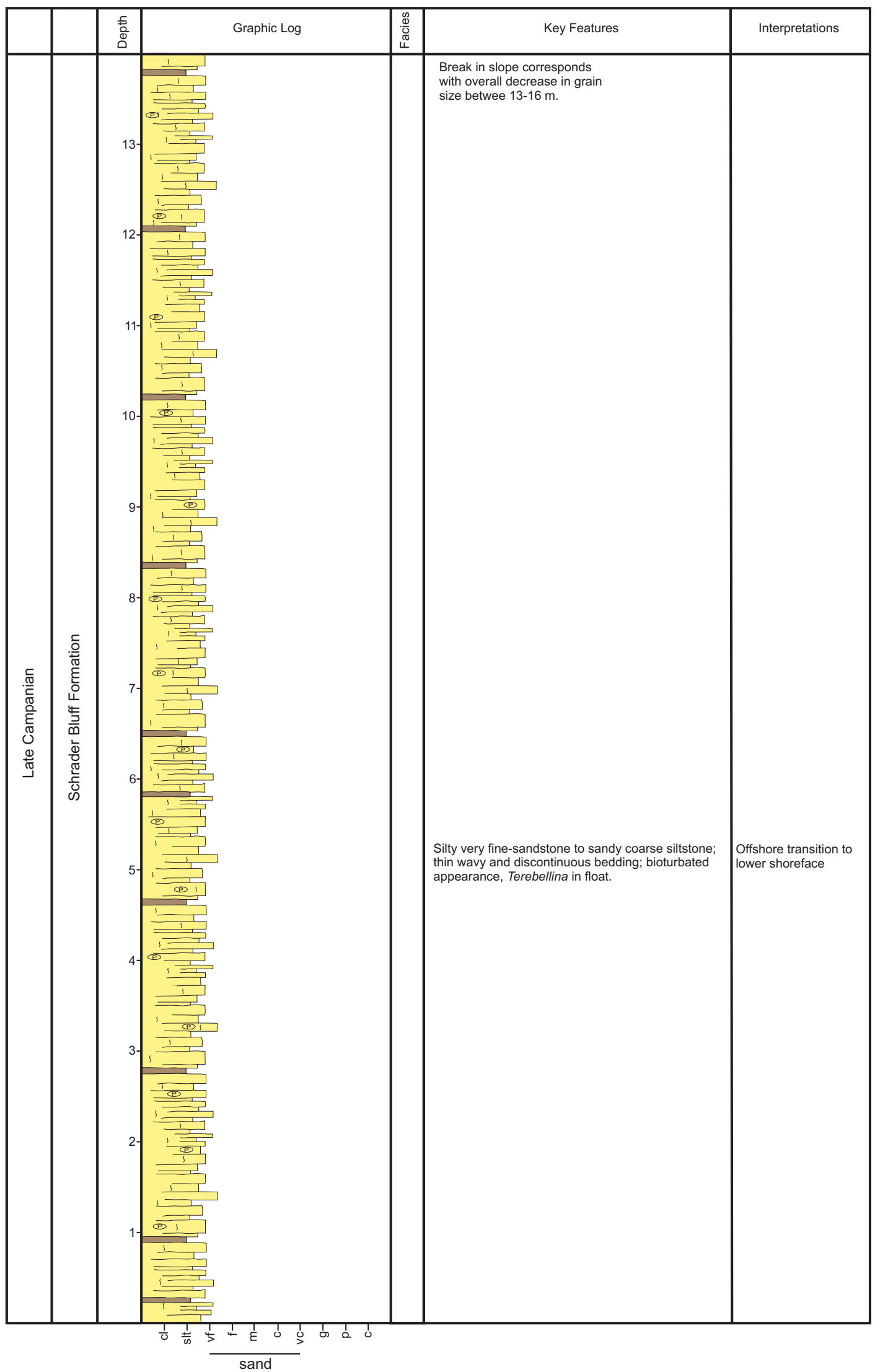

Figure 21. Measured stratigraphic section through probable late Campanian offshore, offshore transition, and shoreface/foreshore deposits of the Schrader Bluff Formation at station 01DL022. See figure 5 (p. 92) for symbol key. 
01DL022

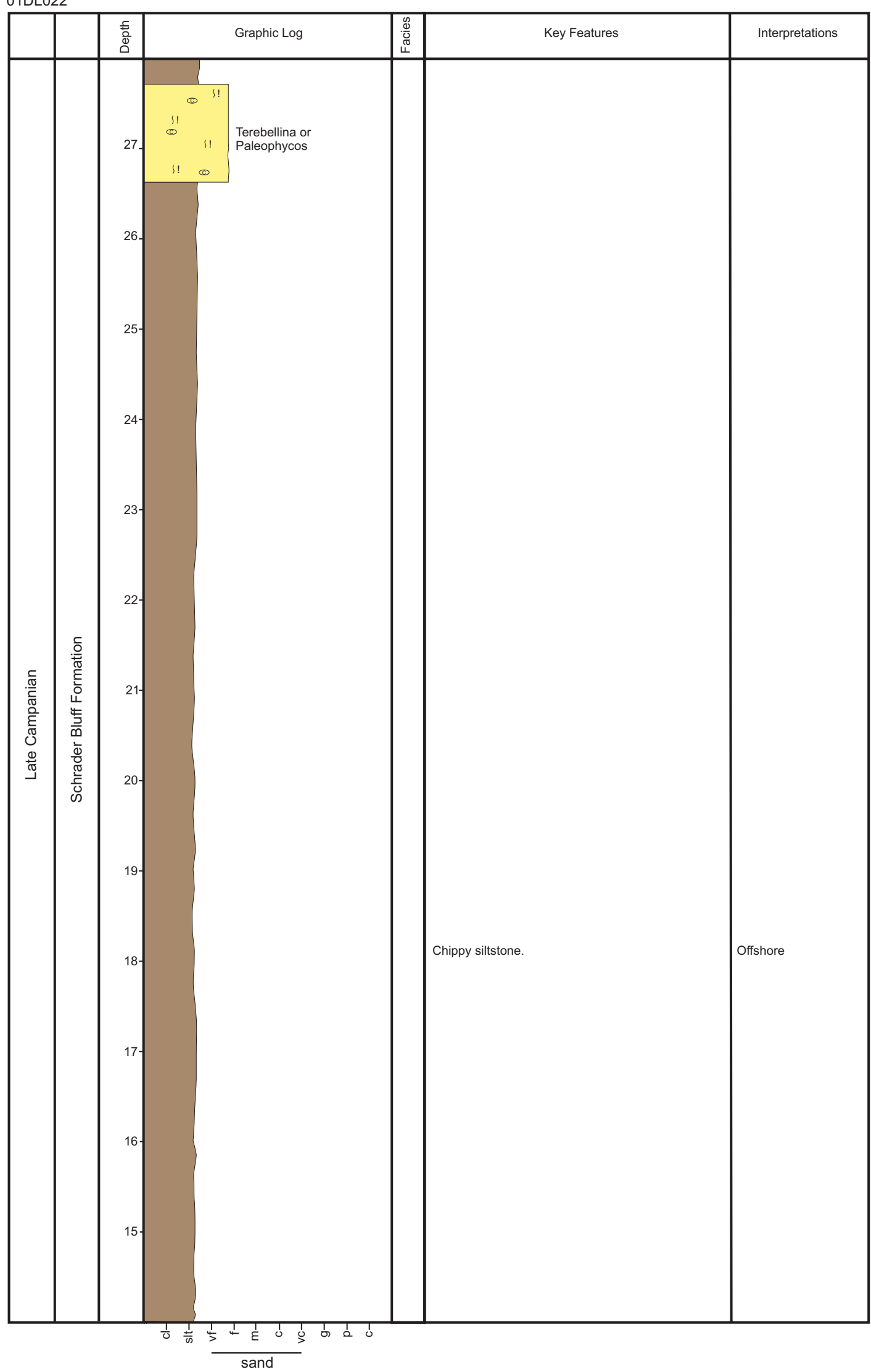

Figure 21. (continued) Measured stratigraphic section through probable late Campanian offshore, offshore transition, and shoreface/foreshore deposits of the Schrader Bluff Formation at station 01DL022. See figure 5 (p. 92) for symbol key. 


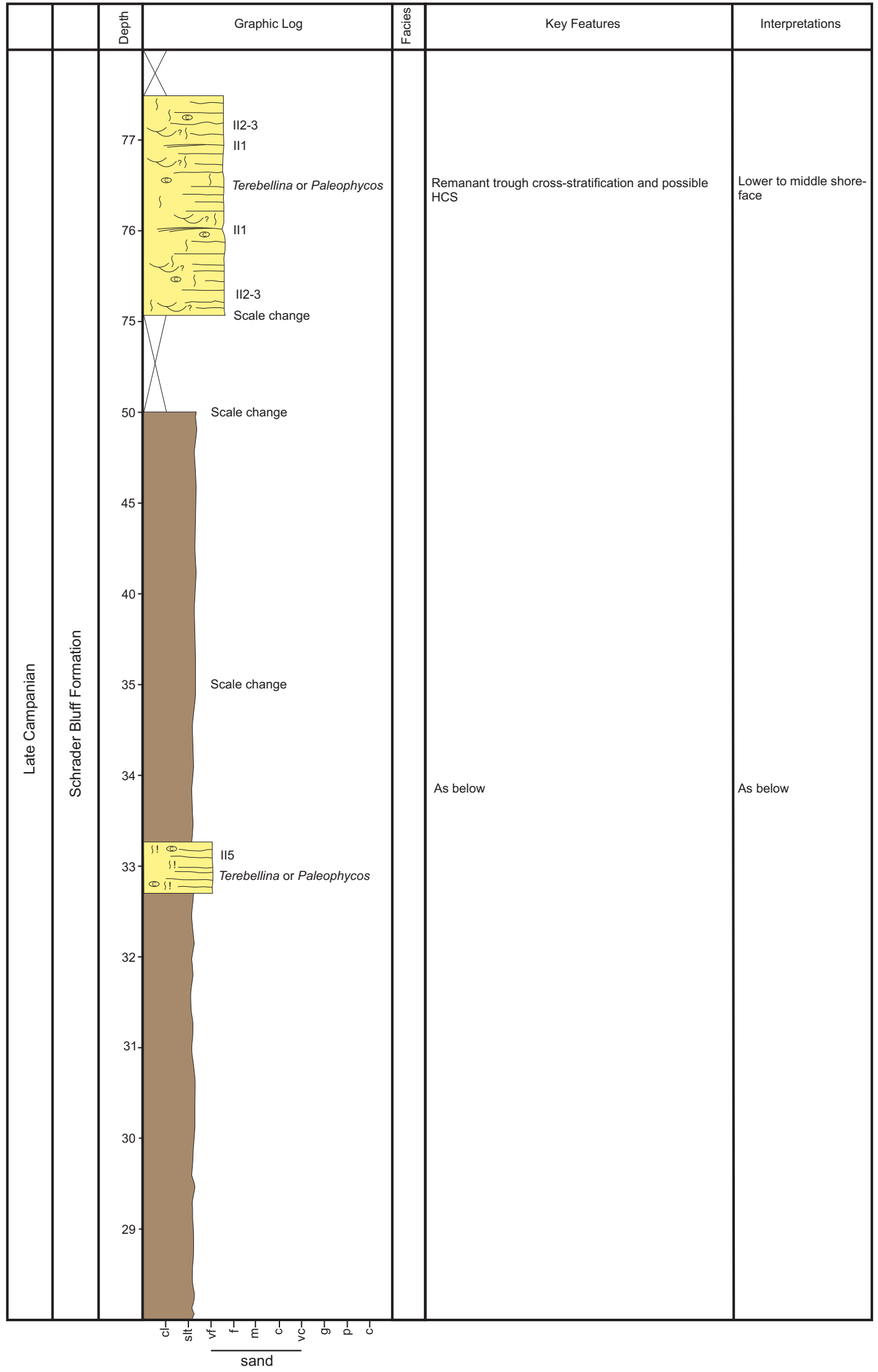

Figure 21. (continued) Measured stratigraphic section through probable late Campanian offshore, offshore transition, and shoreface/foreshore deposits of the Schrader Bluff Formation at station 01DL022. See figure 5 (p. 92) for symbol key. 
01DL022

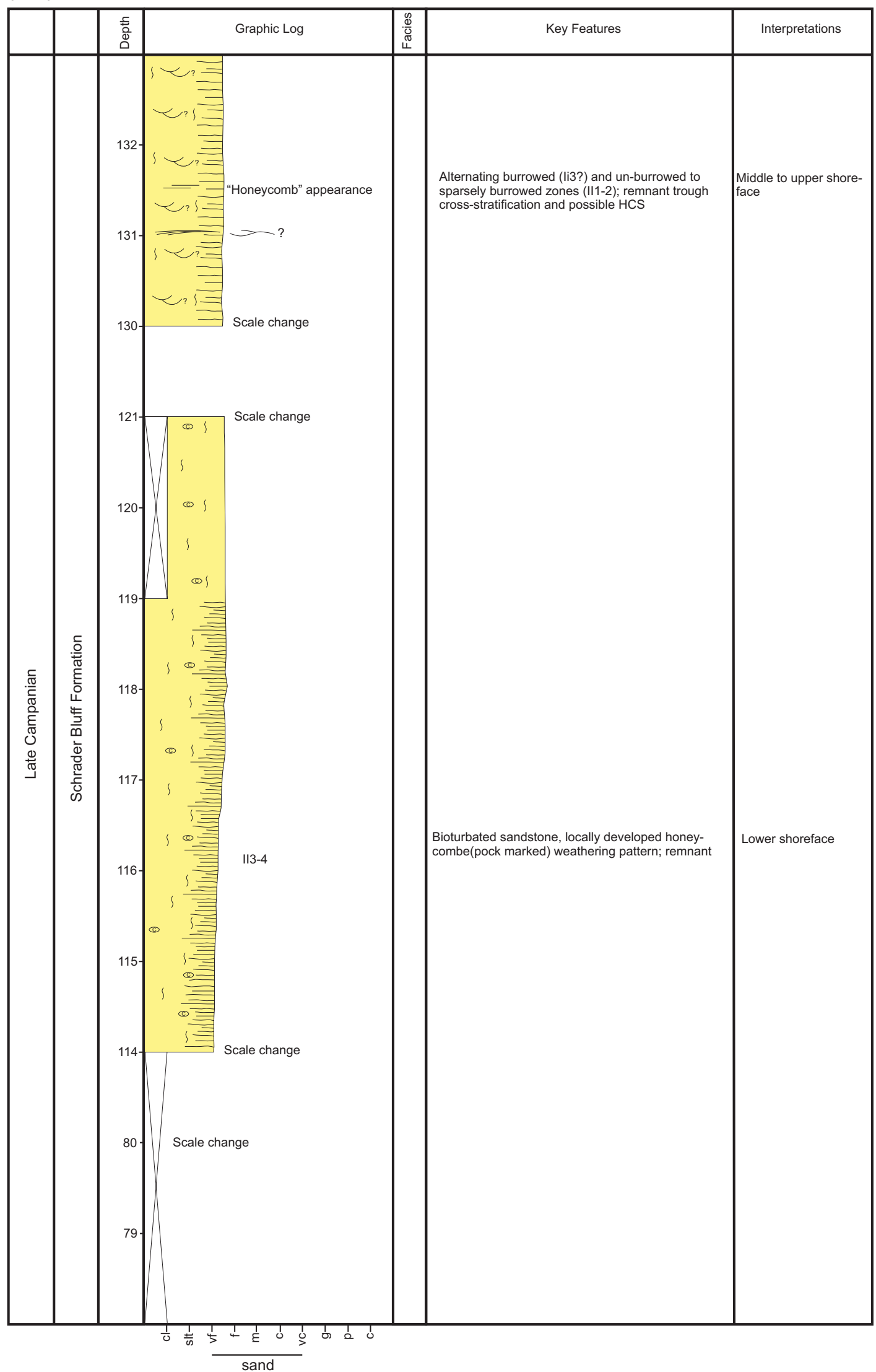

Figure 21. (continued) Measured stratigraphic section through probable late Campanian offshore, offshore transition, and shoreface/foreshore deposits of the Schrader Bluff Formation at station 01DL022. See figure 5 (p. 92) for symbol key. 


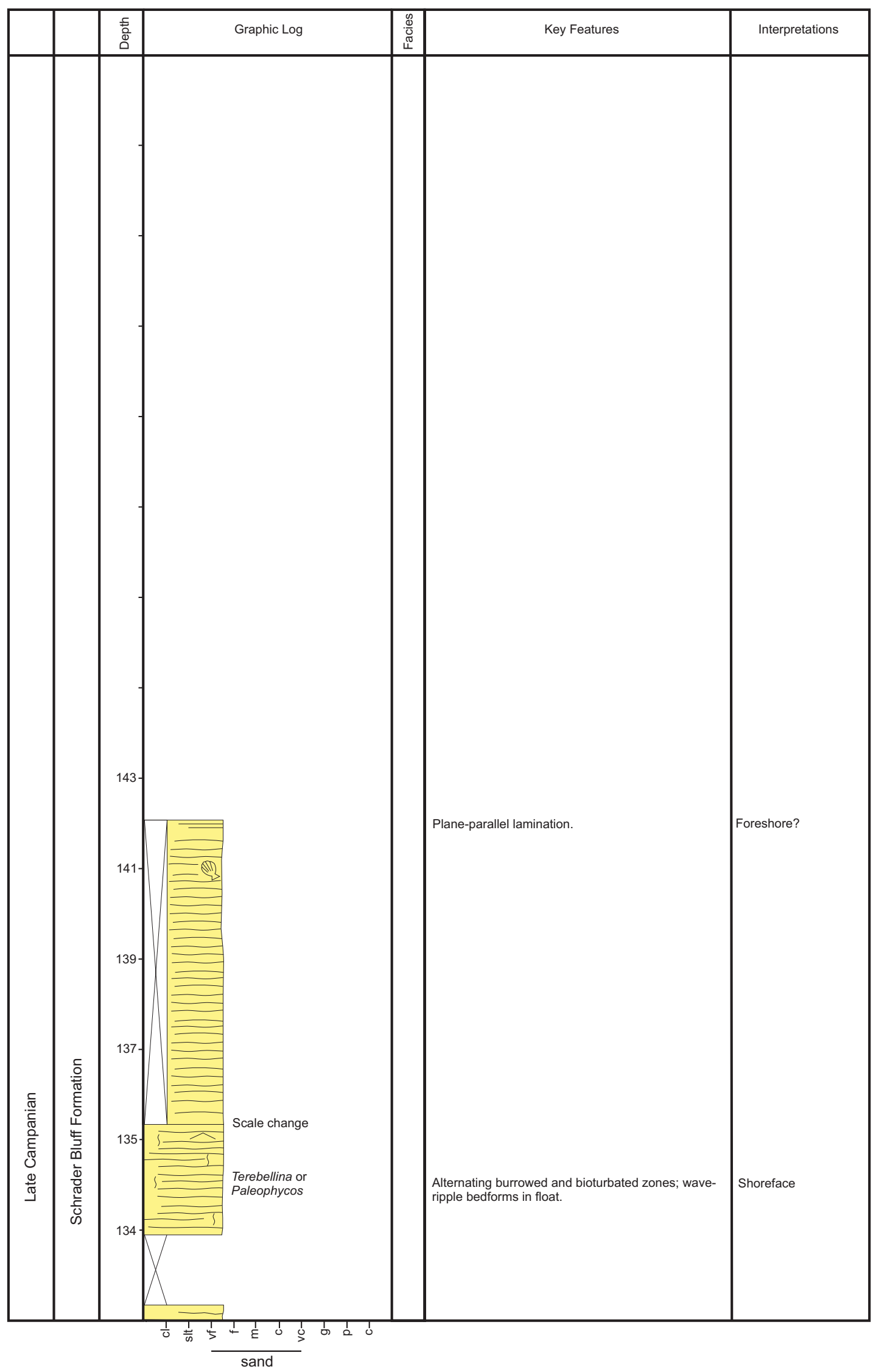

Figure 21. (continued) Measured stratigraphic section through probable late Campanian offshore, offshore transition, and shoreface/foreshore deposits of the Schrader Bluff Formation at station 01DL022. See figure 5 (p. 92) for symbol key. 


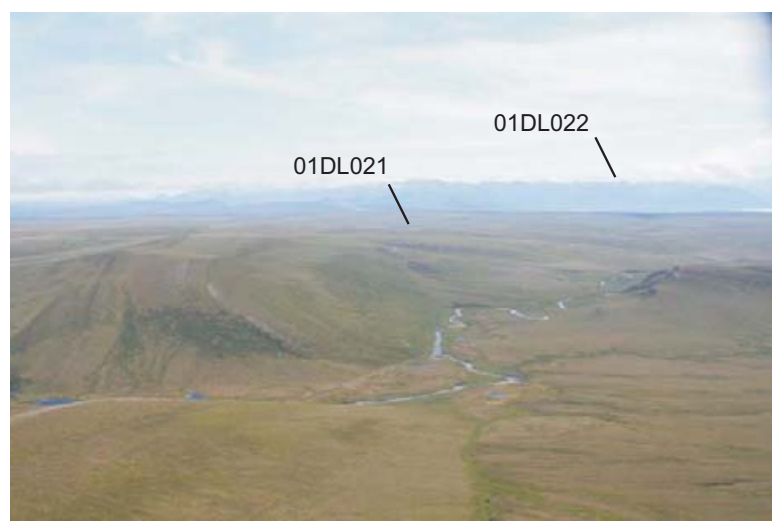

A.

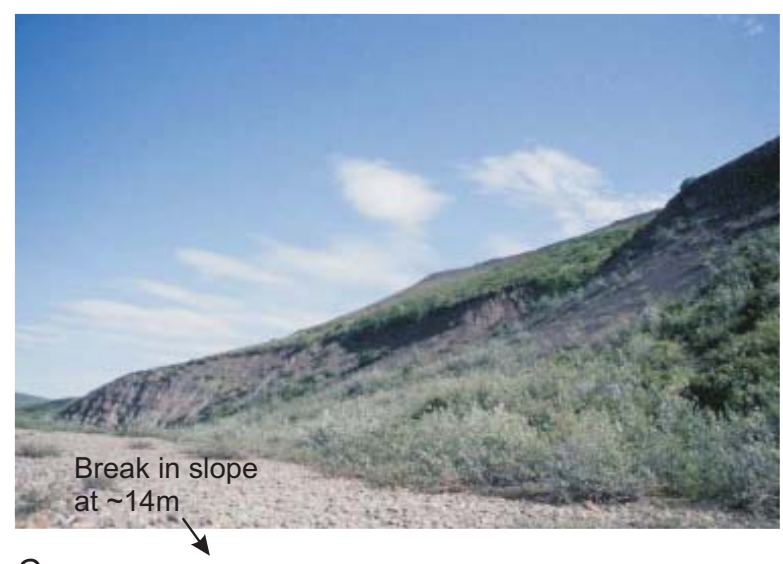

C.

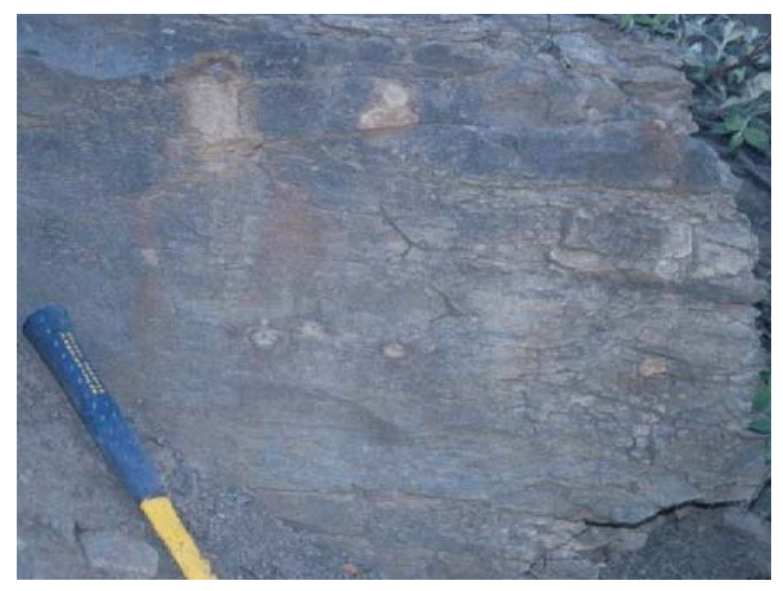

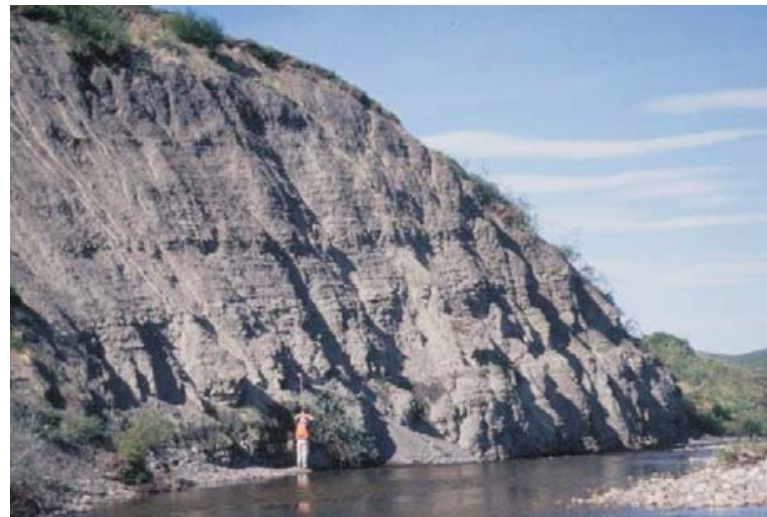

B.

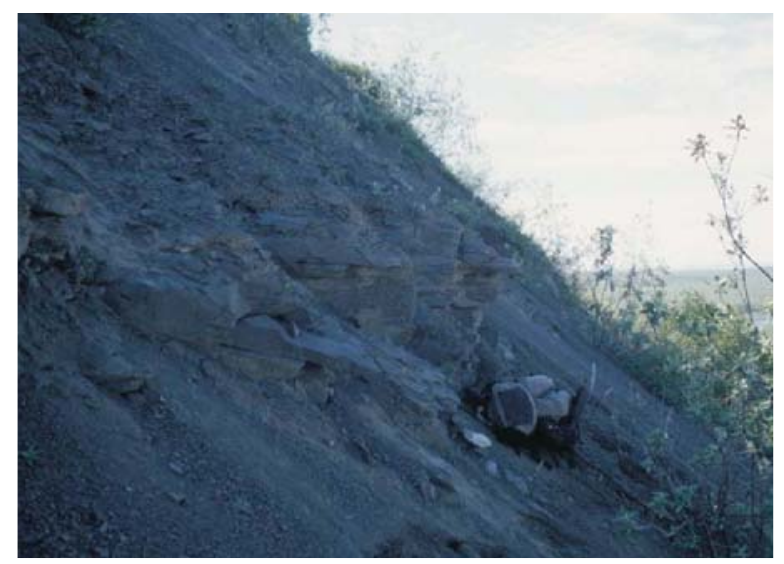

D.

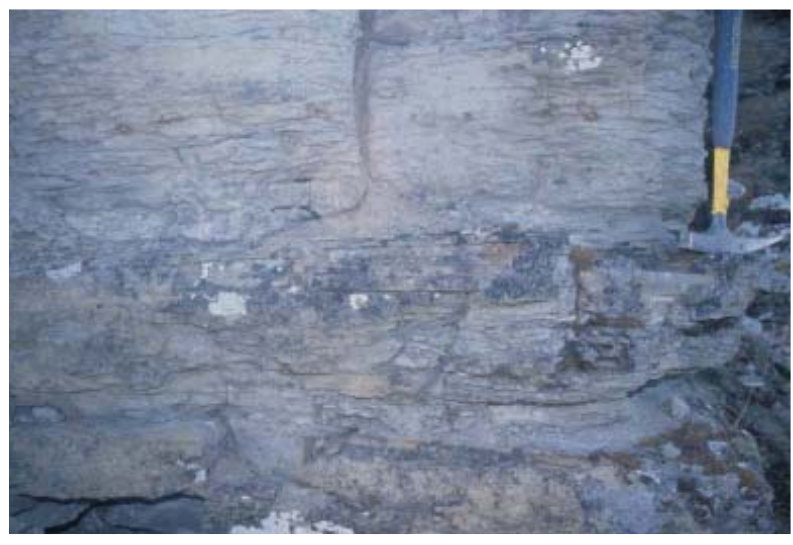

F.

E.

Figure 22 (A-F). Photographs of sedimentary features in probable late Campanian offshore, offshore transition, and shoreface/ foreshore deposits of the Schrader Bluff Formation at station 01DL022. (A) Aerial view toward the east showing station 01DL022 near the right edge of the photograph. Station 01DL021 is just beyond the left edge of the image. (B) View toward the west showing thinly-bedded siltstone and very-fine-grained sandstone in the lower 13-16 m of the exposure. Staff above the geologist's head is $1.5 \mathrm{~m}$ long. (C) View toward the southeast showing the break in slope (arrow) corresponding to the contact between interbedded siltstone and sandstone in the lower 14-16 m of the exposure and the overlying siltstone succession. ( $D-E)$ Resistant ledge of bioturbated very-fine-grained sandstone with centimeter-scale pyritic concretions between 26 and $34 \mathrm{~m}$. These sand bodies represented storm deposits in a proximal offshore setting. (F) Moderately bioturbated(?) very-fine- to fine-grained sandstone between 114 and $119 \mathrm{~m}$. 


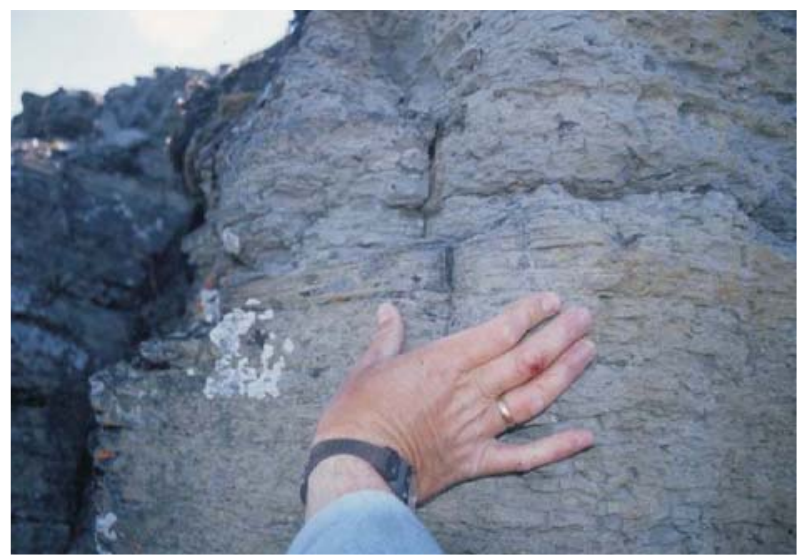

G.

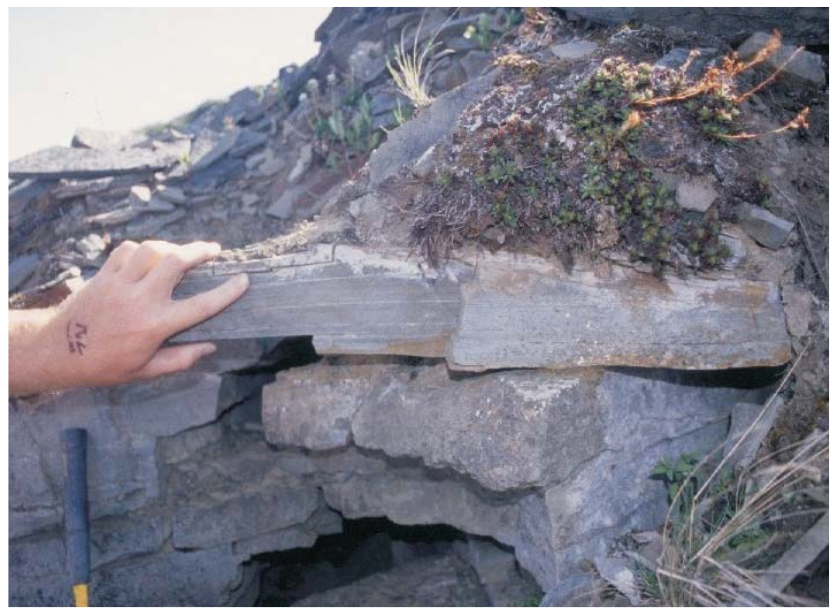

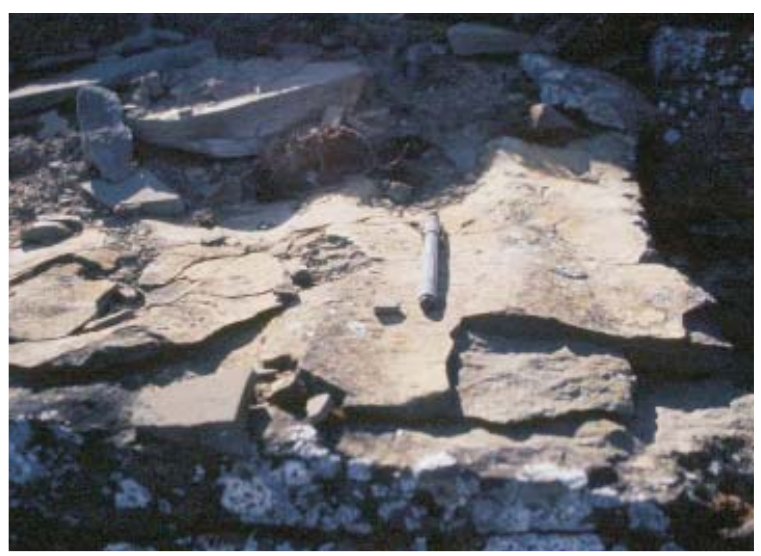

$\mathrm{H}$.

Figure 22 (G-I). Photographs of sedimentary features in probable late Campanian offshore, offshore transition, and shoreface/foreshore deposits of the Schrader Bluff Formation at station 01DL022. (G) Sparsely to moderately bioturbated finegrained sandstone at $119 \mathrm{~m}$. (H) Symmetric to slightly asymmetric two-dimensional wave ripple bedforms preserved on the surface of a sandstone bed at $135 \mathrm{~m}$. (I) Plane-parallel to slightly wavy parting (parting along faintly visible laminae) in fine-grained sandstone at $134 \mathrm{~m}$ interpreted as foreshore deposits.

I.

\section{INTERPRETATION}

The succession at station 22 is interpreted to record deposition as a series of stacked low-energy shoreface successions. The lower 13-16 m are interpreted as offshore transition to lower shoreface deposits. The prominent break in slope at the top of this package corresponds to a flooding surface and parasequence boundary. The overlying siltstone-sandstone package from $14 \mathrm{~m}$ to $77.5 \mathrm{~m}$ is interpreted as the next higher offshore-shoreface parasequence in the stack. Sandstones from $114 \mathrm{~m}$ to the top of the exposure represent the proximal part of the highest offshore-shoreface parasequence in the exposure; offshore shelf (seaward of shoreface) to offshore-transition (transition zone between shoreface and offshore shelf) strata correspond to the covered interval forming the basal $36 \mathrm{~m}$ of this parasequence. Plane-parallel laminae near the top of the succession are interpreted as foreshore deposits. It is possible that the upper parasequence as defined here actually includes two parasequences with a flooding surface at $121 \mathrm{~m}$. The succession of parasequences documented defines a progradational stacking pattern. Available biostratigraphic data suggest correlation with shallower water strata of the Schrader Bluff Formation west of the Trans-Alaska pipeline corridor.

\section{SUMMARY}

Work by DGGS during the 2001, 2002, and 2007 field seasons has documented deep-water through shoreline deposits along an unnamed drainage between the Sagavanirktok and Ivishak rivers. Despite numerous examples of outcrop-scale structural complications and long covered intervals along this trend, these exposures are interpreted to record an approximately 2,460-meter-thick, relatively unbroken succession of lower Turonian deep-water (station 07DL045) through Campanian shallow-water (station 01DL22) deposits (fig. 23). Exposures along this trend correspond to relatively resistant sandstone and tuff lithologies, and shaly lithologies are inferred to underlie the 


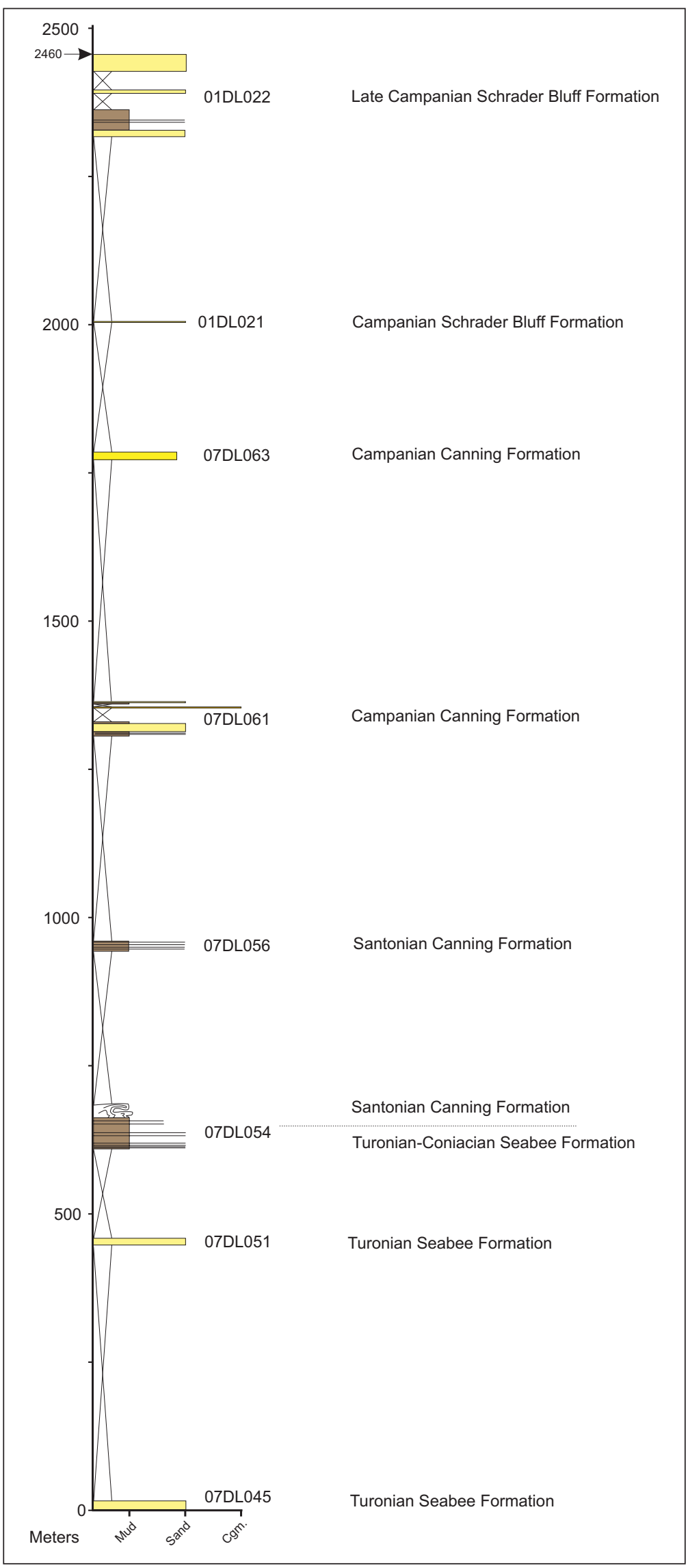

Figure 23. Composite stratigraphic section showing Upper Cretaceous strata constructed from stations 07DL045 through 01DL022. See figure 5 ( p. 92) for symbol key. 
long covered intervals. Our outcrop work suggests that the lower 1,300 m of section (stations 045 through station 061) records deposition in deep-water settings ranging from basin floor to lower slope settings. The limited lateral and vertical extent of these exposures precludes detailed interpretations, but available outcrop information allows tentative interpretations of deep-water architectural elements, including sandstone lobes, channel levee, and channel elements. Approximately $800 \mathrm{~m}$ of slope facies lies between stations 061 and 064 , and approximately $350 \mathrm{~m}$ of outer shelf through shoreface and possible foreshore strata are interpreted at the southeast end of the trend.

\section{ACKNOWLEDGMENTS}

Gil Mull recognized the significance of the succession along Sagashak Creek long ago and freely shared his knowledge of the area. Paige Delaney created fig. 2. We thank you both.

\section{REFERENCES}

Brosgé, W.P., and Whittington, C.L., 1966, Geology of the Umiat-Maybe Creek Region, Alaska: U.S. Geological Survey Professional Paper 303-H, 637 p.

Droser, M.L., and Bottjer, D.J., 1986, A semiquantitative field classification of ichnofabric: Journal of Sedimentary Petrology, v. 56, p. 558-559.

Houseknecht, D.W., and Schenk, C.J., 2001, Depositional sequences and facies in the Torok Formation, National Petroleum Reserve-Alaska (NPRA), in Houseknecht, D.W., ed., NPRA Core Workshop Petroleum Plays and Systems in the National Petroleum Reserve-Alaska: SEPM Core Workshop No. 21, p. 179-199.

_2004, Sedimentology and sequence stratigraphy of the Cretaceous Nanushuk, Seabee, and Tuluvak Formations exposed on Umiat Mountain, north-central Alaska, in U.S. Geological Survey in Alaska, 2004: U.S. Geological Survey Professional Paper 1709-B, 19 p.

Molenaar, C.M., Bird, K.J., and Collett, T.S., 1986, Regional correlation sections across the North Slope of Alaska: U.S. Geological Survey Miscellaneous Field Studies Map MF-1907, 1 sheet.

Molenaar, C.M., Bird, K.J., and Kirk, A.R., 1987, Cretaceous and Tertiary stratigraphy of northeastern Alaska, in Tailleur, I., and Weimer, P., eds., Alaskan North Slope Geology: Pacific Section, SEPM, vol. 1, p. 513-528.

Mulder, T., and Syvitski, J.P.M., 1995, Turbidity currents generated at river mouths during exceptional discharges at the world oceans: The Journal of Geology, v. 103, p. 285-299.

Mull, C.G., 1989, Generalized geologic map of the Brooks Range and Arctic Slope, Northern Alaska, scale 1 inch = 45 miles, in Mull, C.G., and Adams, K.E., eds., Bedrock geology of the eastern Koyukuk Basin, central Brooks Range, and east-central Arctic Slope along the Dalton Highway, Yukon River to Prudhoe Bay, Alaska: Alaska Division of Geological \& Geophyical Surveys Guidebook 7 vol. 1, 309 p.

Mull, C.G., and Harris, E.E., 1989, Dalton Highway road log from Chandalar Shelf (Mile 237.1 to Prudhoe Bay (Mile 414), in Mull, C.G., and Adams, K.E., eds., Bedrock geology of the eastern Koyukuk Basin, central Brooks Range, and eastcentral Arctic Slope along the Dalton Highway, Yukon River to Prudhoe Bay, Alaska: Alaska Division of Geological \& Geophysical Surveys Guidebook 7 vol. 1, p. 101-132.

Mutti, E., and Normark, W.R., 1987, Comparing examples of modern and ancient turbidite systems: Problems and concepts, in Legget, J.K., and Zuffa, G.G., eds., Marine Clastic Sedimentology: London, Graham and Trotman, p. 1-38.

Mutti, E., and Ricci Lucchi, F., 1978, Turbidites: International Geology Review, v. 20, p. 127-166.

Myrow, P.M., Fischer, W., and Goodge, J.W., 2002, Wave-modified turbidites; Combined-flow shoreline and shelf deposits, Cambrian, Antarctica: Journal of Sedimentary Research, v. 72, p. 641-656.

Pickering, K., Stow, D., Watson, M., and Hiscott, R., 1986, Deep-water facies, processes and models; A review and classification scheme for modern and ancient sediments: Earth-Science Reviews, v. 23, p. 75-174.

Spicer, R.A., Parrish, J.T., and Grant, P.R., 1992, Evolution of vegetation and coal-forming environment in the late Cretaceous of the North Slope of Alaska, in McCabe, P.J., and Parrish, J.T., eds., Controls on the Distribution and Quality of Cretaceous Coals: Geological Society of America Special Paper 267, p. 177-192.

Swift, D.P.J., Niedoroda, A.W., and Brown, R.J., 1985, Fluid and sediment transport dynamics on continental shelves, in Tillman, R.W., Swift, D.P.J, and Walker, R.G., eds., Shelf Sands and Sandstone Reservoirs: SEPM Short Course No. 13, p. 47-133.

Weimer, P., and Slatt, R.M., 2007, Introduction to the Petroleum Geology of Deepwater Setting: AAPG Studies in Geology No. 57, AAPG/Datapages Discovery Series 8, 1 CD.

Whittington, C.L., 1956, Revised stratigraphic nomenclature of Colville group, in Gryc, G. and others, Mesozoic sequence in Colville River region, northern Alaska: American Association of Petroleum Geologists Bulletin, v. 40 , p. 244-253. 
This page has intentionally been left blank. 


\section{APPENDIX A-1}

\section{NORTH SLOPE FIELD TOUR}


This page has intentionally been left blank. 


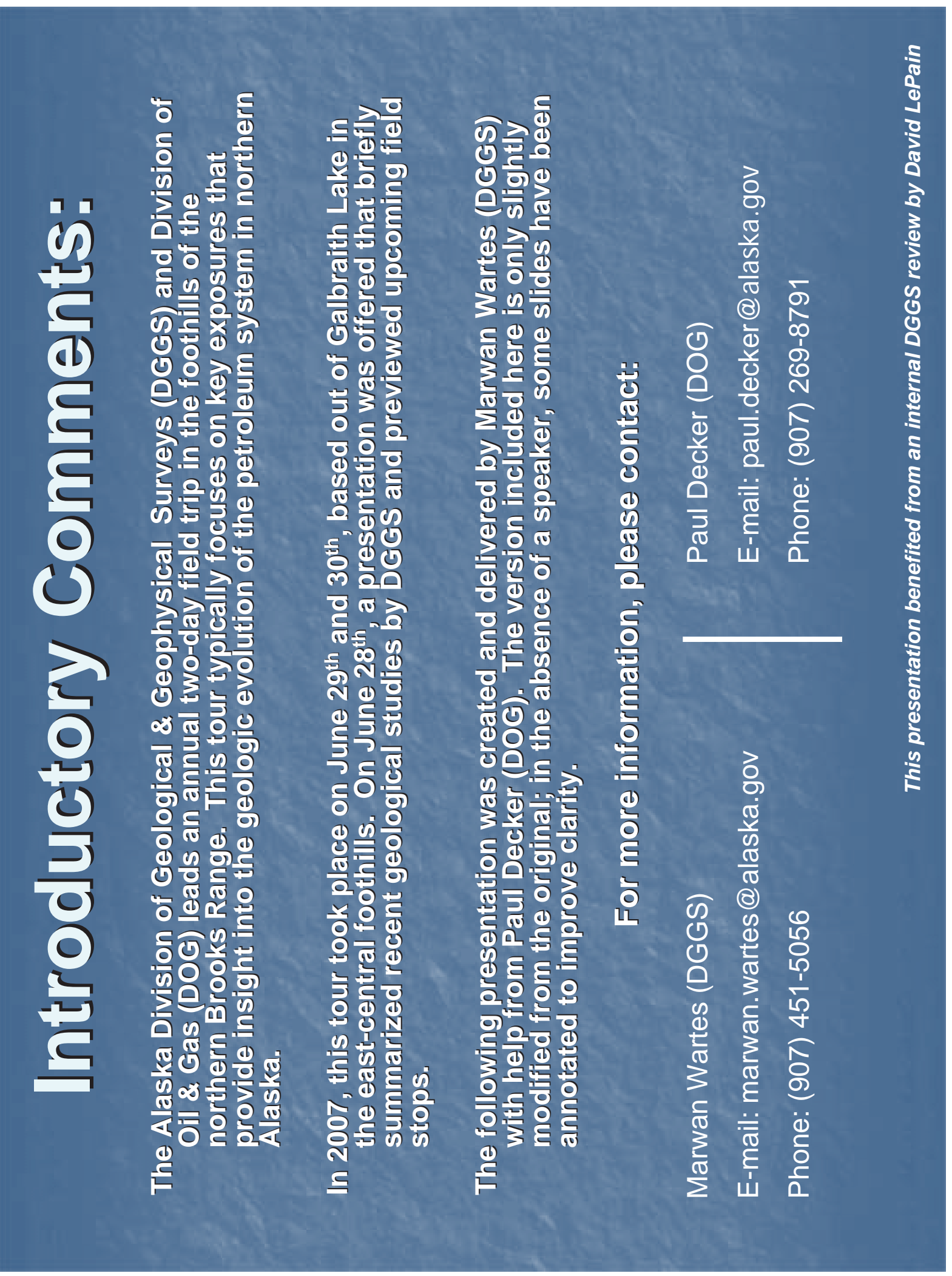




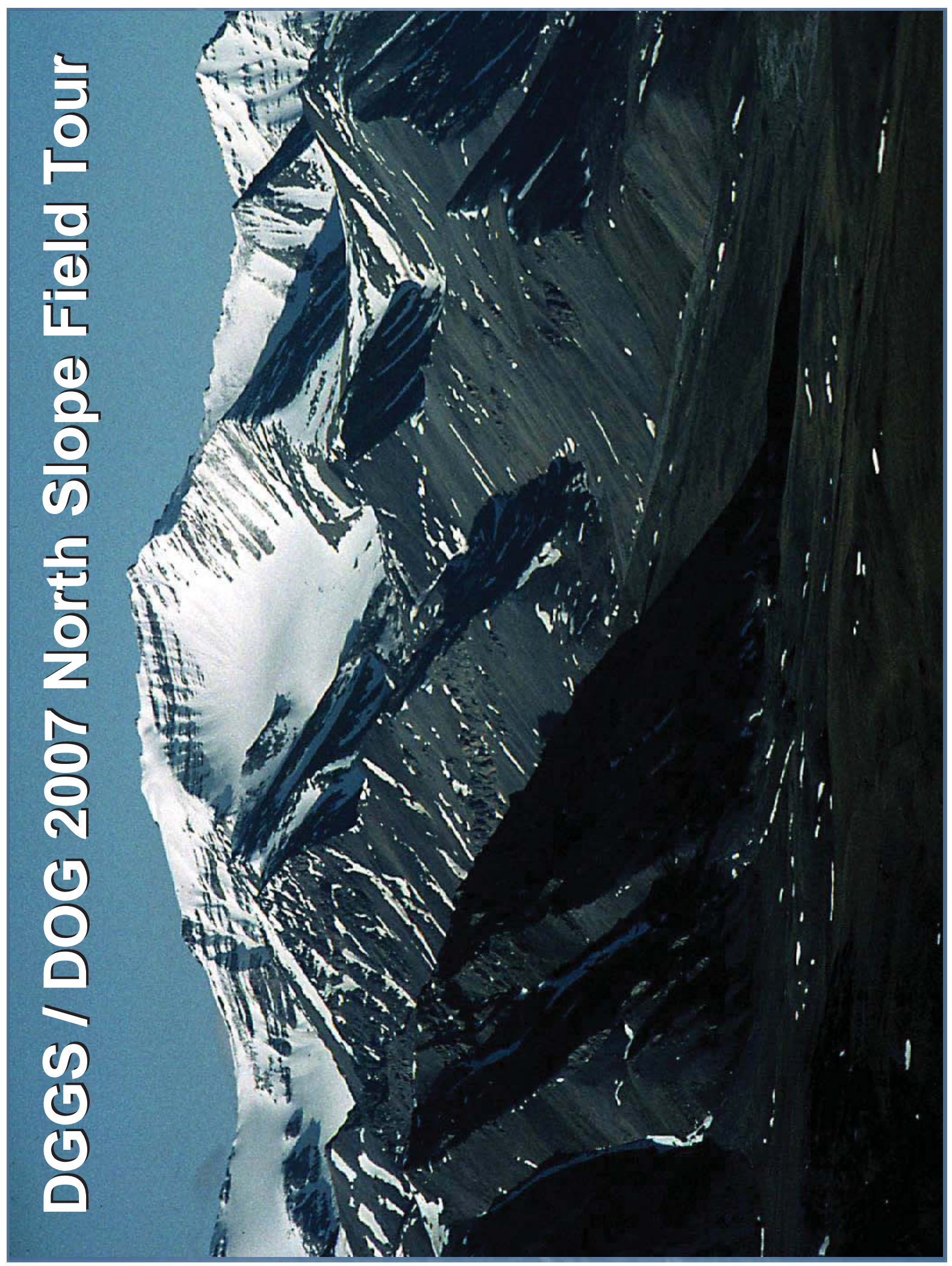




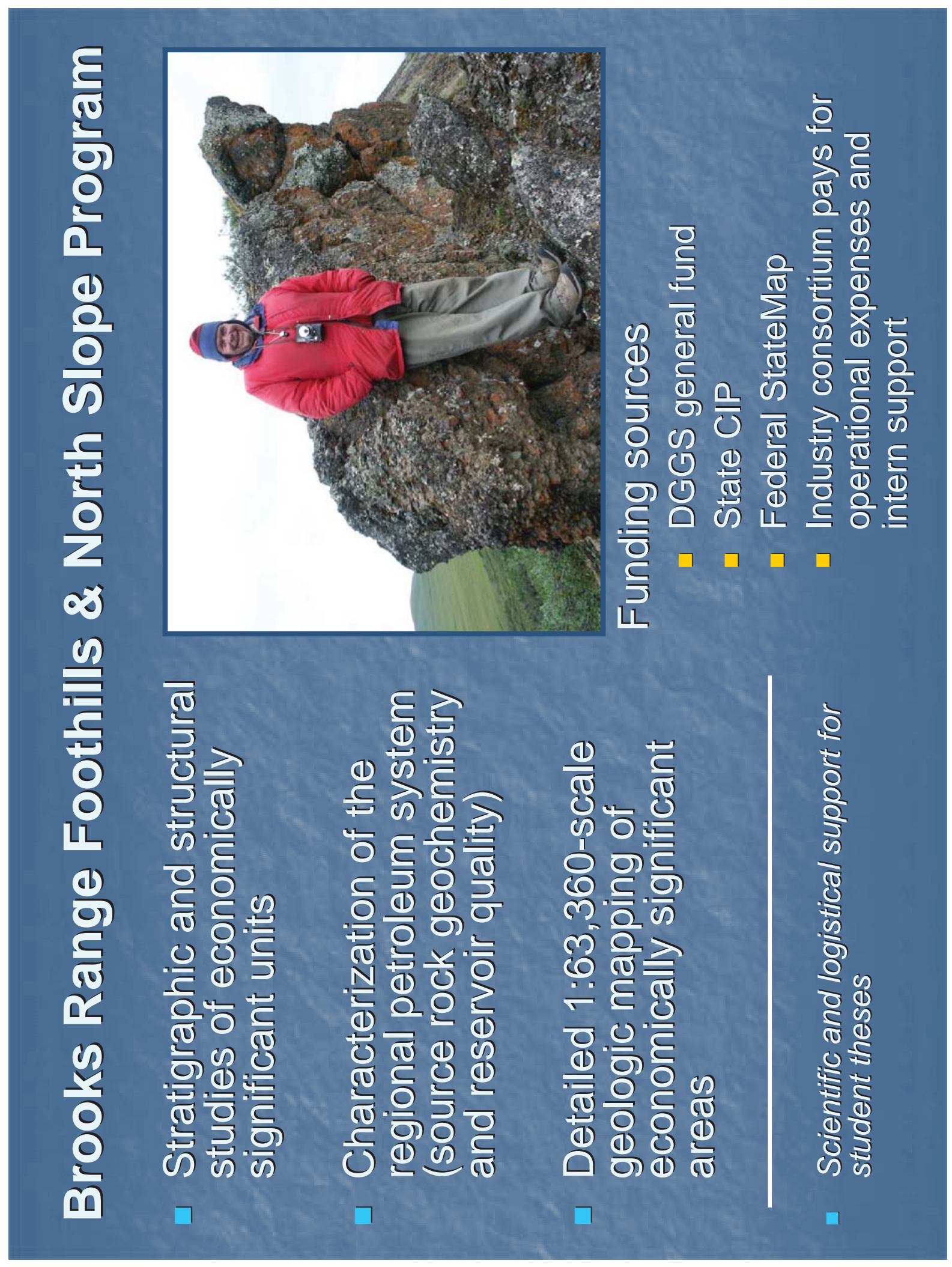




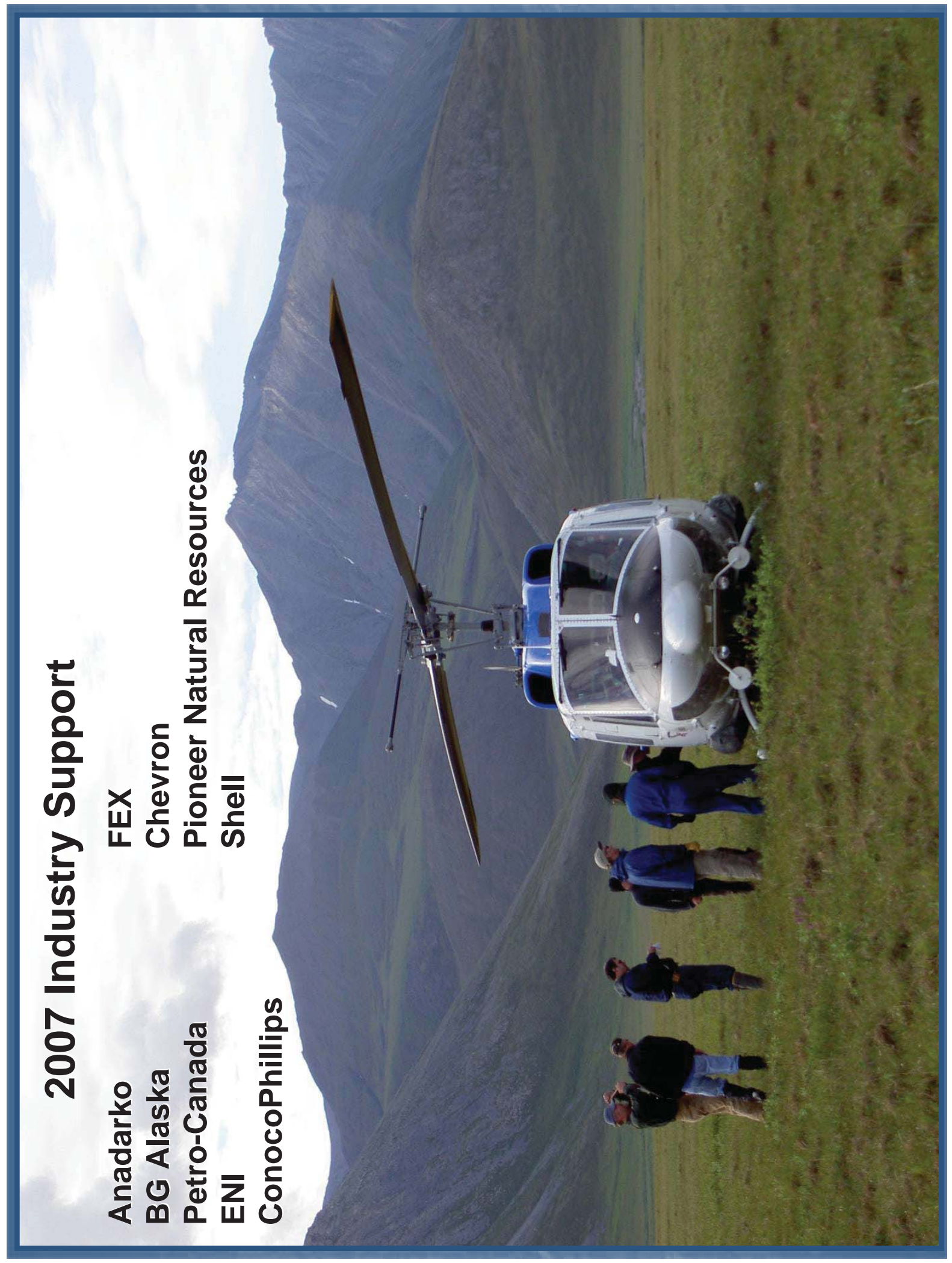



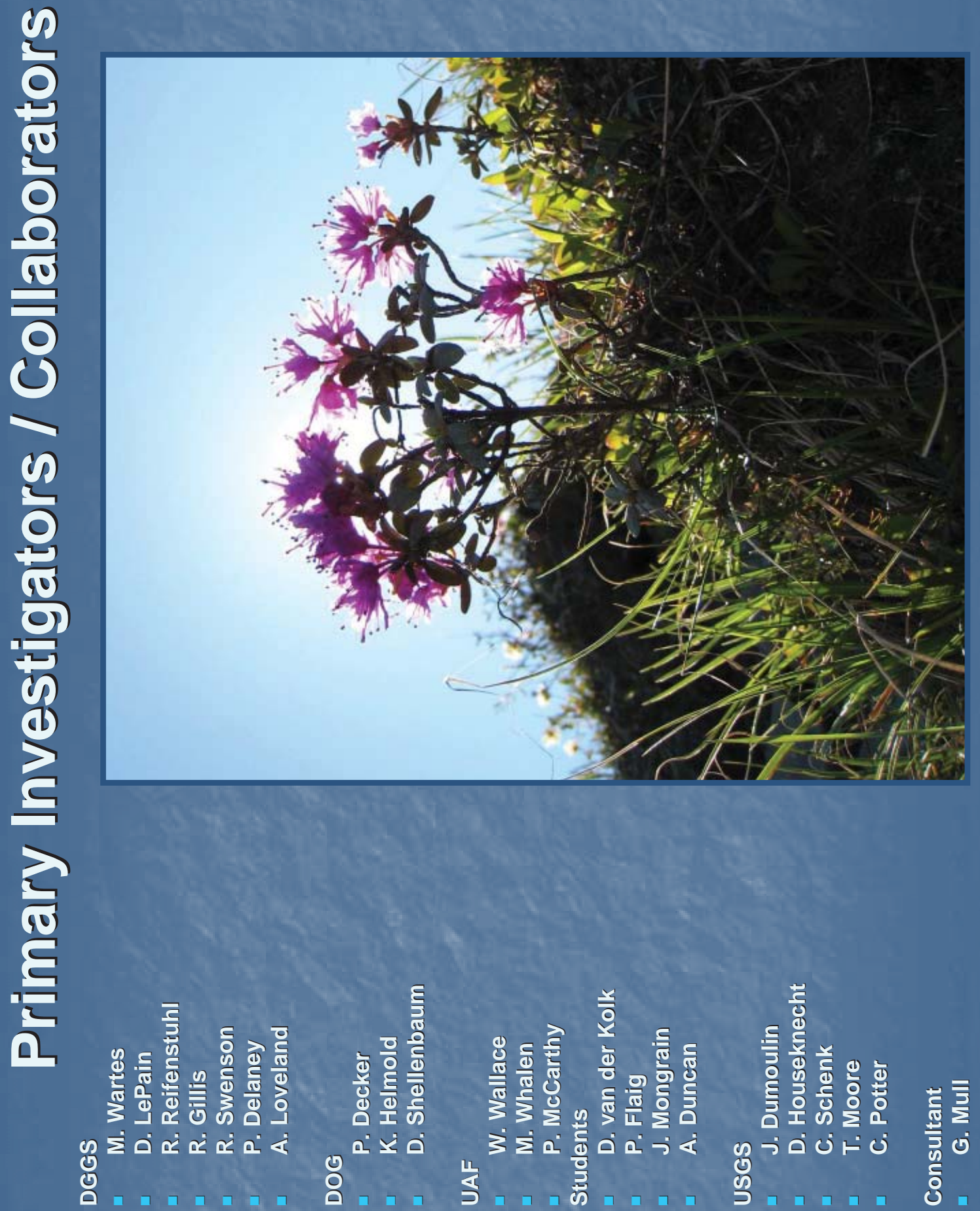

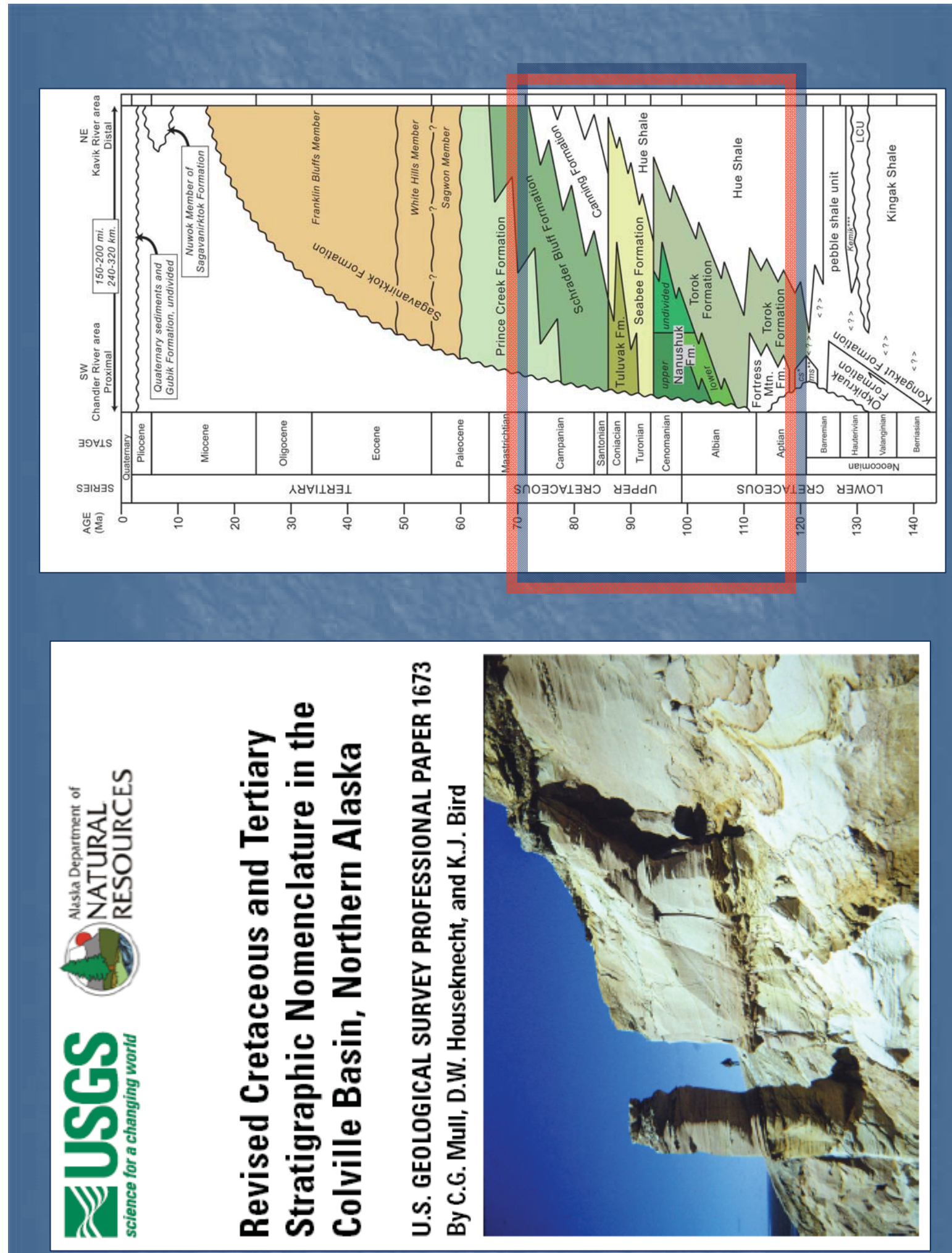


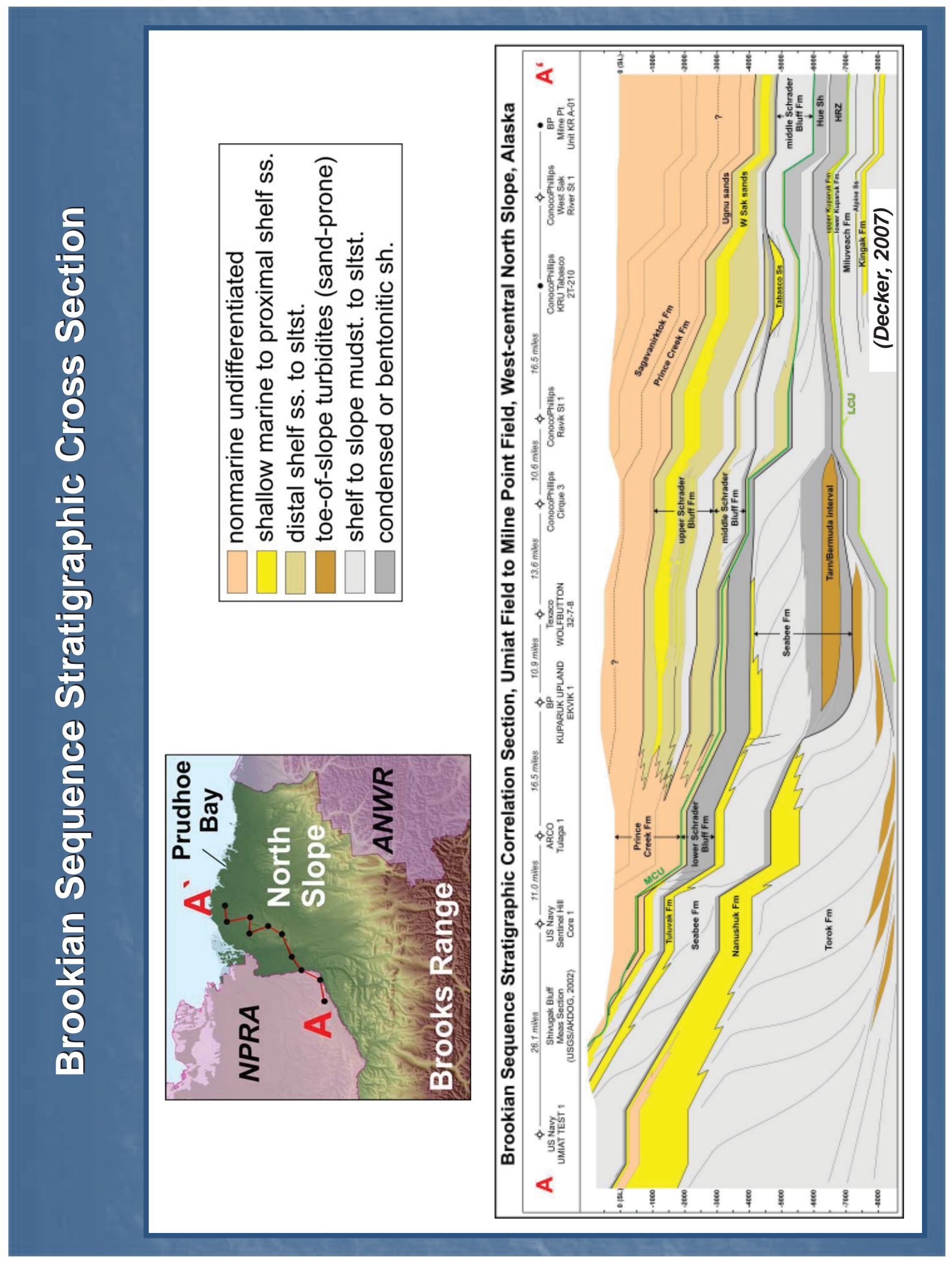




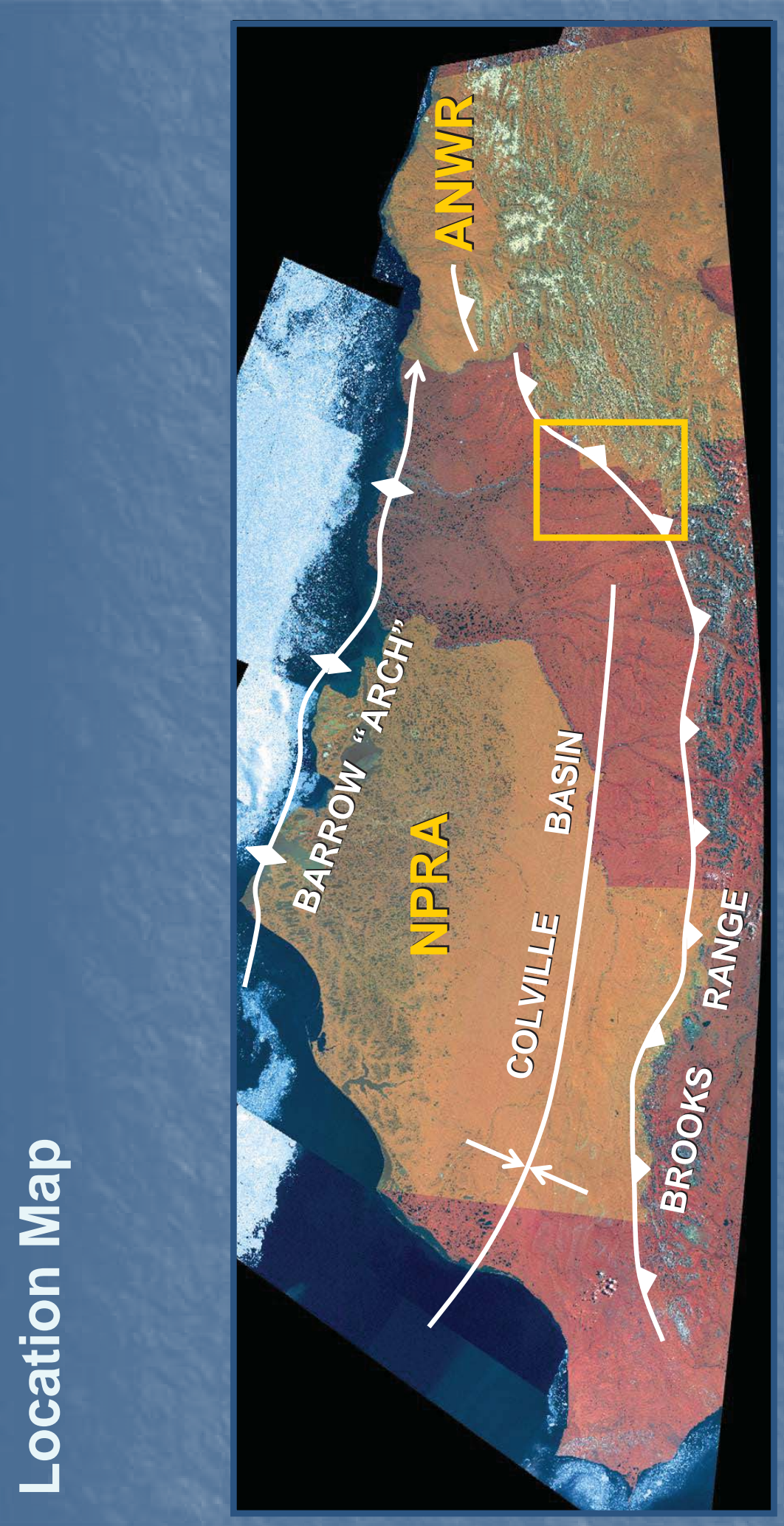




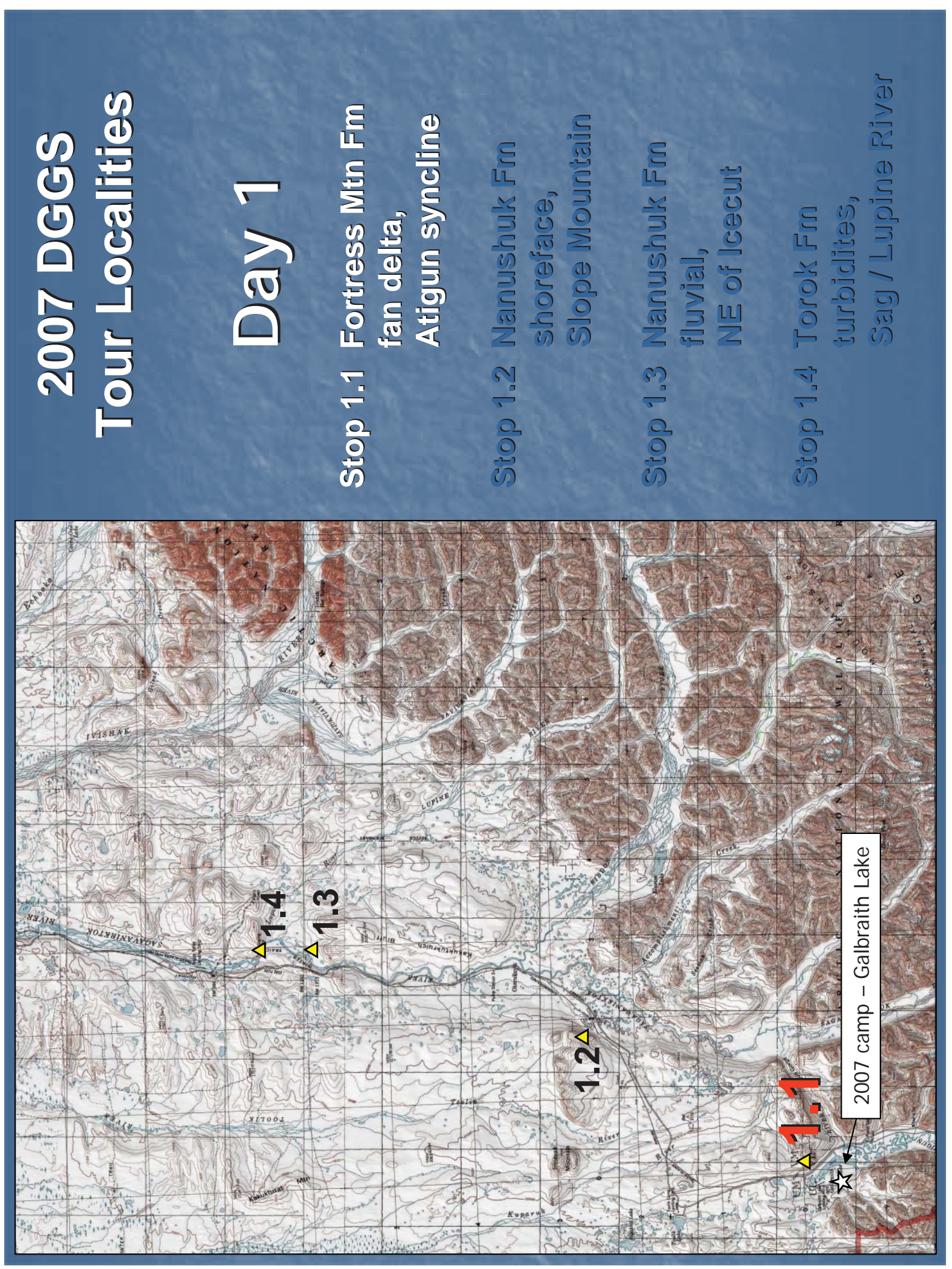



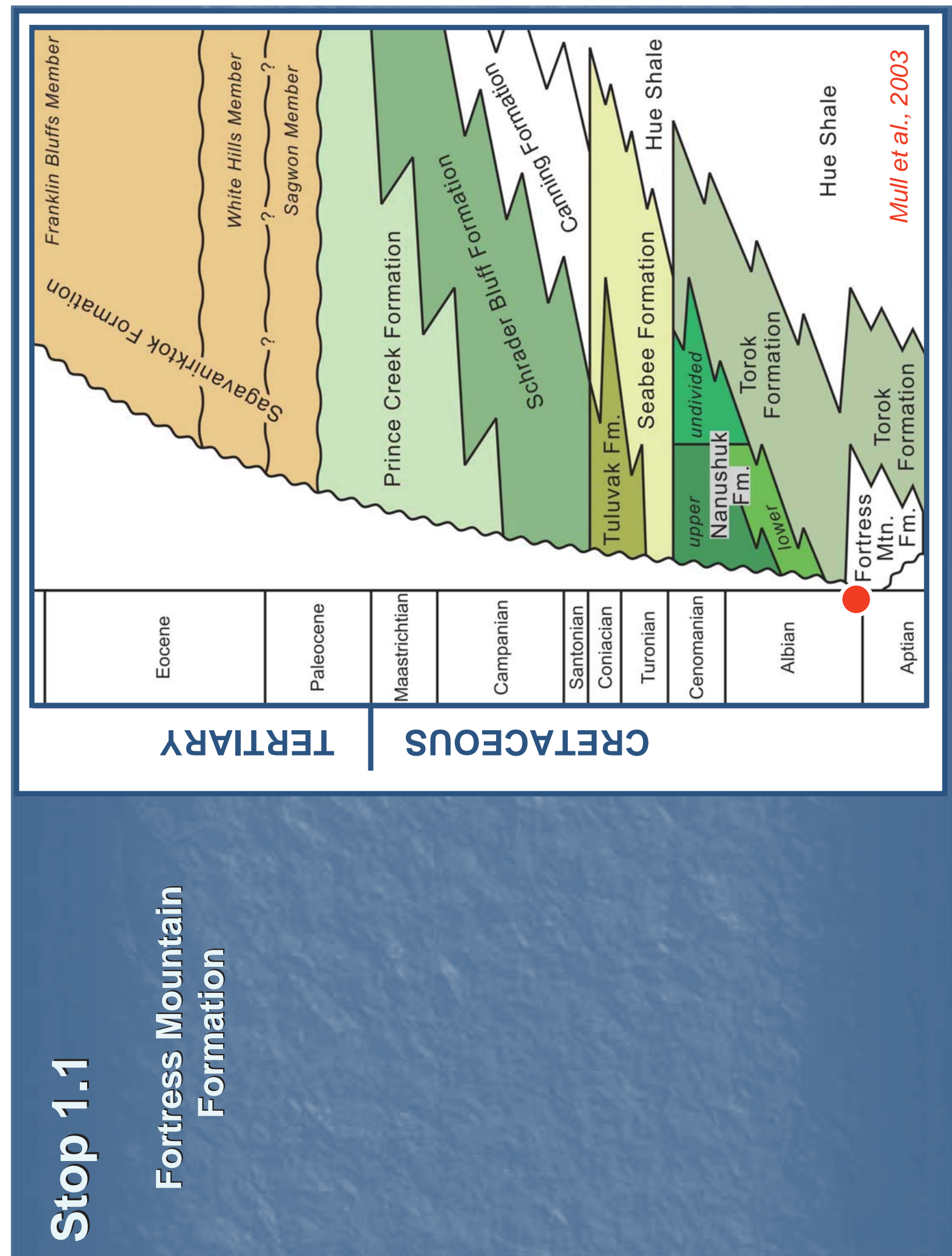


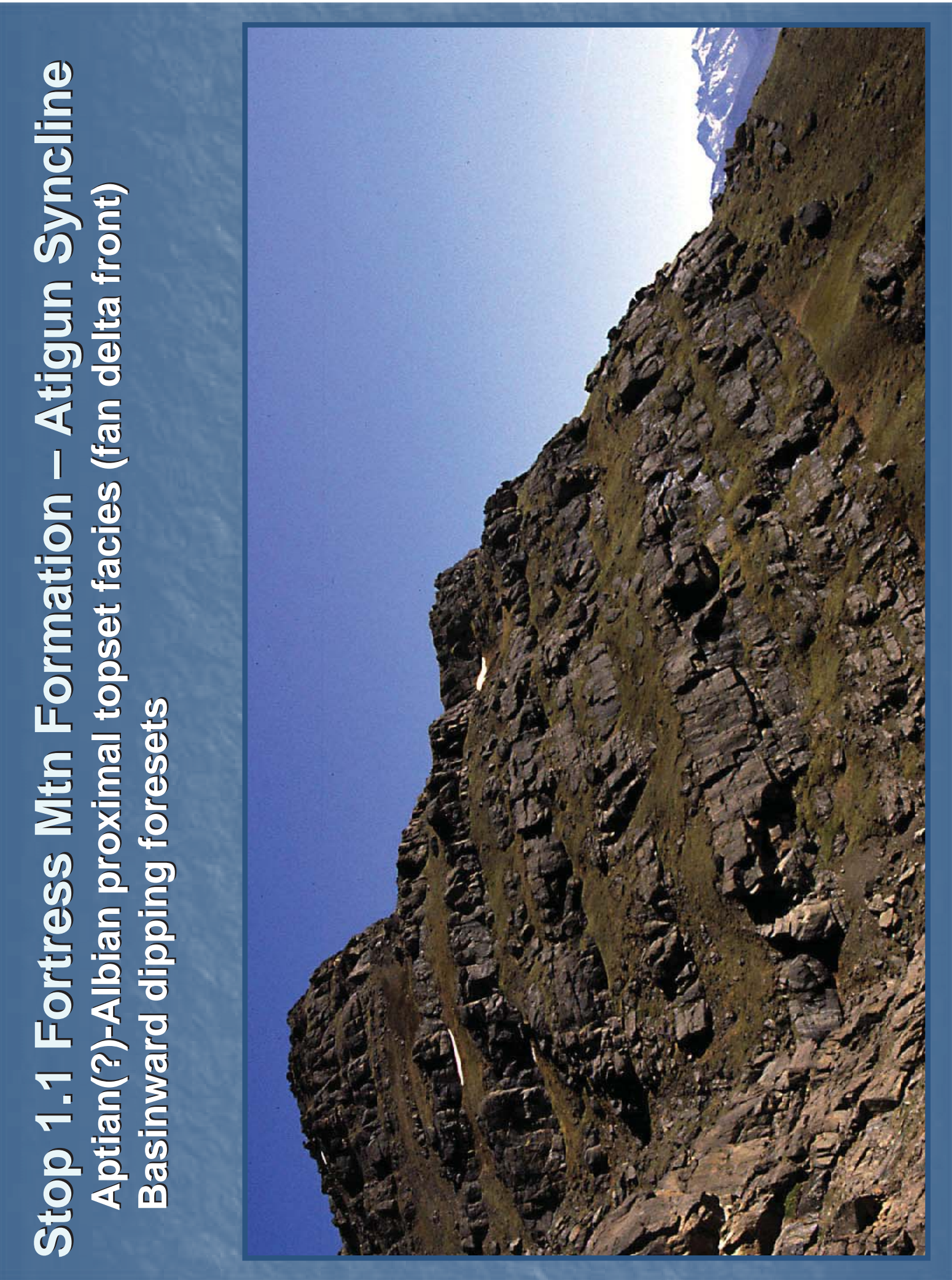




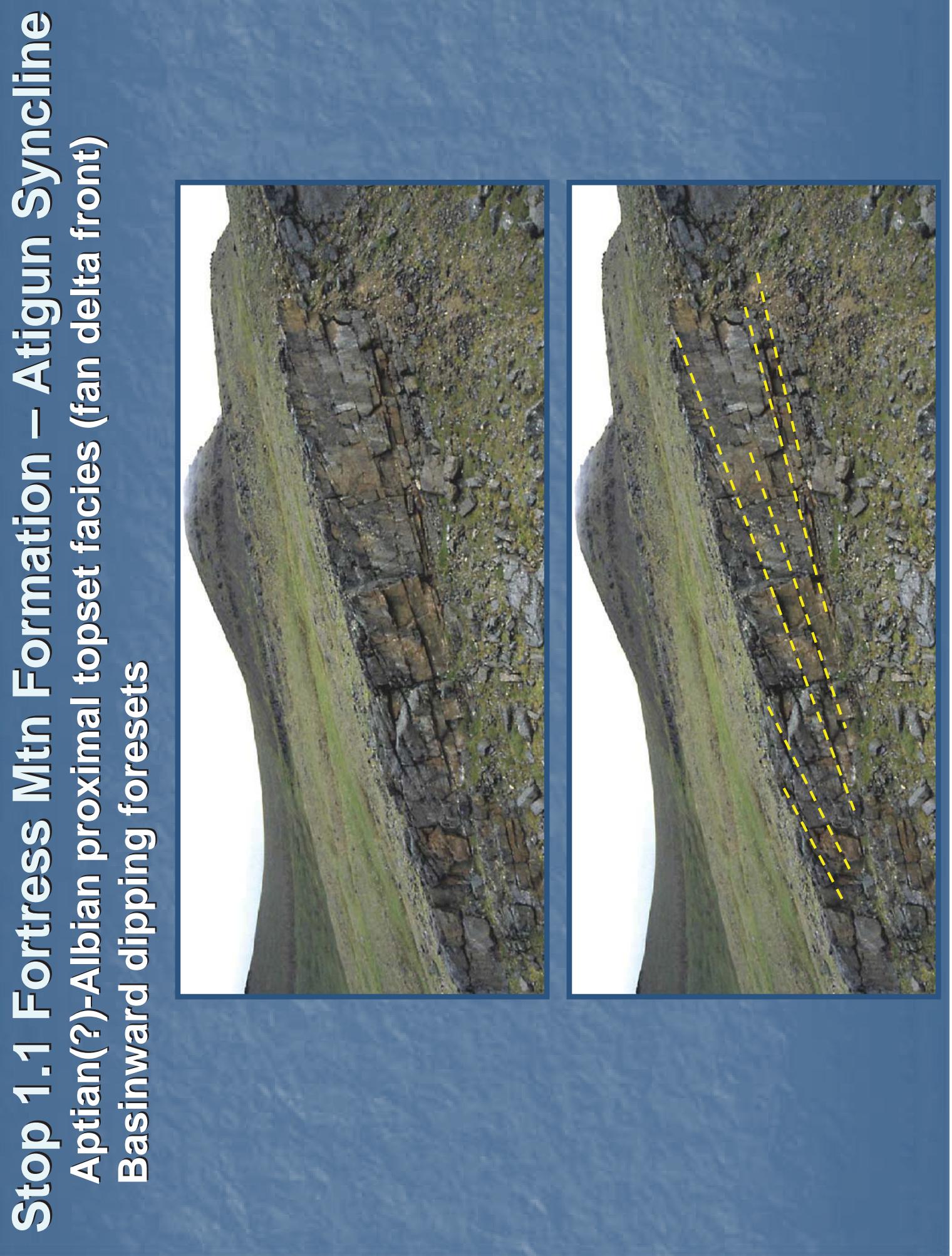




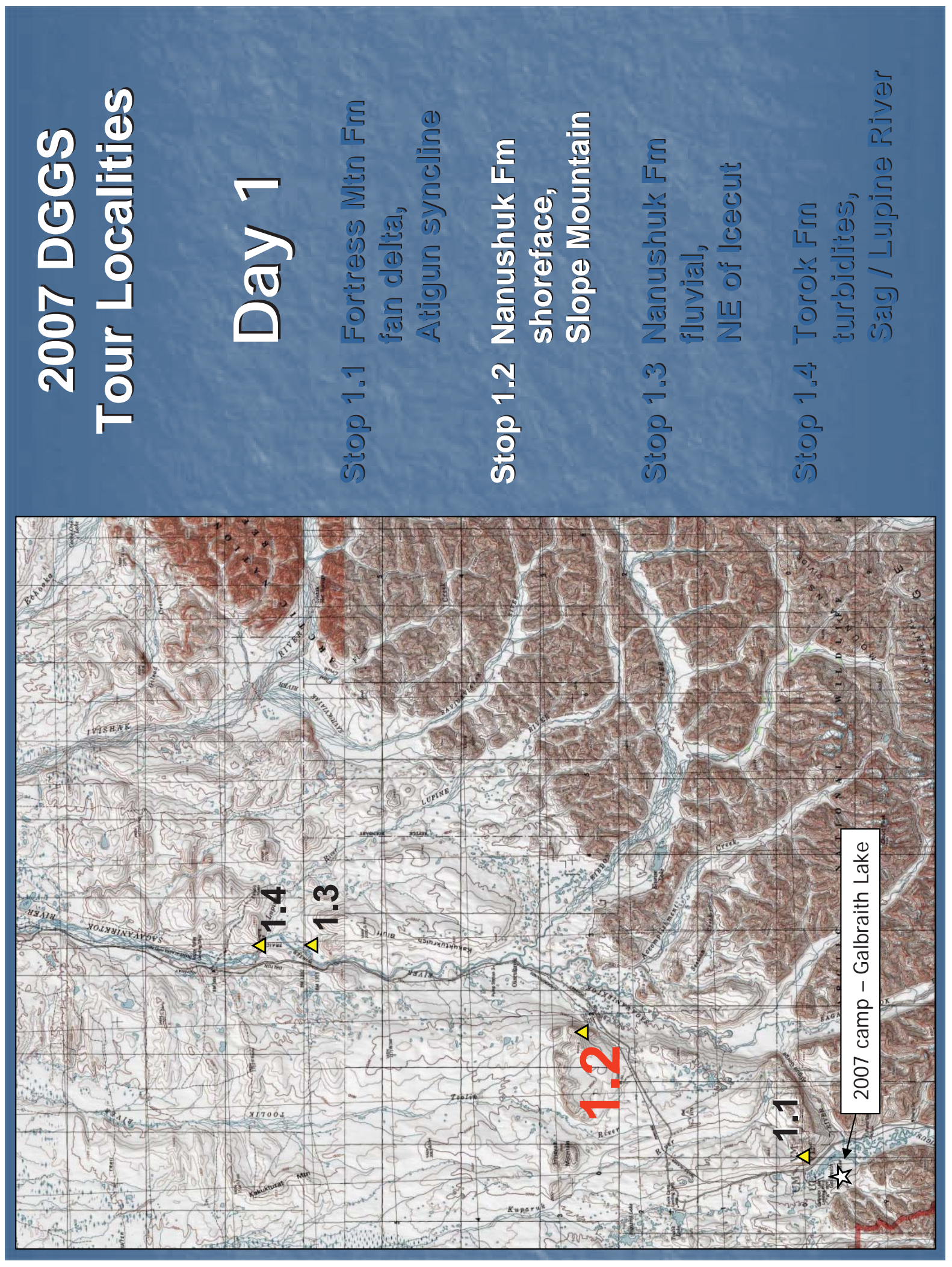



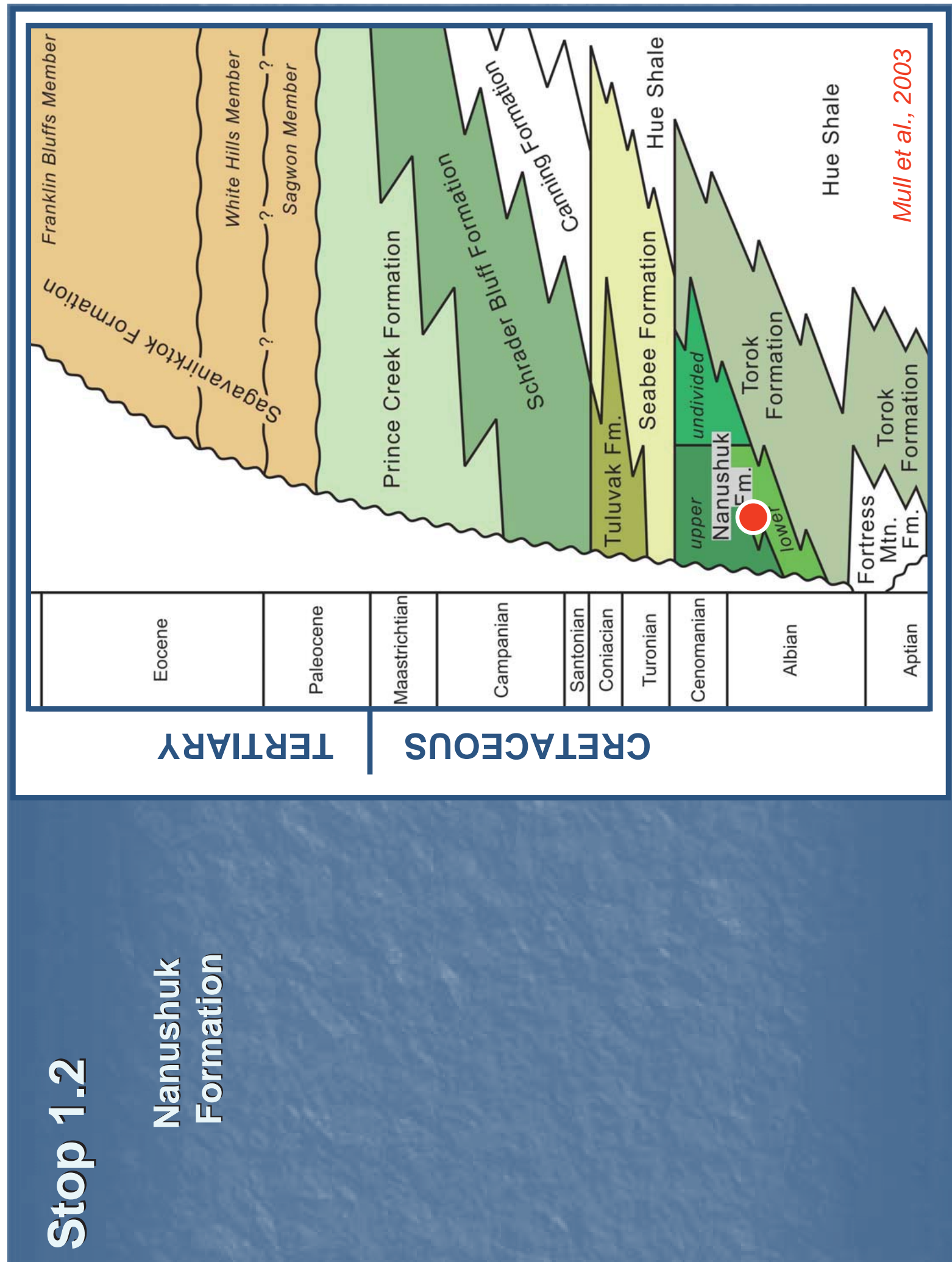


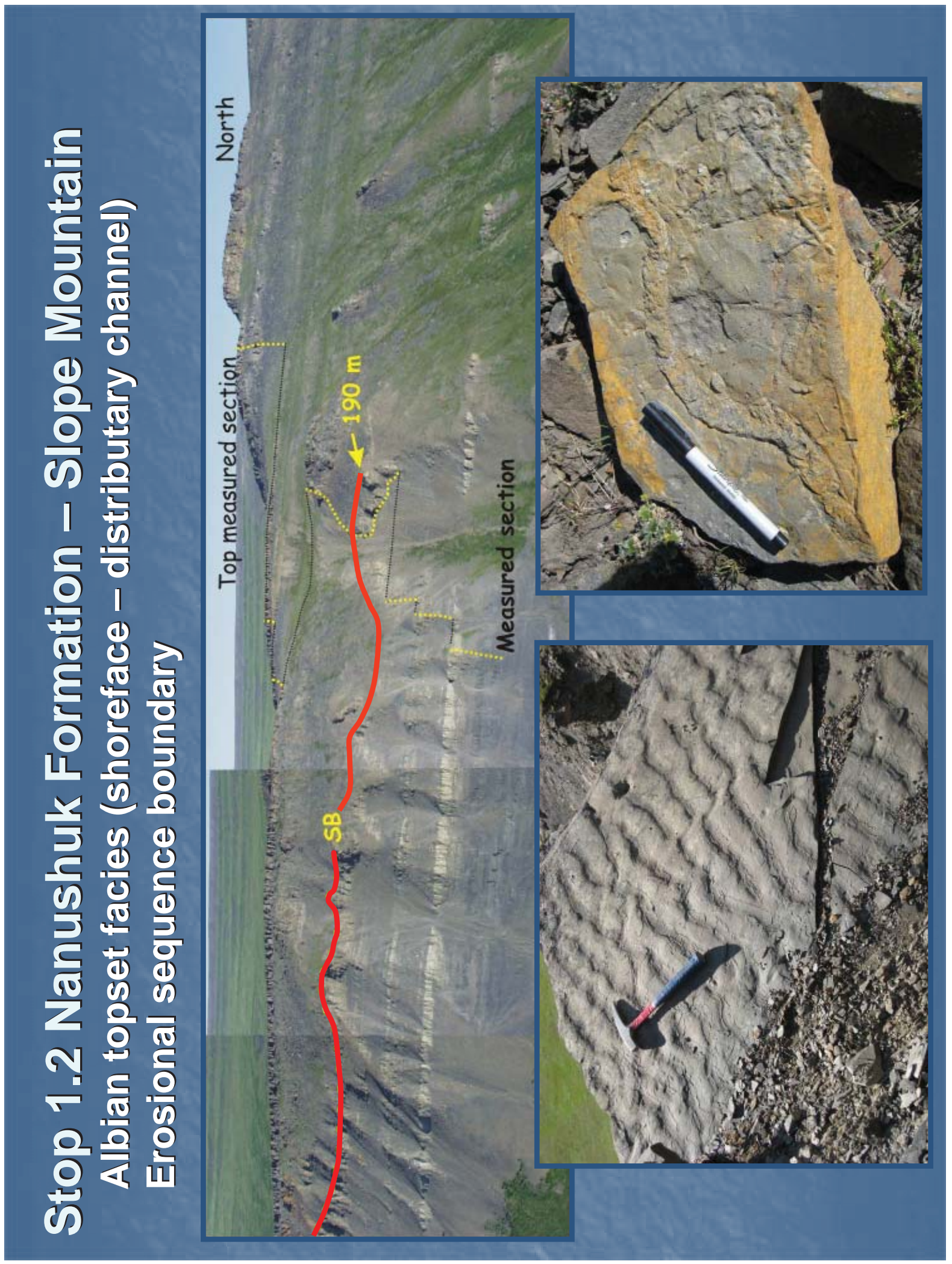




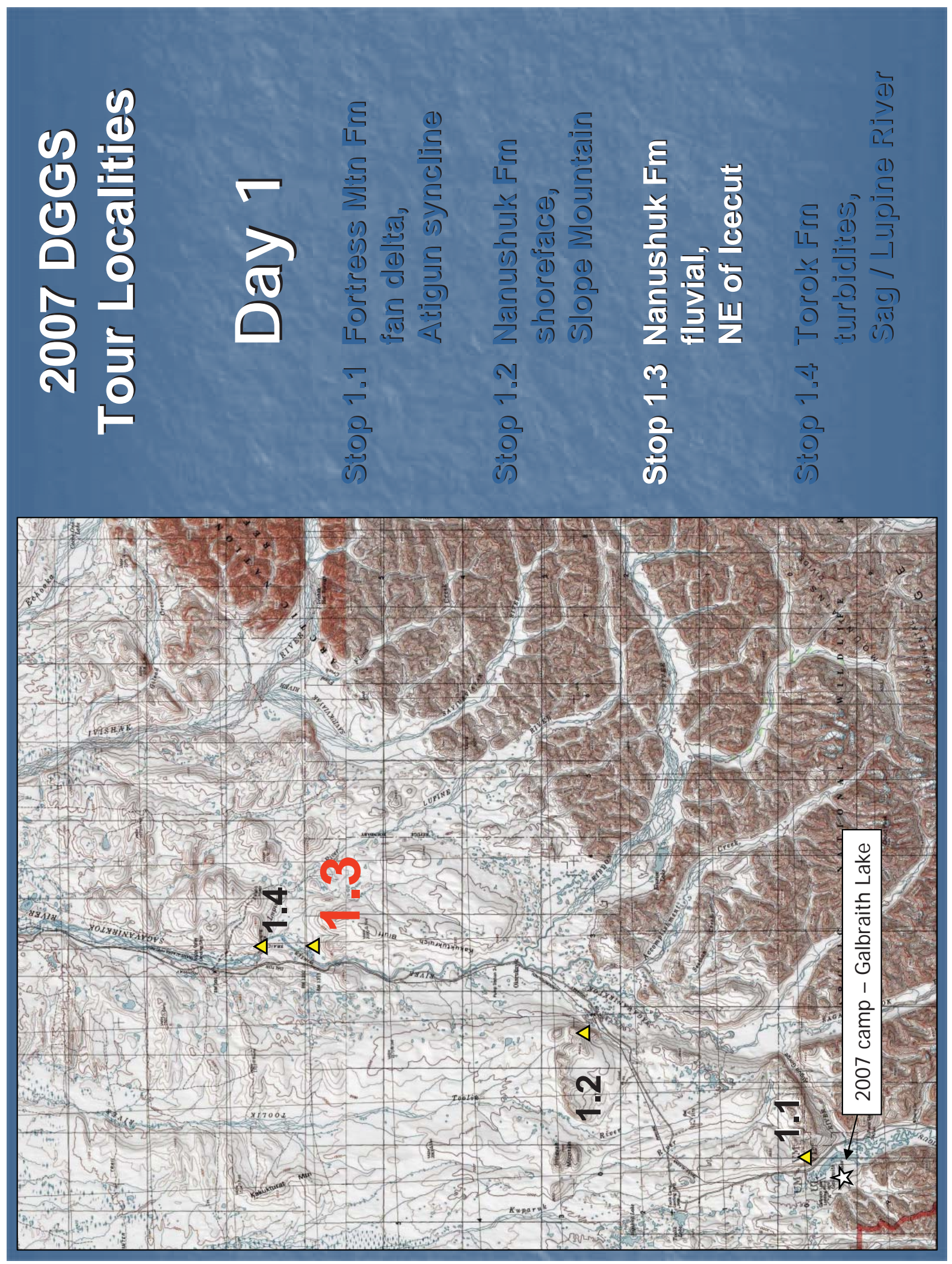



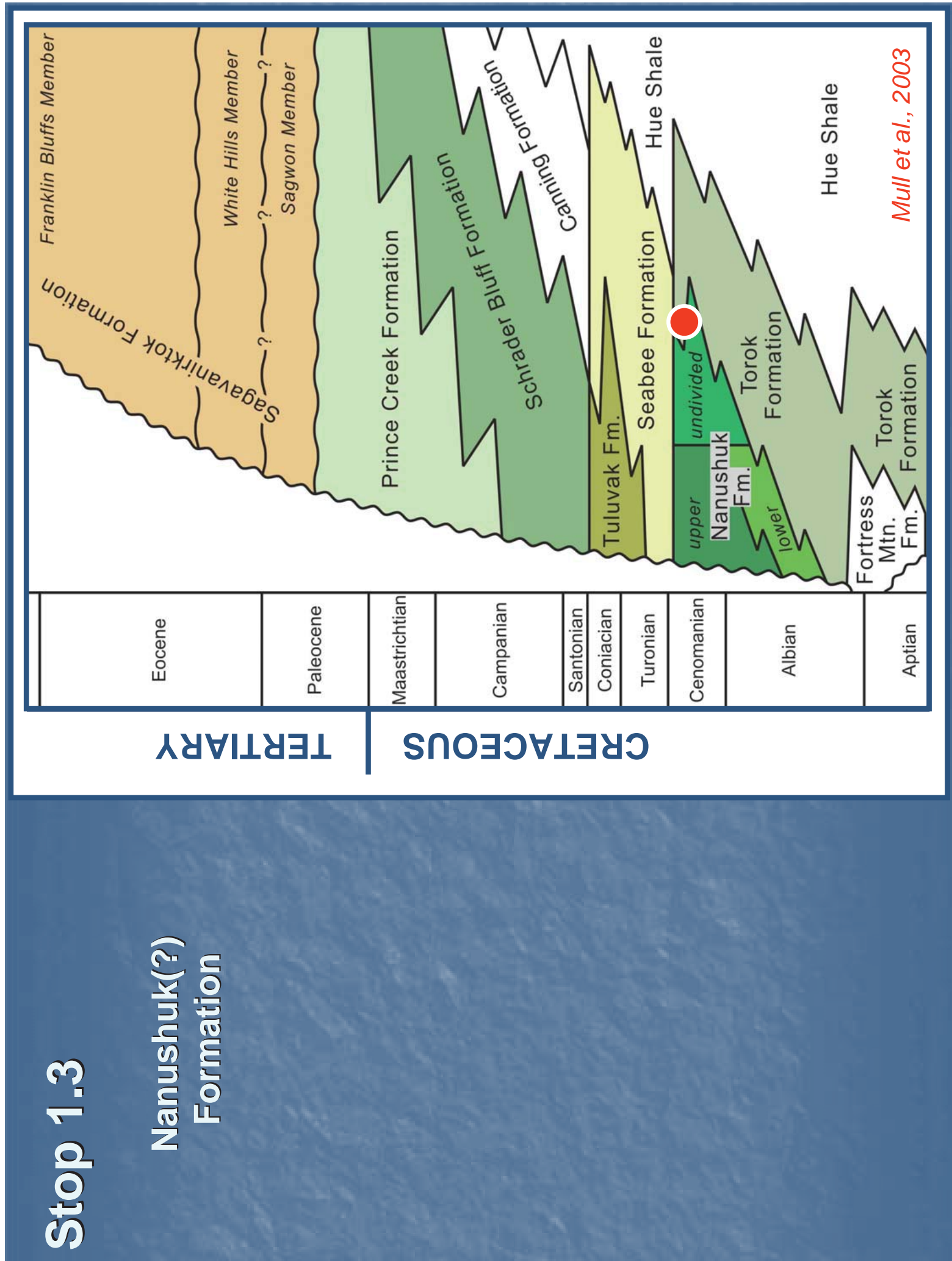

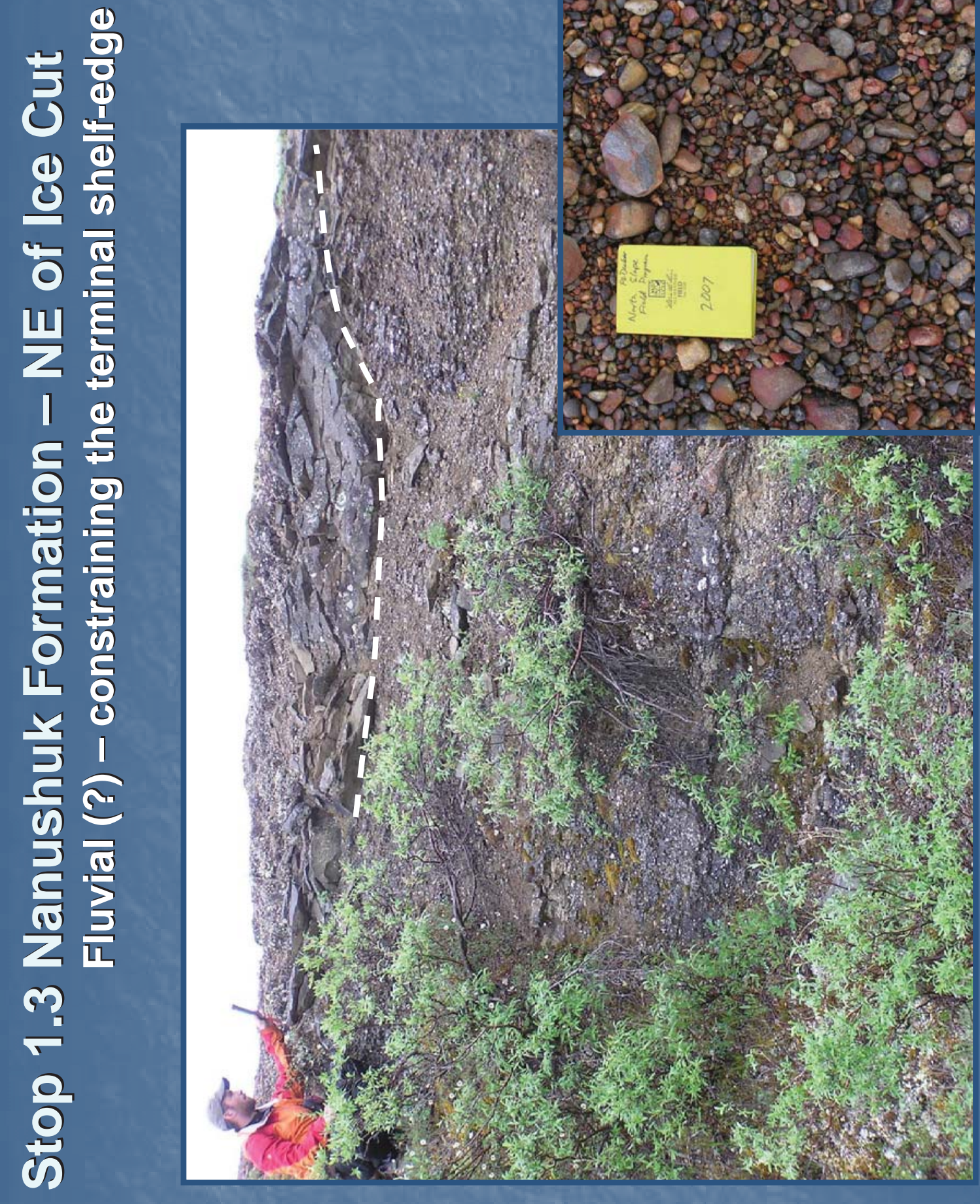

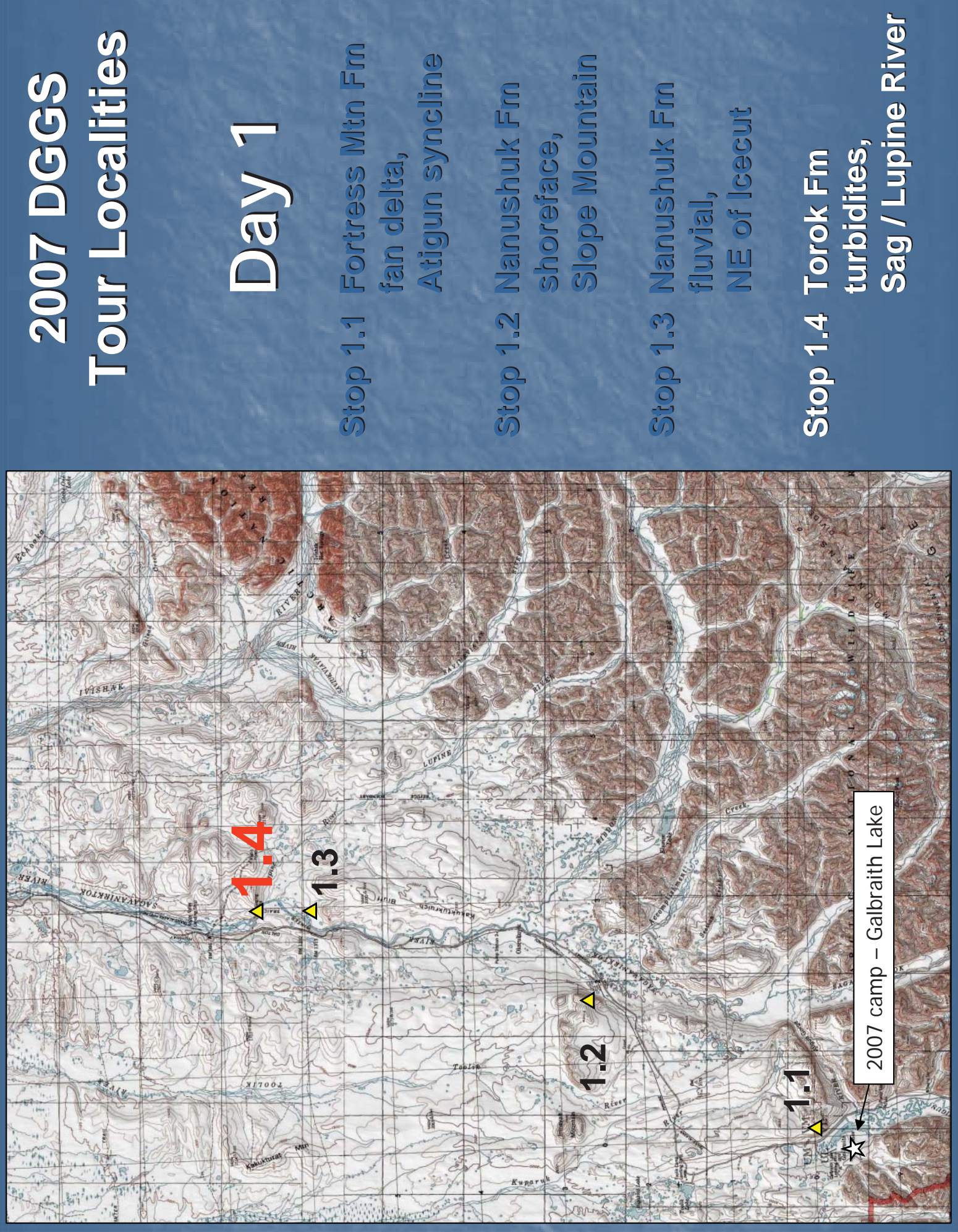

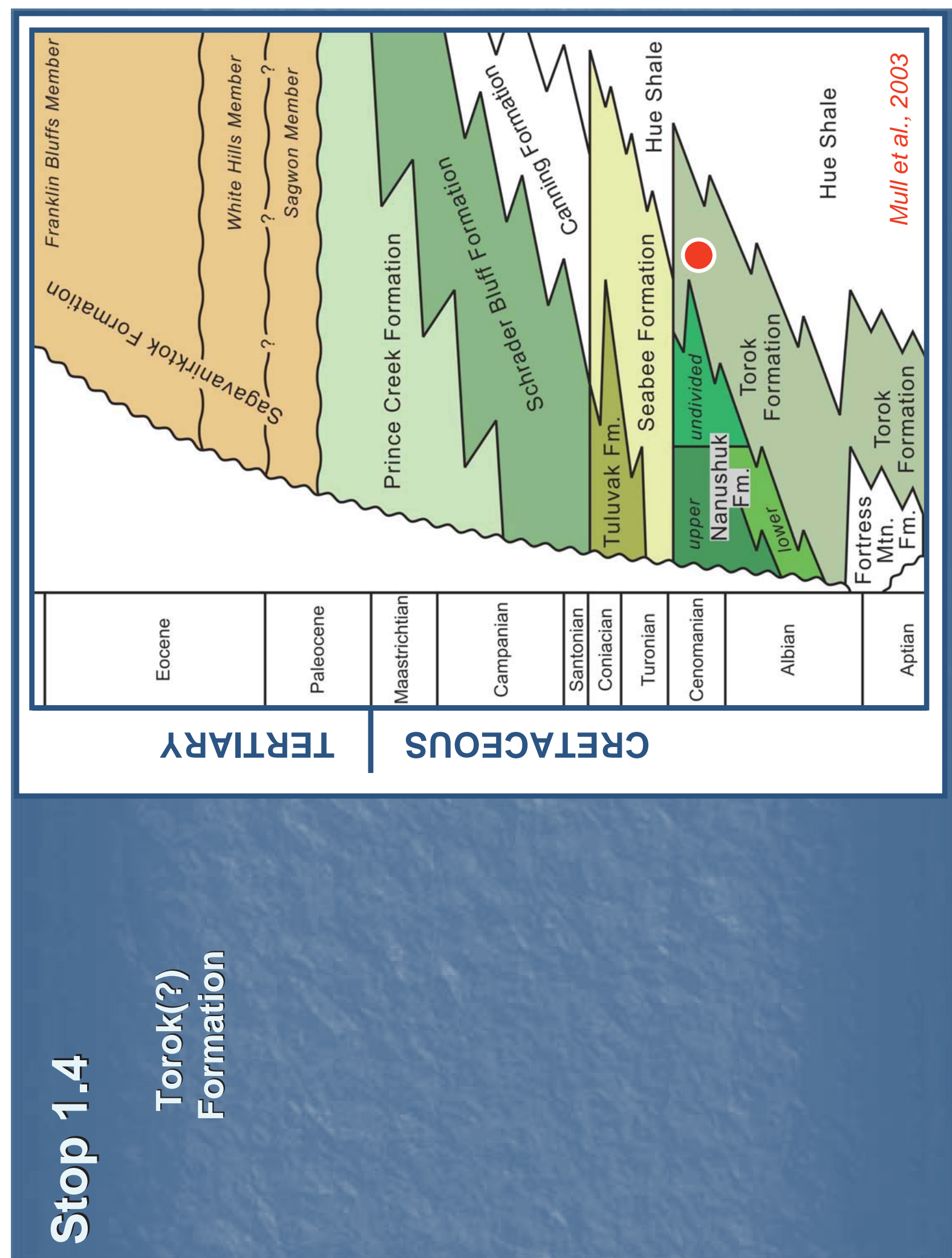


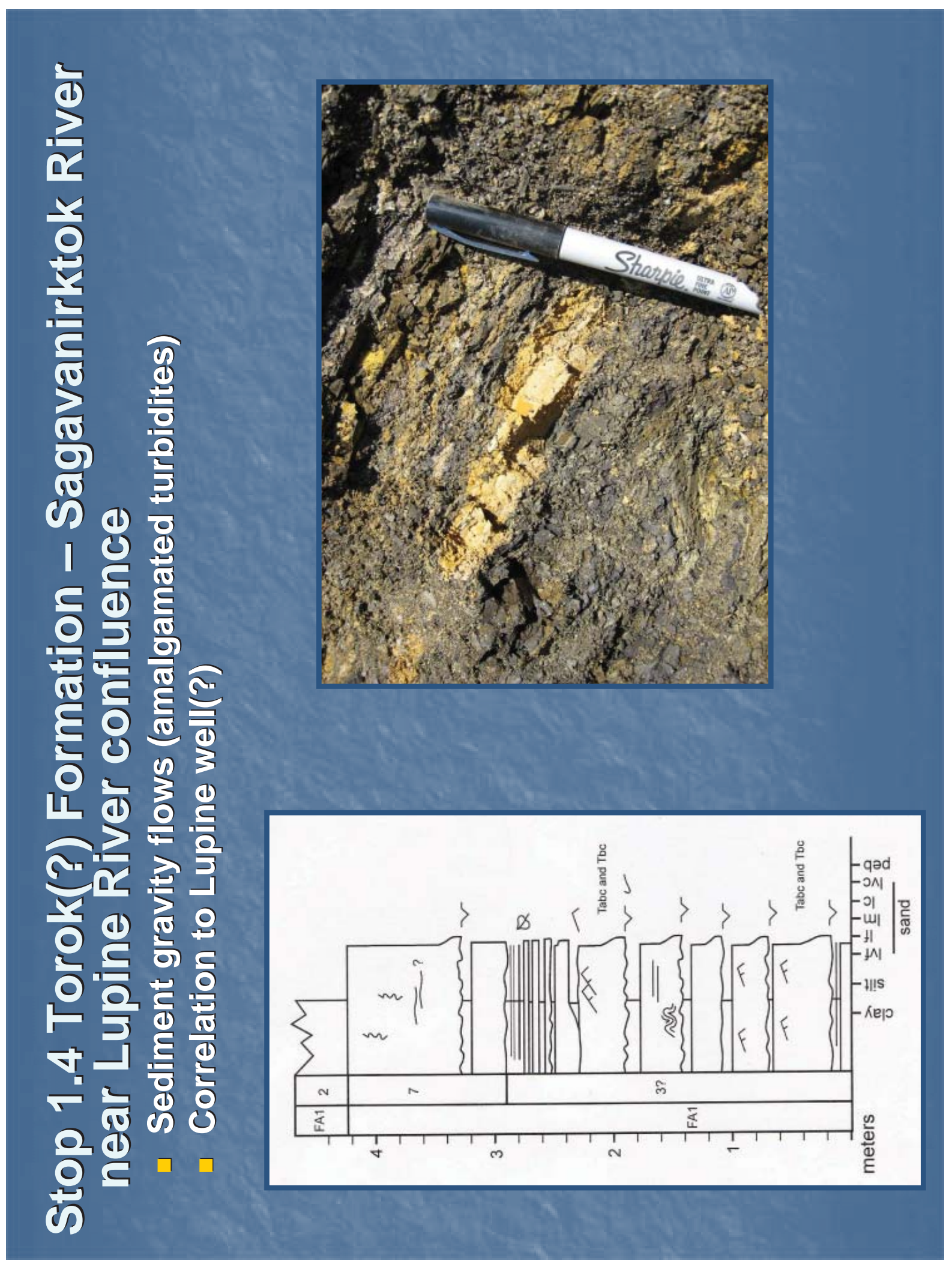




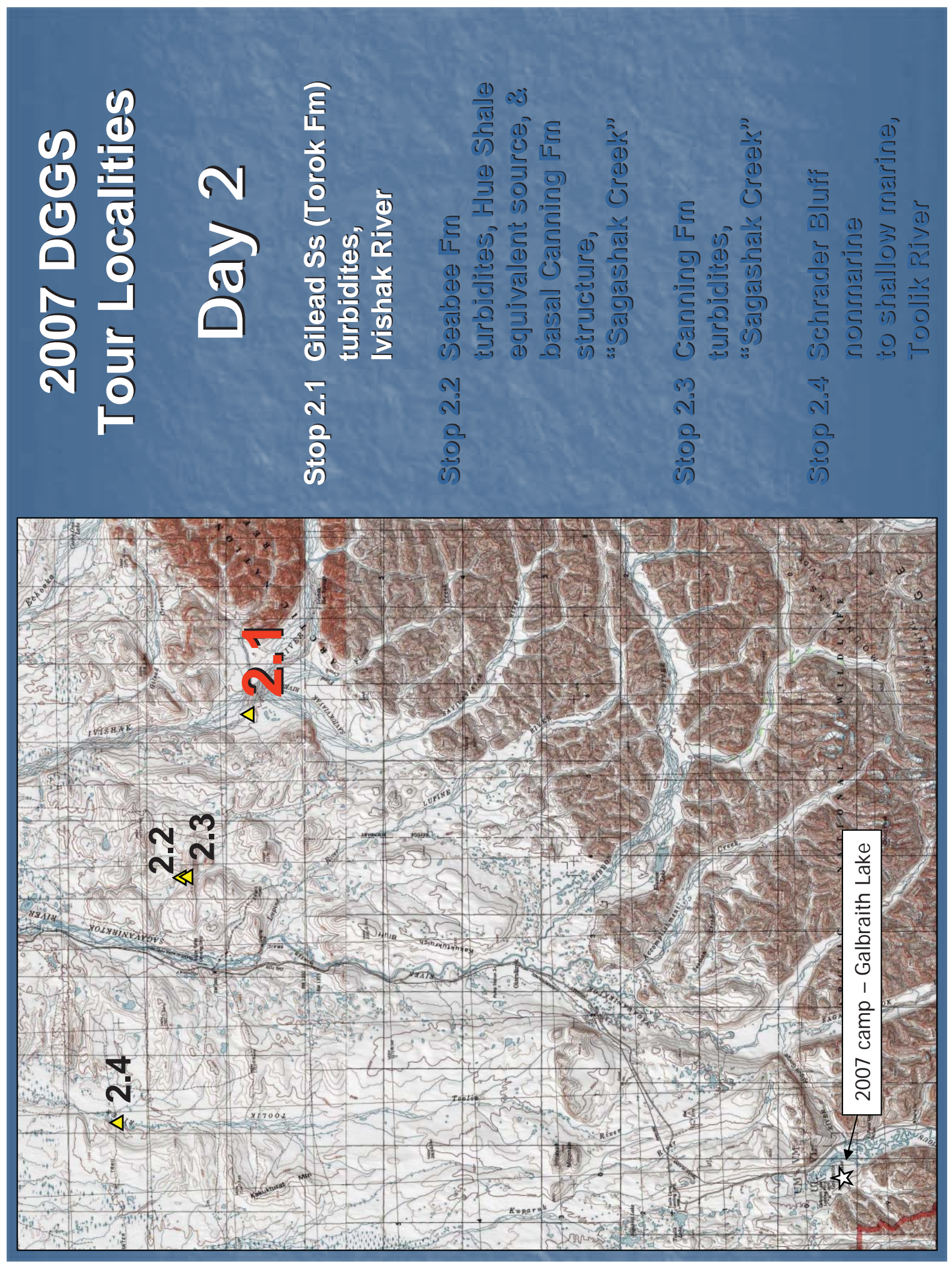



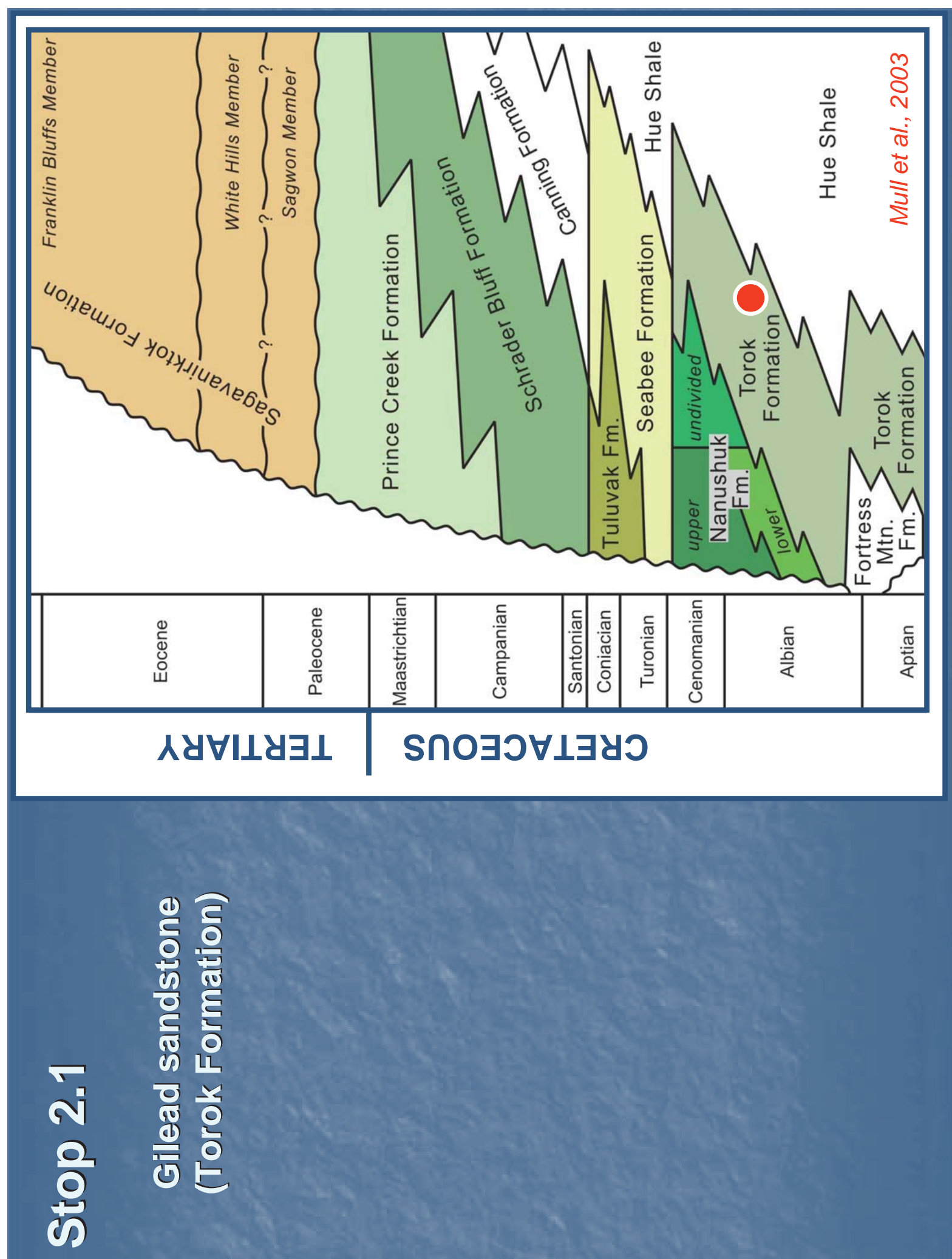


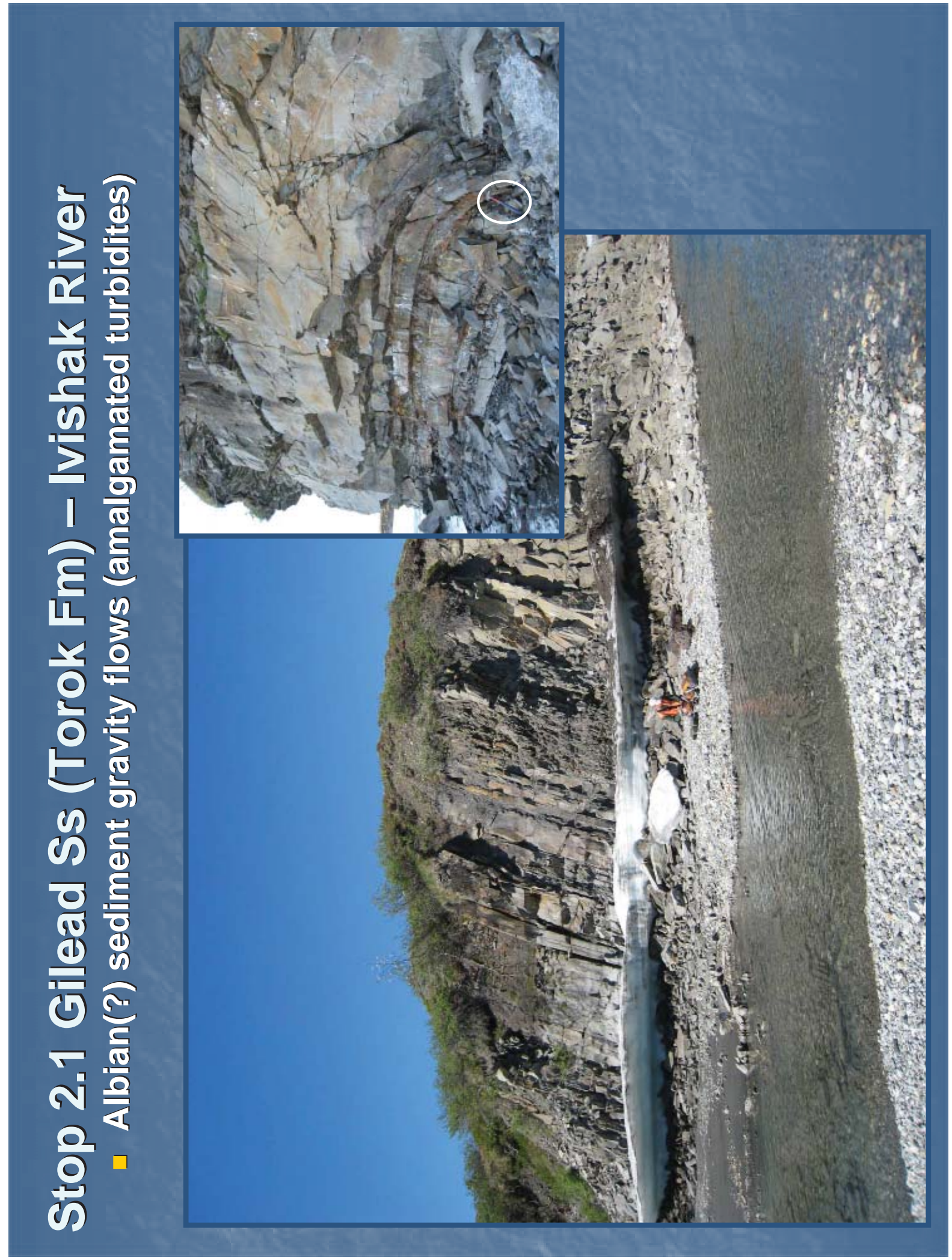



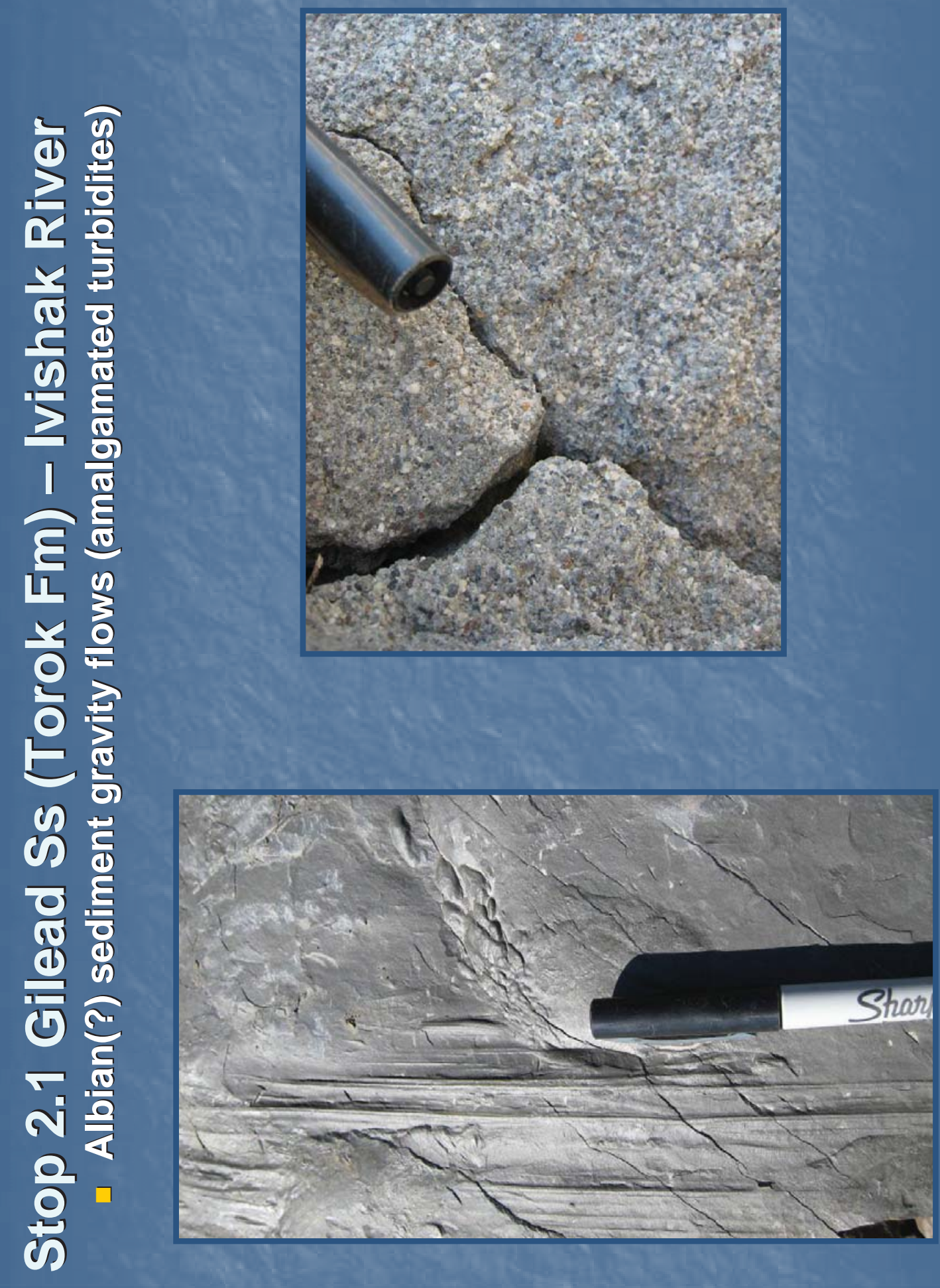


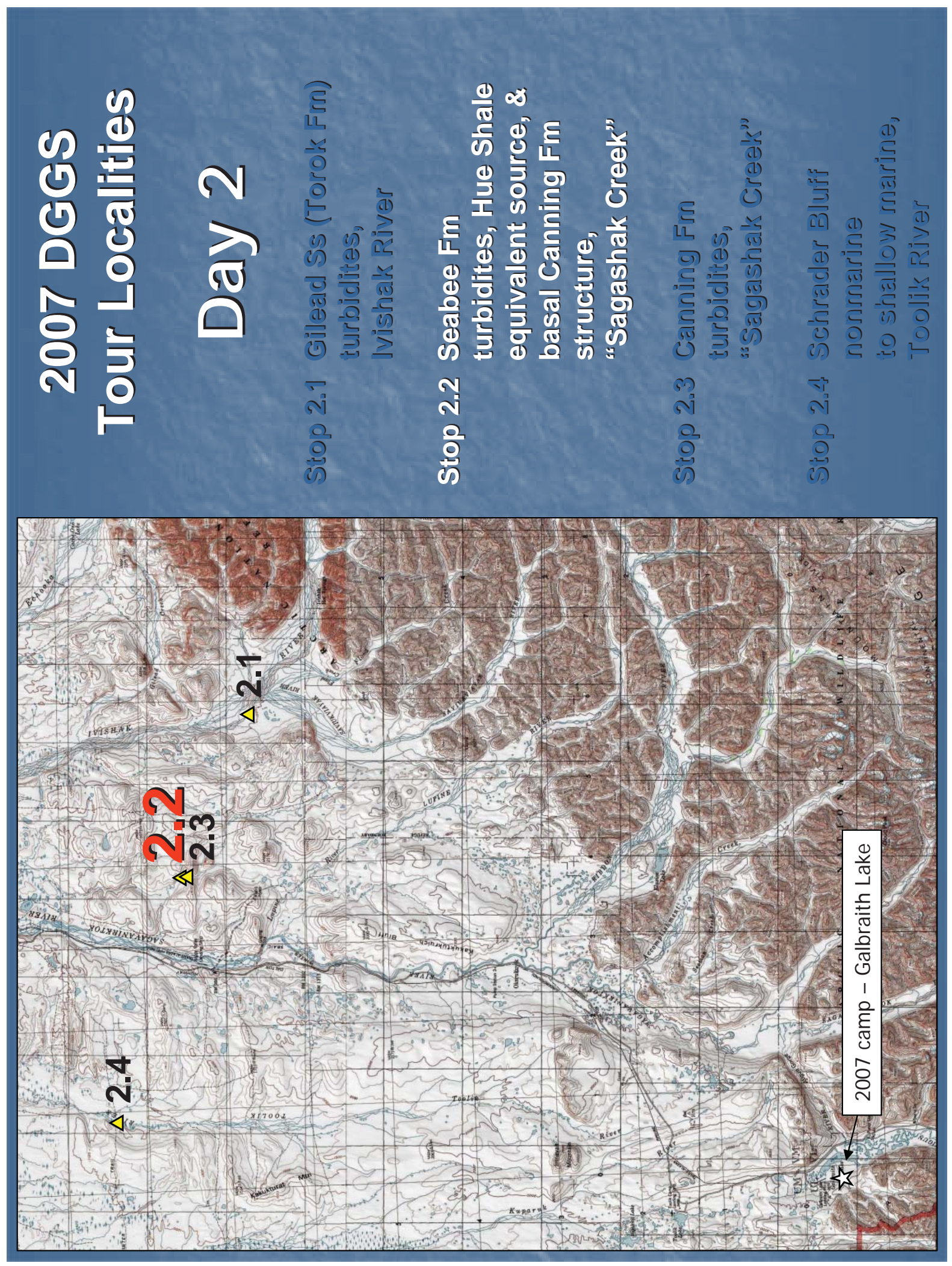



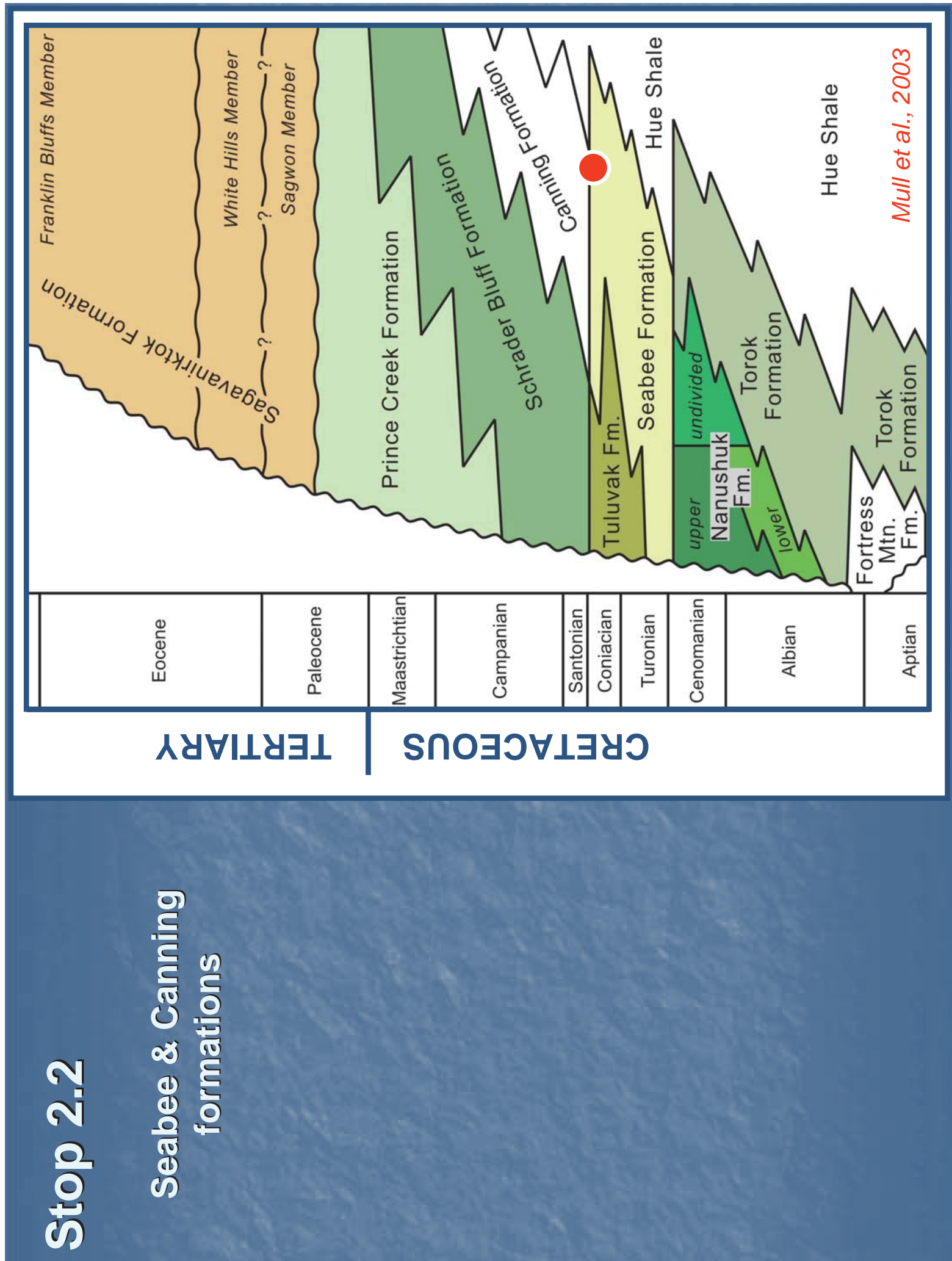


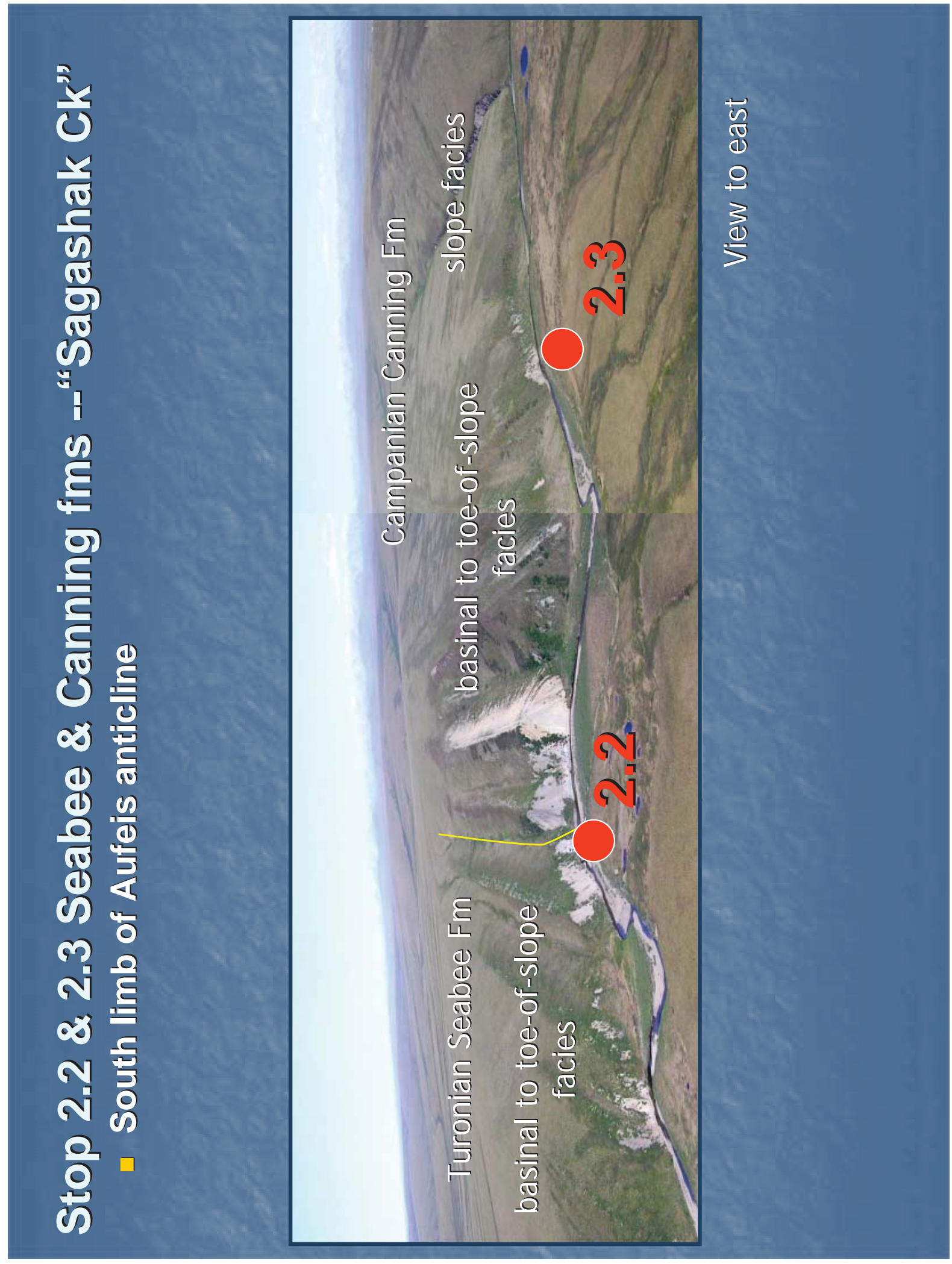



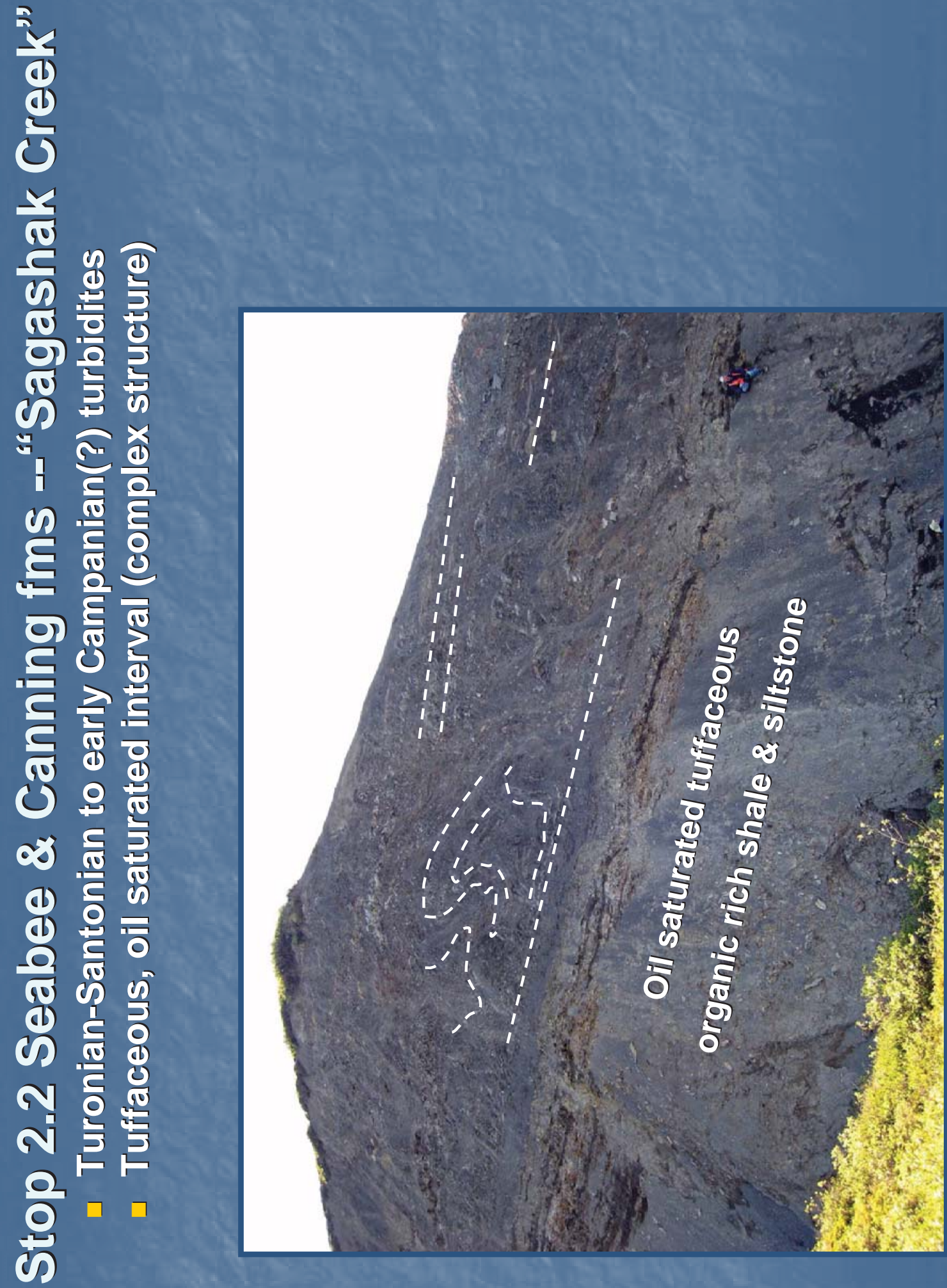


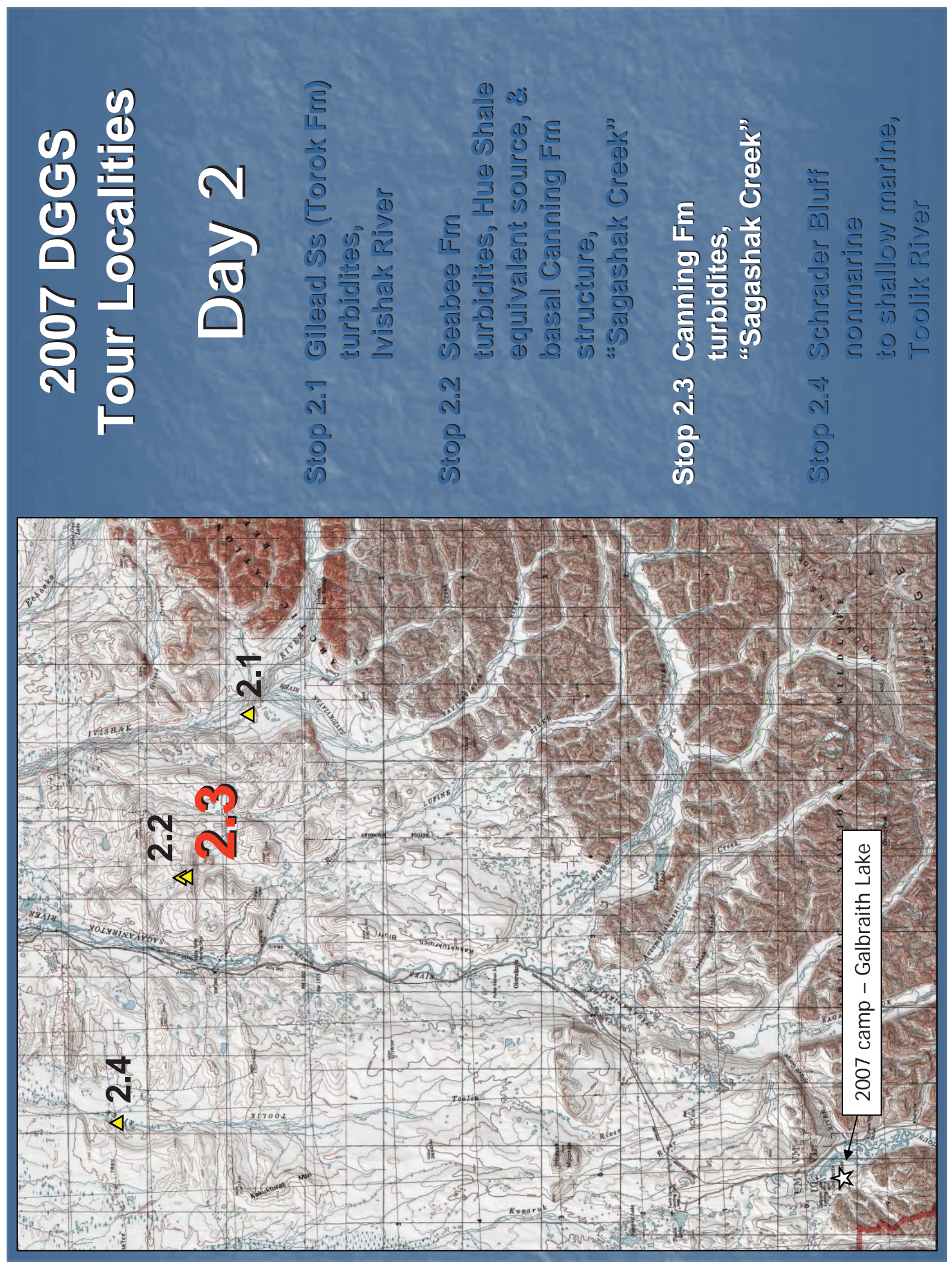



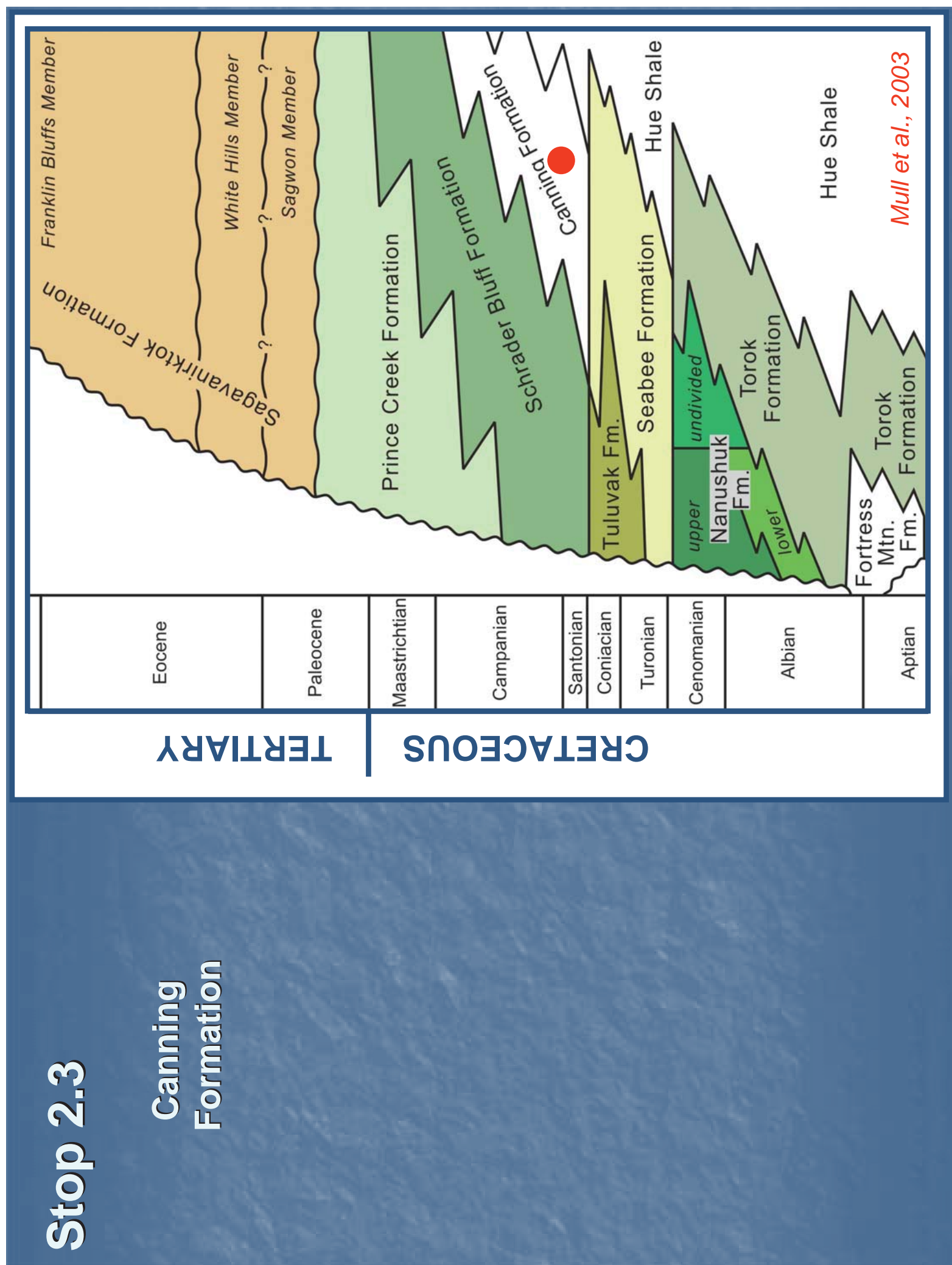


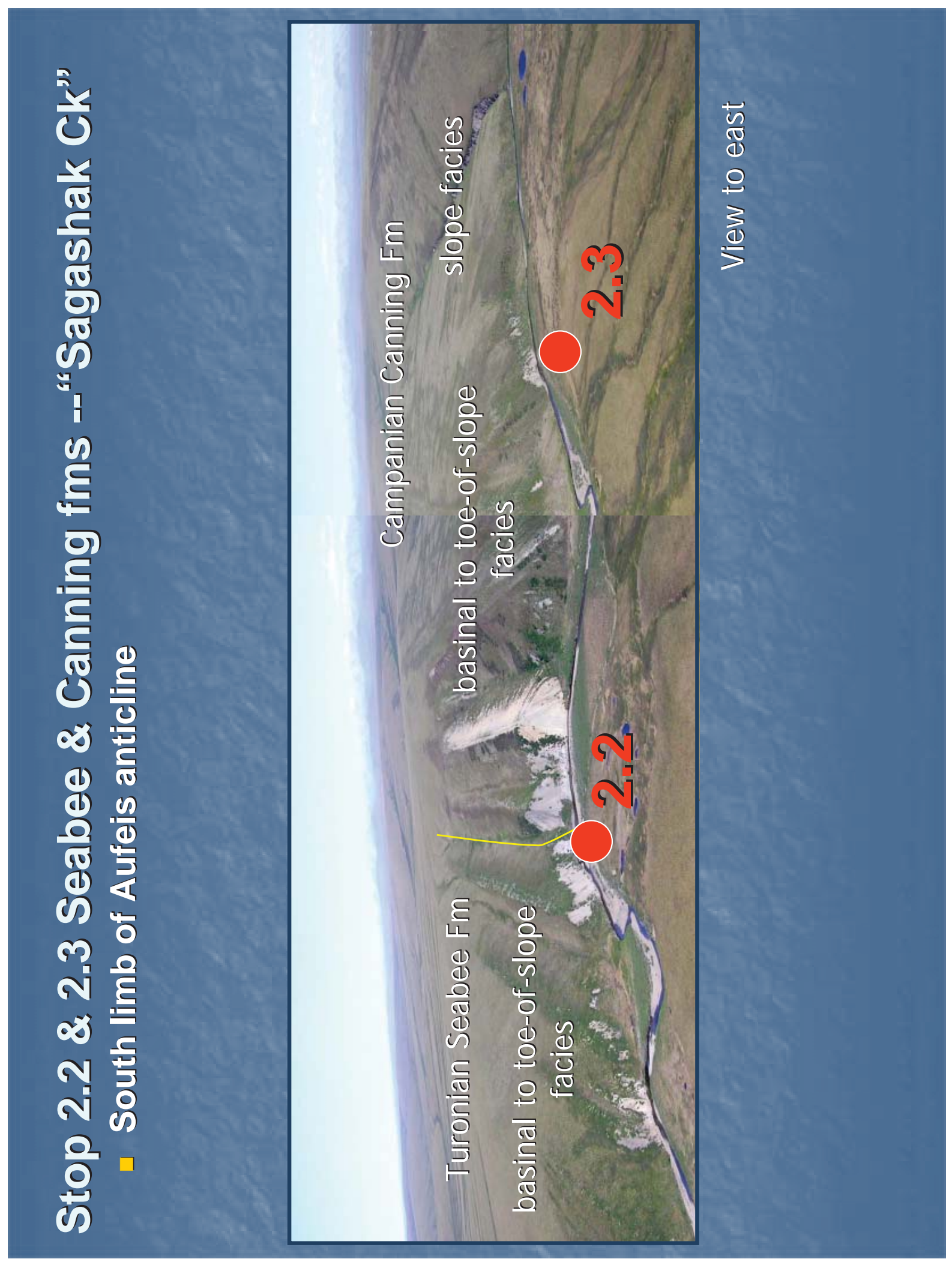




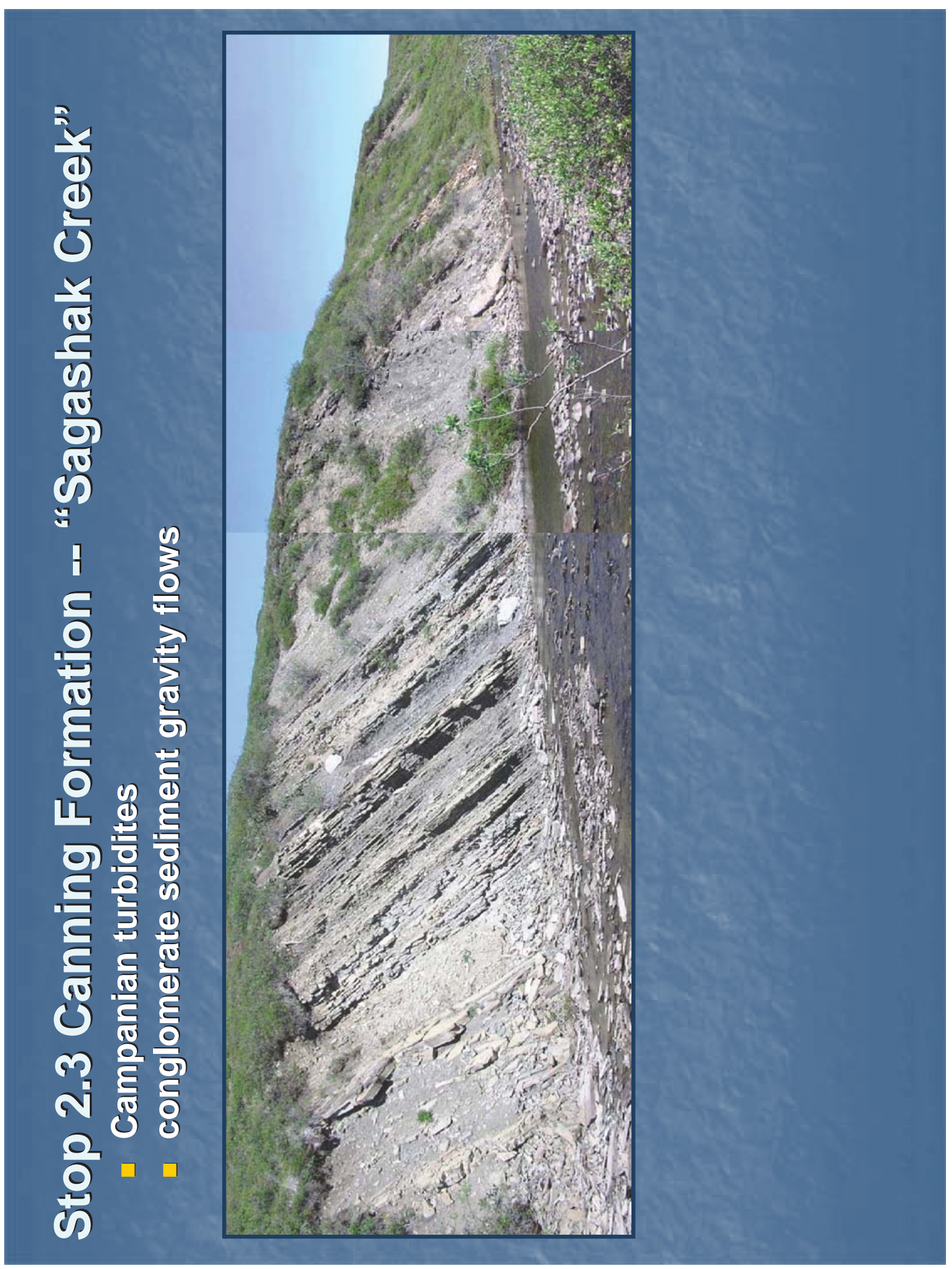




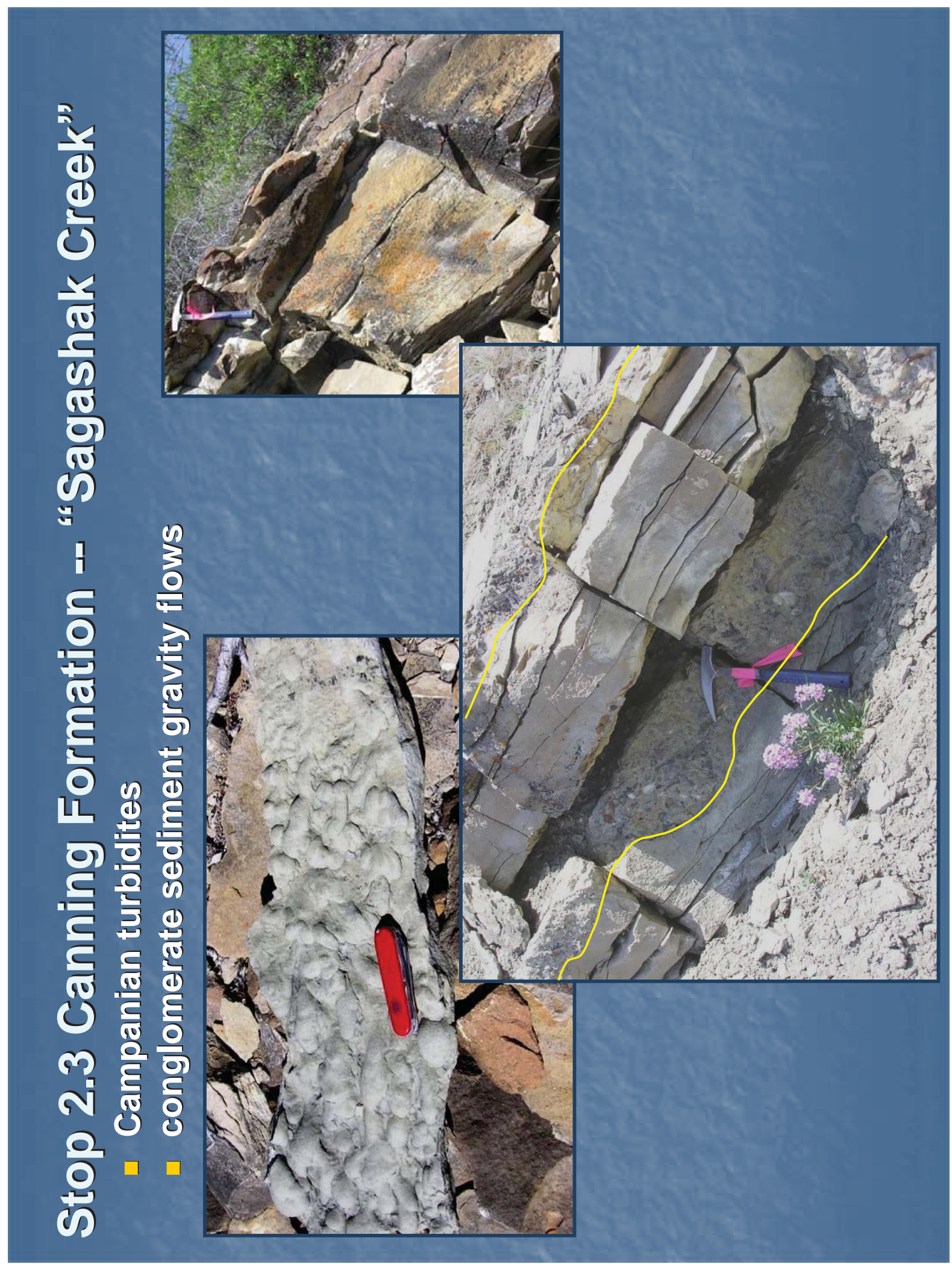




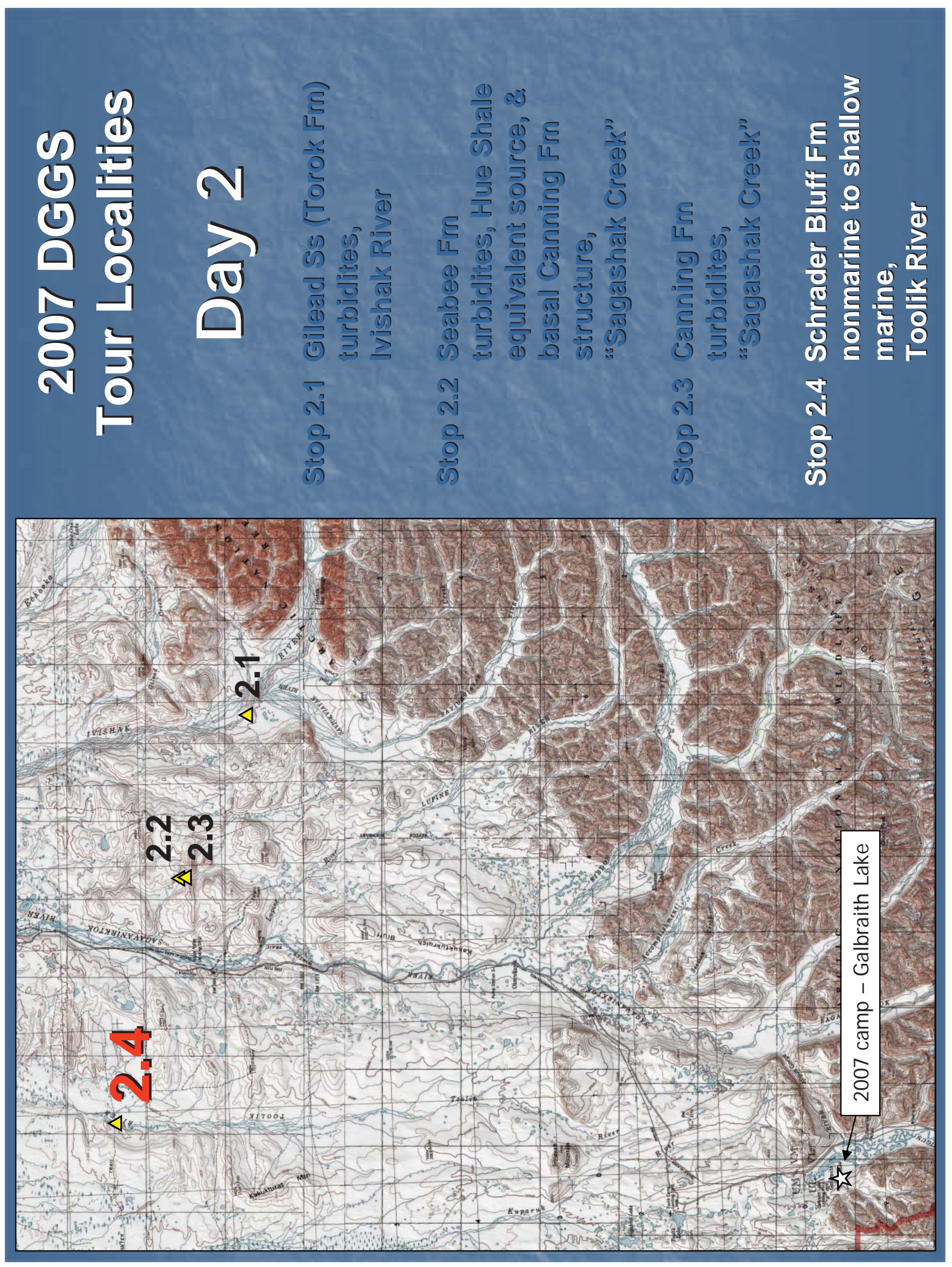



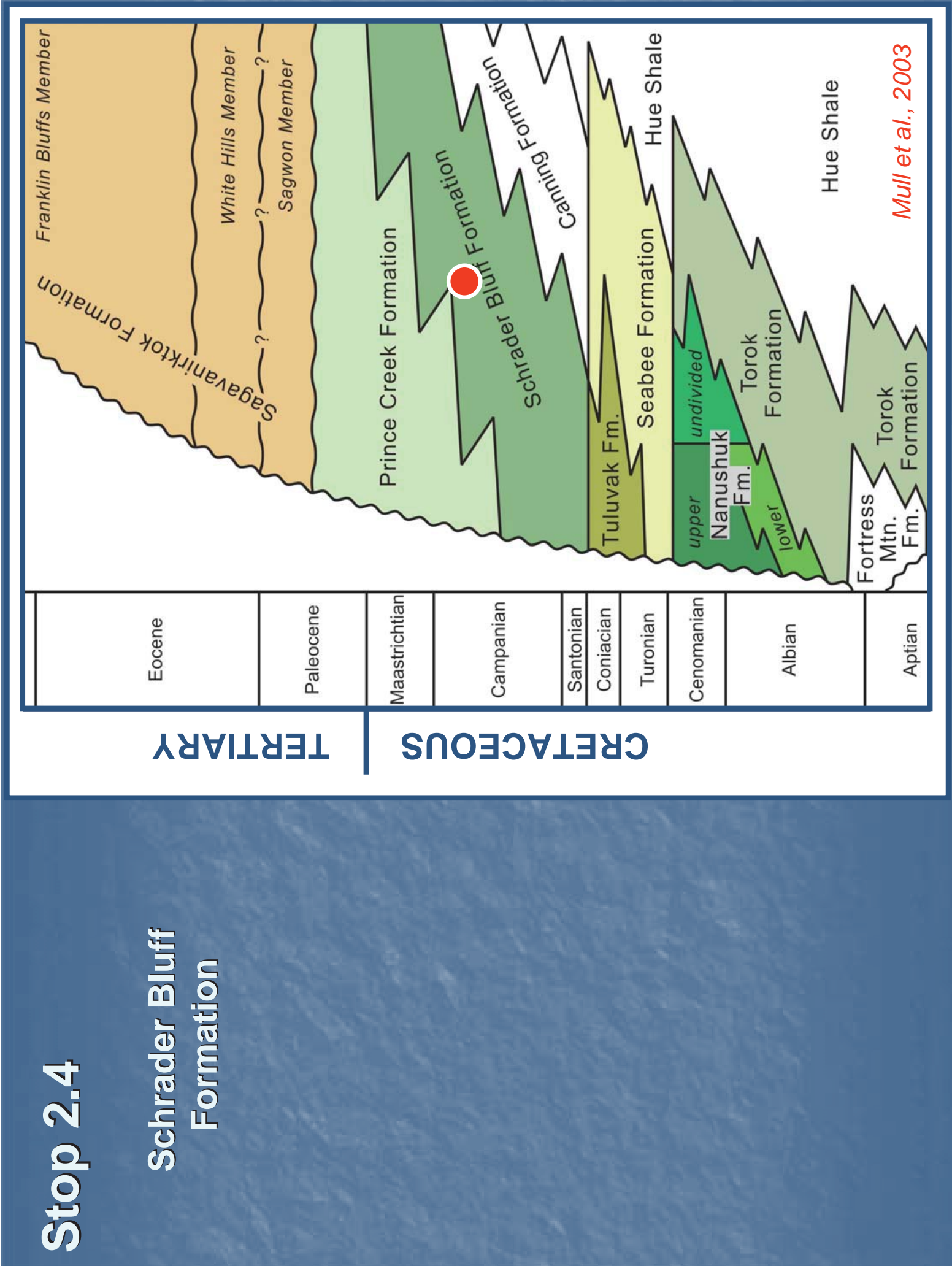


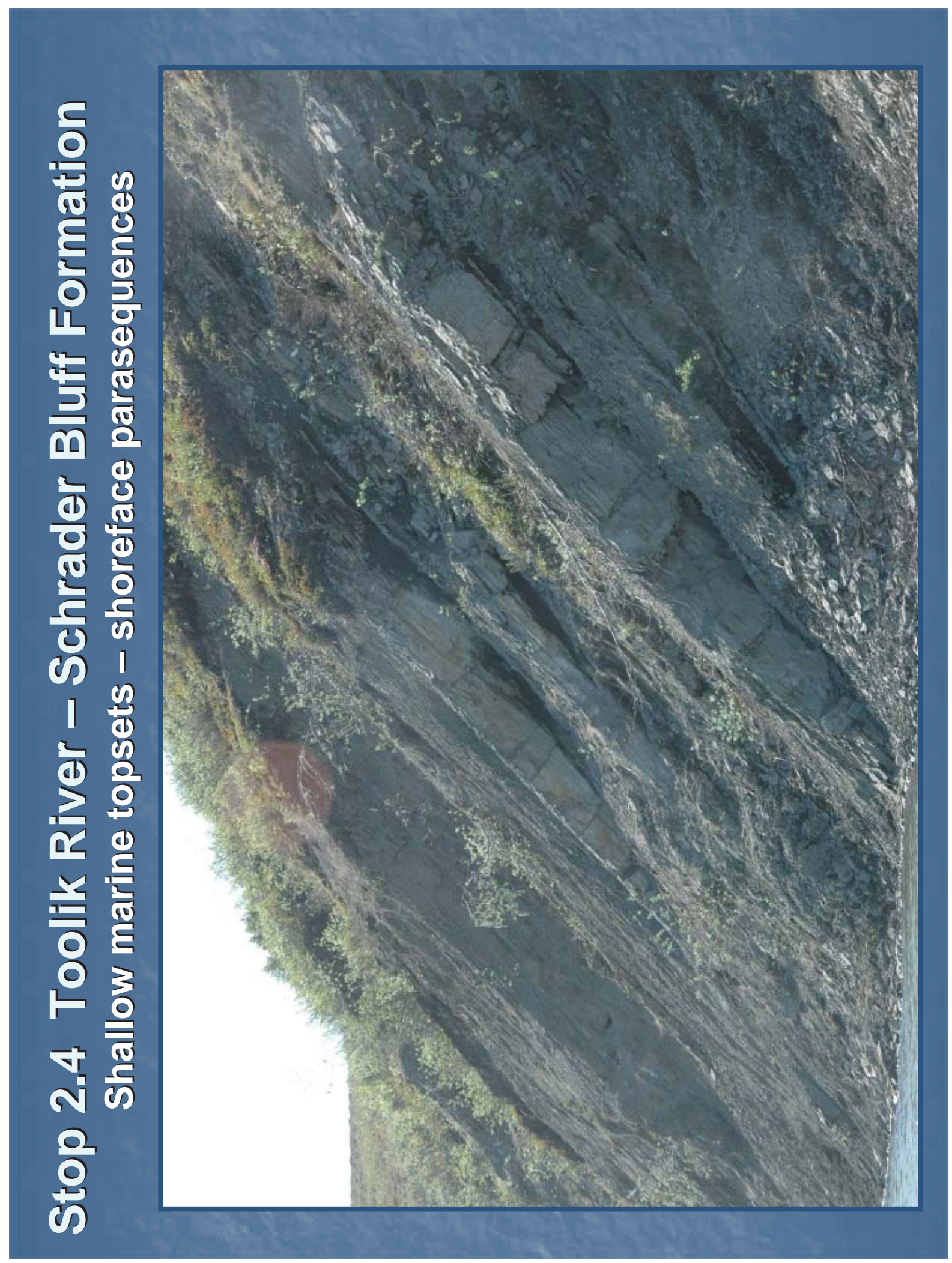




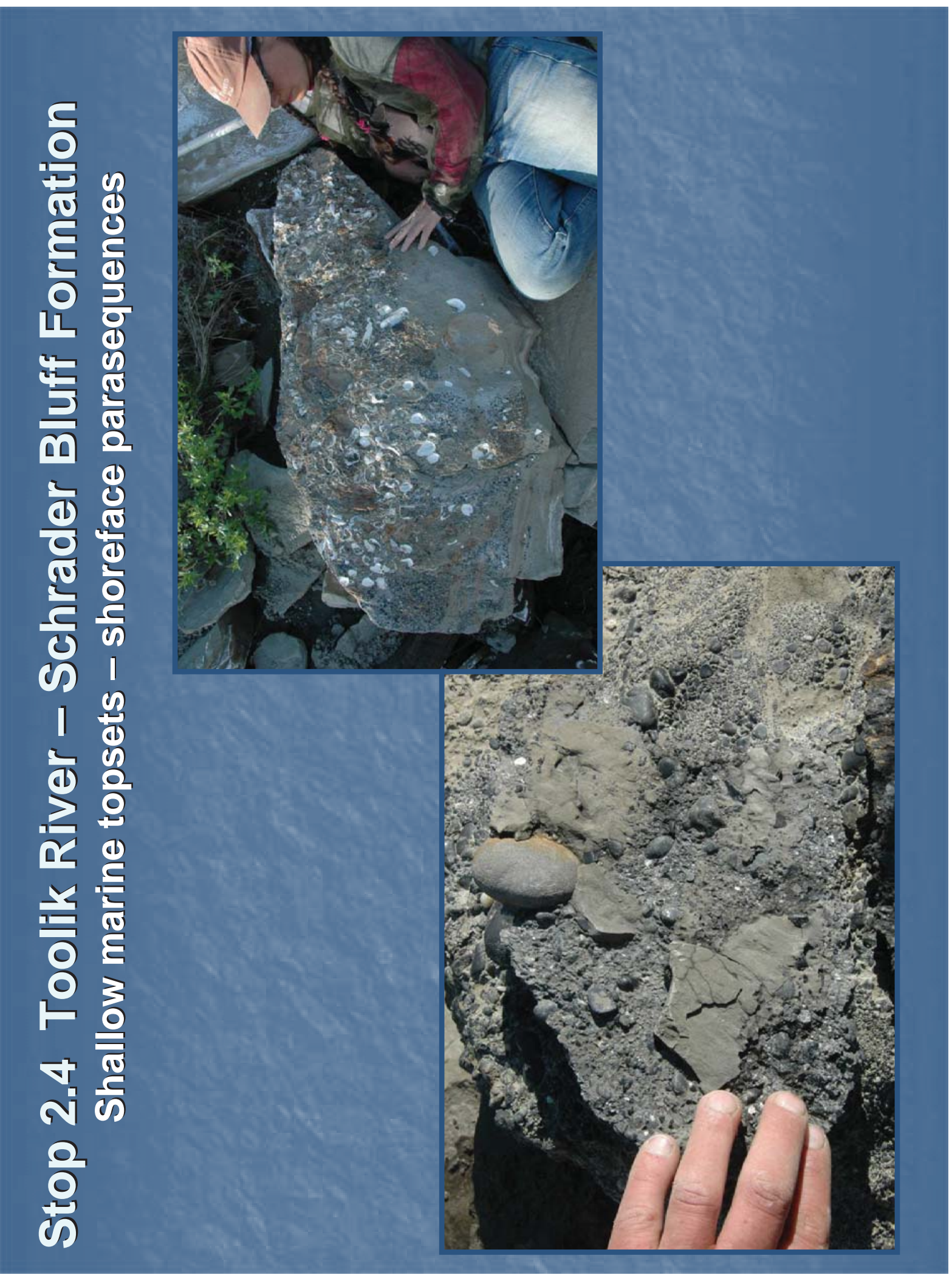




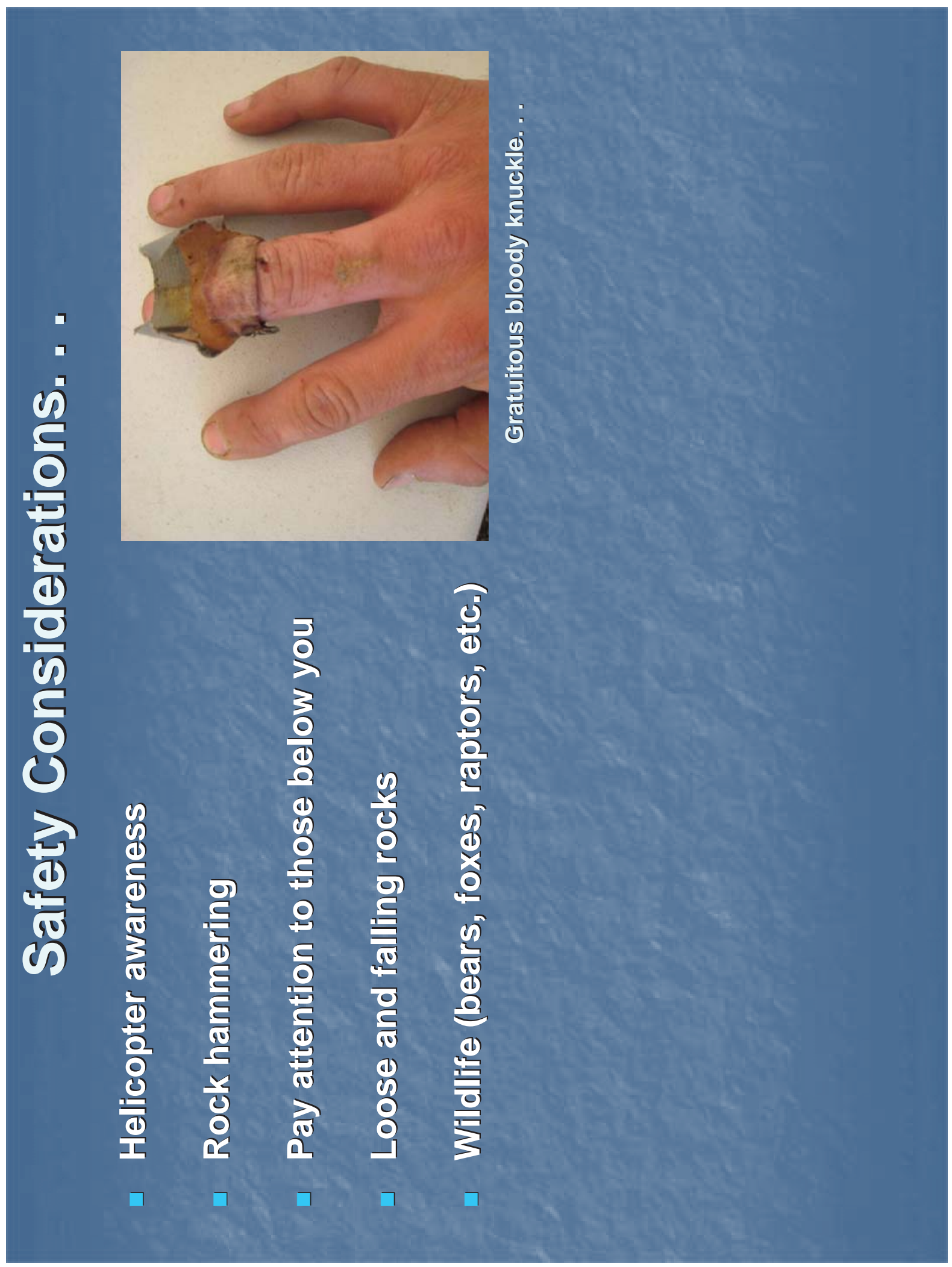




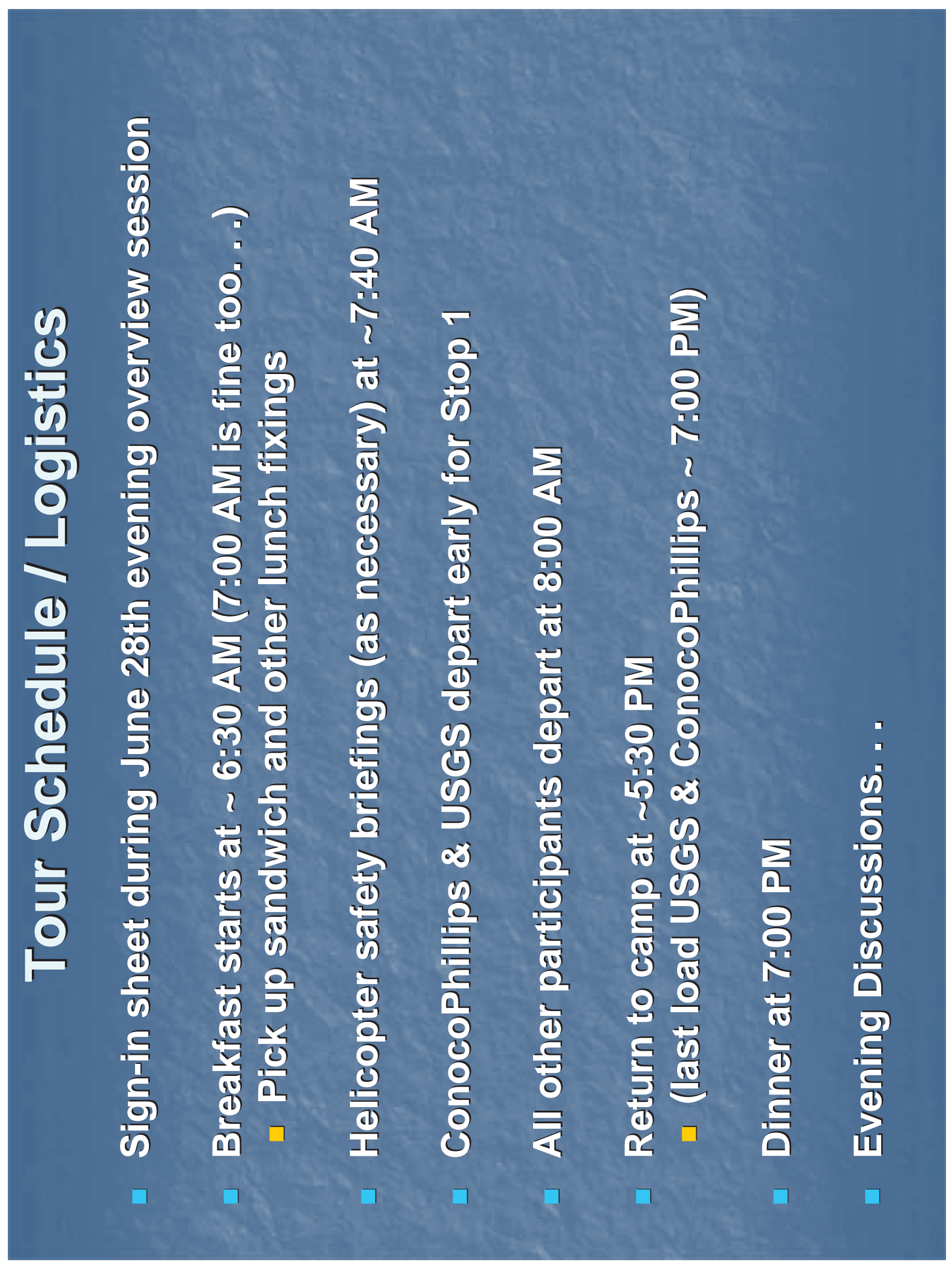




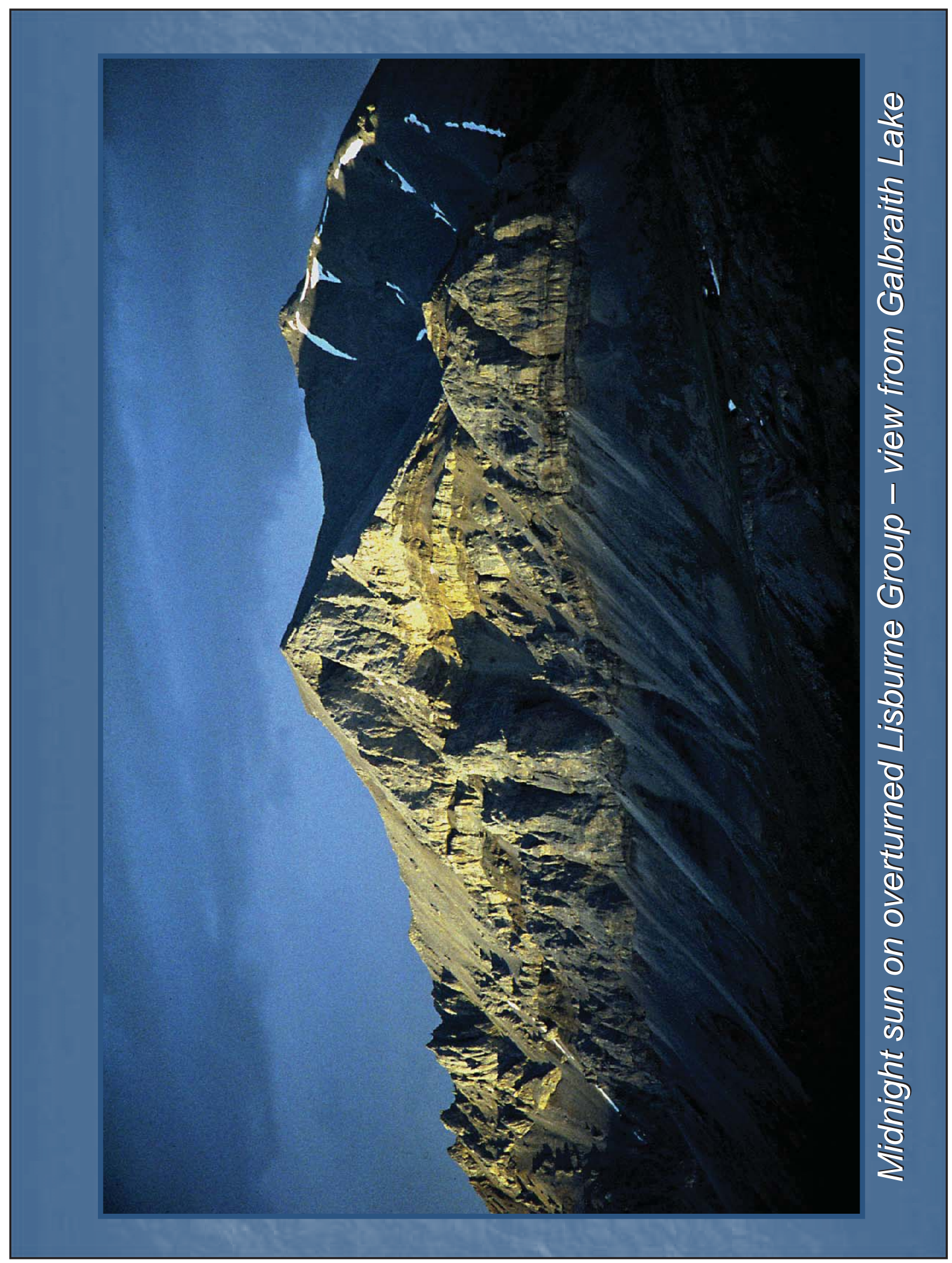




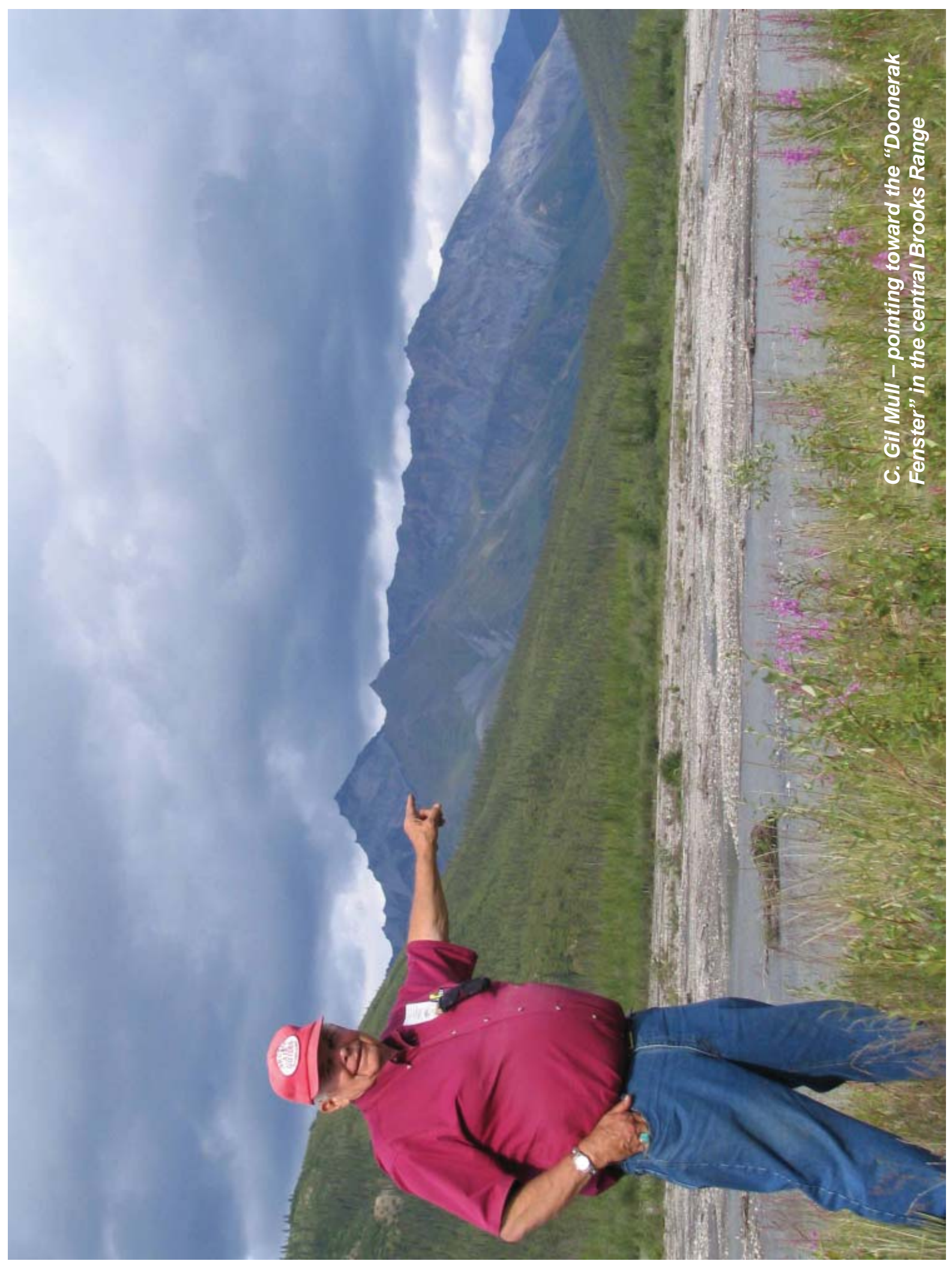




\section{APPENDIX C-1}

\section{ANALYTICAL DATA AND CALCULATED AGES}



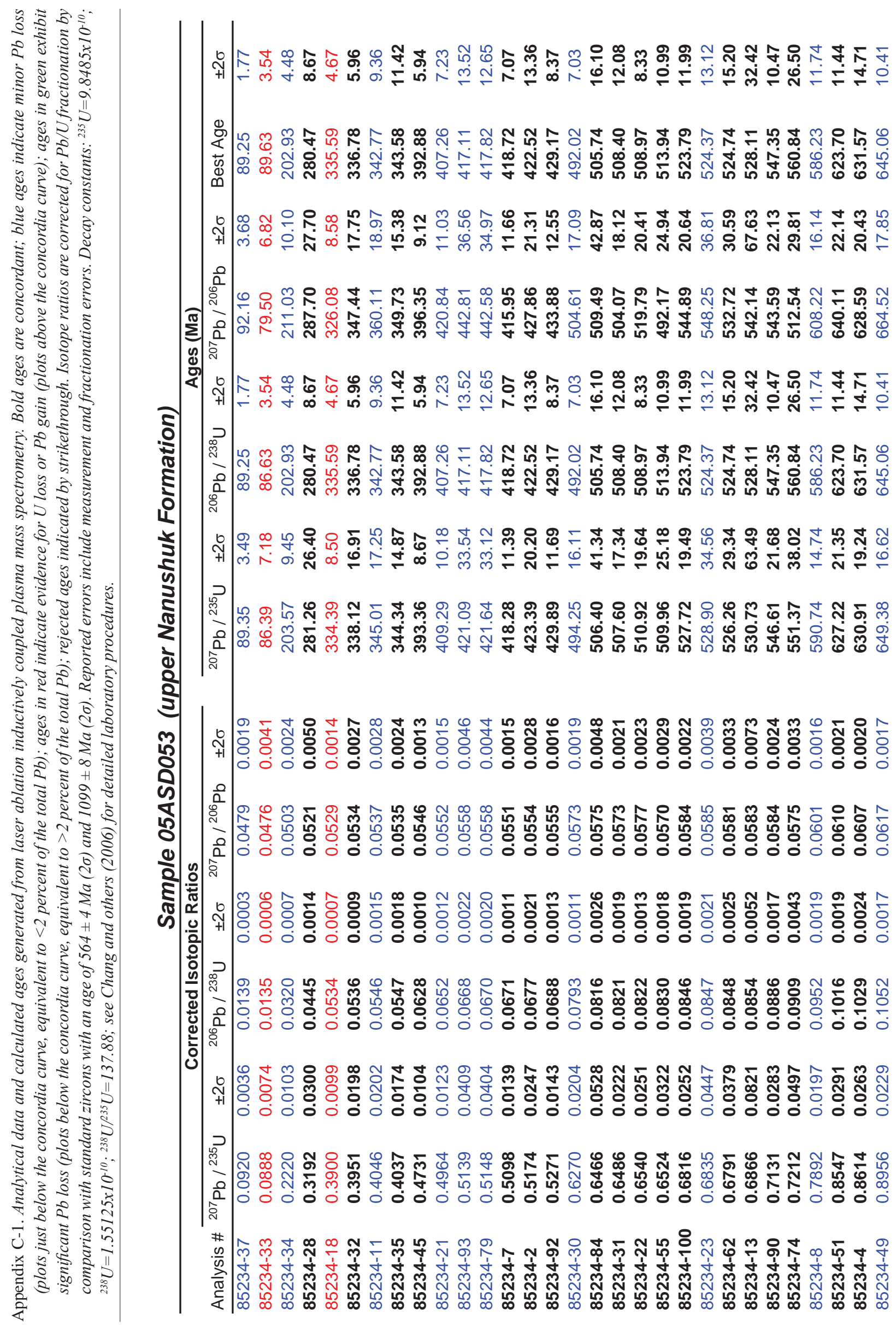


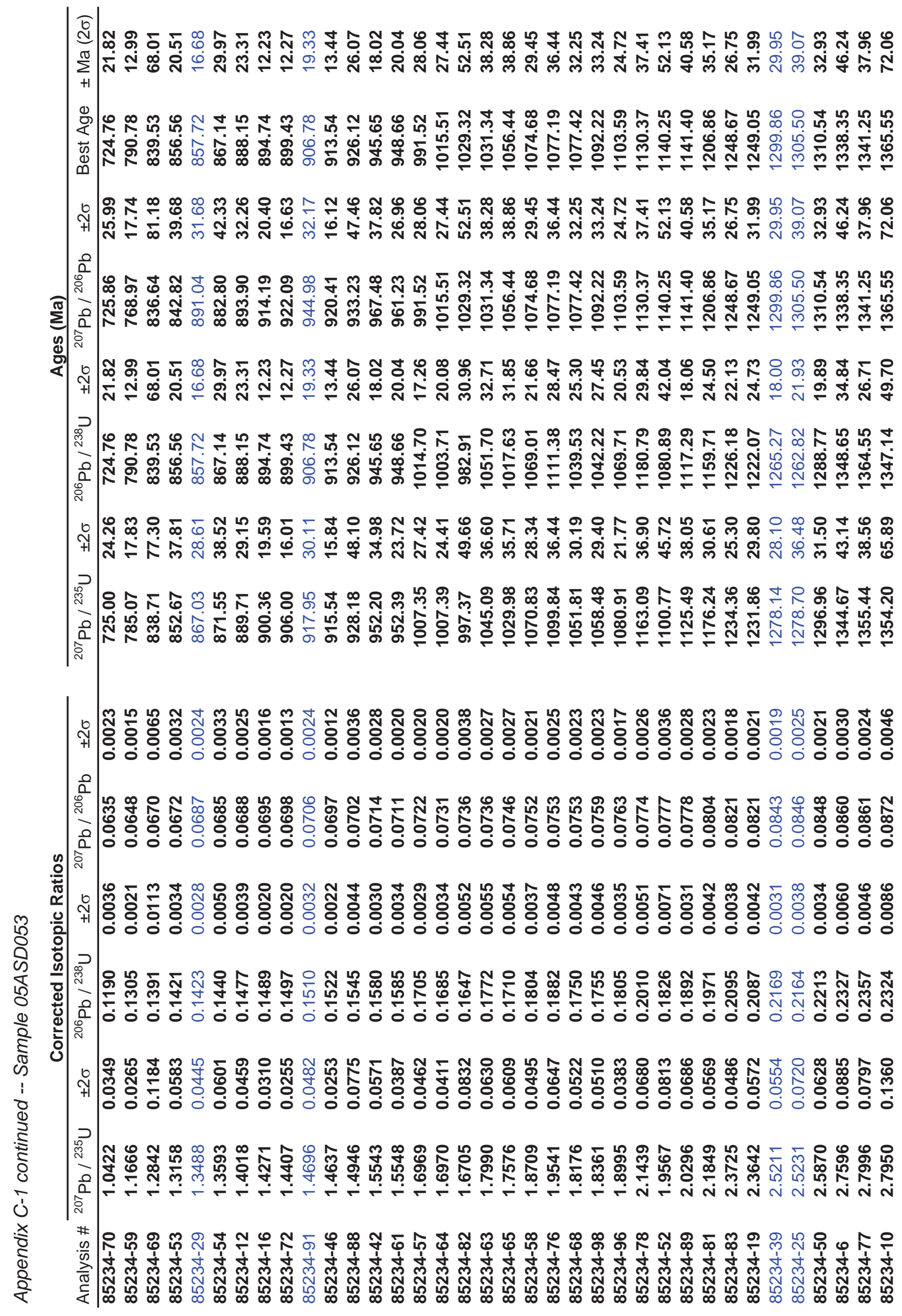




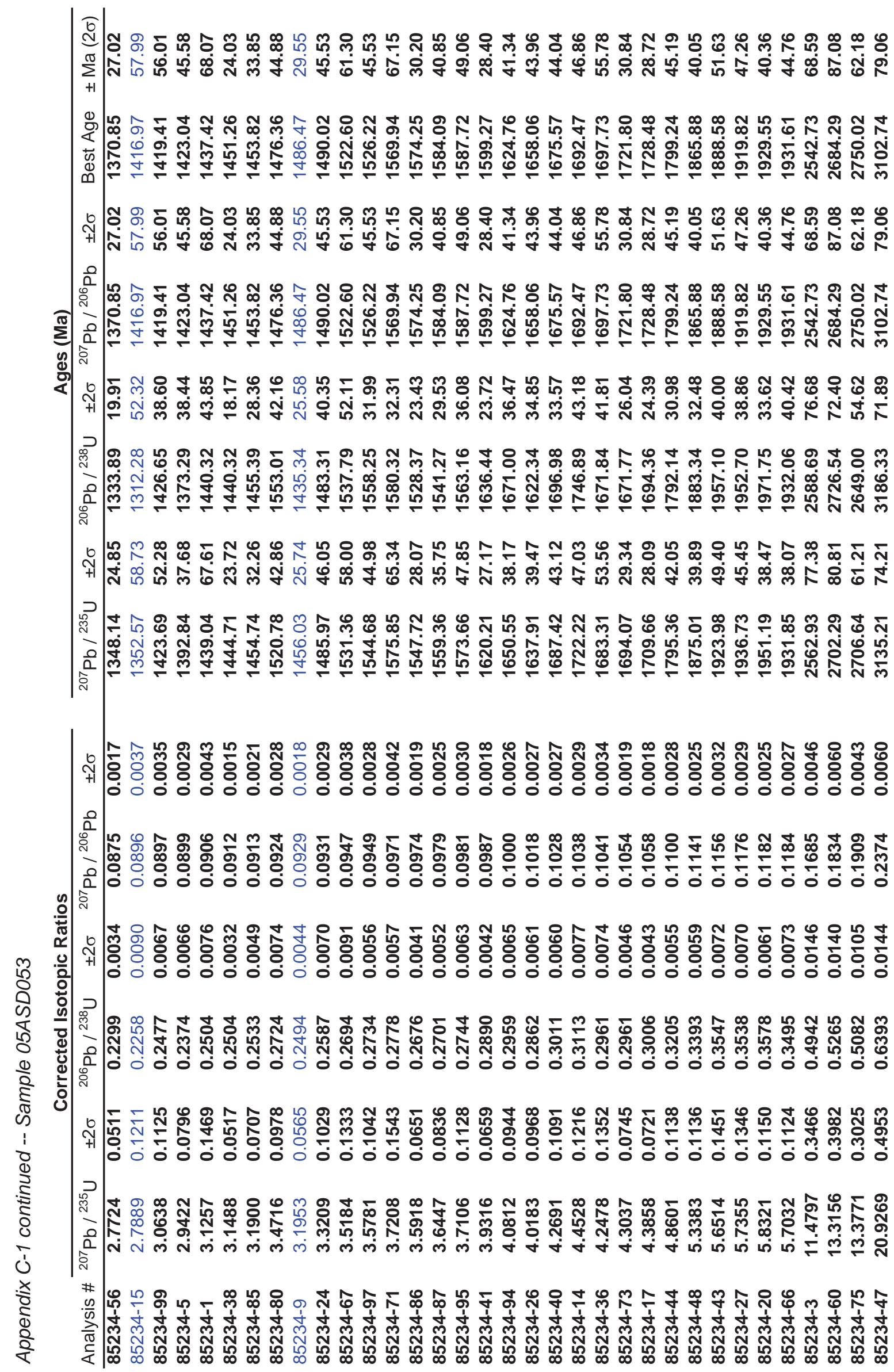




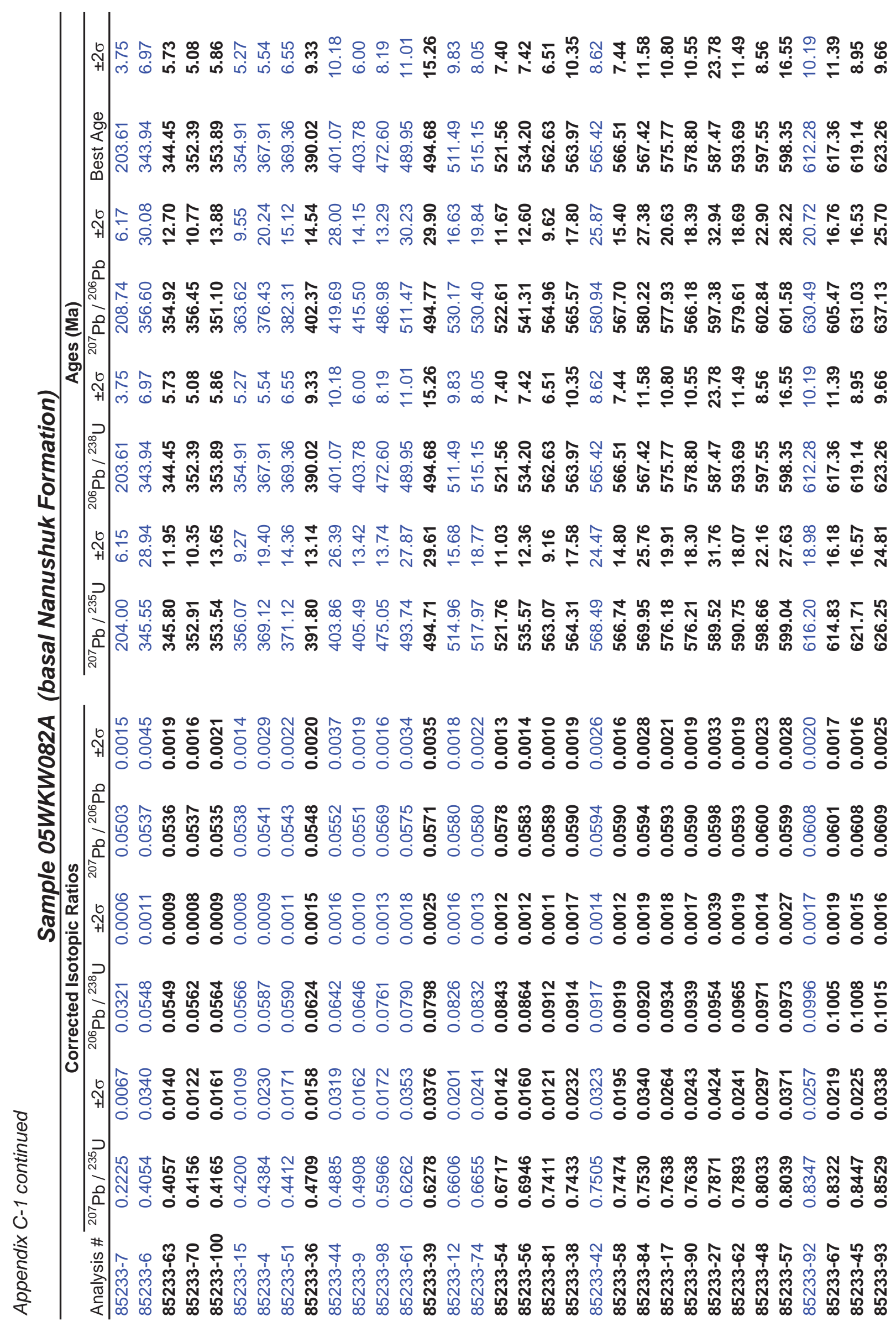




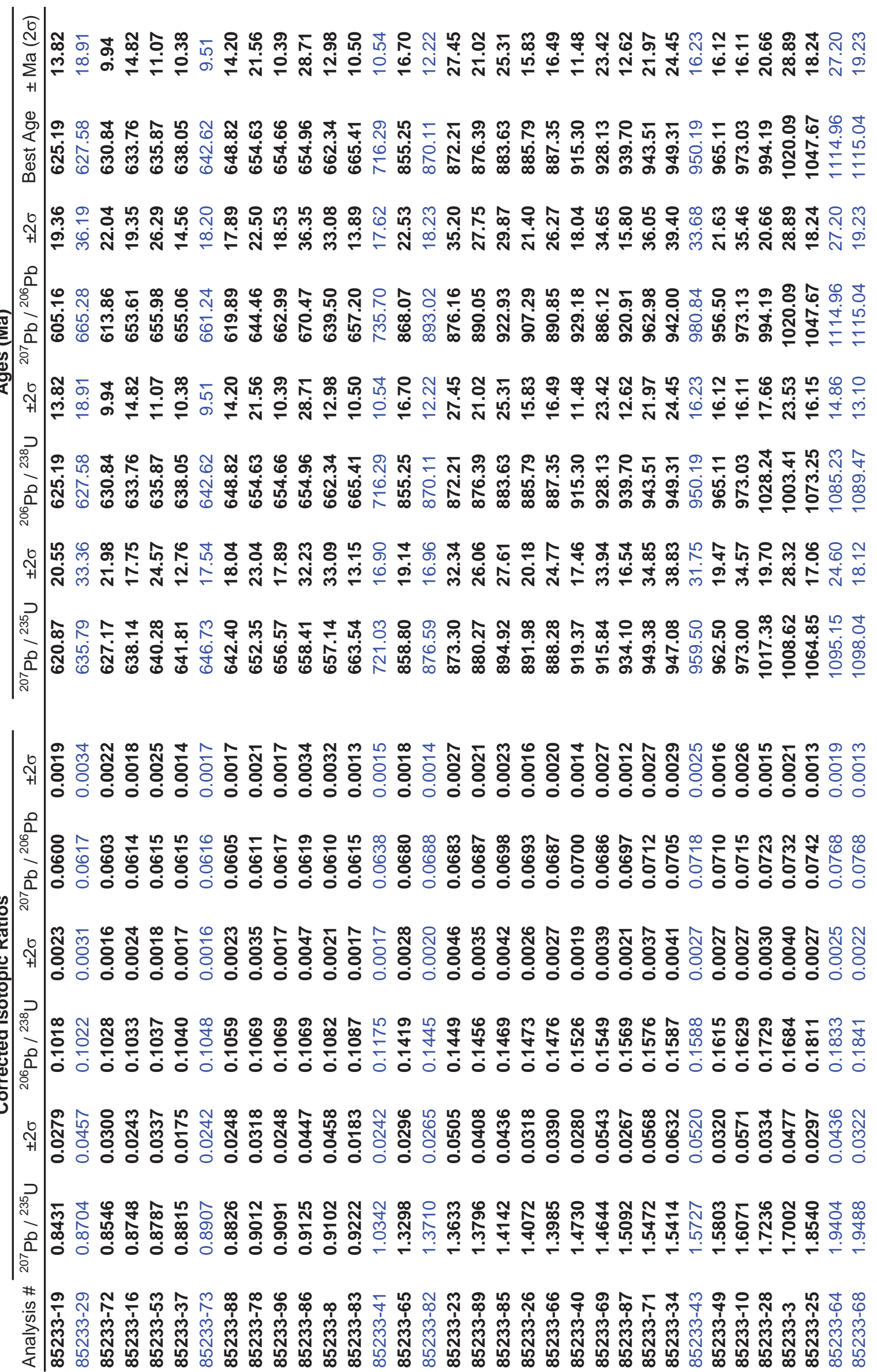




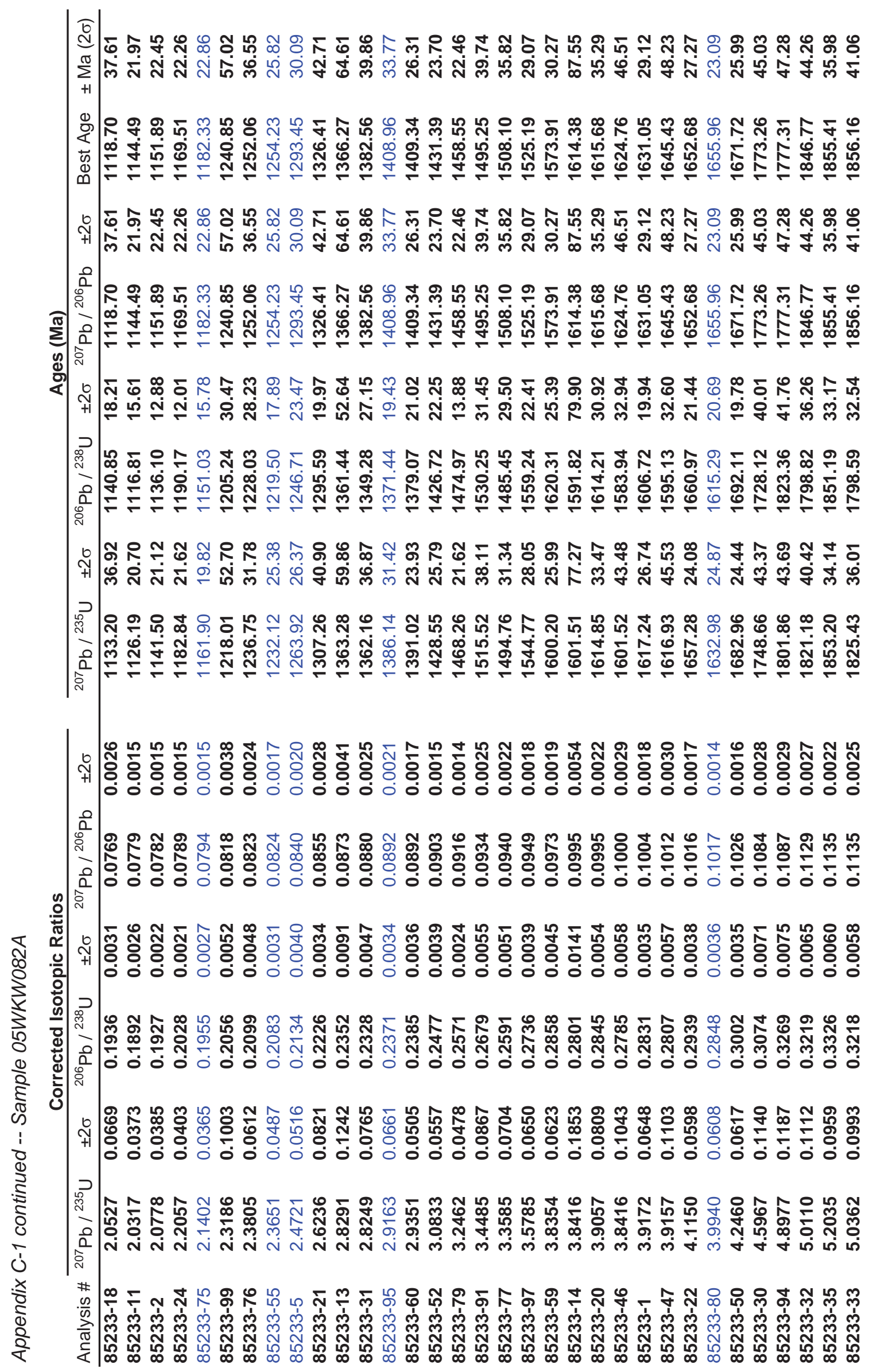




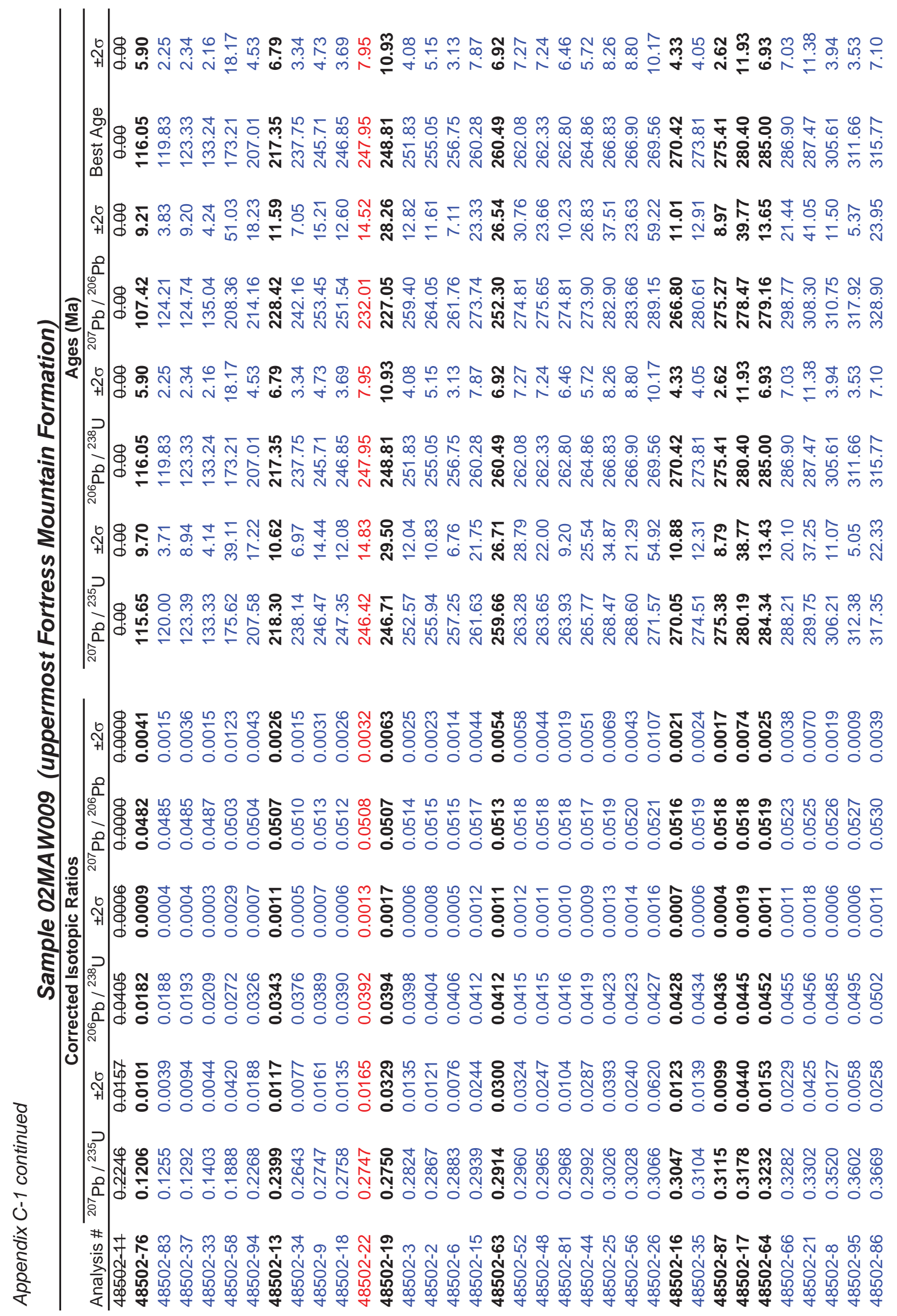




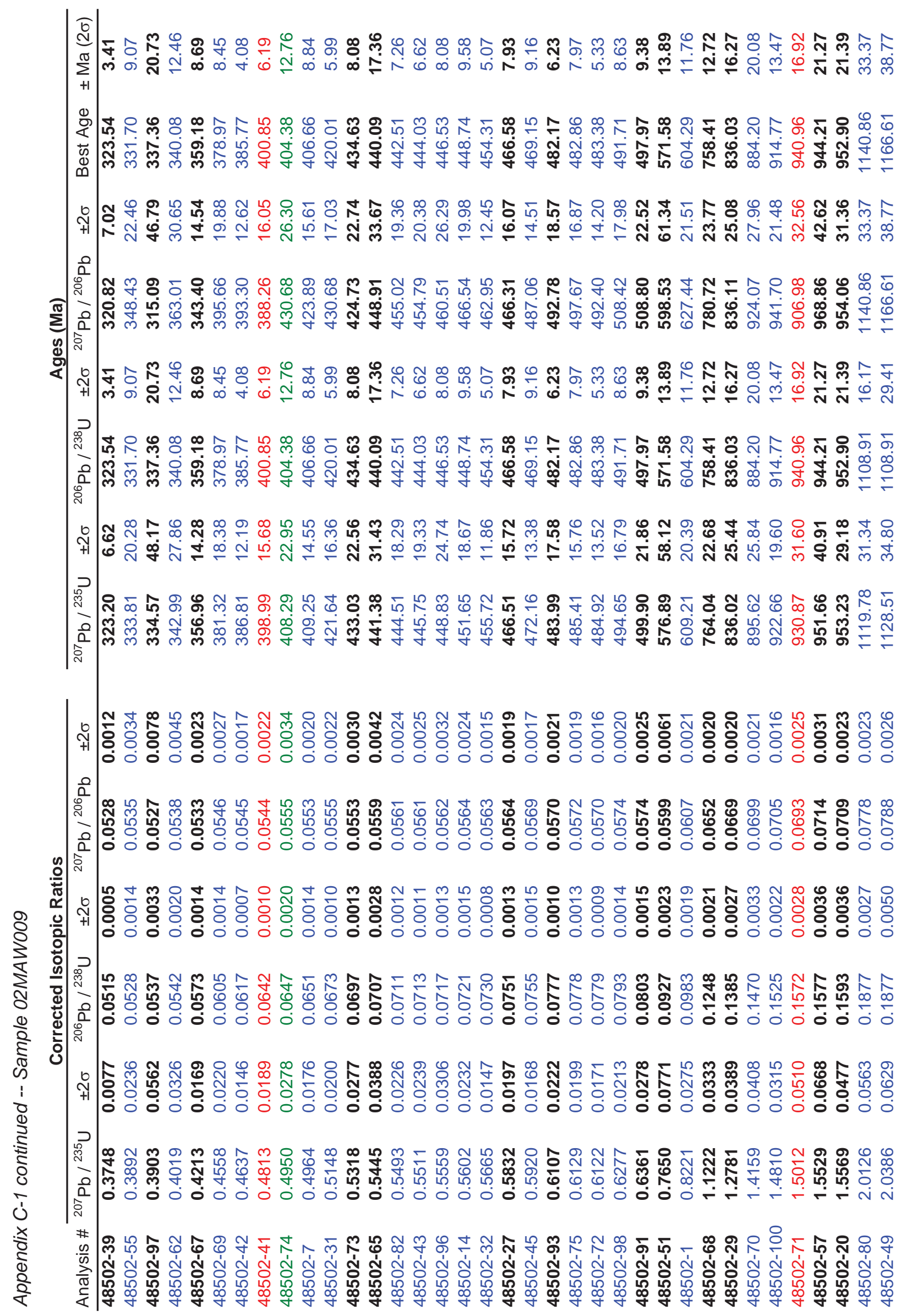




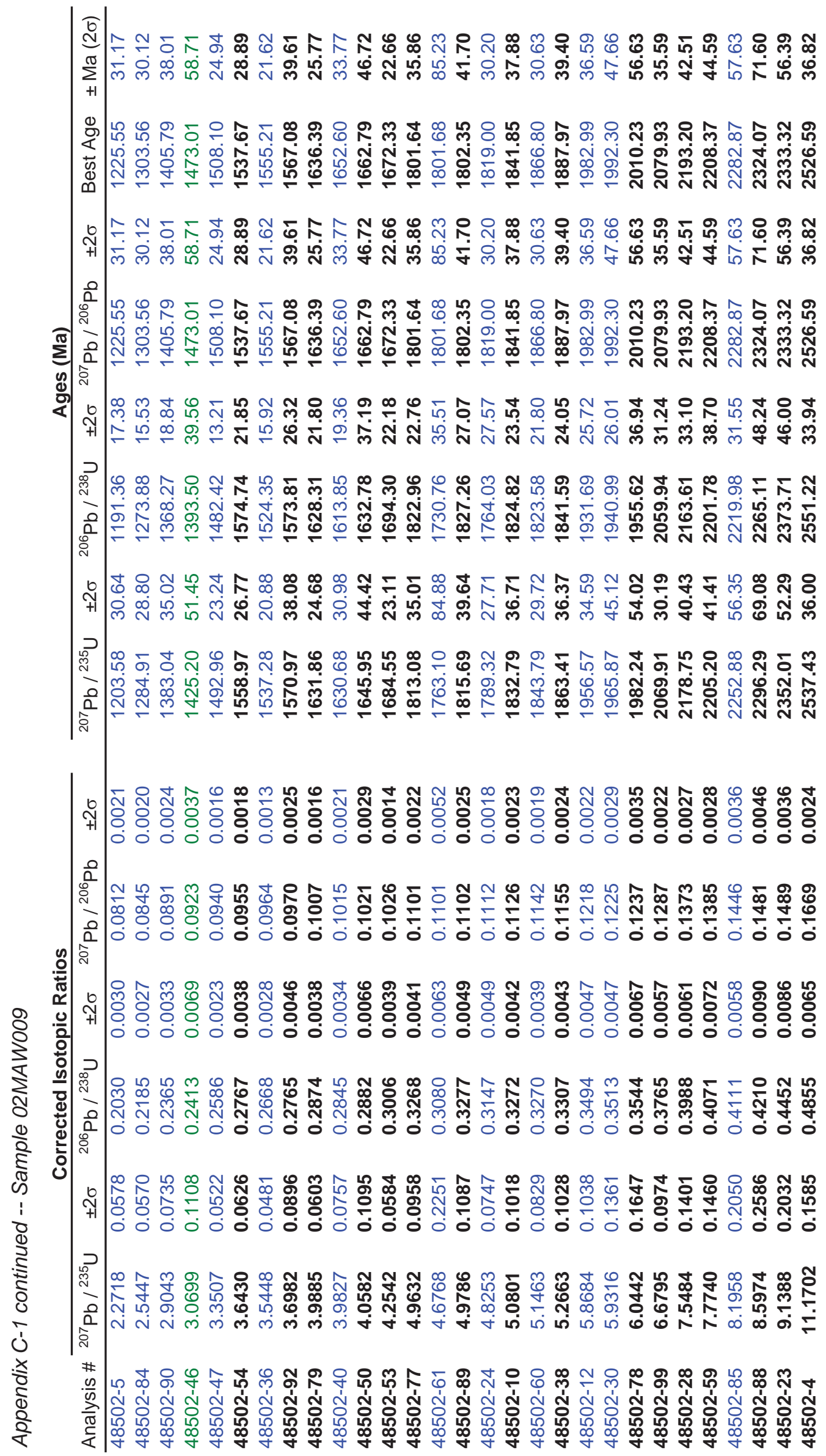




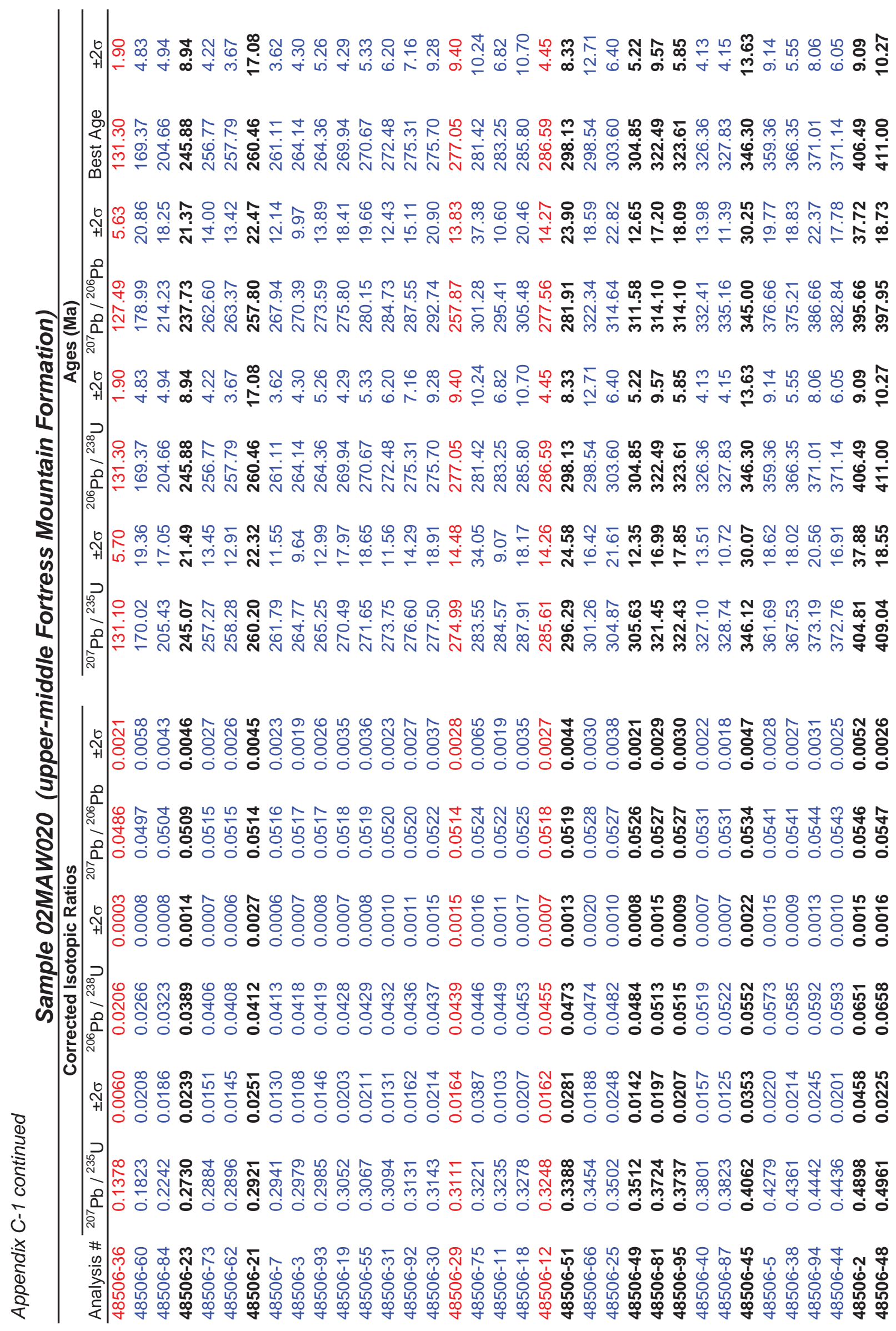


点

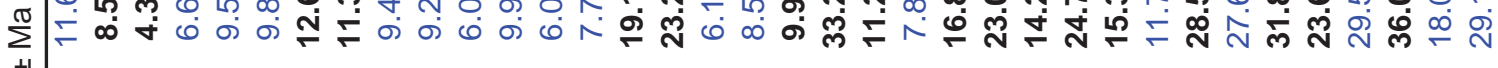

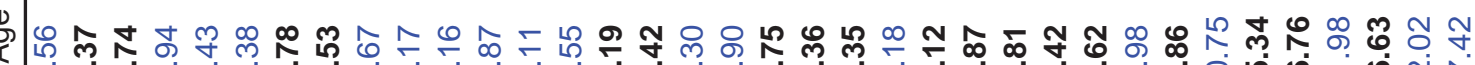

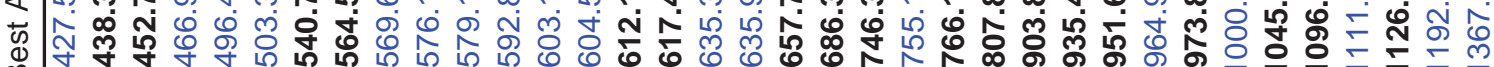

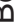

๒

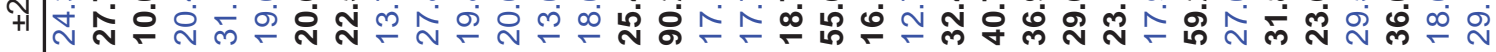
응

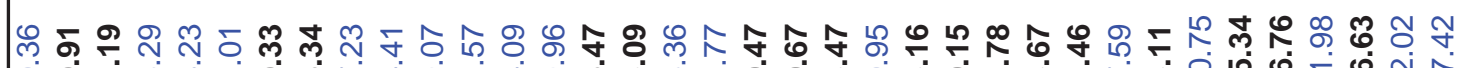
(ำ

운 +1

兽

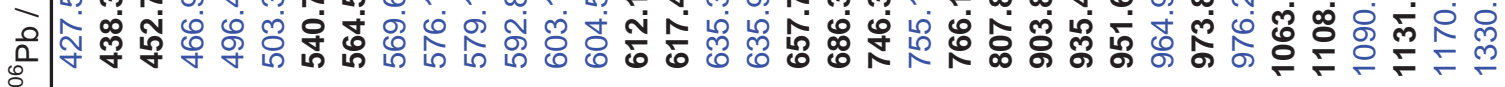
$\stackrel{\circ}{\circ}$

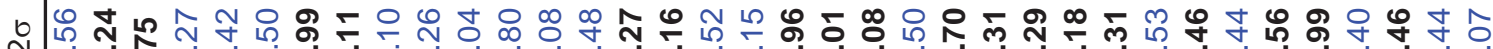
+1 N $\supset$

赵

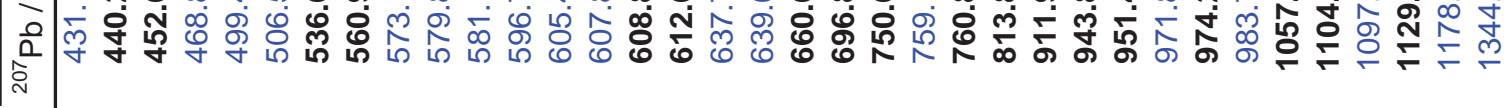

ט +1 $\circ$

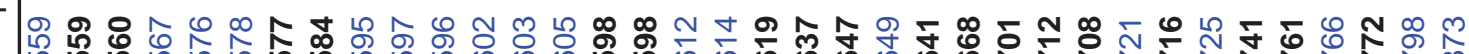

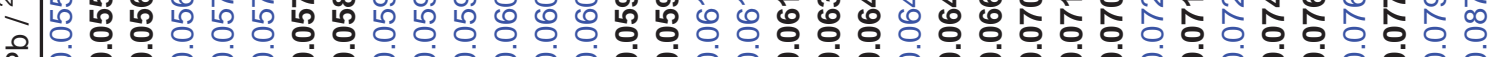
ยิก

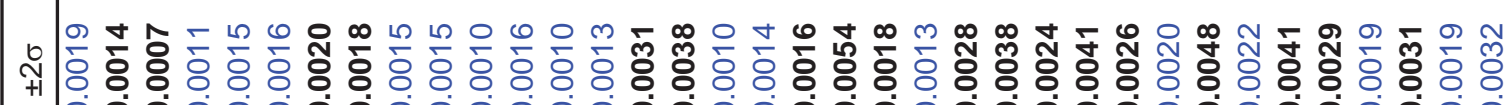
ᄀ)

○ オ

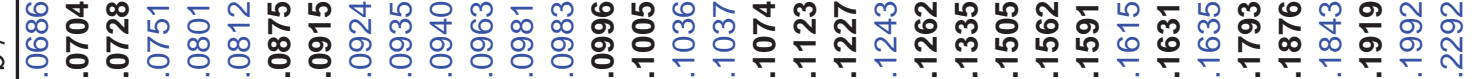
屯े

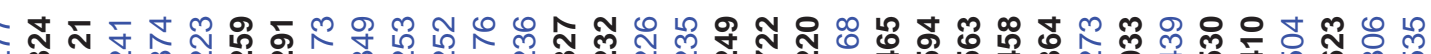

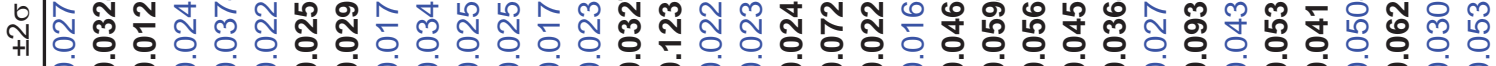

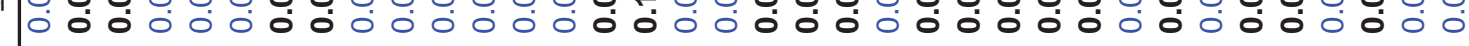
ح)

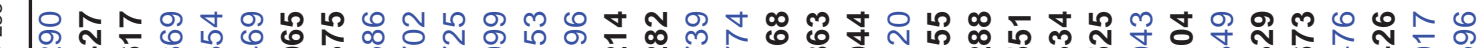

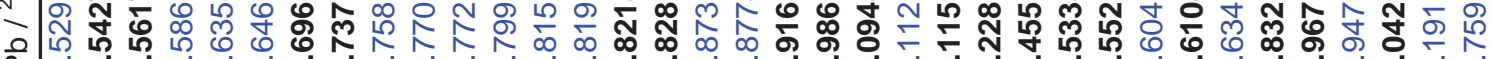

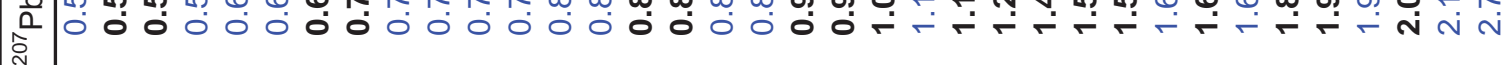
ì

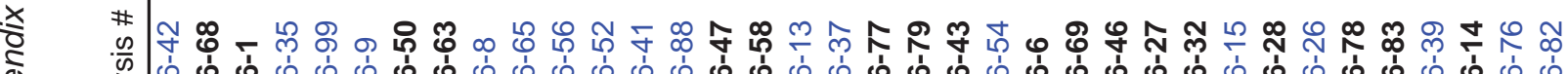

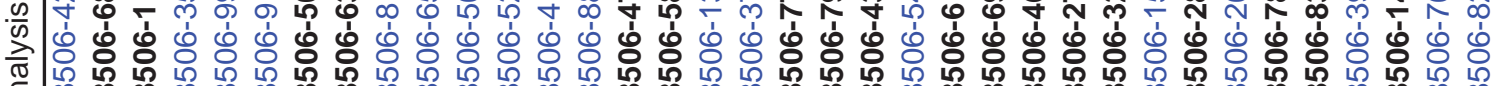
定| 


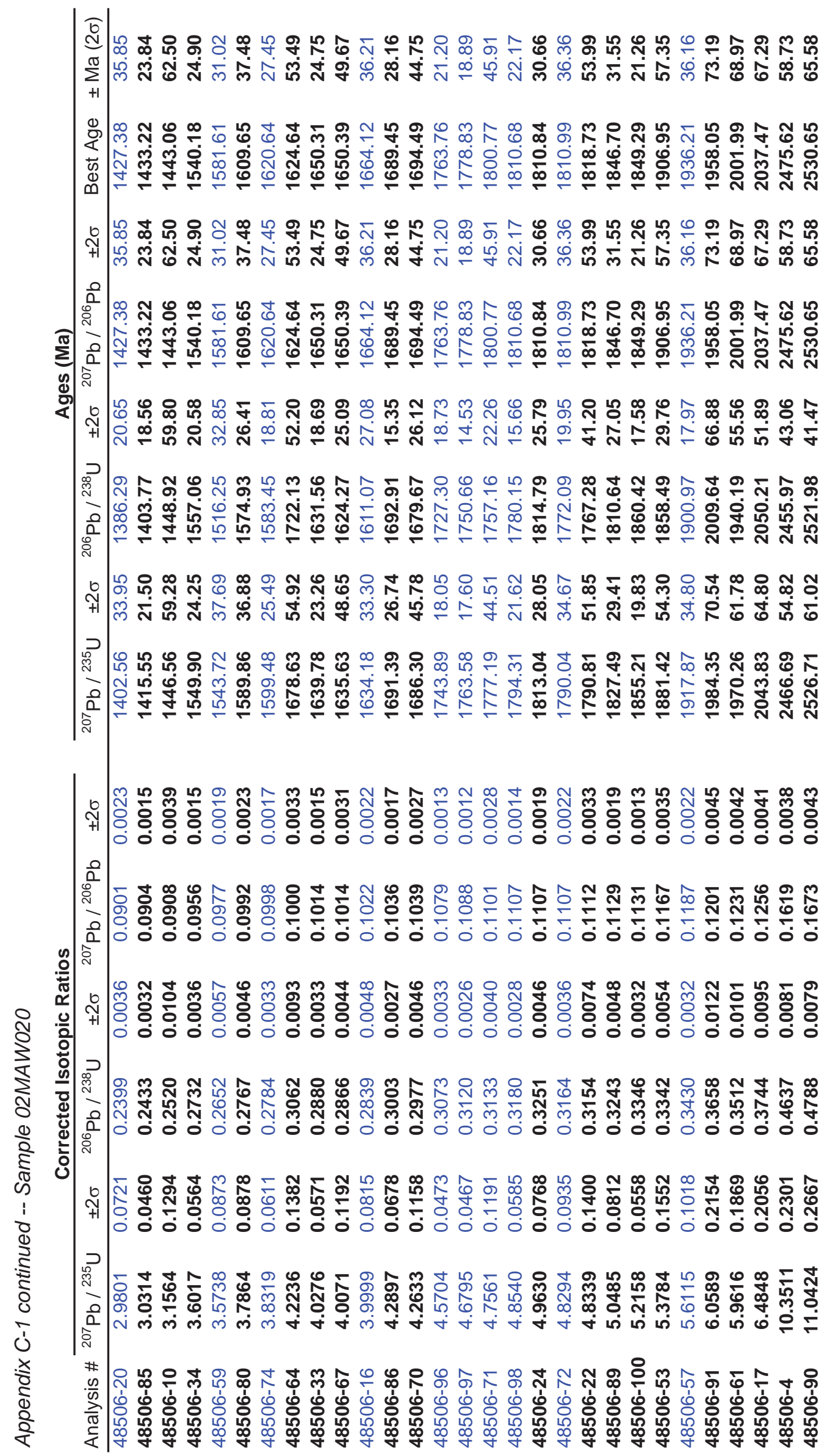




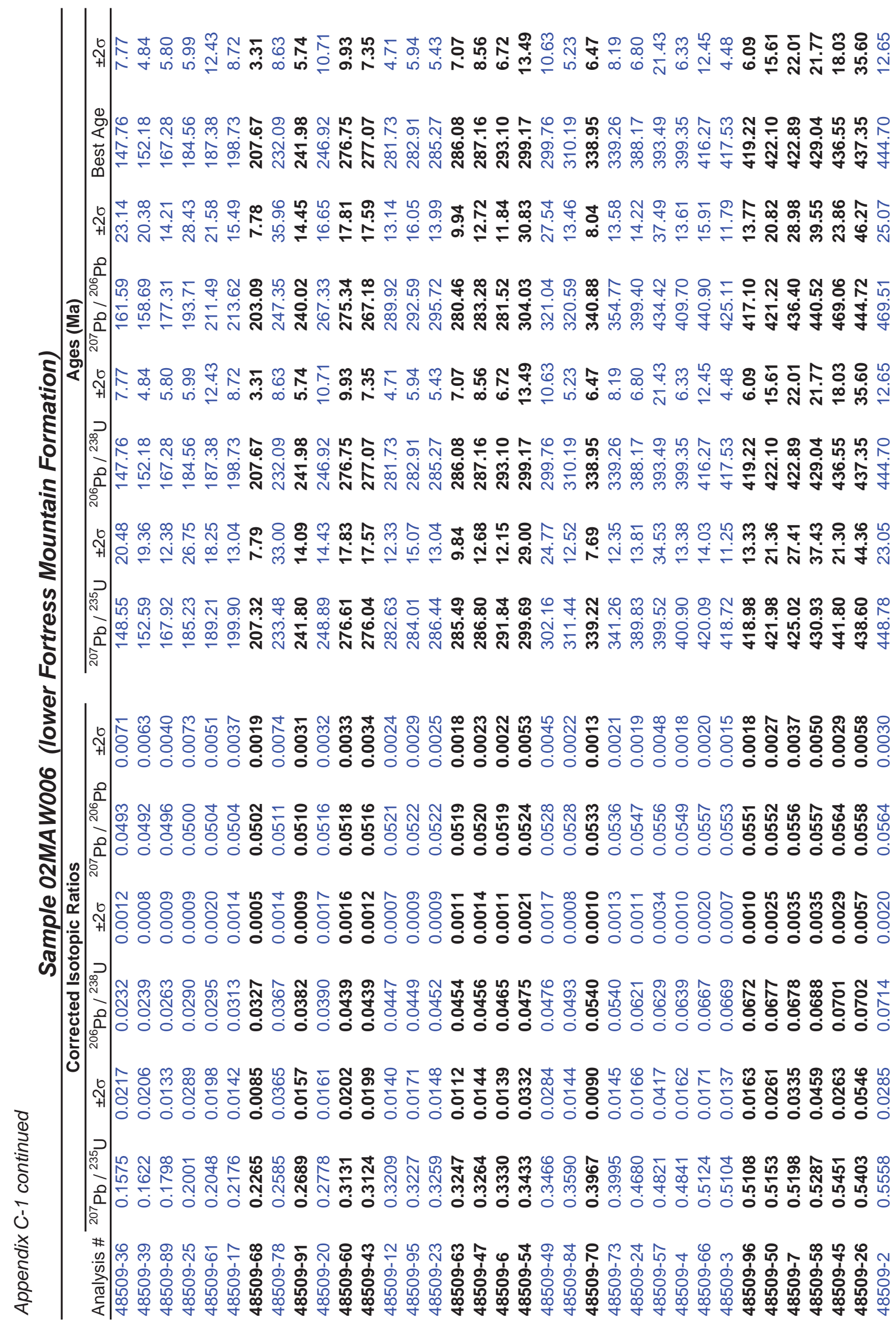




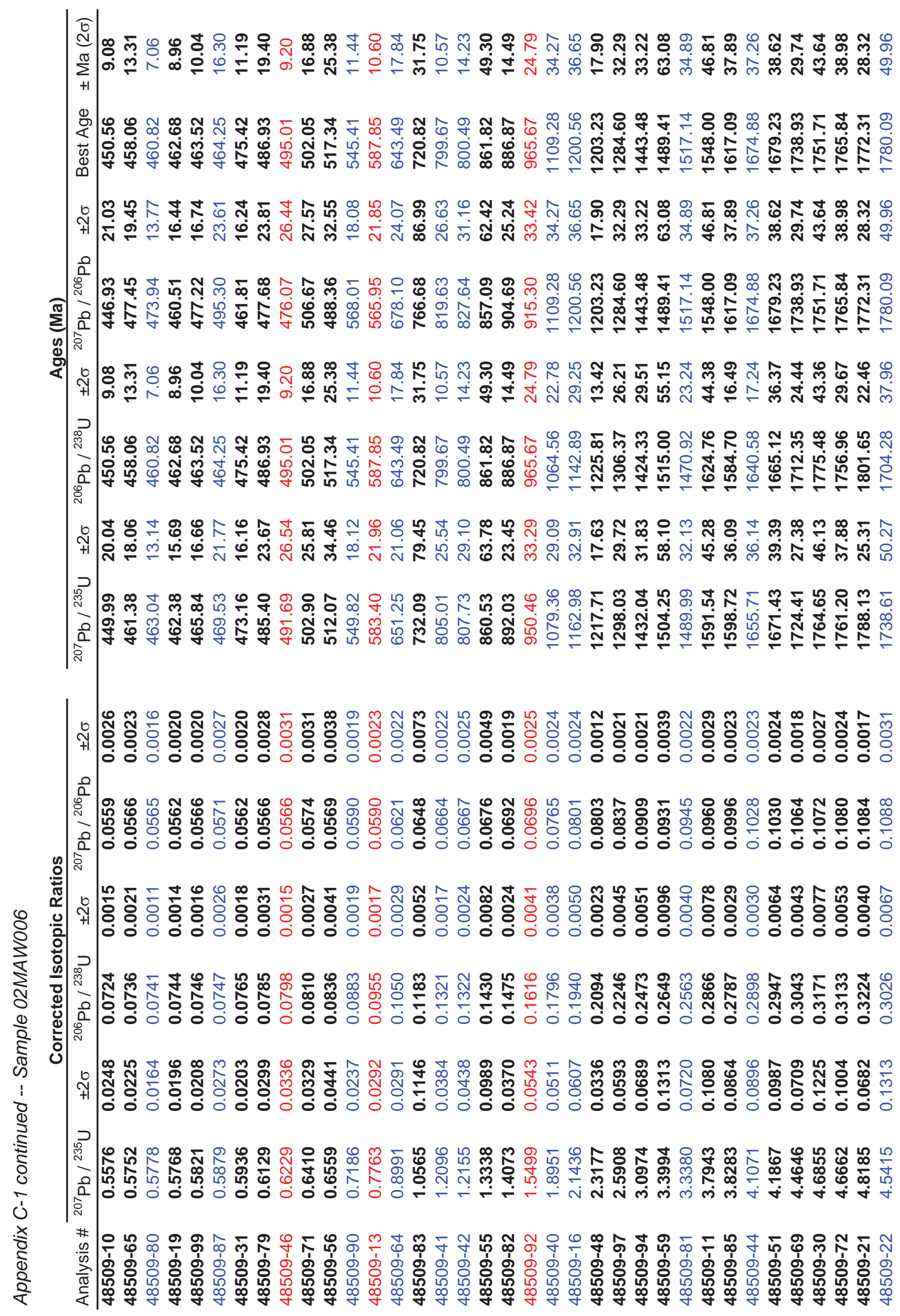




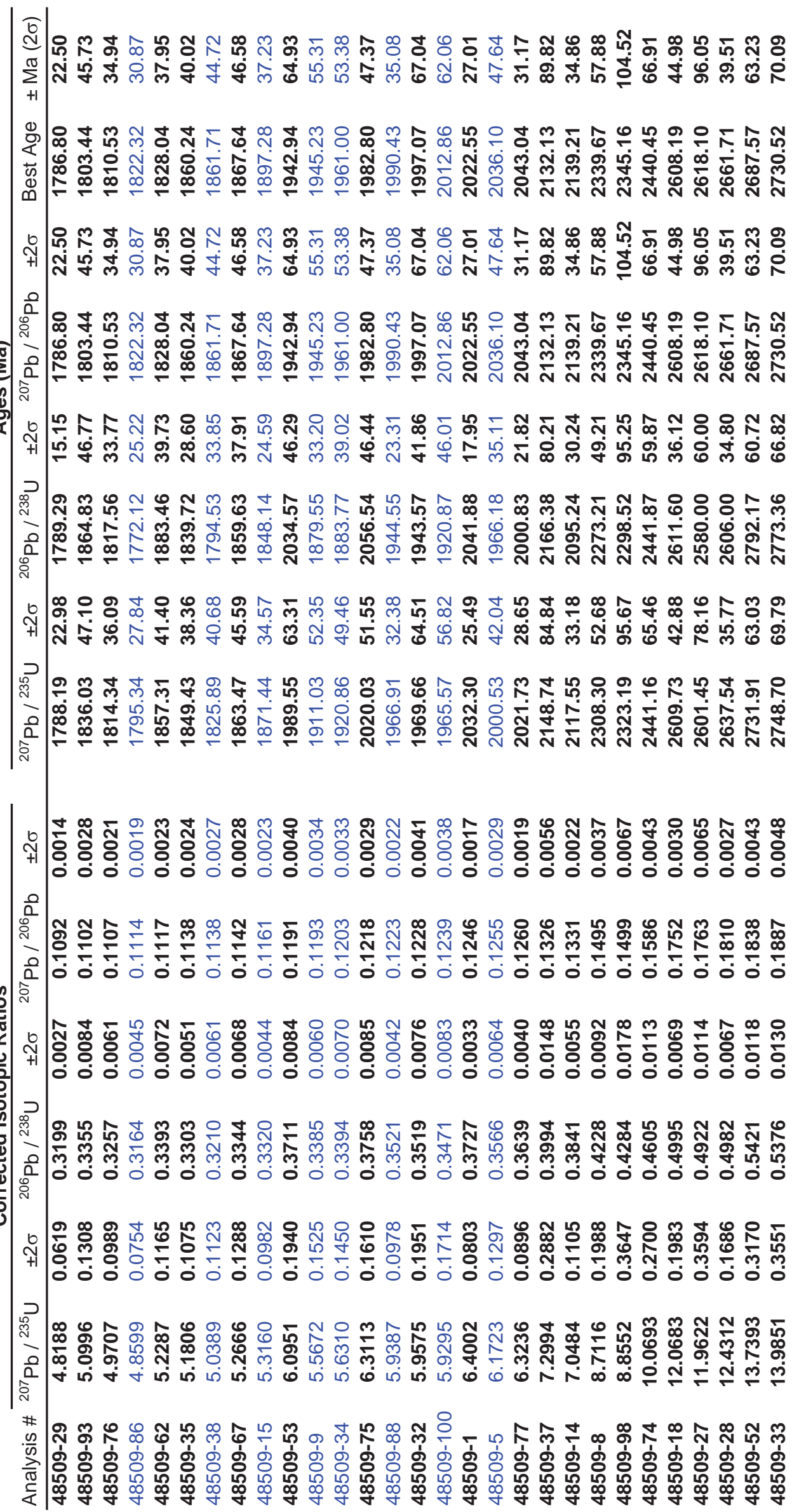




\section{APPENDIX D-1}

\section{MISCELLANEOUS OBSERVATIONS FROM} P.L. DECKER FIELD NOTES

EASTERN HORSESHOE MEASURED SECTION 06DL003

COLVILLE RIVER BETWEEN ETIVLUK AND AWUNA RIVER CONFLUENCES 
This page has intentionally been left blank. 


\title{
Miscellaneous observations from P.L. Decker field notes \\ Eastern Horseshoe measured section 06DL003 \\ Colville River between Etivluk and Awuna River confluences
}

June 20-23, 2006

\author{
$0 \mathrm{~m} \quad$ Latitude-longitude $(\mathrm{NAD} 27$ datum $)=68.97803^{\circ} \mathrm{N}, 155.65768^{\circ} \mathrm{W}$ \\ Base of section just below base of lowest resistant sandstone-conglomerate bench at \\ downstream end of horseshoe bend \\ Bedding: 109, 35NE \\ 0-4.5 m \\ $4.5 \mathrm{~m}$ \\ 5.5-13 m \\ 13-15 m \\ $16.1 \mathrm{~m}$ \\ 16.1-17.6 m \\ 17.6-19.6 m \\ 19.6-20 m \\ 20-21.9 m \\ 21.9-24 m \\ 24-25.4 m \\ 25.4-26 m \\ 26- 27 m \\ $28 \mathrm{~m}$ \\ Sandstone: lower to upper fine-grained, light brown weathering, light green-gray fresh, lithic, \\ nondescript medium bedded, no trace fossils, no hydrocarbon odor or stain \\ Samples: 06DL003-2-1 $\rightarrow$ POROSITY and PERMEABILITY \\ 06DL003-2-2 $\rightarrow$ THIN SECTION \\ Possible hummocky/swaley cross-stratification \\ Interbedded lower to upper fine-grained sandstone and granule-pebble conglomerate, planar \\ laminated to small-scale hummocky/swaley cross stratification? Probable sigmoidal lateral \\ accretion surfaces at 8-10 m \\ Sample: $\quad$ 06DL003-10 $\rightarrow$ LITHOLOGY (interbedded) \\ Sandstone: medium-grained, abundant Macaronichnus, trough cross-bedded and pebble \\ stringers \\ Samples: 06DL003-15-1 $\rightarrow$ POROSITY and PERMEABILITY \\ 06DL003-15-2 $\rightarrow$ THIN SECTION \\ Top of interbedded sandstone-conglomerate package \\ Sandstone: medium-grained, plane-parallel laminated, capped by small-scale trough cross- \\ bedded sandstone \\ Coal, grading to carbonaceous mudstone at top \\ Sample: $\quad$ 06DL003-18 $\rightarrow$ COAL (sulfur) \\ Sandstone: medium-grained, finely laminated, carbonaceous \\ Sandstone: medium-grained, planar cross-laminated lower part, shallow trough cross-bedded \\ upper part \\ Samples: 06DL003-21-1 $\rightarrow$ POROSITY and PERMEABILITY \\ 06DL003-21-2 $\rightarrow$ THIN SECTION \\ Covered interval \\ Sideritized sandstone: fine-grained, rusty, ripple laminated to thin bedded \\ Sideritized mudstone: nodular, massive \\ Sandstone: fine-grained, thin ripple laminated, Arenicolites? \\ Sandstone: fine-grained, climbing ripples
}


$29.3 \mathrm{~m}$

30-100 m

$102 \mathrm{~m}$

123-124 m

$131 \mathrm{~m}$

$134 \mathrm{~m}$

$142 \mathrm{~m}$

$143 m$

$152 \mathrm{~m}$

154-156 m

$182.3 \mathrm{~m}$

$182.5 \mathrm{~m}$

$183 \mathrm{~m}$

$186 \mathrm{~m}$

202-206.5 m

206.5-208 m

208-209.7 m
Coal, $3 \mathrm{~cm}$ thick

Covered interval, except for a few outcrops of sandstone, etc. Offset section back down to river level using sandstone/coal contact at $131 \mathrm{~m}$

Shale: dark gray-yellow bloom, fissile

Samples: 06DL003-102-1 $\rightarrow$ RockEval/TOTAL ORGANIC CARBON

06DL003-102-2 $\rightarrow$ MICROPALEONTOLOGY

Growth-position tree to $20 \mathrm{~cm}$ diameter in sideritized sandstone. Main part preserved only 10 cm diameter

Base of sandstone/top of coal used to offset section from top of slope back down to river level

Top of sideritic marker bed involved in bidirectional thrusting; section involved is $~ 132-138 \mathrm{~m}$

Coal, black, cleated, bituminous or sub-bituminous

Sample: $\quad$ 06DL003-142 $\rightarrow$ COAL (sulfur)

Carbonaceous shale

Sample: $\quad$ 06DL003-143 $\rightarrow$ MICROPALEONTOLOGY

Slickensides parallel bedding; plunge 10 to 038

Sideritic siltstone concretions: buff weathering, medium gray fresh, up to $1 \mathrm{~m} \times 5 \mathrm{~m}$, irregular, elongate parallel bedding. Some appear at first glance to erosionally truncate underlying mudstone/sandstone, but actually are replacive; visual effect is enhanced by differential compaction. Appear to be early formed features

Carbonaceous shale: subfissile, soft

Sample: $\quad$ 06DL003-182.3 $\rightarrow$ MICROPALEONTOLOGY

Tonstein ash in coal. Bentonitic tuff: very light tan, sticky, vitric, speckled with hand lens, irregular thickness 5-10 cm interbed in coal and carbonaceous shale interval. Occurs in mostly covered slope between 176 and $185 \mathrm{~m}$, but is absent a short distance laterally where only 176$178.8 \mathrm{~m}$ interval is obscured by cover

Sample: $\quad$ 06DL003-182.5 $\rightarrow$ GEOCHRONOLOGY

Coal, black, cleated, bituminous or sub-bituminous

Sample: $\quad$ 06DL003-183 $\rightarrow$ COAL (sulfur)

Slickensides on calc-filled shear joint or minor fault; plunge 56 to 010 (indicates backthrusting toward 190)

Covered interval

Sandstone: lower very-fine-grained, brown, thin-bedded to ripple-laminated, heavily rooted? (is this one of the zones we later realized were burrowed by Diplocraterion, etc?) overlain by similar lithology with abundant ball and pillow structure suggestive of rapid emplacement of overlying marine sandstone

Sandstone: fine-grained, hummocky/swaley cross-stratification, sharp based, massiveamalgamated with clay pebbles in lower two-thirds, thin-bedded upper third, ripple-laminated top; very light hydrocarbon odor, no geochemical sample 
214-216 m

$216 \mathrm{~m}$

228.3-227.8 m

239.5-240 m

$254 \mathrm{~m}$

$255 \mathrm{~m}$

257-257.3 m

$257.3 \mathrm{~m}$

257.8-258 m

$258 \mathrm{~m}$

$259.2 \mathrm{~m}$

264-266 m

$267 \mathrm{~m}$

$272 \mathrm{~m}$
Sandstone: upper very-fine-grained, quartz + lithic grains, very well sorted, hummocky/swaley cross-stratification; very similar to sandstone between 208 and $209.7 \mathrm{~m}$. Thins laterally to $<1 \mathrm{~m}$ within $40 \mathrm{~m}$ downstream and within $10 \mathrm{~m}$ upstream. At $215.2 \mathrm{~m}$, sampled sandstone with good light oil odor and stain

Samples: 06DL003-215-1 $\rightarrow$ POROSITY and PERMEABILITY 06DL003-215-2 $\rightarrow$ THIN SECTION 06DL003-215-3 $\rightarrow$ RockEval/TOTAL ORGANIC CARBON, BIOMARKERS

Erosive scour on upstream side cuts out $\sim 60 \mathrm{~cm}$ of underlying med brown lower very-finegrained, rippled sandstone with abundant small (1-2 cm wide, 1-5 cm tall) Diplocraterion traces

Top of underlying, partly truncated medium brown lower very fine-grained bed at $215 \mathrm{~m}$ has both straight-crested wave ripples and ladderback ripples. Straight ripple crests: azimuth 143 (not restored)

Bedding: 105, 30NE

Excellent tempestites: hummocky cross-stratified and thin-ripple-laminated lower very-finegrained sandstone-siltstone

Sandstone: upper fine-grained, thin rippled beds, abundant mud-lined burrow shafts not quite vertical, mostly truncated Rosselia, at least one small Rosselia with mud bulb; diminutive Diplocraterion traces at top of bed (first thought to be roots, but reinterpreted all as burrows)

Sandstone: upper very-fine-grained, quartz + lithics, very well sorted, swaley cross-stratified to low-angle, long-wavelength hummocky cross-stratification, fair light oil odor Sample: $\quad$ 06DL003-254 $\rightarrow$ RockEval/TOTAL ORGANIC CARBON, BIOMARKERS

Sandstone: fine-grained, low-amplitude hummocky/swaley cross-stratification, rippled top; straight crested ripples: azimuths 131 and 132 on $30^{\circ}$-dipping bed

Float: ammonite (sampled), fair preservation, asymmetric, $4 \mathrm{~cm}$ diameter; bivalve impression Sandstone: planar to wavy laminated, carbonaceous (grain size?)

Sandstone: lower very-fine-grained (different bedding than immediately underlying unit)

Contact with $20 \mathrm{~cm}$ erosional relief; overlying unit is lower to upper fine-grained sandstone; underlying unit is lower very-fine-grained sandstone down to $257.3 \mathrm{~m}$

Sandstone: lower to upper fine-grained, faintly planar laminated to massive-amalgamated, mud chips and chert pebbles at scoured base

Samples: 06DL003-258-1 $\rightarrow$ POROSITY and PERMEABILITY 06DL003-258-2 $\rightarrow$ THIN SECTION

Sandstone: upper very-fine- to upper medium-grained, rare chert pebbles and plant fragments with red-brown oxidized halos, poorly sorted, occasional Schaubcylindrichnus frey (formerly known as Terebellina), 2 x $5 \mathrm{~mm}$; interpreted as transgressive unit

Intensely developed, large ball and pillow structure

Planolites traces, meniscate, dense at rippled top of sandstone with large, abundant ball and pillow structure in upper $35 \mathrm{~cm}$

Diplocraterion traces, $1 \mathrm{~cm}$ diameter U-tube, $7 \mathrm{~cm}$ across trace, good spreiten 
$272.5 \mathrm{~m}$

$272.5-273 \mathrm{~m}$

$273-274 m$

$280 \mathrm{~m}$

$305 \mathrm{~m}$

$348.3-350.2 \mathrm{~m}$

$350.2-356 \mathrm{~m}$

$356-382.5 \mathrm{~m}$

$383.5-386.7 \mathrm{~m}$

$421.2 \mathrm{~m}$

$439-440 \mathrm{~m}$

$440-442 \mathrm{~m}$

$442-443.7 \mathrm{~m}$

$443.7-449 \mathrm{~m}$

$449 \mathrm{~m}$
Bergaueria trace

Sideritized sandstone-mudstone: mottled light yellow, bioturbation index $\sim 0.5$

Grits with medium-coarse sandstone, chert-quartz pebbles, large wood fragments, burrowed, mottled transgressive surface of erosion and transgressive sandstone cap

Samples: 06DL003-274-1 $\rightarrow$ POROSITYandPERMEABILITY

06DL003-274-2 $\rightarrow$ THIN SECTION

Mudstone: medium gray weathering, dark brown fresh, slightly silty, blocky-chippy, firm Sample: $\quad$ 06DL003-280 $\rightarrow$ MICROPALEONTOLOGY

Mudstone: medium brown-purplish-brown weathering, dark brown fresh, silty, blocky, firm Sample: $\quad$ 06DL003-305 $\rightarrow$ MICROPALEONTOLOGY

Sandstone: (lower of two prominent sandstone exposed near center of steep scree-covered slope) lower very-fine-grained, thin-bedded to laminated, extensively rippled, carbonaceous partings, abundant Gyrochorte (bilobate) horizontal grazing traces.

Bedding on top of sandstone: $119,13 N E$

Mudstone: dark gray-brown, firm, subfissile weathering, blocky fresh

Sample: $\quad$ 06DL003-352 $\rightarrow$ MICROPALEONTOLOGY

Covered interval

Sandstone: (upper of two prominent sandstone exposed near center of steep scree-covered slope) lower very-fine-grained, thin-bedded to laminated, wave-rippled, common Gyrochorte; top of bed rippled, no transgressive grit, no shale exposed above

Bedding at 385 m: 085, $8 N$

Base of upper cliffs; bottom of lower of two uppermost benches; lower parasequence is upwardcoarsening and -thickening shoreface succession. Cone-in-cone in $3 \mathrm{~cm}$ sideritic mudstone

Coarse-grained uppermost portion of shoreface succession; sporadically deposited in zone 1-2 $\mathrm{m}$ thick; possible transgressive grit cap or foreshore facies. Top of parasequence at $440 \mathrm{~m}$

Shale: medium-dark gray, yellow bloom

Covered interval

Apparently abrupt, but unexposed basal contact overlain by sandstone-granule-pebble conglomerate beds capping measured section

Top of section at top of cliffs 


\section{APPENDIX D-2}

\section{MISCELLANEOUS OBSERVATIONS}

FROM P.L. DECKER FIELD NOTES

KILLIK BEND MEASURED SECTION 06DL007

COLVILLE RIVER 
This page has intentionally been left blank. 


\section{Miscellaneous observations from P.L. Decker field notes Killik Bend measured section 06DL007 Colville River}

June 26-29, 2006

$0 \mathrm{~m}$

$0-2 \mathrm{~m}$

$15 \mathrm{~m}$

$16.5 \mathrm{~m}$

$27 \mathrm{~m}$

$27.5-27.6 \mathrm{~m}$

$28.5 \mathrm{~m}$

28.7-29 m

$31.3 \mathrm{~m}$

$35-36 \mathrm{~m}$

$36-39.8 \mathrm{~m}$

$40.1 \mathrm{~m}$
Latitude-longitude $(\mathrm{NAD} 27$ datum $)=68.99067^{\circ} \mathrm{N}, 153.98618^{\circ} \mathrm{W}$

Base of section at lowest exposed bed just above river level at north end of exposure; light greenish-gray sandstone parasequence

Rosselia, textbook 3-dimensional exposures of robust forms, concentric mud bulbs up to $6.5 \mathrm{~cm}$ diameter $\mathrm{x} 17 \mathrm{~cm}$ long

Sandstone: medium-dark olive green, lower medium-grained, pervasive Macaronichnus, high visible porosity, friable

Samples: 06DL007-15-1 $\rightarrow$ POROSITY and PERMEABILITY 06DL007-15-2 $\rightarrow$ THIN SECTION

Top of lower, upward-coarsening parasequence; Macaronichnus in upper trough-cross-bedded, amalgamated sandstone, overlain here by covered, coal, and carbonaceous mudstone interval

Discrete surface capping silty sandstone, overlain by lower medium-grained sandstone with and symmetric to slightly asymmetric ripples

Omission surface, pronounced grain size jump, moderate erosional relief

Sandstone: medium grayish-brown weathering, lower medium-grained, mottled, tight

Samples: 06DL007-28.5-1 $\rightarrow$ POROSITY and PERMEABILITY 06DL007-28.5-2 $\rightarrow$ THIN SECTION

Rosselia colony in upper fine- to upper medium-grained sandstone; multistory occupation in beds 2-10 cm thick

Sandstone: light greenish-gray weathering, lower fine-grained, fair visible porosity, scattered Teredo-bored fossil wood

Samples: 06DL007-31.3-1 $\rightarrow$ POROSITY and PERMEABILITY 06DL007-31.3-1 $\rightarrow$ THIN SECTION

Sandstone event beds $5-10 \mathrm{~cm}$ thick with sharp basal surfaces grading upward to slightly darker, carbonaceous, rippled sandstone preserved in upper parts, indicative of cyclical flows with only minor basal erosion; common branch- to log-sized Teredo-bored wood clasts; interval capped by 15-20-cm-thick sideritic horizon with lenticular concretions upwards of $5 \mathrm{~m}$ long; unit interpreted as distributary mouth bar sandstone

Sandstone: light brown weathering, lower fine-grained, massive, low-angle, and trough-crossbedded; channelized basal surface incises ( 1-2 m?) into underlying sandstone event beds, abundant Teredo-bored wood clasts and some bedding surfaces completely matted with wood fragments mostly 2-4 cm diameter; abundant Skolithos shafts $0.5 \mathrm{~cm}$ wide, $30-40 \mathrm{~cm}$ long at 37.5-38 m. Unit interpreted as distributary channel sandstone

Samples: 06DL007-37-1 $\rightarrow$ POROSITY and PERMEABILITY

06DL007-37-2 $\rightarrow$ THIN SECTION

Top of 15-20 cm siderite marker bed offset at low-angle thrust 
40.5-40.9 m Skolithos in $~ 1 \mathrm{~m}$ bed with low-angle trough cross-beds; uppermost bed of probable distributary channel facies; bed not evident in footwall of small thrust described at $40.1 \mathrm{~m}$, probably absent due to offlapping/laterally accreting geometry of distributary channel beds

42-42.3 m Sandstone: medium gray, rusty brown mottled, lower very-fine-grained, argillaceous, intensely burrowed (rusty mottling), Thalassinoides $1-2 \mathrm{~cm}$ diameter defined by locally branched, irregularly cylindrical, curved, subvert to inclined and subhorizontal burrows

$43.2 \mathrm{~m} \quad$ Claystone: light green-gray, slightly silty, sparsely carbonaceous, moderately firm, crumbly Sample: 06DL007-43.2 $\rightarrow$ MICROPALEONTOLOGY

45.8-46 m Small, forked and non-forked rootlets in upper $20 \mathrm{~cm}$ of irregular bedded sandstone with $\sim 10 \mathrm{~cm}$ beds; base scoured into thin, irregular bedded sandstone with carbonaceous ripple-laminated caps and partings

$48.7 \mathrm{~m} \quad$ Shale: dark gray, fissile, $\sim 20-30 \mathrm{~cm}$ thick Sample 06DL007-48.7 $\rightarrow$ MICROPALEONTOLOGY

49.6-51.7 m Sandstone: Red-brown-orange-tan mottled weathering, upper very-fine- to upper fine-grained, irregular bedded and irregular erosional profile, beds 3-10 cm, heavily bioturbated with abundant but mostly partial Rhizocorallium and Paleophycos up to $1.5 \mathrm{~cm}$ diameter creating lenticular splitting character, carbonaceous debris on bioturbated laminae Sample: 06DL007-50 $\rightarrow$ THIN SECTION

51-51.7 m Sandstone: medium-light gray, upper very-fine-grained, laminated to $1 \mathrm{~cm}$ thin beds, Rhizocorallium, some Paleophycos

51.7-54 m Sandstone: medium gray, lower fine-grained, rooted with roots to $10 \mathrm{~cm}$ tall, beds $2-10 \mathrm{~cm}$ thick, upward thickening; mottled, light brown, very thin clay drapes at bed partings, pedogenically and/or bioturbationally churned

Sample: 06DL007-53.5 $\rightarrow$ THIN SECTION

59.7-60 m Sideritized horizon used as marker bed for thrust fault with $\sim 4.5 \mathrm{~m}$ offset; overlies shale interval (thickness not recorded here)

$60-\sim 62 \mathrm{~m}$

Sandstone: light brown-red weathering, light gray fresh, lower fine-grained, plane-parallel laminated

Sample: 06DL007-60.5 $\rightarrow$ THIN SECTION

62.9-68.8 m Upward-coarsening and -thickening package: medium-dark gray, green-gray, and olive-streaked shale in lower part, becoming silty to very-fine-grained current-rippled sandstone in upper $1 \mathrm{~m}$, capped by lower to upper fine-grained bioturbated sandstone with good Rhizocorallium in uppermost $5 \mathrm{~cm}$; this interval is lowest of three consecutive, very similar upward-coarsening and thickening intervals up to $72.4 \mathrm{~m}$, capped finally by carbonaceous shale and coal; cyclical successions interpreted as probable bay-fills with mud grading upward into crevasse splay siltstone-sandstone

68.8-71.2 m Upward-coarsening and -thickening mudstone-siltstone-sandstone package: second of three consecutive probable bay-fill cycles; upper sandstone is light green-gray, lower very-fine- to upper fine-grained, lithic-micaceous, asymmetric ripple-laminated, sparsely rooted; cap is slightly coarser, mottled, Rhizocorallium up to $5 \times 12 \mathrm{~cm}$ with $1 \mathrm{~cm}$ diameter tubes Sample: 06DL007-70.5 $\rightarrow$ THIN SECTION (non-reservoir lower very-fine-grained sandstone) 
72.4-72.8 m

$72.8 \mathrm{~m}$

$79.5 \mathrm{~m}$

79.5-80.2 m

$80.2 \mathrm{~m}$

$90.5 \mathrm{~m}$

$95 \mathrm{~m}$

$97.5 \mathrm{~m}$

97.5-102.5 m

$104.3 \mathrm{~m}$

$104.5 \mathrm{~m}$

$104.8 \mathrm{~m}$

111-111.3 m

112.2-115.8 m

138.1-138.2 m
Carbonaceous shale and coal: $\sim 40 \mathrm{~cm}$ total thickness; base used as marker for measuring through small reverse fault

Fault: $\quad$ 071, 61SE, slickensides rake 70SW, displacement $\sim 3-4 \mathrm{~m}$

Top of coaly interval, used as marker bed for small thrust

Fault: $\quad 095,55 S$, slickensides not readily measurable

Pebbly sandstone surface at top of mottled, irregular bedded, rusty weathering sandstone overlying coaly interval; surface interpreted as transgressive surface of erosion

Sandstone: fine-medium-grained, heavily bioturbated, rippled, micaceous mud drapes, fairly straight-crested ripples with $\sim 8 \mathrm{~cm}$ wavelength; "string of pearls" trace $\sim 2 \mathrm{~cm}$ diameter and other crawling traces $1-2 \mathrm{~cm}$ diameter at $79.7 \mathrm{~m}$

Sharp basal surface of swaley/hummocky cross-stratified sandstone; bed bottom has sole marks with slight preferred orientation, but inaccessible for measurement

Bedding: 065, 50SE

Large Inoceramus impression on bedding (photos); Gyrochorte, robust, $1 \mathrm{~cm}$ diameter

Sandstone: lower medium-grained, plant debris, trough-cross-bedded; interpreted as waveinfluenced delta front (upper shoreface equivalent)

Samples: 06DL007-95-1 $\rightarrow$ POROSITY and PERMEABILITY 06DL007-95-2 $\rightarrow$ THIN SECTION

Top of trough-cross-bedded upper member of wave-influenced delta front unit

Upward-coarsening and -thickening mudstone-siltstone-sandstone package; change to mostly lower very-fine-grained sandstone occurs at $\sim 101.5 \mathrm{~m}$. Upper sandy meter contains abundant marked rounded depressions-possible dinosaur track impressions

Siltstone: occasional Diplocraterion $3 \mathrm{~cm}$ wide, $4 \mathrm{~cm}$ tall

Robust sideritized traces on bedding planes in siltstone; subhorizontal, curved, U-shaped to rounded acute angle bends, non-spreitenated; also diminutive Diplocraterion 1-2 cm tall, Skolithos to $8 \mathrm{~cm}$ long

Excellent 3-dimensional expression of depression features-possible dinosaur track impression on bed bottom: rounded sandstone-filled depression $40 \mathrm{~cm}$ diameter, $\sim 15 \mathrm{~cm}$ deep

Excellent roots to $1-2 \mathrm{~cm}$ wide, $30 \mathrm{~cm}$ long, forks at multiple depths

Sandstone: upper fine- to lower medium-grained, light red-gray weathering, trough cross-bedded, large scale, beds massive- to thick-bedded, local mudstone rip-up conglomerate with coaly debris in basal part up to $60 \mathrm{~cm}$ thick; possible fluvial channel; same unit as sandstone on skyline to north of syncline

Samples: 06DL007-113-1 $\rightarrow$ POROSITY and PERMEABILITY

06DL007-113-2 $\rightarrow$ THIN SECTION

\section{Coal}

Sample: 06DL007-140 $\rightarrow$ COAL (sulfur)

Buff, flat-topped, convex-based, sandstone-filled cast in medium-dark gray, thin-bedded sandy siltstone and silty sandstone; probable gutter cast or possible dinosaur track filled with contrasting sediment 
140.6-142.5 m Shale: dark rusty red, heavily oxidized, fissile; overlain by light olive-light brown planar laminated siltstone

$\sim 150 \mathrm{~m}$ (float) Fossil bivalve, articulated, well preserved cast $\sim 3 \mathrm{~cm}$ wide, $4 \mathrm{~cm}$ long, $2 \mathrm{~cm}$ thick with both beaks, etc. (in float below steeply-dipping beds near synclinal axis; unlikely to have been derived from much higher or lower in section)

$152 \mathrm{~m} \quad$ Carbonaceous shale: dark olive-gray

Sample: 06DL007-152 $\rightarrow$ MICROPALEONTOLOGY

153.3-153.6 m Coal, 30 cm thick

Samples: 06 DL007-153.4 $\rightarrow$ VITRINITE

06DL007-153.5 $\rightarrow$ COAL (sulfur)

$154 \mathrm{~m} \quad$ Silty mudstone: medium olive-gray

Sample: 06DL007-154 $\rightarrow$ MICROPALEONTOLOGY

156-160.5 m Sandstone: lower very-fine- to lower fine-grained, mottled rusty and light gray weathering, nonplanar thin-bedded 1-10 cm, carbonaceous; gradational base overlying mottled light brownlight gray, thin laminated carbonaceous sandy siltstone and interbedded silty sandstone

160.5-161.5 m Covered interval

161.5-162 m Sideritic mudstone

162-163.5 m Sandstone: lower to upper fine-grained

163.5-164 m Carbonaceous mudstone, poorly exposed

164-166.5 m Sandstone: upper fine- to lower medium-grained, light pinkish gray to light red-brown weathering, medium-thick bedded, trough-cross-bedded, granule-pebble sideritic mud clasts; highest bed exposed in syncline

$166.5 \mathrm{~m} \quad$ Top of section

Latitude-longitude $(\mathrm{NAD} 27$ datum $)=68.98625^{\circ} \mathrm{N}, 153.97368^{\circ} \mathrm{W}$ 